\title{
Processos urbanos de patrimonialização mundial: espaços de contradição e ressignificação dos tecidos urbanos patrimoniais
}

\section{Versão corrigida}

(Versão original encontra-se na unidade que aloja o Programa de Pós-graduação)

Tese apresentada ao Programa de Pós-Graduação em Arquitetura e Urbanismo do Instituto de Arquitetura e Urbanismo da Universidade de São Paulo, como parte dos requisitos para obtenção do título de Doutora em Arquitetura e Urbanismo

orientação | Prof. Dr. Manoel Antônio Lopes Rodrigues Alves 


\section{AUTORIZO A REPRODUÇÃO TOTAL OU PARCIAL DESTE TRABALHO, POR QUALQUER MEIO CONVENCIONAL OU ELETRÔNICO, PARA FINS \\ DE ESTUDO E PESQUISA, DESDE QUE CITADA A FONTE.}

Ficha catalográfica elaborada pela Biblioteca do Instituto de Arquitetura e Urbanismo com os dados fornecidos pela autora.

A447

Almeida, Maisa

Processos Urbanos de Patrimonialização Mundial: espaços de contradição e ressignificação dos tecidos urbanos patrimoniais/ Maisa Almeida; orientador Manoel Antonio Lopes Rodrigues Alves. -- São Carlos, 2017.

$390 \mathrm{p}$.

Tese (Doutorado - Programa de Pós-Graduação em Arquitetura e Urbanismo, Teoria e História da Arquitetura e do Urbanismo) -- Instituto de Arquitetura e Urbanismo, Universidade de São Paulo, 2017.

1. Cidade contemporânea. 2. Processos de patrimonialização mundial. 3. Processos hegemônicos de produção da cidade. 4. Tecidos urbanos tradicionais. 5. Patrimônio mundial. I. Lopes Rodrigues Alves, Manoel Antônio, orient. II. Título. 


\section{FOLHA DE JULGAMENTO}

Candidato(a): Maisa Fonseca de Almeida

Título da tese: "Processos urbanos de patrimonialização mundial: espaços de contradição e ressignificação dos tecidos urbanos patrimoniais"

Data da defesa: 08/03/2017

Orientador: Prof. Dr. Manoel Rodrigues Alves

Comissão Julgadora:

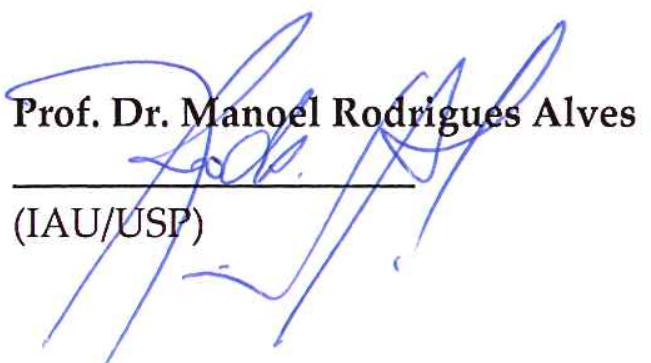

$\underline{\text { Resultado: }}$

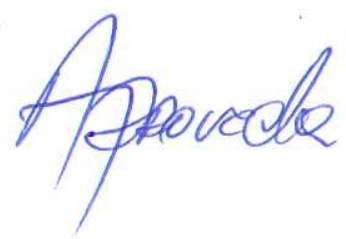

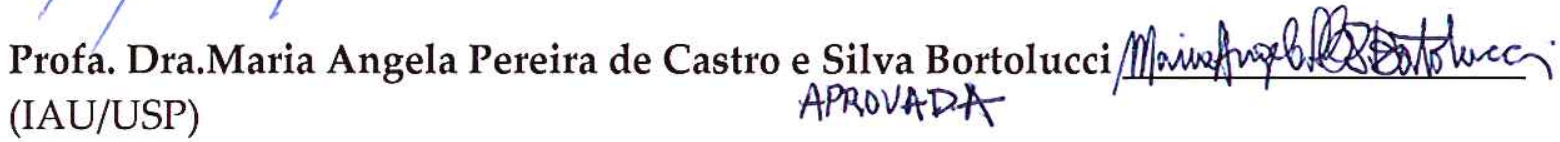

Profa. Dra. Aline Coelho Sanches Corato APROVADO

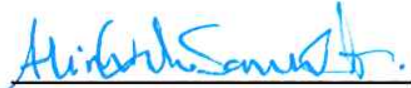
(IAU/USP)

Profa. Dra. Beatriz Mugayar Kuhl APRONAOA (FAU/USP)

Prof. Dr. Carlos Maria Tapia Martin (ETSA/US)

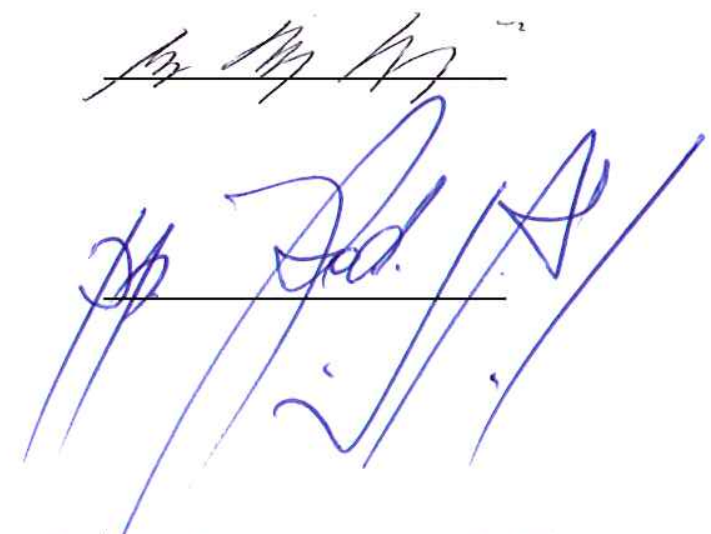

Coordenadora e Presidente da Comissão de Pós-Graduação do Programa de PósGraduação em Arquitetura e Urbanismo: Profa. Dra. Cibele Saliba Rizek. 

Ao Danilo, Luca e Raul, que me proporcionaram um novo olhar, viver e amar. 



\section{AGRADECIMENTOS}

Posso descrever o processo de desenvolvimento desta pesquisa como um período prazeroso, pois ele me trouxe muito conhecimento, boas oportunidades de reflexão, inflexão, diálogos, docência, e a construção de novas amizades, do casamento, de uma família maior com a maternidade - e em nenhum desses momentos estive isolada, muito pelo contrário, aprendi a compartilhar quase todos os meus momentos, alguns deles em silêncio, outros nem tanto.

Desse modo, meus agradecimentos se fazem especialmente àqueles que compartilharam suas vidas comigo durante o percurso, seja por um rápido momento, seja me acompanhando do início ao final da trajetória, incentivando-me, dialogando, questionando, permitindo-me argumentar, aprender e conhecer, e aos que tão bem cuidaram de mim e de minha família durante todo o processo.

O adjetivo "prazeroso" não busca reduzir as dificuldades e obstáculos do percurso, no qual o desafio esteve sempre presente na busca por uma temática indissociável das palavras "interdisciplinar", "múltiplo", "amplo", ao mesmo tempo "particular", "singular", "único" e de todos - conceitos que podem ser vistos como contraditórios, ou difíceis de ser atingidos pela sua dualidade original, mas cujas particularidades e especificidades tornaram a jornada muito mais atrativa e enriquecedora.

Esta pesquisa foi desenvolvida junto ao Programa de Pós-graduação do Instituto de Arquitetura e Urbanismo da Universidade de São Paulo, com uma bolsa da Coordenação de Aperfeiçoamento de Pessoal de Nível Superior (CAPES), e, durante esse período, realizei um estágio doutoral no Centro de Estudos da Metrópole (CES) da Universidade de Coimbra, com uma bolsa de pesquisa "Jovens Investigadores". Agradeço àquele programa e a este centro de pesquisa pela credibilidade em minha pesquisa.

A Manoel Rodrigues Alves, meu orientador, agradeço as provocações, discussões, revisões do trabalho e incentivo pela busca da construção de um novo objeto de pesquisa, principalmente, no âmbito nacional, e que trouxe uma nova oportunidade de reflexão à pesquisa.

Também a ele agradeço o convite para fazer parte, como pesquisadora, do Laboratório de Estudos do Ambiente Urbano Contemporâneo (LEAUC). Foi por meio desse grupo de pesquisa, de suas discussões, diálogos e do meu conhecimento de investigações transdisciplinares sobre a cidade contemporânea, que nossa pesquisa se permitiu inovar e 
transpor campos de conhecimento, na tentativa de compor questionamentos novos sobre as transformações do processo de conformação do conteúdo cultural e social do espaço urbano.

Nesse ambiente de pesquisa fui acolhida com a oportunidade da convivência intelectual com colegas cujas investigações sobre a cidade contemporânea eram provocantes e convidavam à reflexão, e que originaram inquietações e a busca contínua pela compreensão das transversalidades do processo no campo do patrimônio. Gostaria de agradecer especialmente à Prof.a Cibele Rizek, aos pesquisadores Andrei Zaiatz, Bianca Habib, Camila Moreno, Elaine Saraiva, Érica Emi, Esther Audibert, Jéssika França, Marília Sé, Maíra Daitx, Magaly Marques, Tainá Hermoso, Thamine Ayoub, Valéria Garcia e agradeço especialmente e com muito carinho à grande generosidade de Thaís Rosa.

Também gostaria de agradecer aos colegas de docência ao longo desses seis anos, com quem pude dialogar, discutir, aprender e compartilhar da atividade didática e de ensino, especialmente a Cesar Elias, Leandro Schenk, Luciana Ceron, Marcelo Carlucci, Sabrina e Sálua Poleto.

A Carolina Fidalgo agradeço a gentileza de compartilhar alguns de seus achados de sua pesquisa de doutorado, que nortearam o início de minha trajetória nesta pesquisa, e que permitiram um entendimento mais amplo do conceito de bem cultural.

Aos professores Carlos Tapia e Maria Ângela Bortolucci pelas contribuições durante a banca de qualificação, com seus comentários e direcionamentos fundamentais para o aprofundamento das reflexões deste trabalho. A Maria Ângela agradeço especialmente a oportunidade ao final da pesquisa de retomar muitas dessas questões.

A amiga e pesquisadora Joana D'Arc Oliveira pelas discussões e contribuições à pesquisa e para além delas, sempre disposta a motivar-me e provocar-me a organizar minhas reflexões, acrescentando seu ponto de vista sobre o campo do patrimônio.

Em Coimbra, pela recepção e supervisão de meu estágio de pesquisa pelo professor Paulo Peixoto. Além de conectar-me a questões do bem cultural da Universidade de Coimbra e da cidade, por meio dele foi possível compreender uma série de questões relacionadas à pesquisa de campo e realizar as entrevistas. Também gostaria de agradecer ao Prof. José António Raimundo Mendes da Silva, ao engenheiro Sidónio Simões e aos arquitetos e urbanistas Nuno Ribeiro Lopes e Cátia Marques, pelas entrevistas concedidas.

Em Belém, pela recepção da professora Jéssika França, que me apresentou sua cidade e sua pesquisa em Belém, por seu intermédio foi possível conhecer e compreender um pouco mais 
de perto meu objeto de estudo, e também realizar as entrevistas. Também gostaria de agradecer aos professores da UFPA Saint-Clair Trindade Junior, Juliano Pamplona Ximenes Ponte e Maria Goretti da Costa Tavares, e à superintendente do IPHAN no Pará, Maria Dorotéa de Lima, pelas entrevistas concedidas. Em especial, a Juliano Ximenes, por prontamente disponibilizar dados sobre a cidade, e a Maria Goretti pelo passeio pela Feira Livre do Ver-o-Peso e pela indicação do grupo circular e de tantos outros contatos de interesse para a pesquisa.

A Fabiane Caldeira do Serviço de Informação ao Cidadão (SIC-Iphan) do Instituto do Patrimônio Histórico e Artístico Nacional de Brasília agradeço a gentileza de nortear-me na solicitação e por, conjuntamente a Andressa Furtado da Silva de Aguiar do Arquivo Central do Iphan seção Rio de Janeiro, disponibilizar a documentação versão digital de candidatura de Ver-o-Peso.

Aos funcionários do Instituto de Arquitetura e Urbanismo da Universidade de São Paulo Mara Lino, Flávia Cavalcanti, Evandro Bueno, Daniel Picon, Marcelo e Sérgio Celestini, Fátima Mininel, Andréia Salla, aos bibliotecários da Escola de Engenharia de São Carlos, em especial Gisele Rodrigues Mazzi, Ana Gláucia Fiscarelli, Eli Rodrigues de Moraes, Elena Gonçalves e Rosana Paschoalino (in memorium). E, também, a Raquel Santini e Gracielli Pepe agradeço pela amizade e pela disposição em auxiliar-me em questões que me permitiram desenvolver esta investigação com maior tranquilidade.

Aos professores do IAU-USP, Joubert Lancha, Ruy Sardinha e Marcel Fantin pela gentil contribuição de indicar-me leituras que enriqueceram minha compreensão dos temas da pesquisa.

Aos amigos Camila e Daniel Pileggi, pela amizade que ao longo dos anos tem se fortalecido. Sem vocês minhas realizações durante estes anos não teriam sido tão completas.

A amizade de Jorge Oliveira e Camila Sant'ana, sonhadores, inquietantes e inspiradores amigos cuja afinidade e interesse pela docência e pesquisa tornam nossos encontros cada vez mais prazerosos e estimulantes, nossas discussões sempre me permitiram ampliar meu olhar para além de meus temas de pesquisa.

A minha família, sem seu amor e cuidados esta pesquisa não teria sido possível. Em particular ao Eduardo, pelo incentivo e apoio intelectual a novos desafios, e ao Celso pela revisão da redação do texto. 


\section{IMAGEM DE CAPA}

Montagem feita a partir de fotos capturadas pela autora durante as atividades de pesquisa em campo, no período que compreende o desenvolvimento desta tese. As imagens deslocadas compõem o cenário da ressignificação da identidade desses espaços urbanos, o que, em certa medida, representa o fenômeno dos processos de classificação numa esfera global. 
"Há uma reação de um grupo de intelectuais, que acham que o ICOMOS e, sobretudo, a UNESCO é neste momento uma máquina dependente da máquina do turismo, e, portanto, perfeitamente subvertida em relação ao que eram os seus princípios. "

Prof. José António Raimundo Mendes da Silva Entrevista concedida à autora em junho de 2012.

"Então a gente meio que parou com isso, porque também essa reconfiguração das instituições envolvidas é sempre uma questão de política, deixou de ser técnica. " 



\section{RESUMO}

ALMEIDA, Maisa Fonseca de. Processos Urbanos de Patrimonialização Mundial - espaços de contradição e ressignificação dos tecidos urbanos patrimoniais. 2017. $390 \mathrm{f}$. Tese (Doutorado) Instituto de Arquitetura e Urbanismo, Universidade de São Paulo, São Carlos, 2017.

Adentrando o debate sobre a produção do espaço urbano da cidade contemporânea, esta pesquisa analisa em que medida os processos de patrimonialização mundial regidos pela Organização das Nações Unidas para a Educação, a Ciência e a Cultura (UNESCO) e seus desdobramentos são conformes, ou não, com processos hegemônicos de produção da cidade. Nesse campo de disputas e conflitos, verificam-se as transversalidades e fenômenos de um processo atrelado a uma lógica de reprodução do capital e ao consumo mercantil das cidades. Neste sentido, a sua compreensão permite desvelar aspectos da reprodução financeirizada do capital no espaço urbano, e responde a hipótese que esse trabalho apresenta, de que os tecidos urbanos tradicionais da cidade são desconstituídos de seu significado ao recriar novas articulações urbanas que intensificam e reduzem realidades complexas diante de seus processos de patrimonialização regidos pela assistência e cooperação internacional da UNESCO. Tal processo de ressignificação, por meio da dissolução das condicionantes físicas, históricas e socioculturais que constituem de maneira dinâmica a identidade dos tecidos urbanos tradicionais das cidades, pode resultar em contradições em relação à articulação dos nomeados bens culturais aos seus contextos locais e na dissolução das relações de identidade e culturais do próprio lugar. Assim, considerada uma questão que perpassa o patrimônio, este trabalho analisa como estudo de caso o processo de classificação recente e ainda em andamento do Ver-o-Peso (BR) e apresenta como contraponto o patrimônio mundial da Universidade de Coimbra (PT), buscando por meio desta análise questionar e verificar as condições e os processos na cidade que podem levar tanto à criação de espaços simplificados de significado, diante de um processo de homogeneização da cultura, quanto a ações de preservação no âmbito nacional e internacional, principalmente relacionadas a uma agência multilateral internacional de preservação do patrimônio que corroboram para este processo. Dessa forma, a pesquisa se insere no quadro de discussões relativas ao processo de produção do espaço urbano da cidade relacionado à intervenções no patrimônio e a preservação de conjuntos históricos das cidades, contribuindo particularmente para avaliar o papel dos processos de classificação a patrimônio mundial das cidades na proteção e preservação do patrimônio cultural.

Palavras-chave: Cidade contemporânea. Processos de patrimonialização mundial. Processos hegemônicos de produção da cidade. Tecidos urbanos tradicionais. Patrimônio mundial. 



\section{ABSTRACT}

ALMEIDA, Maisa Fonseca de. World Patrimonialization Urban Processes - spaces of contradiction and resignification of heritage urban fabrics. 2017. $390 \mathrm{f}$. Tese (Doutorado) Instituto de Arquitetura e Urbanismo, Universidade de São Paulo, São Carlos, 2017.

As part of the debate on the production of the urban space of the contemporary city, this research analyzes to what extent the processes of global patrimonialization governed by the United Nations Educational, Scientific and Cultural Organization (UNESCO) and its developments are or are not in conformity with hegemonic processes of production of the city. In this field of disputes and conflicts we verify the transversality and the phenomena of a process linked to a logic of reproduction of capital and to the mercantile consumption of cities. In this sense, its understanding allows us to unveil aspects of the financial reproduction of capital in urban space, and responds to the hypothesis that this work presents, that is the traditional urban fabrics of the city are deconstituted of their meaning when recreating new urban articulations that intensify and reduce complex realities in the face of its patrimonial processes governed by UNESCO's international assistance and cooperation. Such a process of resignification, through the dissolution of the physical, historical and socio-cultural conditioning factors that dynamically constitute the identity of the traditional urban fabrics of the cities, may result in contradictions in relation to the articulation of the so-called cultural goods for their local contexts and in the dissolution of identity and cultural relations of the place. Thus, considered as an issue that pervades the heritage, this work analyzes, as a case study, the recent and ongoing classification process of the Ver-o-Peso (BR) and presents as a counterpoint the world heritage of the University of Coimbra (PT). This analysis seeks to question and verify the conditions and processes in the city that can lead both to the creation of simplified spaces of meaning, before a process of homogenization of culture, and preservation actions at national and international level, mainly related to an international multilateral agency for the preservation of heritage that corroborate this process. In this way, the research is part of discussions about the process of production of the urban space of the city related to interventions in heritage and the preservation of historical sets of cities, contributing particularly to evaluate the role of classification processes to cities' world heritage in the protection and preservation of cultural heritage.

Keywords: Contemporary city. Processes of global patrimonialization. Hegemonic processes of production of the city. Traditional urban fabrics. World Heritage. 



\section{LISTA DE IMAGENS}

Imagem 1 - Capa de publicação oficial da UNESCO de abril de 2014

Imagem 2 - Capa de publicação oficial da UNESCO de outubro de 2012.

Imagem 3 - Números de bens culturais patrimônio mundial por região.

Imagem 4 - Números de bens culturais patrimônio mundial inscritos por ano por região...........

Imagem 5 - Estudo de uma imagem refletida em movimentos de rotação...

Imagem 6 - Rua Sofia, a primeira parte da Universidade de Coimbra, Coimbra.....

Imagem 7 - Rua Sofia, a primeira parte da Universidade de Coimbra, Coimbra.....

Imagem 8 - Vista da Zona da Alta desde o largo D. Dinis, edifícios da Química e da Faculdade de Medicina, Coimbra, 2012

Imagem 9 - Vista da Zona da Alta desde o largo D. Dinis e fachada frontal da Faculdade de Letras da Universidade de Coimbra, Coimbra, 2012.

Imagem 10 - Vista do Mercado de Carne, Solar da Beira e Feira Livre do Ver-o-Peso e baía do Guajará, Belém, 2014.

Imagem 11 - Vista das docas do Ver-o-Peso e ao fundo o conjunto da Praça Frei Caetano Brandão, Belém, 2014.

Imagem 12 - Verticalização residencial do bairro Umarizal, ao fundo e a frente a horizontalidade predominante da área patrimonial do bem cultural Ver-o-Peso e sua área de entorno, Belém, 2016.

Imagem 13 - Vista da baía do Guajará para o Complexo Ver-o-Peso e bairro Umarizal com a sua verticalização residencial, Belém, 2016...

Imagem 14 - Vista da baía do Guajará para o bairro Cidade Velha, Porto do Sal, no Centro Histórico, embarcações atracadas próximo a um trapiche com pouca infraestrutura, e a presença de baixadas e palafitas junto a orla, Belém, 2016.

Imagem 15 - Nesta área, em 1969, ficava a Farmácia do Povo, Armarinho Nicolau \& Cia. Estas edificações foram construídas no século XVII, no local que anteriormente abrigou a casa que serviu de Ver-o-Peso, para cobranças dos impostos devidos à Câmara, Belém.

Imagem 16 - Vista da Feira Livre do Ver-o-Peso, Solar da Beira, e ao fundo uma das torres do Mercado de Peixe, um espaço de grande fluxo de pessoas durante a maior parte do dia, com grande misto de atividades ligadas principalmente ao consumo de produtos populares, Belém, 2016.

Imagem 17 - Doca na vazante em 1969, as embarcações ficavam adernadas, até que chegasse a enchente da maré. Ao fundo o Mercado de Peixe, Belém...

Imagem 18 - Doca na vazante, ano de 1969, e ao fundo a feira do Açaí. Ao fundo o Mercado de Peixe, Belém.

Imagem 19 - Vista da Feira do Açaí, doca do Ver-o-Peso e ao fundo Mercado de Peixe, no início da tarde de um sábado, com algumas embarcações atracadas e veículos utilizados para distribuições estacionados, Belém, 2016...

Imagem 20 - Vista da doca do Ver-o-Peso com algumas embarcações de pescadores atracadas e ao fundo a composição da paisagem do casario da Avenida Marquês de Pombal, às $12 \mathrm{~h}$ de uma quarta-feira, Belém, 2016

Imagem 21 - Vista interna da feira livre do Ver-o-Peso no setor da farinha, Belém, 2016.......... Imagem 22 - Erveira da barraca "cheirosinha", Feira Livre do Ver-o-Peso, Belém, 2016.............. Imagem 23 - Vista interna da feira livre do Ver-o-Peso no setor de hortifruti, Belém, 2016......... Imagem 24 - Vista interna da feira livre do Ver-o-Peso no setor de mercearia, Belém, 2016...... Imagem 25 - Fotomontagem da composição da paisagem do Centro Histórico, Belém, 2016.... Imagem 26 - Fotomontagem da composição da paisagem da orla, Belém, 2016. 


\section{LISTA DE IMAGENS}

Imagem 28 - Vista da Ladeira do Forte, Belém, 2016.

Imagem 29 - Vista da Rua Siqueira Mendes, Belém, 2016

Imagem 30 - Vista do Solar da Beira e da Feira Livre, anterior à reforma e padronização das barracas da Feira Livre, Belém.

Imagem 31 - Vista da Feira Livre, Ver-o-Peso, Belém, 2004.

Imagem 32 - Torres do Mercado de Peixe e Feira Livre de Ver-o-Peso das margens do rio Guajará, Complexo Ver-o-Peso, Belém, 2016.

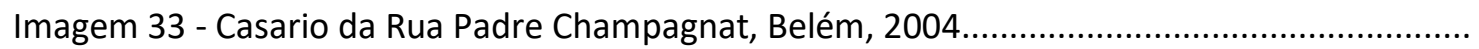

Imagem 34 - Vista do Polo Joalheiro, Belém, 2016.

Imagem 35 - Vista da área de intervenção do projeto Feliz Lusitânia, Belém, 2004......................

Imagem 36 - Igreja de Santo Alexandre, Belém, 2004.

Imagem 37 - Vista do Forte do Presépio, Belém, 2016.

Imagem 38 - Vista da Casa das 11 Janelas, foto capturada da baía de Guajará, Belém, 2016.....

Imagem 39 - Estação das Docas, vista das margens do rio Guajará, Belém, 2016.

Imagem 40 - Estação das Docas, vista interna entre os galpões e, nos jardins as imagens de importantes personagens da história da cidade, Belém, 2016.

Imagem 41 - Vista do interior do barco de passeios fluviais "tribo dos Kayapós", que faz passeios pela orla de Belém diariamente com a apresentação de danças típicas regionais, Belém, 2016.......

Imagem 42 - Vista do interior da Estação das Docas, com a identidade e comunicação visual de uma das empresas privadas locais relacionadas ao projeto cultural gastronômico em Belém, Belém, 2016..

Imagem 43 - Imagem 27 - Esquema explicativo das intervenções na área, políticas de preservação e diretrizes de classificação da UNESCO.

Imagem 44 - Vista da orla de Puerto Madero, Buenos Aires (Argentina), 1989.

Imagem 45 - Vista aérea da urbanização de Puerto Madero, Buenos Aires, 1989.

Imagem 46 - Vista da orla de Puerto Madero, Buenos Aires, 1989.

Imagem 47 - Vista do conjunto da urbanização de Puerto Madero, Buenos Aires, 1989..............

Imagem 48 - Vista de elementos históricos de Puerto Madero, Buenos Aires, 1989...

Imagem 49 - Esquema explicativo relativo a classificação do patrimônio imaterial relacionado a cidade de Belém.

Imagem 50 - Vista do edifício, sem uso atualmente, capturada em ângulo semelhante (na praça do relógio), com a Catedral da Sé ao fundo, Belém, 2016.

Imagem 51 - Vista da maquete eletrônica da proposta do novo centro comercial Bechara Mattar Diamond na área de entorno do Ver-o-Peso, Belém, 2014.

Imagem 52 - Feira livre do Ver-o-Peso e coberturas das barracas atualmente, Belém, 2014.......

Imagem 53 - Fotomontagem da proposta de projeto para a Feira livre do Ver-o-Peso apresentado pela prefeitura, Belém, 2014.

Imagem 54 - Fotomontagem da proposta de projeto para a Feira livre do Ver-o-Peso apresentado pela prefeitura, Belém, 2014.

Imagem 55 - Vista interna da maquete eletrônica da nova Feira Livre do Ver-o-Peso, na parte do setor de frutas e alimentação (açaí), Belém.

Imagem 56 - Vista da maquete eletrônica e da orla, com a proposta da nova Feira Livre do

Ver-o-Peso, na parte do setor de alimentação, Belém.

Imagem 57 - Vista da maquete eletrônica com a vista da Baía de Guajará da nova feira livre do Ver-o-Peso, na parte do setor de artesanato, Belém. 


\section{LISTA DE IMAGENS}

Imagem 62 - Esquema explicativo relativo a classificação do patrimônio material relacionado a cidade de Coimbra.

Imagem 63 - República de estudantes "Bota-abaixo", Zona da Alta, Coimbra, 2012....................

Imagem 64 - República de estudantes com faixa em protesto

Imagem 65 - Manifesto crítico contra a candidatura da Universidade de Coimbra....

Imagem 66 - Registro fotográfico histórico de manifestação política nas Escadas Monumentais

Imagem 67 - Registro fotográfico histórico de manifestação política na área protegida, Coimbra...

Imagem 68 - Escadas monumentais com manifestação política, Coimbra

Imagem 69 - Vista do Pátio da Universidade antes da intervenção de nova pavimentação, Coimbra

Imagem 70 - Fachada do Paço das Escolas e a Torre do Relógio, Coimbra.....

Imagem 71 - Modelo virtual da proposta vencedora do concurso para intervenção no futuro Museu das Ciências, Coimbra.

Imagem 72 - Corte da proposta vencedora do concurso do Museu das Ciências, Coimbra..........

Imagem 73 - Fachada da Casa das Caldeiras, Coimbra.

Imagem 74 - Croqui do auditório Faculdade de Direito, Coimbra...

Imagem 75 - Croqui do auditório Faculdade de Direito, Coimbra...

Imagem 76 - Croqui, com vista da entrada principal do auditório da Faculdade de Direito, Coimbra

Imagem 77 - Vista do acesso principal do auditório da Faculdade de Direito, Coimbra...............

Imagem 78 - Maquete do auditório da Faculdade de Direito, Coimbra.

Imagem 79 - Croqui do Museu Nacional Machado de Castro, Coimbra.

Imagem 80 - Foto do acesso principal do Museu Nacional Machado de Castro, Coimbra............. Imagem 81 - Vista da fachada posterior do Museu Nacional Machado de Castro, Coimbra.......... Imagem 82 - Pátio do Museu Nacional Machado de Castro, Coimbra..

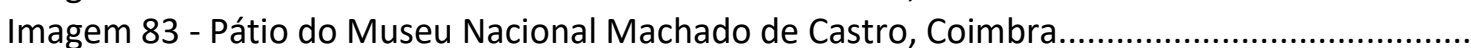

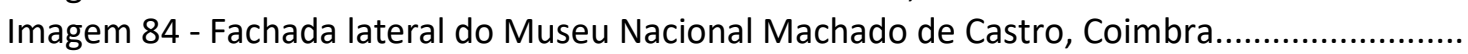

Imagem 85 - Colégio de São Bento, Coimbra

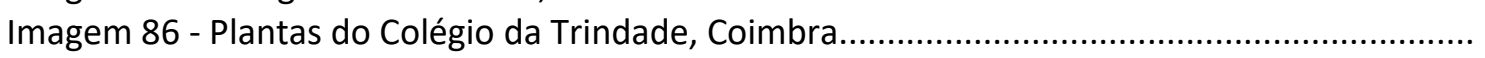

Imagem 87 - Colégio da Trindade, Coimbra...

Imagem 88 - Maquete da proposta do edifício do Tribunal Universitário Judicial e Europeu.......

Imagem 89 - Maquete da proposta do edifício do Tribunal Universitário Judicial e Europeu........

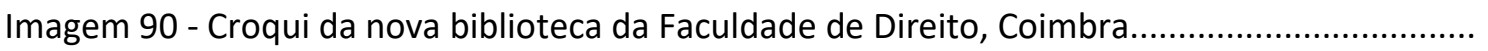

Imagem 91 - Maquete da proposta da biblioteca da Faculdade de Direito, Coimbra.....................

Imagem 92 - Foto da Praça 8 de maio, Coimbra.

246

246

246

247

247

Imagem 93 - Croqui de Fernando Távora para a proposta de intervenção na Praça 8 de maio...

Imagem 94 - Praça 8 de Maio, Coimbra.

Imagem 95 - Vista da ponte Rainha Isabel desde o Paço das Escolas, Coimbra.............................

Imagem 96 - Vista do Parque de Coimbra e da ponte Rainha Isabel, Coimbra................................

Imagem 97 - Vista geral do Museu de Santa Clara-a-Velha, Coimbra......

Imagem 98 - Construção do Centro de Convenções e Espaço Cultural do Convento de São Francisco, Coimbra.

Imagem 99 - Modelo Virtual do Centro de Convenções e Espaço Cultural do Convento de São Francisco, Coimbra.

Imagem 100 - Modelo Virtual do Centro de Convenções e Espaço Cultural do Convento de São Francisco, Coimbra.

Imagem 101 - Modelo Virtual do Centro de Convenções e Espaço Cultural do Convento de São Francisco, Coimbra.

Imagem 102 - Modelo Virtual do Centro de Convenções e Espaço Cultural do Convento de São Francisco, Coimbra. 


\section{LISTA DE MAPAS}

Mapa 1 - Brasil e do estado do Pará com a localização da cidade de Belém

Mapa 2 - Identificação de alguns bairros da cidade, CHB e entorno, e Ver-o-Peso, Belém.

Mapa 3 - Densidade populacional, em habitantes por hectare, nos setores censitários definidos pelo IBGE para os municípios de Belém e Ananindeua (PA) em 2000.

Mapa 4 - Densidade populacional, em habitantes por hectare, nos setores censitários definidos pelo IBGE para os municípios de Belém e Ananindeua (PA) em 2010...

Mapa 5 - Densidade populacional, em habitantes por hectare, nos setores censitários definidos pelo IBGE para o município de Belém (PA) em 2000.....

Mapa 6 - Densidade populacional, em habitantes por hectare, nos setores censitários definidos pelo IBGE para o município de Belém (PA) em 2010...

Mapa 7 - Esquema viário geral com a mancha urbana da região metropolitana de Belém

Mapa 8 - Medianas de idades, em anos, nos setores censitários definidos pelo IBGE para o município de Belém (PA) em 2000.

Mapa 9 - Medianas de idades, em anos, nos setores censitários definidos pelo IBGE para o município de Belém (PA) em 2010.

Mapa 10 - Renda familiar média, em Reais, nos setores censitários definidos pelo IBGE para o município de Belém (PA) em 2000.

Mapa 11 - Renda familiar média, em Reais, nos setores censitários definidos pelo IBGE para o município de Belém (PA) em 2010.

Mapa 12 - Porcentagem de residências do tipo apartamento em relação ao total de residências nos setores censitários definidos pelo IBGE para o município de Belém (PA) em 2000.

Mapa 13 - Porcentagem de residências do tipo apartamento em relação ao total de residências nos setores censitários definidos pelo IBGE para o município de Belém (PA) em 2010.

Mapa 14 - Porcentagem de residências atendidas pela rede de esgoto em relação ao total de residências nos setores censitários definidos pelo IBGE para o município de Belém (PA) em 2000.

Mapa 15 - Porcentagem de residências atendidas pela rede de esgoto em relação ao total de residências nos setores censitários definidos pelo IBGE para o município de Belém (PA) em 2010.

西

Mapa 16 - Ilustração da gênese urbana de Belém com a localização do núcleo pioneiro da cidade de Belém.

Mapa 17 - Ilustração do sentido da expansão urbana ao longo do tempo, localizando o núcleo urbano pioneiro da cidade de Belém, o bem cultural Ver-o-Peso.

Mapa 18 - Imagens esquemáticas da produção do espaço urbano em Belém, de 1616 a 1997......

Mapa 19 - Área de tombamento do Conjunto arquitetônico e paisagístico de Ver-o-Peso pelo IPHAN, com a identificação do complexo Ver-o-Peso e seus elementos constituintes, Belém.......

Mapa 20 - Cidade de Belém com a identificação das áreas protegidas segundo o IPHAN, dos bens culturais e do Complexo Estação das Docas, área de entorno de Ver-o-Peso, Belém...

Mapa 21 - Levantamento das principais atividades de uso e ocupação do solo do Complexo Vero-Peso, Belém.

Mapa 22 - Levantamento das principais atividades e fluxos da área do Complexo Ver-o-Peso, Belém

Mapa 23 - Esquema da setorização da feira livre do Ver-o-Peso, Belém

Mapa 24 - Identificação do ZEEPH do CHB ....

Mapa 25 - Identificação da primeira e segunda propostas de classificação de bens culturais a patrimônio mundial pela UNESCO, do Centro Histórico e entorno, Belém. 


\section{LISTA DE MAPAS}

Mapa 29 - Identificação da proposta para o novo instituto gastronômico, na área adjacente.......... 201

Mapa 30 - Portugal e região de Coimbra, com a localização da cidade de Coimbra............................ 213

Mapa 31 - Referente ao processo de Reconquista de Portugal .................................................. 218

Mapa 32 - Fundação da primeira Universidade Portuguesa por D. Dinis em 1290........................ 218

Mapa 33 - Relativa ao estabelecimento definitivo da Universidade em Coimbra.......................... 218

Mapa 34 - Referente ao período do reinado de D. João V, Coimbra........................................... 218

Mapa 35 - Período da reforma pombalina, no século XVIII, Coimbra............................................. 219

Mapa 36 - Período de extinção das ordens religiosas, Coimbra..................................................... 219

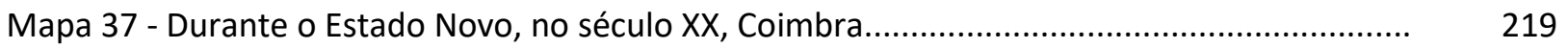

Mapa 38 - Referente ao período atual, séc. XXI, Coimbra............................................................ 219

Mapa 39 - Delimitação da área de proteção candidata, e leituras arquitetônicas e estruturais do conjunto, Coimbra.

Mapa 40 - Localização dos edifícios principais da zona de proteção do Patrimônio Mundial, Coimbra, 2014.

Mapa 41 - Mapa com a localização de uma rua de repúblicas, Zona da Alta.................................. 228

Mapa 42 - Mapa de localização das Escadas Monumentais, Coimbra.......................................... 232

Mapa 43 - Identificação das Áreas de Reabilitação Urbanas na Cidade de Coimbra....................... 233

Mapa 44 -Mapa de identificação do Paço das Escolas, Coimbra.................................................. 236

Mapa 45 -Mapa de identificação do futuro Museu das Ciências, Coimbra..................................... 238

Mapa 46 - Mapa de identificação da Casa das Caldeiras, Coimbra................................................ 239

Mapa 47 - Mapa de identificação do auditório da Faculdade de Direito, Coimbra......................... 240

Mapa 48 - Mapa de identificação do Museu Nacional Machado de Castro, Coimbra...................... 241

Mapa 49 - Mapa de localização do Colégio de São Bento, Coimbra..............................................

Mapa 50 - Mapa de identificação do Colégio da Trindade, Coimbra........................................... 245

Mapa 51 - Mapa de identificação da nova biblioteca da Faculdade de Direito, Coimbra.................. 247

Mapa 52 - Mapa de identificação da Praça 8 de maio, Coimbra.................................................... 248

Mapa 53 - Mapa de identificação do Parque de Coimbra, Coimbra............................................... 250

Mapa 54 - Mapa de identificação do Museu de Santa Clara-a-Velha, Coimbra.............................. $\quad 250$

Mapa 55 - Mapa de identificação do Centro de Convenções e Espaço Cultural, Coimbra................. 251 


\section{LISTA DE QUADROS}

Quadro 1 - Etapas do processo de classificação como patrimônio mundial pela UNESCO

Quadro 2 - Quadro comparativo dos bens dos conjuntos urbanos classificados como patrimônio mundial em Portugal, segundo a UNESCO

Quadro 3 - Quadro comparativo dos bens de conjuntos urbanos indicados (candidatos) a patrimônio mundial no Brasil, segundo a UNESCO

Quadro 4 - Quadro comparativo dos bens de conjuntos urbanos classificados como patrimônio mundial no Brasil, segundo a UNESCO. 


\section{SIGLAS}

AAPBEL Associação dos Amigos do Patrimônio de Belém

APA

Área de Preservação Ambiental

ASAPAN Associação dos Agentes do Patrimônio na Amazônia

ARU

Área de Reabilitação Urbana

CAUE13 Conseil d'Architecture, d'Urbanisme et de l'Environnement

CES

Centro de Estudos Sociais

CDP

Companhia Docas do Pará

$\mathrm{CHB}$

Centro Histórico de Belém

CiVViva

Associação da Cidade Velha e Cidade Viva

CNRC

Centro Nacional de Referência Cultural

CODEM

Companhia de Desenvolvimento e Administração da Área Metropolitana de Belém

CONDEPHAAT

Conselho de Defesa do Patrimônio Histórico, Arqueológico, Artístico e Turístico

EIV

Estudo de Impacto na Vizinhança

FAU

Faculdade de Arquitetura e Urbanismo

FEDER

Fundo Europeu de Desenvolvimento Regional

FUMBEL

Fundação Cultural do Município de Belém

HPIP

$I A B$

Heritage of Portuguese Influence

IAB

Instituto de Arquitetos do Brasil

IAU

Instituto de Arquitetura e Urbanismo

IBGE

Instituto Brasileiro de Geografia e Estatística

IDESP

Instituto de Desenvolvimento Econômico, Social e Ambiental do Pará

IGESPAR

INCR

INE

Instituto de Gestão de Patrimônio Arquitetônico e Arqueológico

Inventário Nacional de Referências Culturais

IPCA

Instituto Nacional de Estatística

IPHAN

Índice Nacional de Preços ao Consumidor Amplo

IPEA

Instituto do Patrimônio Histórico e Artístico Nacional

JESSICA

Instituto de Pesquisa Econômica Aplicada

LCCU

Joint European Support for Sustainable Investment in City Areas

MinC

Lei Complementar de Controle Urbanístico

NEURB

Ministério da Cultura

$O A B$

Núcleo de Estudos Urbanos

ONU

ONUBR

Ordem dos Advogados do Brasil

Organização das Nações Unidas

PAC

Organização das Nações Unidas no Brasil

$\mathrm{PCH}$

PMB

POS_C

RUAS

Programa de Aceleração do Crescimento

SECON

SECULT

Programa de Reconstrução das Cidades Históricas

Prefeitura Municipal de Belém

Programa Operacional Sociedade do Conhecimento

Associação para Recriar a Universidade Alta e Sofia

Secretaria Municipal de Economia

SEPLAN

Secretaria de Estado de Cultura do Pará

SEURB

Secretaria de Planejamento da Presidência da República

SPHAN

SRU

Secretaria Municipal de Urbanismo

Serviço do Patrimônio Histórico e Artístico Nacional

UC

Sociedade de Reabilitação Urbana

UFPA

Universidade de Coimbra

USP

Universidade Federal do Pará

ZEIP

Universidade de São Paulo

ZEP

Zona Especial de Preservação do Patrimônio Histórico

Zona Especial de Proteção 


\section{SUMÁRIO}

INTRODUÇÃO

1. PROTEÇÃO DOS BENS CULTURAIS

Órgãos nacionais de proteção e políticas de preservação do patrimônio cultural 46 urbano.

Organismos internacionais de proteção do patrimônio cultural. 57

Patrimônio mundial - a ideia de patrimônio comum de todos os povos. 61

Cartas Patrimoniais Internacionais. $\quad 64$

O local e a localidade nos processos de patrimonialização mundiais. 67

2. PATRIMÔNIO E A CIDADE CONTEMPORÂNEA

Patrimônio e aspectos de conformação da cidade contemporânea. $\quad 78$

Processos de renovação urbana e o planejamento estratégico. 83

Questões da cidade contemporânea e a memória do lugar. 91

Processos de Patrimonialização Mundial. 93

As manifestações culturais e o espaço urbano patrimonial. $\quad 97$

3. PONTO E CONTRAPONTO - ESTUDOS DE CASO 103

$\begin{array}{ll}\text { A definição dos objetos de estudo. } & 104\end{array}$

O caso brasileiro - Belém, Ver-o-Peso. 114

O processo de patrimonialização de Ver-o-Peso (Brasil). 115

$\begin{array}{ll}\text { Breve caracterização de Belém. } & 118\end{array}$

Espacialização de dados demográficos de Belém. 119

O vai e vem da canoa, o rio, a floresta e o tributo. 144

Conceito de paisagem cultural em Belém. 153

Registro de mapas das áreas protegidas, atividades e fluxos cotidianos. 157

$\begin{array}{ll}\text { Políticas Culturais de Preservação e a Centralidade. } & 168\end{array}$ 
Intervenções na área do Complexo Ver-o-Peso e entorno

Chaves de interpretação do processo.

Considerações sobre o processo de patrimonialização de Belém 208

O contraponto internacional - Coimbra (Portugal), Alta e Sofia. 211

Breve histórico do Bem Cultural da Universidade de Coimbra

Expansão urbana de Coimbra e o bem cultural da Universidade 218

O processo de patrimonializaçãomundial de Coimbra. 220

Área de Reabilitação Urbana - ALTA 235

Propostas futuras para a ARU - ALTA 244

Área de Reabilitação Urbana - BAIXA 248

Área de Reabilitação Urbana - RIO 249

Intervenções e propostas futuras - área externa às ARU 250 CONSIDERAÇÕES FINAIS 257

REFERÊNCIAS 275

ANEXO 1 _ lista do patrimônio mundial no Brasil. 287

ANEXO 2 _ lista do patrimônio mundial em Portugal.

ANEXO 3 _o tombamento do Ver-o-Peso.

ANEXO 4_levantamento do inventário de referências culturais do Ver-o-Peso.

ANEXO 5 _descrição do bem cultural da Universidade de Coimbra pela UNESCO. 293

ANEXO 6 _descrição do bem cultural do Ver-o-Peso pela UNESCO. 296

APÊNDICE A_entrevistas em Coimbra $\quad 302$

APÊNDICE B_ entrevistas em Belém 351 


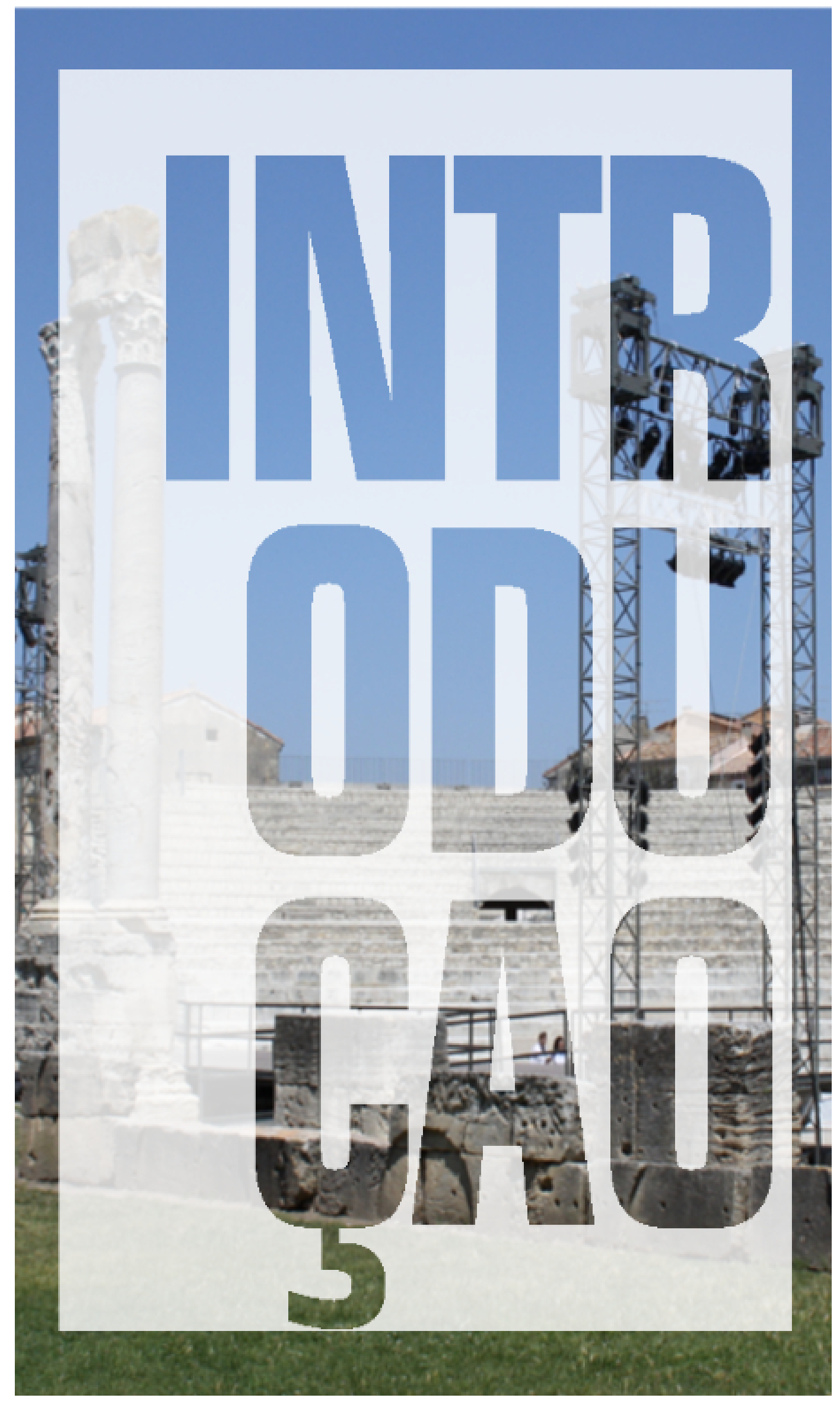




\section{IMAGEM DE CAPA DA INTRODUÇÃO}

Montagem feita a partir de foto capturada pela autora no Teatro Antigo de Arles (França), em junho de 2010, durante o início do desenvolvimento do projeto de pesquisa para o ingresso no curso de doutorado. Na imagem do patrimônio, figura um cenário representado em primeiro plano em relação à paisagem da cidade como segundo plano. 


\section{INTRODUÇÃO}

Na contemporaneidade, constata-se uma cidade emergente que requer revisões de ações da sua dimensão territorial. As tipologias urbanas, os padrões de comportamento social, as normas e normativas de planejamento, assim como as propostas de territorialização entre o espaço público e o privado não mais são suficientes para seus paradigmas, dentre outros, para territorialidades difusas e indeterminadas. Faz-se necessário buscarmos respostas, ao menos interpretações, alternativas para a (re) significação da noção de 'lugar urbano': espaços de domínio público caracterizados por distintas situações discursivas que podem tomar forma e serem redefinidos por atividades transitórias dos múltiplos públicos que acomodam (ALVES, 2007, p. 37).

Vivemos, atualmente, um fenômeno econômico, sociopolítico e cultural, quanto à preservação patrimonial na cidade contemporânea sob o efeito da globalização, o qual responde a parâmetros próprios e que "requer revisões de ações da sua dimensão territorial". Observamos, desde a década de 1970, a elaboração de resoluções,de documentos, de convenções e de recomendações que têm sido divulgados por organismos intergovernamentais e internacionais, como a United Nations Educational, Scientific and Cultural Organization (UNESCO), o International Council on Monuments and Sites (ICOMOS), a Organization of American States (OEA), e o Council of Europe ${ }^{1}$, os quais têm sido adotados, em muitos países, por meio de medidas legislativas e regulamentações específicas.

São novos paradigmas da conservação do patrimônio, relacionados à globalização, à mercantilização, às indústrias culturais, ao turismo, aos novos modos de habitar, à identidade do local e do lugar nas cidades. Diante desses novos paradigmas, cabe aos órgãos de preservação nacionais identificar, proteger e difundir seus bens culturais materiais e imateriais indispensáveis para a identidade de um povo em seu espaço.

Essas ações - que são legisladas, instrumentalizadas e possuem diferentes mecanismos de atuação nas nações - são importantes ante as mudanças políticas e sociais ao longo do tempo. Devem buscar uma forma de resistência a processos agressivos de

\footnotetext{
${ }^{1}$ Organização das Nações Unidas para a Educação, a Ciência e a Cultura (UNESCO), Conselho Internacional dos Monumentos e Sítios (ICOMOS), Organização dos Estados Americanos (OEA), e o Conselho da Europa.
} 
exploração do solo, do ambiente natural e da paisagem dos lugares. E são possíveis apenas por meio de uma atuação técnica fundamentada no conhecimento, na experiência e na vivência no campo da preservação. No que tange à conservação dos bens culturais, os órgãos de preservação devem atender ao interesse coletivo e não ao interesse individual.

A partir dessas considerações, a motivação principal desta pesquisa foi o desejo de compreender os aspectos de alguns patrimônios singulares e sua relação com um universo mais amplo, assim como a transformação de sua escala de interação para além da comunidade local. Ao relacionar a dimensão local à dimensão global, constatamos algumas contradições entre as resoluções internacionais e as legislações nacionais de proteção ao patrimônio, cujo resultado mais visível tem sido a redução das características particulares do lugar para melhor adequá-las à classificação mundial do patrimônio.

As recomendações internacionais "elaboradas sob o patrocínio da Unesco são típicos tratados multilaterais". Inserem-se "entre as fontes formais de Direito Internacional Público, conforme o artigo 38 do Estatuto da Corte Internacional de Justiça" (SILVA, 2012, p. 60). São instrumentos de cooperação em relação a uma política internacional, a qual decorre do próprio Tratado de Constituição daquela Organização e que permeia as suas atividades.

Paralelamente, verifica-se um processo de descentralização do poder do Estado nos países quanto a esse campo de atuação, e que resulta em tentativas de configurações de sistemas alternativos a burocracias centralizadas. Tal processo teve início no Brasil no final dos anos 1980, por meio de uma maior participação da sociedade na preservação e proteção do patrimônio cultural com a universalização dos direitos de cidadania.

Legitimado pela Constituição Federal de 1988, esse processo reestrutura as competências públicas e institucionais em relação ao Estado, e corresponde à sua descentralização e a uma gestão democrática das políticas públicas. Com novas modalidades de colaboração ligadas ao patrimônio, as ações de preservação na atualidade fazem emergir a necessidade de se analisarem as transformações decorrentes no espaço urbano e suas novas configurações territoriais.

O interesse pela análise das transformações decorrentes desse processo num panorama global parte da experiência vivida e do conhecimento adquirido pela autora durante um curso de Master realizado no contexto europeu, Etudes Urbaines en Régions 
Méditerranéennes ${ }^{2}$ (Estudos Urbanos em Regiões Mediterrâneas) pelas Universidad de Sevilla, Università degli Studi di Genova e Université Paul Cézanne Aix-Marseille III. Nesse período, tomamos conhecimento de uma bibliografia específica, travamos contato com professores, pesquisadores e atores da sociedade civil envolvidos em projetos de preservação e conservação de patrimônios, e realizamos viagens pedagógicas a algumas cidades e regiões de Portugal, Espanha, Itália e França.

A autora cursou um semestre em Aix-en-Provence (França) e realizou um estágio de pesquisa no Conseil d'Architecture, d'Urbanisme et de l'Environnement (CAUE13) des Bouches-du-Rhône em Marselha (França). Por meio desse estágio, pudemos compreender melhor algumas questões relacionadas à identificação, à nomeação e à classificação dos mais diversos tipos de bens culturais na França, suas normativas e seus instrumentos legais de conservação e preservação.

Conhecemos, na mesma época, uma agência especializada em estudos sobre o melhor aproveitamento do patrimônio na França, por meio de publicações específicas Agência Regional do Patrimônio-Provence-Alpes-Côte d'Azur, com sede na cidade de Aix-enProvence. Alguns desses documentos analisavam os impactos econômicos e sociais do patrimônio nas cidades e forneceram subsídios para os questionamentos que apresentamos nesta pesquisa.

Nesse panorama, a classificação de um patrimônio mundial, conforme a UNESCO, é vista nesta pesquisa como uma oportunidade de repensar a valorização e a preservação do patrimônio cultural, tanto no Brasil como internacionalmente. Partindo do conceito de patrimônio comum a todos os povos, partilhado e apreciado por todos, formulamos questionamentos em relação à legitimidade de seus processos classificatórios para a história

${ }^{2}$ No trabalho final de conclusão do curso, pelo programa Erasmus Mundus, realizado de setembro de 2008 a julho de 2009, e orientado pelo professor Victor Fernandez Salinas, foram discutidas a questão do patrimônio cultural e algumas de suas classificações e de seus desdobramentos na imagem e na percepção da cidade através de sua paisagem. Essas inquietações relacionadas ao patrimônio e às cidades foram sugeridas pelo professor Salinas em sua disciplina no curso e, posteriormente, em suas orientações do trabalho final. 
e para a memória do lugar, e buscamos verificar as relações de identidade que são mantidas ou rompidas por meio de seus processos de patrimonialização ${ }^{3}$.

Consideramos tanto a existência de um processo de internacionalização das cidades, relacionado à produção do espaço urbano e atrelado ao campo do patrimônio, quanto a transescalaridade ${ }^{4}$ dos fenômenos sociais, econômicos e culturais envolvidos nesse processo. Centramo-nos na observação da escala local do bem cultural ${ }^{5}$, e procuramos entender as organizações, as diretrizes de preservação e conservação ${ }^{6}$ patrimoniais, as estratégias, as disputas e as coalizões entre sujeitos individuais e coletivos que constituem os grupos hegemônicos no protagonismo político das cidades.

Alguns bens particulares podem ser classificados e valorizados como patrimônio, por conta da busca do lucro, no uso do solo urbano, pelas classes dominantes que conduzem processos de patrimonialização. Essas classes se apropriam dos critérios e das práticas de preservação para materializar o cultivo de um consumo sofisticado, sem a preocupação com a criação de políticas públicas de integração social e econômica das comunidades locais dessas áreas. Essas reflexões trazem consigo um caráter de contemporaneidade em relação à produção do espaço urbano nas cidades, ao indagar, por um lado, o real papel de atuação do Estado e das agências multilaterais internacionais, e, por outro, a existência de disputas intra e internacionais.

Nossa tese parte do argumento de que, em um contexto de produção do espaço urbano da cidade contemporânea, os processos de patrimonialização mundial regidos pela UNESCO são conformes aos processos hegemônicos de produção da cidade. Entre disputas e conflitos, verificam-se as transversalidades e os fenômenos da lógica de reprodução do capital e do consumo mercantil das cidades. Assim, desvelam-se aspectos da reprodução financeirizada do capital no espaço urbano. A hipótese que este trabalho apresenta é a de que os tecidos urbanos tradicionais da cidade são desconstituídos de seu significado quando

${ }^{3}$ Os processos de patrimonialização constituem um meio de reconhecimento, identificação e classificação de um bem, seja ele material ou imaterial, como patrimônio cultural.

${ }^{4} \mathrm{O}$ termo transescalaridade refere-se a uma perspectiva de análise e de fenômenos que perpassam a questão nacional. Esse termo busca responder a uma análise dos "movimentos contemporâneos de transnacionalização e desterritorialização da cultura" (CANCLINI, 1994, p. 100).

${ }^{5}$ Este trabalho se utiliza da expressão "bem cultural" "como denominador comum das várias denominações dadas a essa categoria de bens: bens de valor artístico, bens de valor arqueológico, bens de valor histórico, bens de valor paisagístico, entre outras" (SILVA, 2012, p. 32).

${ }^{6}$ De acordo com o artigo $3^{\circ}$ da Carta de Veneza, de 1964,"A conservação e a restauração dos monumentos visam a salvaguardar tanto a obra de arte quanto o testemunho histórico". 
se recriam novas articulações urbanas que intensifiquem e reduzam realidades complexas diante de seus processos de patrimonialização regidos pela assistência e cooperação internacional da UNESCO.

Para sustentar essa hipótese, ancoramo-nos no conceito de patrimônio ${ }^{7}$ como um bem correspondente tanto a uma ideia de influência e de pertencimento quanto a uma identificação do indivíduo em relação a um coletivo. Tal conceito vincula-se à ideia de propriedade e identificação, que transcende o físico - o momento presente e o existente - e que pode remeter à nostalgia - à memória daquilo que já não existe - e ao futuro.

Estudaram-se processos de classificação de bens culturais materiais a patrimônio mundial pela UNESCO, nos quais observamos especificidades e conceitos em relação ao patrimônio, aos instrumentos, aos mecanismos de atuação e ao desenho das relações entre o campo de preservação do patrimônio mundial e a produção da cidade. Percebemos que a atuação da UNESCO trata de implementar um "modelo de sucesso" inspirado nos patrimônios já classificados pela organização, como, por exemplo, a criação de uma estratégia de marketing urbano e de competição entre cidades. Esse modelo mobiliza consultores internacionais e aciona o "sucesso" de outras cidades (VAINER, 2000, p. 8) e suas candidaturas a patrimônio mundial.

Este trabalho culmina como detalhamento dos dois objetos de estudo, um deles localizado na área central de uma cidade brasileira e o outro localizado na área central de uma cidade portuguesa. Estudamos, então, as possíveis transversalidades de seus processos de patrimonialização mundial e os fenômenos urbanos atrelados a esses processos. Nossas observações sobre tais processos verificam contradições na implementação dos "modelos", devido ao fato de a patrimonialização mundial ser conduzida por grupos políticos em coalizão com setores privados, sem, todavia, uma participação democrática da sociedade e da comunidade local.

A análise desenvolvida neste trabalho busca verificar a articulação ou a desarticulação dos processos de classificação em andamento, regidos pelo organismo

\footnotetext{
${ }^{7}$ Segundo sua definição semântica, em que a palavra patrimônio liga-se à sua origem etimológica (do latim patrimonium), que está associada à ideia de "uma herança paterna, de bens de família, dote dos ordinandos, bem, ou conjunto de bens culturais ou naturais, de valor reconhecido para determinada localidade, região, país, ou para a humanidade" (FERREIRA, 1999, p. 1515).
} 
internacional da UNESCO no contexto local do bem patrimonial. Para tanto, investigaram-se as intervenções urbanas nas áreas protegidas ou de entorno aos bens culturais em questão, as quais, ao serem atreladas ao consumo mercantil das cidades, podem resultar numa dissolução das relações culturais e de identidade do próprio lugar.

No primeiro capítulo desta tese, o estudo fundamenta-se no tema da preservação do patrimônio cultural urbano, da sua legislação nacional, estadual e municipal, e das políticas públicas no Brasil, a partir dos autores Maria Cecília Londres Fonseca e Leonardo Barci Castriota. A análise dos fenômenos relacionados aos processos de patrimonialização pela UNESCO basearam-se em algumas das cartas patrimoniais internacionais e nas autoras Beatriz Kuhl e Fraçoise Choay. O conceito e a forma de operacionalização da classificação como Patrimônio Mundial, bem como suas diretrizes e normativas específicas internacionais que se sobrepõem à legislação nacional, foram fundamentados no autor Fernando Fernandes da Silva.

No segundo capítulo, abordamos o conceito moderno de patrimônio segundo as referências dos autores Néstor García Canclini, Françoise Choay, Ignacio González-Varas e Ulpiano Meneses, que discutem o universo cultural e os valores que resultam no sentido e no valor do bem. O autor Fernando Carrión Mena fundamentou nossa compreensão da matriz consolidada dos centros históricos, da ideia de conjunto urbano, e da articulação entre a cidade e o território. Tal visão de conjunto urbano nos leva a compreender que, na ausência de alguns de seus elementos históricos e culturais simbólicos e de identidade com o lugar, o seu significado original pode ser rompido, configurando na cidade espaços simplificados de signos e, portanto, reduzidos de significado.

Percebemos haver estratégias urbanas de competitividade entre cidades e uma concepção urbana de internacionalização da cidade por meio da valorização de seu patrimônio cultural e de um planejamento estratégico atrelado à ideia de empreendedorismo urbano das cidades. Tais estratégias evidenciam ideias e conceitos de empresas embasados em modelos de planos estratégicos internacionais e nacionais. Partimos dos autores Georges Benko, Leo Van Den Berg e H. Arjen Van Klink para compreender essas estratégias. E para embasar nosso pensamento crítico acerca do empresariamento da cidade e de sua relação centrada na cultura, buscamos o apoio dos autores David Harvey e Carlos Vainer, e em relação as intervenções em áreas patrimoniais, a 
criação de espaços de consumo e turismo, e a constituição de uma paisagem tematizada, fundamentamos nossa discussão com os autores Manuel Delgado e Francesc Muñoz.

O autor Pierre Warnier nos norteou na compreensão do fenômeno da mundialização da cultura e sobre este fenômeno ao longo do tempo, o qual Renato Ortiz afirma não se tratar de uma transformação a uma cultura global, mas de uma cultura mundializada. E Everaldo Batista da Costa associa essa mundialização à busca da renda de monopólio por meio do patrimônio mundial, como uma estratégia global de apoderamento territorial soberano, numa visão do espaço urbano das cidades patrimonializadas cujas "normas públicas nacionais e internacionais contribuem para a dominação ideológica via espaço geográfico" (COSTA, 2015, p. 17).

No terceiro capítulo, nosso trabalho analisa os estudos de caso do processo de patrimonialização mundial ${ }^{8}$.Em primeiro lugar, o bem cultural Ver-o-Peso, na cidade de Belém do Pará (Brasil), o qual está, desde 2014, em processo de análise de sua candidatura a patrimônio mundial pela UNESCO ${ }^{9}$. Como contraponto internacional, analisamos o bem cultural Universidade de Coimbra, na cidade de Coimbra (Portugal), o qual, durante o início desta pesquisa, em 2011, e, quando da visita de campo exploratória, em 2012, ainda aspirava ao título de patrimônio mundial, para o qual foi classificado em 2013.

Esta nossa análise busca compreender a produção de um espaço urbano em áreas patrimoniais, vinculada à preservação do patrimônio, mas que, a nosso ver, não é centrada na conservação das características culturais de um conjunto patrimonial. Essa produção do espaço urbano pode permitir uma redução de significado ${ }^{10}$ desse conjunto quando se atém à valorização e proteção de apenas alguns de seus elementos, de maneira desarticulada e

${ }^{8} \mathrm{O}$ uso do termo patrimonialização mundial refere-se aos processos regidos pela UNESCO.

${ }^{9}$ Ver-o-Peso (Belém-PA), Brasil, foi incluído na Lista Indicativa pela UNESCO em 2014. Segundo o Instituto do Patrimônio Histórico e Artístico Nacional do Brasil, "a Lista Indicativa funciona como um instrumento de planejamento de preparação de candidaturas, assemelhando-se a um inventário, e é composta pela indicação de bens culturais, naturais e mistos, apresentados pelos países que ratificaram a Convenção do Patrimônio Mundial da UNESCO. Essa iniciativa pode ensejar a participação de gestores de sítios, autoridades locais e regionais, comunidades locais, ONGs e outros interessados na preservação do patrimônio cultural e natural do país" (IPHAN, 2016).

${ }^{10} \mathrm{Como}$ se trata de uma das questões principais deste trabalho, retomá-la-emos e aprofundá-la-emos no capítulo terceiro, na análise do estudo do caso e do seu contraponto. 
contraditória em relação à cidade historicamente consolidada, caracterizada por manter relações dinâmicas com o seu território.

Percebemos que esses processos analisados, nos quais ocorre uma redução de significado, estão atrelados à ação de uma agência internacional especializada em proteger e preservar o patrimônio cultural no território. A escala de atuação dessa agência rompe com as barreiras do Estado-nação, e se sobrepõe à legislação de proteção dos bens culturais de cada país, estabelecendo diretrizes e normativas de um direito mundial da cultura. Trata-se, assim, de um processo dialético de proteção cultural do local, pois, diante do esvaziamento do ambiente e da paisagem cultural da cidade, a preservação do patrimônio poderia ser favorecida justamente por meio de instrumentos considerados legítimos, segundo normativas e regulamentações de cada Estado ${ }^{11}$ para a sua proteção e salvaguarda.

Para fundamentar a nossa análise no estudo de caso de Belém, partiu-se do documento científico de intenção de candidatura a patrimônio mundial entregue à UNESCO. Com base nesse documento, e para uma melhor compreensão das dinâmicas territoriais da cidade, elaboramos mapas por meio de geoprocessamento antes de fazermos uma visita exploratória a cidade. Essa metodologia foi distinta da aplicada no estudo de caso de Coimbra, em que, após a apreciação da documentação da UNESCO, realizamos a visita exploratória à cidade.

No caso de Coimbra, a leitura foi estruturada em documento científico mais completo e elaborado, composto de sete volumes: Candidatura a Patrimônio Mundial; Plano de Gestão; Textos Gerais; Influências; Execução; Planos Diretores; e Zona de Proteção. O documento continha mais de duas mil páginas e foi desenvolvido por uma equipe de coordenação geral ${ }^{12}$. Esse documento foi constituído pelo reitor da Universidade de Coimbra e por mais dois pró-reitores, que coordenaram áreas diferentes. O dossiê de Coimbra foi dividido em algumas partes: os conteúdos e a investigação; a área de reabilitação e a preservação física; e a preservação do patrimônio e a reabilitação. Já no caso de Belém, a

\footnotetext{
${ }^{11}$ Esses instrumentos são diferentes, embora possam apresentar semelhanças de um país a outro, e podem estar em constante mudança, assim como pode haver distinção no próprio conceito de patrimônio desses países.

${ }^{12}$ Fernando Seabra Santos (2003 - 2011) e João Gabriel Silva (2011 - atualmente), reitores da UC, Clara Almeida Santos (2011 - atualidade), vice-reitora da UC, Henrique Madeira (2011 atualidade), vice-reitor da UC, José António José António Raimundo Mendes da Silva (2003 - 2011), pró-reitor da UC, António Filipe Pimentel (2007 - 2009, pró-reitor da UC, João Gouveia Monteiro (2003 - 2007), pró-reitor da UC. 
documentação era preliminar, incipiente ainda, composta de poucos textos específicos, de nenhuma cartografia e de muitos documentos históricos referentes a tombamentos pelo órgão de preservação nacional, o Instituto do Patrimônio Histórico e Artístico Nacional (IPHAN). Outros documentos também foram consultados em relação às legislações vigentes: documentos históricos relacionados à fundação do núcleo urbano da cidade histórica, à sua expansão pelo território e às concepções de planos urbanísticos para estas cidades.

Estruturamos nossa discussão segundo Saint-Clair Cordeiro da Trindade Júnior, especificamente em relação à cidade de Belém e à região Amazônica, onde verificamos a ausência de uma valorização do patrimônio cultural das cidades ribeirinhas, de um planejamento total da cidade e de um patrimônio pensado como um sistema de rede.

Além de documentação primária, recorremos à história oral, por meio de dez entrevistas ${ }^{13}$ com intelectuais e com atores da sociedade civil. Cinco dessas entrevistas relacionam-se ao processo de candidatura da Universidade de Coimbra, realizadas com pessoas que vivem nos municípios de Coimbra e Évora, em Portugal; e outras cinco relacionam-se ao processo de candidatura de Ver-o-Peso, realizadas com pessoas que vivem no município de Belém. As entrevistas foram estruturadas por meio de um roteiro previamente elaborado, em entrevistas soltas, e algumas delas estão parcialmente transcritas nesta tese. Entre outras questões, permitiram-nos perceber as dinâmicas territoriais das cidades em que se localizam os objetos de estudo e a relação das nomeações dos bens culturais e suas áreas de entorno, segundo alguns critérios articulados à estruturação de novas dinâmicas territoriais.

As entrevistas em Portugal nos permitiram aprofundar nossos conhecimentos em relação ao título do Patrimônio Mundial, aos conceitos, aos critérios e às formas de operacionalização concernentes à Convenção do Patrimônio Mundial de 1972. Permitiramnos também compreender mais a fundo o ordenamento territorial de cidades candidatas ao título de Patrimônio Mundial: trata-se de uma questão patrimonial e de uma totalidade urbana que é inserida em um processo de patrimonialização global (COSTA, 2015, p. 35) em

\footnotetext{
${ }^{13} \mathrm{~A}$ autora agradece aos entrevistados que compartilharam seus conhecimentos e reflexões acerca do tema, consubstanciadas em seus trabalhos investigativos e práticos sobre a produção da cidade e sobre a preservação do patrimônio, e isenta os entrevistados de quaisquer responsabilidade e/ou imprecisão que, porventura, estejam contidas na presente tese.
} 
razão de um planejamento estratégico da cidade, que é inserida em um contexto de competitividade entre cidades.

As entrevistas em Belém permitiram-nos compreender melhor as questões específicas do contexto da região Amazônica, em que o tema da natureza e do patrimônio imaterial emerge como uma questão central neste trabalho. Esse tema baliza nossos entendimentos e estrutura nossas reflexões acerca do tema e do conceito de patrimônio cultural, além de reforçar a necessidade de uma abordagem mais ampla, estruturada e fundamentada no processo de candidatura de Belém, que seja idealizada por meio de um sistema de redes do patrimônio atrelado ao território, tal como um patrimônio territorial ${ }^{14}$.

Essas entrevistas também revelaram, em primeiro lugar, o estado atual do processo de candidatura; em segundo lugar, revelaram o andamento do desenvolvimento da documentação necessária a esse processo; em terceiro lugar, revelaram o envolvimento dos técnicos do patrimônio, assim como a influência da política na definição da continuidade do processo e da criação de sua documentação; e revelaram, por fim, a existência de novos interesses patrimoniais na área e na cidade, cujos conceitos, critérios e formas de operacionalização não são relacionados diretamente ou não dependem de uma supervisão direta do IPHAN. Tudo isso nos fez compreender que tais aspectos têm balizado outros novos processos de classificação. E nossa análise crítica das entrevistas em Belém permitiunos concluir ações do ordenamento territorial da cidade que permanecem desarticuladas da preservação patrimonial, com a ausência de um planejamento total e global do território.

Como já dissemos anteriormente, desenvolvemos, no caso de Belém do Pará, por meio de instrumentos de cartografia, mapas que pudessem nos informar as dinâmicas atuais relacionadas ao bem cultural e ao território, mapas que partiram de um levantamento historiográfico que já havia sido efetuado por Saint-Clair Cordeiro Trindade Júnior, José Júlio Lima e Luna Bilbas, do material iconográfico do Museu de Arte Sacra de Belém e de mapas do IPEA. Outros mapas também foram desenvolvidos e estabelecidos por critérios de análise ambiental, com o intuito de contextualizar o bem cultural e sua relação com a cidade. Saliente-se que essa cartografia não busca constituir uma análise detalhada e precisa, ela

${ }^{14} \mathrm{O}$ conceito de patrimônio territorial sugere novos enfoques e perspectivas sobre o conceito e a valorização patrimonial segundo um sistema de recursos culturais estendidos em redes e que incorporam a paisagem como recurso patrimonial de primeira ordem. A reflexão sobre esse conceito foi desenvolvida na pesquisa da autora, "Percurso Patrimonial", sob a orientação do Prof. Víctor Fernandes Salinas. Ver: ALMEIDA, 2009, p. 47. 
busca antes verificar possibilidades de interações e aspectos socioeconômicos do conjunto patrimonial e de sua importância em relação à cidade e à metrópole, e que caracterizam a sua conexão com outras partes da cidade, a sua dimensão simbólica, as atividades e o contexto do bem cultural. Essa análise ambiental foi fundamentada em sínteses dos aspectos contextuais na formação da estrutura urbana da cidade e em dados do IBGE. Para o processo de elaboração dos mapas, foram utilizados o geoprocessamento e uma metodologia própria de sistematização dos dados. Ainda como metodologia de análise do espaço urbano, desenvolvemos, em uma reflexão conjunta com a Prof. ${ }^{a}$ Jéssika Paiva França, um mapa temático que representa uma forma de levantamento e uma tentativa de conhecimento da complexidade do sítio patrimonial protegido, e que foi complementada pela produção de um levantamento iconográfico e técnico sobre a área objeto de análise.

Outro importante produto de nosso trabalho foi a elaboração de três esquemas de análise do estudo de caso brasileiro: o primeiro corresponde a uma leitura cronológica, com a identificação de intervenções na área, associando com a legislação vigente, com seus agentes e suas diferentes instâncias de atuação; o segundo configura uma análise de suas formas de concepção, de agenciamento e de implementação; e o terceiro é uma análise do processo de classificação a patrimônio mundial, nacionalmente e internacionalmente.

Consideramos importante anexar ao final do trabalho, para eventual consulta, as listas do Patrimônio Mundial no Brasil e em Portugal, bem como alguns documentos de consulta (o tombamento do Ver-o-Peso, o levantamento preliminar do inventário de referências culturais do conjunto Ver-o-Peso, e a descrição dos bens culturais da Universidade de Coimbra e de Ver-o-Peso no site da UNESCO, em seu idioma original). As entrevistas realizadas e muitas delas transcritas parcialmente foram organizadas ao final do trabalho, como apêndice.

Nas conclusões do trabalho, as questões inicialmente apresentadas são retomadas. Ali, buscamos, em primeiro lugar, identificar algumas regularidades no padrão de interação entre o campo de preservação patrimonial da UNESCO e a produção da cidade; em segundo lugar, reconhecer, nas intervenções patrimoniais da área protegida e apresentada como candidata, questões relacionadas à identidade do conjunto patrimonial urbano e as especificidades territoriais deste ambiente urbano; e, por fim, em terceiro lugar, identificar transversalidades desse processo na área de entorno à área protegida, e algumas 
especificidades dessa interação quando suas regulamentações específicas são adotadas, em uma escala local e de comunidade. 


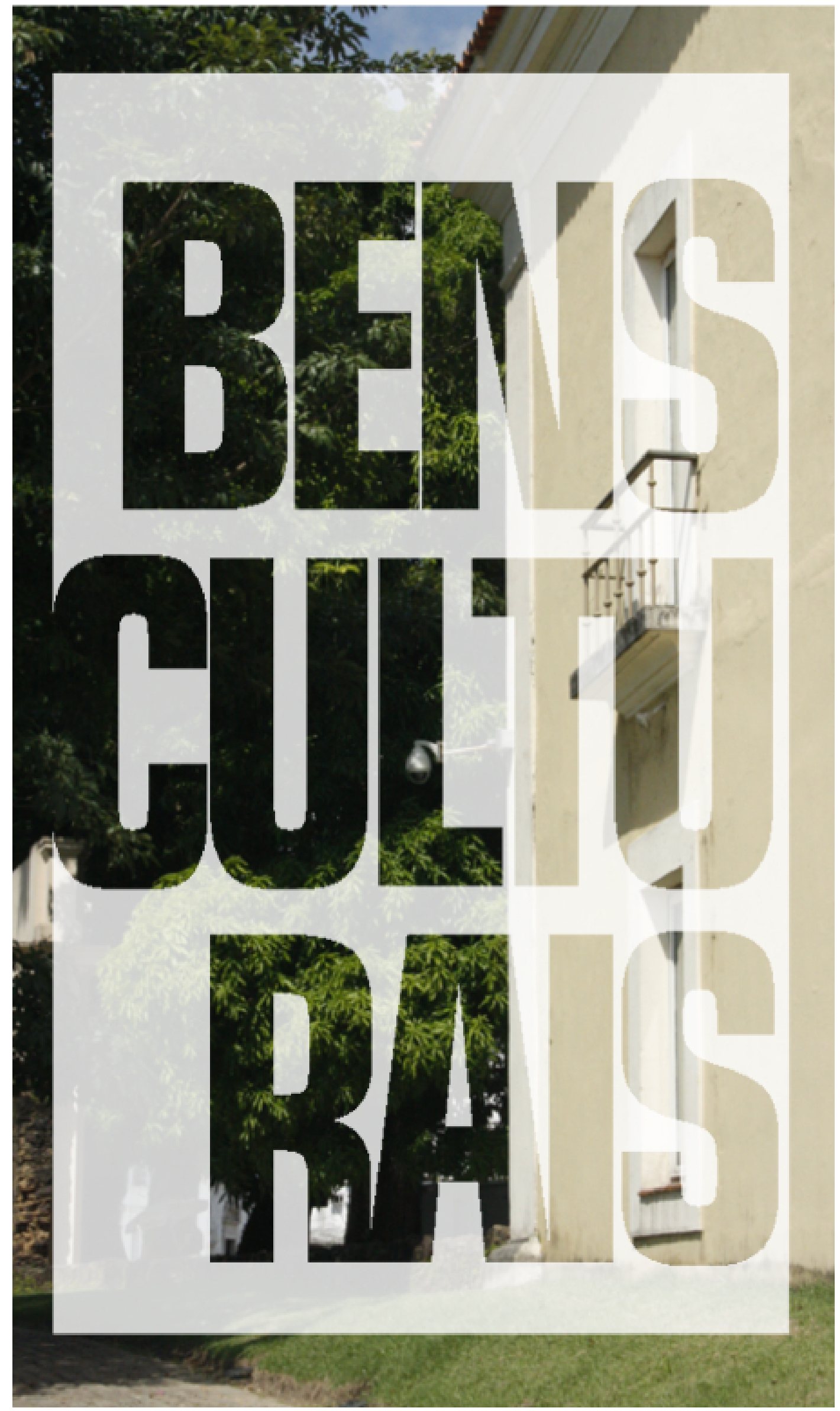




\section{IMAGEM DE CAPA DO CAPÍTULO}

Montagem feita a partir de foto capturada pela autora em julho de 2016, durante as atividades de pesquisa em campo na cidade de Belém, no período que compreende o desenvolvimento desta tese. Belém também é conhecida como "Cidade das Mangueiras", e a imagem remete a bens culturais significativos da identidade da cidade, o patrimônio da Casa das Onze Janelas (à direita na imagem), o Forte do Presépio (à esquerda na imagem) e a mangueira, este último introduzido na cidade pelos jesuítas durante o período da colonização. A mangueira pode figurar como um dos primeiros elementos simbólicos e históricos representativos de uma globalização cultural, por ter sido trazido do sul e do sudeste asiáticos e introduzido na cultura local e brasileira. 


\section{PROTEÇÃO DOS BENS CULTURAIS}

Nossa discussão é estruturada, sobretudo, em relação ao Brasil, país reconhecido já por Mário de Andrade ${ }^{15}$ pela sua pluralidade cultural, fruto da miscigenação de muitos povos. Essa diversidade traz consigo um grande desafio às formulações de políticas de preservação ${ }^{16}$ da cultura nacional: confrontar-se e contrapor-se às ideias de uma homogeneização cultural ${ }^{17}$, de modo a proteger e a preservar particularidades de processos e de contextos culturais do país.

Essas políticas se fazem necessárias, a fim de enfrentar os novos paradigmas da conservação do patrimônio, principalmente numa época de globalização, diante da maior exposição dos bens culturais e das diferentes condições em que eles existem. Assim, os órgãos de preservação nacionais são incumbidos de identificar, proteger e difundir seus bens culturais materiais e imateriais. Vale salientar a importância da atuação do IPHAN no Brasil, desde a sua fundação, e sua função de proteger, registrar e difundir diversos bens culturais que caracterizam aquela pluralidade cultural brasileira apontada por Mário de Andrade.

Num contexto internacional, a singularidade do patrimônio material brasileiro pode vir a ser menos reconhecida e valorizada que os bens culturais de outras nações mais antigas, anteriores à chegada dos europeus no Brasil. Outra reflexão proposta por este trabalho diz respeito à existência de um patrimônio cultural imaterial ainda carente de reconhecimento nacional e internacional, e que está diretamente relacionado ao seu patrimônio material no espaço urbano por meio da conformação e da formalização de um

\footnotetext{
${ }^{15}$ Mario R. M. de Andrade foi um dos idealizadores de uma instituição nacional de proteção do patrimônio no Brasil e participou das discussões preliminares sobre a estruturação e os objetivos do antigo Serviço do Patrimônio Histórico e Artístico Nacional (SPHAN), criado em 1937. Segundo Maria Cecília Londres Fonseca (1997, p. 111), "Mário de Andrade já assinalara, na proposta entregue ao ministro Gustavo Capanema em 1936, que o patrimônio cultural da nação compreendia muitos outros bens além de monumentos e obras de arte".

${ }^{16}$ As políticas de preservação se propõem a atuar, basicamente, no nível simbólico, com o objetivo de reforçar a identidade coletiva, a educação e a formação de cidadãos (FONSECA, 1997, p. 11).

${ }^{17} \mathrm{~A}$ globalização dos fluxos culturais e mercantis acaba uniformizando, com alguma intensidade, contextos culturais amplos, mediante propostas de projetos democráticos que ora sustentam, ora desconsideram culturas singulares para o conjunto da nação, mas que se contrapõem em alguma medida às próprias legislações vigentes em cada país, e as suas considerações específicas sobre tradições, culturas locais, de minorias ou de uma região, e a patrimônios singulares (SILVA, 2003).
} 
espaço na cidade que garanta que a expressão simbólica de seus conteúdos seja protegida e preservada.

\section{Órgãos nacionais de proteção e políticas preservação do patrimônio cultural urbano.}

Desde seu "achamento" ${ }^{18}$, em 1500, até a sua independência como nação, em 1822, o Brasil esteve subordinado, como colônia, à coroa portuguesa e a seu sistema político monárquico. Era uma situação de dominação pela metrópole e de repressão à colônia, fundamentadas num modelo de exploração colonial mercantil.

Nesse período, o estabelecimento de valores e de identidade buscava legitimar a relação hierárquica da subordinação da colônia à metrópole. Portanto, sem uma noção de nacionalidade, o Brasil não possuía, no período, um patrimônio cultural propriamente dito brasileiro.

Posteriormente, com a independência, em 1822, e com o estabelecimento de uma normativa jurídica brasileira, através da Constituição, inicia-se um período em que o país construirá sua própria imagem e identidade, buscando legitimar-se enquanto nação. As constituições brasileiras "de 1824 e 1891 eram omissas quanto à proteção dos bens culturais imóveis" (SILVA, 2003, p. 120). O reconhecimento e as solicitações de se proteger o patrimônio histórico e artístico brasileiro remontam à década de 1920, a partir de algumas iniciativas locais e estaduais descentralizadas ${ }^{19}$, em "projetos com objetivo de criar mecanismos para a proteção legal do patrimônio" (FONSECA, 1997, p. 103).

Em 1931, a Carta de Atenas, documento organizado pelo Escritório Internacional dos Museus Sociedade das Nações, expressa um interesse em doutrinar as ações e os princípios gerais da proteção do patrimônio, em âmbito internacional e nacionais dos países. A carta reconhece a existência de uma diversidade de patrimônios e a necessidade de uma abordagem particular em cada caso, regulamentadas por uma legislação nacional, respeitando técnicas de conservação e de restauração. Dentre as ações aconselhadas para a conservação do patrimônio e a colaboração internacional, salientam-se: ações, de instância nacional, em relação à educação de crianças e jovens, para a proteção do patrimônio; a

\footnotetext{
${ }^{18}$ Termo com que o escrivão Pero Vaz de Caminha refere-se à chegada da frota de Pedro Álvares Cabral ao Brasil, na sua Carta ao Rei D. Manuel I, em 1500 (CAMINHA, 1500).

19“"Proteção e revitalização do patrimônio cultural no Brasil: uma trajetória." SPHAN, Pró-Memória, Brasília: 1980, p. 10-11.
} 
criação de uma documentação internacional, por meio da publicação de um inventário do patrimônio nacional; a constituição de arquivos históricos nacionais; e a publicação de artigos sobre a conservação do patrimônio.

Mas é apenas com a Constituição Brasileira de 1934, e a partir das disposições preliminares do seu artigo 10, que se define essa proteção como competência da União e dos Estados. Nesse mesmo ano, cria-se a Inspetoria dos Monumentos Nacionais, "norteada por uma perspectiva tradicionalista e patriótica" (FONSECA, 1997, p. 103), desativada, porém, em 1937.

Os monumentos históricos, artísticos e naturais, assim como as paisagens ou os locais particularmente dotados pela natureza, gozam da proteção e dos cuidados especiais da Nação, dos estados e dos municípios. Os atentados contra eles cometidos serão equiparados aos cometidos pelo patrimônio nacional (Constituição de 1937, artigo 134).

Com a participação de Mário de Andrade, em 1936, iniciam-se a idealização e as discussões preliminares sobre a estruturação e os objetivos de uma Instituição nacional de proteção do patrimônio. Em 1937, foi criado o antigo Serviço do Patrimônio Histórico e Artístico Nacional (SPHAN) ${ }^{20}$, atual IPHAN, através de um decreto presidencial, sob a direção de Rodrigo M. F. de Andrade ${ }^{21}$. Tal Instituição começou a funcionar experimentalmente.

Durante o Estado Novo no Brasil (1937 a 1945), e com a Constituição de 1937, confere-se também aos municípios a responsabilidade de proteção dos bens culturais.

Somente com o Decreto-lei 25 , de 30 de novembro de 1937, que se regulamenta a proteção dos bens culturais no Brasil. Esse texto, além de explicitar os valores que justificam a proteção, pelo Estado, de "bens móveis

\footnotetext{
${ }^{20}$ No processo de institucionalização de uma política preservacionista no Brasil, em 1937, com a lei n ${ }^{\circ}$ 378, o SPHAN (1937-1946) passa a ser vinculado e integrado ao antigo Ministério da Educação e Saúde Pública (MES), e é criado o seu conselho consultivo, com uma estrutura de divisão técnica ("Divisão de Estudos e Tombamento (DET), a que estavam vinculadas a Seção de Arte, a Seção de História e também o Arquivo Central e a Divisão de Conservação e Restauração (DCR)" (FONSECA, 1997, p. 103) e uma atuação regional representada em distritos. Nesse período também eram de responsabilidade do SPHAN iniciativas de uma cultura museológica, com a criação de museus regionais a partir de 1938.

${ }^{21}$ Rodrigo Melo Franco de Andrade atuou na direção da Instituição de 1937 a 1969.
} 
e imóveis", tem como objetivo resolver a questão da propriedade desses bens. Desde então, todas as constituições brasileiras têm ratificado a noção de patrimônio em termos de direitos e deveres, a serem observados tanto pelo Estado como pelos cidadãos (FONSECA, 1997, p. 32).

O SPHAN, ancorado no art. 180 da Constituição de 1937, define, como seu patrimônio histórico e artístico nacional, "o conjunto dos bens móveis e imóveis existentes no país e cuja conservação seja de interêsse [sic] público, quer por sua vinculação a fatos memoráveis da história do Brasil, quer por seu excepcional valor arqueológico ou etnográfico, bibliográfico ou artístico ${ }^{22 " \prime}$ (Decretro-lei $\mathrm{n} \div 25$, de 30 de novembro de 1937). E também eram classificados como patrimônio e sujeitos a tombamento os "monumentos naturais, bem como os sítios e paisagens que importe conservar e proteger pela feição notável com que tenham sido dotados pela natureza ou agenciados pela indústria humana" (Decretro-lei no25, de 30 de novembro de 1937).

Inicialmente, a Instituição era subordinada ao Ministério da Educação. Posteriormente, veio a ser Departamento, Instituto, Secretaria e novamente Instituto, o Instituto do Patrimônio Histórico e Artístico Nacional (IPHAN). Em seu projeto inicial, elaborado por Mário de Andrade, algumas modificações foram feitas para atender a uma política ancorada na ideia de tradição e de civilização, a qual apresentava um viés historicista, de especial ênfase na relação com o passado. Assim, os bens culturais classificados apropriavam-se do passado como instrumento de educação, a partir de heróis nacionais, de personagens históricas e da ideia do homem nacional.

Com o artigo 175 da Constituição de 1946, utiliza-se a expressão “Poder Público" pela primeira vez ao definir que "as obras, monumentos e documentos de valor histórico e artístico, bem como os monumentos naturais, as paisagens e os locais dotados de particular beleza ficam sob a proteção do Poder Público", em vez de inferir-se a responsabilidade da proteção à União, aos Estados e aos municípios.

Ainda com Rodrigo Melo Franco de Andrade à frente do IPHAN, foram instituídos o tombamento e os livros do tombo, como instrumentos legais de proteção, por meio do decreto-lei $n^{\circ} 25$, de 30 de novembro de 1937. Pode-se afirmar que os tombamentos eram, principalmente, relacionados ao passado colonial da arquitetura e da arte barrocas,

\footnotetext{
${ }^{22}$ Ver: Decretro-lei nํ25, de 30 de novembro de 1937.
} 
concentradas em sua maioria no estado de Minas Gerais, nos monumentos religiosos católicos. Assim, o colonial brasileiro remetia à formação do país, segundo uma tendência modernista que buscava a afirmação da nacionalidade e do homem brasileiro.

Em 1964, estabeleceu-se a UNESCO no Brasil. E, posteriormente, as reuniões no âmbito internacional da UNESCO e as discussões entre especialistas, ocorridas entre 1968 e 1969, forneceram subsídios teóricos para a formulação de um regime internacional e a elaboração dos anteprojetos de convenção e de recomendação concluídos em junho de 1971 (SILVA, 2012, p. 73), como, por exemplo, a proposta de elaboração de uma Lista do Patrimônio Mundial, apresentada em 1968 por Robert Brichet.

Em 1972, é firmado o compromisso internacional da Convenção para a Proteção do Patrimônio Mundial, Cultural e Natural, também conhecido como Recomendação de Paris, criada pela UNESCO. Nesse mesmo ano, o escritório da UNESCO no Brasil iniciou suas atividades em Brasília (ONUBR, 2016).

No Brasil, foi criado, pela Secretaria de Planejamento da Presidência da República (SEPLAN) durante o propalado milagre econômico (de 1968 a 1973) do regime militar brasileiro, o Programa de Reconstrução das Cidades Históricas (PCH; 1973-1979), uma política integrada de preservação do patrimônio cultural. Esse Programa foi composto a partir de ações dos governos federal, estadual e municipal, e tinha como metas a preservação e o desenvolvimento econômico de alguns dos conjuntos urbanos brasileiros patrimonializados e o estímulo à visitação turística.

A partir da década de setenta, sobretudo quando o regime militar entrou em crise, essa política começou a ser criticada, e seu caráter nacional contestado, por se referir apenas às produções das elites. Nesse momento, coube a intelectuais com um novo perfil (especialistas em ciências físicomatemáticas e sociais, administradores, pessoas ligadas ao mundo industrial) definir novos valores e novos interesses. Durante as duas décadas que se seguiram, essa mudança evoluiu de uma modernização da noção de patrimônio - o que significou vincular a temática da preservação à questão do desenvolvimento - à politização da prática de preservação, na medida em que os agentes institucionais se propuseram a atuar como mediadores dos grupos sociais marginalizados junto ao Estado. Esses intelectuais viram na área da cultura, "marginal" no conjunto das políticas estatais, um espaço possível de resistência ao regime autoritário. Seu objetivo último era justamente o de ampliar o alcance da política federal de patrimônio, no sentido de democratizá-la e colocá-la a serviço da construção da cidadania (FONSECA, 1997, p. 13-14). 
A partir da década de 1970, e a partir principalmente da atuação de Aloísio Magalhães, nomeado diretor do IPHAN em 1979, algumas leis e exigências de ações são criadas a fim de democratizar a proteção do patrimônio brasileiro. Inicia-se, então, um processo de participação popular na preservação do patrimônio.

Desse período, destaca-se, dentre outras iniciativas, a implantação do Centro Nacional de Referência Cultural (CNRC) por Aloísio Magalhães, em meados da década de 1970, quando "os critérios adotados pelo IPHAN começaram a ser objeto de reavaliações sistemáticas, que levaram à proposta de uma nova perspectiva para a preservação de bens culturais" (FONSECA, 2000, p. 83).

Esse período também é marcado pela atuação de alguns intelectuais, por meio do IPHAN, na idealização de iniciativas de valorização e de preservação cultural vinculadas à arte do saber fazer e do produzir regionais, que criaram ou aperfeiçoaram novas metodologias de registros do patrimônio local, antes considerado "marginal". Assim, fazia-se frente a uma acelerada industrialização que se espalhava pelo país, "como o mundo ocidental vivendo o que Aloísio Magalhães definia como 'achatamento'[sic], 'uma espécie de fastio, monotonia, achatamento de valores causado pelo próprio processo de industrialização muito acelerado e sofisticado. Enfim, o mundo começou a ficar chato'[sic]" (MAGALHÃES, 1997, p. $115^{23}$ apud CASTRIOTA, 2009, p. 214).

Outro problema das políticas de preservação em geral é o fato de que as eventuais demandas da sociedade em relação à cultura são extremamente difusas. Se entre os produtores culturais - cineastas, atores, músicos, escritores etc. - essas demandas são mais definidas e, frequentemente, veiculadas através de organizações corporativas (associações, sindicatos etc.), falar de uma demanda social em termos da constituição de um patrimônio cultural da nação é bastante problemático, sobretudo em uma sociedade como a brasileira, onde, ao lado da pluralidade dos contextos culturais, existem profundas desigualdades econômico-sociais e a autonomia de uma esfera cultural sequer faz sentido para alguns grupos da sociedade nacional. Nesses casos, fica mais complexo o papel político dos intelectuais que atuam, dentro do Estado, como organizadores de uma demanda cultural ainda não explicitada, no sentido de defender os interesses de grupos carentes de organização própria. Foi com base nessa realidade que se

${ }^{23}$ MAGALHÃES, Aloísio. E triunfo?: a questão dos bens culturais no Brasil. Rio de Janeiro, Nova Fronteira: Fundação Roberto Marinho, 1997. 
formularam, nos anos 70-80, vários projetos do CNRC, posteriormente integrado à Fundação Nacional Pró-Memória (FONSECA, 1997, p. 14-15).

O CNRC propunha experiências inovadoras quanto à preservação de bens culturais e de produtos brasileiros, associando à cultura diferentes campos do conhecimento, tais como o "design, a indústria e a informática" (FONSECA, 2000, p. 83); afinal, o produto brasileiro não tinha, até então, uma imagem internacional mais forte. Essa era a pesquisa a que o CNRC se propunha.

\begin{abstract}
O Brasil possui, em nível constitucional, legislação específica de proteção a bens culturais desde 1937. Com o passar do tempo, à existência dos órgãos federais de patrimônio histórico foram-se somando instituições estaduais de preservação - sobretudo na década de 70, e o aparecimento dos conselhos municipais ao longo dos anos 80 - como é o caso do CONPRESP na cidade de São Paulo. Assim, legal e institucionalmente há o reconhecimento da necessidade de proteção dos bens culturais em diversas modalidades. Mas a aplicação desta legislação e a ação dos órgãos públicos de preservação implicam resultados diversos e suscitam reações diferentes quando aplicadas a bens móveis e imóveis (CHAUÍ, 1992, p. 38).
\end{abstract}

Esse período é reconhecido, pela historiografia, como a fase moderna de atuação do IPHAN, diante de sua fase anterior, reconhecida como heroica, caracterizada pela atuação de Rodrigo Melo Franco de Andrade e sua atuação em relação a edifícios históricos cujas integridades físicas estavam muito comprometidas. Na nova fase moderna, despertava-se em cidadãos comuns o interesse pela educação patrimonial, por meio de ações isoladas e pontuais, em que a comunidade era vista como o principal agente a proteger ou oficializar seus ofícios de cultura.

O Brasil aderiu à lista da Convenção para a Proteção do Patrimônio Mundial, Cultural e Natural da UNESCO em 1977. Vale ressaltar que, inicialmente, essa lista concentrava-se nos bens de interesse histórico; ao longo do tempo, a abrangência desses bens foi-se ampliando, com a adoção do conceito de "patrimônio cultural", em relação à herança das referências culturais como patrimônio. Assim, paralelamente, a lista brasileira de bens inscritos e indicados a classificação foi-se diversificando. Tal revisão conceitual pela UNESCO fortaleceu, no Brasil, a possibilidade de reconfigurar a participação da sociedade civil no processo de valorização de um bem cultural. 
Em 1980, Ouro Preto (MG) é a primeira cidade brasileira a integrar a lista de patrimônio mundial pela UNESCO. Com o reconhecimento desse conjunto patrimonial, interrompeu-se a evolução das discussões a respeito do patrimônio imaterial, pois as políticas de preservação desse bem tornaram-se balizadoras para as noções referentes ao patrimônio no país. Em seguida, também são reconhecidos, no Brasil ${ }^{24}$, outros patrimônios materiais urbanos mundiais pela UNESCO, tais como o Centro histórico de Olinda (PE), em 1982, as Ruínas de São Miguel das Missões (RS), em 1983, o Centro histórico de Salvador (BA), em 1985, o Santuário de Bom Jesus de Matozinhos, em Congonhas (MG), em 1985, o Conjunto urbanístico de Brasília (DF), em 1987, o Centro histórico de São Luís (MA), em 1997, o Centro histórico de Diamantina (MG), em 1999, o Centro histórico da Cidade de Goiás (GO), em 2001, a Praça de São Francisco, em São Cristóvão (SE), em 2010, as Paisagens cariocas entre a montanha e o mar, no Rio de Janeiro (RJ), em 2012, e o Conjunto moderno da Pampulha, em Belo Horizonte (MG), em 2016.

Nos anos de 1980, o debate sobre a preservação do entorno do bem cultural protegido é retomada pelo IPHAN $^{25}$, em sua publicação especializada no tema do patrimônio. Esse debate remete ao dispositivo da legislação francesa relacionado à existência de uma área de abrangência e de entorno, dispositivo que obriga a solicitação de autorizações prévias, pelos órgãos responsáveis, para construções novas, para transformações ou modificações na natureza, que possam interferir no campo de visibilidade de um imóvel inscrito ou classificado como patrimônio, circunscrito em uma área de proteção determinada.

A partir da Constituição Federal de 1988, retoma-se a discussão sobre o que constitui o patrimônio cultural, sobre sua relação com a sociedade, sobre sua preservação e sobre o que o grupo ou Instituição afirmam ser patrimônio. Especificam-se os bens culturais que o patrimônio abriga: "Os bens de natureza material e imaterial, tomados individualmente ou em conjunto, portadores de referência à identidade, à ação, à memória dos diferentes grupos formadores da sociedade brasileira" (Constituição da República Federativa do Brasil de 1988, artigo 216), com o objetivo de "proteger as belezas naturais e os monumentos de

\footnotetext{
${ }^{24}$ Ver: Anexo 1, Lista do Patrimônio Mundial no Brasil.

${ }^{25} \mathrm{Em}$ relação a essa discussão sobre a insuficiência da legislação brasileira e a proteção dos monumentos e seus entornos, e os comentários sobre a legislação francesa neste mesmo período, ver: REIS, 1980. 
valor histórico ou artístico, podendo impedir a evasão de obras de arte" (Constituição da República Federativa do Brasil de 1988, artigo 216).

Esse período foi marcado, politicamente, no Brasil, pela redefinição do papel do Estado, em relação à universalização dos direitos de cidadania, à descentralização e à gestão democrática das políticas públicas nas diferentes esferas (municipal, estadual e federal), legitimadas pela Constituição Federal de 1988. Essa nova gestão descentralizada e com a participação social na formulação de políticas urbanas foi uma resposta, em parte, ao crescimento dos movimentos sociais que reivindicavam uma reforma urbana das cidades (CASTRIOTA, 2009, p. 173).

A partir desse momento, pode-se afirmar que é competência comum da União, dos estados, do distrito federal e dos municípios o zelo pelas instituições democráticas relacionadas à conservação e à proteção do patrimônio cultural. Como competência dos municípios, há a promoção à proteção do patrimônio histórico-cultural local, observadas as legislações federal, estadual e municipal e a ação fiscalizadora federal e estadual.

No panorama internacional, a UNESCO diversifica a classificação de bens culturais, adotando, em 1992, a nova categoria de reconhecimento de bens culturais como "Paisagem Cultural". Esse conceito relaciona-se às crenças, costumes artísticos e tradicionais das comunidades e às interações dos seres humanos com o território e com o meio ambiente, e busca proteger e preservar as diversas representações de técnicas específicas do uso da terra pelo homem que garantam e sustentem a diversidade biológica.

Atualmente, são reconhecidos no Brasil dois bens culturais como patrimônio mundial, segundo o conceito de Paisagem Cultural: Paisagens cariocas entre a montanha e o mar, no Rio de Janeiro (RJ), reconhecido em 2012, e o Conjunto moderno da Pampulha, em Belo Horizonte (MG), reconhecido em 2016. Esses processos de patrimonialização correspondem aos dois últimos processos reconhecidos e classificados como patrimônio mundial, em relação a todas as suas categorias de patrimônio material pela UNESCO no Brasil.

A classificação desses processos pode demonstrar um reconhecimento da UNESCO dos patrimônios culturais brasileiros como bens mais abrangentes do que suas classificações anteriores, uma vez que relaciona também, em seus processos indicativos, aspectos da paisagem natural e/ou patrimônio imaterial ligado às manifestações culturais desses lugares. 
Em 2000, foi criado o Programa Monumenta ${ }^{26}$, um plano conjunto de preservação urbana $^{27}$ entre o Governo Federal Brasileiro e o Banco Interamericano de Desenvolvimento (BID). Aqui, o tombamento passou a ser visto como um reconhecimento do patrimônio, e instituiu-se o tombamento em nível federal. Nesse mesmo período, o Ministério da Cultura instituiu um Comitê de Especialistas para a elaboração da "Lista de Prioridades do Monumenta", relacionando os 101 sítios e conjuntos urbanos sob proteção federal no Brasil.

Em 2000, também se retomou a discussão sobre o patrimônio imaterial, com o Programa Nacional do Patrimônio Imaterial (PNPI), instituído pelo Decreto n‥ 3.551, de 4.08.2000 28 , o qual "viabiliza projetos de identificação, reconhecimento, salvaguarda e promoção da dimensão imaterial do patrimônio cultural".

Em 2001, foi criado o Estatuto da Cidade ${ }^{29}$, que enfatizou dois instrumentos de política urbana para a valorização e para a proteção do patrimônio histórico. São eles a outorga onerosa e a transferência do direito de construir ${ }^{30}$. Além disso, estabeleceu diretrizes gerais da política urbana nacional, determinando que tais mecanismos fossem aplicados por meio de um processo compartilhado entre Poder Público e cidadãos. Esse processo compartilhado e a ênfase nesses instrumentos de preservação auxiliaram na concretização de uma espécie de conceito de função social da propriedade e, em relação à nossa investigação específica, do patrimônio histórico e cultural, pois relaciona a proteção e a preservação dos bens culturais com outras questões urbanas, como a adequação da infraestrutura, as políticas habitacionais e a inclusão social.

Nesse panorama, nosso trabalho reconhece, como abordagem sobre a memória e a identidade de uma comunidade, a consideração de seus habitantes e as manifestações culturais realizadas naquele espaço urbano. Além disso, salienta, em relação à moradia, não somente a necessidade de melhorar a qualidade da habitação ou de incentivar a habitação

\footnotetext{
${ }^{26}$ Ver: MONUMENTA, 2013.

${ }^{27}$ Ver: DUARTE, 2010.

${ }^{28}$ Ver: Programa Nacional do Patrimônio Imaterial, 2013.

${ }^{29}$ O Estatuto da Cidade foi criado no ano de 2001 por meio da Lei $n^{\circ} .10257 / 2001$.

${ }^{30} \mathrm{~A}$ Outorga Onerosa é um dos instrumentos regulamentados pelo Estatuto da Cidade, e refere-se, quanto ao patrimônio histórico imóvel, à possibilidade de concessão, em caso de tombamento ou da circunscrição do imóvel em zona de interesse cultural especial definida por zoneamento e/ou pelo Plano Diretor municipal, emitida pelo município para que o proprietário de um imóvel edifique acima do limite estabelecido pelo coeficiente de aproveitamento básico em uma outra região da cidade, mediante contrapartida financeira a ser prestada pelo beneficiário dessa concessão, de modo a transferir seu direito de construir a outro imóvel.
} 
nos centros históricos, mas também o papel dos imóveis históricos protegidos e tombados como concretização do direito a moradia da população de baixa renda ${ }^{31}$. Esse é o caso de Salvador, na Bahia (BRAGA, 2013, p. 19): após críticas ao programa de tombamento, que em certa medida expulsava a população moradora originalmente na área, passou-se a incorporar a questão habitacional ao Plano de Reabilitação Integrado e Participativo do centro histórico da capital baiana.

Também em resposta às demandas dos movimentos sociais, em 2003 é criado o Ministério das Cidades, com a proposta de tratar da política de desenvolvimento urbano e das políticas setoriais de habitação, de saneamento ambiental, de transporte urbano e de trânsito. Esse processo dar-se-ia de forma articulada e solidária entre os estados e municípios, os movimentos sociais, as organizações não governamentais, os setores privados e demais segmentos da sociedade.

O ano de 2003 também foi marcado pela adoção da Convenção para Salvaguarda do Patrimônio Cultural Imaterial, pela UNESCO, buscando complementar a Convenção do Patrimônio Mundial, de 1972, relativa aos bens tangíveis. Esse conceito de patrimônio imaterial ou intangível "compreende as expressões de vida e tradições que comunidades, grupos e indivíduos em todas as partes do mundo recebem de seus ancestrais e passam seus conhecimentos a seus descendentes" (Convenção de 1972).

Em 2009, é instituída a Chancela Nacional da Paisagem Cultural ${ }^{32}$ como forma de preservação no Brasil, mesmo ano da criação da Coordenação de Paisagem Cultural do IPHAN. A partir dessa portaria, a "porção peculiar do território nacional, representativa do processo de interação do homem com o meio natural, à qual a vida e a ciência humana imprimiram marcas ou atribuíram valores" (Portaria n 127, de 30 de abril de 2009), pode vir a ser reconhecida como um bem cultural brasileiro.

\footnotetext{
${ }^{31}$ Algumas possibilidades de promoção da moradia para a população de baixa renda nessas áreas e imóveis tombados são: a utilização de benefícios ficais e tributários sobre imóveis urbanos, por meio de políticas de subsídios para tarifas de energia elétrica e saneamento, em função do interesse social do imóvel; e os instrumentos como ZEIS, direito de preempção, IPTU progressivo, programas de locação social, dentre outros.

${ }^{32}$ Segundo o IPHAN, essa medida foi atribuída em relação ao conceito de paisagem cultural, estabelecido pela UNESCO, "em consonância com a UNESCO, o Iphan regulamentou a paisagem cultural como instrumento de preservação do patrimônio cultural brasileiro em 2009, por meio da Portaria no 127" (IPHAN, 2016).
} 
Essa visão de uma paisagem cultural pretende ampliar o conceito de bem cultural; abrange, assim, uma perspectiva contemporânea que integra diversas ideias tradicionais do campo da preservação inseridas em um contexto, e busca valorizar uma ideia de conjunto representativo de uma cultura e civilização.

Em 2010, é estabelecido o Programa de Aceleração do Crescimento (PAC) das Cidades Históricas, uma iniciativa de gestão do patrimônio em conjunto com os seus gestores, com governos locais, com Instituições civis organizadas e com política de atuação internacional, a partir de termos de cooperação com outros países. Damos como exemplo a cidade de Belém do Pará, estudo de caso de nosso trabalho, a qual, em razão da celebração dos seus quatrocentos anos, recebeu financiamento do programa para a revitalizar edificações históricas. Esse programa apresentava, como sua previsão inicial de atuação, quarenta e quatro cidades brasileiras e a disponibilização de um bilhão de reais em obras públicas até o ano de 2015, além de trezentos milhões de reais destinados a uma linha de crédito para proprietários de imóveis de cidades tombadas pelo IPHAN (IPHAN, 2016). Na visita em campo, em 2016, à cidade de Belém, verificamos que muitas das obras de revitalização previstas estavam em andamento, mas atrasadas quanto a seus prazos de entrega inicialmente previstos.

Paralelamente, a UNESCO cria novos centros de capacitação e formação regionais, dentre eles o Centro Lúcio Costa de Formação em Patrimônio, em 2011, no Rio de Janeiro, um Centro de Categoria II da UNESCO, para a gestão do patrimônio na América Latina. Inicialmente, esse Centro esteve vinculado ao IPHAN, mas a partir de novembro de 2015 foi vinculado a um conselho gestor multilateral por meio de uma cooperação internacional entre os países em sua região de abrangência, "composta por 17 países de língua oficial portuguesa e espanhola da América do Sul, África e Ásia" (ONUBR, 2016). Esse centro representa uma tentativa de criar uma estrutura física e virtual, de promover a cooperação regional e de ampliar a atuação das instituições envolvidas na preservação de bens culturais e naturais nos países patrocinados pela UNESCO, o que reforça o interesse desse organismo internacional em se aproximar dos países periféricos, como o Brasil e a América Latina. 
Organismos internacionais de proteção do patrimônio cultural.

Algumas organizações internacionais de proteção dos bens culturais são anteriores à criação e atuação da UNESCO, segundo Silva (2012,p.30). Uma delas era a União PanAmericana, que protegia instituições científicas e artísticas, monumentos históricos e bens móveis de valor histórico contra o tráfico ilícito. Houve também o Pacto Roerich, de 1935, um tratado de caráter universal, e a Convenção de Haia, de 1899 e 1907, que, assim como o Pacto, reconhecia a neutralidade dos bens culturais para além dos tempos de conflito armado, visando a protegê-los e a preservá-los.

Após a Segunda Guerra Mundial, ao mesmo tempo em que o conceito moderno de patrimônio ampliou sua abrangência no contexto urbano, incorporando a ideia de conjunto, foram criados novos organismos intergovernamentais e internacionais de assistência e cooperação especializados na preservação e proteção do patrimônio cultural. Esses organismos desempenham uma atuação multilateral e são organizados em relação a um conjunto de nações, rompendo com as barreiras do Estado-nação. Ao ser implementadas, as ações dessas instituições internacionais e suas diretrizes e normativas acabam sobrepondose à legislação de proteção dos bens culturais de cada país.

Tal dinâmica estabeleceu um direito mundial da cultura ${ }^{33}$ por meio de convenções internacionais, de programas intergovernamentais e de acordos de cooperação, que, muitas vezes, têm o objetivo de auxiliar na criação de políticas holísticas. Resoluções e documentos de recomendações, consultoria e assessoria técnica, comunicação e divulgação de material, nomeação e classificação de bens culturais segundo categorias específicas - muitas são as formas de atuação dessas instituições.

${ }^{33}$ Os direitos mundiais da cultura estabelecidos por organismos e instituições internacionais multilaterais ligados à preservação do patrimônio podem definir que as políticas culturais preservacionistas são atribuições de cada Estado, salvo algumas exceções relacionadas à atribuição de valor e à solicitação de preservação realizada por Estados terceiros, diante de consulta prévia e coletiva aos Estados membros. 
Assim, [com o campo de atuação da UNESCO em relação à proteção dos bens culturais] tem início, na ordem jurídica internacional, a adoção de instrumentos jurídicos instituídos exclusivamente para a proteção dos bens culturais. Até a fundação da Unesco, a comunidade internacional era carente de instrumentos protetores dos bens culturais: à exceção do Pacto Roerich (1935), não há notícia de convenções internacionais que tratassem exclusivamente da proteção dos bens culturais.

Outra contribuição dada pela Unesco é a ampliação da tutela internacional dos bens culturais, pois as medidas jurídicas adotadas anterioremente tinham como objeto a proteção dos bens culturais imóveis apenas em tempos de guerra. A proteção internacional em tempos de paz, prevista pelo pacto Roerich, resumia-se ao campo programático, isto é, não havia previsão dos meios a serem empreendidos para assegurar uma proteção daquela natureza (SILVA, 2012, p. 59).

Nesse contexto, esta pesquisa analisa as transversalidades da cooperação internacional de proteção ao patrimônio cultural da instituição multilateral UNESCO na preservação do patrimônio cultural de conjuntos urbanos de centros históricos e sua relação com a produção do espaço urbano. A UNESCO foi criada pela organização internacional de caráter governamental United Nations ${ }^{34}(\mathrm{ONU})$, em 1945, para uma atuação vinculada a esta organização, a fim de auxiliar a "manutenção da paz e da segurança estreitando a colaboração entre as nações através da educação, da ciência e da cultura a fim de assegurar o respeito universal pela justiça, pela lei e pelos direitos humanos e liberdades fundamentais para todos" 35 (UNESCO, 2016).

Segundo suas diretrizes e conceitos orientadores, a UNESCO propõe-se a auxiliar o estabelecimento de um diálogo intercultural entre sociedades globalizadas, reconhecendo, porém, a diversidade quanto ao conceito de patrimônio mundial ${ }^{36}$. Seus princípios também buscam respeitar a resistência e a estabilidade cultural das sociedades, em um mundo considerado instável (UNESCO, 2016). A assistência internacional oferecida consiste em benefícios à comunidade internacional, "representada pelo Comitê do Patrimônio Mundial,

\footnotetext{
${ }^{34}$ A Organização das Nações Unidas, fundada em 1945 com 51 Estados Membros, tem o objetivo de promover cooperação internacional entre os Estados e é composta atualmente por 193 Estados Membros (UNESCO, 2016).

${ }^{35}$ Tradução nossa da carta das Comissões Nacionais para a UNESCO apresentada na 20ạ Conferência Geral, no dia vinte e sete de novembro de 1978, em Paris (UNESCO, 2016).

${ }^{36} \mathrm{O}$ processo de patrimonialização, segundo a UNESCO, é contraditório na elaboração dos direitos mundiais da cultura, em que um bem é valorizado por meio de sua singularidade, mas que em seu sistema de classificação e patrimonialização confronta-se com um processo de redução de sua intensidade singular, de seu contexto e, por consequência, de sua relação com o lugar.
} 
aos bens pertencentes ao patrimônio cultural da humanidade, mediante o sistema de cooperação internacional" (SILVA, 2012, p.29). Ainda segundo Fernando Silva, essa assistência é promovida pelas instituições Comitê do Patrimônio Mundial, Fundo do Patrimônio Mundial, ICOMOS e ICCROM.

Inseridas em um processo de multiplicação, de aceleração e de intensificação das interações entre as sociedades e suas culturas no mundo, algumas organizações internacionais buscaram auxiliar a expansão e a universalização das práticas patrimoniais, como é o caso da UNESCO e de sua Convenção de $1972^{37}$.

\begin{abstract}
Essa expansão pode ser simbolizada pela Convenção relativa à proteção do patrimônio mundial cultural e natural, adotado em 1972 pela Conferência geral da UNESCO. Este texto decalcava do conceito de monumento histórico o de patrimônio cultural universal: monumentos, conjuntos edificados, sítios arqueológicos ou urbanizados, apresentando «um valor universal excepcional do ponto de vista da história da arte ou da ciência». Era assim proclamada a universalidade do sistema ocidental de pensamento e de valores na matéria. Para os países prestes a reconhecerem a sua validade, a Convenção criava um conjunto de obrigações relativas «à identificação, proteção, conservação, valorização e transmissão às gerações futuras do patrimônio cultural» (CHOAY, 2010, p. 223).
\end{abstract}

Essa Convenção esteve inicialmente vinculada a questões do Direito Internacional do Meio Ambiente, preocupando-se com a preservação dos patrimônios culturais e naturais, os quais deveriam ser pertinência exclusiva das normas jurídicas dos países, e, portanto, do Estado-nação no qual estavam inseridos.

No entanto, a questão patrimonial tornou-se mais abrangente e vinculou-se também a outras áreas do conhecimento, à medida que o conceito de patrimônio evoluiu e ampliouse devido ao reconhecimento e à valorização como bens culturais dos conjuntos das cidades históricas ou modernas, dos monumentos e das obras de arte como representações de um coletivo. Paralelamente, foram criadas organizações internacionais de proteção ao patrimônio, preocupadas, sobretudo, com as guerras que destruíram muitos dos bens

\footnotetext{
${ }^{37} E m$ 1972, os países membros da UNESCO referendaram a petição "Convenção para a Proteção do Patrimônio Cultural e Natural do Mundo". Na petição, ficou proposta a proteção de monumentos, de construções, de lugares arqueológicos, assim como de formações físicas ou biológicas, que tivessem um valor universal e excepcional (UNESCO, 2016).
} 
culturais significativos das civilizações de alguns países. Nesse ponto de vista, os bens culturais são reconhecidos para além das satisfações das necessidades materiais do indivíduo isolado, sobrepondo-lhes as necessidades materiais e espirituais enquanto coletivo, "a criatividade do ser humano, enquanto um ser universal" (SILVA, 2012, p. 21).

A Convenção de 1972 foi estabelecida, portanto, como um instrumento internacional normativo ${ }^{38}$, a partir de regras em comum, além das diferenças culturais e das tradições particulares dos países. Esses instrumentos internacionais normativos associam legalmente recomendações, segundo as quais a UNESCO funcionaria como um organismo de assistência e cooperação internacional aberto a discussões e a consultas em relação a temas éticos, intelectuais e normativos.

Atualmente, esse organismo ampliou a compreensão dos bens culturais imóveis no âmbito da cidade em relação a seu contexto local, abrangendo também "os monumentos e os conjuntos [que] compreendem realizações exclusivas da ação humana; os lugares notáveis, as realizações conjuntas do homem e da natureza". Apresenta também três ordens distintas de classificação do patrimônio cultural edificado: monumentos, conjuntos e sítios culturais, os quais, segundo Silva $(2012$, p. 87), são reconhecidos, respectivamente, como cidades mortas (monumentos), cidades históricas vivas ou cidades novas do século XX (conjuntos) e lugares notáveis (sítios).

Tais discussões buscam "um acordo universal destes temas, indicando objetivos e mobilizando a opinião internacional" (UNESCO, 2016). No ver desse organismo, são iniciativas estatais elaborar e indicar uma lista de intenção de candidatura de bens culturais a patrimônio mundial. Essas iniciativas são interpretadas por nosso trabalho como uma recomposição das funções, das competências públicas e institucionais do Estado, na medida em que se submetem ou se alinham a normativas e diretrizes internacionais, consideradas supranacionais. Essa recomposição, associada à descentralização, às modalidades e às ações de colaboração relacionadas ao patrimônio, já comentadas anteriormente, fazem emergir a necessidade de se analisarem, no campo do patrimônio cultural no espaço urbano, suas

\footnotetext{
${ }^{38}$ Esse instrumento internacional normativo tem o objetivo de, tal como um fórum central, abordar temas éticos, normativos e intelectuais atuais, a partir de um intercâmbio multidisciplinar e de entendimento mútuo. Assim, quando é possível e conveniente, proporciona-se um acordo universal desses temas, indicando objetivos e mobilizando a opinião internacional.
} 
novas configurações territoriais, segundo uma perspectiva interdisciplinar e uma nova interpretação, a que este trabalho busca responder.

Patrimônio mundial - a ideia de patrimônio comum de todos os povos.

O processo de classificação a patrimônio mundial pela UNESCO apresenta algumas especificidades e particularidades em relação a outros processos de patrimonialização brasileiros relacionados às diretrizes e às normativas internacionais, a partir das quais um bem poderá ser classificado como mundial. Como nossa análise se fundamenta no conceito de patrimônio material mundial, voltaremos nossa atenção para o processo particular de classificação no qual cada uma das etapas é requisito necessário para o Comitê do Patrimônio Mundial em relação ao processo de classificação.

Assim, observamos a existência de duas instâncias técnicas de atuação: a instância nacional - que idealiza e formula o processo de classificação e patrimonialização por meio de uma elite intelectual, que assume também a função de ator político - e a instância internacional - que conduzirá o processo de classificação, por meio de seus critérios específicos, estabelecidos pela Convenção do Patrimônio Mundial (Convenção de 1972). Tais critérios podem ser diretrizes ou documentos ou recomendações, assim como assistência ou auxílio de implementação da Convenção por meio da consultoria de órgãos de preservação e conservação do patrimônio associados à UNESCO, como é o caso do ICOMOS.

Para ilustrar e compreender melhor os critérios dessa seleção, elaboramos um quadro em que se descreve cada uma das cinco etapas do processo de classificação a patrimônio mundial, segundo a UNESCO ${ }^{39}$ :

${ }^{39} \mathrm{O}$ processo de classificação à Lista do Patrimônio Mundial descrito neste trabalho e resumido no quadro é o de nomeação de bem cultural realizada pelo próprio Estado-nação, em período de paz. Nele, apenas os países que assinaram a Convenção do Patrimônio Mundial podem apresentar candidaturas para bens culturais de seu território(UNESCO, 2016). 


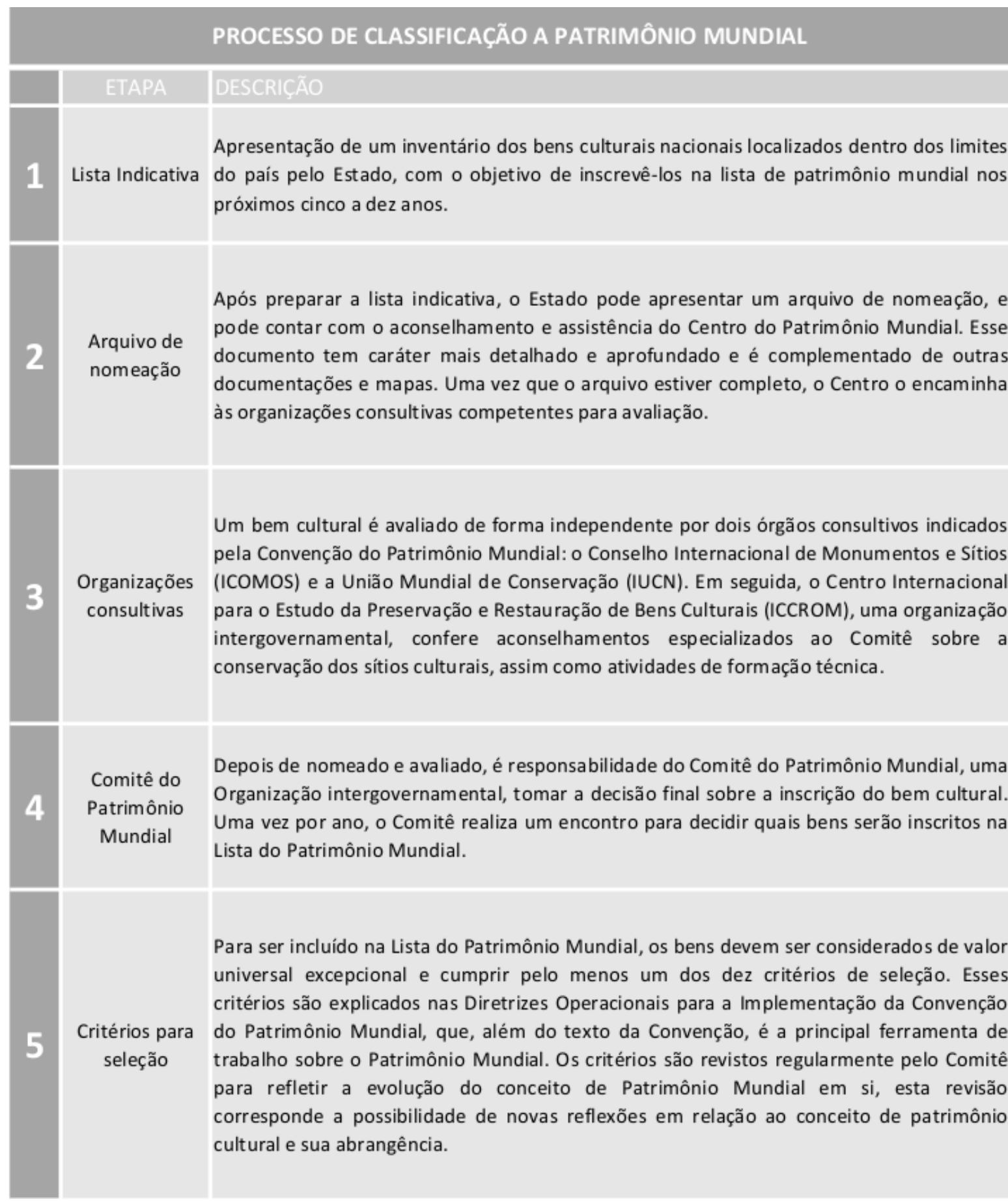

Quadro 1 - Etapas do processo de classificação como patrimônio mundial pela UNESCO. Fonte: autoria própria e tradução nossa (UNESCO, 2016).

Para figurar na lista indicativa de bens culturais nacionais pela UNESCO, o Estado deve ser signatário da convenção a patrimônio mundial da UNESCO ou ter seu bem cultural indicado por algum país signatário, e o Estado deve seguir o processo operacionalizado por aquela Instituição. Embora as informações obtidas pela página oficial da UNESCO na internet façam referência à assistência e ao aconselhamento do Centro do Patrimônio Mundial a partir de uma segunda etapa - posterior a essa inicial -, acabamos percebendo, em nossa 
pesquisa, a existência de consultorias internacionais por meio do ICOMOS ainda na etapa inicial, com aconselhamentos de bens culturais singulares e menos presentes em outros processos classificatórios.

Após a etapa inicial de solicitação pelo Estado à UNESCO - que consideramos uma fase de idealização e de formulação do processo -, segue-se uma outra etapa de elaboração de documentação técnica, e nela configuram mais explicitamente a assistência e o aconselhamento do Centro do Patrimônio Mundial. Essa segunda etapa exige uma continuidade da elaboração de documentação técnica, do estabelecimento, pelo órgão consultor internacional, de diretrizes de adequação às medidas de conservação e de preservação do bem cultural. Para que essa fase seja conduzida e finalizada, é necessária uma articulação entre os órgãos nacionais de preservação e de planejamento urbano, em diferentes instâncias de atuação.

A etapa seguinte, que consideramos uma etapa de avaliação, é fundamentada numa documentação técnica consistentes em a qual o processo classificatório não tem continuidade. Nessa documentação devem constar a comprovação do valor intrínseco do bem cultural, a elaboração de um dossiê descritivo desse valor e um plano detalhado administrativo e de proteção. A cada etapa do processo, a documentação recebe maior aconselhamento e assistência das Instituições e órgãos consultores relacionados à UNESCO. Dentre algumas das recomendações particulares, salienta-se a de uma instância de governança do bem cultural.

Após a implementação das recomendações dos órgãos consultores internacionais, a próxima e penúltima etapa de classificação é regida pelo Comitê do Patrimônio Mundial, configurado por representantes de vinte e um países - que contribuem financeiramente com o Fundo do Patrimônio Mundial. Refere-se à decisão final sobre a inscrição do bem cultural na Lista do Patrimônio Mundial, o que acontece na maioria das vezes em uma reunião anual, realizada em um encontro para decidir quais bens serão inscritos na Lista.

Uma vez inscrito na lista o bem cultural, na última etapa, a imagem, a informação e a promoção turística cultural do bem são difundidas pela UNESCO, por meio de sua página oficial na internet, de suas comunicações especializadas sobre o tema e do reconhecimento do bem por esse organismo internacional. 
Cartas Patrimoniais Internacionais.

Com a Revolução Francesa, surge a necessidade de se debaterem aspectos relativos à definição e à gestão do patrimônio nos âmbitos nacional e mundial. Nesse contexto, aparecem as cartas patrimoniais, documentos internacionais ou instrumentos teóricos com textos concisos de caráter indicativo, referentes à atuação de profissionais e de instituições da área da conservação e preservação do patrimônio.

Segundo Beatriz Kühl (2010), "as cartas patrimoniais são fruto da discussão de um determinado momento. Antes de tudo, não têm a pretensão de ser um sistema teórico desenvolvido de maneira extensa e com absoluto rigor, nem de expor toda a fundamentação teórica do período". Essas cartas não permitem reinterpretações aprofundadas para as diversas realidades culturais de cada país e não se arrogam o direito de ser ou não incorporadas como propostas legislativas.

A reinterpretação das cartas internacionais para as realidades locais pode levar à criação de cartas nacionais ou internacionais de um conjunto específico de nações, e pode “ter papel importantíssimo na construção normativa relacionada à preservação dos bens culturais de vários países" (KUHL, 2010). Salienta-se, portanto, que as cartas patrimoniais não têm a função de legislar sobre o patrimônio; contudo, fornecem embasamento conceitual para que os órgãos competentes dos países possam legislar.

Ainda anterior à definição, pela UNESCO, da existência de um patrimônio comum a todos os povos, é importante ressaltar que as discussões internacionais por meio de cartas patrimoniais são consolidadas pela primeira vez com a Carta de Atenas ${ }^{40}$, de 1931, que reuniu deliberações de consenso de vários países.

A grande preocupação naquele momento relaciona-se à ação de conservação do patrimônio arquitetônico e urbano ${ }^{41}$, em um período de grande crescimento das cidades. A Carta de Atenas reconhece a diversidade dos casos específicos e a possibilidade de soluções

\footnotetext{
${ }^{40} \mathrm{~A}$ carta de Atenas, de 1931, aborda questões relacionadas às principais preocupações do período, que envolviam a legislação, as técnicas e os princípios de conservação dos bens históricos e artísticos, e foi organizada pelo Escritório Internacional dos Museus Sociedade das Nações.

${ }^{41} \mathrm{Na}$ época, o termo "monumento" ainda é utilizado para definir o bem, seja ele monumento de interesse histórico, artístico ou científico, ainda numa visão anterior ao conceito de "patrimônio cultural".
} 
particulares para cada caso, e aborda temas referentes aos aspectos legais, aos aspectos técnicos construtivos e aos princípios norteadores da ação de conservação.

O documento alega a necessidade de concepção e de fortalecimento de organizações nacionais e internacionais, de caráter operativo e consultivo, voltadas à preservação e restauro do patrimônio. Vale ressaltar um importante aspecto do documento: a preocupação com a legislação de cada país e com a necessidade de se estabelecerem princípios comuns entre os signatários, integrados às condições locais e à opinião pública, principalmente para assegurar o predomínio do interesse geral sobre o individual.

Ressaltamos um aspecto que a conferência recomenda respeitar, em relação ao que a Carta de Atenas de 1931 define como "o caráter e a fisionomia das cidades, sobretudo na vizinhança dos monumentos antigos, cuja proximidade deve ser objeto de cuidados especiais": a preocupação com uma manutenção das características das construções do entorno do bem cultural. A ideia de preservação exposta pelo documento, porém, apresenta um enfoque bastante conservador ao definir, por exemplo, a manutenção de algumas "perspectivas particularmente pitorescas", em vez de se avaliar a manutenção destes aspectos em detrimento de outros processos relacionados à área e à dinâmica urbana da cidade.

Posteriormente, a Recomendação de Paris a Paisagens e Sítios, de 1962, elaborada em uma Conferência Geral da UNESCO e organizada pelo Escritório Internacional dos Museus, foi o primeiro documento a abranger o conceito de paisagem, bem como seus respectivos territórios, sejam eles centros urbanos ou sítios naturais. Essa Recomendação propõe que os Estados Membros apliquem e adotem leis nacionais ou alguma outra medida para salvaguardar e preservar o caráter das paisagens e sítios que apresentem interesse cultural ou estético, o que estende a abrangência às paisagens e aos sítios, naturais, rurais ou urbanos, e complementa as medidas de proteção à natureza.

Em maio de 1964, a Carta de Veneza reconhece a existência de um patrimônio comum da humanidade que deve ser preservado e transmitido com autenticidade às gerações futuras. A Carta enaltece a necessidade de que as medidas relativas "à conservação e à restauração do patrimônio" sejam elaboradas "em comum" e formuladas "num plano internacional, ainda que caiba a cada nação" aplicá-las "no contexto de sua própria cultura e de suas tradições" (Carta de Veneza, 1964). A Carta define, ainda, a conservação e a 
restauração como um campo interdisciplinar, e sugere que a conservação do patrimônio esteja atrelada a uma função útil à sociedade, mas dentro de limites estabelecidos pela disposição ou pela decoração dos edifícios.

A partir dos anos de 1960, reformula-se a matriz conceitual e o campo de abrangência da questão do patrimônio. Os bens imóveis edificados sofrem uma ampliação em relação às tipologias consideradas patrimônio cultural, não apenas centradas em uma arquitetura icônica e consagrada, mas abrangendo também tipologias que anteriormente eram reconhecidas como "menos nobres" (CASTRIOTA, 2009), como uma arquitetura menor ou modesta.

Essa revisão conceitual foi possível diante da valorização da ideia de um conjunto patrimonial, integrado ao seu entorno, consolidada no documento da Carta de Veneza de 1964, e permitiu uma descentralização dos parâmetros culturais adotados na valorização e no reconhecimento dos bens culturais - descentralizada em nível internacional ou mesmo nacional no que tange ao predomínio de algumas culturas consideradas hegemônicas - em relação à discussão local da arquitetura e da cidade. Esse novo conceito de valorização patrimonial segundo uma ideia de conjunto arquitetônico, reconhecido por meio da cultura e dos processos históricos, oferece uma possibilidade de melhor incorporação às culturais locais e regionais das cidades.

Em 1976, o ICOMOS define, por meio da "Carta de Turismo Cultural", questões relacionadas à conservação e à salvaguarda do patrimônio e aos impactos tanto positivos como negativos resultantes da atividade do turismo no mundo. Segundo essa Carta, os impactos devem ser avaliados e mensurados, o que demonstra uma primeira orientação quanto à gestão do turismo nos sítios com patrimônio significativo dos povos locais.

Considera-se que, desde a Carta de Burra ${ }^{42}$ (ICOMOS, 1980), a teoria da conservação passa por uma mudança de paradigma que coloca a manutenção da significância como o objetivo central da conservação patrimonial.

A chancela da Paisagem Cultural Brasileira ${ }^{43}$ é definida pelo Iphan (2009) como uma "porção peculiar do território nacional, representativa do processo de interação do homem

\footnotetext{
${ }^{42} \mathrm{~A}$ Carta de Burra estabelece princípios e procedimentos para a conservação, a preservação, a restauração e a reconstrução de bens culturais de valor estético, histórico, científico ou social para as gerações passadas, presentes ou futuras (ICOMOS, 1980).

${ }^{43}$ Portaria $n^{\circ} 127$, de 30 de abril de 2009 - Estabelece a chancela da Paisagem Cultural Brasileira.
} 
com o meio natural". Com essa nova visão do patrimônio cultural, abre-se uma perspectiva contemporânea para se pensarem, de forma mais integrada, ideias e conceitos tradicionais do campo da preservação.

No panorama europeu, a Convenção Quadro do Conselho da Europa sobre o Valor do Patrimônio Cultural para o Desenvolvimento da Sociedade, documento também conhecido como Convenção de Faro, de 2005, centra-se nos significados do patrimônio, em sua interpretação e no uso que dele faz a sociedade. Nessa Convenção, o patrimônio é considerado um fator de coesão social que suscita um sentimento de envolvimento do cidadão na construção da sociedade.

Assim, desde os anos de 1980, com as questões trazidas pela Carta de Burra, pela chancela da Paisagem Cultural Brasileira e pela Convenção de Faro, o ator social é dotado de importância em relação ao patrimônio, seja ela de preservação ou socioeconômica. Assim, a participação do cidadão torna-se fundamental na construção de iniciativas relacionadas aos bens culturais. Esse envolvimento do cidadão traz novas orientações para o processo de identificação e de valorização do patrimônio urbano, uma vez que pode redirecionar o reconhecimento de valor dos bens culturais, anteriormente restrito aos centros históricos das cidades. Em nosso entendimento, essas questões já se faziam presentes em cartas anteriores, mas numa abordagem mais generalizada.

\section{O local e a localidade nos processos de patrimonialização mundiais.}

Em 1968 é proposta, por Robert Brichet ${ }^{44}$, para a UNESCO, a elaboração de uma lista de classificação dos bens culturais, baseada no artigo $8^{\circ}$ da Convenção de Haia, de 1954 . Essa lista estabelece critérios e noções de patrimônio para a inscrição dos bens no Registro Internacional de Bens Culturais sob Proteção Especial. Os bens culturais e naturais podem, então, ser reconhecidos internacionalmente segundo uma nova classificação, na medida em que são inscritos em uma nova lista correspondente ao conceito de "valor universal excepcional", mediante a sua aprovação por um comitê específico, o Comitê do Patrimônio

\footnotetext{
${ }^{44}$ Portaria ${ }^{\circ}$ 127, de 30 de abril de 2009 - Estabelece a chancela da Paisagem Cultural Brasileira.
} 
Mundial, ao qual são atribuídas as funções de "organizar, manter em dia e publicar a lista desses bens que representam o patrimônio cultural e natural da humanidade" 45 .

Desde o início de suas atividades, o comitê tem a finalidade de estabelecer um modelo de Lista do Patrimônio Mundial que busque representar um número equilibrado de bens culturais e naturais de todas as áreas do planeta ${ }^{46}$, ancorando-se em um discurso da universalidade.

Segundo Fernando Fernandes da Silva (2012, p. 92), essa lista, limitada a um número razoável de bens por conta de sua "natureza jurídica do regime de proteção da Convenção, e que contempla apenas os bens de 'valor universal excepcional'”, busca, por um lado, corresponder a uma série de propósitos (dos quais se destacam: a atribuição de valor do bem quando indicado pela lista, a publicidade que será ofertada ao bem, a educação em relação à opinião pública mundial e os "perigos que ameaçam os bens culturais de interesse universal"), e, por outro, angariar fundos por meio de campanhas internacionais que promovam a contribuição voluntária.

Se, por um lado, a divulgação do bem patrimonial busca a sensibilização e o envolvimento do ator social, seja em seu processo de preservação e de conservação, seja no processo de sua identificação e de sua valorização, por outro, ela pode ser veiculada a uma ampla audiência tal como uma informação de um produto turístico, que traz seu reconhecimento como patrimônio de valor excepcional. As publicações dessa Organização são feitas nos idiomas inglês, francês e espanhol, com ampla tiragem impressa e grande visibilidade, disponível também na página oficial da UNESCO na internet, e ofertadas a um público global.

Nos dois exemplos que seguem abaixo, as capas da revista comunicam sobre os temas do "turismo sustentável". Segundo a UNESCO, essas atividades podem garantir o envolvimento de populações locais e trazer um resultado satisfatório nos esforços para se atingir o desenvolvimento local.

O turismo sustentável, as indústrias culturais e criativas, bem como a revitalização urbana baseada em seu patrimônio são poderosos subsetores

\footnotetext{
${ }^{45}$ Artigo 11, parágrafo $4^{\circ}$, da Convenção Relativa à Proteção do Patrimônio Mundial, Cultural e Natural, de 1972.

${ }^{46}$ Documento CC-77/Conf. 001/9, UNESCO, Paris, 30 de setembro de 1977, p. 3.
} 
econômicos que geram empregos verdes, estimulam o desenvolvimento local e incentivam a criatividade.

Os sistemas de conhecimentos autóctones e indígenas, bem como as práticas de gerenciamento ambiental, proveem valiosos critérios e ferramentas para enfrentar desafios ecológicos, prevenir perdas de biodiversidade, reduzir a degradação de terras e mitigar os efeitos da mudança climática (UNESCO NO BRASIL, 2016).

Tal abordagem do papel da cultura no desenvolvimento sustentável dos lugares se aproxima das discussões estabelecidas a partir da Carta do Turismo Cultural de 1976, em relação à criação de atividades ligadas ao patrimônio e que tragam benefício socioeconômico à comunidade local na qual o patrimônio se insere.
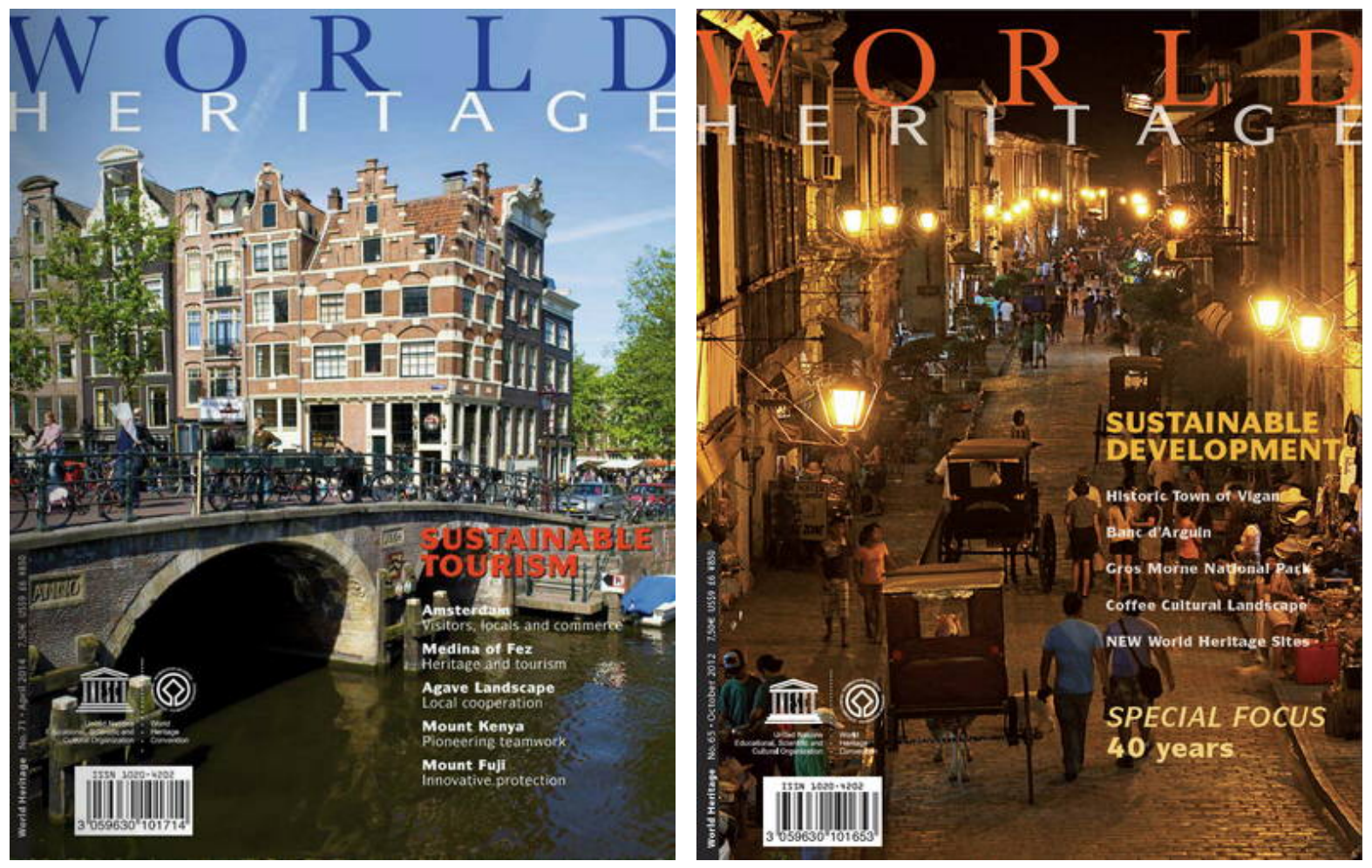

Publicação oficial da UNESCO produzida na França, com tiragem trimestral nos idiomas inglês, francês e espanhol, com artigos sobre sítios urbanos como Patrimônio Mundial. Imagem 1, à esquerda: capa da edição de abril de 2014. Imagem 2, à direita: capa da edição de outubro de 2012. Fonte: Revista World Heritage, $2016^{47}$.

${ }^{47}$ World Heritage and Sustainable Tourism.World Heritage.Paris, n. 65, out. 2012.Disponível em: <http://whc.UNESCO.org/en/review/65/>. Acesso: 9 jul. 2016.

World Heritage and Sustainable Tourism.World Heritage.Paris, n. 71, abr. 2014.Disponível em: <http://whc.UNESCO.org/en/review/71/>. Acesso: 9 jul. 2016. 
Os bens inscritos na Lista, ainda segundo Fernandes Silva (2012, p. 92), submetem-se a um regime jurídico alicerçado em alguns princípios, tais como a manutenção da soberania do Estado em cujo território situa-se o bem cultural, o que correspondendo à legislação nacional aplicável, e os direitos soberanos territoriais. Em contrapartida, "o Estado-parte na Convenção reconhece a obrigação primordial de 'identificar, proteger, conservar, valorizar e transmitir às futuras gerações' o patrimônio cultural mencionado no artigo $1^{\circ \prime \prime}$, e deve seguir medidas discriminadas pela Convenção a fim de garantir a execução dos objetivos mencionados, além de, periodicamente, serem redigidos relatórios em que constem as medidas legislativas e regulamentares ou quaisquer outras adotadas, que visem à aplicação da Convenção. Em relação a medidas colaborativas, a comunidade internacional obriga-se a cooperar na proteção dos bens culturais inscritos na Lista do Patrimônio Mundial, quando solicitado pelo Estado interessado.

A Convenção outorga ao Comitê a competência para definir critérios diante dos quais o bem poderá ou não ser incluído na Lista do Patrimônio Mundial. Isto é, a partir desses critérios estabelecidos, será definido o valor universal excepcional do bem ${ }^{48}$, sua autenticidade e a comprovação, se o Estado que apoiou a candidatura a patrimônio adotou as medidas protetoras adequadas e suficientes em relação ao bem inscrito.

Desse modo, a lista de bens culturais considerados de valor universal excepcional busca representar e selecionar bens conforme algumas representatividades e diretrizes ${ }^{49}$, apresentadas abaixo:

(i) - representa uma realização artística única, uma obra-prima do gênio criativo humano ou;

(ii) - exerce grande influência, por um período de tempo ou dentro de uma área cultural específica do mundo, a respeito do desenvolvimento da arquitetura, das artes monumentais, do planejamento de cidades ou do modelo de paisagens, ou;

(iii) - representa um testemunho especial ou no mínimo excepcional de uma civilização ou tradição cultural desaparecida;

(iv) - é um excepcional exemplo de um tipo de construção ou conjunto arquitetônico ou paisagem que ilustre significativo(s) estágio(s) da história humana, ou;

${ }^{48}$ Convenção de 1972 , artigos $1^{\circ}$ e 11 , parágrafo $2^{\circ}$; Diretrizes, parágrafo 24 , alínea a, itens i a vi.

${ }^{49}$ Convenção, Id., artigos $1^{\circ}$ e 11 , parágrafo $2^{\circ}$; Diretrizes, parágrafo 24 , alínea a, itens i a vi, parágrafo 24. 
(v) - é um exemplo excepcional de ocupação humana tradicional ou de uso de terra representativo de uma cultura (ou culturas), especialmente quando se torna vulnerável sob o impacto de mutações irreversíveis, ou; (vi) - é direta ou claramente associado com eventos ou tradições vivas, com ideias ou com crenças, com obras artísticas e literárias de importância universal excepcional (o Comitê considera que esse critério deve justificar a inclusão na lista somente em excepcionais circunstâncias ou aliadas a outros critérios) (UNESCO, 2016).

Segundo essas diretrizes, é possível admitir-se um bem a partir de mais de um dos critérios estabelecidos pelo Comitê, acrescentando-se que a "grande maioria das inscrições foi sustentada em dois ou mais critérios" (SILVA, 2012, p. 94) de seu valor excepcional como bem. Assim, o Comitê estabelece tais critérios, buscando precisar a noção de valor excepcional de representatividade e seletividade equilibrada e contemplar todas as áreas geográficas do mundo, da maneira que, segundo o seu ponto de vista, melhor expresse em cada região aquele valor ${ }^{50}$.

É importante salientar a Carta de Veneza, de 1964, segundo a qual o critério da "autenticidade" de um bem cultural é reconhecido em sua caracterização de concepção original, enquanto "modelo, material, artesanato ou ambiente" 51 , em que "privilegia-se o aspecto exterior do bem, e em que uma utilização do mesmo segundo a época em que foi concebido torna-se secundário" (SILVA, 2012, p. 94).

As disposições da seção II da Convenção do Comitê do Patrimônio Mundial estabelecem e disciplinam, como obrigações do Estado no qual se circunscreve o bem, medidas para a sua conservação e preservação, através, sobretudo, de seu caráter legislativo em âmbito nacional. Estabelecem, ainda, outras especificidades relacionadas ao bem cultural, cujo inventário é feito inicialmente a partir de uma lista indicativa fornecida ao Comitê pelos Estados interessados. Essas listas são a base de uma análise comparativa que busca selecionar o bem cultural segundo os critérios exigidos pelas diretrizes da Convenção.

O processo de inscrição de um bem cultural na Lista do Patrimônio Mundial é constituído de duas etapas distintas. A primeira etapa é caracterizada pela atuação do Estado, ao cumprir com o disposto na seção II da Convenção, que indica as obrigações e

\footnotetext{
${ }^{50}$ Documento CC-81/Conf. 003/6, 1982, p. 9.

${ }^{51}$ Diretrizes, parágrafo 24 , alínea $b$, item i.
} 
atribuições dos Estados signatários de proteção do bem cultural. Assim, "a proteção nacional é executada mediante uma política legislativa, e, dependendo das peculiaridades que envolvam o bem, o Estado requerente propõe um plano de gestão para uma proteção mais eficaz" (SILVA, 2012, p. 99). Por assim dizer, essa organização sobrepõe-se à decisão do Estado à medida que disciplina as ações de proteção àquele patrimônio. A segunda etapa é caracterizada pela atuação de um comitê da UNESCO, após consulta ao ICOMOS. Nessa fase, o comitê poderá conceder ou recusar a proposta da inscrição do bem, após consulta anterior ao Estado interessado.

\begin{abstract}
A eleição de patrimônios mundiais não implicou na criação de um coletivo que tivesse uma identidade "mundial" ou "global", e nem mesmo foi significativa para o desenvolvimento de nações mais carentes de recursos. Ao contrário, acirrou a disputa entre diversas nações ou cidades por ganhos políticos ou comerciais, consolidando ou mesmo reforçando hierarquias existentes. Por um lado, o procedimento da Convenção de 1972, ao fazer repousar sobre os Estados nacionais a responsabilidade de elaboração de uma lista indicativa a partir da qual seriam selecionados os bens do patrimônio mundial, acentuou esta disputa. Por outro lado, o crescente protagonismo das cidades enquanto agentes de políticas públicas contribuiu para instigar a contenda e fazer emergir fenômenos de escalada no domínio da dramatização do patrimônio (PEIXOTO, 2010, p. 7).
\end{abstract}

Portanto, diante dos procedimentos da inscrição do bem, sobretudo nos países de pequena participação, tais como países africanos, asiáticos e latino-americanos, cita-se a dificuldade imposta pelo grande número de exigências feitas pela da UNESCO para que seu patrimônio seja eleito como mundial, relacionadas à sua proteção em âmbito nacional. 


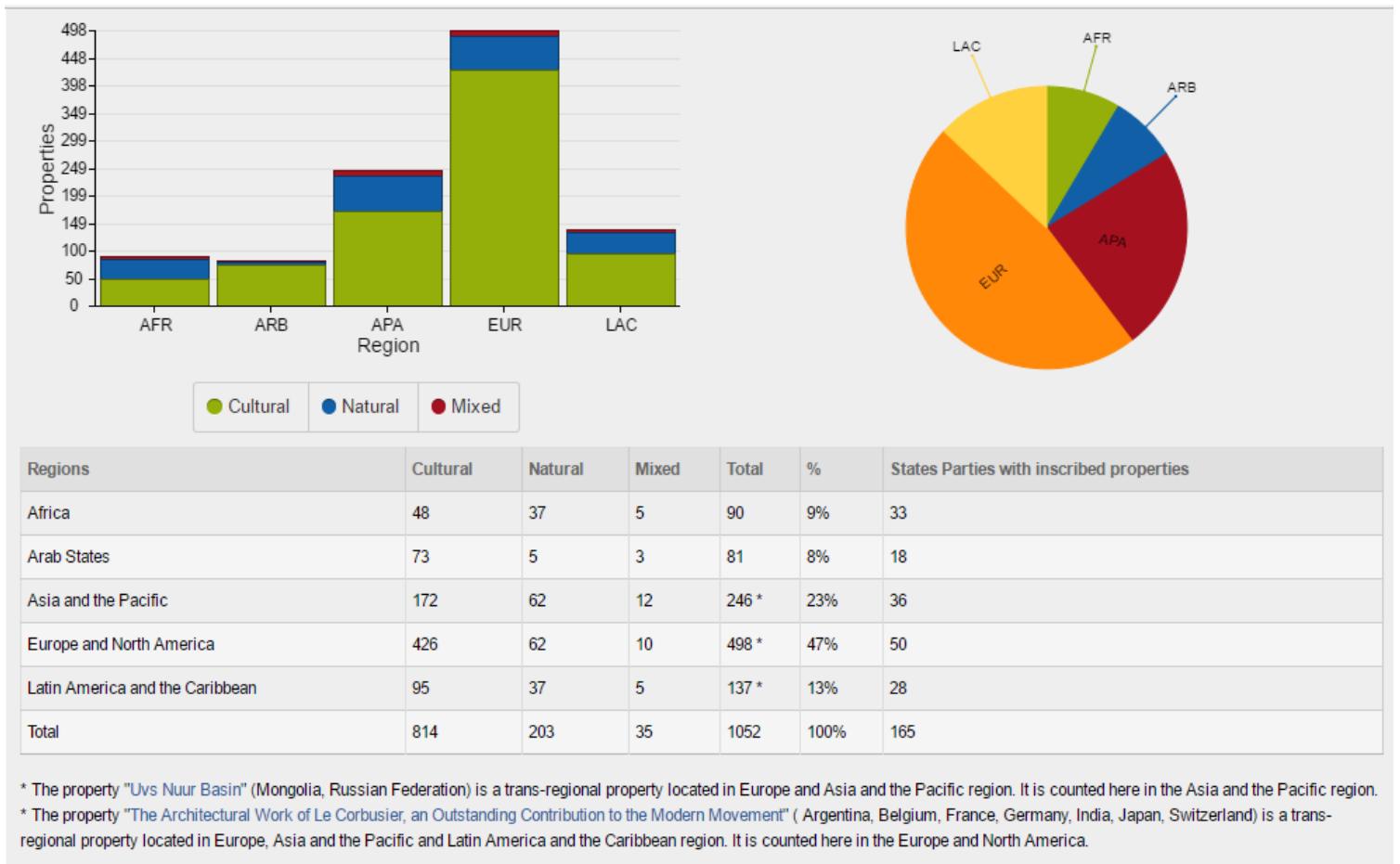

Imagem 3 - Números de bens culturais como patrimônio mundial por região. Fonte: UNESCO, 2016.

Os gráficos e tabelas demonstram o número de bens classificados como patrimônio mundial em relação a suas áreas no mundo, divididas em: África; Estados Árabes; Ásia e o Pacífico; Europa e América do Norte; América Latina e o Caribe. Por meio desses gráficos, é possível visualizar o grande número de bens classificados como culturais na Europa e América do Norte, com 426 bens culturais inscritos, em relação as outras áreas do mundo.

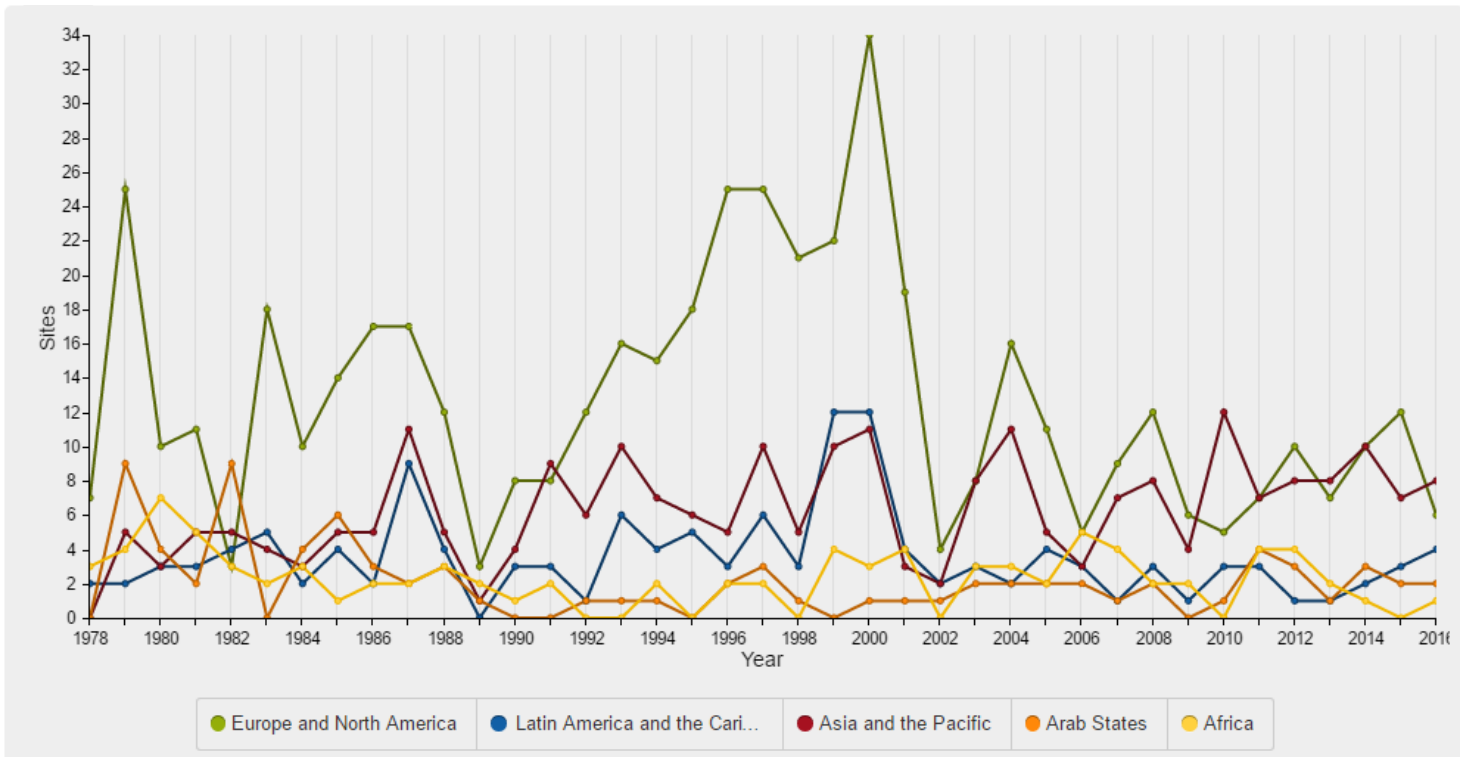

Imagem 4 - Números de bens culturais como patrimônio mundial inscritos por ano por região. 
Fonte: UNESCO, 2016.

Esse último gráfico expõe o número de bens classificados por região e por ano. Por meio dele, verificamos um aumento expressivo do número de classificações na Europa e América do Norte, e América Latina entre o ano 1998 e 2001, sendo que a Europa e América do Norte vivenciaram um período mais longo com grande número de processos classificatórios. De um modo geral, pode-se considerar que o número de bens classificados como mundial na América Latina apresenta-se semelhante ao número de bens classificados na África e os Estados Árabes, salvo o período entre os anos de 1992 e 2001.

Dos resultados expostos, percebemos que, de um modo geral, são beneficiados, nos processos "classificatórios mundiais", em detrimento de outros, os Estados que já oferecem melhores condições de preservação ao seu patrimônio (PEIXOTO, 2010). São Estados que podem instituir serviços de proteção, de conservação e de valorização, que apresentam capacidade para desenvolver medidas de segurança, ou que contam com o suporte de institutos ede centros preservacionistas, ou que já estejam habituados a desenvolver projetos educativos em relação ao patrimônio, e ainda que contribuam regularmente com o Fundo do Patrimônio Mundial. 


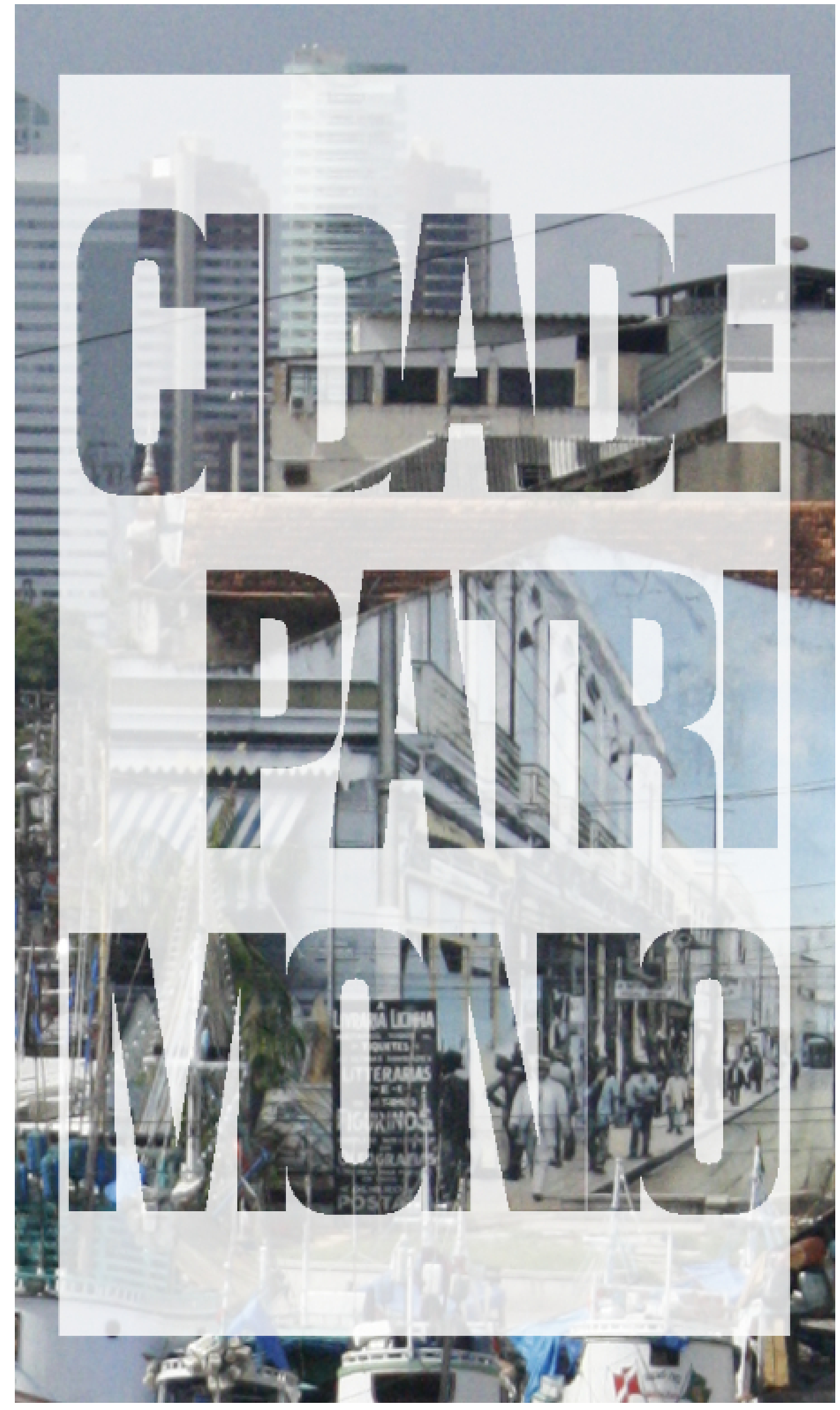




\section{IMAGEM DE CAPA DO CAPÍTULO}

Montagem feita a partir de foto capturada pela autora em julho de 2016, durante as atividades de pesquisa em campo na cidade de Belém, no período que compreende o desenvolvimento desta tese. A imagem mostra as docas de Ver-o-Peso, com embarcações atracadas em primeiro plano, alguns edifícios da área patrimonial e seu atual estado de conservação, a grande pintura na fachada lateral destes edifícios, com a representação de uma rua em um período histórico na cidade, e ao fundo a paisagem distante dos altos e novos edifícios do bairro Umarizal. 


\section{PATRIMÔNIO E A CIDADE CONTEMPORÂNEA}

Ainda há muita relutância em considerar o desenvolvimento urbano, a mercantilização, as indústrias culturais e o turismo como contextos a ser incorporados no âmbito da discussão contemporânea sobre a preservação e conservação dos bens culturais, no entanto, não os considerar seria negar "as condições em que hoje os bens históricos existem" (CANCLINI, 1994, p. 95). Isso nos leva a perceber que "o conjunto de bens e tradições surgidos e mantidos no território historicamente habitado por uma comunidade" (CANCLINI, 1994, p. 95) está exposto a um universo mais amplo, relacionado culturalmente a outras escalas de interação além da comunidade local. Muitos hábitos novos têm sido incorporados, transpondo as fronteiras originais e anteriormente mais difíceis de ser transpostas por uma comunidade.

Esse intercâmbio cultural é facilitado "pelos meios de comunicação de massa, tantas vezes acusados de substituir e maltratar o folclore. Na verdade, o rádio, a televisão, o cinema, os vídeos e os discos tornaram-se recursos-chave para a documentação e a difusão da própria cultura" (CANCLINI, 1994, p. 95).

Com base nessa afirmação, reforçamos outra questão pertinente ao campo da preservação do patrimônio, a do enfrentamento de uma questão dialética sobre o que será transmitido - a decisão de lembrar ou esquecer -, uma questão relacionada com a história e a memória, e a seleção de camadas que serão preservadas e protegidas para as gerações futuras. Essa decisão sobre a preservação interfere diretamente na vida da comunidade local e na configuração da paisagem cultural dos lugares. Portanto, essas ações devem ser baseadas em observações aprofundadas dos conjuntos urbanos nos quais se inserem esses bens culturais, de acordo com uma perspectiva social e culturalmente inclusiva, visando compreender o território, suas complexidades, suas especificidades e suas relações, para estruturar permanências e a preservação das relações culturais entre os habitantes e do lugar. 
Patrimônio e aspectos da conformação da cidade contemporânea.

Segundo Choay (2010, p. 11), a definição de patrimônio está originalmente relacionada às estruturas familiares, econômicas e jurídicas de uma sociedade estável; ele é enraizado no espaço e no tempo. O reconhecimento como patrimônio também está relacionado à ideia de bem cultural e à identidade de um coletivo, e pode ser constituído por outros elementos além dos monumentos arquitetônicos, tais como os elementos simbólicos que representam a relação do ser humano com seu ambiente. Esses bens e elementos configuram uma herança e caracterizam um processo cultural através do qual é construída uma percepção da atualidade indissoluvelmente ligada ao território.

Entendendo o conceito de cultura, de acordo com a definição de Marilena Chauí, como um "duplo registro", um "sentido antropológico amplo de invenção coletiva e temporal de práticas, valores, símbolos e ideias que marcam a ruptura do humano em face das coisas naturais" (CHAUI, 1992, p. 39), em que a cultura é percebida como um dado ou um acontecimento, o homem deve ser, então, considerado um ser cultural.

A cultura corresponde a um trabalho, "entendendo por trabalho o movimento pelo qual os seres humanos são capazes de uma relação com o ausente e o possível, são capazes de negar as condições imediatas de sua experiência e são capazes de criar o novo como plenamente humano" (CHAUI, 1992, p. 39). Considera-se cultura, portanto, a criação das obras culturais - obras de pensamento e obras de arte - as quais são vistas como valor e avaliação do humano no mundo através de um trabalho que é reconhecido como cultural.

O conceito de patrimônio cultural é intangível, uma vez que se conecta ao universo da constituição do valor. $E$, ainda que esse valor não transcenda o bem em si, à medida que Ihe é atribuído significado pelos próprios homens em sociedade, também lhe é atribuída a representatividade como um signo significativo de culturas e civilizações, o que amplia o sentido das "raízes do valor" nessa sociedade.

A importância desta categoria está em que é pelo valor que, em nossa sociedade, bens materiais ou imateriais, práticas, hábitos, produtos tangíveis ou intangíveis da atividade humana são selecionados e investidos de uma significação específica plena de consequências, em vários níveis e escalas. O patrimônio cultural -- abstração que inclui tais bens marcados consciente ou inconscientemente por valores -- é constituído não pelas coisas materiais ou imateriais elas próprias, mas pelos valores de que elas 
são produto, vetor, suporte, referência, álibi, emblema etc. Portanto, discutir qualquer tópico no campo do patrimônio cultural é defrontar-se, desde o início e o tempo todo, com a problemática do valor. E como o valor não é imanente aos bens, não deriva deles automaticamente, não faz parte intrínseca dessas coisas, produtos e práticas, mas é instituído pelos homens em sociedade, segundo as mais variadas matrizes e contingências sociais, se quisermos entender o universo do patrimônio cultural é preciso entender, antes de mais nada, as raízes do valor na sociedade. Vale a pena, portanto, fixar alguns traços que permitem conceituar valor (MENESES, 2000, p. 29).

Segundo Meneses (2000), no âmbito do consentimento coletivo e da problemática de sua valorização, existem questões inerentes ao universo cultural e aos valores estabelecidos na sociedade que o reconhece como tal, e que resultam no próprio sentido e valor daquele bem. Assim, no conjunto de ações constitutivas de uma cultura relacionada à existência de um Estado-nação, a cultura nacional pode ser a origem determinante de seu significado, e imanente no processo de sua identificação em um sistema de interpretação complexo, na medida em que as ações de abstração e valorização transformam um bem em patrimônio.

Em conformidade com esse processo de ações constitutivas de uma cultura da existência de um Estado-nação, Jean-Pierre Warnier (2000, p. 102) afirma que as ações podem fazer parte de uma política cultural ligada a um projeto nacional, seja ele democrático ou imposto por uma minoria, inserido em um projeto ao mesmo tempo político, econômico e cultural. E, nesse processo, em que são selecionados e sobrepostos às camadas históricas alguns elementos culturais e históricos, ressaltam uma imagem e um determinado valor nessa sociedade.

Segundo González-Varas (2008, p. 341), o conceito de patrimônio moderno, no contexto urbano, ampliou sua abrangência, por meio de uma nova perspectiva de atribuição de significados. Essa visão patrimonial considera a importância da ideia de conjunto, uma vez que a interpretação dos bens também envolve o conhecimento de seus elementos dinâmicos históricos e culturais do lugar.

Tal visão corresponde a um conceito moderno de patrimônio urbano - à medida que ele adquire um sentido mais amplo, para além dos monumentos históricos, e é entendido como território -, em que recebem maior atenção as marcas visíveis da atividade humana em suas manifestações de cultura. Tais marcas trazem ao bem cultural um caráter de 
excelência, como um lugar de convivência e de intercâmbio cultural representado pelo território e pela cidade (GONZÁLEZ-VARAS, 2008, p. 341). Entretanto, na ausência dessa configuração de conjunto, rompe-se uma relação de significado com o território por conta de uma simplificação de seus signos representativos.

As definições sobre a abrangência do conceito de patrimônio foram muito discutidas conjuntamente a outros campos do conhecimento ${ }^{52}$, almejando abarcar a complexidade tanto das discussões que se apresentavam e que relacionavam a ideia de conjunto urbano aos bens patrimoniais da cidade, como das discussões sobre o crescimento das cidades. 0 arquiteto Roberto Pane ${ }^{53}$ afirmava, em meados do século $X X$, que o sentido desses bens se faz representar justamente por estarem juntos ("propio dal loro stare insieme ${ }^{54 ")}$ e por meio dessa relação é que eles podem ser definidos como bens culturais. Tal leitura do conjunto distingue a cidade moderna da concepção da cidade antiga e de sua figura museológica, que, segundo Choay (2010, p. 204), isola e retira suas obras históricas representativas do tecido urbano original, de modo a reduzir a sua própria historicidade e representatividade simbólica.

Essa visão inovadora e ampliada do ambiente urbano considera como bens culturais não apenas os monumentos históricos isolados, mas também os tecidos urbanos tradicionais representativos de signos de culturas e civilizações, tais como o território, a paisagem, as edificações e as vias de circulação da cidade. Ao reconhecer nesse ambiente a existência de relações de significância, passa-se a considerar a noção de patrimônio atrelada a um projeto mais amplo de conservação patrimonial na cidade.

Nesse processo de reconhecimento entre o homem e o patrimônio cultural urbano, o valor do bem ou dos conjuntos de bens deve ser identificado como o conjunto dos lugares, bairros, coleções ou práticas ${ }^{55}$ que uma sociedade herda de seu passado e que pretende

\footnotetext{
${ }^{52} \mathrm{Tal}$ como recomenda a Carta de Atenas, de 1931, em relação à ação de conservação do patrimônio arquitetônico e urbano, é necessária a colaboração de representantes de outros campos do conhecimento, tais como ciências físicas, químicas e naturais, arqueólogos e arquitetos (CARTA DE ATENAS, 1931).

${ }^{53}$ Ver: CASIELLO, 2010.

${ }^{54}$ Tradução nossa: próprio de eles estarem juntos.

${ }^{55}$ Esses conjuntos são caracterizados por esta pesquisa com patrimônio material e imaterial. Utilizouse a definição do Instituto do Patrimônio Histórico e Artístico Nacional do Brasil (IPHAN), segundo a qual os bens culturais imateriais estão relacionados aos saberes, às habilidades, às crenças, às práticas, ao modo de ser das pessoas, e o patrimônio material é um conjunto de bens culturais 80
} 
preservar e transmitir às gerações futuras. Uma vez classificado, tal bem pode requisitar sua conservação, sua valorização e sua preservação, por conta de representar a identidade e significado cultural e/ou da memória histórica do conjunto da população de determinados coletivos sociais nos seus âmbitos territoriais.

Torna-se imprescindível, então, definir o conceito atual de bem cultural, de acordo com a evolução desse conceito ao longo do tempo. Assim, este trabalho entende como patrimônio o conjunto de bens culturais cujo significado e importância estão centrados na relação de seus elementos históricos e culturais ${ }^{56} \mathrm{com}$ as suas próprias referências culturais, vistos como os elementos constituintes e representativos de uma civilização e do lugar.

Esse entendimento de bem cultural leva-nos a discutir alguns aspectos da conformação da cidade contemporânea, em que a produção do espaço urbano liga-se à questão do patrimônio cultural como elemento estratégico de reprodução do capital, inserido em um contexto de valorização capitalista no qual não prevalece um equilíbrio entre as ações de planejamento urbano da cidade e as ações de preservação dos bens culturais. Segundo David Harvey (2005, p. 222), tal processo segue uma lógica de produção da cidade contemporânea condicionada pela emergência de modos mais flexíveis de acumulação do capital e de transformações na organização do capitalismo, inseridos em uma ideologia neoliberal de globalização econômica.

No espaço urbano, o mercado capitalista está em contínua expansão, e a renda monopolista pode aumentar seu fluxo de renda em função do controle exclusivo sobre algum espaço ou mercadoria, direta ou indiretamente, comercializáveis (HARVEY, 2005, p.222). Assim adquiriu, nas últimas décadas, maior importância, tanto nacional quanto internacionalmente, o interesse pela "inovação cultural local" com a inserção dos bens culturais e com proteção ou reinvenção de tradições locais, vinculadas a uma ideia de "empreendedorismo urbano".

classificados segundo sua natureza: arqueológico, paisagístico e etnográfico; histórico; belas artes; e das artes aplicadas (IPHAN, 2016).

${ }^{56}$ Os elementos históricos e culturais de uma comunidade enquanto patrimônio, segundo a definição de Choay (2010, p. 11), constituem algo que se origina nas estruturas familiares, econômicas e jurídicas de uma sociedade estável, e que é enraizado no espaço e no tempo. 
O padrão de conduta na governança urbana que combina poderes estatais (local, metropolitano, regional, nacional ou supranacional), diversas formas organizacionais da sociedade civil (câmaras de comércio, sindicatos, igrejas, instituições educacionais e de pesquisa, grupos comunitários, ONGs etc.) e interesses privados (empresariais e individuais), formando coalizões para fomentar ou administrar o desenvolvimento urbano/regional de um tipo ou outro (HARVEY, 2005, p. 230).

No empreendedorismo urbano, segundo David Harvey, as políticas urbanas seguem uma visão planificada estrategicamente de maneira competitiva. As ações são conduzidas por uma coalizão entre interesses da iniciativa privada e poderes estatais de diferentes instâncias, entre instituições de pesquisa, de educação e de preservação do patrimônio e diversos atores da sociedade civil e do Poder Público.

Nessa dinâmica, as políticas urbanas comportam-se cada vez mais como agentes econômicos ao aplicar métodos do mercado financeiro. Essas políticas, quando combinadas ao planejamento estratégico, estão orientadas para a gestão empresarial das cidades, ou, segundo Harvey (2005), para o "empresariamento urbano". Busca-se, assim, orquestrar a "dinâmica do processo de investimento e a provisão de investimentos públicos chave, no lugar e tempo certos, para fomentar o êxito na competição interurbana e inter-regional" (HARVEY, 2005, p.231), em ações que são incorporadas à gestão do território e a estratégias de revalorização econômica.

Nestas estratégias, a cultura tornou-se um aspecto central na configuração urbana, em que a cidade é reconhecida como "cidade-empresa-cultural", segundo Otília Arantes (2000, p.16). Tal fenômeno é reconhecido como uma "via de mão única" por Carlos Vainer, a qual "vem sendo difundida (para dizer o menos) no Brasil e na América Latina pela ação combinada das agências de cooperação e instituições multilaterais (Banco Mundial, BID, Agência Habitat das Nações Unidas, PNUD etc.) e de consultores internacionais" (VAINER, 2000, p.8). Nossa pesquisa incorpora nessa lista a ação da UNESCO, filiada à ONU, combinada com consultores internacionais, a qual aciona de modo semelhante o "sucesso" de outras cidades e suas candidaturas a patrimônio mundial.

A produção de uma nova configuração do espaço urbano é, portanto, orientada por conceitos e técnicas do planejamento empresarial, "originalmente sistematizados na Harvard Business School, o planejamento estratégico, segundo seus defensores deve ser adotado pelos governos locais em razão de estarem as cidades submetidas às mesmas 
condições e desafios que as empresas" (VAINER, 2000, p. 76). Entretanto, essa teoria econômica da empresa desconsidera alguns aspectos do contexto socioeconômico, cultural e espacial da cidade.

O planejamento urbano da cidade contemporânea, em vez de ocupar-se em solucionar as questões de seu "crescimento desordenado, reprodução da força de trabalho, equipamentos de consumo coletivo, movimentos sociais urbanos, racionalização do uso do solo" (VAINER, 2000, p. 76), objetivará torná-la mais competitiva, e suas ações concentrarão investimentos para requalificá-la, angariando novos investimentos e a criação de espaços para o consumo.

Esse novo conceito de cidade demanda uma reconfiguração das funções dos governos locais: vende-se a cidade a partir de um projeto que implica na sua apropriação por "interesses empresariais globalizados e depende, em grande medida, do banimento da política e da eliminação do conflito e das condições de exercício da cidadania" (VAINER, 2000, p. 78). Idealiza-se o espaço público e tenta-se submetê-lo pela simplificação, reduzindo sua complexidade e domesticando o espaço.

\section{Processos de renovação urbana e o planejamento estratégico.}

Segundo Dumont (1995), a concorrência interurbana e inter-regional não é um fenômeno exclusivo do século XX, mas conheceu, no final desse século, uma nova dimensão com os meios de comunicação, com a revolução urbana e com uma volta ao urbanismo cultural. Essa nova dimensão possibilitou que iniciativas locais das cidades alcançassem uma escala global e vice-versa, trazendo uma série de contradições que a sua própria questão de escalas, locais e globais, pode proporcionar aos processos de renovação urbana.

Assim, conformam-se nas cidades processos de planejamento urbano que, segundo Benko (2000), seguem uma planificação estratégica orientada para o mercado. As intervenções em infraestrutura na cidade constituem-se sob o pretexto de requalificá-la, tornando-a mais atrativa para investimentos de capital, buscando valorizá-la economicamente. Esses processos são inseridos em um contexto de políticas urbanas que se comportam cada vez mais como agentes econômicos, ao aplicar métodos do mercado 
financeiro e ferramentas do Marketing Estratégico e City Marketing, ferramentas similares a de empresas.

Segundo Berg e Klink (1995), quando o planejamento urbano torna-se um "mercado urbano", os conceitos de Marketing Estratégico e City Marketing têm a finalidade de promover e de manter empregos. Essas estratégias buscam tornar a cidade mais atrativa como lugar de investimento ${ }^{57}$, de residência e como núcleo atrativo para visitantes. Neste contexto, "as cidades se comportam como agentes econômicos" (DUMONT, 1995), por meio de políticas que estão centradas, principalmente, na competitividade regional e, no caso de nossa pesquisa, numa escala também global, como uma forma de promoção e concorrência entre as cidades.

En aras de mantener su posición relativa y de no verse relegadas a la decadencia, los gobiernos locales y metropolitanos se ven obligados a adoptar estrategias globales de marketing urbano, muy entroncadas con las de tipo empresarial. Estas estrategias van encaminadas a hacer más atractiva la ciudad como lugar de inversión, de residencia y como núcleo de atracción de visitantes. La planificación estratégica, la cooperación entre ciudades, y la creación de redes intra e interregionales se convierten pues en elementos indispensables para guiar a la ciudad con éxito dentro de un «mercado urbano» (BERG; KLINK, 1995, p. 39).

As políticas urbanas têm sido concebidas a partir de uma competição interurbana e inter-regional e da necessidade de reelaboração das configurações locais e regionais, em virtude de sua participação nos mercados globais de produção e consumo.

Georges Benko (2000, p. 4) afirma que as ferramentas de Marketing Estratégico e City Marketing, utilizadas na criação de uma imagem da cidade, reproduzem, todavia, uma visão da cidade que, até certo ponto, pode ser divergente tanto para seus administradores, empresas e outras coletividades, quanto para a sua coletividade local, devido aos seus diferentes reconhecimentos, identificações e relações com a cidade. Esse processo de transformação da cultura configura uma "âncora identitária" da cidade e é definido por Otília Arantes (2000, p.14) como "políticas de image-making, na mais trivial acepção

\footnotetext{
${ }^{57}$ Algumas dessas estratégias correspondem à aplicação de mecanismos como isenção de impostos, infraestrutura urbana, distritos industriais, entre outros, vislumbrando como objetivo principal o investimento de capital na cidade.
} 
marqueteira da expressão, pois quem diz image-making está pensando, queira ou não, em políticas business-oriented, para não falar ainda em market-friendly".

Essa nova imagem da cidade é produzida segundo um sistema de simplificação e codificação que a torna mais facilmente apreensível, negociável, segundo uma ideia de consumo. Por essa razão, pode ser divergente em sua origem e significação, uma vez que não representa uma memória coletiva e não se origina de uma comunicação pública, de ações voluntárias e da história da coletividade local.

De acordo com Benko (2000, p.5), isso se dá como consequência de um sistema que tem o objetivo de garantir à cidade a identificação e o desenvolvimento tanto de uma vantagem competitiva a partir de elementos históricos e culturais, como da criação de uma imagem cultural do lugar. Essa imagem do lugar, ou nova imagem do lugar, corroboram para a configuração de espaços segundo uma lógica de generalização de suas formas de consumo e de visita, em ações de transformação de conjuntos patrimoniais em lugares turísticos (DELGADO, 2003).

Ainda segundo Otília Arantes (2000, p. 17), é possível chamar esse processo de requalificação cultural (termo utilizado pelos promotores desse modelo de produção do espaço urbano), ou de planejamento estratégico de um "culturalismo de mercado". Esse planejamento funciona como "um empreendimento de comunicação e promoção", viabilizado por uma "adequada política de image-making", necessária para promover um "produto inédito", configurado pela própria cidade.

A dinâmica das cidades contemporâneas conforma-se através da requalificação e da renovação da cidade, buscando torná-la mais atrativa para investimentos. Reforça-se sua posição no "mercado urbano", em que se têm aliado políticas de competitividade, as quais se desdobram em ações cujo mote é uma oferta econômica cada vez mais ampla, como, por exemplo, ações urbanas vinculadas ao patrimônio cultural.

Nesse contexto, os processos de patrimonialização a Patrimônio Mundial, em centros históricos, articulam-se a uma dinâmica de concorrência entre as cidades e à busca por ampliar suas relações econômicas mercantis. Neles, os papéis das políticas urbanas, da arquitetura e do urbanismo são reduzidos, em certa medida, à produção e à reprodução de imagens urbanas (MUÑOZ, 2005, p. 82), a partir de intervenções de renovação e de revitalização de áreas específicas da cidade, previamente selecionadas na estrutura urbana 
por serem consideradas mais suscetíveis a tais alterações, as quais são concebidas para uma valorização da cidade diante de um mercado global de cidades. É esse um processo paradoxal, na medida em que tal classificação passa a ser vista como um instrumento de legitimação cultural de determinados coletivos, nos quais, todavia, a amplitude do conceito de bem cultural lhe permite apresentar-se com pouca ou nenhuma clareza de abrangência e de delimitação (seja ela territorial ou de outro tipo), de ambiência e/ou de uma paisagem cultural.

Para tanto, citamos o manifesto ${ }^{58}$ crítico escrito por Beatriz Ramo ${ }^{59}$, intitulado "Preservation + UNESCO Study", sobre um projeto de intervenção em área protegida e classificada como patrimônio mundial pela $\mathrm{UNESCO}^{60}$, projeto que venceu um concurso, mas cuja execução não foi aprovada sob a acusação de que colocaria a cidade em risco de expulsão da lista do patrimônio mundial da UNESCO.

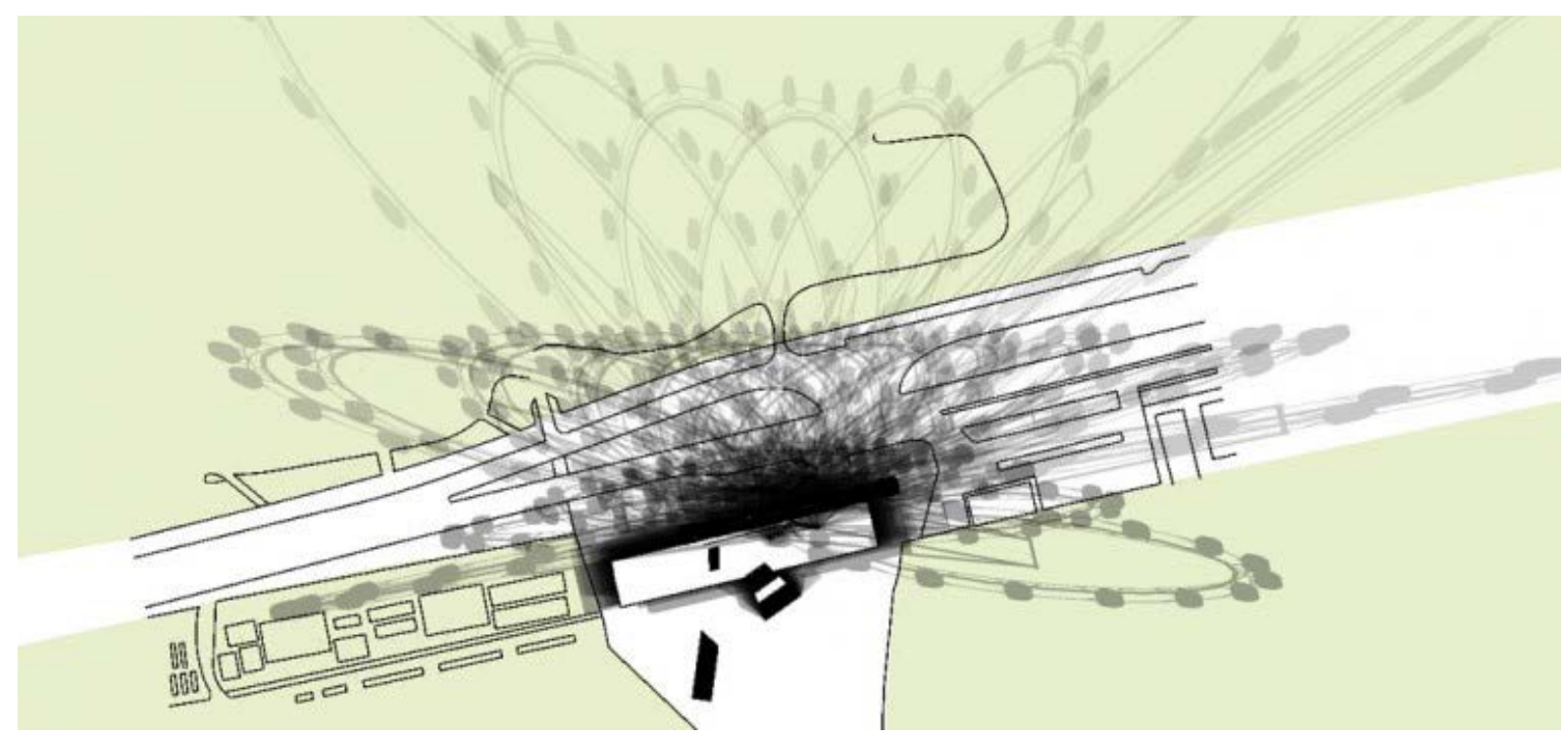

Imagem 5 - Estudo de imagem refletida em movimentos de rotação. Fonte da imagem: RAMO, 2012.

Esse manifesto sugere três pontos controversos no patrimônio tombado pela UNESCO: a definição dos critérios de classificação do patrimônio mundial, na sua

\footnotetext{
${ }^{58}$ Ver: RAMO, 2012.
}

${ }^{59}$ Beatriz Ramo é arquiteta e urbanista espanhola, titular do escritório STAR strategies + architecture, em Rotterdam (Holanda).

${ }^{60} \mathrm{Em}$ 2009, o escritório STAR ganhou a competição para o Mirante de Palmeiral, localizado próximo a um sítio patrimônio mundial pela UNESCO - "ou pelo menos na sua área interna" (RAMO, 2012) segundo o conceito de uma paisagem formada por plantações de palmeiras em Elche, na província de Valência (Espanha). 
compreensão do que é ser "universal", "único" e "excepcional"; a sua normativa e a suas diretrizes de conservação, as quais evidenciavam a dificuldade em se delimitar com precisão os limites de uma área classificada e de uma área de influência/entorno do bem cultural - tal como expõe a imagem refletida em movimentos de rotação; e a falta de clareza dos processos de avaliação de aprovação de projetos nas áreas patrimoniais.

Em relação à preservação dos centros históricos, Beatriz Ramo expressa sua preocupação com a difusão de uma "mania da conservação" promovida pela UNESCO, que, em nosso trabalho, percebemos tratar-se da difusão de um "modelo de conservação". Esse modelo apresenta contradições referentes à sua aplicação em um contexto local complexo. A aplicação de tal modelo pode remeter à criação de uma museologia dos sítios históricos na cidade, proporcionando uma "taxidermia total" dessas áreas da cidade.

A mania da conservação está difundindo-se como o uso do botox. O seu uso impróprio e tão incontrolado expõe seu usuário a graves riscos, se não a morte. Em muitos sítios chega-se a uma taxidermia total. Macabra ilusão de vida que em realidade representa a morte (RAMO, 2012). ${ }^{61}$

Esse manifesto fundamenta-se em uma leitura urbana dos centros históricos como uma área onde devem existir tanto atividades dinâmicas relacionadas à população quanto possibilidades de transformação urbanas e patrimoniais. Essa conotação, vista como vital e que traz uma expressividade natural ao lugar, segundo Beatriz Ramo (2012), é negligenciada com as ações do campo preservação que criam uma "ilusão de vida", tal como uma ilusão da realidade, e não permite a manutenção dessas práticas na cidade.

Assim, o manifesto questiona um conceito "complexo e contraditório" de conservação proposto pela UNESCO, o qual funcionaria como uma "drástica" ampliação da escala de atuação das ações de conservação e de proteção, desde monumentos antigos a conjuntos de paisagens culturais, e que permitiria que todos os lugares habitáveis do planeta fossem potencialmente considerados salvaguardáveis.

${ }^{61}$ Tradução nossa do original: "La mania della conservazione si sta diffondendo come l'uso del botulino. L'uso improprio e incontrollato di entrambi espone l'utente a gravirischi, se non alla morte. In molti siti si arriva alla tassidermia totale. Macabre illusioni di vita che in realtà rappresentano la morte"(RAMO, 2012). 
O manifesto critica ainda o pressuposto de que, segundo a lógica de preservação da UNESCO, não poderá jamais surgir o "novo" próximo aos monumentos protegidos. Em contraposição, Ramo propõe a criação de "reservas urbanas", como "áreas de proteção da conservação" nas cidades, "que serão para sempre destinadas a atividade, a transformações e a liberdade" (RAMO, 2012).

Salientamos que as justificativas de negação ou aprovação de novos projetos nas áreas protegidas podem estar relacionadas a interesses particulares que movem e promovem ações nessas áreas, que não seguem os preceitos do campo da preservação do patrimônio, embora sejam embasadas no conceito de preservação dos bens culturais.

Beatriz Ramo também salienta a existência de lacunas nos critérios específicos de nomeação dos bens culturais considerados mundiais e a demagogia que circunda o conceito de "patrimônio mundial". Tais questões despertaram o interesse de seu escritório em desenvolver um estudo crítico sobre a opinião pública em relação a vários aspectos dos processos de patrimonialização, tais como: a possibilidade de se realizarem novas intervenções nos sítios classificados com o título "patrimônio mundial"; o uso que a UNESCO tem feito desse título, ao atribuir um "marco de qualidade" a uma cidade ou a um sítio; e a possibilidade de exploração imprópria e, por vezes, oportunista desse título com a intenção de inibir novos desenvolvimentos urbanos no território.

A atribuição de um "marco de qualidade", como uma estratégia de valorização do patrimônio cultural, poderia ser definida, como assinalou Carlos Vainer (2000, p.8), como a reformulação de um conceito de patrimônio cultural como parte de um processo atrativo e de dinamização dos territórios, por meio da oferta de investimentos em infraestrutura urbana, em facilidades de licenciamento e, até mesmo, no financiamento para receber novos investimentos na cidade.

Essa estratégia de valorização do patrimônio busca, entre outras coisas, a intensificação de práticas de consumo e de visitação, através da oferta de espaços qualificados e renovados para o ócio e o lazer, e, portanto, mais interessantes e atrativos à indústria do turismo - o qual, por relacionar-se ao patrimônio, recebe a classificação, segundo o ICOMOS, de "turismo cultural"62.

\footnotetext{
${ }^{62}$ Este trabalho utiliza-se da definição de turismo cultural, segundo a Carta de Turismo Cultural de 1976 do ICOMOS, como "aquela forma de turismo que tem por objetivo, entre outros fins, o conhecimento de monumentos e sítios histórico-artísticos" (ICOMOS, 1976). 
No entanto, a sua valorização da gestão do território corresponde a uma estratégia de revalorização econômica das cidades e insere-se no processo de mercantilização e mundialização da cultura, em que novas dinâmicas espaciais surgem e rompem o vínculo com a memória. Esses processos expõem uma dialética quanto à construção da imagem patrimonial, "e que nos leva também a confundir história e memória, uma construção conceptual do tempo e do poder, inerente a nossa condição corporal, que mobiliza e estrutura a duração" (CHOAY, 2010, p.261). Empregamos, aqui, os conceitos de mercantilização e de mundialização da cultura segundo Jean-Pierre Warnier (2000): a cultura é apresentada como uma totalidade complexa do homem enquanto membro de uma sociedade baseado em suas capacidades e hábitos, constituindo características as quais não poderão ser transmitidas de maneira independente à própria sociedade que a fomenta; ou seja, as culturas são singulares, extraordinariamente diversas e localizadas.

Segundo Ortiz (2007), essa esfera do cultural não está sendo globalizada, mas sim mundializada, a partir de um mercado e de tecnologias globais, e inserida numa nova perspectiva mundial, a partir de um novo sistema corporativo e de propaganda que, aliado às novas tecnologias de comunicação, auxilia na criação de uma interculturalidade, que, todavia, não torna a cultura global.

Segundo Rem Koolhaas (2011), em seu texto "La Ciudad Genérica", desde o urbanismo da década de 1990 foi produzida uma cidade desconstituída de uma identidade própria, por meio da redução de suas diferenças sociais e culturais, tal como ele define o espaço urbano: "cidade genérica". Koolhaas entende que a identidade urbana da cidade é constituída de maneira dinâmica por suas condicionantes físicas, históricas e contextuais. Assim, no contexto da "cidade genérica", com seu próprio processo de criação particular, essas condicionantes foram dissolvidas e o seu contexto histórico e cultural foi "expulso", uma vez que não foi preservado nem valorizado, mas que teve seu conteúdo simplificado, ao se reproduzirem apenas alguns de seus signos históricos e culturais.

A pesar de su ausencia, la historia es la mayor preocupación, incluso la [mayor] industria, de la Ciudad Genérica. En los terrenos liberados, alrededor de las casuchas restauradas, se construyen aun más hoteles para recibir a turistas adicionales en proporción directa a la borradura del pasado. Su desaparición no tiene influencia alguna en sus números, o quizás 
sólo sea una urgencia de último minuto. El turismo ahora es independiente del destino [destination]... (KOOLHAAS, 2011).

A reprodução de apenas alguns elementos históricos ou culturais da cidade faz com que a "história" se concentre apenas em uma modesta presença física, em um complexo limitado, que pode ser visto como um serviço, tal como "casuchas restauradas". Nesse processo de construção da cidade genérica de Koolhaas, o entorno do conjunto patrimonial insere-se numa transformação do espaço urbano por meio de uma especialização econômica e funcional, com a construção de "hotéis para receber turistas adicionais", num processo de transformação do patrimônio histórico em um produto turístico.

Essa transformação remete ao aumento do índice de visitação turística de algumas cidades. Assim, embora ausente de sua história, tem alguns de seus elementos históricos e signos culturais reproduzidos pela lógica de produção do espaço para um consumo e um turismo estabelecidos de maneira independente de seu destino.

Calle 42: ostensiblemente, los lugares donde el pasado es preservado son en realidad los lugares donde el pasado más ha cambiado, es lo más distante - como si fuese visto a través del extremo equivocado de un telescopio - o incluso [ha sido] eliminado completamente (KOOLHAAS, 2011).

Portanto, esse processo de transformação do espaço, à medida que apaga o seu passado e a sua história, reduzindo culturalmente seus elementos significativos e representativos, está desconstituído de sentido e de sua memória coletiva com o lugar, embora seja centrado na cultura, como também afirma Otília Arantes (2000, p.16). Além do mais, ao ser inserido na lógica do consumo e da visitação, têm-se nele estabelecido atividades turísticas desvinculadas de algum contexto urbano específico, tornando-a uma atividade que, segundo esse ponto de vista, pode ser considerada desarticulada de seu destino enquanto lugar.

Assim, a partir de uma reflexão crítica sobre o papel que o patrimônio cultural desempenha na atualidade no processo de produção e reprodução do espaço urbano e na configuração do território, esta tese busca versar sobre a gestão do patrimônio, sua renovação e sua conservação, com base na análise de processos de patrimonialização. Consideramos tratar-se de uma questão que perpassa o tema do patrimônio e que está relacionada também à utilização do turismo para o consumo, sob a ótica da renovação 90 
urbana, atrelada a ações de recriação do espaço, as quais intensificam ou reduzem realidades complexas, como a produção de uma cidade estratificada socialmente e a definição de fronteiras de classe.

Questões da cidade contemporânea e a memória do lugar.

Como alguns desdobramentos no urbanismo, também se verifica que as políticas culturais e o planejamento para o desenvolvimento local estão subordinados a relações econômicas e mercantis em seus processos de reabilitação urbana e em ações de intervenção na cidade, o que configura os espaços segundo a lógica da generalização das formas de consumo e da visita.

Esse esvaziamento de significado dos lugares e das localidades cria um conceito de cidade contrário àquele sugerido por $\boldsymbol{A}$ cidade invisível, de Ítalo Calvino (1972). Essa obra apresenta uma reflexão sobre a visão da cidade e dos elementos que a conformam, em uma relação que remete à ideia de um conjunto, no qual qualquer um de seus elementos, ao ser isolado, tanto é suprimido de sua representatividade quanto desarticula o conjunto no qual estava inserido.

Logo, ao agregarem recordações dos acontecimentos passados naquele espaço, esses elementos ampliam o significado cultural daquele que experimenta a cidade. Entretanto, com a supressão de alguns elementos constituintes do tecido urbano da cidade, apaga-se o próprio registro de parte de sua história e reduzem-se suas relações e articulações conjuntas, tanto entre si quanto com a cidade, conformando, assim, um contexto urbano desconstituído de significado.

Em virtude de um processo de produção do espaço desarticulado de seu contexto urbano, têm-se desconstituído de significado algumas intervenções de reabilitação ou revitalização de centros históricos nas cidades nas últimas décadas. Isso se dá por ações relacionadas à conformação desses espaços, tais como, segundo Delgado (2011, p. 12), as intenções ideológicas regidas por intenções políticas, a codificação do espaço, a simplificação dele a partir do esvaziamento de sua complexidade e os paradoxos cognitivos que a caracterizam. Compreende-se, assim, um processo de manipulação da produção do 
espaço urbano que busca favorecer as formas de consumo programado e seu tempo de duração, e que apresenta reflexos no convívio social, nas atividades e nos usos desenvolvidos nestes espaços.

Tais são as questões que comparecem na análise dos estudos de caso deste trabalho. Os objetos patrimoniais que aqui estudamos estão inseridos em áreas centrais das cidades e, se por um lado são regidos por processos de patrimonialização que buscam classificá-los e protegê-los como bens culturais, por outro buscam angariar - através de investimentos na reabilitação e na recuperação deles e das áreas nas quais se inserem - novos investimentos públicos ou privados para a cidade e gerar lucro ao concentrar atividades de consumo.

Orquestra-se uma dinâmica de investimentos que gera novos investimentos, de acordo com Harvey (2005, p.231), "no lugar e tempos certos, para fomentar o êxito na competição interurbana e inter-regional", e que, nos casos estudados neste trabalho, gera uma concorrência também internacional. Durante as últimas décadas, verifica-se, nas políticas urbanas, um processo de "simplificação e festivalização" desses espaços patrimoniais, segundo Muñoz (2005, p.79), "concebidos com a prioridade de conseguir uma maior participação da cidade nos mercados globais da produção e consumo".

Muñoz reconhece e classifica três diferentes tipos de projetos de renovação urbana nas cidades ocidentais: intervenções em beira-mar (ou orlas), intervenções em antigas áreas industriais e intervenções em centros históricos. Tais projetos explicitam três processos que interagem entre si: a especialização econômica e funcional do território, a segregação morfológica dos ambientes urbanos e a tematização da paisagem. Reconfigura-se o patrimônio histórico como um produto turístico, como um espaço de consumo, e de maneira independente de seu contexto e articulações enquanto espaço.

Também apresenta, como um de seus desdobramentos, como já comentamos anteriormente, uma simplificação e uma codificação do espaço através de sua arquitetura, de seu desenho urbano e da manipulação de sua história, a partir da seleção de suas camadas e elementos, tais como fragmentos do passado. Justamente por essa razão, ao serem desarticulados de seu contexto, esses fragmentos permitem sua simplificação e um rápido entendimento, num processo de banalização muito semelhante ao apresentado pela publicidade turística. Permite-se, então, uma assimilação mais rápida do passado urbano e da realidade presente, apresentados em uma versão mais legível, menos complexa, desprovida de diferenças e de contradições cognitivas. 
Processos de Patrimonialização Mundial.

O significado da expressão processo de patrimonialização, em nosso trabalho, referese aos procedimentos e à operacionalização que transformam bens culturais materiais e imateriais em patrimônio protegido e exposto à exibição pública. É um processo de produção cultural e de preservação que envolve questões econômicas, políticas e sociais.

Em nossa investigação, ater-nos-emos a essas questões segundo uma perspectiva do espaço urbano da cidade em que se localiza o bem patrimonial. Segundo esse nosso entendimento, os processos de patrimonialização constituem um meio de reconhecimento, de identificação e de classificação de um bem como patrimônio cultural. Esses processos abrangem desde a questão da valorização do bem cultural, a sua idealização como tal, até a sua nomeação e a sua classificação.

Por meio desses processos de patrimonialização, os bens culturais podem demandar sua preservação, ancorados num consentimento coletivo reconhecido e baseado em instrumentos legítimos de proteção e salvaguarda de acordo com normativas e regulamentações específicas e distintas em cada Estado-nação. Nesse contexto, as políticas e as atividades culturais implicam questões de direito nas quais a legislação perfaz diversas finalidades, fornecendo uma base jurídica às sociedades que têm fins culturais quanto à conservação dos sítios e do patrimônio (SILVA, 2003, p. 58).

\begin{abstract}
A eleição de patrimônios mundiais não implicou na criação de um coletivo que tivesse uma identidade "mundial" ou "global", e nem mesmo foi significativa para o desenvolvimento de nações mais carentes de recursos. Ao contrário, acirrou a disputa entre diversas nações ou cidades por ganhos políticos ou comerciais, consolidando ou mesmo reforçando hierarquias existentes. Por um lado, o procedimento da Convenção de 1972, ao fazer repousar sobre os Estados nacionais a responsabilidade de elaboração de uma lista indicativa a partir da qual seriam selecionados os bens do patrimônio mundial, acentuou esta disputa. Por outro lado, o crescente protagonismo das cidades enquanto agentes de políticas públicas contribuiu para instigar a contenda e fazer emergir fenômenos de escalada no domínio da dramatização do patrimônio (PEIXOTO, 2010, p. 7).
\end{abstract}

Atualmente, diante de um conceito de histeria patrimonial (PEIXOTO, 2010), com o extenso uso do conceito e da noção de patrimônio nos mais diversos discursos, a busca 
desenfreada por alguma forma de patrimônio nas comunidades está diretamente associada aos conceitos de fragmentação e de mercantilização da cultura.

Assim, "a normatização das políticas preservacionistas por fóruns da $\operatorname{UNESCO}^{63}$ (...) criou uma nova dinâmica e remeteu o patrimônio para a esfera da circulação global de valores, signos e mercadorias" (PEIXOTO, 2010, p. 1). Embora essas políticas públicas se amparem na busca pela preservação de um patrimônio dito nacional, como ressalta Peixoto (2010), elas acabam distanciando-se dos Estados nacionais, quando se investem de estratégias de revalorização do território, a partir de um discurso que filtre sua leitura e permita possíveis "traduções" de seus sentidos.

A questão dos processos de patrimonialização mundial permite que reflitamos sobre a valorização e sobre a criação de uma identidade territorial por meio da seleção de elementos culturais que fortaleçam uma imagem a qual se busca preservar e conservar. Essa criação de uma identidade e de "políticas (urbanas) de matriz identitária" (ARANTES, 2000, p. 14) permite-nos questionar a legitimidade daqueles processos em relação à memória identitária coletiva da cidade e de suas referências culturais diante da efetiva participação da população local nas decisões.

Pode-se, ainda, considerar o papel de alguns organismos de assistência e cooperação internacional de proteção ao patrimônio cultural e de instituições multilaterais na disseminação de um novo modelo de gestão urbana, como, por exemplo, a UNESCO, ao reger classificações de Patrimônio Mundial aos bens culturais urbanos segundo a justificativa de sua singularidade e autenticidade, como qualidades excepcionais deles. Cria-se, assim, uma disputa por esse reconhecimento por parte das cidades, pela nomeação de sua cultura e de suas tradições locais, sejam elas reais, idealizadas ou inventadas. Almeja-se a venda da cultura como uma mercadoria e sua promoção em uma escala global, por meio da própria publicidade oferecida pelo reconhecimento dispensado pela UNESCO.

${ }^{63} \mathrm{Em}$ 1972, os países-membros da UNESCO referendaram a petição intitulada "Convenção para a Proteção do Patrimônio Cultural e Natural do Mundo". Na petição ficou proposta a proteção de monumentos, construções, lugares arqueológicos, assim como de formações físicas ou biológicas, que tivessem um valor universal e excepcional, tanto do ponto de vista estético como científico. Essa política de preservação dava continuidade às preocupações já presentes em Conferências Europeias sobre Políticas Culturais (Veneza, 1970, e Helsinki, 1972) em conter as consequências do colonialismo sobre culturas nacionais e em combater o racismo e proteger as culturas nacionais do então chamado "neo-colonialismo". 
Como uma das consequências desse método de dissolução das condicionantes físicas, históricas e contextuais da cidade, de acordo com Muñoz (2010, p. 81), surge a produção de espaços urbanos considerados de indiferentismo. Esses espaços são reconhecidos, principalmente, diante das desarticulações de algumas intervenções de reabilitação e renovação de portos antigos ou centros históricos com o seu contexto local e com a cidade. Conforma-se uma relação que - embora tenha sido estabelecida em espaços distintos e singulares, quando originalmente eram articulados ao seu contexto local, através do desenvolvimento de atividades específicas do lugar - suprime seu significado ao restabelecer novos usos e atividades, e ao reduzir seus elementos e signos culturais.

Tal processo permite aproximações comparativas a outras intervenções de reabilitação e renovação de conjuntos patrimoniais urbanos, não só ao apresentar uma correspondência dos novos usos e da ocupação de seus espaços, como também ao estar inserido em uma lógica de simplificação de sua imagem e de sua codificação. Essa conformação de uma paisagem urbana aproxima-se de um discurso iconográfico estabelecido em algumas simples imagens que são reproduzidas (MUÑOZ, 2010, p. 80), tal como um produto midiático, facilmente consumido pelo visitante.

Reconhecemos essa paisagem como a de uma imagem passadista, que tem sido verificada, em maior ou menor medida, nas áreas protegidas dos estudos de caso estabelecidos neste trabalho. A presença desse conceito de concepção da paisagem foi verificada nas consideradas áreas adjacentes das áreas protegidas como patrimônio - fora da área de limite do tombamento do bem cultural, mas constituinte de sua área adjacente e de sua paisagem como um conjunto. Essas áreas de "borda" apresentam diretrizes menos rígidas de intervenção, que proporcionam novas ocupações e usos do espaço, como renovações construtivas, de modo a proporcionar a estruturação de novos espaços de ócio e de lazer.

Essas áreas também apresentam a preocupação com preservar a identidade e a integridade patrimonial do conjunto, resguardadas por diretrizes protetoras as quais esta pesquisa considera mais amplas e gerais, na medida em que permitem a incorporação de novas atividades e elementos no lugar. Não obstante, são áreas apropriadas por investidores seletos, que buscam concentrar nelas espaços de consumo dirigido a um público também seleto. Reconhece-se ainda nessas áreas uma falta de clareza em relação à definição não 
apenas dos limites da área protegida, mas também de suas possibilidades de intervenção urbana e construtiva.

Ressalta-se, também, a existência de diferentes classificações e nomeações de seus conjuntos urbanos históricos, em relação a sua área de proteção. Reconhecem-se, então, diferentes nomeações de bens adjacentes uns aos outros, os quais têm relações entre si e com a cidade, e que são inseridos em um plano regulador geral de proteção, ou em uma visão única e de totalidade, e que se justificam enquanto uma ideia de conjunto. Numa relação conflituosa na gestão do patrimônio e nas suas relações com o urbanismo, não permitem uma apreensão clara e única da percepção dos limites de sua área de proteção.

É justamente nesses conflitos que esta pesquisa verifica a desarticulação de alguns projetos de renovação e de reabilitação urbana em relação a seu contexto local e à cidade, o que, portanto, corrobora para desconstrução do significado urbano desses bens.

Também reconhecemos, em algumas dessas intervenções, uma contradição na escala cultural do local, que rompe suas relações com as atividades culturais tradicionais do lugar e da cidade. Essa nova escala cultural expõe relações estabelecidas em outro ritmo temporal, à medida que são oferecidos diferentes usos e ocupações do espaço, regidos por uma nova arquitetura e por um novo urbanismo, os quais reduzem as suas especificidades socioespaciais e seus atributos como uma localidade específica, portanto, como uma identidade urbana.

Logo, ao desconsiderar suas condicionantes e seu contexto, tal espaço é suprimido de seus símbolos culturais e valores comuns, que constituem, segundo Manuel Delgado (2003, p. 123), um fator de reconhecimento e identificação do homem com uma cultural local, ou seja, com seu espaço urbano, compartilhado por uma comunidade. E, ainda, conforma uma nova paisagem cultural desvinculada do local, em um entendimento de paisagem urbana como um "fator resultante do lugar, a partir das traduções de suas relações sociais e culturais" (Muñoz, 2010, p. 51).

Assim, esse processo é contraditório exatamente porque estabelece uma ideia de cultura segundo alegações do singular, da autenticidade, do distintivo e do irreplicável (HARVEY, 2005, p. 227), valores que se contrapõem a essa mesma cultura local ao renunciar à sua diversificação funcional e humana. Ao estabelecer grandes processos de especialização de centros históricos dos quais a história foi suprimida, verificam-se dinâmicas que conformam uma dissolução do urbano em mera urbanização, tal como uma submissão sem 
resistência, ou, quando houve resistência, esta não foi suficiente para proteger aquele espaço dos imperativos das distintas ideologias urbanísticas.

As manifestações culturais e o espaço urbano patrimonial.

Em relação à ideia de reordenamento de sítios históricos urbanos, o que está em jogo não é apenas a proteção de determinados bens, mas o conflito entre interesses distintos, entre o setor privado, grupos políticos e a população local, além das interferências e de suas intensidades no contexto local. Fazem-se necessárias metodologias de conhecimento do sítio que garantam legitimidade às interpretações e às atuações no campo da preservação, numa tentativa de reconhecimento mais amplo do bem cultural e de seus aspectos socioculturais em relação a sua população local, orientando as intervenções nesse espaço.

No contexto brasileiro, as abordagens da preservação dos bens culturais foram ampliadas desde os anos de 1970, incorporando o conceito de referências culturais (FONSECA, 2000, p. 84). A ideia de referência procurava sustentar a formulação e a implementação de políticas de patrimônio como um conhecimento auxiliar, e incluía também manifestações culturais representativas de coletivos, de modo a permitir a recomposição de seus valores e funções, além de sua representação material e simbólica. Dessa forma, a reformulação dos conceitos relacionados ao bem cultural configura novas tentativas de redefinições do campo de ação e de aproximação cultural no interior das disciplinas arquitetônicas e urbanísticas.

Do ponto de vista da cultura, considerar apenas uma concentração, em uma determinada área, de um número significativo de monumentos excepcionais, de algum modo a "desvitaliza", uma vez que se deixa de apreender, em toda a sua complexidade, a dinâmica de ocupação e de uso daquele espaço (FONSECA, 2000, p. 86). Nesse sentido, Maria Cecília Londres Fonseca considera como solo cultivado regiões que têm cultura (história e tradições) inscrita nelas, e que o ato da intervenção, mesmo que seja com o objetivo de "preservar o patrimônio", implica uma reorientação do uso desse solo.

Assim, consideramos importante salientar o vínculo das referências culturais no espaço patrimonial, pois elas podem ser mais representativas do que o valor histórico e 
artístico dos bens. Essas referências culturais, aliadas a um ambiente e a um conjunto de construções, expõem o processo cultural e a maneira como determinados sujeitos ocupam aquele solo, utilizam e valorizam os recursos existentes, como constroem sua história, como produzem edificações e objetos, conhecimentos, usos e costumes (FONSECA, 2000, p. 86).

A interferência no significado e na identidade coletiva do lugar pode acontecer devido à disputa e ao conflito de interesses presentes no processo de produção do espaço urbano. Essa produção, no contexto do patrimônio cultural, pode ser condicionada por relações econômicas mercantis nas quais o patrimônio e a cultura são vistos como um elemento estratégico de reprodução do capital.

Essa visão está presente nas políticas públicas concebidas a partir de uma competição interurbana e inter-regional entre as cidades. O fenômeno permite a supressão de alguns de seus elementos históricos que agregam recordações dos acontecimentos passados naquele espaço, configurando na cidade espaços simplificados de signos e, portanto, de significado. Tais processos de reelaboração das configurações locais e regionais podem adquirir uma escala de comunicação social, pública e de massa, tal como uma política cultural, agregando-lhe um outro valor e um novo significado.

Assim, observa-se uma reconfiguração e uma refuncionalização do patrimônio histórico como um produto turístico. Tais interferências no espaço urbano se fazem de modo a transformar e reordenar o espaço para a indústria do turismo e para o consumo, criando atividades de uso que podem ser reconhecidas como independentes de seu contexto e do local.

Essa interferência perpassa a matéria histórica, envolvendo questões culturais, sociais, econômicas e políticas do presente e do futuro, numa busca da identidade em lugares tematizados, e na tentativa de tradução de suas relações sociais e culturais. Assim, torna-se fundamental compreender e analisar quais são as medidas de proteção e o conceito de salvaguarda desses bens em escala local, nacional e internacional, quando essas medidas são estabelecidas por organizações de proteção ao patrimônio, e como elas se associam, ou não, a processos de tematização do espaço urbano e de sua memória.

Do ponto de vista da cultura, se essa proteção preservacionista em uma determinada área considera apenas a existência ou a concentração de um número significativo de monumentos físicos e materiais excepcionais isolados, deixa-se não apenas de apreender toda a complexidade do território, a sua dinâmica de ocupação e o uso daquele espaço, mas 
também de permitir uma ruptura do conjunto patrimonial a partir do arrefecimento de sua imagem enquanto paisagem cultural.

Logo, ao agregarem recordações dos acontecimentos passados naquele espaço, os elementos simbólicos ampliam o significado cultural daquele que experiencia a cidade. Entretanto, com a supressão de elementos constituintes do tecido urbano da cidade, sejam eles elementos físicos ou elementos oriundos da ambiência e dos atores urbanos, apaga-se o próprio registro de parte de sua história e são reduzidas as suas relações e as suas articulações, tanto entre si quanto com a cidade, conformando, assim, um contexto urbano desconstituído de sentido e de significado. 


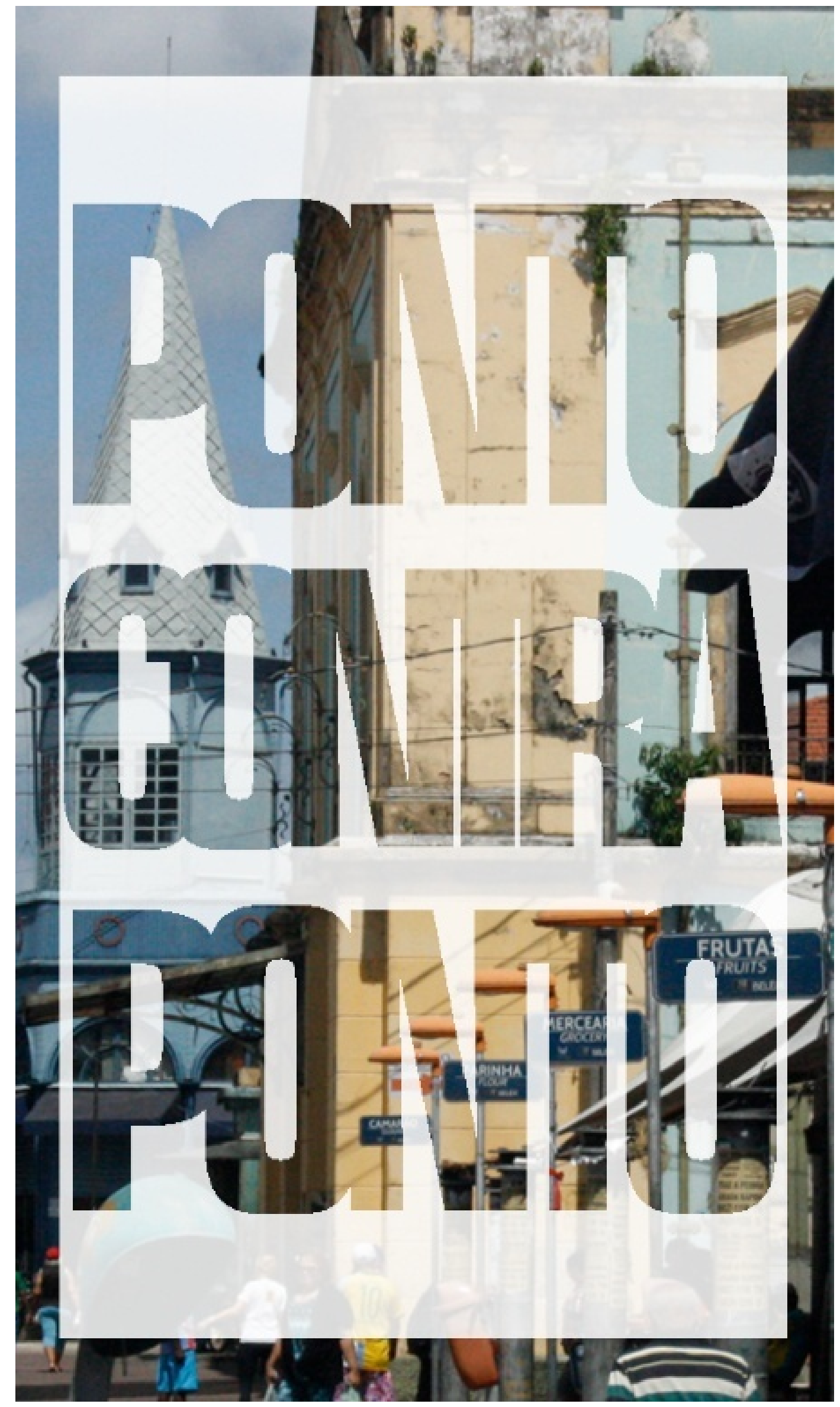




\section{IMAGEM DE CAPA DO CAPÍTULO}

Montagem feita a partir de foto capturada pela autora em julho de 2016, durante as atividades de pesquisa em campo na cidade de Belém, no período que compreende o desenvolvimento desta tese. A imagem mostra uma parte do conjunto candidato a patrimônio mundial e alguns de seus bens culturais: a Feira Livre do Ver-o-Peso, com sua padronização e setorização; o edifício do Solar da Beira e sua ausência de conservação; e, ao fundo, uma das torres do edifício do mercado de peixe. 


\section{PONTO E CONTRAPONTO - ESTUDOS DE CASO}

Este trabalho aborda comparativamente, no campo da preservação do patrimônio, uma realidade brasileira e outra internacional - no caso, portuguesa -, que lhe é culturalmente próxima. Verifica um processo globalizado de produção do espaço urbano, atrelado a uma classificação regulamentada por um organismo intergovernamental e multilateral de preservação do patrimônio.

Vale salientar que nossa análise se refere a processos em andamento, e que, para essa abordagem, faz-se necessária uma organização das informações obtidas mediante o estabelecimento de um ponto final do campo empírico. A organização das informações nos permitirá problematizar algumas frentes em detrimento de outras, devido à própria dificuldade apresentada pelo levantamento de dados e pela organização deles.

Para o desenvolvimento de nossas reflexões, elegemos algumas intervenções urbanas, reconhecidas por esta pesquisa como atreladas a um consumo mercantil da cidade. Tal medida conduziu à dissolução das relações de identidade e de cultura do próprio lugar, e nos expôs algumas contradições da preservação do patrimônio com o seu contexto local.

Os processos aqui investigados fazem parte de um domínio específico da produção do espaço urbano, em áreas patrimoniais centrais da cidade contemporânea. Como uma consequência de suas candidaturas a patrimônio, essas áreas passam por definições ou redefinições dos limites de suas áreas protegidas e de suas áreas de entorno a serem preservadas como patrimônio, e que caracterizam a paisagem cultural daqueles espaços urbanos. Essas (re) definições da área a ser protegida e preservada estão em alguma medida articuladas entre os órgãos de preservação nacional, em suas diferentes instâncias, e os órgãos de planejamento urbano da cidade, por meio de zoneamentos específicos regulamentados por legislações nacionais, estaduais e/ou municipais.

Outros aspectos importantes são as intervenções urbanas relacionadas a esses processos de patrimonialização e a gestão do bem cultural candidato. Esses dois aspectos podem ocorrer de modo compartilhado entre o poder público e o privado, ou de modo não compartilhado. 
Assim, esta pesquisa utilizou, como fonte primária de dados, os documentos de intenção de candidatura a patrimônio mundial apresentados à UNESCO: o documento de intenção - no caso brasileiro - e o dossiê científico de intenção - no caso português.

Desenvolveu-se uma análise, nos dois países, da situação atual dos acordos internacionais de classificação a patrimonial mundial, de suas intenções de candidatura a essa classificação, de suas políticas nacionais de preservação do patrimônio e de suas intervenções no espaço urbano relacionadas a cada bem cultural objeto de análise. Os dados foram sistematizados cronologicamente de modo organizado apenas no estudo de caso brasileiro, por tratar-se do principal objeto de estudo desta pesquisa. Sua análise foi aprofundada e nos permitiu algumas reflexões comparativamente ao contraponto internacional. Tais reflexões comparecerão neste capítulo e nas considerações finais do trabalho.

\section{A definição dos objetos de estudo.}

Os dois estudos de caso definidos para este trabalho são: Ver-o-Peso (cidade de Belém, Brasil) e a Universidade de Coimbra (cidade de Coimbra, Portugal). Esses dois conjuntos urbanos de bens culturais foram vistos como possibilidades de entendimento dos processos de patrimonialização pela UNESCO, a partir de suas nomeações à Lista Indicativa a Patrimônio Mundial.

O contraponto internacional, o bem cultural da Universidade de Coimbra ${ }^{64}$, foi definido logo no primeiro ano desta pesquisa ${ }^{65}$, devido ao interesse por verificar a atuação de agências e organismos internacionais de proteção e preservação do patrimônio. Isso permitiu formular algumas reflexões sobre a atual busca por algum tipo de patrimônio que seja único e singular. Essa singularidade pode ser as "qualidades especiais", segundo a definição de Harvey (2005, p. 223): os atributos do espaço urbano que podem torná-lo negociável pelas cidades.

\footnotetext{
${ }^{64}$ Consideramos o processo de classificação da Universidade de Coimbra, tal como foi estruturado segundo seu dossiê, um processo iniciado em 2004 e finalizado em 2013, com a sua classificação como patrimônio mundial pela UNESCO.

${ }^{65}$ Início da pesquisa concomitante com o ingresso no programa de doutorado, em 2011. 
Em um segundo momento da pesquisa ${ }^{66}$, mediante a possibilidade da análise de algumas cidades brasileiras ${ }^{67}$ e de seus bens culturais candidatos, a eleição de nosso segundo estudo de caso orientou-se por informações e critérios específicos da Convenção do Patrimônio Mundial da UNESCO ${ }^{68}$ no contexto de conjuntos urbanos no Brasil.

Essa comparação foi seguida de um cruzamento de dados entre os critérios dessa Convenção e os critérios de indicação da Universidade de Coimbra. Esse cruzamento originou quadros comparativos dos bens já classificados como patrimônio mundial em Portugal e no Brasil $^{69}$ e de suas Listas Indicativas ${ }^{70}$ naquele momento ${ }^{71}$. Vale salientar que, desde o ano de 2013, a Universidade de Coimbra já havia sido classificada como patrimônio mundial pela UNESCO.

O objeto de estudo brasileiro foi eleito por meio da comparação dos quadros originados e segundo o maior número de semelhanças dos critérios de nomeação e classificação com o bem cultural da Universidade de Coimbra. Tal escolha do bem cultural

${ }^{66} \mathrm{~A}$ definição do segundo objeto de estudo aconteceu mediante as interlocuções ocorridas, em 2014, com o Prof. Manoel Rodrigues Alves e com a sua doutoranda, a professora e pesquisadora Jéssika Paiva França, da Universidade Federal do Pará (UFPA). Essa pesquisadora atualmente desenvolve uma pesquisa intitulada "Aspectos de Conformação do Espaço Público de Lazer e Turismo Portal da Amazônia", centrada na cidade de Belém (Brasil). Por meio de sua pesquisa, verificou-se um interessante caso de estudo brasileiro, que possibilitaria a análise de um processo de patrimonialização em Belém com a recente candidatura de Ver-o-Peso a patrimônio mundial.

${ }^{67} \mathrm{As}$ possíveis cidades e seus bens culturais que foram considerados como possíveis objetos de estudo naquele momento eram Belém e Belo Horizonte, em razão de seus bens culturais candidatos serem conjuntos de bens culturais materiais urbanos e brasileiros.

${ }^{68}$ Convenção Relativa à Proteção do Patrimônio Mundial, Cultural e Natural, de 1972, Id., artigos $1^{\circ} \mathrm{e}$ 11, parágrafo $2^{\circ}$; Diretrizes, parágrafo 24, alínea a itens i a vi, parágrafo 24; UNESCO, 2016.

${ }^{69} \mathrm{~A}$ intenção de trazer todos os bens culturais que compareceram nesse processo é contextualizar o número de cidades com a mesma classificação e reconhecimento desta pesquisa, mas cujos critérios de nomeação são distintos, ou cujos processos de patrimonialização não são considerados recentes em Portugal e no Brasil.

${ }^{70}$ As Listas Indicativas (Tentative Lists) são consideradas um inventário dos Estados Nação em que consta um conjunto de indicações de bens culturais apresentados pelos Estados Nação. Esses bens são nomeados, segundo um entendimento de patrimônio de valor excepcional universal, como elegíveis à classificação como patrimônio mundial pela UNESCO, e com a intenção de que sejam inscritos na Lista do Patrimônio Mundial (World Heritage List). Nesse processo, que corresponde a uma etapa obrigatória para inscrição na Lista do Patrimônio Mundial, os Estados são encorajados a preparar suas Listas com a participação de uma ampla variedade de especialistas, pesquisadores e Instituições relacionados ao tema em questão (UNESCO, 2016).

${ }^{71}$ A cidade de Belo Horizonte foi considerada elegível, naquele momento, devido ao seu estágio ainda como candidata por meio de seu bem cultural, o Conjunto Moderno da Pampulha (Pampulha Modern Ensemble), que foi classificado em 2016 pela UNESCO. 
Ver-o-Peso fundamentou-se na igualdade de critérios específicos considerados de valor excepcional, e propôs um questionamento sobre como cada um dos critérios foi considerado em contextos culturais distintos.

Para uma apreciação mais detalhada dessa seleção, segue abaixo o quadro comparativa com os bens culturais classificados como patrimônio mundial segundo a UNESCO, em Portugal. 


\begin{tabular}{|c|c|c|c|c|c|c|c|c|c|c|c|c|}
\hline \multicolumn{13}{|c|}{ QUADRO COMPARATIVO DO PATRIMÔNIO MUNDIAL EM PORTUGAL SEGUNDO A UNESCO } \\
\hline & \multirow{2}{*}{ ANO } & \multirow{2}{*}{ CONJUNTOS URBANOS } & \multicolumn{10}{|c|}{ CRITÉRIOS DE VALOR EXCEPCIONAL } \\
\hline & & & $\mathrm{i}$ & li & iii & iv & v & vi & vii & viii & ix & $x$ \\
\hline 1 & 1983 & $\begin{array}{c}\text { Centro Histórico de Angra do } \\
\text { Heroísmo (Açores) }\end{array}$ & & & & & & & & & & \\
\hline 2 & 1986 & Centro Histórico de Évora (Évora) & & & & & & & & & & \\
\hline 3 & 1995 & $\begin{array}{l}\text { Paisagem Cultural de Sintra } \\
\text { (Sintra) }\end{array}$ & & & & & & & & & & \\
\hline 4 & 1996 & Centro Histórico do Porto (Porto) & & & & & & & & & & \\
\hline 5 & 2001 & $\begin{array}{l}\text { Centro Histórico de Guimarães } \\
\text { (Guimarães) }\end{array}$ & & & & & & & & & & \\
\hline 6 & 2004 & $\begin{array}{l}\text { Paisagem da Cultura da Vinha da } \\
\text { Ilha do Pico (Açores) }\end{array}$ & & & & & & & & & & \\
\hline 7 & 2012 & $\begin{array}{l}\text { Cidade Fronteiriça e de } \\
\text { Guarnição de Elvas e as suas } \\
\text { Fortificações (Elvas) }\end{array}$ & & & & & & & & & & \\
\hline 8 & 2013 & $\begin{array}{l}\text { Universidade de Coimbra, Alta e } \\
\text { Sofia }\end{array}$ & & & & & & & & & & \\
\hline
\end{tabular}

Quadro 2 - Quadro comparativo dos bens de conjuntos urbanos classificados como patrimônio mundial em Portugal, segundo a UNESCO. Fonte: autoria própria e tradução nossa (UNESCO, 2014).

Do quadro, pode-se verificar que o bem cultural da Universidade de Coimbra apresenta quatro critérios de valor excepcional de inscrição na Lista do Patrimônio Mundial. Para uma melhor compreensão dos parâmetros estabelecidos nas Diretrizes da Convenção da UNESCO, seguem abaixo suas descrições, com um grifo nosso dos critérios dos bens culturais objetos de análise do trabalho:

(i) - Representar uma obra-prima do gênio criador humano;

(ii) - Testemunhar um importante intercâmbio de valores humanos durante um certo período ou numa área cultural determinada do mundo, sobre o desenvolvimento da arquitetura ou tecnologia, das artes monumentais, da planificação das cidades ou da criação de paisagens;

(iii) - Sustentar um testemunho único ou pelo menos excepcional sobre uma tradição cultural ou uma civilização a qual está viva ou que 
desapareceu;

(iv) - Constituir um exemplo excepcional de um tipo de edifício, conjunto arquitetônico ou tecnológico ou de paisagem que ilustra (um) significante período (s) na história da humanidade;

(v) - Constituir um exemplo excepcional de ocupação tradicional humana, uso da terra, ou uso do mar que é representativo de uma cultura (ou culturas), ou interação humana com o meio ambiente, especialmente quando ele se torna vulnerável sob um impacto de irreversível alteração;

(vi) - Estar diretamente ou tangivelmente associado a acontecimentos ou a tradições vivas, a ideias, ou com crenças, com obras artísticas e literárias de significado universal excepcional. (O Comitê considera que este critério deveria preferencialmente ser utilizado conjuntamente a outro critério);

(vii) - Conter fenômenos naturais extremos ou áreas naturais de excepcional beleza e importância estética;

(viii) - Constituir exemplos excepcionais representativos das principais fases da história da Terra, incluindo o registro da vida, significativos processos geológicos em curso no desenvolvimento de acidentes geográficos, ou características geomorfológicas ou fisiográficas significantes;

(ix) - Constituir exemplos excepcionais representativos de processos ecológicos e biológicos significativos em curso na evolução e desenvolvimento de ecossistemas e comunidades de plantas e animais terrestres, água fresca, costeiros e marinhos;

$(x)$ - Conter os mais importantes e significativos habitats naturais para a conservação in-situ da diversidade biológica, incluindo aqueles que contenham espécies ameaçadas de valor universal excepcional do ponto de vista da ciência da conservação (UNESCO, 2016).

Para uma apreciação mais detalhada dessa seleção, segue abaixo o quadro comparativo com os bens culturais brasileiros indicados e, portanto, candidatos a patrimônio mundial segundo a UNESCO.

\begin{tabular}{|c|c|c|c|c|c|c|c|c|c|c|c|c|}
\hline & \multicolumn{12}{|c|}{ QUADRO COMPARATIVA DO PATRIMÔNIO MUNDIAL NO BRASIL SEGUNDO A UNESCO } \\
\hline & \multirow{2}{*}{ ANO } & \multirow{2}{*}{ CONJUNTOS URBANOS } & \multicolumn{10}{|c|}{ CRITÉRIOS DE VALOR EXCEPCIONAL } \\
\hline & & & $\mathrm{i}$ & ii & iii & iv & $\mathrm{v}$ & vi & vii & viii & ix & $\mathrm{x}$ \\
\hline 1 & 1996 & Conjunto Moderno da Pampulha & & & & & & & & & & \\
\hline 2 & 2014 & Ver-o-Peso & & & & & & & & & & \\
\hline
\end{tabular}

Quadro 3 - Quadro comparativa dos bens de conjuntos urbanos candidatos na lista indicativa a patrimônio mundial no Brasil, segundo a UNESCO. Fonte: elaboração e tradução nossa (UNESCO, 2014). 
Reconhecemos a dificuldade de serem estabelecidas comparações entre dois países de estruturas administrativas diferentes, cujos patrimônios culturais não apresentam as mesmas características e cujas legislações, origem de toda ação política, estão fundamentadas em bases que não são idênticas. Não obstante isso, acreditamos que nossa pesquisa permite formulações sobre a problemática no mundo contemporâneo e a lógica da produção do espaço urbano, com as devidas reservas, tomando como ponto de partida uma reflexão sobre os princípios gerais adotados, seus agentes, as ações do Estado, seus desdobramentos no campo da proteção, no campo da preservação, no conceito de patrimônio e na formulação de políticas públicas.

QUADRO COMPARATIVA DO PATRIMÔNIO MUNDIAL NO BRASIL SEGUNDO A UNESCO

\begin{tabular}{|c|c|c|c|c|c|c|c|c|c|c|c|c|}
\hline & \multirow{2}{*}{ ANO } & \multirow{2}{*}{ CONJUNTOS URBANOS } & \multicolumn{10}{|c|}{ CRITÉRIOS DE VALOR EXCEPCIONAL } \\
\hline & & & $\mathrm{i}$ & ii & iii & iv & $\mathrm{v}$ & vi & vii & viii & ix & $\mathrm{x}$ \\
\hline 1 & 1980 & $\begin{array}{l}\text { Conjunto arquitetônico e urbanístico } \\
\text { de Ouro Preto (MG) }\end{array}$ & & & & & & & & & & \\
\hline 2 & 1982 & Centro histórico de Olinda (PE) & & & & & & & & & & \\
\hline 3 & 1983 & $\begin{array}{l}\text { Ruínas de São Miguel das Missões } \\
\text { (RS) }\end{array}$ & & & & & & & & & & \\
\hline 4 & 1985 & Centro histórico de Salvador (BA) & & & & & & & & & & \\
\hline 5 & 1985 & $\begin{array}{l}\text { Santuário de Bom Jesus de } \\
\text { Matozinhos, Congonhas (MG) }\end{array}$ & & & & & & & & & & \\
\hline 6 & 1987 & Conjunto urbanístico de Brasília (DF) & & & & & & & & & & \\
\hline 7 & 1997 & Centro Histórico de São Luís (MA) & & & & & & & & & & \\
\hline 8 & 1999 & $\begin{array}{l}\text { Centro Histórico de Diamantina } \\
\text { (MG) }\end{array}$ & & & & & & & & & & \\
\hline 9 & 2001 & $\begin{array}{l}\text { Centro Histórico da Cidade de Goiás } \\
\text { (GO) }\end{array}$ & & & & & & & & & & \\
\hline 10 & 2010 & $\begin{array}{l}\text { Praça de São Francisco, São } \\
\text { Cristóvão (SE) }\end{array}$ & & & & & & & & & & \\
\hline 11 & 2012 & $\begin{array}{l}\text { Paisagens cariocas entre a } \\
\text { montanha e o mar, Rio de Janeiro } \\
\text { (RJ) }\end{array}$ & & & & & & & & & & \\
\hline
\end{tabular}

Quadro 4 - Quadro comparativo dos bens de conjuntos urbanos classificados como patrimônio mundial no Brasil, segundo a UNESCO. Fonte: elaboração e tradução nossa (UNESCO, 2014). 
Para o desenvolvimento da pesquisa, procuramos compreender as iniciativas legislativas, regulamentares, financeiras ou técnicas do país do objeto de análise, levando em consideração que são ações necessárias para qualquer empreendimento no espaço urbano. E, no caso em estudo principal desta análise, o caso brasileiro, foi feita uma leitura mais detalhada, a fim de pontuar e de reconhecer cada uma das ações e atores, bem como suas relações no processo.

Outra questão importante diz respeito ao fato de o Brasil ser um país historicamente recente, primeiramente como colônia e posteriormente como nação, onde não há uma ideia de tradição nacional culturalmente assimilada anterior ao período reconhecido historicamente como modernismo. Diferentemente de Portugal, as raízes do patrimônio brasileiro não são tão distantes no tempo, e muitas das manifestações culturais originais dos lugares ainda permanecem vivas.

Podemos afirmar que os objetos de estudo deste trabalho são compostos de elementos materiais heterogêneos em seus conjuntos patrimoniais, ou seja, eles são constituintes de uma "paisagem histórica". Essa paisagem foi construída ao longo do tempo e, nela, diferentes estilos arquitetônicos e construtivos se contrapõem e constituem o tecido urbano da cidade e da área de interesse de nossa pesquisa.

Em Coimbra, o bem cultural da Universidade Alta e Sofia é constituído por duas regiões da cidade, e por isso distingue-se das candidaturas convencionais da UNESCO, que se concentram em apenas uma área. Essas duas áreas foram assim divididas devido a dois momentos históricos de consolidação do bem cultural: o período de início das atividades da Universidade, na Rua da Sofia, e o período do Estado Novo, na zona da Alta.

$\mathrm{Na}$ primeira área, foram construídos colégios, que depois se tornaram uma Universidade a qual, atualmente, não faz parte fisicamente do conjunto da Universidade. Essa área é localizada no centro antigo da cidade, caracterizado por seu traçado urbano medieval. Seu desenho urbano é composto por uma expressiva avenida alargada, que rompe com a estrutura urbana medieval dessa região.

Na segunda área, localizam-se os edifícios de valor arquitetônico do período do regime político conhecido em Portugal como Estado Novo, com edifícios datados de 1940 e posteriores a 1965, e constitui a parte edificada patrimonial da Universidade de Coimbra. 

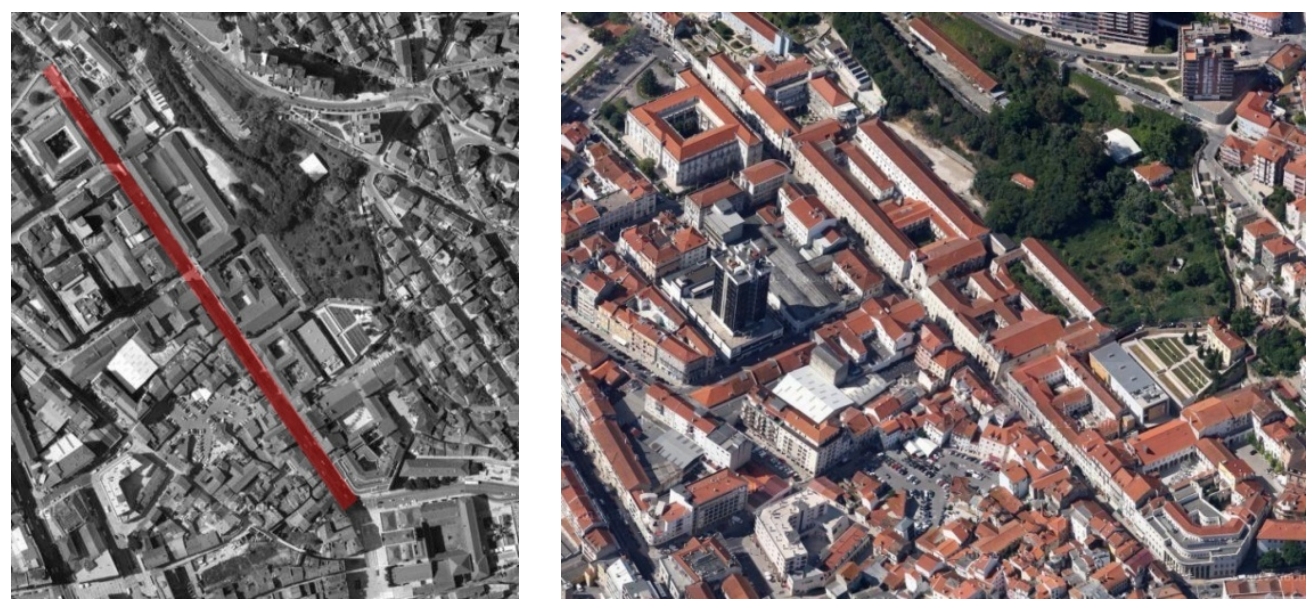

Imagens 6 e 7 - Rua Sofia, considerada pela historiografia a primeira parte da Universidade de Coimbra, 2012. Fonte: autoria própria sobre base e imagem do Google Maps.
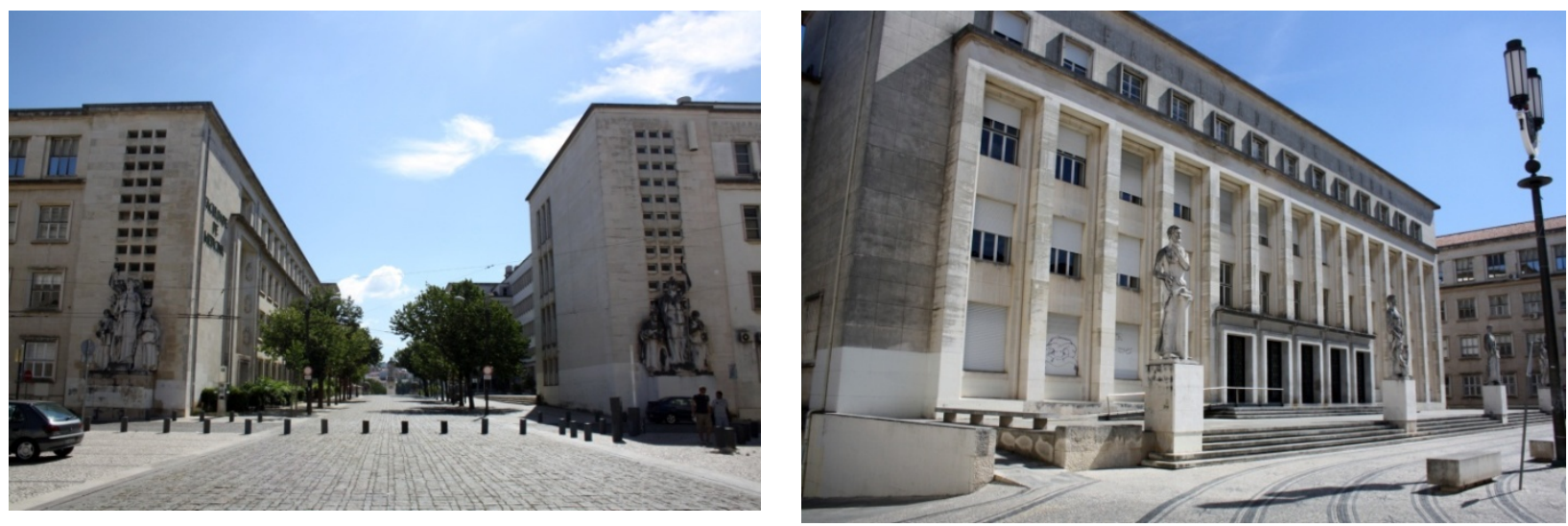

Imagens 8 e 9 - Vista da Zona da Alta desde o largo D. Dinis. À esquerda, o edifício da Química e a Faculdade de Medicina. À direita, a fachada frontal da Faculdade de Letras. Coimbra, 2012. Fonte das fotos: autoria própria.

Em Belém, a proteção do bem cultural Ver-o-Peso limita-se a uma área apenas, cujo conjunto preservado apresenta características tipológicas, morfológicas e construtivas que datam desde o século XVII até o início do século XX. Essas características concentram-se, principalmente, no traçado urbano e nas edificações materiais, marcadas pelo ecletismo de estilos, em que alguns edifícios apresentam, até mesmo, aspectos da Art Nouveau. 

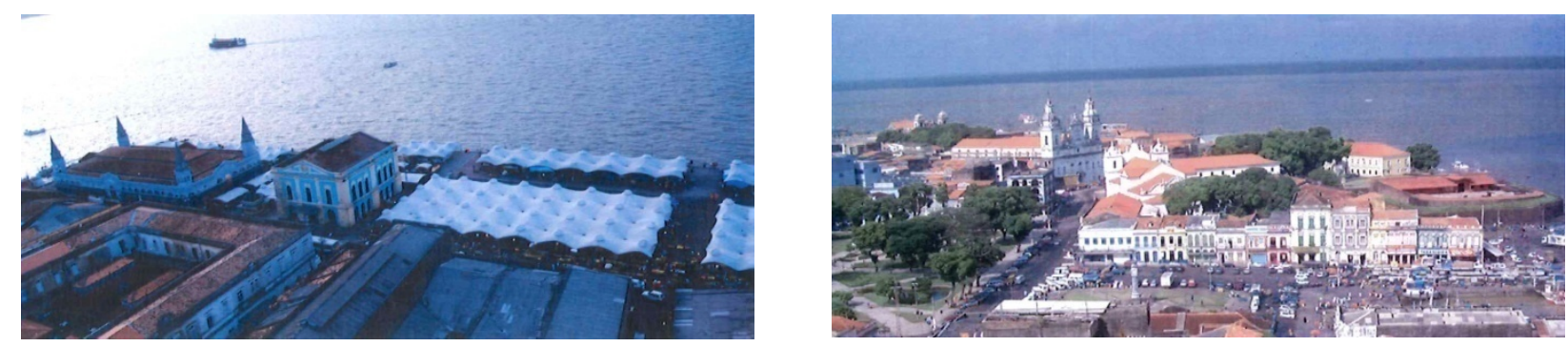

Imagens 10 e 11 - Vista do Mercado de Carne, do Solar da Beira, da Feira Livre do Ver-o-Peso, à esquerda. À direita, vista do conjunto da Praça Frei Caetano Brandão e das docas do Ver-o-Peso. Ao fundo das imagens, a Baía do Guajará, Belém, 2014. Fonte: Documento de intenção de candidatura IPHAN, 2014.

Tais objetos de estudo, embora localizados em ambientes culturais, econômicos e sociais distintos, com diferentes estruturas administrativas e legislativas, permitem-nos observar regularidades em relação à condução de seus processos classificatórios patrocinados pela UNESCO. Essas regularidades estão relacionadas, por um lado, à produção e conformação da cidade contemporânea, e, por outro, ao fato de o patrimônio cultural ser elemento estratégico de reprodução do capital.

Estão inseridos, portanto, em um contexto de valorização capitalista, guiada pela ideologia contemporânea neoliberal da globalização, em que "a cultura se transformou em algum gênero de mercadoria" (HARVEY, 2005, p. 221), e segundo uma ideia de internacionalização das cidades, por meio de propostas de intervenções urbanas relacionadas ao patrimônio cultural e da valorização de seu patrimônio com a classificação a patrimônio mundial. Assim, esses objetos de estudo nos permitem elaborar alguns questionamentos sobre seus processos de patrimonialização, de modo a indagar sobre a legitimidade de sua classificação ou candidatura à classificação, sobre como foram estruturadas suas nomeações, e sobre as alegações do valor singular de seus bens.

Verificamos como essas nomeações buscaram transpor a ideia de nação, por meio de três atos diretivos: primeiro, os projetos de cooperação técnica com uma Instituição internacional; segundo, a formulação de políticas públicas culturais em parceria com as resoluções dessa Instituição, que podem ser direcionadas aos interesses de uma minoria que controla, ou que tem interesse em controlar, direta ou indiretamente, o potencial 
comercializável que tal processo possa promover; e, terceiro, a divulgação ${ }^{72}$ desses bens a uma audiência global, numa concorrência intranacional e internacional entre as cidades.

Veio à tona, então, a seguinte questão, referente ao tema desta pesquisa e relacionada à atuação de um organismo internacional de proteção e preservação do patrimônio: como se dá a operacionalização desse organismo internacional, como são seus modos de atuação, suas medidas normativas e suas regulamentações específicas sobre a preservação de bens culturais tanto no contexto brasileiro quanto no contexto português. Compreender essa questão permitiu-nos perceber como se articulam os elementos significativos de um lugar, o seu contexto urbano, a sua história e memória, os seus agentes e as suas políticas de preservação patrimonial, em relação a um processo hegemônico de produção do espaço urbano nessas cidades.

\footnotetext{
${ }^{72}$ As publicações e tiragens exclusivas da UNESCO são traduzidas nos idiomas inglês, francês e espanhol.
} 


\section{O caso brasileiro, Belém.}

Ver-o-peso, ver-o-tempo, portal de encantos e magia, cenário vivo da cultura popular

Samba-enredo, Dio, Ademar Carneiro e Pedrão do Cavaco, 2004.

Ervas e raízes curam e dão sorte/ O cheiro do norte é sedução/ $\mathrm{Na}$ batida do tambor/ Na magia da floresta/ Na avenida vira samba/Vira canto, vira dança/ A embaixada faz a festa/ O Império Pedreirense vem cantar/ A maior feira popular/ Em céu aberto da América Latina/ Caravelas do além mar/ Chegavam coloridas/ Beijadas pela brisa/ Arquitetura barroca/ Urubus revoando/ Vigilengas cablocas/ Nas ondas bailando/ O relógio marca o tempo/ No largo da enseada/ E o zum zum zum começa de madrugada.

É carnaval, o afoxé desce a ladeira/ a Feira do Açaí vai se alegrar/ Na Bulevar pego o cordão da fé/ Sou festeiro de Nazaré.

Paid'égua é Ver-o-Peso no mercado/ O grito do vendeiro na hora da viração/ Nas barracas iguarias regionais/ O pescado da maré pro meu pirão/ O barro e o miriti do artesanato/ O bate papo do RExPA na gozação/ Ervas e raízes curam e dão sorte/ O cheiro do norte é sedução/ Na praça do pescador/tem viola e cantador/Lindas noites de luar para namorar/ Hoje o progresso chegou/ mas a tradição não sai de lá.

\section{VER-O-PESO}


O processo de patrimonialização de Ver-o-Peso (Brasil).

O Ver-o-Peso, localizado no centro histórico da cidade de Belém (PA), e a sua candidatura a patrimônio mundial pela UNESCO, iniciada em 2014, representaram, para esta pesquisa, a possibilidade de formular reflexões, no contexto brasileiro, sobre o tema do processo de produção do espaço urbano e suas transversalidades no campo do patrimônio.

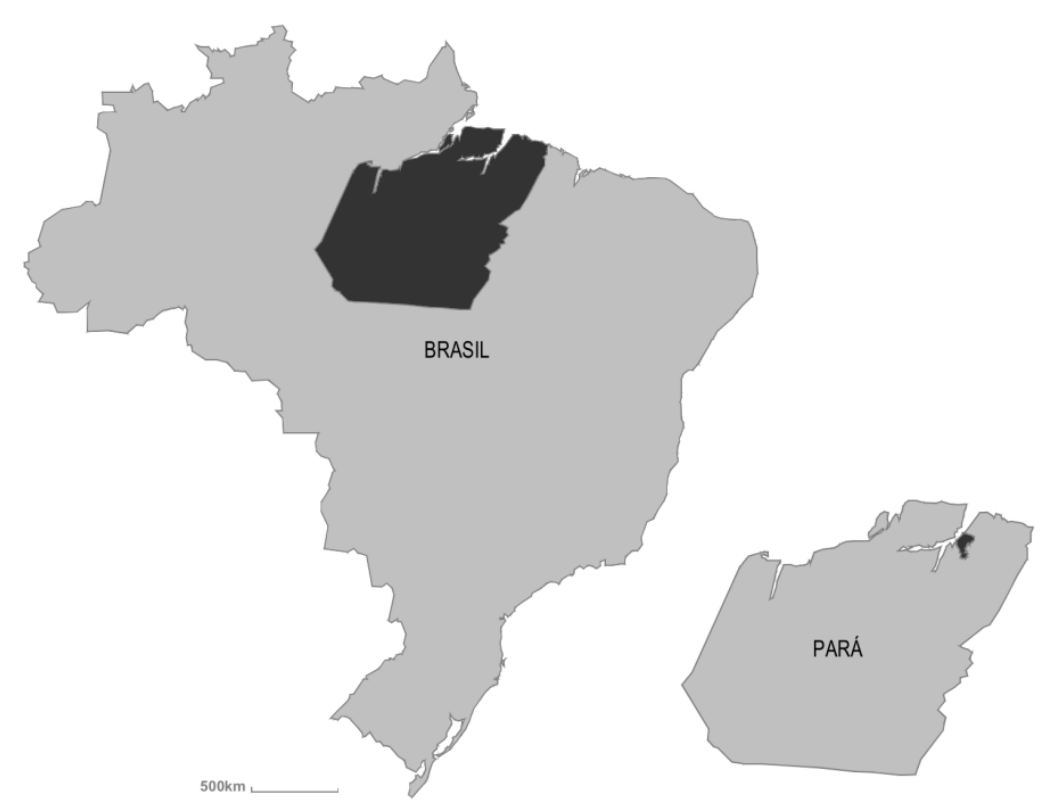

Mapa 1 - Brasil e o estado do Pará, com a localização da cidade de Belém. Fonte da imagem: autoria própria.

Objetivando tanto compreender a elaboração e o desenvolvimento desse processo de candidatura, quanto interpretar as relações desse processo com a cidade de Belém atual, realizamos, durante a visita exploratória a campo, na cidade de Belém, entrevistas em profundidade ${ }^{73}$ com alguns intelectuais que defendem a preservação da cultura, analisam e discutem a questão da identidade do lugar, o espaço urbano e suas relações com o

${ }^{73}$ Entrevista em profundidade é uma técnica qualitativa, não estruturada, direta e pessoal, e que permite explorar um ou mais temas por meio de perguntas originárias de uma abordagem e direcionamento preliminar, como um roteiro, as quais podem ou não ser formuladas em sua totalidade antes da realização da entrevista. Esse tipo de entrevista permite um diálogo em que o entrevistador tem maior liberdade para reformular questões mediante suas interpretações da realidade e da própria entrevista durante a conversa, e o respondente, de expressar de forma livre suas percepções sobre o tema em questão. 
patrimônio cultural da cidade de Belém. São eles: Prof. ${ }^{\text {es }}$ Saint-Clair C. Trindade Júnior, Juliano P. X. Ponte, Maria Goretti da C. Tavares, vinculados à UFPA, e com a representante técnica superintendente do IPHAN-PA, Maria D. Lima.

A primeira entrevista foi realizada com o professor e pesquisador Saint-Clair Cordeiro da Trindade Júnior ${ }^{74}$ e transcrita neste trabalho ${ }^{75}$. Saint-Clair é autor de uma ampla produção científica relacionada ao tema do patrimônio em Belém. Suas reflexões acerca do tema auxiliaram-nos a compreender tanto o contexto do lugar em relação ao bem cultural Ver-o-Peso, quanto as dinâmicas territoriais da cidade em relação à forma urbana e a seus aspectos socioespaciais.

A segunda entrevista, com o professor e pesquisador Juliano Pamplona Ximenes Ponte $^{76}$, parcialmente transcrita neste trabalho ${ }^{77}$, auxiliou-nos a compreender melhor a legislação urbana da cidade em relação ao patrimônio e alguns programas federais de incentivo à preservação patrimonial.

A terceira entrevista, com a professora e pesquisadora Maria Goretti da Costa Tavares $^{78}$, transcrita neste trabalho ${ }^{79}$, auxiliou-nos a compreender os agentes desse processo, suas articulações com a construção de novos processos de patrimonialização, além dos movimentos de resistência popular às ações culturais do poder político.

A quarta entrevista foi com Maria Dorotéa de Lima ${ }^{80}$, atual superintendente do IPHAN-PA e também uma das idealizadoras da proposta de inclusão de Ver-o-Peso na Lista Indicativa do Patrimônio Mundial pela UNESCO, como sua responsável técnica. Essa

\footnotetext{
${ }^{74}$ Saint-Clair Cordeiro da Trindade Júnior, geógrafo e professor vinculado ao Departamento de Geografia da UFPA. Entrevista agendada pela autora da tese e concedida no Núcleo de Altos Estudos Amazônicos, com a presença da pesquisadora Jéssika Paiva França a convite da autora, Belém, 2016.

${ }^{75}$ Ver: Apêndice B - entrevista 1.

${ }^{76}$ Juliano Pamplona Ximenes Ponte, arquiteto e urbanista e professor vinculado Faculdade de Arquitetura e Urbanismo da UFPA. Entrevista agendada pela autora da tese e concedida no Café da Sol, na Doca, a presença da pesquisadora Jéssika Paiva França a convite da autora, Belém, 2016.

${ }^{77}$ Ver: Apêndice B - entrevista 2.

${ }^{78}$ Maria Goretti da Costa Tavares, geógrafa vinculada ao Departamento de Geografia da UFPA. Entrevista agenda pela autora da tese e concedida na sorveteria Cairu, com a presença da professora Olga Lucia Castreghini de Freitas-Firkowski vinculada ao Departamento de Geografia da UFPR, a convite da entrevistada, Belém, 2016.

${ }^{79}$ Ver: Apêndice B - entrevista 3.

${ }^{80}$ Maria Dorotéa de Lima, arquiteta e urbanista, vinculada ao IPHAN-PA desde 2005, respondendo atualmente pela sua superintendência. Entrevista agendada pela autora da tese e concedida no gabinete do IPHAN-PA, com a presença da pesquisadora Jéssika Paiva França a convite da autora, Belém, 2016.
} 
entrevista, também transcrita neste trabalho ${ }^{81}$, fez-nos compreender o atual estágio do processo de patrimonialização de Ver-o-Peso e alguns procedimentos específicos quanto à estruturação de processos e à nomeação de bens culturais materiais e imateriais pelo IPHAN e pela UNESCO. Tais procedimentos permitiram elaborar reflexões sobre as questões culturais atuais em Belém em relação ao Poder Público e perceber a ligação de grupos do setor privado tanto com o bem cultural em estudo como com os recentes bens culturais imateriais classificados como patrimônio mundial.

Citaremos, oportunamente, alguns trechos dessas entrevistas que fundamentem e ampliem nossas interpretações do processo de patrimonialização a patrimônio mundial no contexto específico da cidade de Belém. Algumas delas também serão retomadas ao final do trabalho, nas considerações finais.

Também ao longo e ao final deste capítulo ${ }^{82}$, retomaremos os fundamentos teóricos e conceituais de nosso trabalho: as cartas patrimoniais internacionais; a operacionalização da classificação como Patrimônio Mundial; a existência de um discurso patrimonial e a seleção de camadas relacionadas ao valor e ao sentido estético do patrimônio; o conceito de paisagem cultural e os sistemas de rede; a existência de um processo de homogeneização e mundialização da cultura nos processos de "patrimonialização mundial"; o empresariamento da cidade e sua relação centrada na cultura.

${ }^{81}$ Ver: Apêndice B - entrevista 4.

82 Ao final deste capítulo, elaboramos considerações comparativas entre o estudo de caso do Ver-oPeso e do contraponto internacional da Universidade de Coimbra. 


\section{Breve caracterização de Belém.}

O município de Belém ${ }^{83}$ está inserido na região metropolitana (RM) de Belém ${ }^{84}$, e possui uma área urbana de 1064,92 $\mathrm{km}^{2}$ distribuídos em uma parte continental e em um arquipélago com mais de trinta ilhas. A capital do estado do Pará é conurbada a municípios lindeiros e caracterizada por uma continuada mancha urbana. Sua rede hidrográfica é constituída pelos rios Maguari e Guamá. A cidade também é banhada pela Baía do Guajará e é conformada por uma grande área de várzea, cortada por rios e igarapés e, atualmente, tem uma população estimada em mais de um milhão e quatrocentos mil habitantes, segundo censo demográfico de 2010 do IBGE (IBGE, 2016).

Foi importante para este trabalho compreender, a partir da perspectiva amazônica, a forma ${ }^{85}$ urbana da cidade e a distribuição de usos do solo e estruturas socioeconômicas, utilizadas em planejamento urbano e regional, para fundamentar as análises sobre as complexas dinâmicas territoriais estabelecidas quanto à área de patrimonialização de Ver-oPeso. Assim, utilizamo-nos de instrumentos de cartografia que pudessem informar o que aconteceu, o que está acontecendo e o que pode acontecer com o território, estabelecendo critérios de análise ambiental urbana fundamentados em sínteses dos aspectos contextuais na formação da estrutura urbana da cidade baseado em dados do IBGE.

\footnotetext{
${ }^{83} \mathrm{Em}$ relação às características geográficas e ambientais do território e sua relação com a expansão dos primeiros núcleos urbanos de Belém, vale ressaltar que "Seu sítio é marcado por inúmeros acidentes geográficos característicos da Amazônia tais como, rios, várzeas e terras firmes, alagados, os quais junto a áreas de ocupação institucional vieram a direcionar seu crescimento e ocupação da malha urbana de maneira contínua e compacta na Primeira Légua Patrimonial"(LIMA, 2014, p.4).

${ }^{84} \mathrm{~A}$ RM de Belém foi criada no ano de 1973 e é formada pelos municípios de Ananindeua, Belém, Benevides, Castanha, Marituba, Santa Bárbara do Pará, e Santa Isabel do Pará. A população estimada da região, segundo o último censo demográfico do IBGE, é de mais de dois milhões e quatrocentos mil habitantes (IBGE, 2016).

${ }^{85}$ Este trabalho entende a forma urbana "como a forma física do domínio público da cidade, incluindo os elementos arquitetônicos que ajudam a definir suas fronteiras" (LIMA, 2004, p. 148).
} 


\section{Espacialização de dados demográficos de Belém.}

E o que acontece no centro histórico repercute na cidade [de Belém] como um todo, eu diria muito mais, repercute na metrópole como um todo ${ }^{86}$. Prof. Saint-Clair Cordeiro Trindade Júnior.

Entrevista concedida à autora em julho de 2016.

Partindo dessa ideia sobre a cidade de Belém, buscamos compreender algumas das circunstâncias críticas em relação à dinâmica territorial da cidade. Para tanto, desenvolvemos análises ambientais urbanas, por meio de mapas de informações georreferenciadas ${ }^{87}$, como os de densidade populacional, renda e idade, elaborados a partir de dados obtidos do site do Instituto Brasileiro de Geografia e Estatística (IBGE). Foram aproveitados mapas de setores censitários dos municípios de Belém ${ }^{88}$ e Ananindeua, os quais representam as menores divisões de território utilizadas pelo IBGE para coletar e divulgar dados estatísticos agregados. Aos mapas de setores censitários foram associados dados em comum dos censos de 2001 e 2010 analisar a transformação demográfica na região. Para esse processo de elaboração e criação de novos mapas, foi utilizado o software QGIS.

Para o desenvolvimento desta análise, trabalhamos também com dados demográficos e socioeconômicos do censo de $1990^{90}$ do IBGE sobre a cidade de Belém, para a obtenção de índices do setor censitário e em percentuais em relação ao total da cidade.

Buscamos, assim, caracterizar a distribuição da população, por meio de sua

${ }^{86}$ TRINDADE JÚNIOR, 2016b.

${ }^{87} \mathrm{O}$ georreferenciamento permitiu ao nosso trabalho associar informações com o espaço físico. Assim, as nossas imagens apresentam os dados do IBGE associados a suas áreas geográficas.

88 "Os setores censitários do IBGE na orla do município de Belém em sua maioria ou totalidade consideram a planície de inundação, bancos de areia, mesmo em áreas onde não há palafitas ele considera manchas" (Entrevista do Prof. Juliano Ximenes para a autora da tese, Belém, 2016).

${ }^{89}$ Foram utilizados os setores censitários relativos a cada censo, entre os quais pode haver alguma diferença sutil, mas que não interfere na análise visual dos mapas, nosso principal objetivo. As duas adaptações que foram feitas são relativas aos valores de renda, que foram atualizados pela inflação acumulada de cada época até o valor presente e em relação à categoria das idades de crianças, estipuladas de modo distinto em cada um dos censos, questão que foi solucionada fazendo-se a média ponderada de seus valores e padronizando-os para a elaboração de nossa análise comparativa entre os mapas.

${ }^{90}$ No Censo Demográfico de 1990, ainda não eram disponibilizados mapas digitalizados dos municípios brasileiros com mais de 50 mil habitantes (IBGE, 2016). 
densidade, de sua idade e da renda familiar. Elaboramos, com esses dados, comparações entre diferentes períodos temporais e criamos uma cartografia com a apresentação espacial por setores censitários dos resultados estatísticos.

Essa análise pretendeu caracterizar a distribuição da população na mancha urbana da cidade de Belém, verificando a existência de setores marcados pela maior presença de faixas etárias específicas bem como a espacialização da densidade de ocupação (número de habitantes por domicílio), e verificando, principalmente, os aspectos socioeconômicos da população residente no polígono do Centro Histórico. Por meio dessa caracterização, e da entrevista com o professor Saint-Clair, nossa análise interpretou alguns aspectos das dinâmicas socioespaciais e as relações das áreas habitacionais com a área protegida de Vero-Peso. Percebemos, sobretudo, que tipo de influência ocorre na área e na escala da cidade, ao longo de seu processo de patrimonialização.

Em um macrozoneamento, foram construídas imagens de polígonos ${ }^{91}$ de suas áreas protegidas segundo suas classificações como patrimônio. Essas imagens expõem a sobreposição de diferentes camadas de proteção, com suas diretrizes e normativas específicas de preservação segundo as diferentes instâncias de preservação do patrimônio, municipal, estadual e federal, e a área candidata pela UNESCO. Tal espacialização de dados demográficos ajudou a compreender características e alterações socioeconômicas e espaciais na área de proteção e de entorno do bem cultural Ver-o-Peso durante o período entre os anos 1990 e 2010, período temporal definido em razão da disponibilidade de dados pelo IBGE.

A cidade de Belém é caracterizada como um grande centro urbano da região amazônica e, segundo José Júlio Lima (2004, p. 148), no período dos anos 1980 e 1990, como um padrão urbano e regional desorganizado ante uma "extrema supremacia metropolitana, representada pela dominação tanto em termos do tamanho da população urbana como da importância econômica" da região da cidade consolidada em relação ao seu crescimento periférico e desorganizado no território naqueles anos.

\footnotetext{
${ }^{91}$ Polígono de Voronoi, é baseado no diagrama de Voronoi e é uma ferramenta utilizada para solucionar problemas que envolvem o conceito de proximidade em um plano. Seu princípio é a relação entre pontos localizados em um plano que estão mais próximos de uma fonte geradora do que de outra fonte, resultando em um polígono cujas distâncias entre estes pontos são as menores possíveis (MOURA, 2014). Neste polígono foram definidas das áreas de Ver-o-Peso, Centro Histórico e seu entorno.
} 
Ainda durante as décadas de 1980 e 1990, segundo esse autor, a pobreza na cidade cresceu rapidamente, acentuando desigualdades sociais, de modo semelhante a outras grandes cidades do Brasil. Todavia, esse empobrecimento adveio com algumas particularidades, como por exemplo, o baixo crescimento populacional entre os anos 1970 e 1991, segundo dados do IBGE de 1992: “a região metropolitana de Belém cresceu 3,69\% anualmente (...) a menor taxa entre as quinze municipalidades mais populosas da Amazônia" (LIMA, 2004, p. 147), comparativamente a outras metrópoles, como por exemplo, Manaus, no mesmo período.

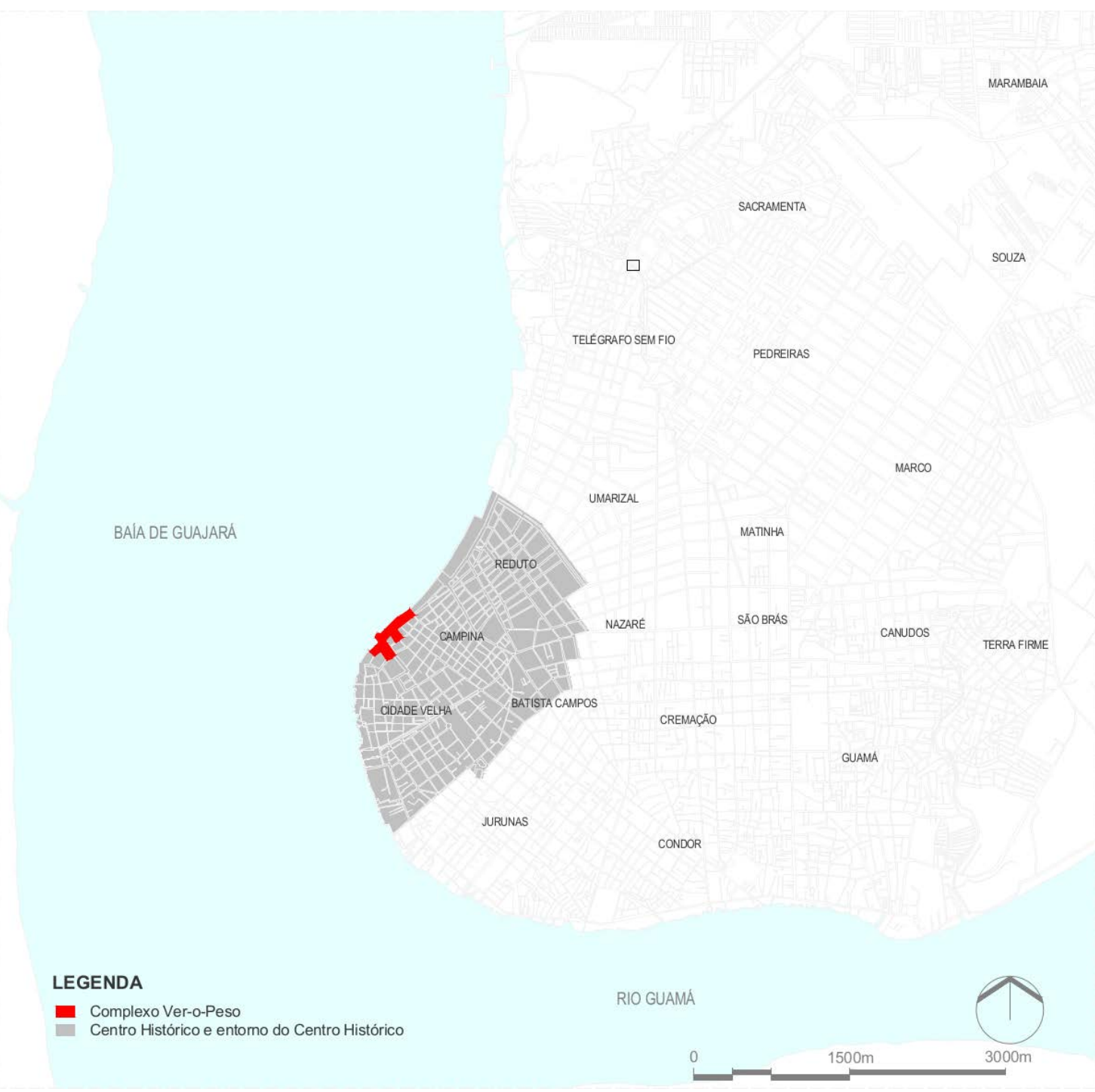

Mapa 2 - Identificação de alguns bairros da cidade, CHB e entorno, e Ver-o-Peso, Belém. Fonte: autoria própria sobre base da PMB. 


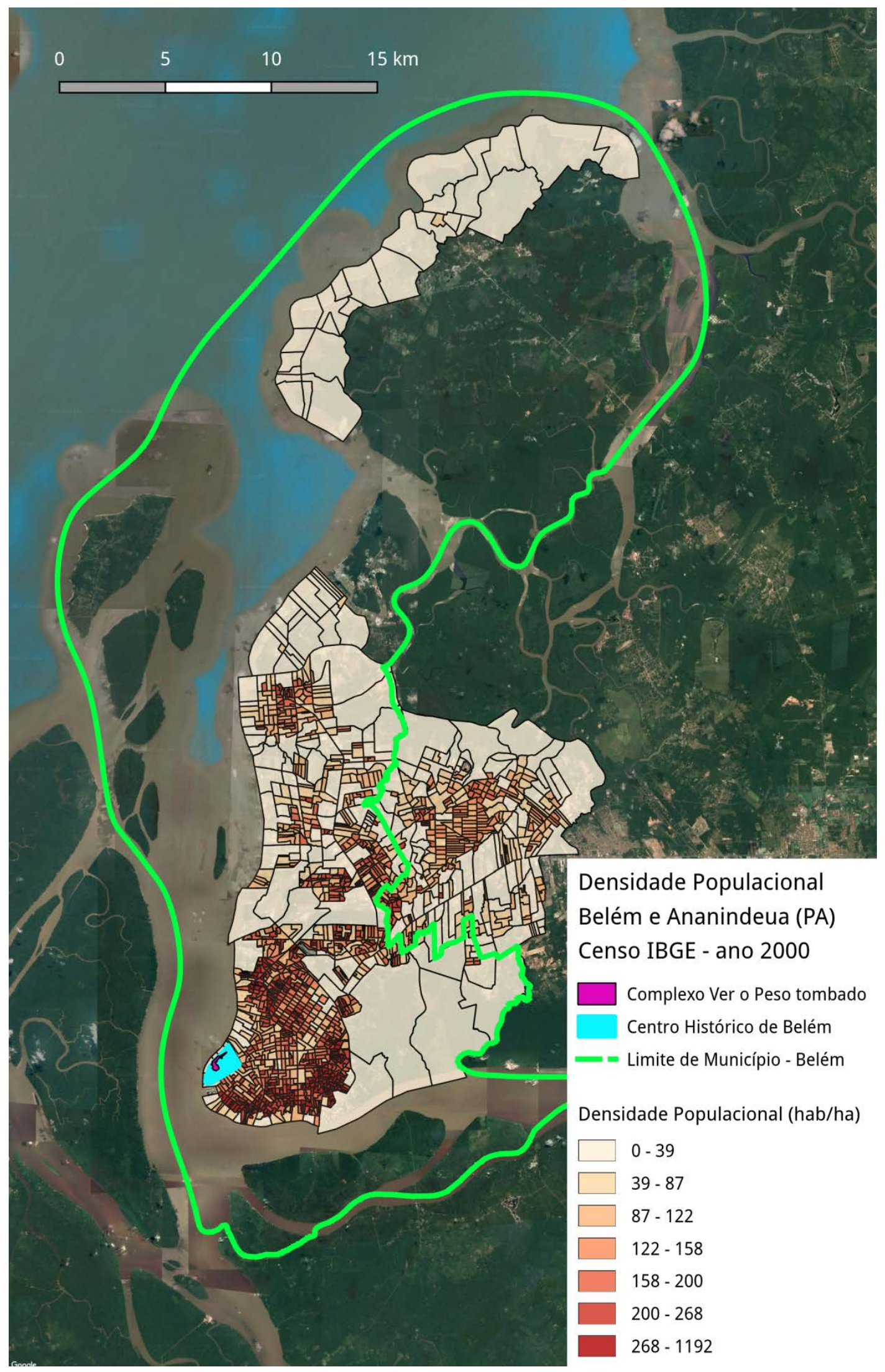

Mapa 3 - Densidade populacional, em habitantes por hectare, nos setores censitários definidos pelo IBGE para os municípios de Belém e Ananindeua (PA) em 2000. Fonte: autoria própria. 


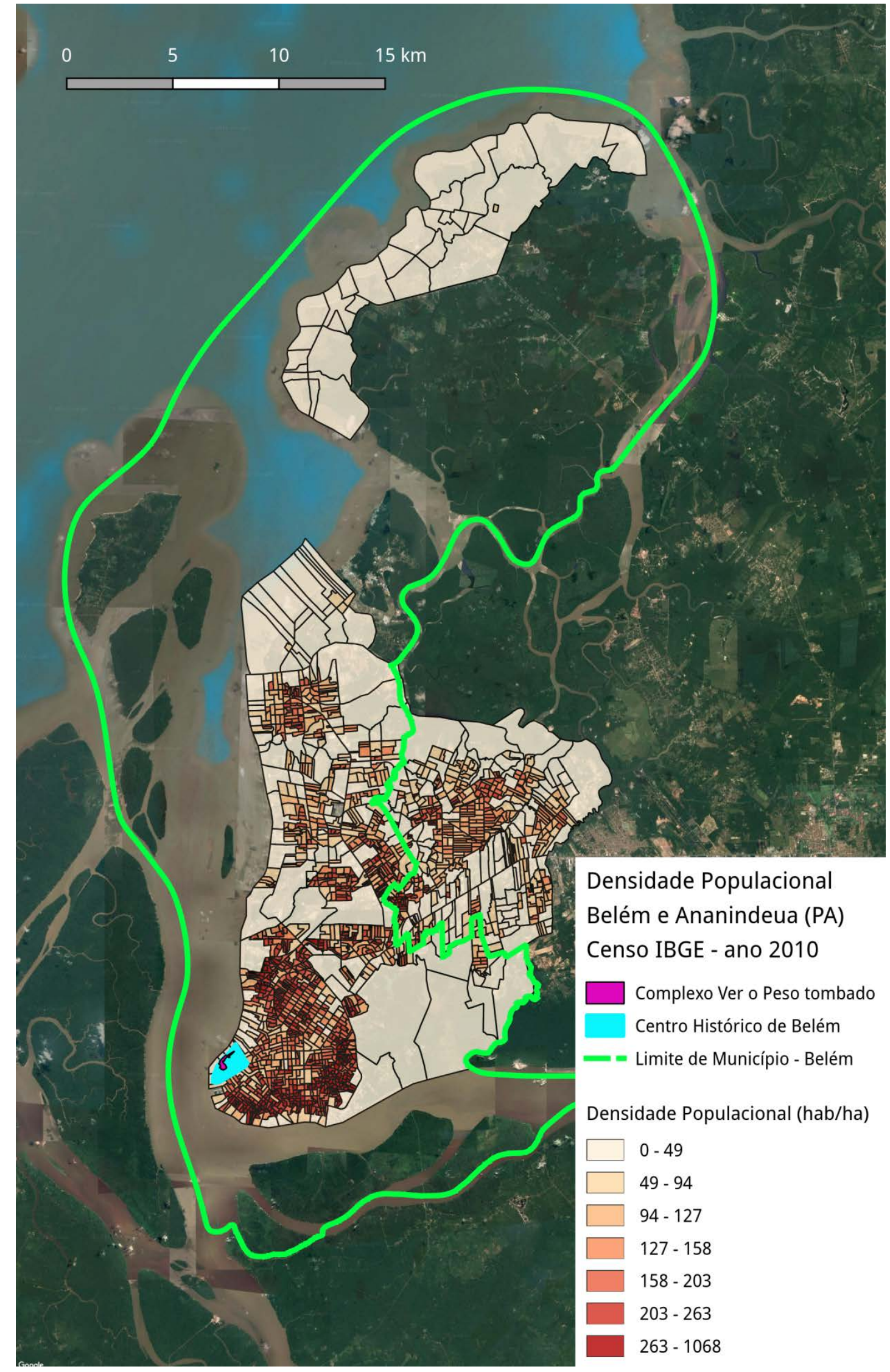

Mapa 4 - Densidade populacional, em habitantes por hectare, nos setores censitários definidos pelo IBGE para os municípios de Belém e Ananindeua (PA) em 2010. Fonte: autoria própria. 
Os mapas de densidade populacional indicam o número total de habitantes de cada setor censitário dividido pela área total do setor, a qual foi expressa em hectares (ha). A escolha desse sistema de medida de área se deu porque ele pode ser mais intuitivo nesse contexto, indicando quantos habitantes há em cada quarteirão ideal de 100 metros de lado, e objetiva uma leitura generalizada e não pontual, permitindo uma leitura da situação das áreas e uma comparação entre elas nas cidades.

As categorias dos setores dos mapas foram criadas em nosso trabalho pela divisão em sete quantis, isto é, foi utilizado o método estatístico de agrupamento de quantidades aproximadamente iguais de setores em cada categoria de cores no mapa. Esse método oculta os poucos casos extremos de densidades populacionais altas e baixas, deixando mais visíveis as diferenças entre as categorias intermediárias. No entanto, ele faz com que os intervalos de densidades populacionais exibidos na legenda de categorias do mapa sejam desiguais, sendo maiores quando próximos da extremidade de valores. A divisão em sete intervalos foi escolhida porque o uso de um maior número de categorias não trazia ganhos em informação visual.

Assim, em relação à densidade populacional dos municípios de Belém e Ananindeua ${ }^{92}$, pode-se afirmar que há uma grande densidade populacional na cidade consolidada historicamente em Belém e nas áreas que a circundam em direção ao continente (áreas periféricas). Pode-se dizer também que, embora a cidade de Belém seja conurbada com a cidade de Ananindeua, há áreas com baixa ou nenhuma densidade populacional entre as duas cidades, o que representa grandes intervalos no território sem ocupação residencial. Em grande parte desses espaços não há ou há poucas edificações: são áreas correspondentes ao Aeroporto Internacional Val de Cans, ao norte, aos novos condomínios residenciais de baixo índice de ocupação e que ainda não estão inteiramente edificados, a norte e nordeste, às Áreas de Proteção Ambiental (APA), tais como o Parque Ecológico Municipal “Gunnar Vingren”, grandes reservas verdes e de mananciais, próximas à Lagoa Água Preta e ao Lago Bolonha, o Parque Estadual do Utinga, a leste, abaixo dele e

${ }^{92}$ No início da década de 1980, a Região Metropolitana de Belém era composta por apenas dois municípios, Belém e Ananindeua, o que significa dizer que, em um primeiro momento, as dinâmicas territoriais da metrópole de Belém estiveram concentradas nessa região. Assim, buscando ampliar a compreensão da densidade populacional na região para além do município de Belém, selecionamos os dois municípios em nosso mapa de densidade populacional. 
próximo às ruínas do Murutucu ${ }^{93}$, no bairro Curió-Utinga, e, a sudeste, o campus da Universidade Federal do Pará.

As outras áreas de maior concentração de densidade populacional a norte de Belém e em direção a Ananindeua evidenciam o crescimento descontinuado e um padrão urbano e regional desorganizado, apontado por José Júlio Lima em suas considerações sobre a totalidade da cidade de Belém (LIMA, 2004, p. 148).

${ }^{93}$ Bem cultural tombado pelo IPHAN, em 1981, como sítio arqueológico do Murutucu, com ruínas do antigo engenho do Murutucu. 

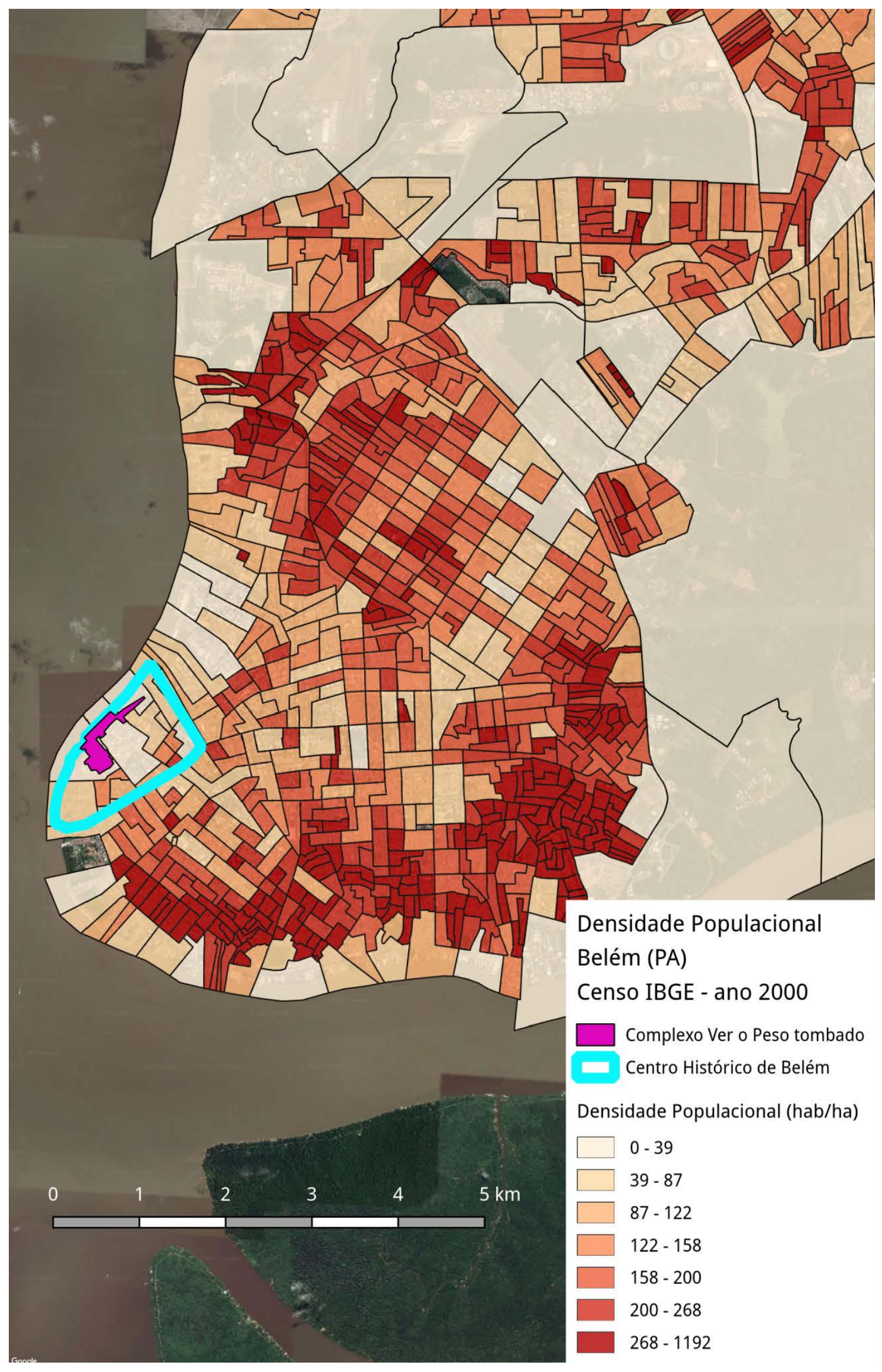

Densidade Populacional (hab/ha)

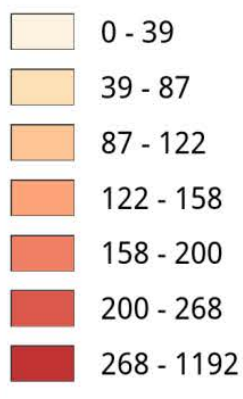

Mapa 5 - Densidade populacional, em habitantes por hectare, nos setores censitários definidos pelo IBGE para o município de Belém (PA), em 2000. Fonte: autoria própria. 


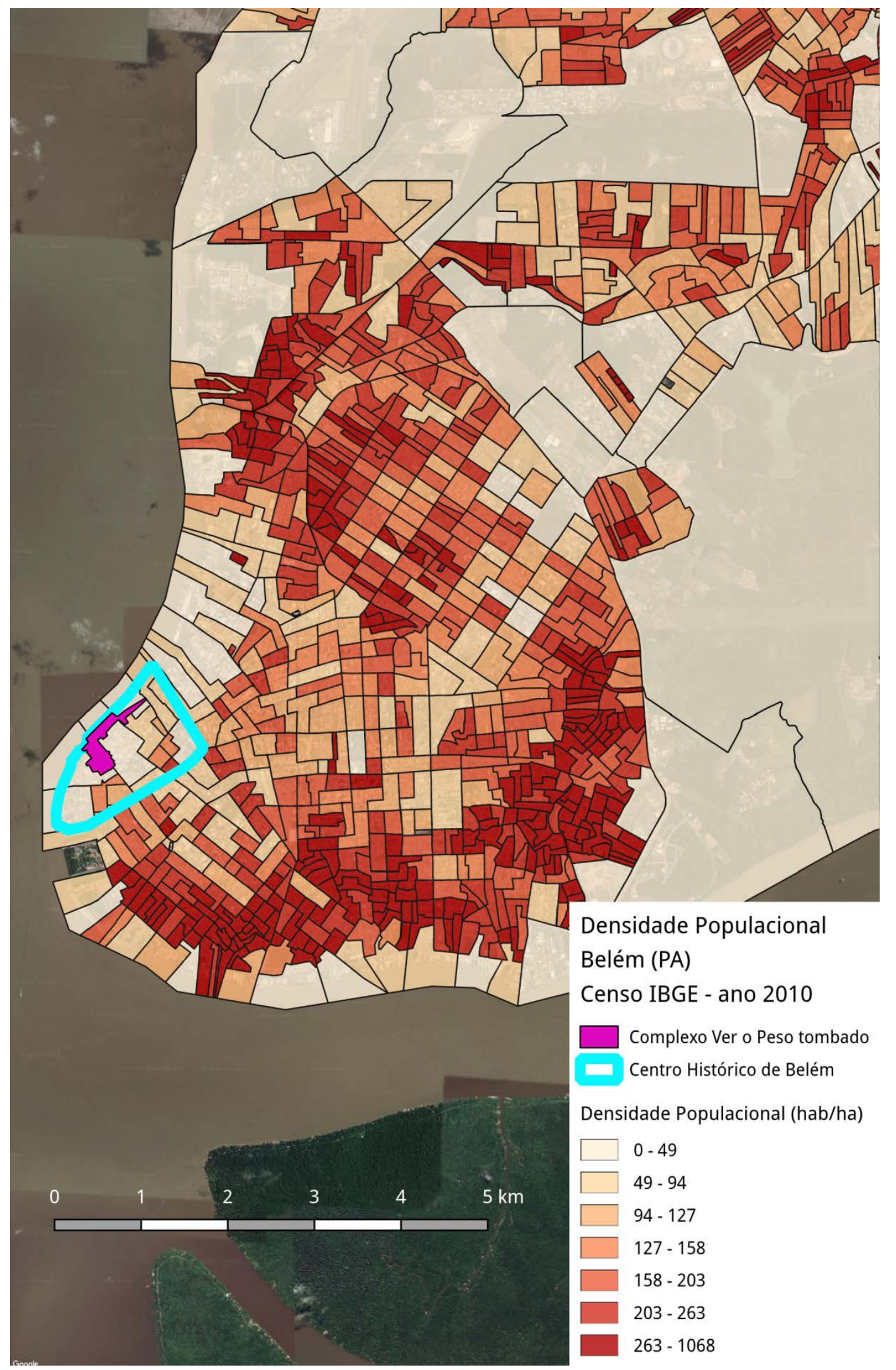

Mapa 6 - Densidade populacional, em habitantes por hectare, nos setores censitários definidos pelo IBGE para o município de Belém (PA), em 2010. Fonte: autoria própria. 
Os mapas de densidade populacional do município de Belém, nos anos de 2000 e 2010, apresentam apenas a sua região central, deixando de exibir os bairros isolados ao norte. O método de construção desses mapas é o mesmo do de densidade populacional da região metropolitana de Belém e Ananindeua.

Por meio desses mapas é possível evidenciar espaços com menor densidade de ocupação no território, e que representam áreas de conexão entre as áreas de maior densidade de ocupação no território. Isso nos sugere que os acontecimentos da vida cotidiana dessas áreas estão mais relacionados ao seu entorno mais próximo, devido à dificuldade de deslocamento ocasionada pelo sistema de transporte viário belenense, de conexões diretas reduzidas, as quais dificultam, juntamente com as grandes distâncias a serem percorridas, os usos dos diversos espaços da cidade.

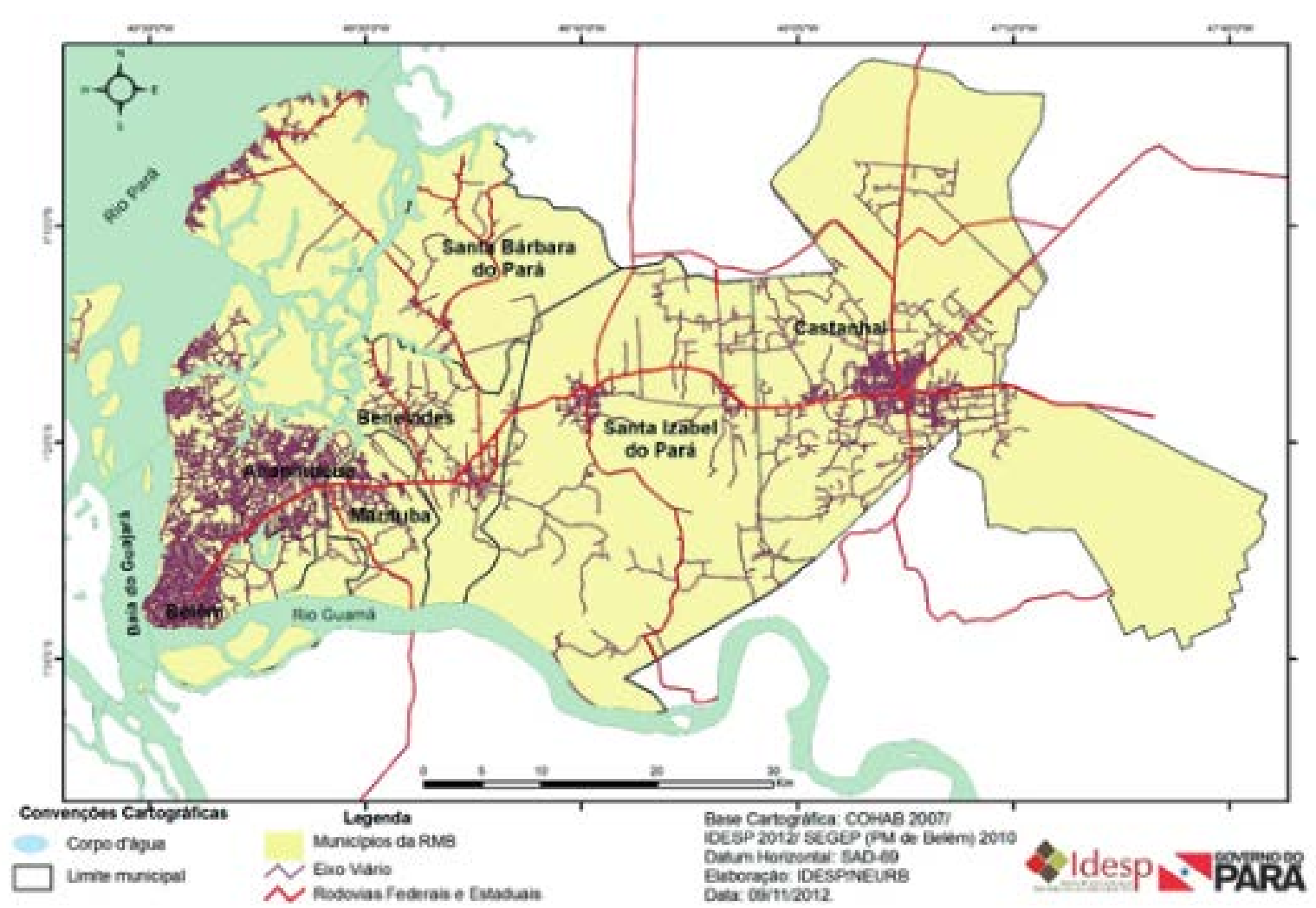

Mapa 7 - Esquema viário geral, com a mancha urbana da região metropolitana de Belém. Fonte: IDESP/NEURB, 2012 apud IPEA, 2015, p. 10.

Essa dinâmica historicamente presente na cidade, como é possível verificar por meio dos mapas de expansão urbana da cidade ao longo do tempo, levou à construção de certa autonomia e autossuficiência comercial, educacional e cultural dos bairros periféricos, e a algumas particularidades, como a presença de pequenos mercados, feiras, comércios e 128 
pontos de memória, quando comparados à região central da cidade, como podemos constatar ao conhecer a cidade e pelas considerações das entrevistas.

Pela renda média da população distribuída por bairro, tu consegues ver onde é que estão os bairros, a concentração é neste cinturão entorno do centro histórico, com algumas manchas para fora que começam a aparecer, mas a grande concentração é ainda entorno, neste cinturão ${ }^{94}$.

Desse modo, e segundo as considerações feitas pelo professor Saint-Clair, percebemos que, de modo geral, os habitantes da cidade não se utilizam com frequência do centro histórico da cidade, cuja ocupação do solo concentra-se em atividades de comércio e de alimentação. Tais atividades são relacionadas, principalmente, ao comércio popular e atacadista no entorno mais próximo à área de proteção de Ver-o-Peso, com grande concentração de instituições culturais mais ao sudoeste do polígono do Centro Histórico, e com maior concentração de alimentação e lazer a nordeste desse polígono.

Então, a classe média em Belém não quer morar no centro histórico, como na Europa, ele é um centro de visitas, de serviços, cultural, mas ela quer morar próximo ao Centro Histórico para que ela possa ir a Estação [das Docas], ela possa usar museu, os equipamentos culturais ali próximo, para o consumo, é uma cultura consumista que é colocada ali, eles não vão tanto ao teatro, eles vão mais aos restaurantes, mais aos bares, as casas que são mais voltadas para a questão do consumo de uma classe média. Então é uma política que reforça um processo de segregação da estrutura metropolitana ${ }^{95}$.

Também é possível verificar que, durante esse período, houve poucas modificações em relação à densidade populacional da região do Centro Histórico. Tais modificações referem-se a um pequeno aumento de densidade populacional na região próxima à travessa Frutuoso Guimarães, uma área de grande concentração da atividade comercial, e uma redução da densidade populacional no setor censitário próximo à Praça Frei Caetano Brandão, entre a rua Siqueira Mendes, a rua Dr. Assis e a Travessa Félix Roque, uma área

${ }^{94}$ TRINDADE JÚNIOR, 2016b.

$95 \mathrm{lbid}$ 
caracterizada pelo uso misto de atividades comerciais, institucionais e residenciais, em cuja proximidade se destaca a presença de grande número de museus.

Em relação à parte externa do entorno do Centro Histórico, no bairro do Reduto, próximo à orla de Guajará, houve uma redução da densidade populacional. Todavia, é importante ressaltar que a metodologia de categorias dos setores censitários adotada nos mapas, devido ao tamanho e forma de distribuição deles, não permite que se determine a causa ou o modo em que se deram as mudanças em relação ao indicador de densidade populacional.

Também se verifica, em direção àquela vertente da cidade, um aumento da densidade populacional no bairro Umarizal, ou uma redistribuição da concentração populacional, pois são verificados setores com densificação e outros com diminuição: Umarizal é um bairro com grande concentração de edifícios residenciais verticalizados. Ainda em relação a uma maior concentração populacional em bairros verticalizados, evidenciam-se no bairro Nazaré alguns adensamentos, e no bairro Batista Campos, algumas diminuições populacionais, segundo nossas análises dos mapas.

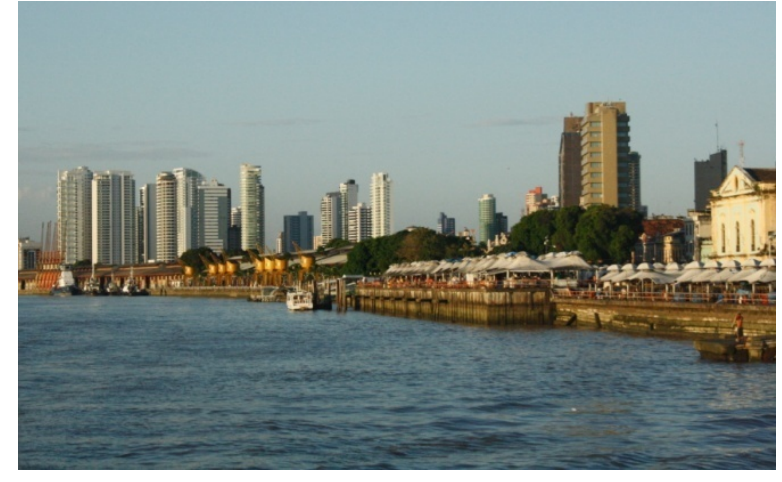

Imagem 12 - Verticalização residencial do bairro Umarizal ao fundo; e à frente a horizontalidade predominante da área do bem cultural Ver-oPeso e sua área de entorno, Belém, 2016. Fonte: autoria própria.

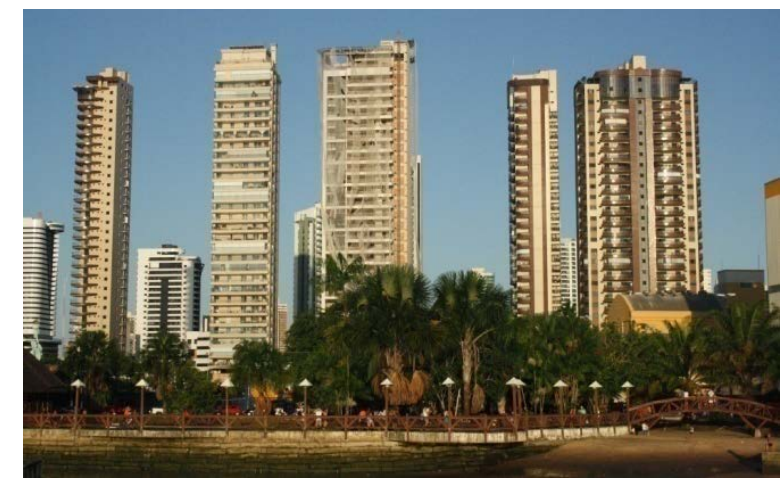

Imagem 13 - Vista da baía do Guajará para o Complexo Ver-o-Rio e bairro Umarizal, com a sua verticalização residencial, Belém, 2016. Fonte: autoria própria.

Ainda próximo do entorno do Centro Histórico, na parte externa de sua delimitação, em direção sudoeste, no bairro do Jurunas, verifica-se a manutenção de altas densidades populacionais. Constatamos, em campo, a predominância de edificações de gabarito baixo, de poucos pavimentos, predominantemente um a dois pavimentos, o que nos leva a deduzir que há concentração de favelas, chamadas de "baixadas" na cidade de Belém. 


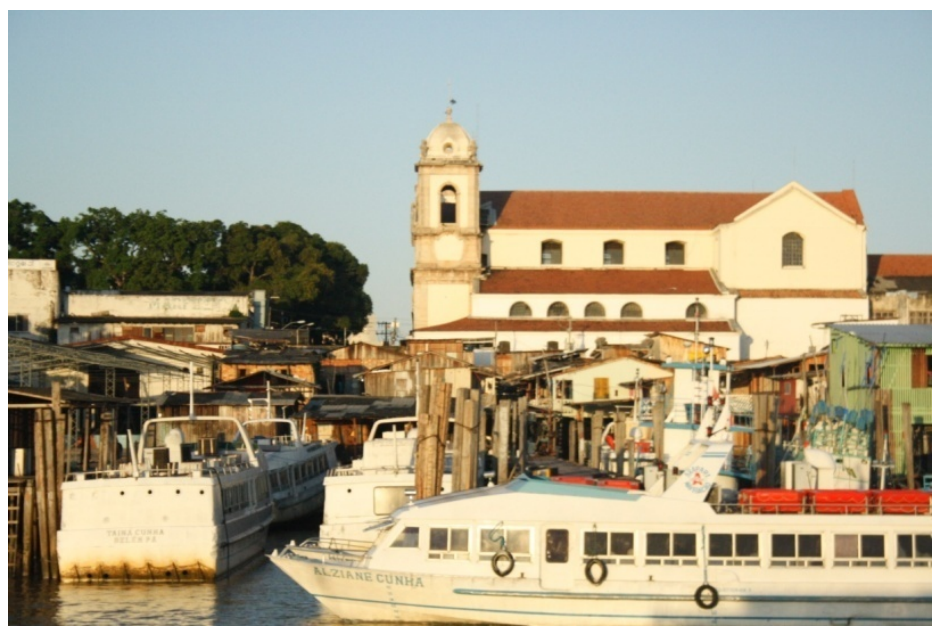

Imagem 14-Vista da baía do Guajará para o bairro Cidade Velha, do Porto do Sal, no Centro Histórico, de embarcações atracadas próximo a um trapiche com pouca infraestrutura, e a presença de baixadas e palafitas junto à orla, Belém. Fonte: autoria própria.

A área do Porto do Sal - repleta de estivas, palafitas, oficinas, estaleiros e inúmeras embarcações, com usos e formas de apropriação orientados por uma população ribeirinha, que historicamente reconhece a orla e o rio como espaços de produção e reprodução da vida - completamente diversa da ocupação recente (e criminosa) de Área de Preservação Permanente da orla do Paranoá.

A localização desse porto popular pode explicar a atenção especial para essa fração da orla de Belém. O Porto do Sal foi construído numa época em que o Ver-o-Peso era dominado por uma elite comercial da cidade, na divisa entre a orla urbanizada e repleta de monumentos históricos da Baía do Guajará e a orla do rio Guamá ocupada por usos industriais regionais, pequenos portos de palafitas, mais precisamente entre o complexo Feliz Lusitânia, o Mangal das Garças e o Portal da Amazônia.

(...)

O Porto do Sal é um espaço popular, com usos genuínos, mas de população não controlada (CARDOSO, 2016, p. 826-827).

Outra região da cidade em que foi possível verificar, por meio da análise dos mapas, uma redução da densidade populacional foi no bairro do Guamá e no bairro da Cremação, nas regiões leste e sudeste da cidade, respectivamente. 


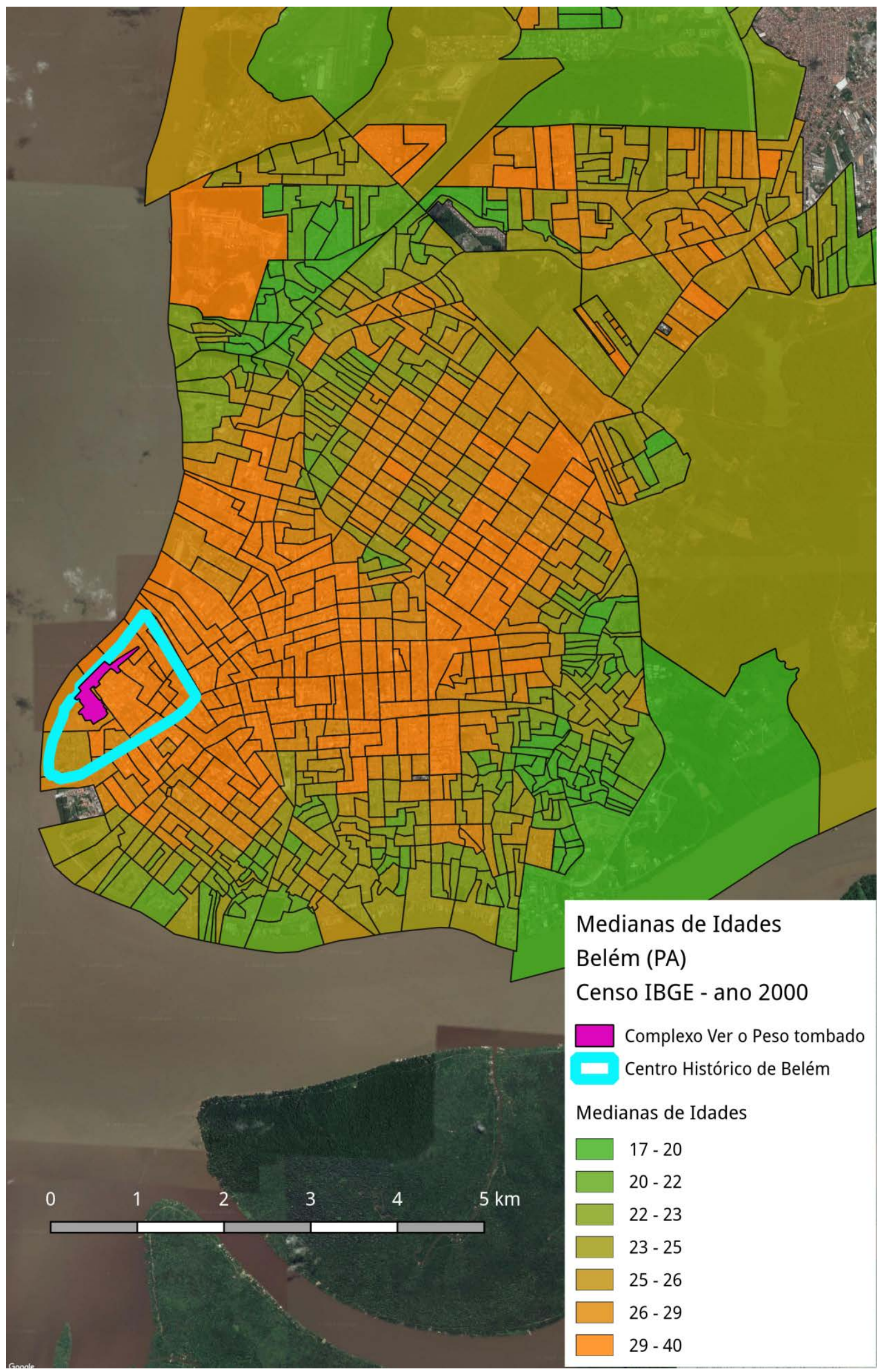

Mapa 8 - Medianas de idades, em anos, nos setores censitários definidos pelo IBGE para o município de Belém (PA), em 2000. Fonte: autoria própria. 


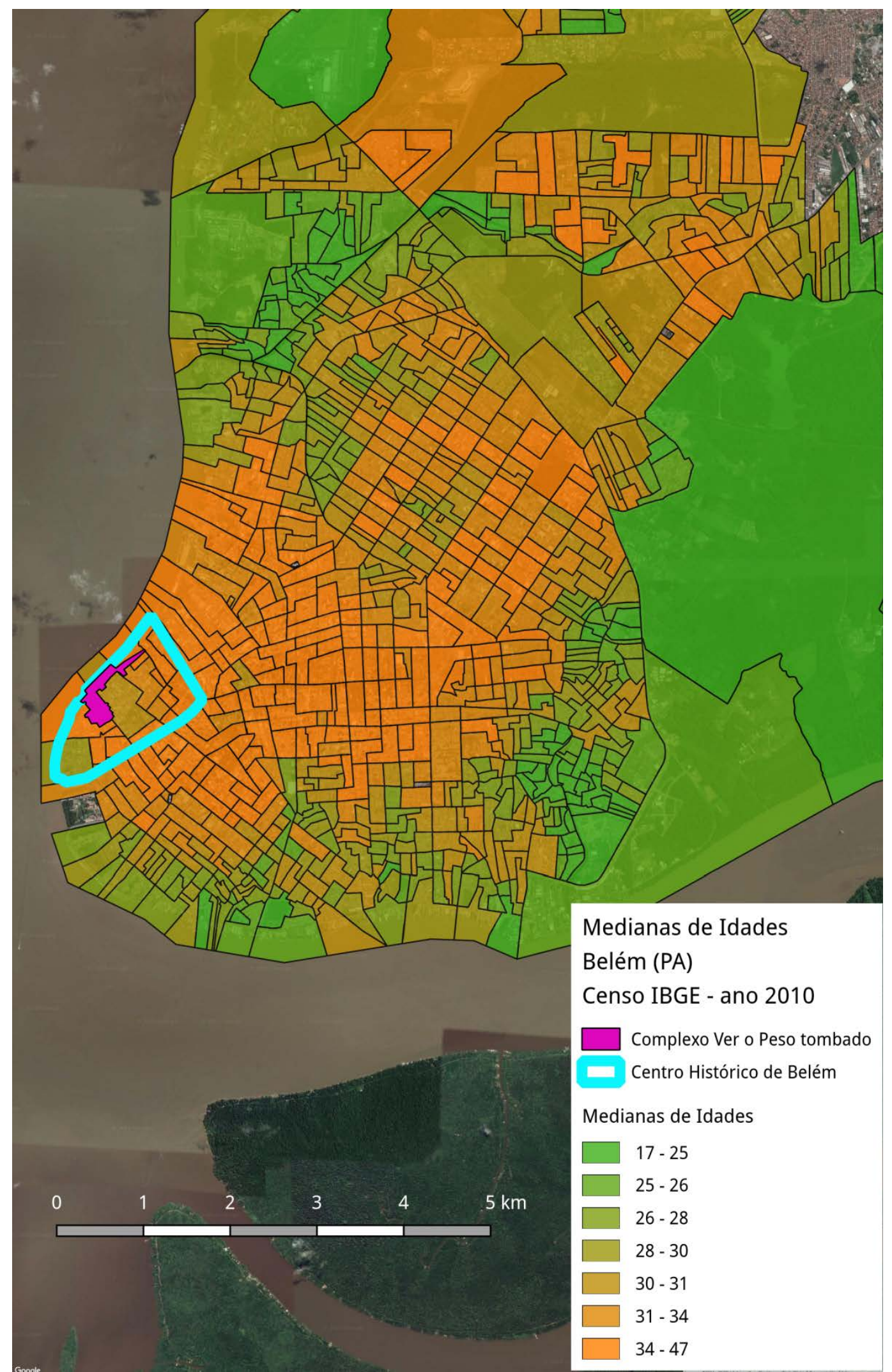

Mapa 9 - Medianas de idades, em anos, nos setores censitários definidos pelo IBGE para o município de Belém (PA), em 2010. Fonte: autoria própria. 


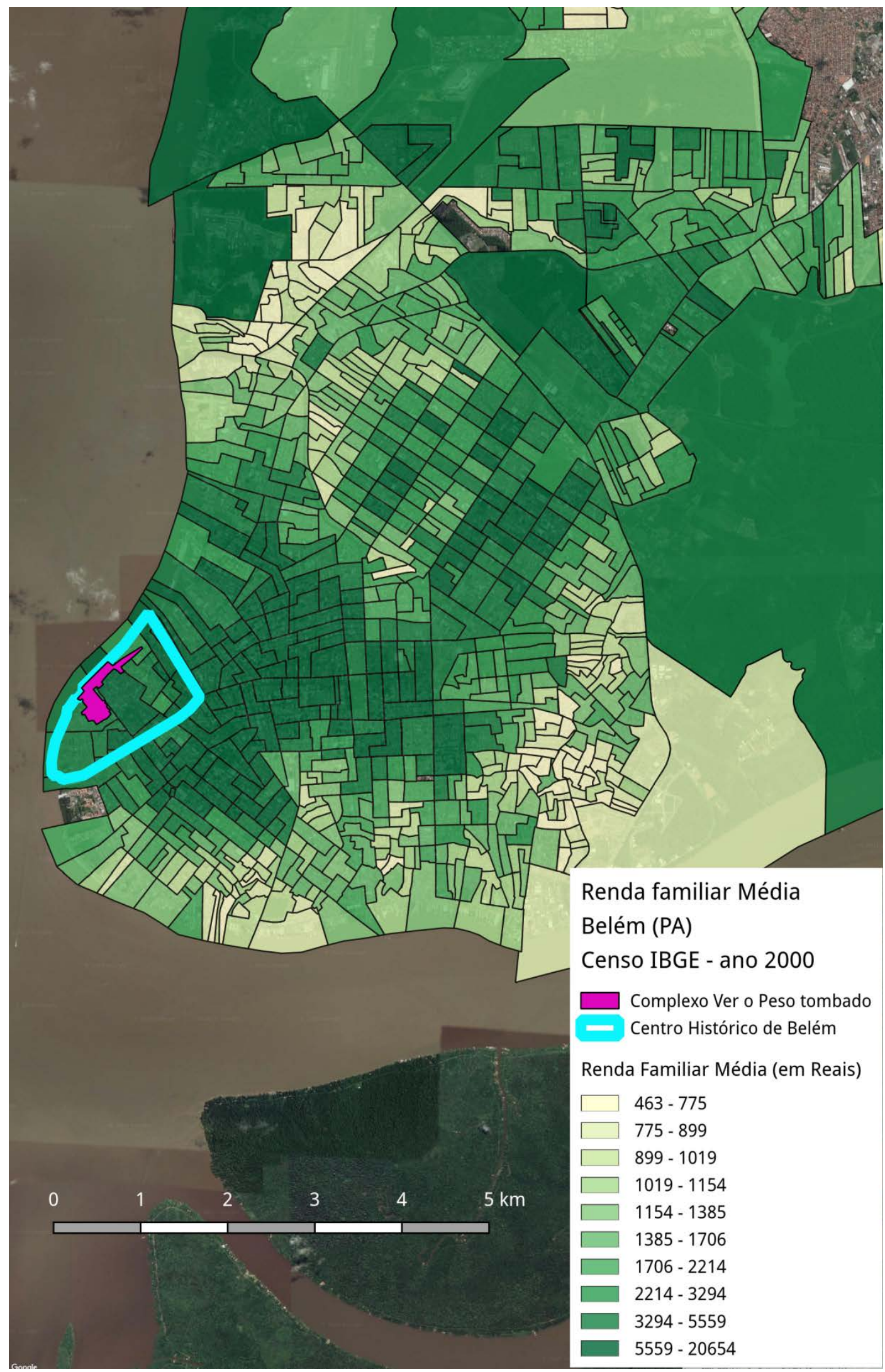

Mapa 10 - Renda familiar média, em Reais, nos setores censitários definidos pelo IBGE para o município de Belém (PA), em 2000. Valores atualizados pelo IPCA acumulado até outubro de 2016. Fonte: autoria própria. 


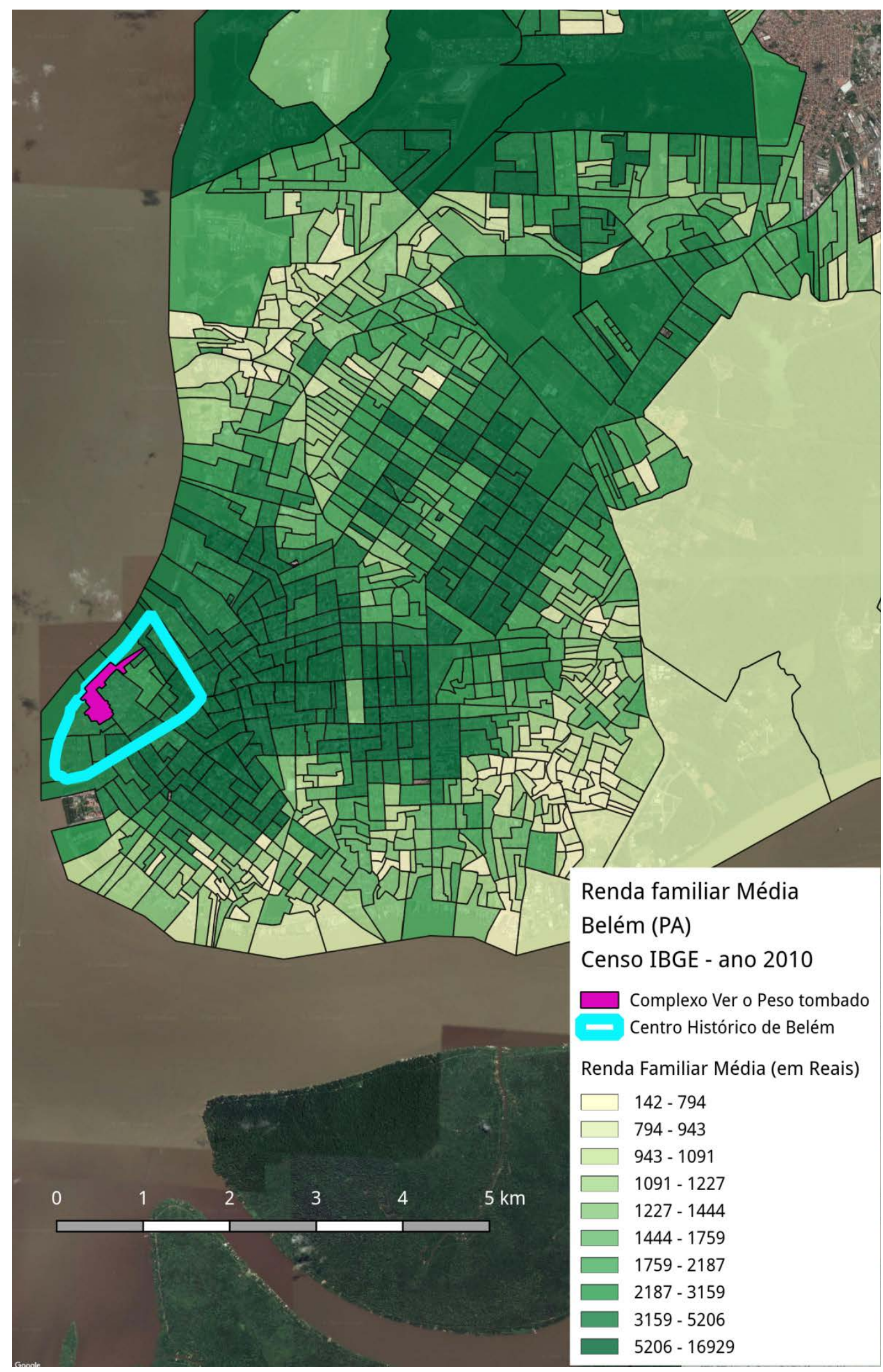

Mapa 11 - Renda familiar média, em Reais, nos setores censitários definidos pelo IBGE para o município de Belém (PA), em 2010. Valores atualizados pelo IPCA acumulado até outubro de 2016. Fonte: autoria própria. 
Os mapas de distribuição de renda no município de Belém foram baseados em valores de renda média familiar por setor censitário. Assim como no caso de idades, o cálculo da média pode ser influenciado por valores extremos nesse tipo de variável, mas o IBGE não divulga os dados de forma que a mediana possa ser calculada. Os valores de renda que constam na legenda de categorias de ambos os mapas (anos 2000 e 2010) foram atualizados para valores presentes (outubro de 2016) através do IPCA (Índice Nacional de Preços ao Consumidor Amplo).

A construção dos mapas de distribuição de renda seguiu o mesmo método de divisão em categorias que os mapas de densidade populacional e de idades medianas, utilizando, no entanto, 10 intervalos. Os setores censitários foram divididos em decis (10 quantis), porque a maior amplitude de renda média pode ser mais bem visualizada com essa categorização mais detalhada.

Obs.: Inflação acumulada utilizada para os cálculos de atualização monetária:

- janeiro de 2000 até outubro de 2016: 199,19\%

- janeiro de 2010 até outubro de 2016: 57,51\%

Por meio desses mapas, é possível evidenciar, de modo geral, a concentração de áreas com menor média de renda familiar ao sul, próximas à Orla do Rio Guamá, em algumas áreas do bairro do Guamá, e em algumas áreas do bairro do Telégrafo Sem Fio, próximo ao terminal Petroquímico de Miramar. Também evidenciamos uma concentração maior da pobreza no bairro do Guamá, e, em relação à totalidade da cidade, uma melhoria na média da renda familiar.

Em relação ao polígono do Centro Histórico e seu entorno, percebemos que, nos setores censitários em que a população se tornou consideravelmente mais jovem, a média da renda familiar reduziu, o que nos traz um indício de uma alteração no perfil de sua população.

Levando-se em consideração alguns comentários do Prof. Juliano Ximenes em relação à concentração de renda da cidade - "como a região metropolitana toda é muito pobre, e Belém é muito pobre, essa área do centro da cidade é uma centralidade metropolitana muito forte, Ver-o-Peso é uma centralidade regional muito grande como entreposto ${ }^{96 \prime}$-, podemos também observar que nossas análises estão concentradas em 
uma região de maior distribuição de renda entre a população, o que atribui um papel de centralidade à área, tanto em relação ao município quanto à metrópole. 


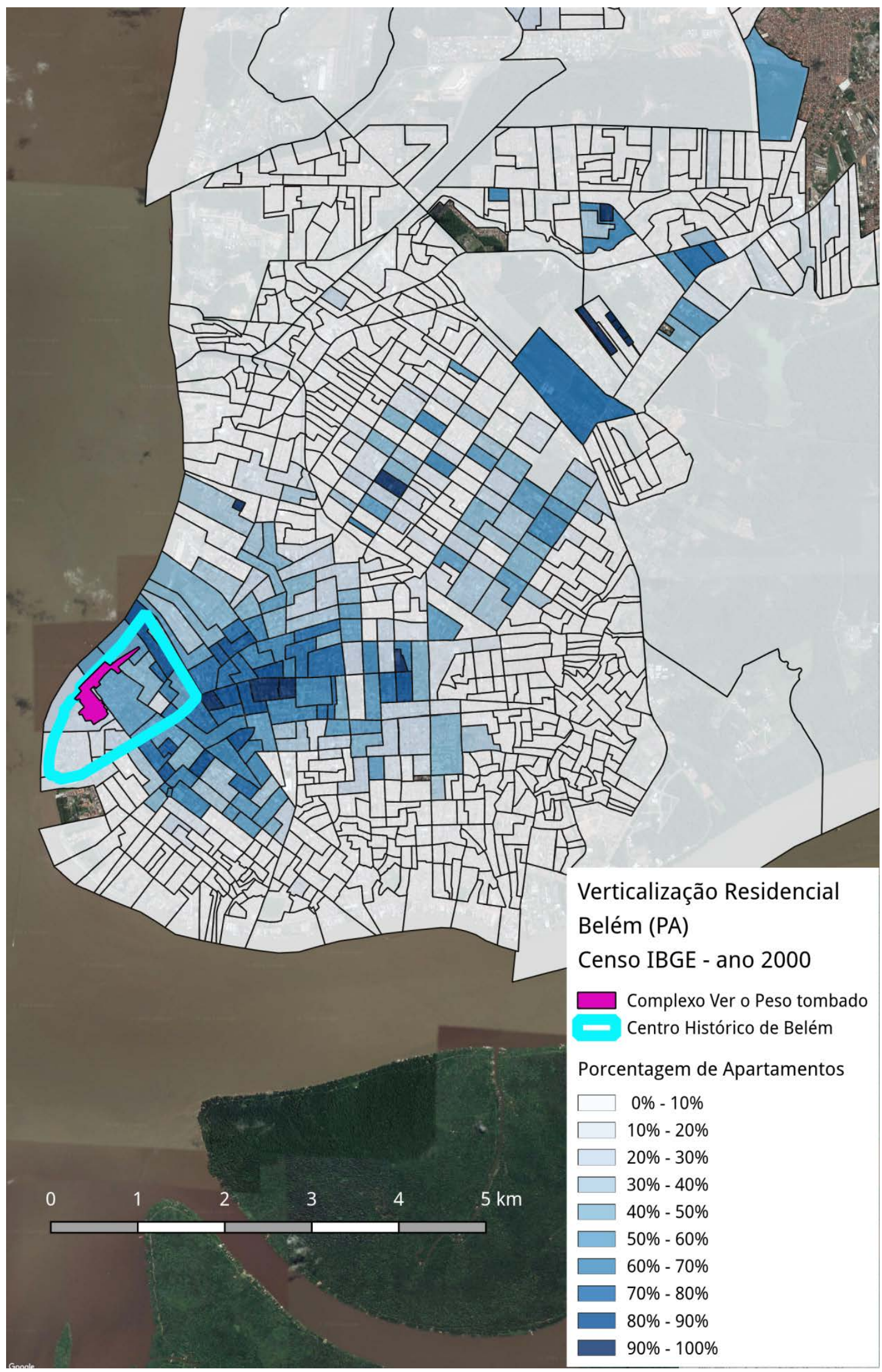

Mapa 12 - Porcentagem de residências do tipo apartamento em relação ao total de residências nos setores censitários definidos pelo IBGE para o município de Belém (PA), em 2000. Fonte: autoria própria. 


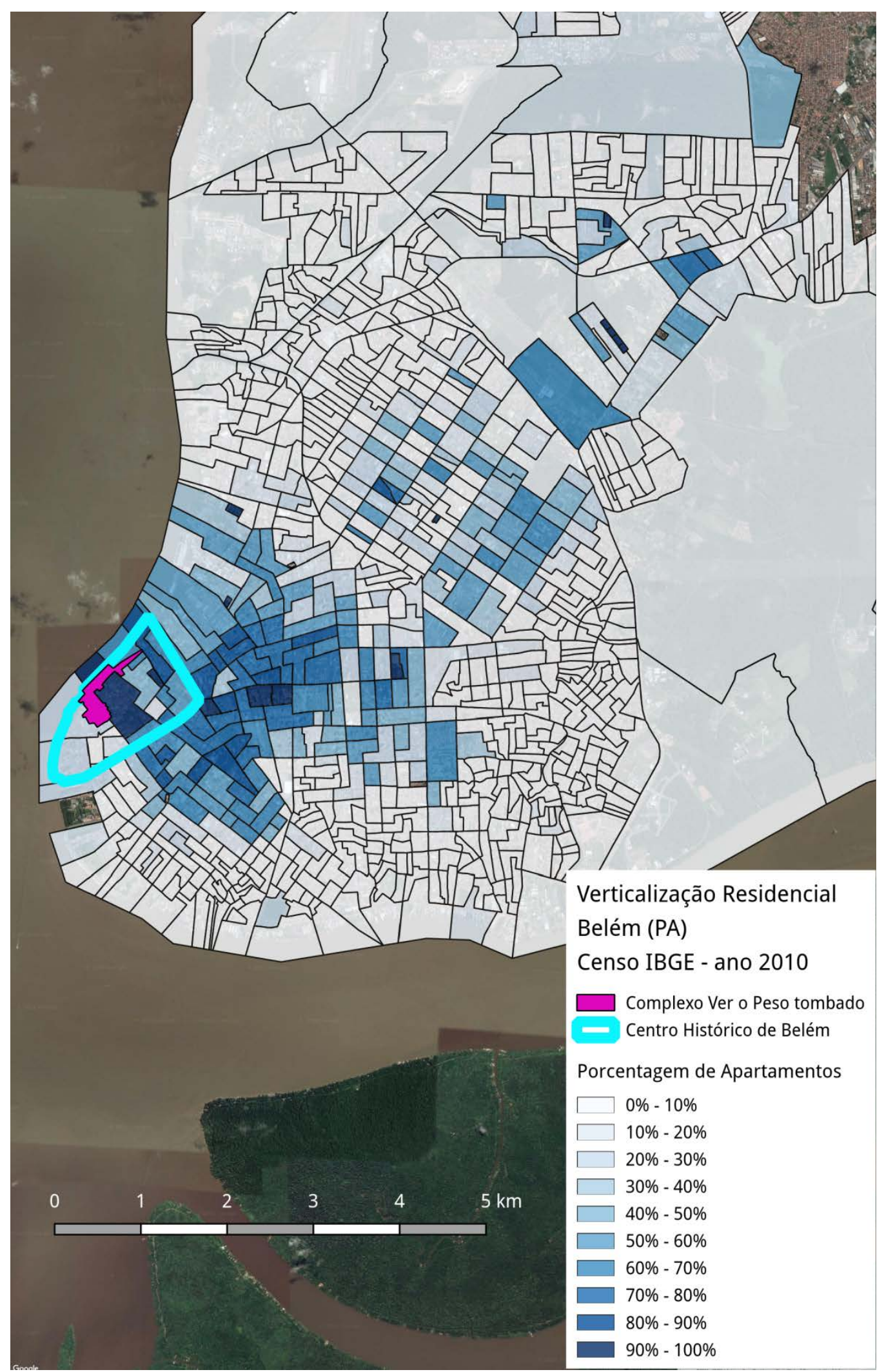

Mapa 13 - Porcentagem de residências do tipo apartamento em relação ao total de residências nos setores censitários definidos pelo IBGE para o município de Belém (PA), em 2010. Fonte: autoria própria. 
Os mapas com índices de apartamentos residenciais procuram demonstrar a proporção de apartamentos em relação ao total de residências particulares. Seu propósito é indicar a verticalização residencial em cada setor censitário, informação que pode ser complementada com densidade populacional, renda média e infraestrutura de esgoto em cada área, indicando características de urbanização. Como se trata de porcentagem, as categorias no mapa foram divididas em dez intervalos iguais em relação à própria variável, permitindo identificar mais facilmente as concentrações de edifícios residenciais de forma visual.

Esses mapas permitem-nos localizar a concentração da verticalidade residencial na cidade e afirmar que, nos bairros de Umarizal, Nazaré e Batista Campos, localiza-se o maior número de edifícios verticais habitacionais na cidade, e que nesses bairros há construções novas que concentram população residencial. Nessas áreas residenciais verticalizadas, percebemos uma ampla cobertura de sistema de esgoto e de urbanização, e uma maior concentração de renda familiar.

Os mapas também nos permitem verificar que a cidade de Belém é bastante horizontalizada, com a predominância de edificações de baixo gabarito, que constituem um padrão de ocupação bastante uniforme na maior parte da cidade.

O mapa de índice de cobertura de esgoto mostra a porcentagem de residências atendidas pela rede de saneamento em relação ao número total de residências de um setor censitário. Assim como o índice de apartamentos, trata-se de um cálculo de porcentagem, por isso foram utilizadas 10 categorias com intervalos iguais de porcentagens. As residências não atendidas pela rede utilizam fossas sépticas ou depósitos em valas, riachos e rios. Esse índice foi utilizado como indicador de urbanização, cuja informação pode ser utilizada em associação àquelas oferecidas nos outros mapas de dados demográficos.

É possível evidenciar, pelas imagens, que a urbanização da cidade incorporou melhorias representativas no sistema de rede de esgoto de diversas regiões da cidade. Destacam-se as melhorias de regiões com grande concentração populacional, de faixa etária mais jovem e edificações residenciais menos verticalizadas; dentre elas, destacam-se principalmente as áreas localizadas no sul do bairro do Jurunas, no bairro do Guamá, Terra Firme e Telégrafo Sem Fio, bairros que apresentam maior número de verticalizações residenciais. Também foi possível evidenciar essas melhorias no bairro do Marco e no bairro Umarizal, bastante verticalizado em algumas áreas. 
Em relação à área central do Centro Histórico e seu entorno, percebe-se que são áreas caracterizadas pela existência de uma grande cobertura de infraestrutura urbana. As melhorias concentraram-se na direção sudoeste, que, por se tratar de áreas com grande presença de edifícios históricos, devem ter passado por intervenções de modernização e urbanização em seus edifícios. Nossas conclusões vão ao encontro da afirmação de Juliano Ximenes de que:

Belém tem uma infraestrutura [urbana] razoável num pedaço muito pequeno da cidade, daqui da Cidade Velha até o bairro do Marco.

$O$ resto é muito inferior, muito pior a infraestrutura, você pode ter áreas mais arborizadas, mas a dificuldade de transporte público é muito maior, a qualificação do sistema de áreas e disponibilidade de equipamentos é pior. A infraestrutura da cidade é muito pequena, muito restrita e concentrada (PONTE, 2016) ${ }^{97}$.

\footnotetext{
${ }^{97}$ Entrevista concedida à autora da tese, no Café da Sol, na Doca, Belém, 2016.
} 


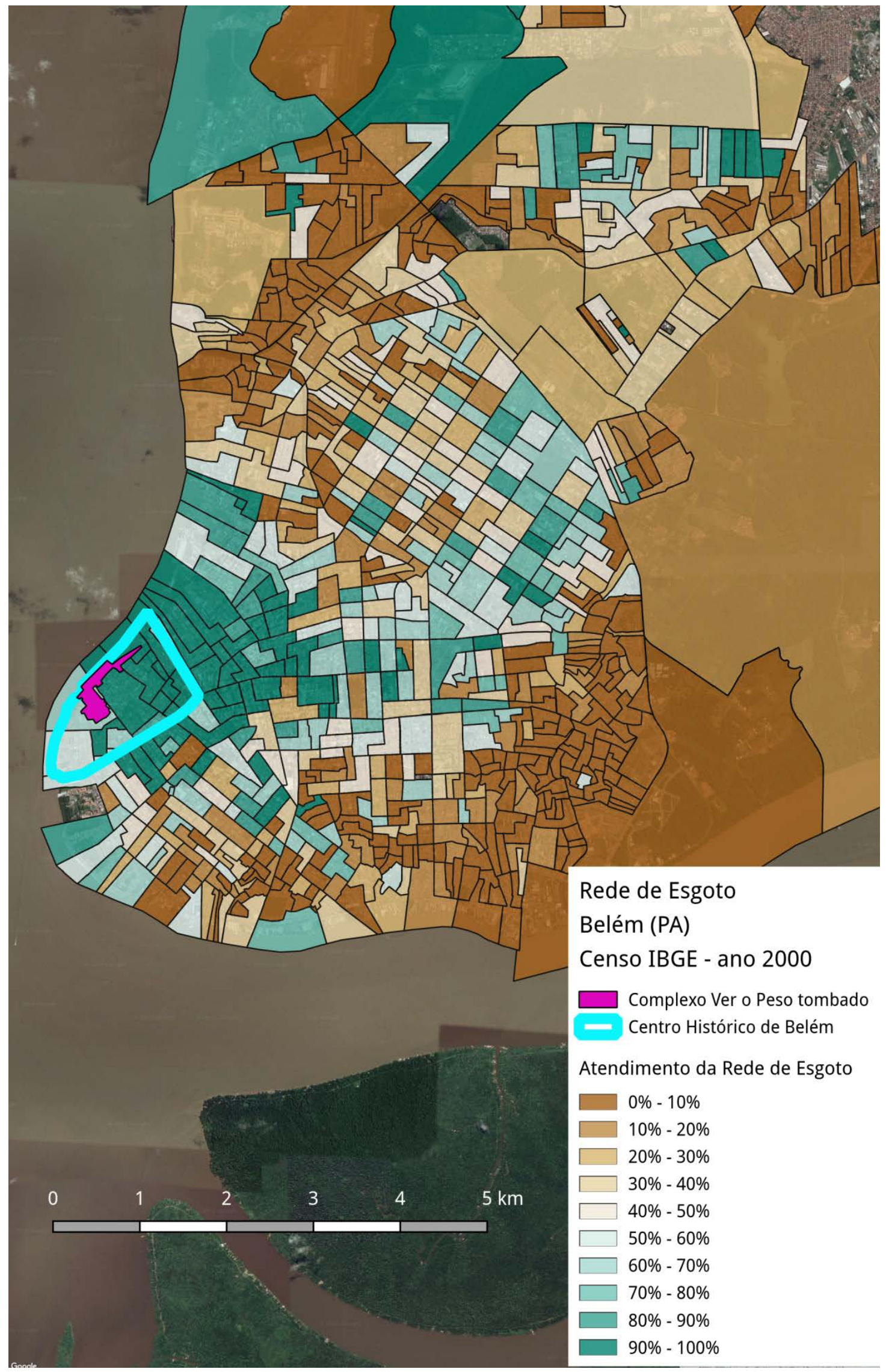

Mapa 14 - Porcentagem de residências atendidas pela rede de esgoto em relação ao total de residências nos setores censitários definidos pelo IBGE para o município de Belém (PA), em 2000. Fonte: autoria própria. 


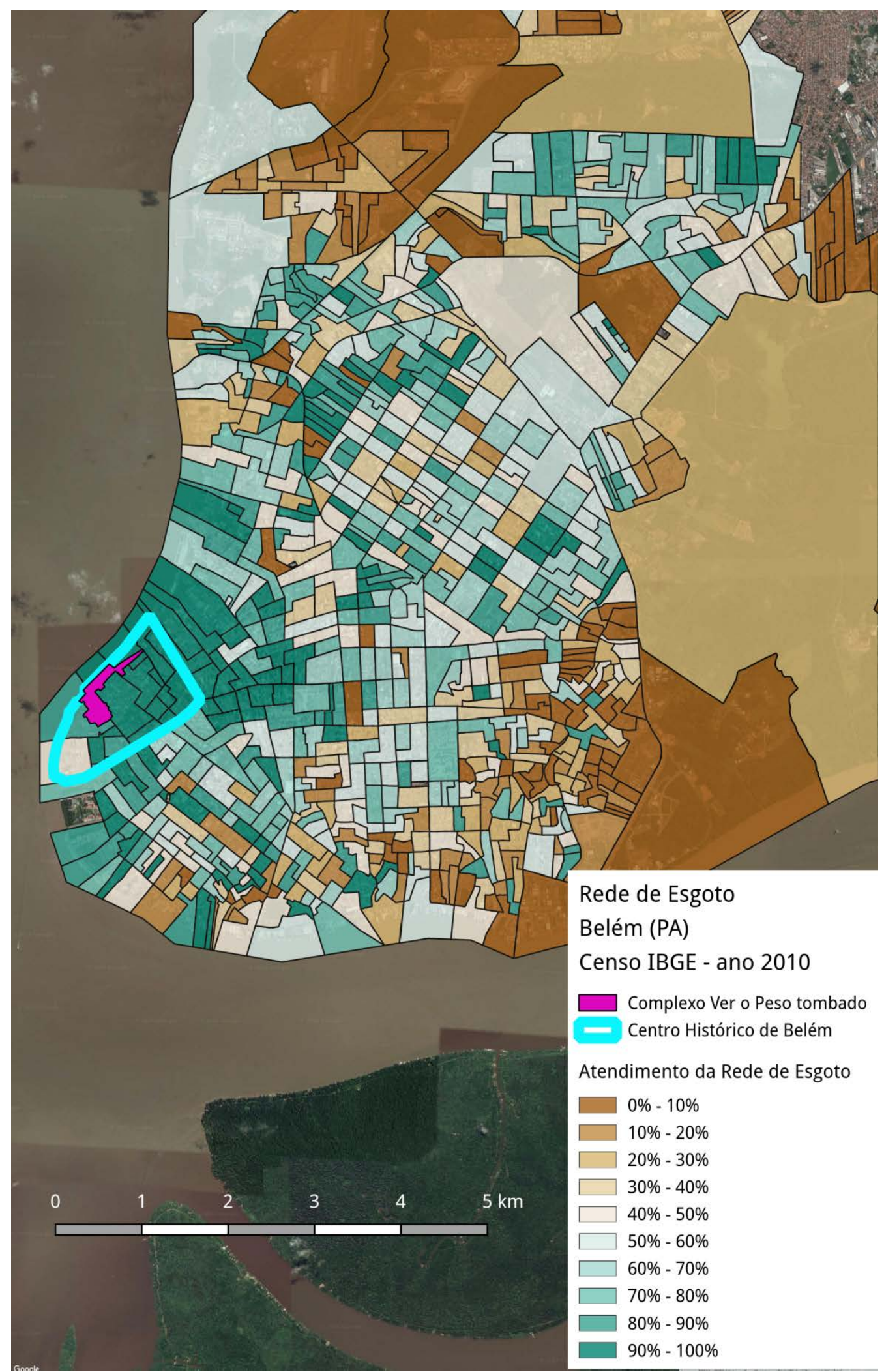

Mapa 15 - Porcentagem de residências atendidas pela rede de esgoto em relação ao total de residências nos setores censitários definidos pelo IBGE para o município de Belém (PA), em 2010. Fonte: autoria própria. 
O vai e vem da canoa, o rio, a floresta e o tributo.

Buscamos construir uma matriz conceitual que delimite, estruture e reconheça a importância do bem cultural do Ver-o-Peso, desde o início de seu funcionamento, no século XVIII, quanto à sua importância histórica, com o objetivo de compreender a concepção de sua candidatura a patrimônio mundial. No início, Ver-o-Peso era uma casa fiscal, ligada ao sistema de tributação de impostos ${ }^{98}$ de gêneros que chegavam à sede das capitanias no Brasil.

Segundo esse sistema de tributação, as mercadorias que chegavam ao continente passavam pela casa fiscal de Ver-o-Peso e depois eram distribuídas para diversos lugares do Brasil. Tal função de entrada de mercadorias atribuiu ao local tanto uma importância relacionada à troca, à venda e ao consumo de produtos, quanto um aspecto cultural e simbólico de espaço de encontros sociais. Tais encontros se ligavam ao ambiente urbano, que se consolidava lentamente, e ao ambiente natural, pois era por meio do rio e de embarcações que muitos dos gêneros originários da floresta Amazônica chegavam ao lugar.

Ao longo da história, constituiu-se uma importante faixa do território da cidade, e o papel da natureza em sua ocupação foi marcante, com os "grandes rios, que desempenharam um papel logístico importante, tanto para a mobilidade de pessoas quanto de mercadorias" (CARDOSO, 2013, p. 59-60). Mas "a região historicamente foi considerada como de difícil ocupação, devido à barreira que o rio e a floresta constituíam à aglomeração urbana" (CORRÊA, 1987 apud CARDOSO, 2013, p. 60), como é possível visualizar na imagem a seguir, com a representação da gênese e da distribuição do núcleo urbano da cidade de Belém ao longo da baía, e com o marco de fundação da cidade de Belém, no século XVII, em 1616, o Forte do Presépio ${ }^{99}$.

O Forte do Presépio era uma edificação de madeira e palha, ao redor da qual desenvolveu-se o núcleo pioneiro, que compreendia um conjunto de quatro ruas principais,

\footnotetext{
98“"Durante 151 anos permaneceu nos hábitos do povo e do comércio a prática do recolhimento do imposto do Ver-o-Peso. Concedido por provisão real à Câmara de Belém, esse pagamento era usado nas demais capitanias e no próprio reino. O presidente Bernardo de Souza Franco, por intermédio da Lei no 22, de 28 de setembro de 1839, extinguiu a repartição do Ver-o-Peso em Belém" (VER-O-SITE, 2016).

${ }^{99}$ Forte do Castelo do Senhor Santo Cristo do Presépio de Belém.
} 
dispostas em leque e convergindo para o forte. "A primeira rua, junto ao rio, chamou-se rua do Norte (atual Siqueira Mendes), cujo traçado indicava, de um lado, a relação com o forte e, de outro, o rumo da metrópole" (documento do Museu do Forte do Presépio, 2000).

\section{PRIMEIRO NÚCLEO URBANO}

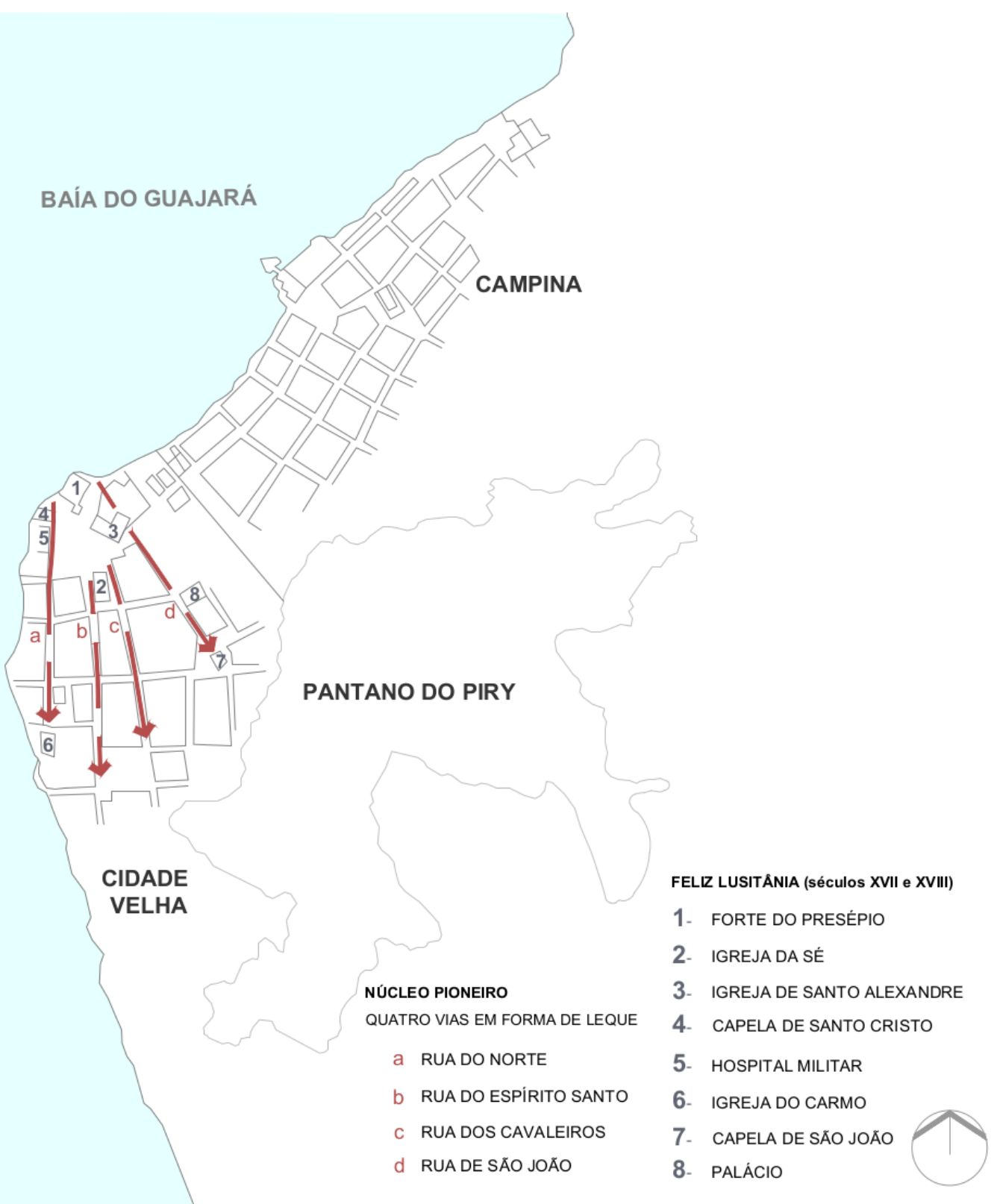

Mapa 16 - Ilustração da gênese urbana de Belém, com a localização do núcleo pioneiro da cidade. Fonte da imagem: autoria própria sobre base iconográfica do levantamento tipográfico do museu do Forte do Presépio, desenvolvido pela sua equipe de arquitetura em 2000.

O Forte foi o ponto principal da ordenação geométrica do traçado de Belém. Ainda no século XVII, a cidade se ampliou para além do limite da fortificação, conformando o que a 
historiografia consagrou como o seu primeiro núcleo urbano, e que originou o povoado de Santa Maria de Belém do Grão-Pará.

A situação geográfica privilegiada transformou a região em um porto comercial, cuja economia era caracterizada pela exploração de produtos através de ciclos extrativistas, que concentrou e constituiu uma dinâmica territorial no local, tal como parte de um sistema de rede. "Tais características formaram uma rede dendrítica, com várias pequenas cidades portuárias distribuídas nas margens dos rios" (CORRÊA, 1987 apud CARDOSO, 2013, p. 60). Nesse sistema, o rio foi o elemento que norteou a localização da cidade, devido às próprias conexões entre as localidades, que estabeleceu o vetor de expansão urbana.

O primeiro edifício construído na área de entorno do Forte, em 1617, foi a Igreja de Nossa Senhora das Graças (atual Sé Catedral de Nossa Senhora da Graça). Sua arquitetura em relação ao largo do forte e a disposição de sua fachada, orientada para ele, expõem a sua composição como um conjunto urbano.

Também desse período é a primeira construção da Capela do Santo Cristo, em 1622, em frente à fortificação. Posteriormente, foi reconstruída ao lado da Casa das Onze Janelas. A segunda Capela e essa Casa datam do século XVIII, durante a administração pombalina, quando se criou a Companhia Geral de Comércio de Grão-Pará e Maranhão, em 1755.

Ao longo de todo o século XVIII, o Ver-o-Peso assistiu aos principais eventos e acompanhou as mudanças urbanísticas que a cidade sofria, em seu crescimento para a outra margem do igarapé do Piri. A conformação cultural do Mercado foi sendo impregnada pelas gentes que chegavam: escravos indígenas dos sertões amazônicos dos rios Negro, Japurá, Solimões e Madeira, negros de Angola e Benguela, colonos portugueses vindos de África e da Metrópole, comerciantes de escravos e drogas do sertão, missionários, cientistas e militares. A Língua Geral, ou Nheengatu, ensinada pelos missionários, era falada por todos. No Ver-o-Peso, ainda naquele século, aportaram no Grão-Pará as primeiras mudas de café vindas de Cayena pelas mãos de Francisco de Melo Palheta, as quais, mais tarde, mudariam a economia e a história do Brasil (VER-O-SITE, 2016).

O século XVIII foi marcado pelo incentivo à produção de café, arroz, tabaco, cana-deaçúcar, cacau, algodão e pela criação de gado na ilha de Marajó, além das atividades extrativistas de madeira, castanha-do-pará, açaí, frutas silvestres, urucu, látex e da produção de baunilha e cravo. No estado do Pará, também estavam concentradas as maiores reservas minerais do país, com bauxita, minério de ferro, manganês, cassiterita, cobre, tungstênio, 
ouro e salgema, produtos que sempre despertaram grande interesse nos mercados nacional e internacional.

A configuração espacial dos atuais bairros da Cidade Velha e da Campina, o "Centro Histórico", remete historicamente aos espaços iniciais da cidade, cuja consolidação urbana se iniciou no século XVII e finalizou nas primeiras décadas do século XX ${ }^{100}$, concomitantemente à consolidação de centros urbanos de outras cidades da América Latina, em que a "matriz [histórica] da cidade se consolida em termos de magnitude e peso específico na estrutura urbana, através de sua preeminência sobre outros processos na cidade" ${ }^{101}$ (MENA, 2003, p. 132). Podemos destacar a sua conformação arquitetônica em vários estágios e estilos:

O complexo do Ver-o-Peso, portanto, constitui-se de um importante patrimônio edificado, situado no centro histórico de Belém, datado dos séculos XVII, XVIII e XIX, uma síntese da conformação arquitetônica da cidade em vários estágios e estilos: edificação militar, barroco jesuítico, arquitetura civil colonial e pós-colonial, estilo neoclássico, estilo eclético e arquitetura industrial (VER-O-SITE, 2016 apud INRC Ver-o-Peso, 2010, Iphan/PA).

A composição da matriz histórica caracteriza-se por diferentes processos tanto em termos temporais como territoriais. Isso gerou diferentes expressões territoriais de centralidade histórica, caracterizadas por arquiteturas e espaços urbanos heterogêneos, pertencentes a diferentes períodos históricos e relacionados aos diferentes momentos de crescimento econômico da cidade de Belém.

Mena (2003, p. 132) informa que o que convencionamos chamar atualmente de "Centro Histórico" correspondia a uma cidade total. Partindo da consideração geral de que a cidade é o espaço que concentra a diversidade, a configuração histórica dessa matriz é constituída e caracterizada pela heterogeneidade, em que a diversidade prevalece e é vista por aquele autor como sua essência primitiva.

${ }^{100}$ Esse período determinado foi resultado de nossa interpretação do processo em relação a outros processos da cidade de Belém, e da aplicação de um corpo conceitual que delimite, estruture e reconheça essa matriz histórica, relacionada ao bem cultural Ver-o-Peso.

${ }^{101}$ Tradução nossa. 
Nas primeiras décadas do século seguinte, considerado o período do auge da borracha, muitos dos elementos culturais da paisagem de Ver-o-Peso foram construídos: o mercado pré-fabricado em ferro trazido da Inglaterra na margem da baía; ampliação do antigo Mercado de Carne, situado nas proximidades; ampliação do aterramento da baía e construção do porto pelos ingleses, além de outras construções seguindo um padrão arquitetônico europeu, de estilo eclético e com grande influência art nouveau, sobretudo nos elementos de ferro trabalhado artisticamente (VER-O-SITE, 2016).

A Belle Époque de Belém, no século XIX, está relacionada ao ciclo da borracha, quando Amazônia foi uma das maiores produtoras de látex do mundo. Esse ciclo trouxe para a região avanços tecnológicos e intensiva modernização no desenvolvimento de Belém. Ela adquire feições sofisticadas ${ }^{102}$, com a construção de prédios monumentais, grandes bulevares, parques e praças ${ }^{103}$. Assim, ao lado de seus edifícios de arquitetura colonial de forte influência portuguesa, surgem novas edificações de estilo eclético e que compõem sua paisagem ${ }^{104}$.

Essa região da cidade consolidada foi adquirindo, ao longo do tempo, um caráter de centralidade, caracterizada pela presença de equipamentos públicos, de instituições e do comércio varejista. Segundo José Júlio Lima (VARGAS, 2015, p.227), essas atividades de uso e ocupação do solo caracterizam a região como uma área economicamente dinâmica em relação a outros bairros da cidade. Tal dinamismo também se reflete na evolução construtiva e urbana histórica do conjunto, caracterizado pelo grande número de exemplares arquitetônicos monumentais remanescentes do século XVIII e do século XIX.

No final do século XIX, a partir da exploração da borracha em grande escala, configura-se uma nova etapa, com a expansão urbana para o interior da parte continental e periférica do território, em relação à cidade consolidada. Inicia-se também uma

${ }^{102}$ Seus aspectos de cidade sofisticada fazem-se em comparação com outras cidades, no mesmo período, no cenário nacional e internacional.

${ }^{103} \mathrm{O}$ apogeu econômico do ciclo da borracha deu-se entre os anos de 1890 e 1911, período sob a intendência do urbanista Antônio Lemos, em que, além dos bondes elétricos, avenidas foram construídas sobre regiões alagadiças, assim como os edifícios do Theatro da Paz, Mercado de São Brás, Mercado Francisco Bolonha, Mercado de Ferro, Palácio Antônio Lemos, corredores e vias com mangueiras e diversos palacetes residenciais.

${ }^{104}$ Essa paisagem da cidade ainda está presente nos dias de hoje em alguns pontos da cidade, tais como nas proximidades do Ver-o-Peso, com o casario colonial da margem esquerda do antigo Piri, na parte posterior do antigo Colégio dos Jesuítas e da Igreja Santo Alexandre, também de mesma ordem religiosa e estilo barroco, atual Museu de Arte Sacra, e na lateral do antigo Forte do Castelo, que corresponde à primeira expansão do núcleo urbano originário da cidade. 
diferenciação da centralidade do espaço urbano e da cidade total, quando a matriz histórica começa a assumir funções de centralidade dentro do crescimento da cidade.

Posteriormente, no final do século XX, a supremacia da borracha brasileira sofre forte declínio, por conta da concorrência da exploração do látex no continente asiático, a qual utiliza métodos mais rentáveis. As atividades do porto de Belém que estavam diretamente ligadas ao ciclo da borracha sofrem, com o declínio, uma grande queda nos lucros. Com isso, iniciou-se um período de restrições orçamentárias. Com a ausência de investimento em modernizações, o porto também experimentou um grande declínio em relação a outros portos do Brasil de do mundo.

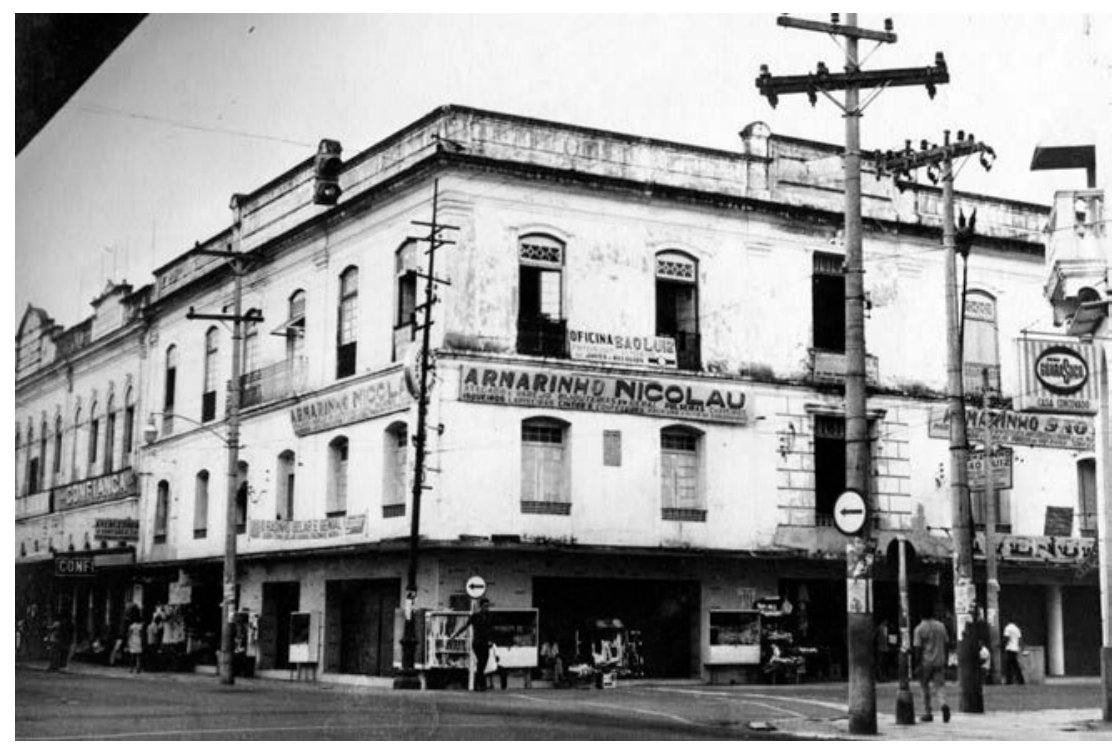

Imagem 15- Nesta área, em 1969, ficava a Farmácia do Povo, Armarinho Nicolau \& Cia. Estas edificações foram construídas no século XVII, no local que anteriormente abrigou a casa que serviu de Ver-o-Peso, para cobranças dos impostos devidos à Câmara. A casa ficava no ângulo da rua dos Mercadores (atualmente rua Conselheiro João Alfredo) com a travessa da Companhia (nos dias atuais, Avenida Portugal). Com apenas um pavimento, a edificação foi derrubada no século XIX para a construção de um sobrado no qual foi instalado um hotel e, posteriormente, estabelecimentos comerciais. Fonte: Acervo IPHAN. 
EVOLUÇÃO DO ESPAÇO URBANO (1616 - 1980)

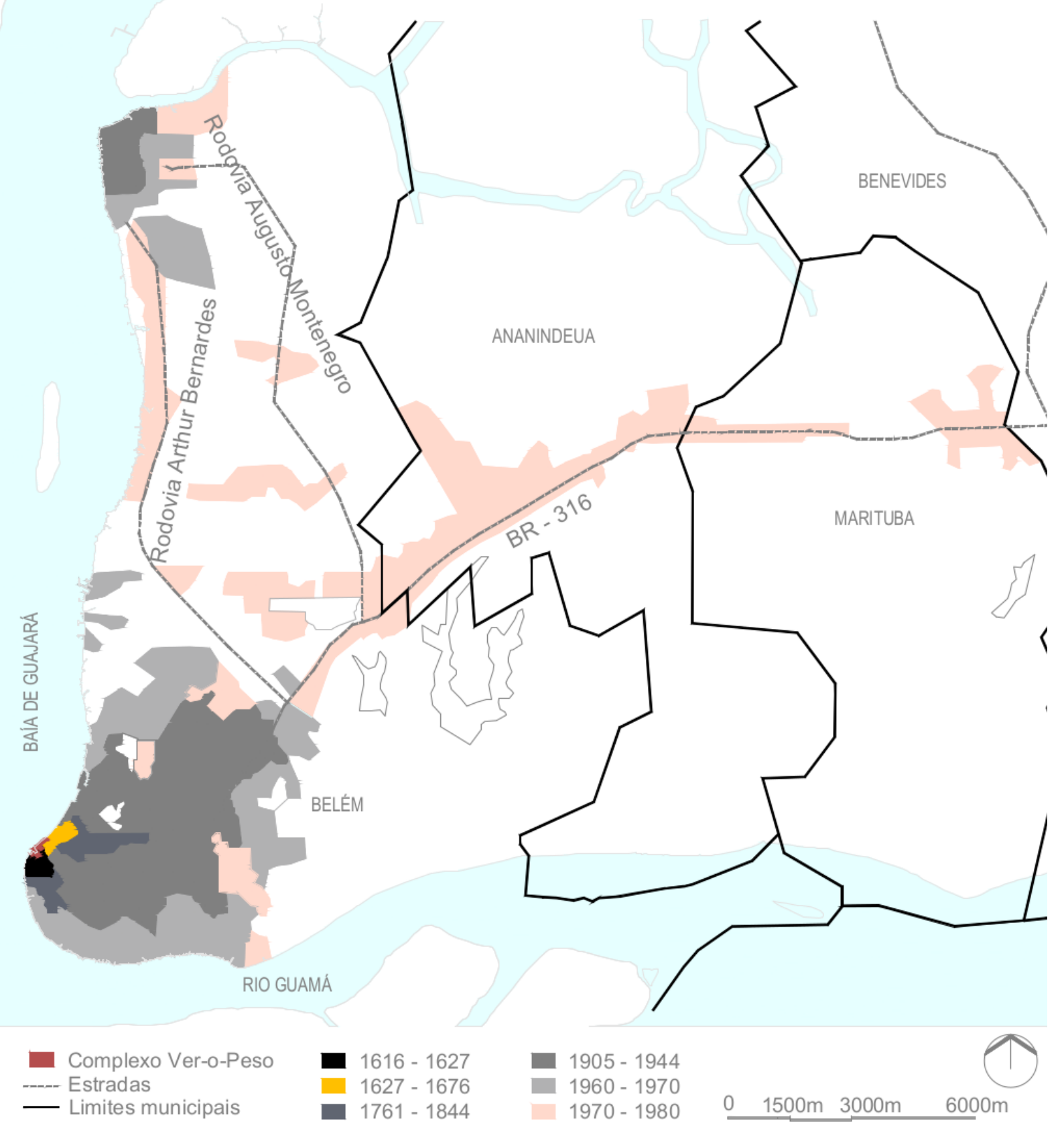

Mapa 17 - Ilustração do sentido da expansão urbana ao longo do tempo, localizando o núcleo urbano pioneiro da cidade de Belém, o bem cultural Ver-o-Peso. Fonte da imagem: autoria própria sobre base de informações de TRINDADE JÚNIOR, 2016a, p. 106. 
EXPANSÃO URBANA INICIAL

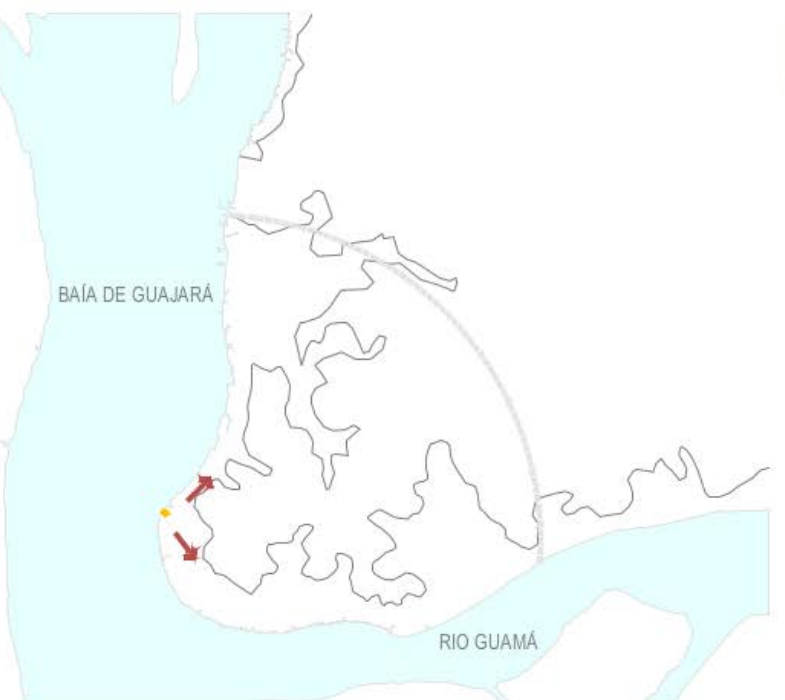

PERIFERIZAÇÃO DAS BAIXADAS

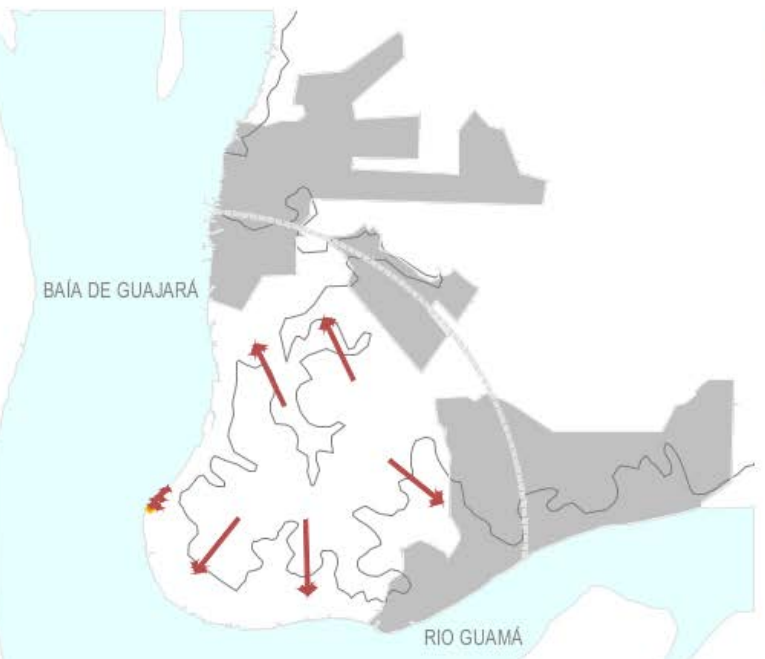

OCUPAÇÃO DAS ÁREAS ALTAS

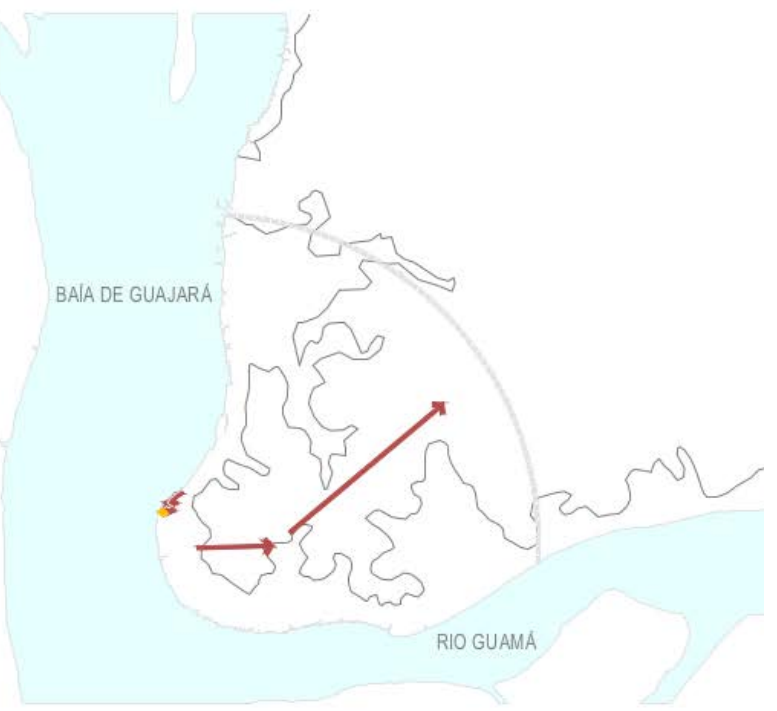

NOVOS EIXOS DE EXPANSÃO URBANA

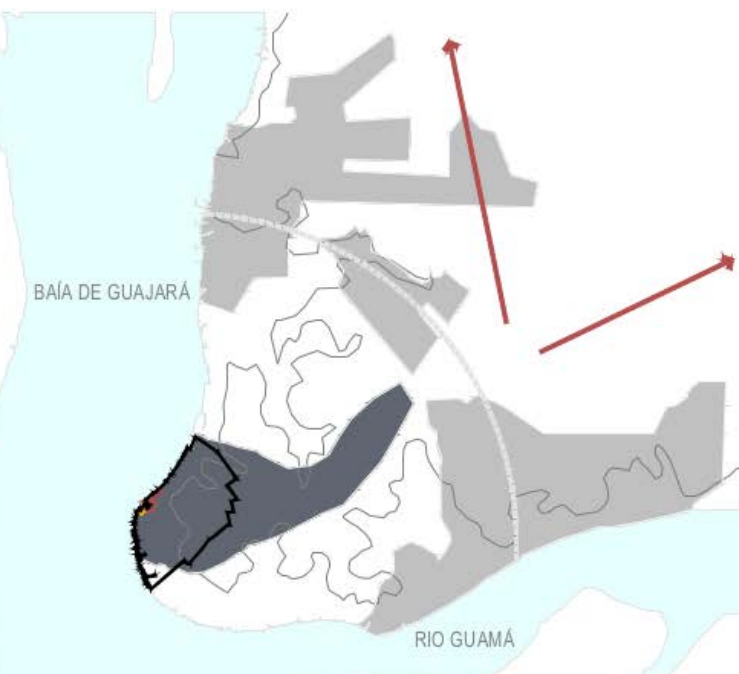

Forte do Presépio

Complexo Ver-o-Peso

$\rightarrow$ Sentido da expansão urbana

- Limite das Baixadas

.numite da Primeira Légua Patrimonial
Complexo Ver-o-Peso

Cinturão Institucional

Densificação da área central

Centro Histórico e entorno

do Centro Histórico de Belém

Mapa 18 - Imagens esquemáticas da produção do espaço urbano em Belém, de 1616 a 1997. Fonte: autoria própria sobre base de informações de TRINDADE JÚNIOR, 2016a, p. 106. 
No plano da estruturação interna do espaço metropolitano, o que se observa é que, até a década de 1950, Belém apresentava uma clara tendência de não ocupação de suas áreas de baixadas, consideradas insalubres, sem infraestrutura, ainda que centralizadas no conjunto do espaço construído (TRINDADE JÚNIOR, 2016a, p. 97).

Segundo Saint-Clair Trindade, com a prioridade dada a terrenos de cotas mais elevadas e a implantação das áreas institucionais, na década de 1940, estabelecidas à altura dos limites da Primeira Légua Patrimonial, a cidade tornou-se uma malha urbana irregular. Essas áreas passaram a atuar como uma espécie de cinturão, obstaculizando a expansão horizontal contínua além dos limites da Primeira Légua Patrimonial, provocando o adensamento e a valorização dos terrenos de nível mais elevado na região.

Em decorrência da densificação em vários setores da cidade, a população procurou estabelecer novas possibilidades de aproveitamento do espaço, ocupando núcleos dos grandes quarteirões e terrenos de cotas mais baixas. A ocupação das áreas de baixada deuse a partir da década de 1950 e intensificou-se nos anos 1960, 1970 e início dos anos 1980. Essas áreas, antes ocupadas por rebanhos leiteiros (que passaram a sofrer a concorrência do leite industrializado vindo do centro-sul do país), deram lugar ao uso residencial do solo, por uma população de baixo poder aquisitivo, como processo de favelização (ver imagem 14).

O chamado "cinturão institucional" foi ultrapassado a partir da década de 1970, com a ocupação de localidades até então consideradas distantes, para além dos bairros integrantes da Primeira Légua. Nesse período, com a institucionalização das regiões metropolitanas brasileiras, o município de Ananindeua passou a fazer parte da RMB: foi instalado seu distrito industrial, o qual constituía um novo vetor de expansão horizontal, onde, por meio de incentivos fiscais do governo federal, surgiram os primeiros conjuntos habitacionais, alcançando definitivamente a área denominada "Segunda Légua Patrimonial"(TRINDADE JÚNIOR, 2016a, p.99). 


\section{Conceito de paisagem cultural em Belém.}

O conjunto urbano do Complexo Ver-o-Peso é constituído por bens materiais e imateriais ${ }^{105}$, que fazem parte de uma paisagem composta por diversas estruturas culturais: a cultura popular amazônica; a relação com o rio e com a floresta, representando a sociobiodiversidade local; as práticas sociais no mundo do trabalho, como os pescadores, os balanceiros e os vendedores de café; a relação dos vendedores com as mercadorias, no preparo e na venda dos produtos; o vai e vem das canoas; os seus imaginários e narrativas; a religiosidade do catolicismo popular (LEITÃO, 2010).

Essa dimensão simbólica de feira, de festas, de rituais, de tradições e de produção artesanal é identificada por aqueles que fazem uso de tal espaço, seja na vida cotidiana e com a frequência de um usuário do dia a dia (morador, trabalhador ou consumidor), seja em visitas esporádicas, em que o conjunto patrimonial é representado na expressão formal, material e espacial do Complexo Ver-o-Peso. Nesse contexto, o rio sempre foi considerado um elemento cultural em relação à cidade, como "um importante condicionante e definidor da morfologia urbana, dos usos do solo e dos atributos das atividades econômicas dispostas territorialmente" (PONTE, 2015, p.41) no município.

Algumas tentativas de identificação e classificação das práticas culturais imateriais do conjunto de Ver-o-Peso foram realizadas, tal como o Inventário de Referências Culturais do Conjunto Ver-o-Peso ${ }^{106}$ (INCR), elaborado pela Associação das Erveiras e dos Erveiros do Vero-Peso (Ver-as-Ervas) em parceria com o IPHAN $^{107}$ pelo Programa Nacional de Apoio à Cultura do Ministério da Cultura. No INRC Ver-o-Peso ${ }^{108}$, foram inventariados setenta e cinco

${ }^{105}$ Os bens culturais materiais do Complexo Ver-o-Peso foram registrados e inventariados no Inventário de Referências Culturais do Conjunto Ver-o-Peso (INCR), elaborado pela Associação das Erveiras e dos Erveiros do Ver-o-Peso (Ver-as-Ervas) em parceria e com a aplicação da metodologia proposta pelo IPHAN, por meio do termo de cooperação firmado entre ambos. (VER-O-SITE, 2016).

${ }^{106} \mathrm{O}$ inventário foi desenvolvido por meio da Lei de Incentivo à Cultura, seguindo a metodologia do Inventário Nacional de Referências Culturais (INRC) pelo IPHAN, realizado entre os anos de 2008 e 2010 (VER-O-SITE, 2016).

${ }^{107}$ O INRC Ver-O-Peso foi realizado em parceria com o IPHAN/PA por meio do Termo de Cooperação firmado entre esta Instituição e a Associação das Erveiras e dos Erveiros do Ver-o-Peso (VER-O-SITE, 2016).

${ }^{108}$ Ver: Anexo 4 - levantamento do inventário de referências culturais do Ver-o-Peso. 
bens culturais, identificados por meio de entrevistas com os trabalhadores do Ver-o-Peso e classificados em quatro categorias: Celebrações; Edificações; Formas de Expressão; Lugar; e Ofícios e Modos de Fazer (VER-O-SITE, 2016).

Na elaboração da intenção de candidatura a patrimônio mundial do conjunto, foi desenvolvido um inventário cultural do Ver-o-Peso, em 2002. Nele, segundo Campelo (2002, p.153), a Feira Livre do Ver-o-Peso, ao manter sua estrutura sem grandes investimentos em infraestrutura, como havia ocorrido em outros mercados brasileiros, foi reconhecida como um polo de resistência em relação às "transformações do mundo moderno".

Ainda nesse inventário, percorrer a Feira-Livre de Ver-o-Peso foi descrito como a melhor forma de conhecer os espaços, as atividades culturais e as tradições do bem cultural. Por esse meio é possível verificar sua historicidade e sua cultura, tal como um "passeio no tempo e no espaço". Nessa ação de reconhecimento do mercado a céu aberto, em que diversas feiras se entrecruzam, é possível identificar as suas referências culturais, expondo os acontecimentos espaciais, sociais e temporais do lugar.

Eu acho que talvez no caso de Belém, pela peculiaridade da floresta, do rio nem tanto (...), mas o nosso caso seria o rio e a floresta, acho que estes elementos seriam fortíssimos para sustentar um discurso, que não é o Vero-Peso, o complexo do Ver-o-Peso, é muito mais do que isso, o Ver-o-Peso entra como uma expressão da relação cidade floresta, uma expressão, mas a patrimonialização é como a cidade consegue trazer a cultura da floresta para dentro de si, e consegue a partir dela preservar a floresta. Porque todo ciclo extrativista é respeitado, o momento do açaí, da pupunha, cada época do ano que você consegue trazer para a cidade por meio dos produtos que vão ser consumidos sem criar aquela subversão do ciclo da natureza, então de certa maneira há um respeito a esse tempo da natureza, a floresta. Os mitos também, são uma coisa fabulosa, como, de certo modo, é possível através dos mitos também construir um pouco de respeito a natureza ${ }^{109}$.

De acordo com Saint-Clair Trindade, o contexto simbólico do Ver-o-Peso remete à relação da cidade com o rio e a floresta, em que a cidade é o elemento que norteia o olhar e a tradução dessa relação. Assim, essa dimensão simbólica configura-se como um sistema de relações que não é unilateral, e tampouco pode ser resumido de forma centralizada. Ao contrário, ele se ocupa do território à medida em que constitui uma rede distribuição em que as práticas sociais e as manifestações culturais são desencadeadas.

${ }^{109}$ TRINDADE JÚNIOR, 2016b. 
Há vários polos pela cidade que podem ser pensados como elementos, a ideia de polo gastronômico já existe e ele é espontâneo, não precisa se criar nada, são necessárias políticas que reconheçam a invisibilidade dessa nossa gastronomia, mas que reconheçam não para vender para o turista (...).

Por toda a cidade nós temos várias referências gastronômicas, é a tapioquinha lá no Mosqueiro, são as sopas da Cremação, (...), o mingau do Ver-o-Peso, as bancas de tacacá, as bandeirinhas de açaí, principalmente, no bairro do Jurunas, porque os bairros centrais já perderam isso, (...), faz parte da dieta alimentar, do cotidiano ${ }^{110}$.

Um aspecto muito importante da configuração do conjunto desse bem cultural no território é a sua conexão com vários outros polos da cidade, que garantem o dinamismo e a tradição de suas ligações com a própria cidade. Nesses polos, tanto quanto no Ver-o-Peso, as referências culturais são reconhecidas e identificadas pela população em sua memória coletiva, tanto pelo seu patrimônio material quanto imaterial. Esses espaços de manifestação cultural, historicamente reconhecidos e valorizados pela memória coletiva da cidade, remetem à própria ocupação e à fundação dos núcleos urbanos nas margens dos rios, ao longo de um sistema hidrográfico, e ao seu papel de distribuição.

Outro aspecto importante, segundo Romero Ximenes Ponte, é a existência de distintos olhares sobre o Ver-o-Peso, desde o olhar do "caboclo que desembarca para vender seus produtos", o olhar da "classe média que busca comida fresca e a baixo preço" e o olhar dos "vendedores da feira" até o olhar dos "bandidos que sobrevivem nos 'poros' da atividade econômica". Esses olhares "resultam na formação de misturas, mestiçagens, modos de ser que permitem o 'acesso' às tensões e constituições da sociedade de Belém" (LEITÃO, 2010, p. 7). O contexto desse bem cultural é plural e complexo, regido por diferentes atores cujos contextos culturais também são muito diversificados entre si, e essas vivências trazem diferentes leituras e percepções desse espaço patrimonial. Assim, pensar o bem cultural do Ver-o-Peso como algo central e unilateral não apenas significa reduzir o significado de seus elementos e sua dinâmica dentro da própria cidade, como também corrobora para um processo de redução da complexidade simbólica do patrimônio histórico dentro de sua paisagem cultural.

${ }^{110}$ Ibid. 
E Belém tem uma coisa assim, que eu acho singular, até mais que Manaus. Eu diria que Manaus é menos uma cidade da floresta do que Belém, porque Manaus foi concebida muito em cima da ideia de zona franca, polo industrial, zona de livre comércio, e isso padronizou muito a cidade, tornou a cidade muito moderna, muito globalizada, muito ligada aos circuitos globais, claro que tem os portos, as feiras, mas eu acho que Belém interage muito mais, traz muito mais para dentro de si, a floresta, a cultura da floresta esses valores do interior da Amazônia, ela é singular por isso. Tu não vês isso nas capitais nordestinas, por exemplo, a relação com o mar é mais forte, e o nosso a relação com o rio. Tu vês isso em Santarém, Belém, Cametá, um pouco em Manaus, um pouco em Rio Branco, menos em Boa Vista mas vê um pouco, Porto velho também, Macapá tem uma forte relação com a floresta e com o rio ${ }^{111}$.

O valor do patrimônio cultural do Ver-o-Peso é reconhecido, em nosso trabalho, pela intensidade de suas traduções da relação da cidade com a floresta e com o rio. Essa relação também se faz presente em outras cidades da região Amazônica, mas Belém traz outras intensidades de expressão que podem estar relacionadas à forma de concepção e de conformação da cidade histórica consolidada. Assim, entendemos que reduzir a dimensão simbólica do bem cultural do Ver-o-Peso poderia permitir equiparar esse seu contexto cultural ao das cidades da região Amazônica, de modo a homogeneizá-lo em suas singularidades.

111 lbid. 
Registro de mapas das áreas protegidas, atividades e fluxos cotidianos.

Este trabalho propõe, como metodologia de análise do espaço urbano, o registro por meio do desenvolvimento de mapas, como ferramentas de interpretação e análise do território e das relações entre bens culturais considerados patrimônio e o espaço urbano. Assim, elaboramos diversos mapas: mapas de identificação das áreas protegidas e das áreas de entorno; mapas das atividades de uso e de ocupação do solo; e mapa de registro de atividades e de fluxos cotidianos da área protegida.

A identificação das áreas protegidas foi importante para a criação de uma cartografia que permitisse correlacionar as áreas tombadas como patrimônio federal pelo IPHAN (Complexo Ver-o-Peso: Ver-o-Peso e seus elementos integrantes) e as áreas que recebem proteção municipal, a fim de nelas localizar a área de proteção proposta pela candidatura a patrimônio mundial. Por meio dessas identificações e localizações no território pudemos observar e compreender melhor algumas dinâmicas de intervenção nas áreas ao longo do tempo.

Posteriormente, a pesquisa nos permitiu compreender que o processo de candidatura a patrimônio mundial operou-se em dois momentos. Assim, elaboramos uma cartografia que nos permitisse comparar a área de seu primeiro momento com a área do segundo momento, que configura a atual candidatura da cidade de Belém por meio de seu patrimônio cultural localizado na região central da cidade.

O mapa de atividades de uso e ocupação do solo e a visita a campo auxiliaram-nos a compreender as dinâmicas de atividades do espaço. A visita a campo nos ajudou nas análises ambientais que foram estruturadas pelos mapas com informações georreferenciadas.

Por fim, após esse processo de levantamentos, de cartografias e de análises, buscamos desenvolver um mapa com o registro dos fluxos e dos fenômenos culturais que acontecem no espaço urbano. Tentamos, assim, demonstrar como se relacionam os visitantes e a população com os bens culturais, com as atividades que ali se desenvolvem e com o seu contexto urbano social. Nossa análise centrou-se em manifestações cotidianas, sem analisar eventos ligados a patrimônios imateriais, tal como o "Círio de Nazaré", e sem aprofundar a questão gastronômica da área, tema que tem sido muito abordado 
recentemente segundo seu viés patrimonial. Ativemo-nos a localizar no bem cultural os espaços setorizados a ele relacionados.

Essa metodologia de análise também pode ser considerada uma prática cartográfica (KITCHIN, 2010, p. 7), em que o mapa constitui uma visualização dos bens culturais como um artefato dinâmico e em contínua evolução ao representar suas atividades e ao ligar-se às manifestações culturais daquele espaço. Assim, o mapa incorpora um conceito atual e ampliado de patrimônio urbano em bairros históricos, que considera o conjunto de seus bens materiais e imateriais.

Essa documentação cartográfica é uma forma de levantamento e de conhecimento da complexidade do sítio patrimonial protegido e é complementada por uma produção iconográfica e técnica sobre a área. Assim, esta pesquisa parte de uma experiência embasada em casos de estudo práticos e em mapeamentos que problematizam o modo como a cartografia pode contribuir para conectar as manifestações culturais (patrimônio imaterial) ao patrimônio material (Ver-o-Peso). Esses mapas são um registro do mundo segundo o questionamento da própria pesquisa ${ }^{112}$ e sua metodologia aplicada, com conteúdos complexos e não estáveis.

Entendemos esse mapa como um registro e não como uma forma de representação ou construção. Concentramos nosso esforço em entender o objeto de estudo e, por meio desses mapas, codificar a nossa leitura sobre esse objeto. Portanto, alguns de nossos mapas têm o intuito de demonstrar como as funções sociais de algumas das práticas e costumes do espaço se relacionam ao seu contexto histórico, social e político. Segundo Rob Kitchin (2010), esse é um tipo de mapa representativo do entendimento de algo complexo, multifocal e contestado, e que rejeita uma noção de alguma "verdade" que pode ser revelada pela exposição de uma intenção ideológica.

Desse modo, tendo como objeto de estudo o processo de patrimonialização de Belém, desenvolvemos um mapa temático ${ }^{113} \mathrm{da}$ área candidata e de sua área de entorno em

${ }^{112}$ Segundo John Pickles, a cartografia não apenas explica o mundo, mas ela é parte da ação recíproca do mundo e de nós mesmos; ela também relata o mundo exposto pelo nosso método de questionamento (KITCHIN, 2010, p. 8 apud PICKLES, John, 2004). Ver: Pickles, J. A History of Spaces: Cartographic Reason, Mapping and the Geo-Coded World, London: Routledge, 2004.

${ }^{113}$ Esses levantamentos e definições foram fruto de reflexões baseadas nos marcos teóricos do trabalho, em discussões sobre o tema com a pesquisadora Jéssika Paiva França e nas entrevistas já citadas. Trata-se de mapas sensoriais, subjetivos da autora da tese, de percepções das atividades e fluxos na área. 
relação às atividades e fluxos no dia a dia. Mais do que um mapa de uso e ocupação do solo, esse mapa busca compreender os conteúdos e fenômenos da área em relação ao cotidiano de seus usuários. Assim, além de definir categorias de uso, nele levantamos e definimos mais detalhadamente as atividades específicas que acontecem nos espaços ${ }^{114}$, pois compreendemos que essas atividades constituem parte das referências culturais do lugar.

Na realidade, há no Ver-o-Peso, um mercado a céu aberto com uma cronologia própria, várias feiras. Horários e feiras intercruzam-se, opõemse, entre ajudam-se e, ao mesmo tempo, permanecem com seus códigos e normas, sua estética, sua moralidade (CAMPELO, 2002, p. 153).

Assim, dentro da lógica do uso do espaço, foram consideradas importantes ao nosso trabalho a chegada de produtos nas docas, principalmente do açaí e do peixe, e sua posterior distribuição, devido à dimensão simbólica dessas atividades historicamente relacionadas à área com o ritual de seu preparo para distribuição. Esse preparo é constituído pelo recebimento das cestas de açaí, pelo ensacamento do produto e sua distribuição na Feira do Açaí e nos veículos e embarcações, que os levarão para outros pontos de distribuição no continente.

\begin{abstract}
A feira do Ver-o-Peso é responsável pelo abastecimento de domicílios, restaurantes, lojas e supermercados direta, referindo-nos aos que vão lá comprar, ou indireta, como ponto central na rede mais extensa de mercados e feiras da cidade e de municípios e localidades vizinhas, considerando-se que boa parte de seus consumidores podem ser, por sua vez, feirantes dos bairros urbanos ou em localidades mais ou menos próximas. Recebe a produção que chega pelo rio, das ilhas ou de outros municípios, e também a que chega de caminhão e redistribui as mercadorias vindas do CEASA (frutas e legumes) (LEITÃO, 2010, p. 24).
\end{abstract}

Por meio deste mapa pudemos evidenciar o dinamismo das atividades que são estabelecidas no espaço patrimonial em distintos e diversos horários do dia, e que são

\footnotetext{
${ }^{114}$ Não se pretende aqui fazer uma análise específica sobre a Feira Livre do Ver-o-Peso, considerada uma das maiores feiras livres a céu aberto do Brasil. Tal investigação envolveria compreender melhor as atividades comerciais mistas em alguns espaços, tal como alimentação, vestuário, artesanato (ver imagem setorização da área), dentre outras, típicas de uma feira livre no contexto amazônico e brasileiro, que exigiria um estudo minucioso e detalhado sobre o tema e seria objeto específico de outra investigação.
} 
concebidos como um sistema de redes dependentes entre si, embora possam constituir-se com alguma autonomia no espaço da cidade. Assim, como já assinalamos, buscamos registrar nossa compreensão da dinâmica das atividades relacionadas ao bem cultural do Ver-o-Peso e que expressam a dimensão simbólica à qual recorremos por um discurso narrativo nosso, fundamentado em entrevistas.

Por meio desse mapeamento, foi possível perceber que alguns espaços do Complexo Ver-o-Peso podem ser considerados espaços de resistência em relação a um processo de patrimonialização mundial, pois a própria assimilação deste processo, com suas diretrizes e normativas específicas, pode vir a reduzir o significado e a dimensão cultural do Complexo. A configuração de um espaço de resistência é percebida na manutenção de atividades no Ver-o-Peso muito enraizadas ainda em tradições antigas, familiares, populares, ligadas ao lugar e ao seu contexto. A definição como um polo de resistência foi reconhecida por Marilu Campelo, como já assinalamos, em razão da elaboração do INRC Ver-o-Peso, finalizado em 2010.

Esse mapa, embora não apreenda com o mesmo dinamismo as questões que ele registra, permite-nos expor a difícil compreensão da complexidade do conjunto patrimonial em estudo. Segundo Romero Ximenes Ponte (LEITÃO, 2010, p. 7), o desafio de compreendêlo consiste um "monumento ao fracasso de imaginação sociológica ocidental, segundo LéviStrauss" (Ibid.), em que a compreensão de seu coletivo e social não corresponde a sistemas hierárquicos e regras de um todo ordenado segundo uma imaginação sociológica ocidental. Ainda segundo Ponte, a compreensão do Ver-o-Peso nos leva entender que ele representa uma "tensão, luta pela vida, pobreza, travessia", e que nele "a cultura, a diversidade (bio, sócio, econômica, cultural, criminal) aparece sem disfarces" (ibid.). 


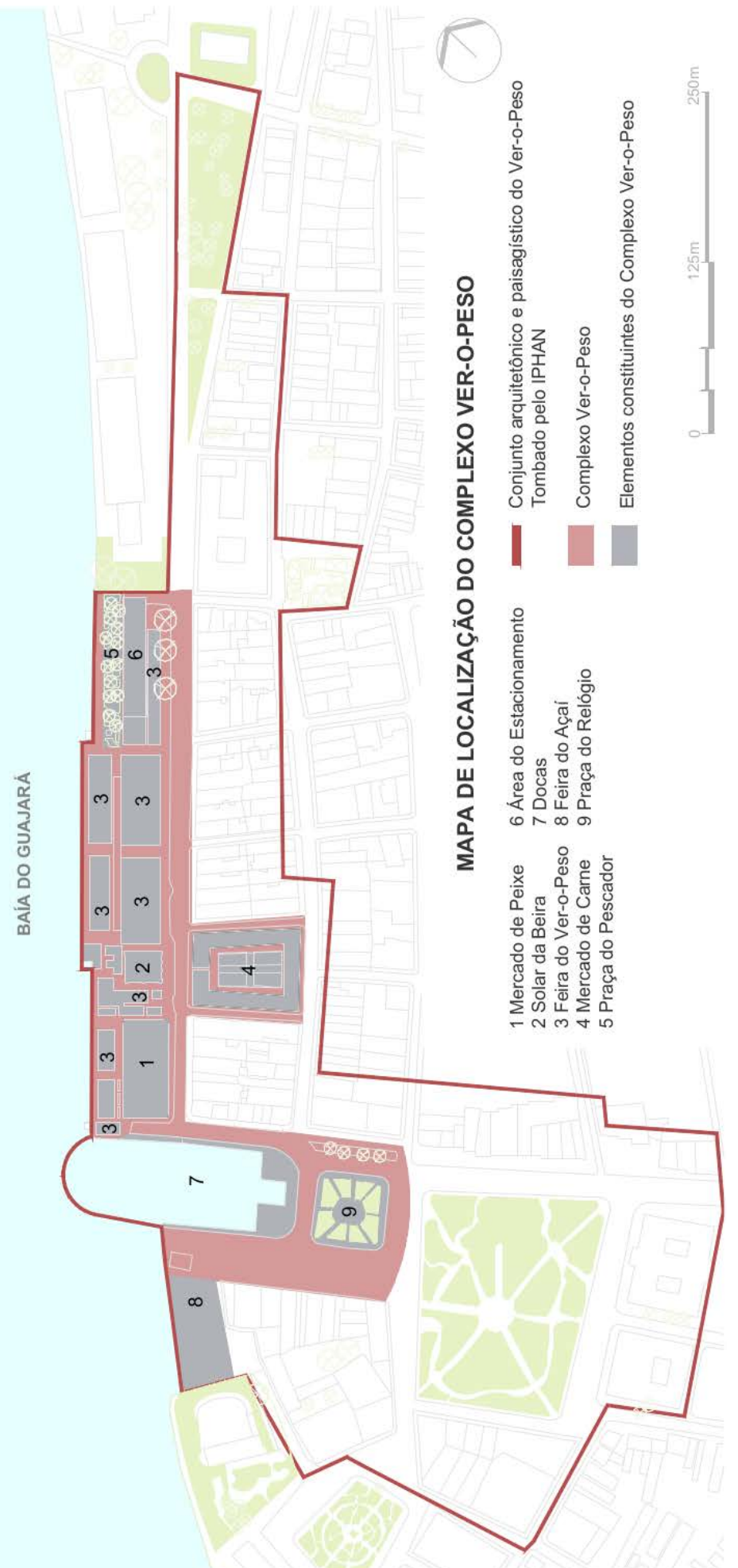

Mapa 19 - Área de tombamento do Conjunto arquitetônico e paisagístico de Ver-o-Peso pelo IPHAN, com a identificação do complexo Ver-o-Peso e seus elementos constituintes, Belém. Fonte da imagem: autoria própria sobre base do Google Maps e LIMA, 2008, p. 32. 


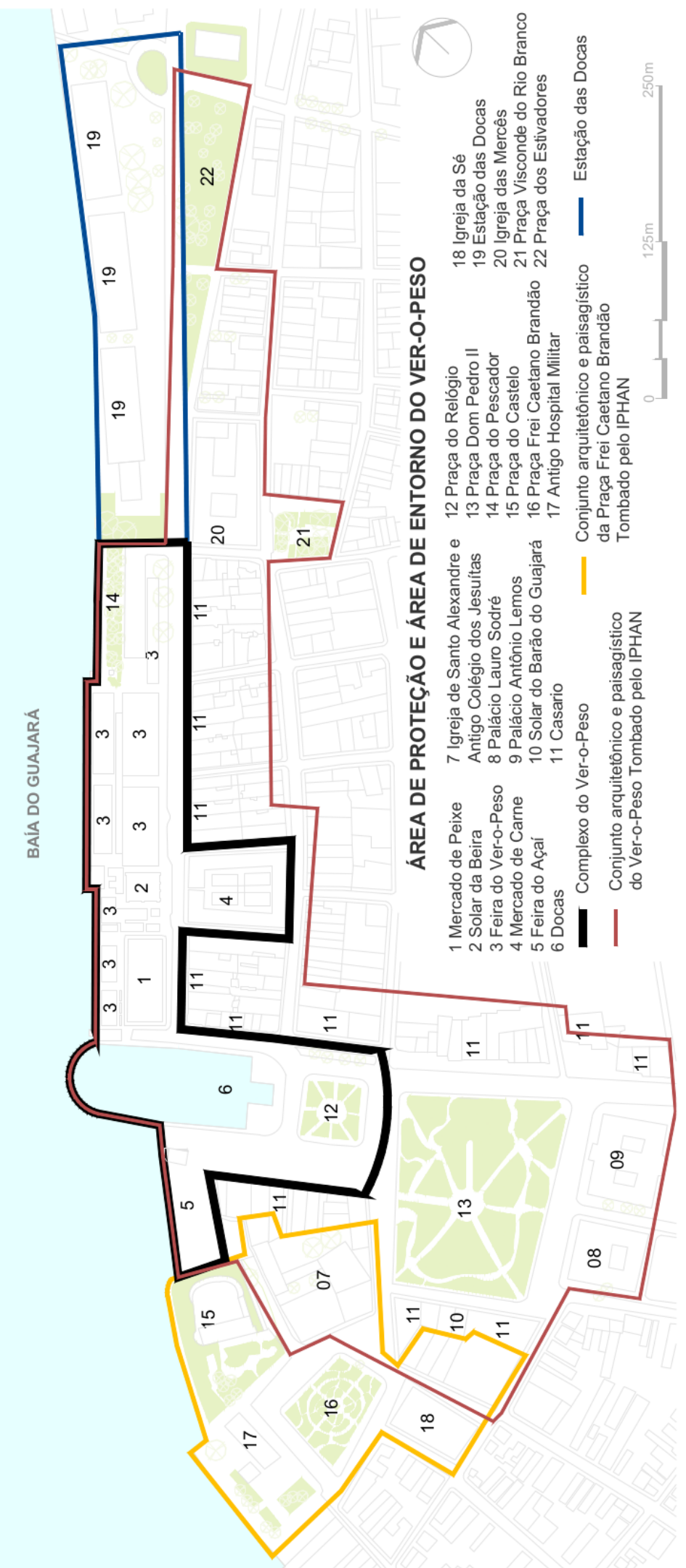

Mapa 20 - Áreas protegidas como patrimônio cultural segundo o IPHAN, identificação dos bens culturais e a definição do Complexo Estação das Docas, área de entorno de Ver-o-Peso, Belém. Fonte da imagem: autoria própria sobre base do Google Maps. 


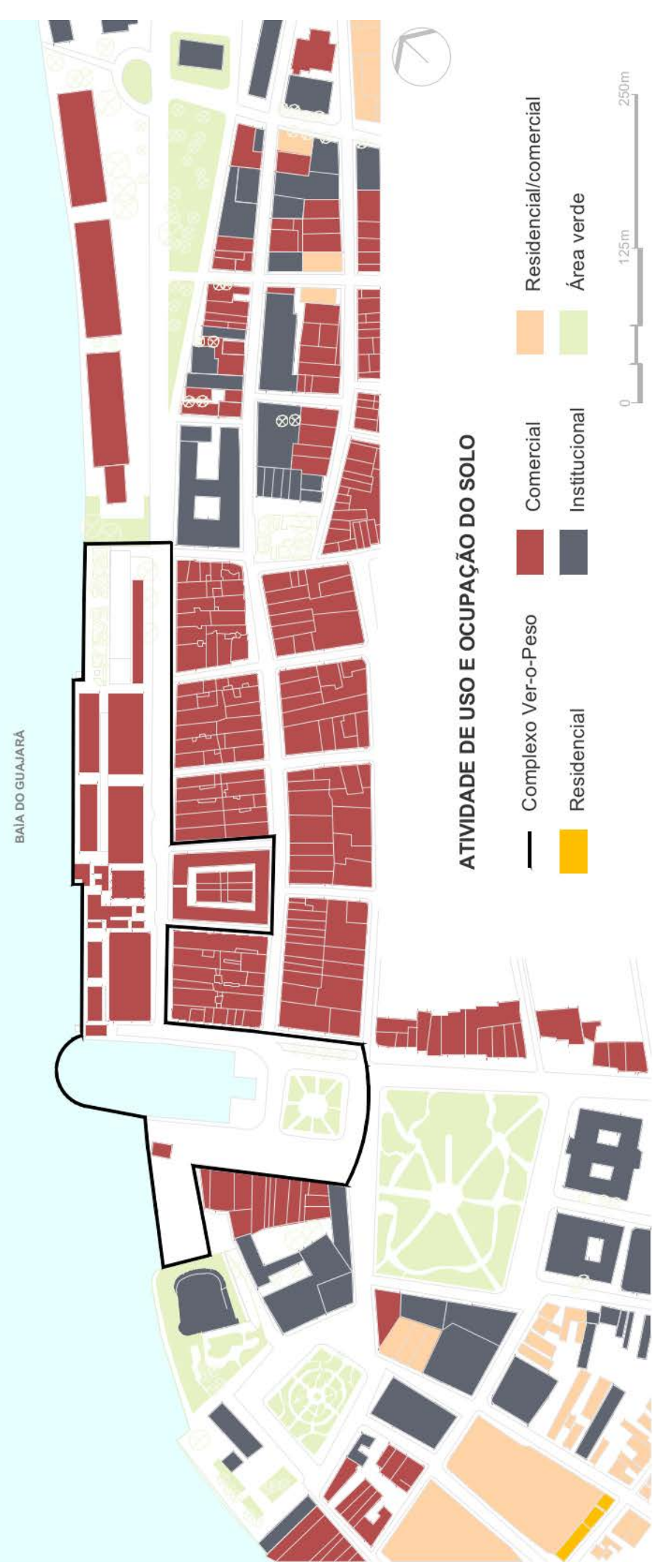

Mapa 21 - Levantamento das principais atividades de uso e ocupação do solo do Complexo Ver-o-Peso, Belém. Fonte da imagem: autoria própria sobre base do Google Maps. 
$\mathrm{O}$ aspecto social dessas atividades envolve os pescadores ${ }^{115}$, que costumam atracar no cais do porto e que dormem dentro dos barcos em redes, esperando a madrugada para dar início à comercialização do pescado a um preço mais baixo. Depois os pescadores e os ajudantes abastecem os caminhões frigoríficos que param próximo às docas, e, pela manhã, os peixes são vendidos no Mercado de Peixe a varejo. O comércio do pescado acontece na pedra (cais do Porto), onde os barcos ficam atracados. Já o açaí é comercializado em maior quantidade e menor preço na Feira do Açaí durante a madrugada, depois pela manhã é revendido no Mercado de Peixe a varejo.

[A Feira do Açaí de madrugada] é algo fabuloso, é uma das cenas mais bonitas que nós temos em Belém, tem que chegar lá por volta de duas, três horas da madrugada que é quando o açaí está chegando, chegando das ilhas, ele chega ali, desembarca e abastece toda a metrópole, então, o movimento é algo muito bonito. E quando tu vais de manhã, tu não tens o elemento material que identifique essa relação da floresta com o rio, que na verdade, é o corpo humano, é a atividade humana que define essa cultura e esse patrimônio que está ali presente. É o momento da cidade que tu tens que olhar aquele tempo, é a demarcação da relação da cidade com o rio. Claro existe lá a Feira do Açaí mas ela fica vazia a partir das sete horas da manhã, quando ela não tem quase nada, a não ser os caroços que mostram que ali tem uma atividade muito dinâmica durante a madrugada $^{116}$.

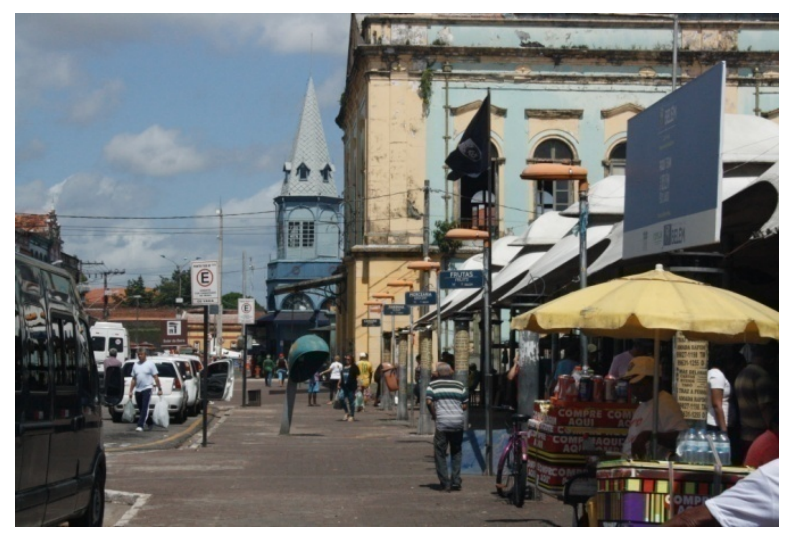

Imagem 16 - Vista da Feira Livre do Ver-o-Peso, do Solar da Beira, e ao fundo uma das torres do Mercado de Peixe, com grande fluxo de pessoas durante a maior parte do dia, num misto de atividades ligadas ao consumo de produtos populares, Belém, 2016. Fonte: autoria própria.

${ }^{115}$ As reflexões e seus respectivos mapeamentos aqui apresentados sobre as atividades dos pescadores, das embarcações com o fornecimento de mercadorias e os espaços com maior intensidade de fluxo de pessoas foram discutidos e contaram com a contribuição da pesquisadora Jéssika Paiva França.

${ }^{116}$ TRINDADE JÚNIOR, 2016b. 


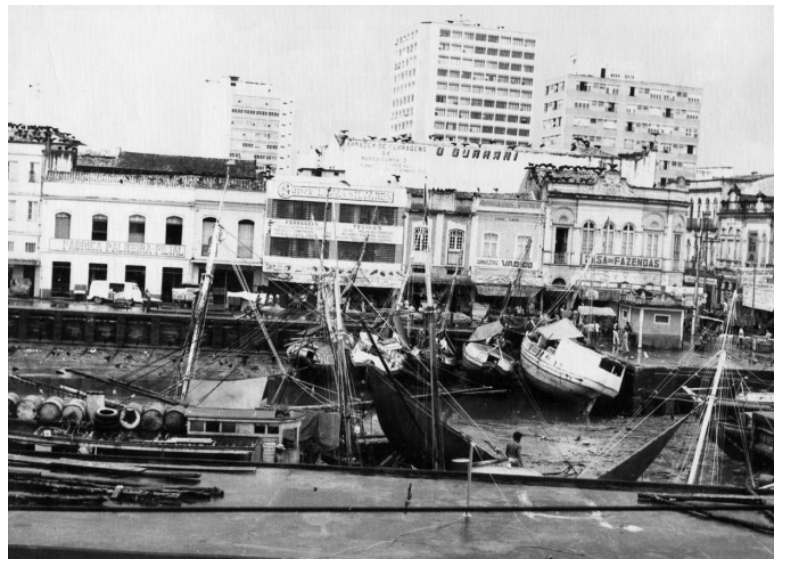

Imagem 17- Doca na vazante, em 1969: as embarcações ficavam adernadas, até que chegasse a enchente da maré. Ao fundo o Mercado de Peixe. A foto tirada da Travessa Marquês de Pombal é parte do documento da proposta para inclusão na lista do patrimônio mundial da UNESCO. Fonte: Acervo IPHAN.

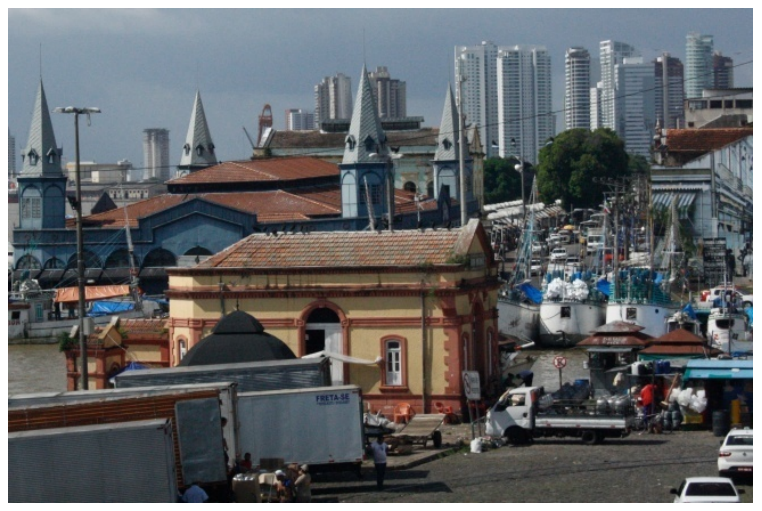

Imagem 19- Vista da Feira do Açaí, da doca do Ver-o-Peso e, ao fundo, o Mercado de Peixe, no início da tarde de um sábado, com algumas embarcações atracadas e veículos utilizados para distribuições estacionados. O sábado é um dia importante e de grande concentração de pessoas na área para o abastecimento e a distribuição de produtos no Ver-o-Peso, principalmente devido à maior fluidez do trânsito viário e a algumas restrições impostas aos usos do espaço em outros dias da semana. Foto capturada do Forte do Presépio, Belém, 2016. Fonte: autoria própria.

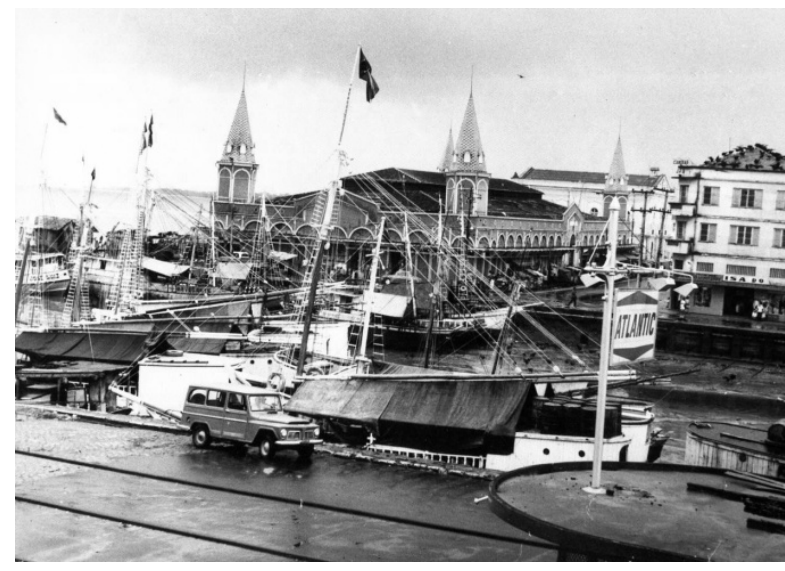

Imagem 18- Doca na vazante, em 1969. Ao fundo, a Feira do Açaí e o Mercado de Peixe. A foto tirada da Avenida Portugal é parte do documento da proposta para inclusão na lista do patrimônio mundial da UNESCO. Fonte: Acervo IPHAN.

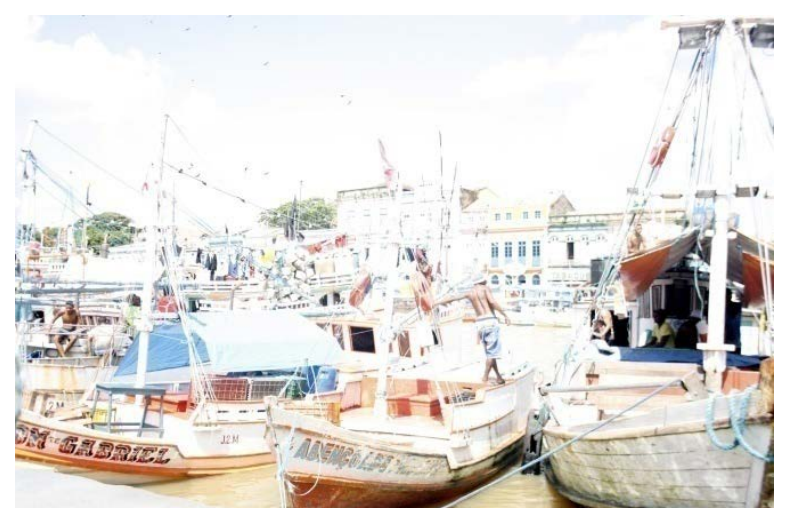

Imagem 20- Vista da doca do Ver-o-Peso, com algumas embarcações de pescadores atracadas e, ao fundo, a composição da paisagem do casario da Avenida Marquês de Pombal, às $12 \mathrm{~h}$ de uma quarta-feira. Nesse horário, encerramse algumas atividades da venda de peixe no Mercado de Peixe e de alguns produtos na parte posterior ao Mercado, próximo à Baía do Guajará. Foto capturada da Avenida Portugal, Belém, 2016. Fonte: autoria própria. 


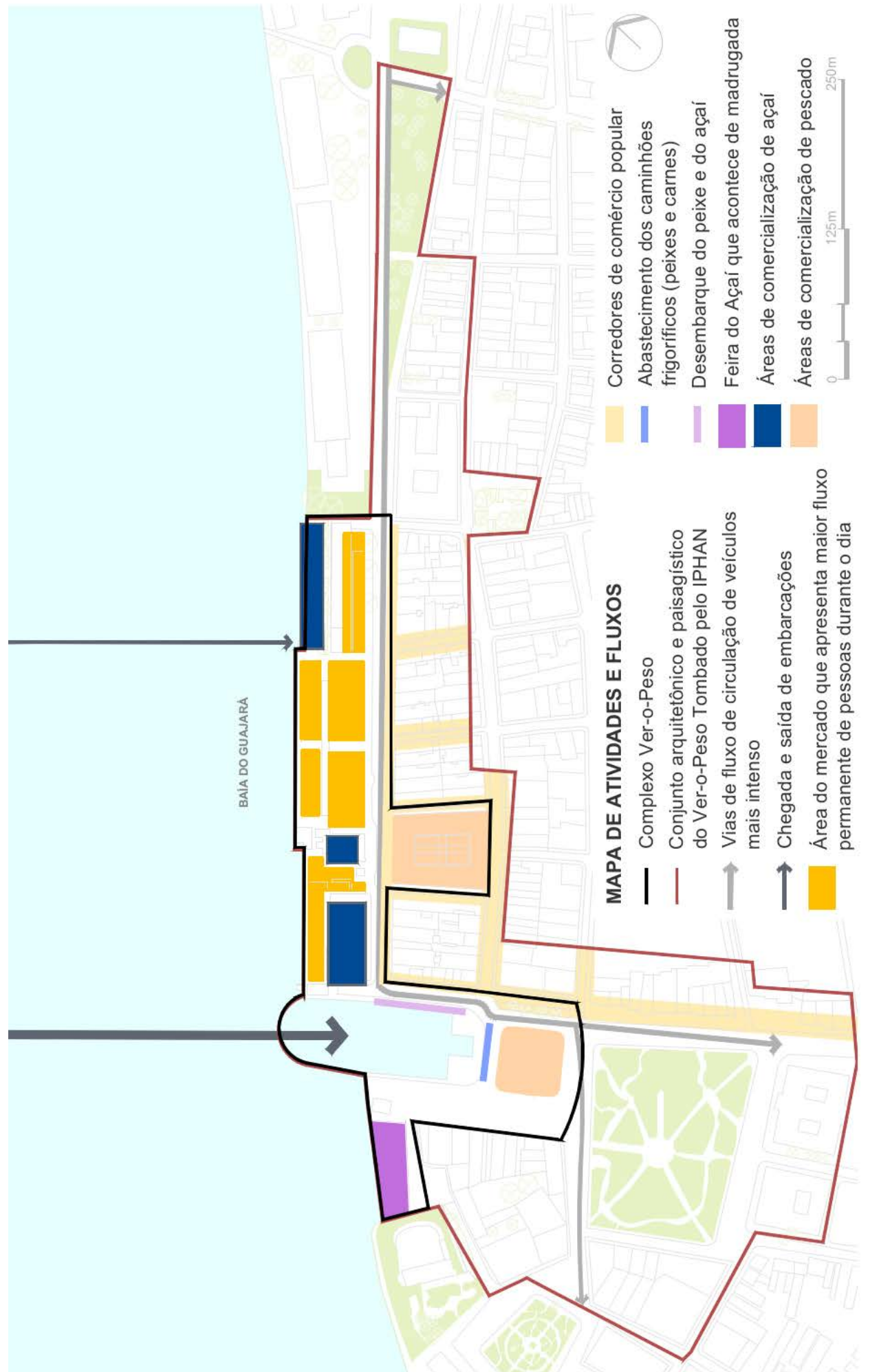

Mapa 22 - Levantamento das principais atividades e fluxos da área do Complexo Ver-o-Peso, Belém. Fonte da imagem: autoria própria sobre base do Google Maps. 

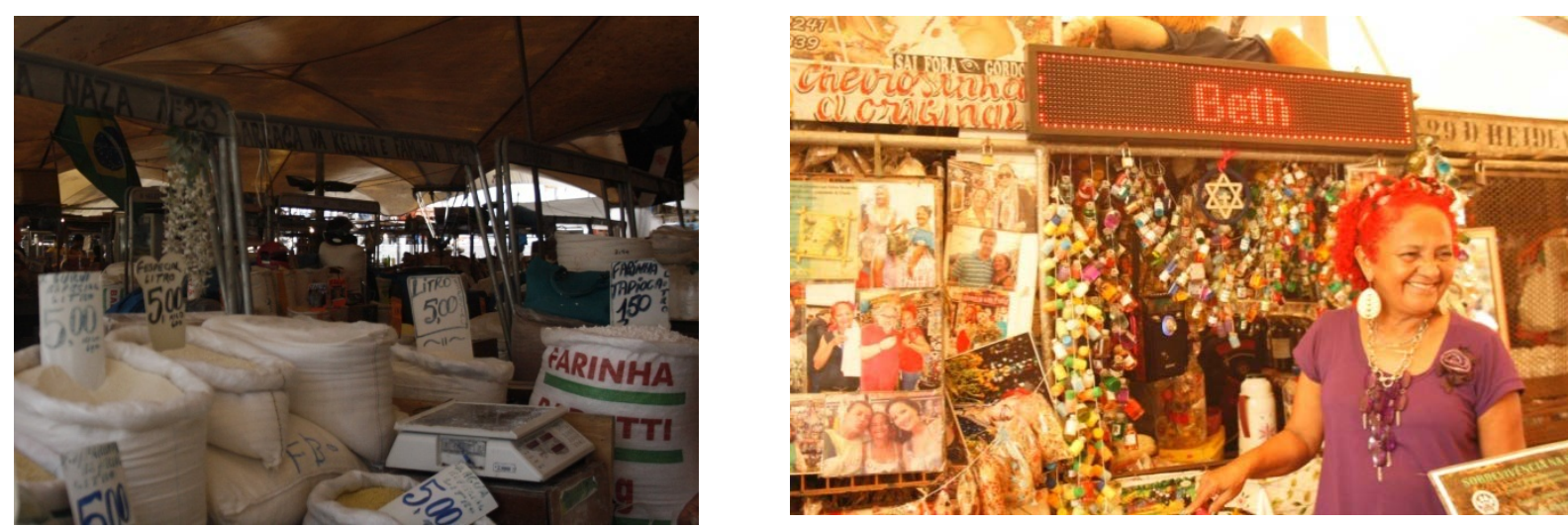

Imagem 21- Vista interna da Feira Livre do Ver- Imagem 22 - Erveira da barraca "cheirosinha", o-Peso no setor de farinha, Belém, 2016. Foto: Feira Livre do Ver-o-Peso, Belém, 2016. Fonte: autoria própria. autoria própria.

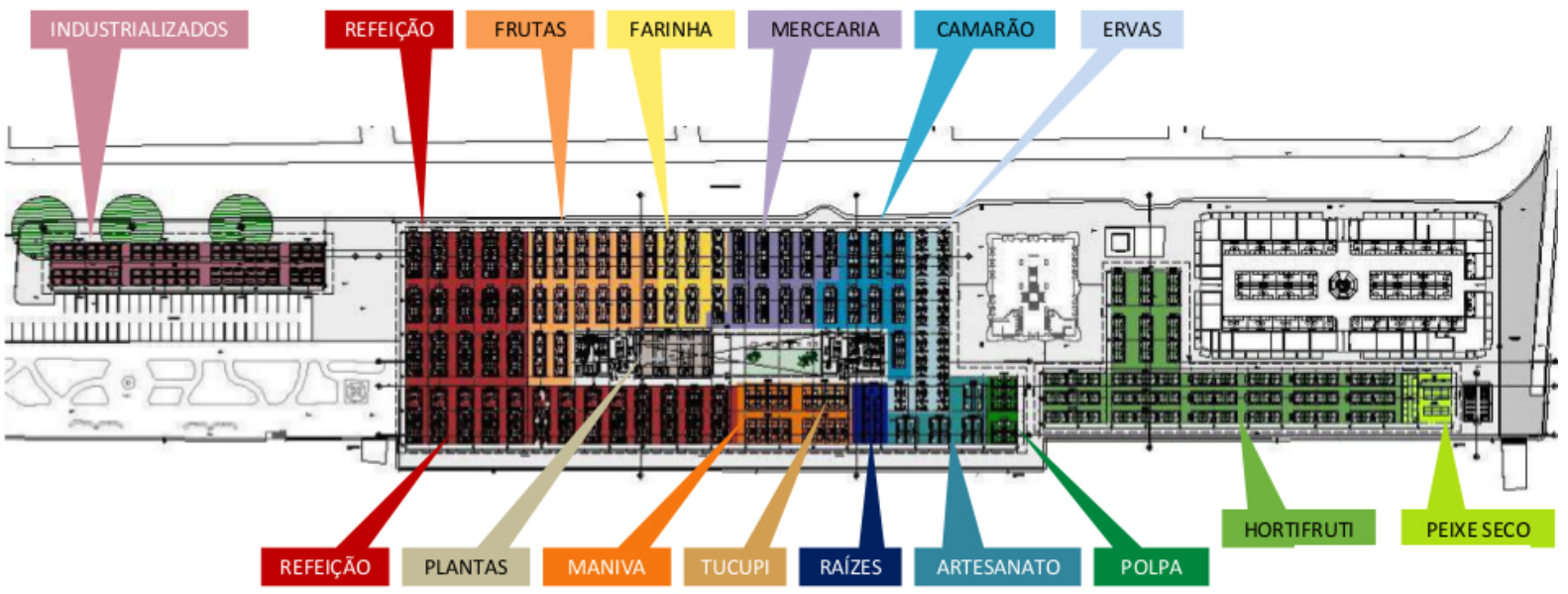

Mapa 23 - Esquema da setorização da Feira Livre do Ver-o-Peso, Belém. Fonte: DPJ, 2016, p. 31.
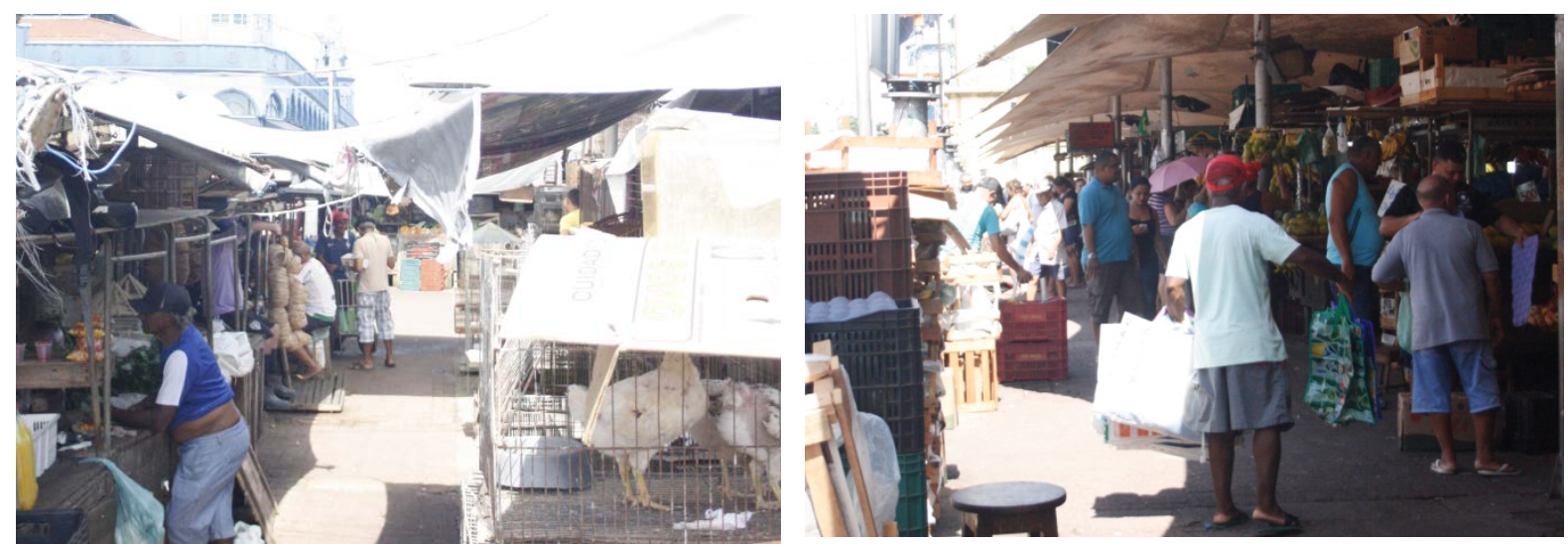

Imagem 23 e 24 - Vista interna da Feira Livre do Ver-o-Peso no setor de hortifrúti, à esquerda, e no setor de mercearia, à direita, Belém, 2016. Fotos: autoria própria. 


\section{Políticas Culturais de Preservação e a Centralidade.}

Os primeiros processos de tombamento e preservação do patrimônio em Belém, ainda pelo antigo Serviço do Patrimônio Histórico e Artístico Nacional (SPHAN), datam de 1937 (VER-O-SITE, 2016) e dos anos seguintes. São eles o Conjunto Arquitetônico e Paisagístico Ver-o-Peso e áreas adjacentes ${ }^{117}$, a Coleção Arqueológica e Etnográfica do Museu Paraense Emílio Goeldi, as Igrejas da Sé, de Santo Alexandre, de São João Batista, e o Colégio Jesuítico.

Efetivamente o Ver-o-Peso é uma página viva da história colonial do Pará. Lá está a marca de mais de três séculos da paisagem e da história colonial paraense.

Os olhos dos nossos antepassados e das gerações que vem de sucedendo através do tempo, não se cansaram de contemplar o Ver-o-Peso, como uma característica de Belém, ligado a vida social, comercial e econômica dos tempos coloniais, imperiais e republicanos. Justifica-se, pois, a preocupação que devemos ter para conservação como um monumento paisagístico a recordar as primícias do século XVII, ao atual (Proposta de tombamento, 11/03/1969, 1969).

O primeiro instrumento legal correspondente a essa inscrição foi a notificação, assinada em 1977, de tombamento do bem cultural Ver-o-Peso ${ }^{118}$ em instância nacional, com base no processo de $1969^{119}$, que havia sido formulado por Ernesto Horácio da Cruz, presidente da Câmara de Ciências Humanas e Patrimônio Histórico e Artístico Estadual, e encaminhado por Aloysio da Costa Chaves, presidente do Conselho Estadual de Cultura do Pará. Posteriormente, em 1987, foi proclamada uma certidão de tombamento pelo IPHAN, "certificando que o tombamento encontrava-se devidamente inscrito nos respectivos livros de tombo" (VER-O-SITE, 2016). Essa classificação compreendeu seu traçado urbano, edifícios

${ }^{117}$ Decreto no 25, de 30 de novembro de 1937. Livro do Tombo Arqueológico, Etnográfico e Paisagístico (inscrição de número 69, fls 16); Livro de Tombo Histórico (inscrição número 460, fls 77) e Livro de Tombo das Belas Artes, sob a inscrição de número 525 (fls 96).

${ }^{118}$ Processo CEC-2/69, que trata do tombamento no Patrimônio Histórico e Artístico Estadual do "Vero-Peso", como monumento paisagístico de Belém, foi formulado pelo Conselheiro Ernesto Cruz, após receber parecer favorável da Câmara de Ciências Humanas e Patrimônio Histórico e Artístico Estadual, e aprovada por unanimidade pelo Conselho Estadual de Cultural, em 25 de março de 1969.

${ }^{119}$ Conjunto arquitetônico e paisagístico "Ver-o-Peso" e áreas adjacentes (Praça D.Pedro II e Boulevard Castilhos França). Processo n'812-T-69, atualmente esta documentação faz parte do arquivo 78.04 01,PA/Belém, P812,190. Fonte: Arquivo do IPHAN/DEPT. 
monumentais, palacetes e residências, mercados de ferro e mobiliário urbano, quadras e docas para barcos.

Vale ressaltar que, anteriormente, em 1964, a Praça Frei Caetano Brandão e a área adjacente foram tombadas pelo IPHAN, como Conjunto Arquitetônico, Urbanístico e Paisagístico da Praça Frei Caetano Brandão ${ }^{120}$, ex-Largo da Sé. Vale salientar que esse conjunto está inserido na área adjacente ao Ver-o-Peso.

Até a década de 1980, muitas edificações antigas foram substituídas por edifícios comerciais e institucionais que descaracterizaram o conjunto. No final dessa década, em 1988, com a Lei de Desenvolvimento Urbano do município, o complexo do Ver-o-Peso é tombado pelo município de Belém, sob a denominação de Centro Histórico de Belém (CHB).

Segundo o Plano Diretor da cidade, de 1993 (Lei n7603/93), já era prevista a preservação do Centro Histórico de Belém. Nesse plano, foram definidas Zonas Especiais de Preservação do Patrimônio Histórico, com o zoneamento do Centro Histórico.

Conforme Anexo I da Lei Ordinária № 7.709, de 18 de maio de 1994, o Centro Histórico de Belém, tombado pela Lei Orgânica, de 30 de março de 1990, em seu artigo 228, parágrafo 2으, compreende, conforme a Lei de Desenvolvimento Urbano - Lei 7.401, de 29 de janeiro de 1988 -, a área envolvida pelo poligonal que tem início na interseção da Avenida Marechal Hermes com Avenida Assis de Vasconcelos; segue por esta até a interseção com a Rua Gama Abreu; segue por esta até sua interseção com a Avenida Almirante Tamandaré; segue por esta até o ponto de coordenadas $777.54 \mathrm{mE}$ e $9.838 .245 \mathrm{mN}$, nas margens da Baía do Guajará; dobra à direita e segue, continuando às margens da Baía do Guajará até o ponto de coordenadas $778.940 \mathrm{mE}$ e $9.841 .245 \mathrm{mN}$, localizados na foz do igarapé sem denominação; sobe por este até sua interseção com o prolongamento da Avenida Marechal Hermes; dobra à direita e segue por esta até o início da poligonal (VER-O-SITE, 2016).

No ano de 1994 é estabelecida a possibilidade de preservação do patrimônio cultural por meio da definição de "Zonas Especiais de Interesse Social - ZEIS, mediante outorga onerosa, construções, com coeficiente superior ao do aproveitamento básico 1,4 (um vírgula

${ }^{120}$ Conjunto Arquitetônico, Urbanístico e Paisagístico da Praça Frei Caetano Brandão, ex-Largo da Sé, Data do tombamento: 28.07.1964. Livro do tombo: LAEP, insc. 35, fl. 09. Este conjunto é constituído por alguns bens imóveis tombados isoladamente pelo IPHAN e inseridos no perímetro tombado, são eles: Igreja da Sé, 234-T-40;Colégio dos Jesuítas e Igreja de Santo Alexandre, 235-T40; Forte do Castelo, 644-T-61; Hospital Militar (antigo Hospital Real), 707 - T-63; e Praça Frei Caetano. Fonte: Arquivo do IPHAN/DEPT. 
quatro) ${ }^{121 "}$ e a autorização do Poder Executivo e o parecer do órgão Técnico da Prefeitura Municipal de Belém.

Posteriormente, com a Lei № 7.938, de 13 de janeiro de 1999, foi criado o Conselho Municipal de Cultura do Município de Belém. E em relação à "produção do espaço urbano", o seu Art. 19 (Seção II) define que os objetivos de suas políticas devem ser orientados para “recuperar, preservar e valorizar a paisagem urbana da cidade, sobretudo pela preservação dos seus elementos naturais e dos elementos representativos do patrimônio históricocultural".

A política municipal de patrimônio cultural de Belém segundo a disposição da Seção IV do artigo 20 do Plano Diretor Municipal de Belém"122, de 2008, é "entendida como força social de interesse coletivo e direito social básico, [e] visa garantir como vetor de desenvolvimento econômico e de inclusão social". Em seu anexo VI, são definidos zoneamentos especiais por meio de Zonas Especiais de Preservação do Patrimônio Histórico (ZEIP), em que as macrozonas do ambiente urbano são seis: Centro Histórico; praça Batista Campos, cemitério da soledade e horto municipal; complexo de São Brás; Fazenda Forte da Barra/ sítio Penacova (bairro Miramar); vila de Mosqueiro e entorno; educandário Nogueira de Farias e entorno (Ilha de Gotijuba). Como macrozonas do ambiente natural estão a área tombada da UFPA e entorno e as ruínas do Murucutu.

Ainda, parte da orla do Centro Histórico, ao sul do Complexo Ver-o-Peso, é estabelecida como área de interesse para fins de recuperação urbanística e paisagística (ver imagem 11 do trabalho, com um trapiche de pouca infraestrutura e a presença de baixadas e palafitas junto à orla, que fazem parte dessa área).

No caso de Belém, a OODC [Outorga Onerosa do Direito de Construir] apareceu, pela primeira vez em 1990, no Art.118 do Capítulo de Política Urbana, da Lei Orgânica do Município (BELÉM, 1990). Com a denominação de "solo criado", referido instituto foi citado como um dos instrumentos tributários e financeiros destinado a assegurar as funções sociais da cidade e da propriedade. A Lei Orgânica, contudo, não estabeleceu as condições para aplicação dessa taxação, o que só viria a acontecer após a aprovação do Plano Diretor em 1993. Desde então, a OODC, foi regulamentada por três grandes legislações urbanísticas: O Plano Diretor Municipal de 1993, a

${ }^{121}$ Ver: BELÉM (Município). Lei $n^{\circ} 7683 / 94$. Estabelece medidas aplicáveis à legislação do Plano Diretor Urbano de Belém, de que trata a Lei ${ }^{\circ} 7603 / 93$ de 13 de janeiro de 1993.

${ }^{122}$ Ver: BELÉM (Município). Lei $N^{\circ} 8655$, de 30 de julho de 2008. Dispõe sobre o Plano Diretor do Município de Belém, e dá outras providências. 
Lei Complementar de Controle Urbanístico de 1999 e o Plano Diretor de 2008 (TOURINHO, 2009, p. 3).

A OODC nunca se mostrou um instrumento eficiente em Belém, embora previsto no Plano Diretor do Município de Belém (Lei 7.603, de 13 de janeiro de 1993) por meio de seu Art. 37, com a instituição de dois zoneamentos para fins de outorga onerosa: "um para estabelecer o estoque de potencial construtivo a ser outorgado onerosamente; e outro que destinado a estabelecer o próprio estoque" (TOURINHO, 2009, p. 3). Essas zonas foram classificadas em dois tipos: zonas com adensamento até o coeficiente básico e zonas adensáveis acima do coeficiente básico potencial.

Entre a aprovação do Plano Diretor de 1993 e a aprovação da Lei Complementar de Controle Urbanístico (LCCU) transcorreram seis anos. O Projeto da LCCU foi elaborado por dois técnicos da Prefeitura Municipal a partir de discussões com agentes do mercado imobiliário e dos movimentos sociais, sobretudo com os primeiros, foi instituído pela Lei Complementar 02 em 19 de julho de 1999. É, portanto, anterior ao Estatuto da Cidade (TOURINHO, 2009, p. 5-6).

O projeto da Lei Complementar de Controle Urbanístico (LCCU) foi elaborada por funcionários técnicos da Prefeitura Municipal de Belém, no período anterior ao Estatuto da Cidade, por meio de discussões "com agentes do mercado imobiliário e dos movimentos sociais, sobretudo com os primeiros, foi instituído pela Lei Complementar de 02 em 19 de julho de 1999" (TOURINHO, 2009, p. 6).

Há a questão da outorga e do gabarito no entorno do Centro Histórico, por exemplo, quando acaba aqui na Avenida Assis de Vasconcelos, aqui a gente está na Doca, que corresponde a uma faixa de entorno do Centro Histórico, em que o nível de proteção é mais baixo, mas que é necessário observar o gabarito e os índices urbanos específicos, e também uma outorga também aqui incidente. $O$ problema desta outorga em Belém é que os vereadores fazem um monte de trambiques, então, historicamente esvaziam a outorga, há poucos exemplos efetivos de aplicação da outorga, de cobrança. Porque houve uma época em que os vereadores conseguiram colocar o coeficiente básico igual ao máximo, se não tem diferença entre o básico e o máximo que tu podes construir para cobrar a outorga, tu não podes cobrar a outorga, se não há um intervalo (...).

Depois houve um questionamento no município de que a outorga não era efetiva se não tivesse uma lei específica, o que era uma bobagem, o que não tem nada a ver, a outorga era prevista constitucionalmente, está 
prevista no plano diretor, ela era praticamente autoaplicável, só tem que dar alguns parâmetros, na época era 1,4 o básico, daí de 1,4 para cima, até 2 , até 4 . Então esse excedente acima de 1,4 poderia ser outorgado. Mas em tese formalmente, não há outorga no Centro Histórico, atualmente, há exemplos muito pontuais de outorga fora do Centro Histórico, eles são aqui, nos bairros do Reduto, Umarizal, entre outros ${ }^{123}$.

Entretanto, sem que houvesse estudos técnicos consistentes para uma avaliação da capacidade de suporte da infraestrutura, seria perceptível que a instituição da OODC ocorresse de forma equivocada. Por meio da LCCU, foi implementada uma estratégia de igualar o coeficiente básico ao coeficiente de aproveitamento máximo, permitindo que a OODC tivesse incidência apenas sobre a área construída excedente ao cálculo do coeficiente máximo dos quadros de modelos urbanísticos referentes a cada zona.

Posteriormente, a outorga onerosa passou a incidir novamente sobre a área resultante da subtração obtida a partir da aplicação dos coeficientes de aproveitamento máximo e básico através da Lei 8.655 de 30 de julho de 2008 (Plano diretor do Município de Belém).

O Plano diretor do Município de Belém (2008) previu, em suas disposições transitórias, algumas alterações na LCCU de 2008, como alterações nos modelos urbanísticos e nos limites de zoneamento. A Lei 7.603/1993, que institui o primeiro Plano diretor de Belém, e a Lei 7.877/1998, que estabeleceu o coeficiente básico e máximo iguais a quatro e seis respectivamente, dentre outras, forma revogadas. Em contrapartida, foi mantida a incidência da OODC apenas na área construída que excede a calculada com base nos coeficientes máximos permitidos.

${ }^{123}$ PONTE, 2016. 


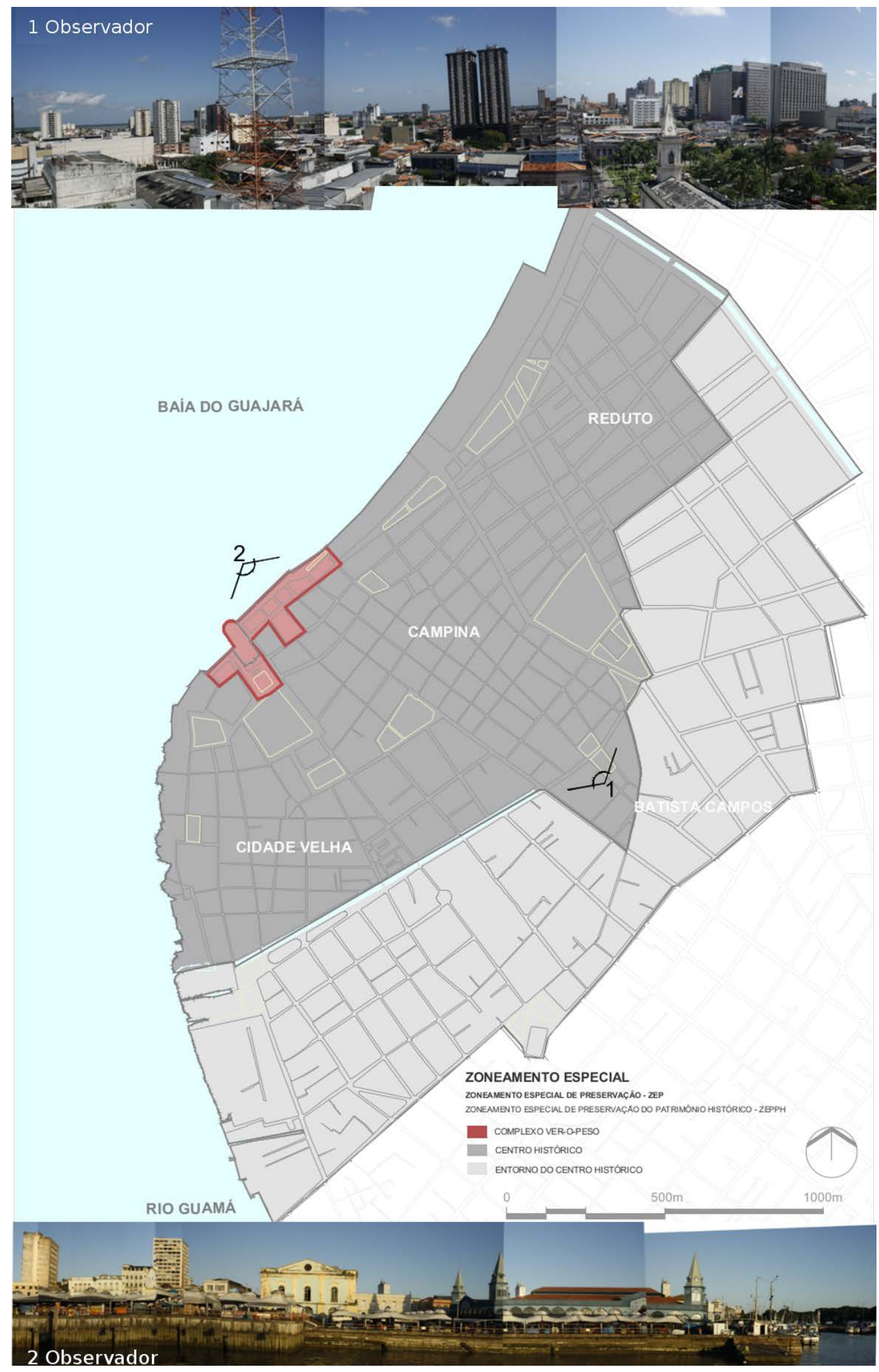

Mapa 24 - Identificação do ZEPPH do CHB. Imagens 25 e 26 - Fotomontagem da composição da paisagem do CHB capturada pelos observadores1 e 2 respectivamente, Belém, 2016. Fonte das fotos: autoria própria. Fonte da imagem de mapa: autoria própria sobre base da PMB. 


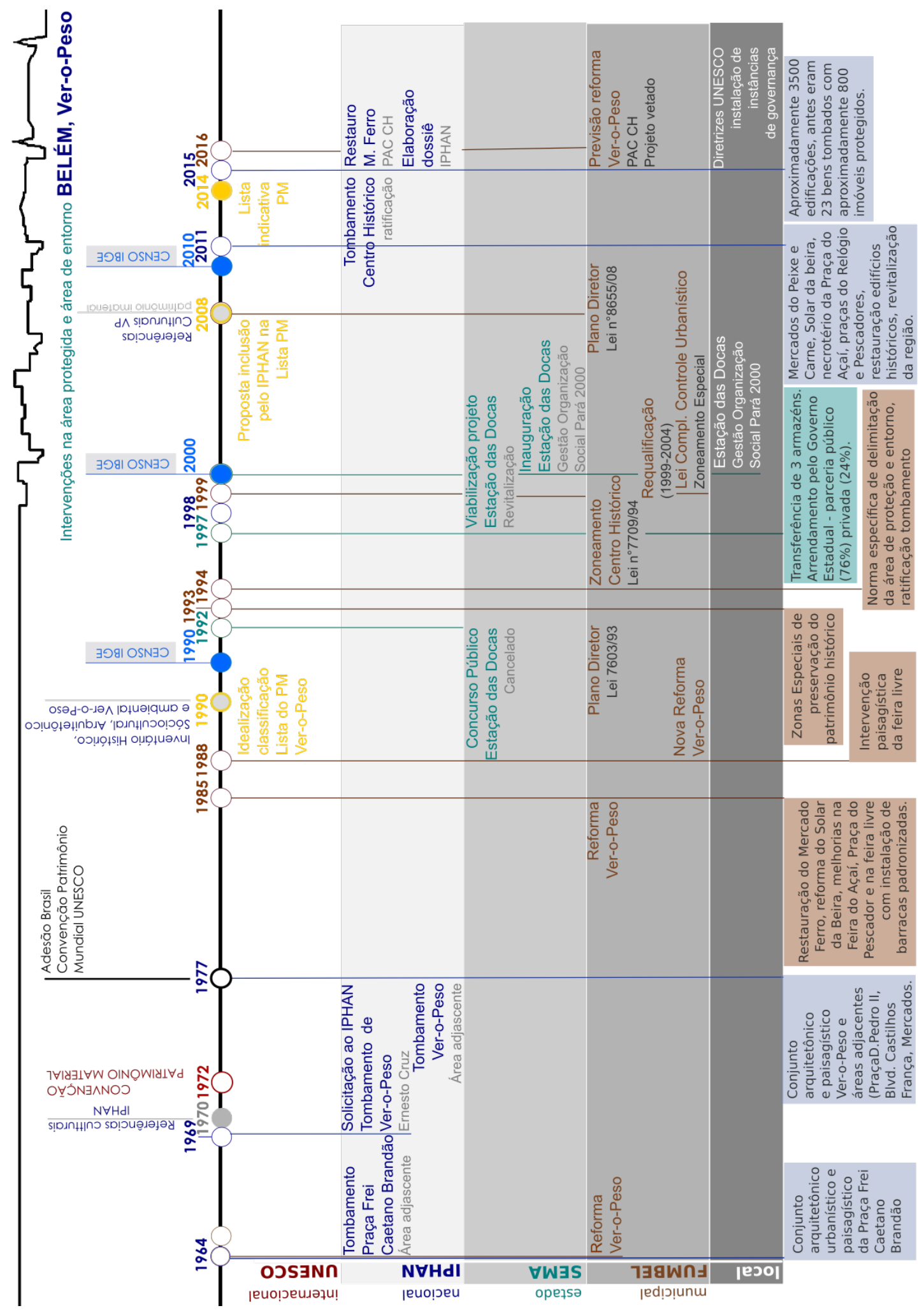

Imagem 27 - Esquema explicativo das intervenções na área do Complexo Ver-o-Peso e entorno, políticas de preservação e diretrizes de classificação da UNESCO. Fonte: Elaboração própria sobre VER-O-SITE, 2016; MOURA, 2014; IPHAN, 2016; UNESCO, 2016. 


\section{Intervenções na área do Complexo Ver-o-Peso e entorno.}

Pode-se afirmar que os principais avanços em relação aos processos de tombamento e preservação do patrimônio cultural material da área central de Belém acontecem a partir dos anos de 1960. Nesse período, também se verificam algumas dinâmicas de reconfiguração urbana da área, tal como a primeira reforma do Ver-o-Peso, em um processo de assimilação das transformações urbanas de modernização ocorridas na Amazônia na época (CARDODO, 2016, p. 825).

Essas transformações urbanas influenciam a totalidade urbano-regional da cidade consolidada historicamente em Belém e transformam suas relações e articulações com o interior da própria cidade em direção ao continente. Nesse contexto, em 1968, durante o governo Alacid Nunes, o Ver-o-Peso é reformado ${ }^{124}$ e, no ano seguinte, é feito o primeiro pedido de tombamento do Ver-o-Peso por Ernesto Cruz (VER-O-SITE, 2016).

Posteriormente, durante a década de 1980, o Ver-o-Peso passou por duas reformas. Uma delas ocorreu em 1985, com intervenções no Mercado de Ferro, no Solar da Beira, na Praça do Pescador e na padronização das barracas, na ampliação e no reordenamento do espaço da Feira Livre, na reconfiguração da Feira do Açaí e na desobstrução da Ladeira do Castelo.

Essas políticas de requalificação [de retorno ao centro da cidade], a primeira ideia que se teve foi na década de 80 (...), a primeira ideia de volta ao centro foi nessa década de 80 , com uma reforma do Ver-o-Peso, e depois houve uma requalificação da Feira do Açaí e se abriu o que eles passaram a chamar, a partir daquele momento, da primeira rua de Belém, e (...) historicamente eles não comprovaram isso, a primeira rua de Belém sempre foi a rua do Norte, a Siqueira Mendes. Se a gente for entender um pouco a história você também vai achar que é, porque o forte é um elemento que deu sentido para a cidade e depois a cidade cresceu a partir do forte.

Ao lado do Forte [do Presépio], havia algumas casas na ladeira [do Castelo],e ela estava totalmente obstruída, na década de 80 quando fizeram essa requalificação do Ver-o-Peso e da Feira do Açaí e tudo mais aí, abriram essa rua, inclusive o atual secretário de cultura começou a dizer que aquela foi a primeira rua de Belém, mas em documentos, em nada foi

\footnotetext{
${ }^{124}$ Ver: Documento de consulta pública à proposta de intervenção para a Feira do Ver-o-Peso.
} 
comprovado que aquela rua foi a primeira de Belém, e talvez nem seja, pela [composição da paisagem e do conjunto da] estrutura das casas ${ }^{125}$.
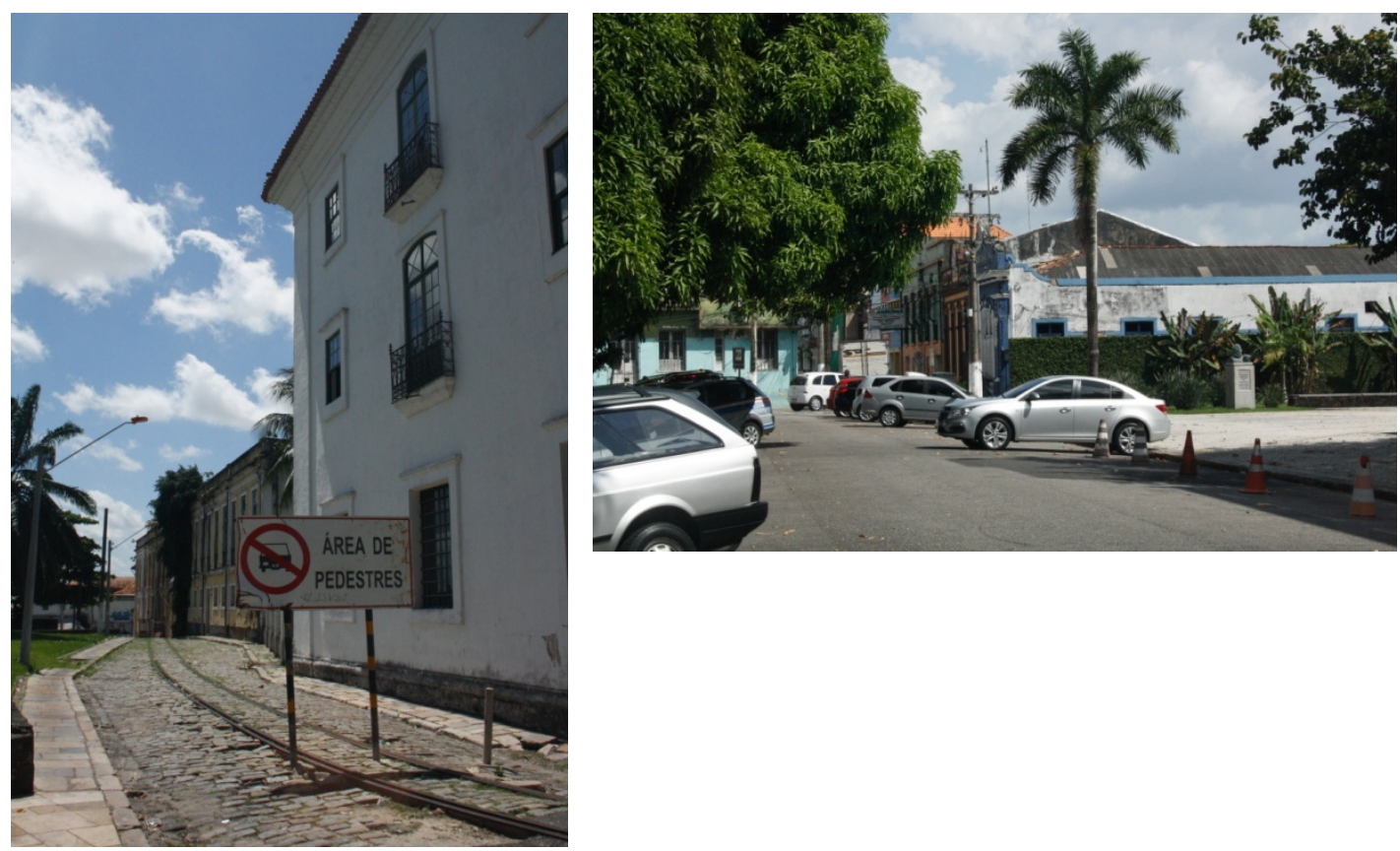

Imagem 28 - Vista da Ladeira do Forte à esquerda. Imagem 29 - Vista da Rua Siqueira Mendes à direita. Belém, 2016. Fonte: autoria própria.

Em 1988, a Feira Livre passou novamente por uma intervenção paisagística. Quanto às políticas de preservação municipais em Belém, o período dos anos de 1980 foi marcado pela substituição de muitas edificações antigas por edifícios comerciais e institucionais, e muitas destas novas construções descaracterizaram o conjunto da paisagem cultural de sua área central. Finalmente, com a legislação urbanística do primeiro código de obras de Belém, em 1988, o CHB é tombado pelo município como patrimônio histórico cultural, e criam-se algumas diretrizes que regulamentam essas ações na área.

A legislação urbanística em Belém é muito recente, o primeiro código de obras de Belém é de 1988. Então houve um período imenso de absoluta desregulação do mercado imobiliário, com o prefeito biônico durante a ditadura, não tinha legislação nenhuma (...).

A legislação é muito recente, por isso que você vê coisas além dos processos de corrupção que acontecem hoje, contemporaneamente, você vê, por exemplo, na verticalização muito exemplos distantes da legislação, porque ela é muito recente, você vai ver prédios relativamente altos aqui

${ }^{125}$ TRINDADE JÚNIOR, 2016b. 
no Reduto, que embora seja o entorno do Centro Histórico os prédios são do início dos anos 90, são anteriores aos dos anos 80 , são anteriores ao tombamento do Centro Histórico como conjunto (PONTE, 2016) ${ }^{126}$.

A partir da década de 1990, os governos estadual e municipal dão início a uma série de ações de recuperação, restauro e revitalização das áreas centrais e patrimoniais na cidade, que eram valorizadas pela memória coletiva da população. Para tanto, foram organizadas, pelo poder público, equipes multidisciplinares de pesquisadores encarregados de realizar um levantamento técnico para "buscar referenciais históricos, sociais, econômicos e de ocupação territorial da Amazônia e do Pará (...) prospecções rigorosas permitiram reconstituir elementos essenciais à leitura dos prédios e de suas volumetrias" (MOURA, 2004).

Inclui-se aqui a revitalização do Complexo Ver-o-Peso por meio de um concurso público de arquitetura ${ }^{127}$ (Documento de consulta pública. In: IPHAN, 2016), lançado em 1998 pelo Instituto de Arquitetos do Brasil ${ }^{128}$ (MOURA, 2004), núcleo Pará, e que foi realizado no ano de 1999. O programa dessa intervenção abrangia todo o conjunto de prédios históricos considerados patrimônio do Complexo Ver-o-Peso: o Mercado do Peixe; o Mercado da Carne com estrutura metálica importada da Inglaterra; o Solar da Beira; o antigo necrotério na Praça do Açaí; as praças do Relógio e dos Pescadores.

Tratava-se de uma intervenção em patrimônio tombado, uma vez que o Complexo e sua área adjacente são um conjunto arquitetônico e paisagístico classificado pelo IPHAN desde 1977. Essa intervenção previa ações que foram efetivamente realizadas ao longo de quatro fases construtivas, iniciadas em 1999 e finalizadas em 2004: a restauração dos edifícios históricos do conjunto, a revitalização e as melhorias urbanísticas da região, tais como circulação e infraestrutura, e uma reforma de toda a Feira Livre do Ver-o-Peso.

\footnotetext{
${ }^{126}$ PONTE, 2016.

${ }^{127} \mathrm{O}$ projeto vencedor do concurso é de autoria do escritório Flávio Ferreira Arquitetura e Urbanismo, do Rio de Janeiro.

${ }^{128}$ Desse concurso participou, como membro do júri, a arquiteta e urbanista Maria Dorotéa Lima, atual superintendente do IPHAN -PA.
} 


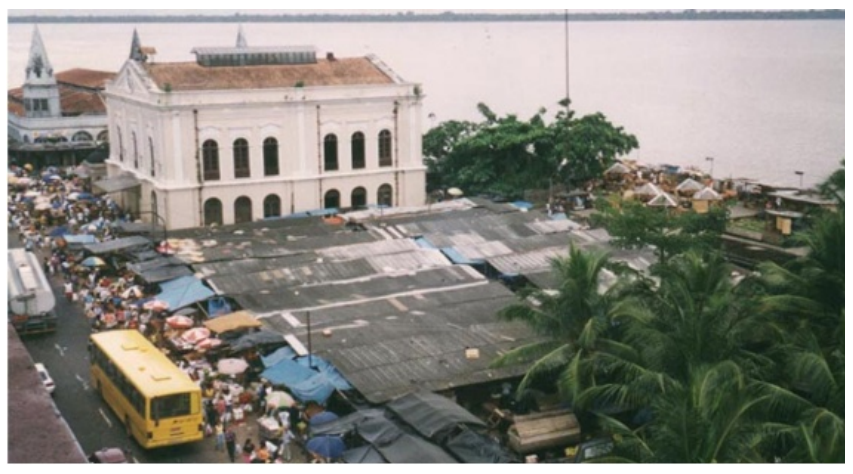

Imagem 30- Vista do Solar da Beira e da Feira Livre, anterior à reforma e à padronização das barracas da Feira Livre, Belém. Fonte da imagem: SEURB.

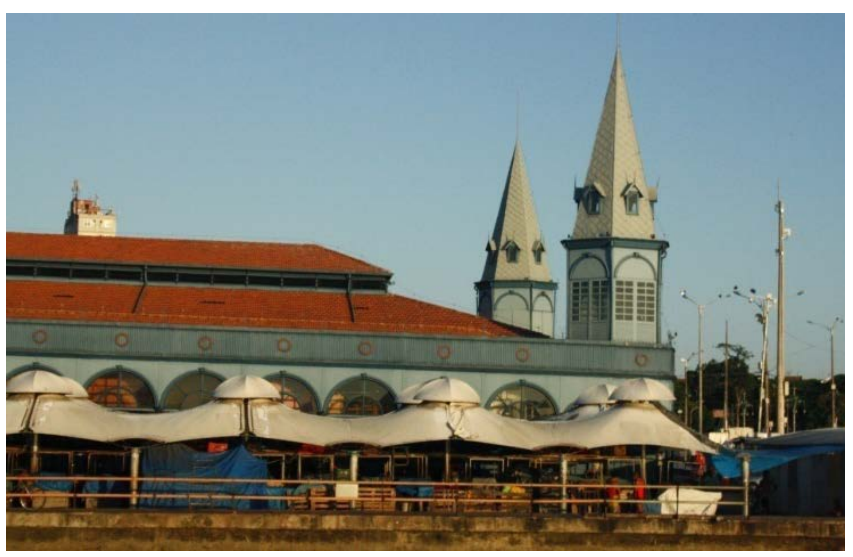

Imagem 32- Torres do Mercado de Peixe e Feira Livre do Ver-o-Peso, das margens do rio Guajará, Belém, 2016. Fonte da imagem: autoria própria.

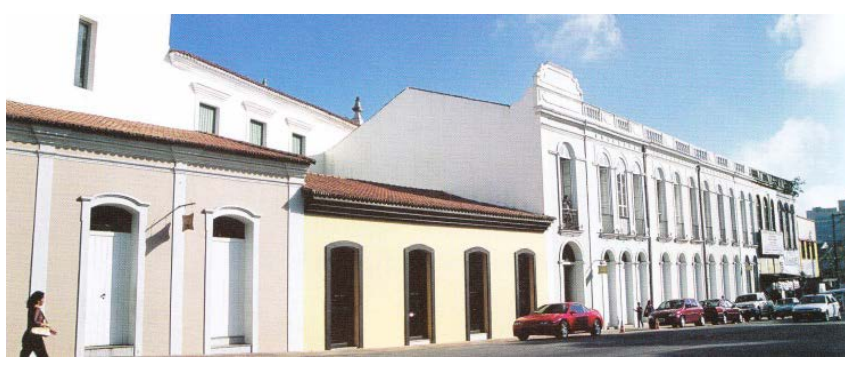

Imagem 34- Casario da Rua Padre Champagnat, Belém, 2004. Fonte: CARDOSO, 2004, p.34.

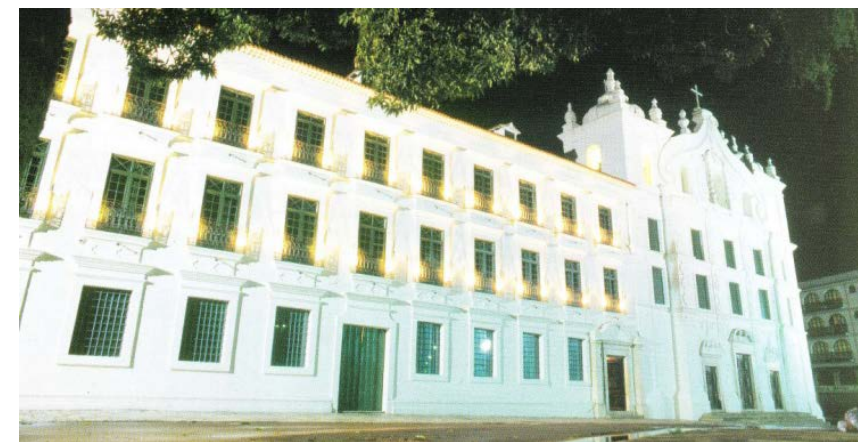

Imagem 36- Igreja de Santo Alexandre, Belém, 2004. Fonte: CARDOSO, 2004, p. 28.

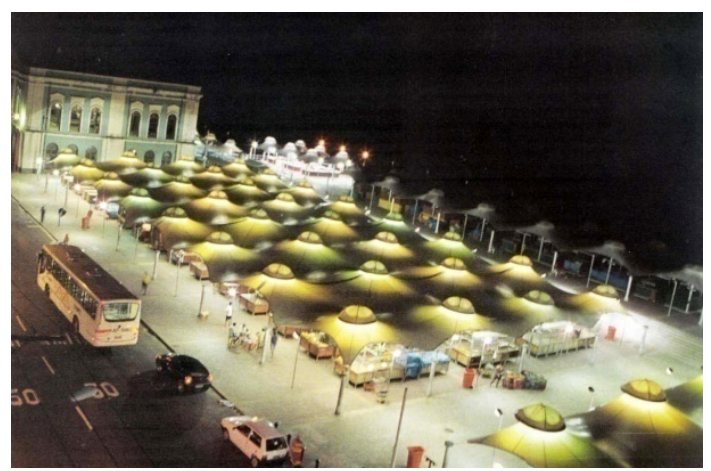

Imagem 31- Vista panorâmica da Feira Livre, Complexo Ver-o-Peso, Belém, 2004. Fonte: RAMID, 2004, p. 51.

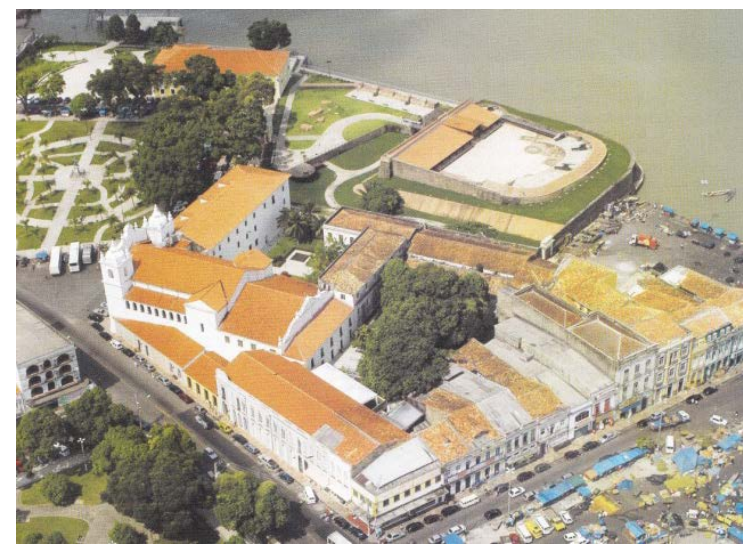

Imagem 33- Vista da área de intervenção do projeto Feliz Lusitânia, Belém, 2004. Fonte: RAMID, 2004, p.25.

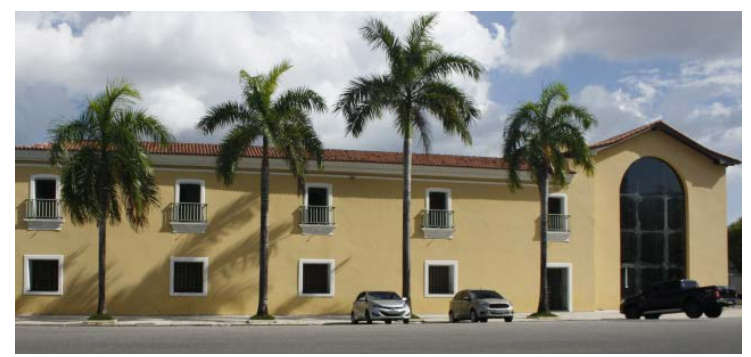

Imagem 35- Vista do Polo Joalheiro, Belém, 2016.Fonte: autoria própria.

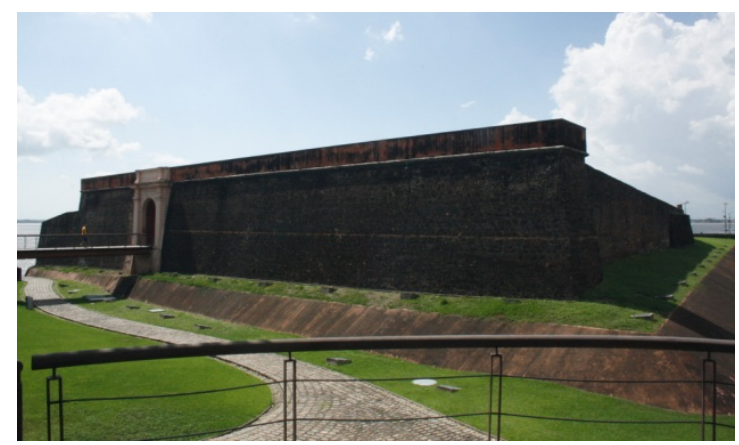

Imagem 37- Vista do Forte do Presépio, Belém, 2016. Fonte: autoria própria. 
Quando chega o início dos anos 2000, aí vem essa política novamente de requalificação, com os mesmos personagens que estavam lá na gestão na década de 80 , os mesmos voltaram e aí já trouxeram novidades e aí vem Feliz Lusitânia, vem Estação das Docas, e o interessante desse momento é que ao lado de uma política estadual de requalificação aparecia uma política municipal de requalificação com uma proposta de inclusão social, completamente diferenciada, de diálogo com as pessoas, de bolsa escola, de famílias de bolsa escola, e com a ideia pegar essas famílias e trabalhar a geração de renda na área central (TRINDADE JÚNIOR, 2016b).

Assim, essas ações de 1999 iniciam um período de uma série de intervenções no patrimônio histórico-cultural tombado do Centro Histórico e de retomada de interesse pelo centro da cidade. Tal retomada deu-se concomitantemente ao retorno de alguns membros da equipe técnica dos anos de 1980 à secretaria da cultura do estado do Pará, equipe que idealizara a primeira ideia de retorno ao centro da cidade.

O período seguinte, a partir dos anos 2000, também foi marcado por uma série de intervenções no patrimônio. Essas intervenções incluíram também bens não tombados, mas que constituem parte do Centro Histórico segundo a legislação municipal. Citamos dentre elas a construção do Complexo Cultural Estação das Docas ${ }^{129}$, inaugurado em maio de 2000, uma obra realizada nos desativados galpões do antigo porto da cidade. A intervenção na Estação das Docas é parte das diretrizes de intervenções propostas para a revitalização da orla de Belém, ações setorizadas por uma determinação do próprio poder público de Belém, por meio do PRÓ-BELÉM, como uma estratégia de apreensão de uma grande extensão e diversidade de usos e ocupação do solo, de modo a permitir a implantação de diversas ações em diferentes momentos e com financiamentos distintos.

O período, de acordo com Saint-Clair Cordeiro da Trindade Júnior (2002), foi marcado pela realização de intervenções com financiamento e investimento público, de modo compartilhado por meio da concessão dos galpões e pela gestão do complexo pela Organização Social Pará 2000. Esse tipo de financiamento expõe um "padrão de conduta na governança urbana", segundo Harvey (2005, p. 230), em que o poder estatal (local e regional) é combinado com interesses privados (empresariais), formando "coalizões para

${ }^{129}$ Instituições envolvidas no projeto da Estação das Docas: Prefeitura Municipal de Belém, Governo do Estado do Pará, Organização Social Pará 2000 (associação de direito privado, sem fins lucrativos e de interesse coletivo, destinada à produção de cultura, lazer, turismo e serviços no Pará). 
fomentar ou administrar o desenvolvimento urbano" de algumas áreas específicas da cidade.

Tais ações de intervenção são setorizadas e desarticuladas entre si, o que revela a ausência de um planejamento global que incorpore todas as ações de modo articulado entre elas e com a cidade. Citamos como algumas destas ações: o Complexo Ver-o-Rio (1999), o Complexo do Ver-o-Peso, o Terminal Fluvial Turístico da Praça Princesa Isabel (1998), o Projeto Cidade Criança e o Parque Mangal das Garças (2005).

Ainda segundo Saint-Clair Trindade Júnior, essas intervenções na orla de Belém não abrangem aspectos da dimensão simbólica do rio, tal como condicionante histórico e cultural, pois elas não conseguem fortalecer os valores culturais e as representações sociais, tal como foram concebidas, pois nelas "a relação com o rio se apresenta numa dimensão meramente contemplativa, onde o cenário beira-rio passa a ter como pano de fundo emoldurado a paisagem hidrográfica" (TRINDADE JÚNIOR, 2002, p. 144).

O complexo "Estação das Docas" pode ser comparado a importantes propostas internacionais de revitalizações relacionadas à água e à cidade, em orlas e frentes marítimas, na medida em que a relação de seus novos espaços mantém alguns elementos históricos sem a preocupação da redução do significado de seu conjunto.

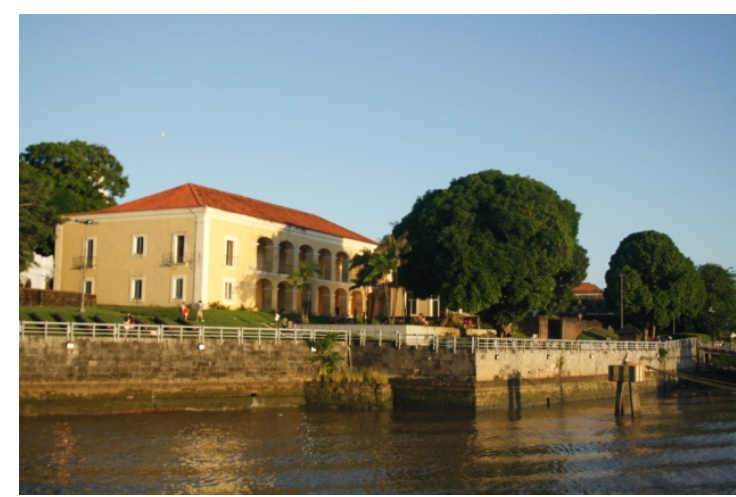

Imagem 38- Vista da Casa das 11 Janelas, foto capturada da baía de Guajará, Belém, 2016. Fonte: autoria própria.

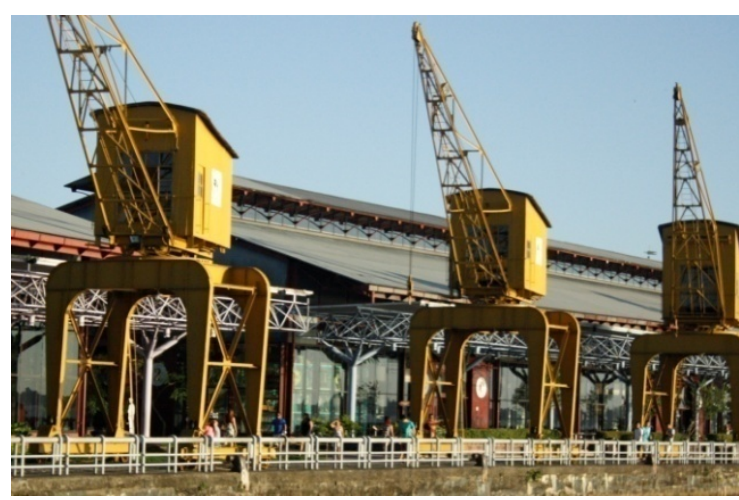

Imagem 39- Estação das Docas, foto capturada da baía de Guajará, Belém, 2016. Fonte: autoria própria. 


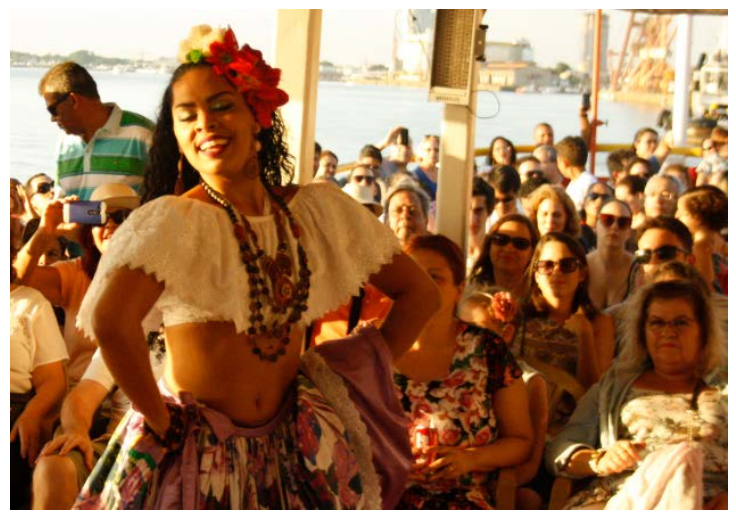

Imagem 40-Dança e música "típica regional" com trajes também "típicos" por dançarina no interior do barco de passeios fluviais pela orla de Belém, Belém, 2016. Fonte: autoria própria.

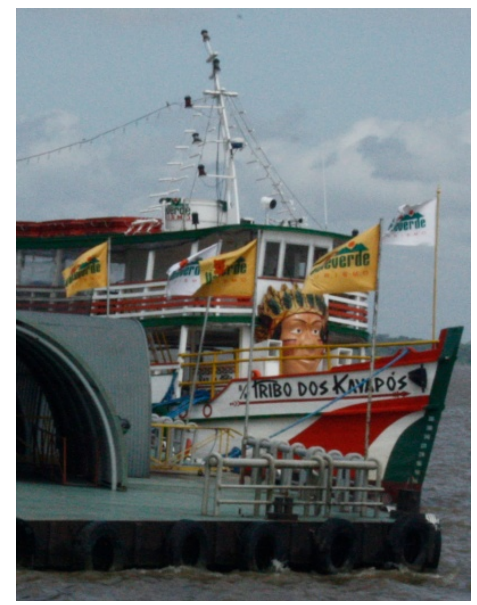

Imagem 42- Vista do interior do barco de passeios fluviais "tribo dos Kayapós", que faz passeios pela orla de Belém diariamente com a apresentação de danças típicas regionais, imagem à esquerda, Belém, 2016

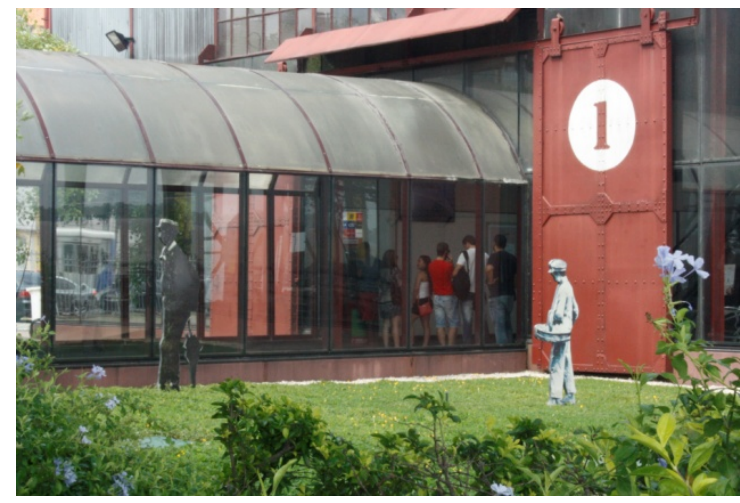

Imagem 41- Estação das Docas, vista interna entre os galpões e, nos jardins, as imagens de importantes personagens da história da cidade, Belém, 2016. Fonte: autoria própria.

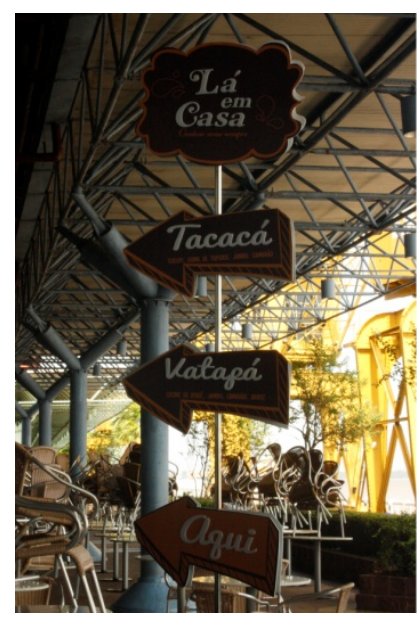

Imagem 43 - Vista do interior da Estação das Docas, comunicação visual de uma das empresas privadas locais relacionadas ao projeto cultural gastronômico, à esquerda, Belém, 2016. Fonte: autoria própria.

Como algumas das propostas internacionais, citamos uma intervenção do tipo Waterfront em orla marítima, a intervenção da Operação Puerto Madero (Argentina), de 1989. Foi um processo originado como parte de estratégias de intervenção urbana de revitalização e re-funcionalização de antigas construções portuárias obsoletas da cidade de Buenos Aires. Esse plano de ação de intervenção foi orientado para promover a atividade imobiliária e permitir sua intervenção nessas áreas da cidade. 


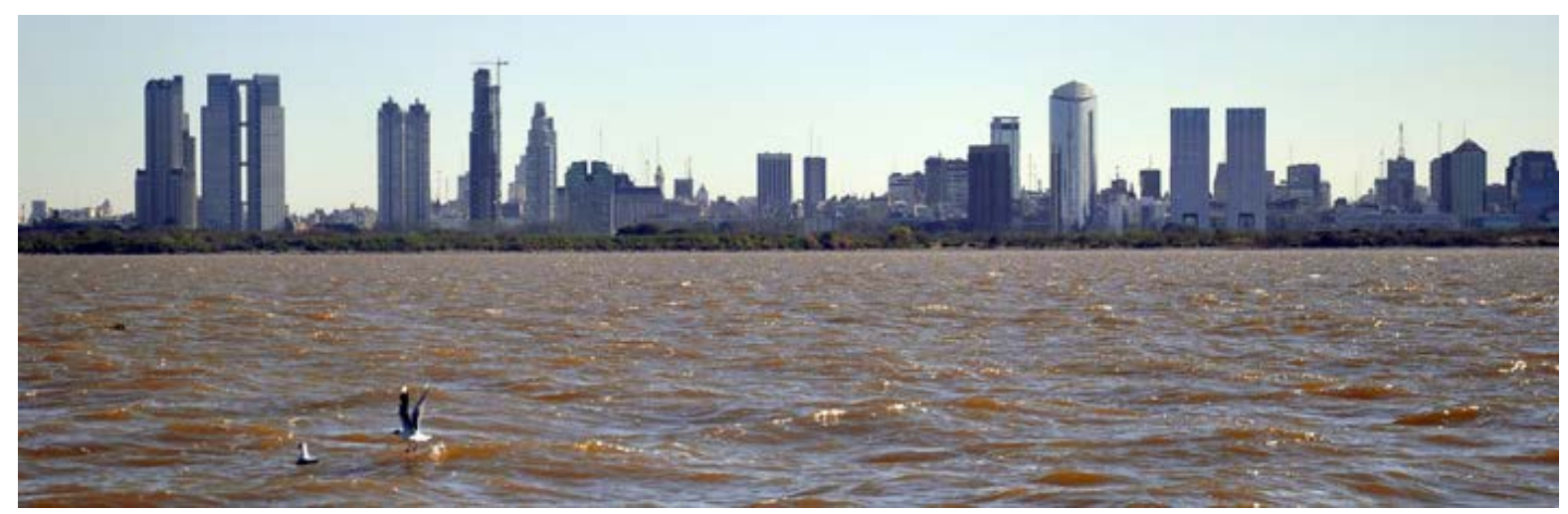

Imagem 44- Vista da orla de Puerto Madero, Buenos Aires, 1989. Fonte: PUERTO MADERO, 2017.

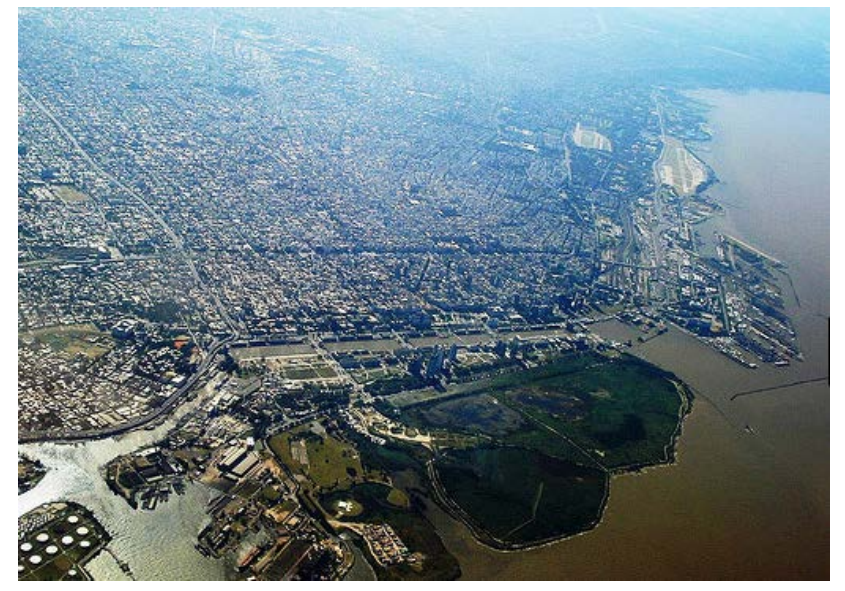

Imagem45- Vista aérea da urbanização de Puerto Madero, Buenos Aires, 1989. Fonte: PUERTO MADERO, 2017.

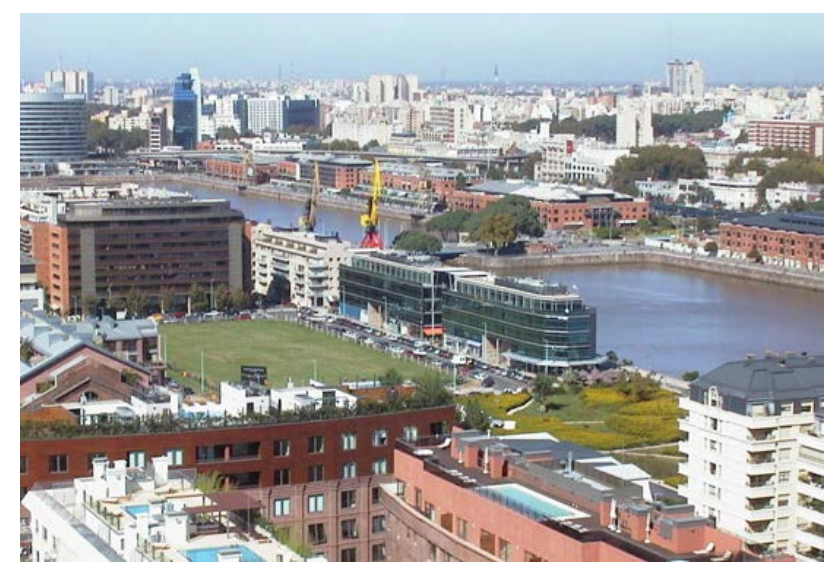

Imagem 47- Vista do conjunto da urbanização de Puerto Madero, Buenos Aires, 1989. Fonte: PUERTO MADERO, 2017.

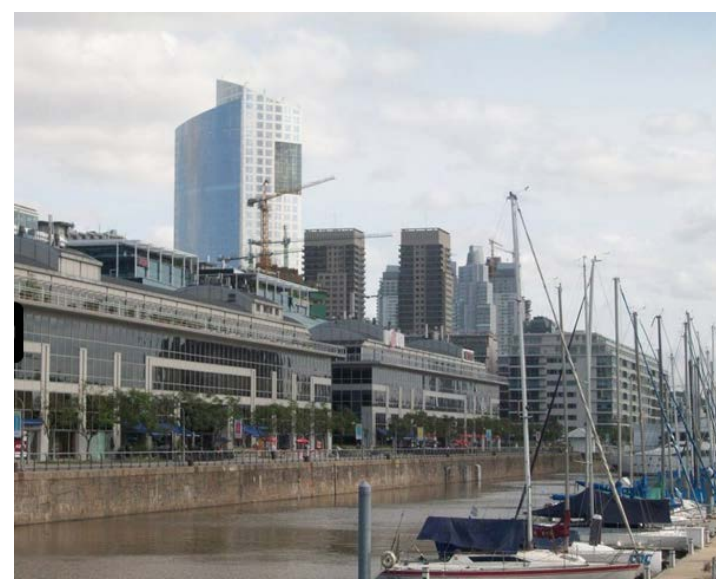

Imagem 46- Vista da orla de Puerto Madero, Buenos Aires, 1989. Fonte: PUERTO MADERO, 2017.

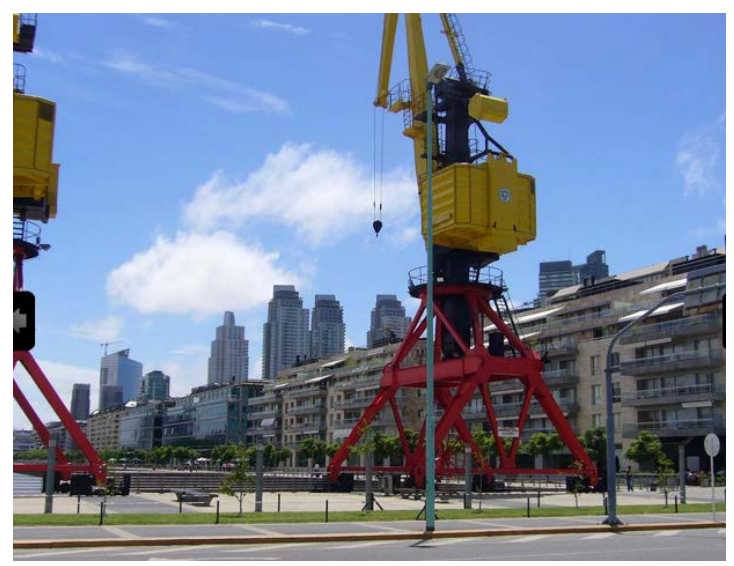

Imagem 48- Vista de elementos históricos de Puerto Madero, Buenos Aires, 1989. Fonte: PUERTO MADERO, 2017.

A representações espaciais nas orlas comportam idéias paradoxais como a de abertura de "janelas para os rios" nos espaços das orlas fluviais, que aparecem sob novas formas paisagísticas, novos usos e mesmo sob formas diferenciadas de gestão urbana. A mediação disso tudo se dá, em grande parte, pelo elemento cultural, que se torna emblemático nas políticas de 
intervenção urbanística que se propõem à "revitalização" do espaço, especialmente para fins turísticos (TRINDADE JÚNIOR, 2002, p. 145).

Segundo Saint-Clair Trindade Júnior, os novos espaços propostos pela Estação das Docas e outras intervenções na orla de Belém são semelhantes ao tipo Waterfront, pois refutam o sítio pela concepção arquitetônica e espacial de seus projetos. Tais projetos negam seus elementos culturais e o dinamismo original das práticas sociais daquele espaço, negam a sua relação com o lugar, com o rio e com toda a dimensão simbólica que há entre o homem, a floresta, o rio e a cidade.

Salientamos também que os instrumentos e normativas de preservação do patrimônio histórico localizado na área da Estação das Docas favorecem, segundo a legislação municipal, a implantação de novos empreendimentos pela iniciativa privada, pois permitem obras de renovação arquitetônica e urbana em alguns espaços que, segundo nossa percepção, deveriam ser considerados com mais especificidade e particularidade, e que se localizam nos limites entre as áreas protegidas do tombamento e sua área externa.

A intervenção da Estação das Docas permite-nos verificar a existência de espaços que consideramos como "de transição" entre as áreas internas e externas aos limites da área de tombamento. Nessas áreas, as intervenções no patrimônio não são pautadas por diretrizes e normativas específicas de preservação para esses espaços na cidade, visto que se inserem nas diretrizes da área central do CHB. Essas áreas "de transição" fazem parte de um planejamento urbano da cidade que é desarticulado entre suas ações de preservação do patrimônio no $\mathrm{CHB}$, com intervenções propostas de modo pontual, correspondendo de forma isolada a determinadas áreas da cidade e, deste modo, descaracterizando a ideia e a identidade do conjunto.

Em algumas das áreas "de transição" em relação ao Complexo Ver-o-Peso, "a arquitetura e o desenho urbano são utilizados como instrumentos para a produção estandardizada de paisagens comuns" MUÑOZ (2005, p. 79), como é o caso do exemplo que assinalamos e de outros mais recentes que veremos adiante no trabalho. Percebemos que essas áreas são pré-selecionadas pela iniciativa privada para um "cultivo do consumo sofisticado e, por outro [lado], na aposta quanto à permanência do jogo da especulação imobiliária e o lucro desenfreado como critério no uso do solo urbano" (CHAUÍ, 1992, p. 38), justamente por serem mais suscetíveis a renovações arquitetônicas. 
Portanto, a área mais próxima ao bem cultural do Complexo Ver-o-Peso, e que não constitui uma área adjacente, proporcionou a criação de espaços sofisticados de consumo em que o elemento histórico foi reduzido de significado e está presente apenas como uma espécie de certificado de autenticidade do valor cultural do lugar. Retomamos, desse modo, o manifesto crítico do escritório STAR (RAMOS, 2014) em relação à delimitação territorial com precisão dos limites de uma área classificada e de uma área de influência/entorno do bem cultural.

No entanto, se a sua área fosse caracterizada como uma área de entorno de um bem cultural tombado nacionalmente pelo IPHAN desde 1977, em relação ao conjunto arquitetônico e paisagístico Ver-o-Peso e áreas adjacentes, esse órgão nacional poderia ter sido consultado de modo a intermediar a formulação das propostas de intervenção, levando a soluções projetuais fundamentadas em uma tradição técnica de intervenção no patrimônio e por meio de seus registros das referências culturais do lugar.

Outra questão importante a ressaltar é que as intervenções urbanísticas realizadas nessa área, no período em questão, propõem-se a atribuir-lhe novos usos, que programam e formatam a vida urbana em novos ritmos e atividades (TRINDADE JÚNIOR, 2002, p.144). Muitas das novas atividades são ligadas a um novo tipo de consumo, diferente de sua raiz histórica e cultural de consumo popular, um consumo associado ao turismo, ao ócio e ao lazer, e que, segundo nossos levantamentos de campo, também criam novas temporalidades de uso daqueles espaços. Com esses novos usos, a espontaneidade da vida cotidiana que caracterizava a relação cultural daquele espaço é perdida ou reduzida de significado, e desenvolvem-se atributos falsos que não podem ser considerados representativos de uma cultura local. 


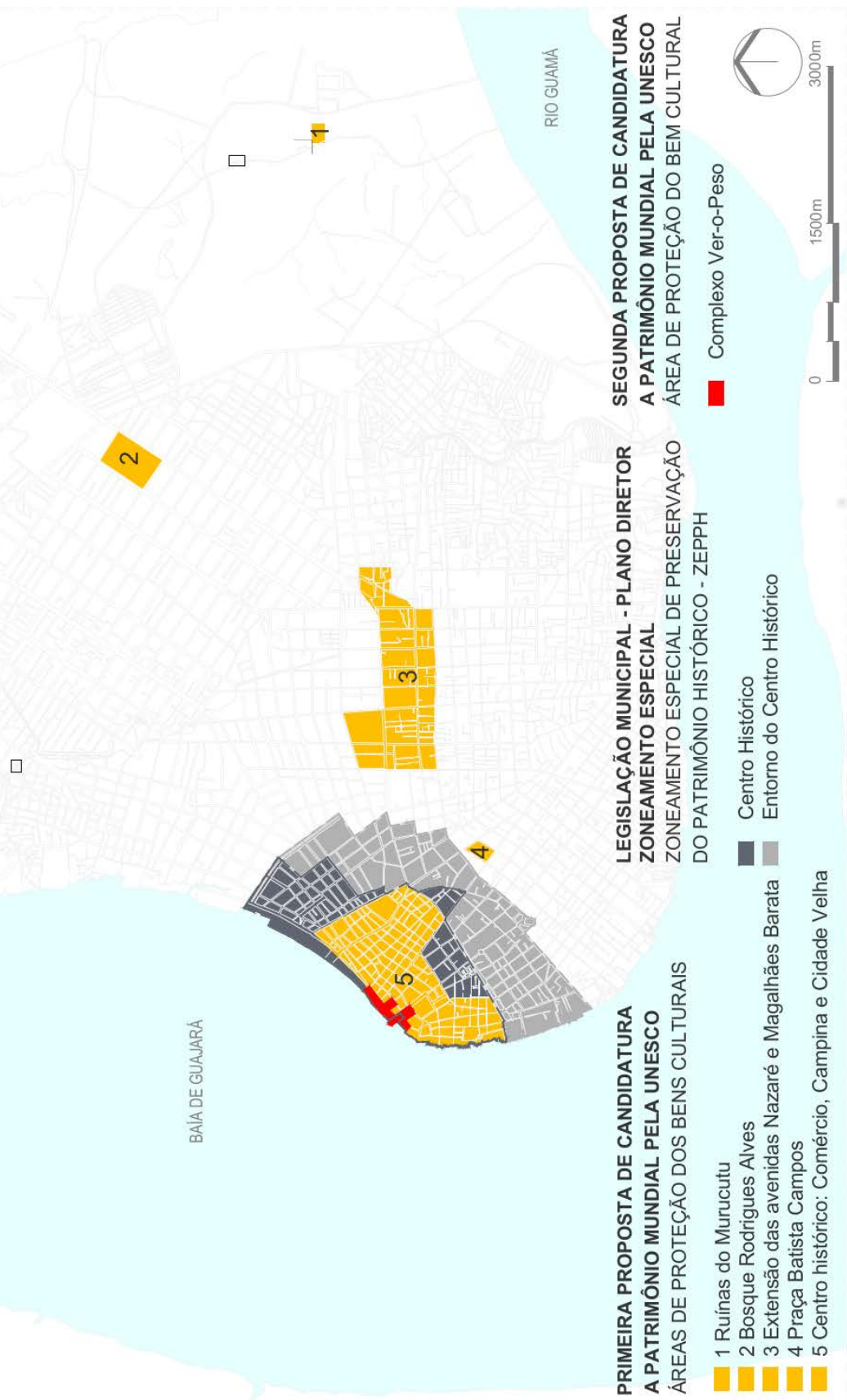

Mapa 25 - Localização da primeira e segunda proposta de classificação de bens culturais a patrimônio mundial pela UNESCO, e com a definição dos polígonos das áreas protegidas segundo o plano diretor da cidade, como centro histórico e seu entorno, Belém. Fonte da imagem: autoria própria.

Nossa pesquisa também nos permitiu compreender que o processo de candidatura a patrimônio mundial em Belém, questão central ao nosso trabalho, foi constituído de dois momentos. 
Num primeiro momento, nos anos de 1990, houve a idealização do processo, que, mesmo com a mudança da equipe política no governo, teve continuidade, embora lenta quanto à definição dos bens culturais da cidade e à definição da área de proteção e de área de entorno a ser classificadas. Essa primeira etapa do processo recebeu uma consultoria internacional $^{130}$, a qual, no entanto, não teve desenvolvimento técnico por alguns anos.

Em nossa pesquisa não conseguimos identificar todos os atores e instituições que ofereceram consultorias, mas as entrevistas nos revelaram que eram, em sua maioria, de órgão consultor da UNESCO, o ICOMOS. Por alguns depoimentos, soubemos que houve também uma consultoria francesa, que pode estar mais diretamente relacionada à atuação da UNESCO, com sede oficial em Paris.

Identificamos a participação do consultor Francesco Lucarelli ${ }^{131}$ na elaboração do primeiro processo de candidatura. Lucarelli, professor vinculado a Università degli Studi di Napoli "Federico II", desenvolveu atividades "científico culturais" pela UNESCO desde o ano de 1984, colaborando com o Centro do Patrimônio Mundial em estudos sobre centros históricos da África e da América Latina inseridos na lista do Patrimônio Mundial. Essa colaboração resultou em uma série de publicações sobre o tema do patrimônio cultural no Brasil, de 1984 a 2006.

No final dos anos de 1990, a candidatura fundamentou-se num inventário histórico, sociocultural, arquitetônico e ambiental do Ver-o-Peso, realizado pela Fundação Cultural do Município de Belém (VER-O-SITE, 2016), segundo uma metodologia do IPHAN, o qual foi concluído em 2003.

Uma equipe multidisciplinar promoveu intensos estudos sobre o lugar, registrando o antes e o depois, mostrando desde sua gênese, vinculada à história de Belém, e como atualmente sofre com a concorrência de supermercados e entrepostos atacadistas mantendo, contudo, uma grande importância como área de abastecimento da cidade. No âmbito da feira

\footnotetext{
${ }^{130}$ Consultoria internacional de Francesco Lucarelli, contratado pela prefeitura do município de Belém para coordenar o trabalho de organização da documentação da candidatura durante a gestão do prefeito Edmilson Rodrigues, com a participação de Cristóvão Fernandes Duarte como superintendente regional do IPHAN do Pará, na época também professor da Universidade da Amazônia.

${ }^{131}$ Lucarelli também participou como coordenador em alguns processos de candidatura a patrimônio mundial, como foi o caso de seu trabalho pela Prefeitura de Nápoles na preparação da candidatura do Centro Histórico desta cidade na lista do Patrimônio Mundial, em 1995. 
articulam-se eventos, festas e mitos que consolidam a identidade e a cultura paraense (LEITÃO, 2010, p. 12-13).

Essa candidatura foi estabelecida sob o conceito de paisagem cultural e reconhecia a existência de quatro períodos distintos que consolidavam os valores históricos e arquitetônicos da cidade de Belém ao longo de seus quatrocentos anos, desde o período de sua fundação aos dias atuais, e buscava caracterizar esse conjunto paisagístico por meio dos bens culturais nomeados. Os quatro períodos foram definidos como militar religioso, setecentismo, da borracha e do declínio da borracha.

Elaborou-se um documento preliminar, conduzido pelo IPHAN, relativo a essa idealização do processo ${ }^{132}$. Nele, a candidatura era intitulada "Belém, um percurso ao longo de quatro séculos ${ }^{133 "}$ e considerava os seguintes bens culturais da cidade: as ruínas do Murucutu; o bosque Rodrigues Alves; a extensão das avenidas Nazaré e Magalhães Barata; a praça Batista Campos e o Centro Histórico da cidade, constituído pelos bairros da Campina e Cidade Velha.

E no caso do Ver-o-Peso, que era uma coisa que há alguns anos o prefeito [Edmilson Rodrigues] teve uma iniciativa de fazer isso, primeiro de tudo ele quis pular o IPHAN, mandando direto para Brasília, e acabou voltando para o IPHAN, depois voltou e veio parar aqui comigo. E depois com a mudança de prefeito entraram outras pessoas, e resolveram ampliar do Ver-o-Peso, e ficou uma coisa meio fora da realidade, uma coisa muito gigantesca para atingir todas as exigências da UNESCO e que seria um percurso da Belém ao longo do tempo a partir dos bens tombados na cidade, e era uma coisa gigantesca. $E$, também chegaram a desenvolver estudos, trouxeram pessoas de fora, mas não avançou aqui dentro do IPHAN, com a documentação que eles haviam dado entrada, depois deram entrada num texto (LIMA, 2016).

Durante esse período de desenvolvimento da documentação da candidatura e de sua posterior interrupção, foram realizados alguns projetos de intervenção urbana na cidade: o Espaço Palmeira, a Via dos Mercadores, a retirada de marquises e de placas de lojas do centro comercial em parceria com o comércio local e a recuperação do Palacete Pinho.

Num segundo momento da candidatura, foi redefinido o bem cultural a ser nomeado, Ver-o-Peso, de modo a constituir uma menor área de abrangência e proteção,

\footnotetext{
${ }^{132}$ Documento de rascunhos do processo de candidatura a patrimônio mundial de 2004.

${ }^{133}$ Ver: Belém se candidata a patrimônio da humanidade, 2004.
} 
centrada em seu Centro Histórico, cuja área de entorno, também menor, foi definida segundo áreas de classificação de tombamentos anteriores realizados pelo IPHAN.

No grupo tinha um técnico do [governo do] estado [do Pará]da área de patrimônio, eles que inclusive estavam nessa tentativa de insistir pela SECULT de insistir que ficasse o Feliz Lusitânia, mas no final a gente acabou fechando que essa área ficaria como área de entorno, fechou mais a indicação do Ver-o-Peso que isso seria trabalhado e justificado no dossiê (LIMA, 2016).

Assim, em 2004, um primeiro documento de intenção de candidatura ${ }^{134}$ foi apresentado à UNESCO pelo IPHAN, com a nomeação de bens culturais da cidade de Belém à classificação como Paisagem Cultural, segundo o conceito de "paisagem cultural" dessa organização internacional.

Embora o documento tenha sido elaborado e entregue por um órgão nacional do Estado, o IPHAN, seguindo as diretrizes operacionais da UNESCO, este organismo internacional participou no processo de elaboração e desenvolvimento da proposta de nomeação dos bens culturais da candidatura, por meio de "consultores" também internacionais, cuja participação balizou o processo de elaboração da candidatura conjuntamente ao IPHAN, segundo Maria Dorotéa Lima:

Houve uma reunião aqui da UNESCO para discutir critérios para novas indicações, naquela tentativa de ampliar o leque dos patrimônios já reconhecidos para diversificar de coisas que não estavam contempladas, já tinha muito centro histórico brasileiro, e nós colocamos a questão do Ver-oPeso, mas havia uma orientação de Brasília para a gente trabalhar a questão da arquitetura do ferro, e a gente conduziu num outro sentido de relacionar o espaço e as práticas, por que ali tu tens em termos de arquitetura o que a gente colocou na candidatura [como] uma evolução, uma transformação no tempo em que as práticas se mantiveram, e ganharam força ali naquele local, [e que] criou uma espécie de um tipo de território, e acabou que gostaram dessa proposta, apesar de ter ido com a indicação da candidatura do ferro, o próprio grupo de consultores teve essa ideia que no Ver-o-Peso deveriam ser trabalhadas outras questões (LIMA, 2016).

${ }^{134} \mathrm{O}$ dossiê de candidatura apresentado à UNESCO em 2004 era formado por um relatório de 300 páginas (segundo relato do Prof. Saint-Clair Trindade, durante nossa entrevista). Desse documento tivemos acesso apenas aos documentos de rascunho, durante a pesquisa de campo e no gabinete da superintendência do IPHAN em Belém. 
Vale retomar o conceito de Paisagem Cultural adotado pela UNESCO no ano de 1992 (IPHAN, 2016), que considera a existência de uma grande variedade de paisagens que são representativas de diferentes regiões no mundo. Essa abordagem considera a combinação de bens culturais naturais, materiais e imateriais, e busca expressar a relação entre o homem e seu ambiente natural.

Outra questão importante é que, no ano de 2004, as cidades do Rio de Janeiro e Paraty também pleiteavam o reconhecimento de seus bens culturais segundo o critério de Paisagem Cultural. Posteriormente, em 2012, o conjunto "Rio de Janeiro, paisagens cariocas entre a montanha e o mar" (Rio de Janeiro: Carioca Landscape between the Mountain and the Sea) foi classificado; já a candidatura "Caminho do Ouro de Paraty e sua paisagem" (Gold Route in Parati and its landscape) ainda não foi classificada.

Porém, com a mudança de governo na prefeitura municipal de Belém, em 2005, a elaboração e o desenvolvimento de uma documentação técnica relativa ao processo de classificação a patrimônio mundial não teve continuidade, principalmente por questões ligadas à ausência de uma combinação dos poderes estatais (local e nacional), segundo a entrevista com Maria Dorotéa Lima. E, ainda que tenham sido feitas solicitações de complementações técnicas por parte do IPHAN-PA à prefeitura municipal, considerada a responsável técnica local pelo processo, elas não foram atendidas, mesmo após a demonstração de interesse pela própria prefeitura municipal em dar continuidade a ao processo.

A segunda proposta foi estruturada a partir ideia de território e de sua relação com o bem cultural, e configurou a continuidade do processo de classificação a patrimônio mundial de Belém, concentrando-se no conjunto cultural tombado nacionalmente pelo IPHAN, o Vero-Peso e suas manifestações culturais.

A documentação da segunda proposta define o Ver-o-Peso como um grande mercado ao ar livre de produtos de extração, agricultura e artesanais trazidos da região Amazônica. O Ver-o-Peso é constituído por pequenas e grandes feiras, lojas que vendem produtos populares, assim como dois mercados (um que vende carne e o outro que vende peixe) ao longo da Baía de Guajará, em uma relação permanente com as ilhas vizinhas e com as cidades pequenas de onde muitos dos produtos vendidos são trazidos. O Ver-o-Peso é caracterizado como um lugar de intensa vida social e intercâmbio cultural, onde práticas de 
trabalho tradicionais ocorrem e relações sociais são estabelecidas, envolvendo ofícios não apenas de natureza comercial, mas também simbólica.

Assim, segundo verificamos por meio da documentação indicativa entregue pelo IPHAN à UNESCO (UNESCO, 2016), em 2014, o processo foi estruturado a partir do conjunto classificado pelo IPHAN como patrimônio arquitetônico e paisagístico brasileiro no ano de 1977 e de sua documentação datada de 1969. Sua área de proteção é definida pelo Complexo Ver-o-Peso ${ }^{135}$ e constituída pelos seguintes bens culturais: Boulevard Castilhos França, Mercado de Carne e Mercado Bolonha de Peixe, casario, praças do Relógio e Dom Pedro II, doca de embarcações, Feira do Açaí e Ladeira do Castelo, situados entre as margens da baía do Guarajá e a parte antiga de Belém (Fonte: IPHAN, 2016).

No caso do Ver-o-Peso, é até interessante, porque é até um potencial mesmo grande, é o maior potencial realmente da nossa cultura, tudo bem, está certo, mas existem outros, a gente precisa descentralizar essas políticas, e fazer com que as pessoas conheçam a cidade, e vivam a nossa cidade, porque elas não vivem.

Então se voltou a atenção para esse centro histórico, que se tornou uma vitrine da cidade, e acha que tudo tem que ser feito ali e a cidade ficou vazia de políticas culturais, de preservação patrimonial, que existem, mas estão descobertos, não estão resguardadas, porque as políticas não se voltam para eles (TRINDADE JÚNIOR, 2016b).

Trata-se de um processo de patrimonialização concentrado na área central da cidade, e que, segundo Everaldo Costa (2015, p.27), levanta o problema da efetiva preservação de um bem cultural em um processo de patrimonialização mundial, segundo um espectro do "global-local" e em que a "totalidade urbana - para além da noção de conjunto tombado - é inserida na 'totalidade-mundo', ao mesmo tempo em que desconsidera que o bem cultural é parte integrante "de um contexto social e territorial que extrapola os limites dados pelo tombamento, tal como um verdadeiro paradoxo" (COSTA, 2015, p.35).

Ou seja, entendemos que a configuração de uma reduzida área patrimonial desconsidera seu contexto social e territorial que extrapola os limites de seu tombamento, como é o caso de Ver-o-Peso, um bem cultural que se articula com a dinâmica da cidade por

${ }^{135} \mathrm{O}$ conjunto paisagístico e arquitetônico Ver-o-Peso e áreas adjacentes (Praça Pedro II e Avenida Boulevard Castilhos França, Mercado de Carne e Mercado Bolonha de Peixe) foi tombado pelo IPHAN em 1977 (IPHAN, 2016). 
um sistema de redes e que se configura segundo um conceito de paisagem cultural que não está apenas localizado no Centro Histórico da cidade de Belém.

Então, há uma ausência completa de políticas que transformem em formas, esses conteúdos, não só para ficar na paisagem, não é isso, mas porque estes conteúdos, essas práticas sócias espaciais elas precisam de formas para se reproduzir, do ponto de vista da qualidade ambiental, da qualidade de vida dessas pessoas e do trabalho que elas têm, mas também do ponto de vista da necessidade que esses conteúdos e essas práticas socioespaciais precisam para existirem, se elas não têm as formas elas vão se precarizando e desaparecendo, e a tendência tem sido essa, se tornarem menores, se tornarem precárias e as pessoas deixarem de frequentar (TRINDADE JÚNIOR, 2016b).

Esse paradoxo entre a reduzida área central, limitada pelo tombamento, que é nomeada a patrimônio mundial, e o contexto territorial da cidade, com bens culturais não consolidados e localizados fora de sua área central, é agravado pela ausência, na cidade de Belém, de políticas de preservação patrimonial que protejam esses outros conteúdos e referências culturais para além de seu Centro Histórico e do Ver-o-Peso.

Enfim, por meio da entrevista com Maria Dorotéa Lima, percebemos que a documentação técnica do processo não está sendo desenvolvida e que há uma divergência entre o trabalho dos técnicos da prefeitura municipal responsáveis e o órgão de preservação nacional, IPHAN, com representação no Pará.

É sempre uma questão de política, deixou de ser técnica, que a princípio haviam uns técnicos bons, pessoas com um bom currículo em práticas para trabalhar nesse dossiê, e aí com essa mudança de configuração das instituições, aí a questão está meio parada porque não dá para trabalhar sem a prefeitura, essa parte do dossiê ficou um pouco como responsabilidade deles e está desarticulado, porque até constituir outro comitê e o grupo, porque era o IPHAN que estava conduzindo, mas depois que a prefeitura constituiu esse grupo, e aí eles que deveriam tomar a frente para trabalhar termo de referência e tudo mais, e aí eles resolveram trabalhar esta questão da gastronomia porque tem um projeto aí com o governo do estado voltado para isso, que é um grande caixa preto também(TRINDADE JÚNIOR, 2016b).

Outra questão que foi possível evidenciar é que há outros processos de patrimonialização a patrimônio mundial imaterial pela UNESCO em Belém em andamento ou já concluídos. Esses novos processos de patrimonialização mundial se mostraram mais 
interessantes para alguns grupos que estavam à frente do processo de patrimonialização mundial de Ver-o-Peso, por exemplo. Quando questionada em relação ao processo da gastronomia em Belém, a superintendente do IPHAN-PA explicitou que, para que este processo seja desenvolvido e classificado, não demanda atuação técnica do IPHAN, e por isso tal órgão não tem sido consultado e não tem conduzido processos específicos como esse.

Não, tem várias categorias, eu não conheço bem isso e não sei como funciona, mas tem cidade da alegria, cidade da gastronomia, tem várias categorias, formaram um grupo [de pessoas interessadas], chamaram consultoria internacional, tudo o que poderiam ter feito por Ver-o-Peso e não fizeram, ai direcionaram para isso, porque não passava pelo IPHAN e era um processo mais rápido, e conseguiram esse título e esqueceram, largaram o outro de lado, e atropelou todo o processo, porque quando a gente começou este trabalho a assessoria de relações internacionais do IPHAN que acompanha estes processos por Brasília veio aqui, a gente fez uma visita na área, a gente explicou como tudo como funcionava o processo para este grupo todo e já fez uma avaliação para discutir a questão da poligonal (LIMA, 2016). 


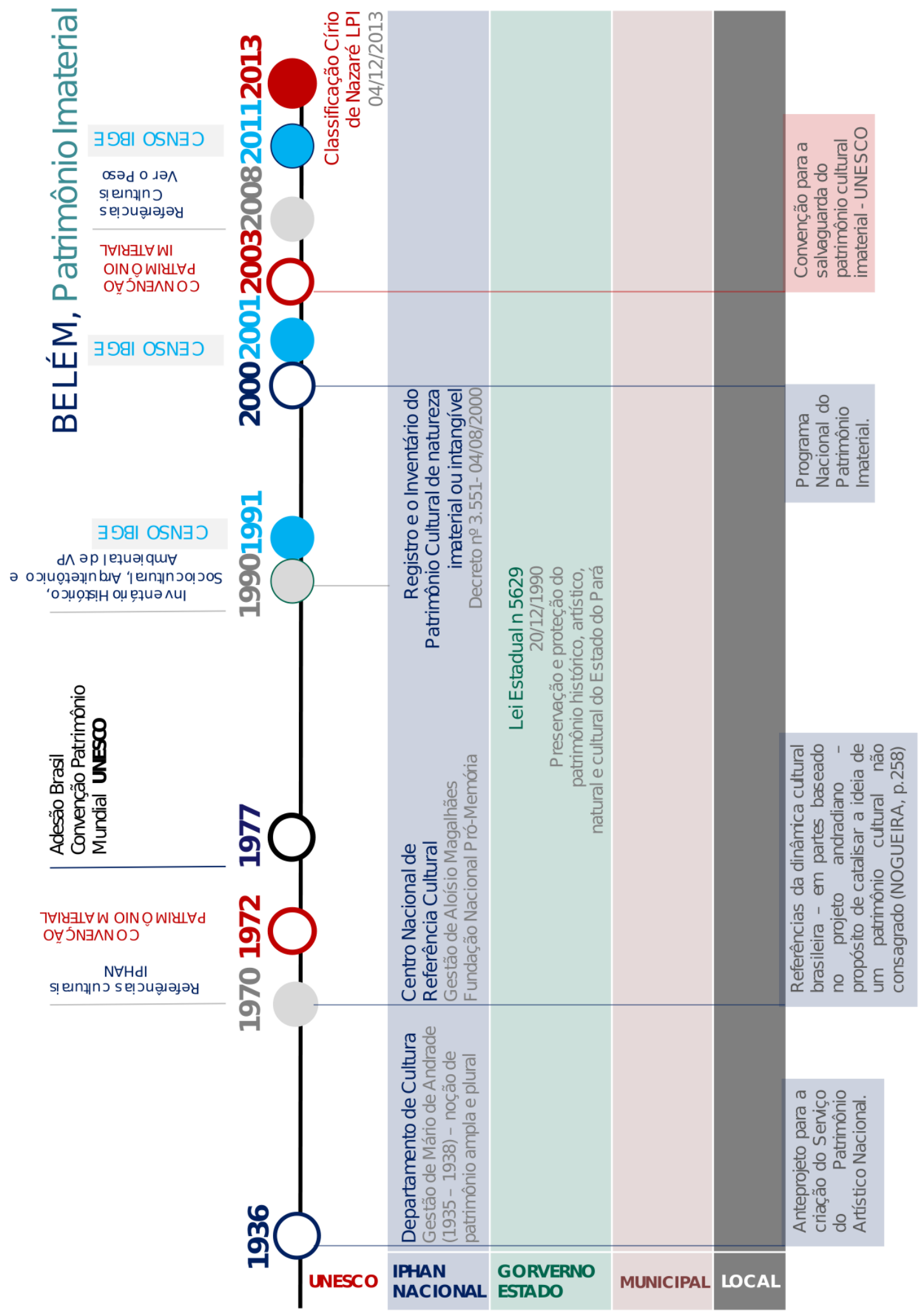

Imagem 49 - Esquema explicativo relativo à classificação do patrimônio imaterial relacionado à cidade de Belém. Fonte: autoria própria sobre VER-O-SITE, 2016; IPHAN, 2016; UNESCO, 2016. 
Muitas das propostas de intervenção urbana em Belém foram questionadas pela sociedade civil devido à ausência de uma consulta prévia à população na definição desses projetos conduzidos e financiados pelo poder público ou de propriedade pública. Foi o que aconteceu em relação ao seguintes projetos: a reforma da feira do Ver-o-Peso; a definição de novos usos atribuídos a espaços patrimoniais, como foi o caso da Casa das Onze Janelas; ou ainda, a aprovação de projetos de renovação urbana em área adjacente a Ver-o-Peso e tombada pelo IPHAN como conjunto paisagístico e arquitetônico, sem os devidos estudos preliminares e de consulta a este órgão de preservação nacional, como foi o caso da proposta para o Centro Comercial na área patrimonial da Praça Frei Caetano Brandão.

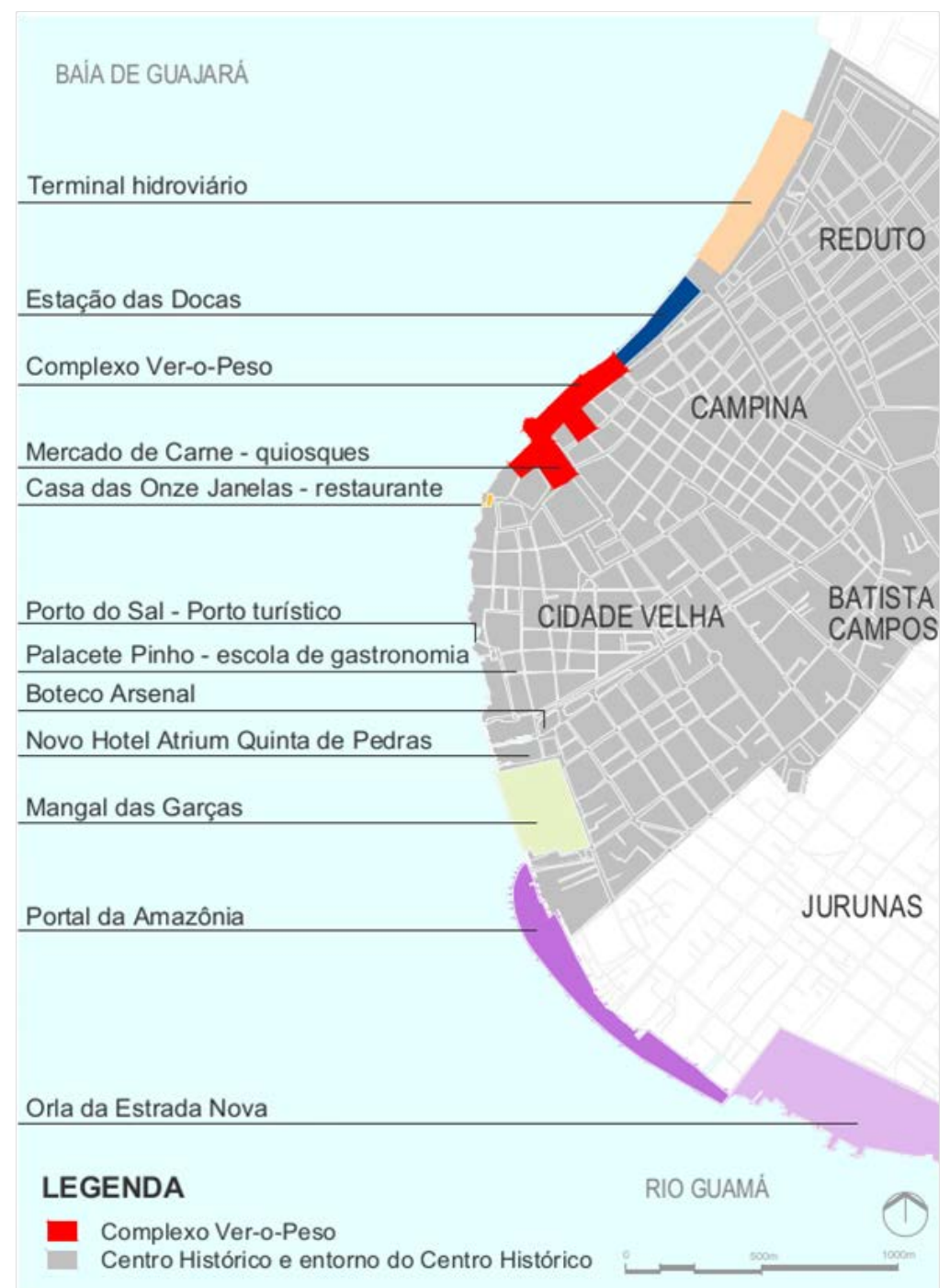

Mapa 26 - Identificação dos projetos na orla do Centro Histórico de Belém. Fonte: autoria própria sobre base de BILBAS, 2016. 


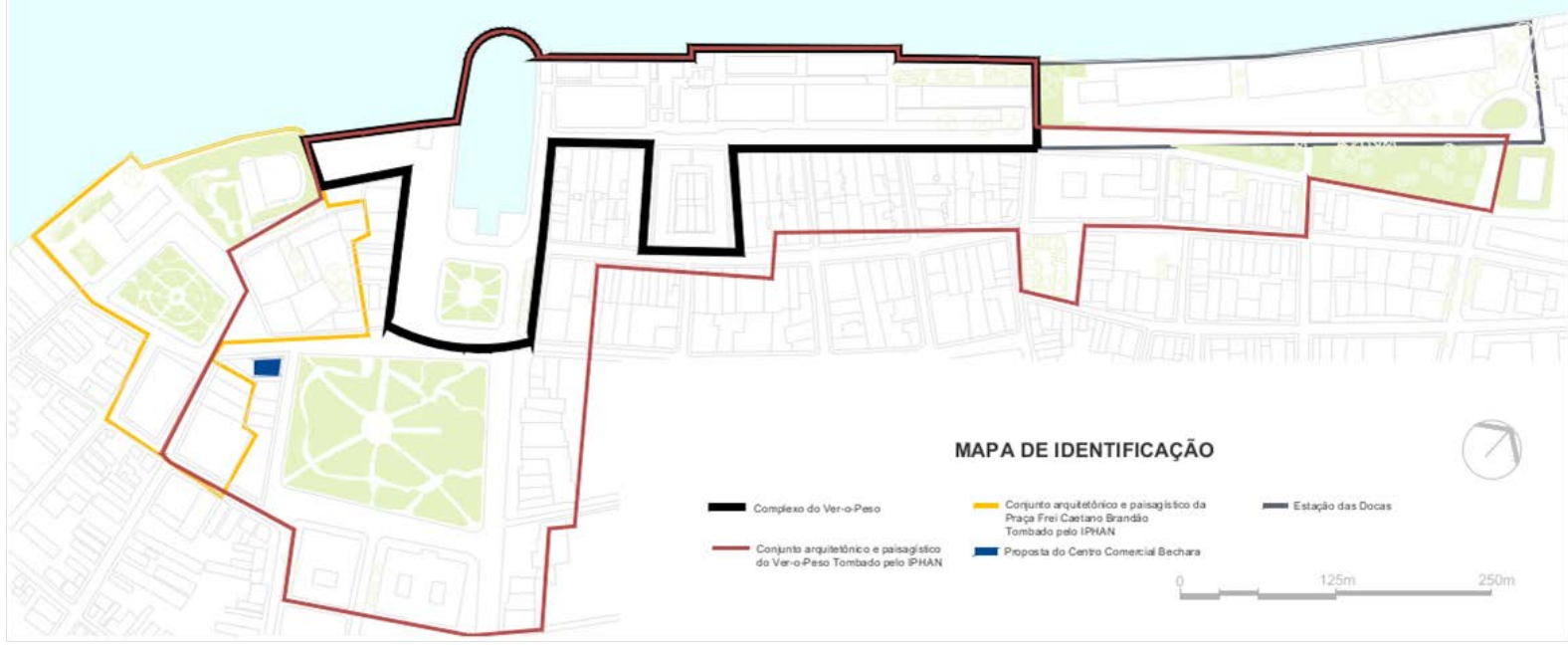

Mapa 27- Identificação da proposta para o novo centro comercial Bechara Mattar Diamond na área de entorno do Ver-o-Peso, Belém. Fonte: autoria própria.
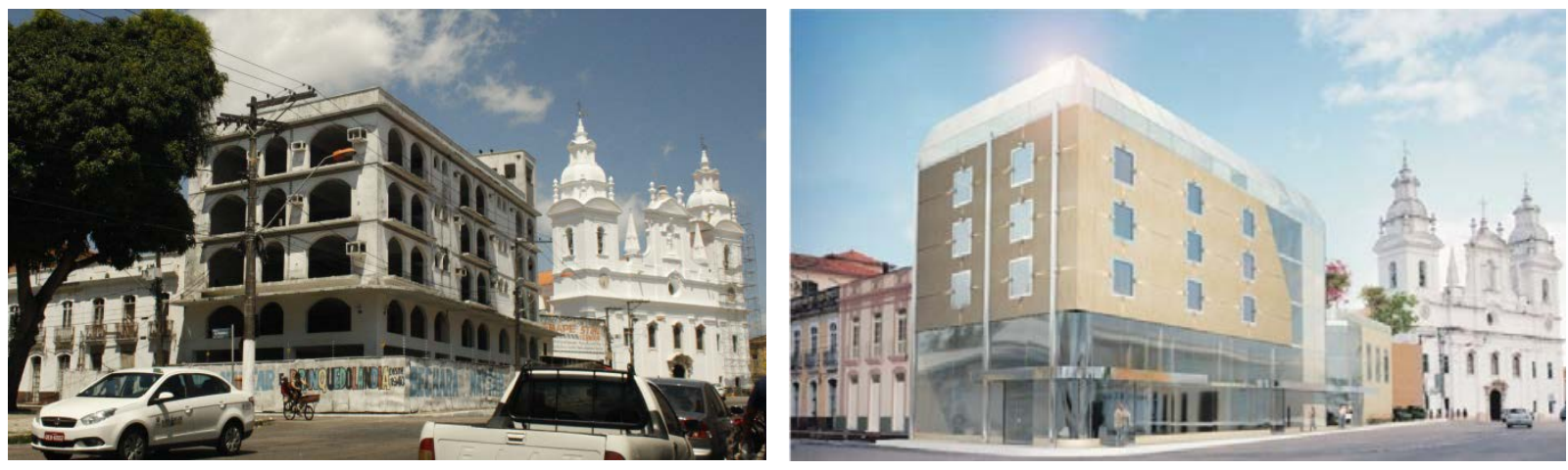

Imagem 50 - Vista do edifício, sem uso atualmente, capturada em ângulo semelhante (na praça do relógio), com a Catedral da Sé ao fundo, Belém, 2016. Fonte: autoria própria.
Imagem 51-Vista da maquete eletrônica da proposta do novo centro comercial Bechara Mattar Diamond na área de entorno do Ver-oPeso, Belém, 2014. Fonte: Página de abaixoassinado Change.org ${ }^{136}$.

Também em 2014, a prefeitura de Belém, SEURB e SECON contrataram uma empresa privada para realizar a reforma do Ver-o-Peso no âmbito do PAC das Cidades Históricas. Essa proposta era referente apenas à Feira do Ver-o-Peso e foi finalizada e apresentada publicamente à população em 2015.

${ }^{136}$ Disponível em: <https://www.change.org/p/n\%C3\%A3o-\%C3\%A0-constru\%C3\%A7\%C3\%A3o-doshopping-bechara-mattar-diamond-no-centro-hist\%C3\%B3rico-sem-estudo-de-impacto-devizinhan\%C3\%A7a-eiv>. Acesso em: 20 dez. 2016. 
Segundo a nota publicada pelo IPHAN ${ }^{137}$ : "os demais projetos para a Feira do Açaí, Solar da Beira e Pedra do Peixe estão sendo contratados pela Prefeitura de Belém e poderão ser submetidos aos mesmos procedimentos posteriormente. Além destes, estão sendo demandados à prefeitura projetos para o estacionamento e para as instalações provisórias para mobilização e remanejamentos necessários durante a obra".

Em relação a este projeto de requalificação do Ver-o-Peso, a gente fez um debate aqui no NAEA, questionando um pouco inclusive isso, porque o projeto arquitetônico para a feira de certa maneira sugeria uma transformação da feira em uma espécie de mercado, e para nós a feira é simbolicamente do ponto de vista arquitetônico muito significativa, é a configuração da barraca. Inclusive o que chamou a atenção neste projeto de requalificação era a maquete eletrônica que eles jogaram na mídia, você tinha as barraquinhas, aí eles jogaram uma maquete eletrônica que cobria as barraquinhas, desestruturando aquela concepção de feira.

Acho que isso é importante, nós temos uma concepção de feira, inclusive as nossas feiras aqui, diferente das feiras de São Paulo, são permanentes, elas não são de rodízio, nós temos uma feira apenas que é a da Batista Campos, apenas que ela acontece de sexta, sábado e domingo. Mas normalmente as feiras são permanentes, e elas têm uma marca definitiva no espaço, como o Ver-o-Peso, e sempre remete a questão das barracas. Então, do ponto de vista paisagístico, do ponto de vista da paisagem, nós temos um imaginário do que seja a feira pra gente então isso é importante (TRINDADE JÚNIOR, 2016b).

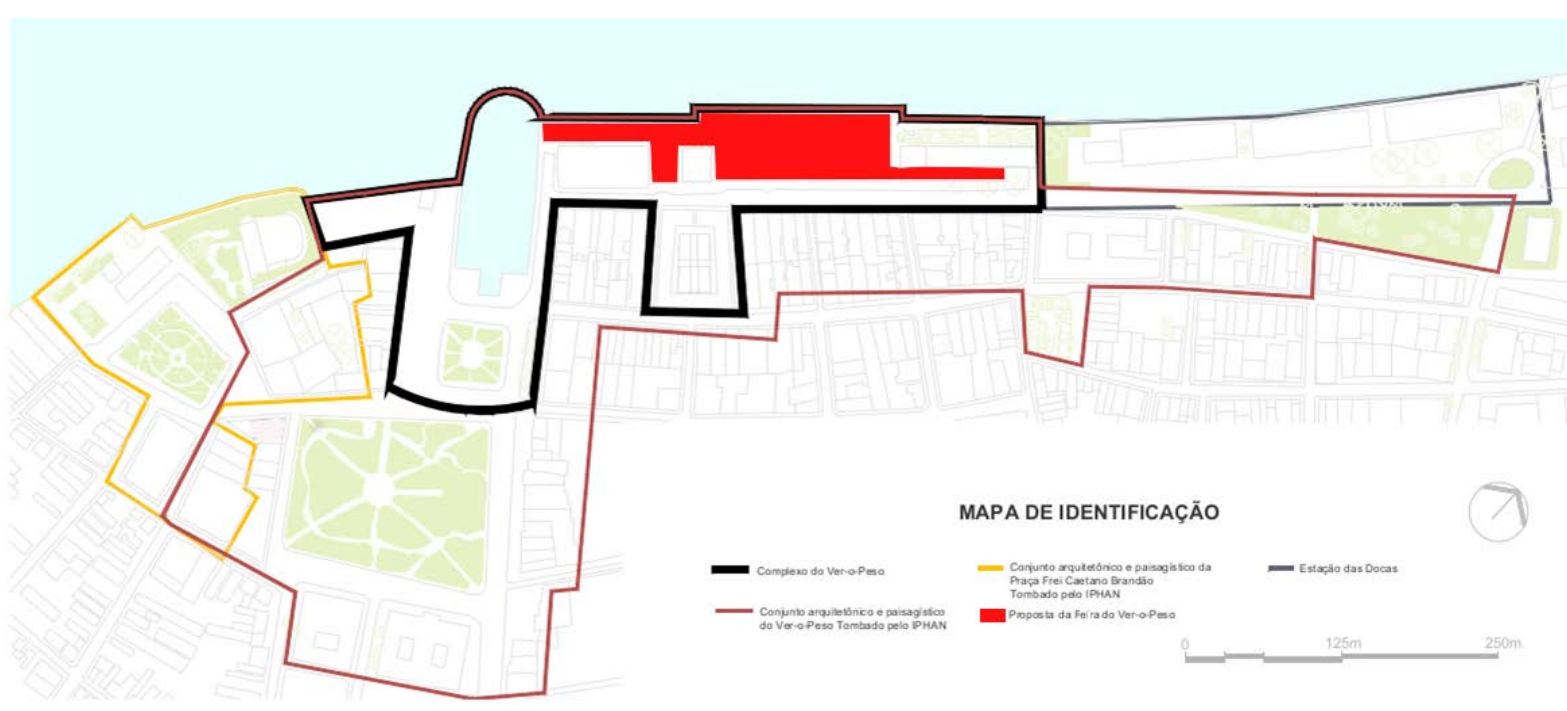

Mapa28 - Identificação da proposta para a nova Feira Livre do Ver-o-Peso, na área de proteção, Belém. Fonte: autoria própria.

${ }^{137}$ Nota: Iphan abre consulta pública sobre a reforma do Ver-o-Peso (Documento de consulta pública à proposta de intervenção para a Feira do Ver-o-Peso elaborado pela empresa DPJ arquitetura \& engenharia Itda, 2016) 


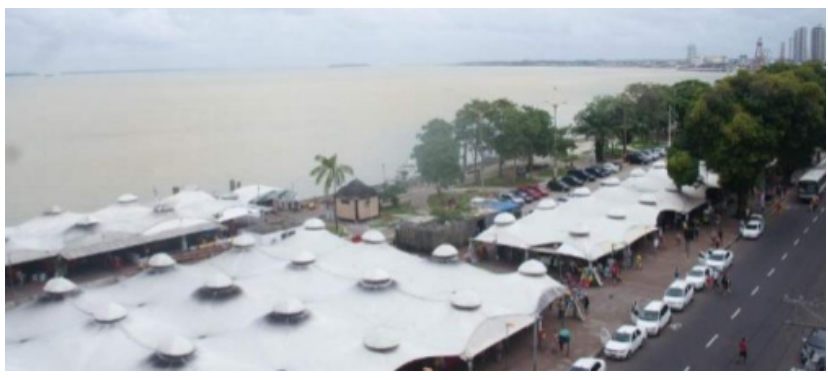

Imagem 52- Feira livre do Ver-o-Peso e coberturas das barracas atualmente, Belém. Fonte: documento de consulta pública, IPHAN, 2016.

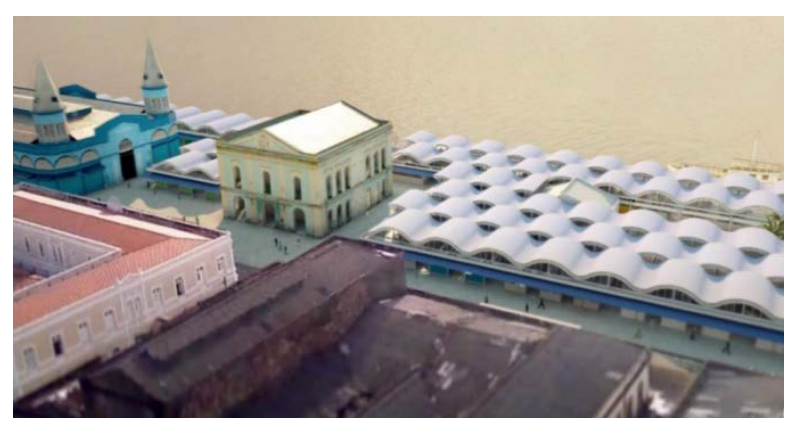

Imagem 54 - Fotomontagem da proposta de projeto para a Feira livre do Ver-o-Peso apresentado pela prefeitura, Belém. Fonte: documento de consulta pública, IPHAN, 2016.

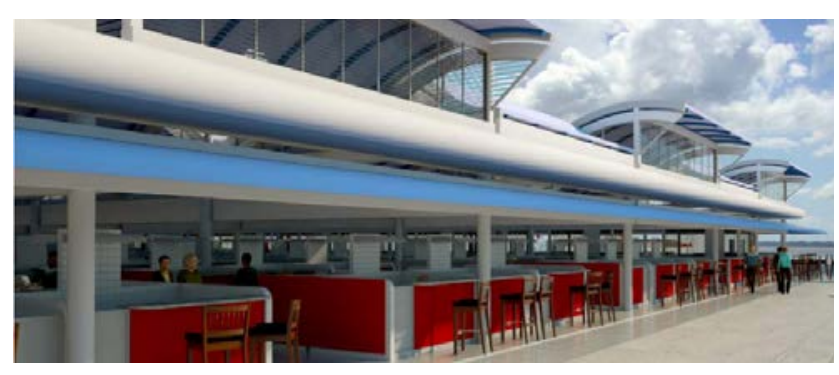

Imagem 56 - Vista da maquete eletrônica e da orla, com a proposta da nova Feira Livre do Ver-o-Peso, na parte do setor de alimentação, Belém. Fonte: DPJ, 2016, p.58.

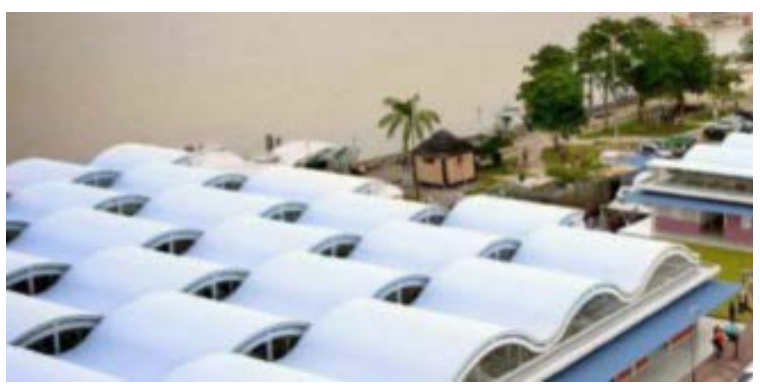

Imagem 53 - Fotomontagem da proposta de projeto para a Feira livre do Ver-o-Peso apresentado pela prefeitura, Belém. Fonte: documento de consulta pública, IPHAN, 2016.

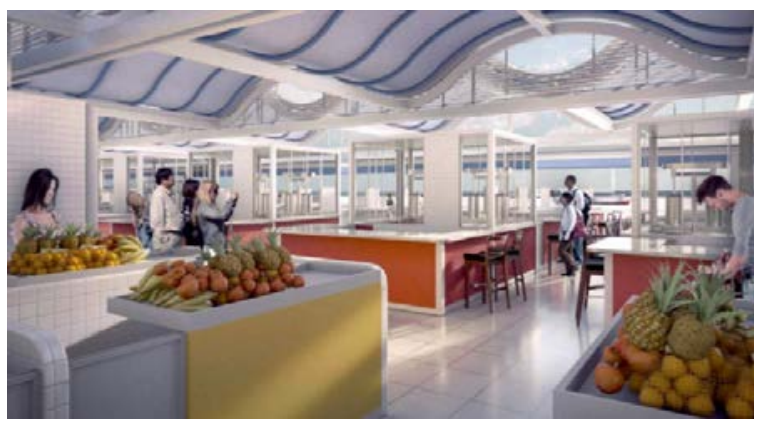

Imagem 55 - Vista interna da maquete eletrônica da nova Feira Livre do Ver-o-Peso, na parte do setor de frutas e alimentação (açaí), Belém. Fonte: DPJ, 2016, p. 29.

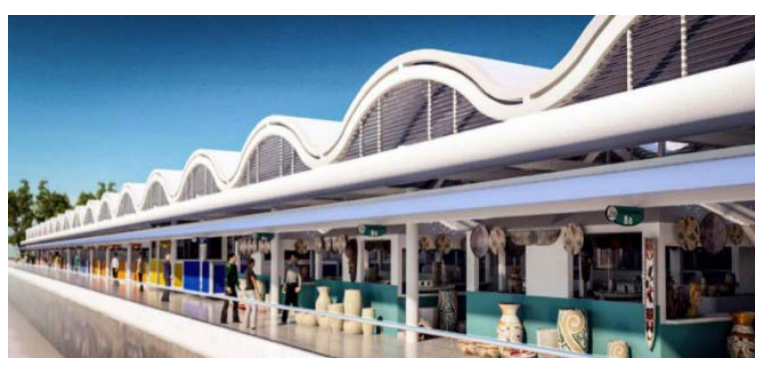

Imagem 57 - Vista da maquete eletrônica com a vista da Baía de Guajará da nova Feira Livre do Ver-o-Peso, na parte do setor de artesanato, Belém. Fonte: DPJ, 2016, p.59.

O projeto básico para a reforma do Ver-o-Peso apresentava a proposta de uma nova estrutura de cobertura da feira, como uma "ideia de apresentar uma solução ritmada que não se configurasse como uma grande cobertura plana, e sim faixas onduladas, aliando as funções de: cobrir, ventilar e iluminar" (DPJ, 2016, p. 22). Por meio da nova cobertura, com 
telhas termo acústicas onduladas, propunha-se a qualificação do espaço em termos de conforto ambiental (ventilação e iluminação zenital, ventilação cruzada, acústico e térmico). A solução estrutural era de uma estrutura de aço com perfis tubulares para sustentar essa cobertura e uma modulação para abrigar os equipamentos dos feirantes.

Essa nova configuração da proposta era maior do que a hoje existente, devido aos seguintes fatores: o aumento do tamanho dos equipamentos que abrigam os 818 permissionários; a mudança na configuração da Feira; a previsão de maiores corredores de circulação; outras melhorias em relação ao depósito de lixo, sanitários etc. (DPJ, 2016, p. 32).

Os equipamentos foram projetados com modelos diferentes, vedados em alvenaria e revestidos internamente com cerâmica, e externamente pintados em cores diferentes, referentes a cada um dos setores da feira.

Após esse projeto ser contestado por algumas entidades e pela sociedade civil, em março de 2016 foi aberta uma consulta pública à sociedade civil pelo IPHAN, em acordo com o Ministério Público Federal, pelo período de trinta dias (2 a 31 de março de 2016), durante o qual foram feitas críticas e contribuições à proposta. Posteriormente, era prevista uma audiência pública com a apresentação do projeto e o recebimento de contribuições da sociedade civil. Esse processo foi interrompido e não chegou a ser realizado.

Refletimos também sobre as questões pertinentes aos instrumentos estabelecidos pelo Estatuto da Cidade em relação ao patrimônio histórico, tais como a outorga onerosa e a transferência de construir, além de outros mecanismos que poderiam auxiliar na concretização do conceito de função social da propriedade, e que foram previstos pelo Plano Diretor de Belém, mas não foram devidamente aplicados.

Há a questão da outorga e do gabarito no entorno do Centro Histórico, por exemplo, quando acaba aqui na Avenida Assis de Vasconcelos, aqui a gente está na Doca, que corresponde a uma faixa de entorno do Centro Histórico, em que o nível de proteção é mais baixo, mas que é necessário observar o gabarito e os índices urbanos específicos, e também uma outorga também aqui incidente. $\mathrm{O}$ problema desta outorga em Belém é que os vereadores fazem um monte de trambiques, então, historicamente esvaziam a outorga, há poucos exemplos efetivos de aplicação da outorga, de cobrança. Porque houve uma época em que os vereadores conseguiram colocar o coeficiente básico igual ao máximo, se não tem diferença entre o básico e o máximo que tu podes construir para cobrar a outorga, tu não podes cobrar a outorga, se não há um intervalo (PONTE, 2016). 
Também é importante ressaltar que alguns edifícios verticalizados foram construídos na área do Centro Histórico, de modo a não respeitar a horizontalidade imposta pelo plano diretor atual. A configuração que prevalece do conjunto patrimonial, segundo nossa observação, são as edificações de um a quatro pavimentos em alguns pontos, em outros há edificações de um a dois pavimentos.

A legislação urbanística em Belém é muito recente, o primeiro código de obras de Belém é de 1988. Então houve um período imenso de absoluta desregulação do mercado imobiliário (...) antes disso havia um código de postura $1974(\ldots)$

A legislação é muito recente, por isso que você vê coisas além dos processos de corrupção que acontecem hoje, contemporaneamente, você vê, por exemplo, na verticalização muito exemplos distantes da legislação, porque ela é muito recente, você vai ver prédios relativamente altos aqui no Reduto, que embora seja o entorno do Centro Histórico os prédios são do início dos anos 90 , são anteriores aos dos anos 80, são anteriores ao tombamento do Centro Histórico como conjunto (PONTE, 2016).

Em 2015, o tombamento em instância federal foi ratificado, e ampliou-se o número de edificações de interesse cultural para 3500 bens materiais. Também no ano de 2015 "o Pavilhão do Brasil na Expo Milão, (...) na Itália sob o tema 'Alimentando o mundo com soluções', contou com a culinária paraense como estrela da festa" (CARDOSO, 2016, p.826). Devido ao sucesso do evento, e como seu desdobramento, o Governo do Pará e a Prefeitura Municipal de Belém promoveram os “'Dialógicos Gastronômicos', com a presença de chefs de renome internacional e, no decorrer do evento, foi apresentado o projeto do Centro Global de Gastronomia e Biodiversidade da Amazônia" (CARDOSO, 2016, p. 826).

Ela [Belém], é a cidade gastronomia, ela tem chancela da UNESCO, nada passa pelo IPHAN, uma coisa é a coisa do patrimônio imaterial, a chancela do IPHAN, e outra coisa é essa chancela da UNESCO. E aí a grande questão que está se discutindo é a questão da gestão disso tudo, porque se quer a discussão questão da gastronomia, mas que ela seja ampliada, que haja a participação dos diversos setores ligados a restauração, tanto um grande restaurante como os pequenos, tanto os que estão fora do circuito, como o Ver-o-Peso. E aí esse ano em função dessa criação dessa Chancela, o Governo do Estado fez um projeto também gerenciado em Roberto Smeraldi com a participação da Joana, que ela é administradora do "Lá em Casa", para o polo de Gastronomia, só que sem nenhuma discussão com a sociedade sobre isso. E o mais grave é que decidiram implantar este polo 
[gastronômico] dentro da Casa das Onze Janelas, do lado do Forte do Castelo, que é um local onde funcionava antigamente um restaurante, um bar que já tinha tradição na cidade, embora não fosse local, que era o "boteco das onze", que era uma concessão lá de proprietários lá de Pernambuco, mas já tinha uma tradição, e nos altos funciona o Museu de Arte Contemporânea do Pará, então se criou o grande celeuma, principalmente para a classe artística porque vai se colocar lá esse projeto e vai se tirar o museu, ainda não se sabe pra onde, então são duas discussões, uma é a discussão sobre a concepção do projeto que discutir o polo [gastronômico] de gastronomia sem discutir amplamente com diversos setores da sociedade e o que é essa gastronomia, porque tem uma discussão sobre cultura alimentar, que posso te dar a indicação de pessoa que vem discutindo isso, a Tainá Marajoara que vem discutindo da cultura Marajoara, da cultura alimentar amazônica melhor dizendo, de identidade de produto, e outra coisa é a gastronomia mais gourmetizada, na verdade o projeto veio para atender os restaurantes e a gastronomia gourmetizada, e não dialogou com esses outros setores, com Ver-o-Peso, então essa é a discussão do polo [gastronômico], então todo mundo se reuniu, está tentando resistir, por conta de todo esse debate, isso chegou nacionalmente essa discussão, e chegou também com o Atala, que ia ser uma das principais figuras e ele saiu, evidentemente (TAVARES, 2016).

Logo foram veiculadas as informações de que esse Centro ou Polo Gastronômico seria implantado no complexo Feliz Lusitânia, na Casa das Onze Janelas, onde atualmente funciona o Museu de Arte Contemporânea, e de que ele seria gerenciado pelo famoso chef Alex Atala, do instituto ATÁ. Essa ação faria parte da inclusão de Belém na Rede de Cidades Criativas da UNESCO, com destaque para a gastronomia. A implantação do Polo Gastronômico teria o apoio do governo do estado do Pará, e o governador Simão Jatene já havia assinado um decreto de desocupação do museu, segundo informa o jornal G1 ${ }^{138}$.

${ }^{138}$ Ver: Chef Alex Atala desiste de participar de Polo Gastronômicoem Belém, 2016 


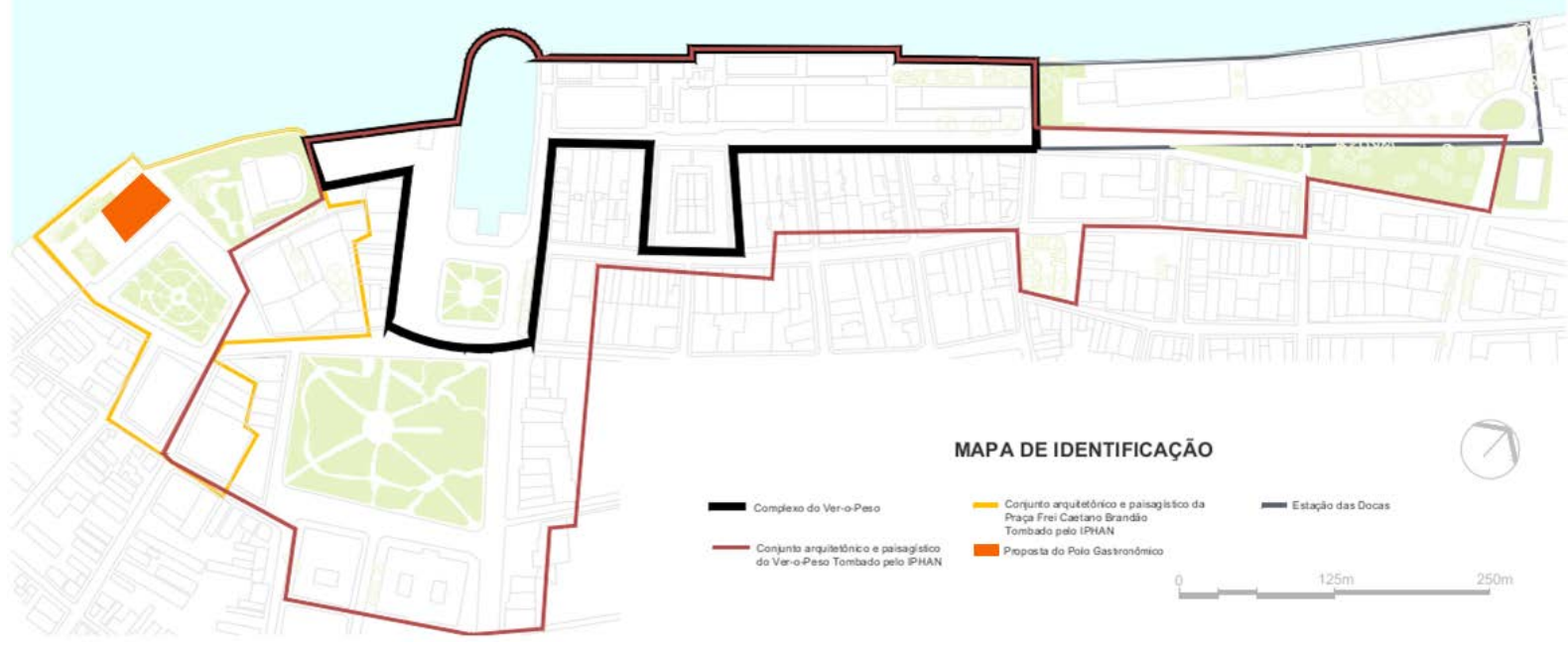

Mapa29 - identificação da proposta para o novo instituto gastronômico, na área adjacente, Belém. Fonte: autoria própria.

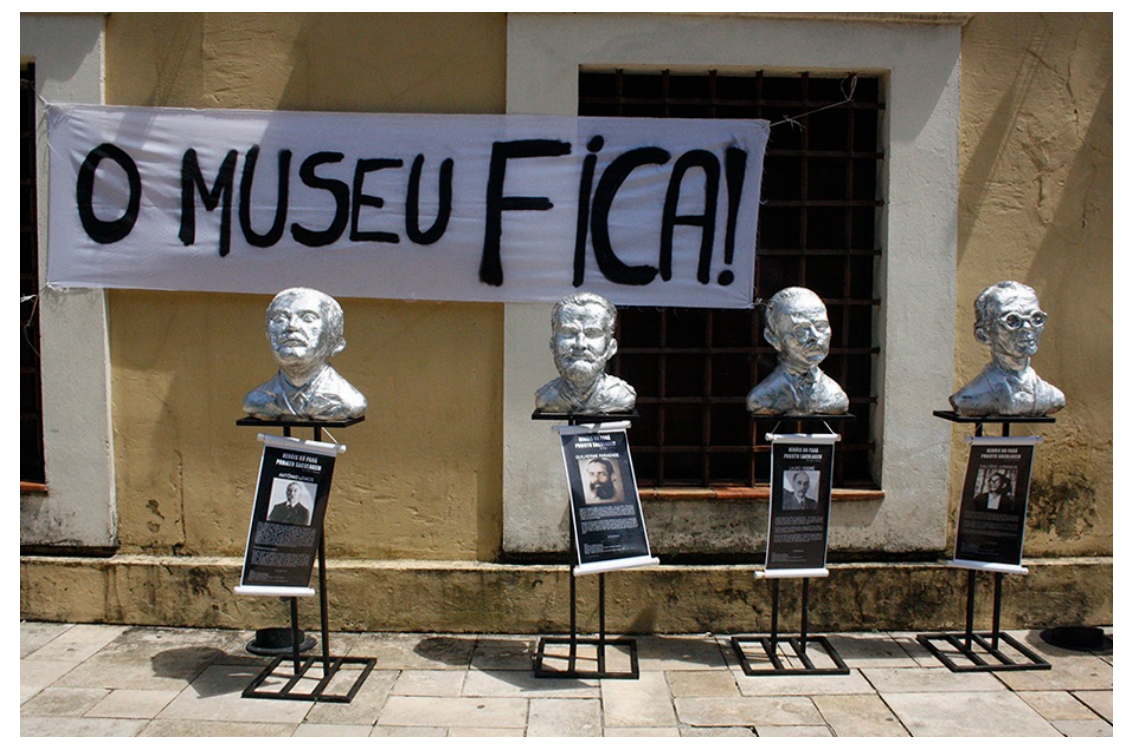

Imagem 58 - Ocupação do projeto circular na Casa das Onze Janelas, julho de 2016, Belém. Fonte: autoria própria.

No entanto, após as críticas em relação ao fechamento do espaço do museu, o chef Alex Atala informou que não mais participaria do projeto do Polo Gastronômico de Belém, e criticou a "inflexibilidade do governo" e a "ausência de real diálogo" entre as partes interessadas na permanência do funcionamento do museu e no novo instituto.

Atualmente, em relação à questão da orla continental de Belém, algumas diretrizes propostas serão revistas, tais como o já citado Plano de Reestruturação da Orla de Belém, 
que foi elaborado pela SEURB, e que se adequará a uma metodologia do Ministério do Meio Ambiente em um programa intitulado "Projeto Orla", do Governo Federal.

Essa revisão enaltece a importância do rio como um dos principais símbolos da região amazônica, para a contemplação e lazer, e como meio de transporte e sustento econômico, e cuja "visualização do rio e o acesso à orla, pela população, tornaram-se limitados e muitas vezes totalmente impedidos" devido à ocupação da área "por atividades privadas, em detrimento da geração de espaços com destinação pública" (SEGEB, 2016). 


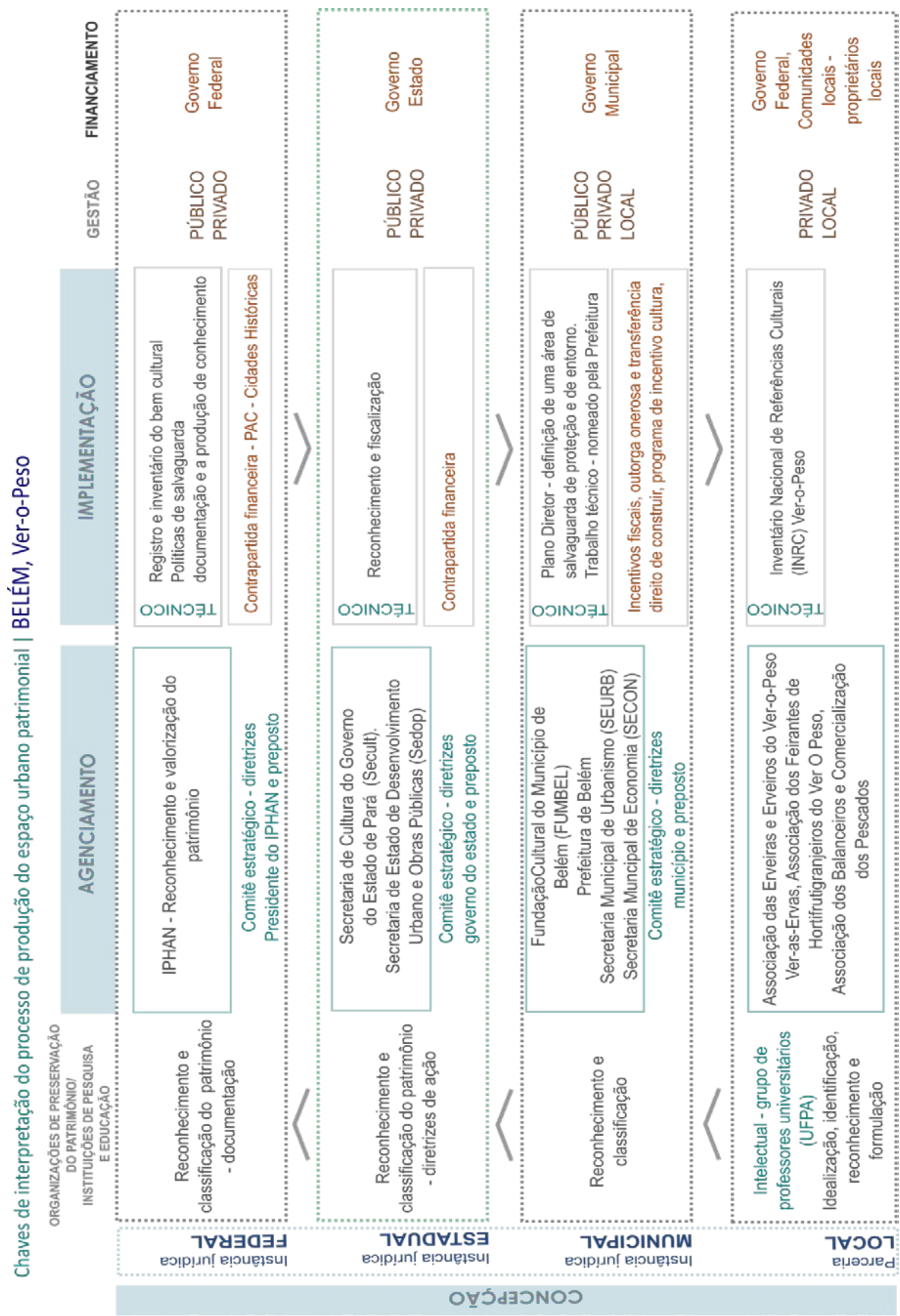

Imagem 59-Esquema explicativo das chaves de interpretação do processo de classificação a patrimônio cultural. Fonte: autoria própria. 


\section{Chaves de interpretação do processo.}

Em relação a sua administração e seu contexto econômico, e mediante as políticas de gestão cultural desse bem, verifica-se a existência de áreas de gestão compartilhada, com um financiamento misto, público e privado, e áreas de gestão pública, com instâncias governamentais públicas distintas entre si. São reconhecidas, nos projetos Ver-o-Rio e Praça do Pescador, inseridos no Complexo Ver-o-Peso, tentativas de auxiliar na economia local por meio de uma gestão também local desses espaços, seguindo os preceitos da Carta Internacional sobre o turismo cultural do ICOMOS.

Assim, sua gestão busca incentivar cooperativas de trabalhadores e de pequenos empreendedores locais, de maneira distinta do projeto da Estação das Docas, cuja gestão é compartilhada e em que se verifica um favorecimento de investimentos de grupos de empreendedores privados considerados mais aptos a requalificar e a oferecer atividades voltadas aos interesses de um público de maior potencial solvável, e, portanto, seleto (VAINER, 2000).

Outra importante questão diz respeito às políticas públicas culturais empreendidas na área. É necessário pensar articuladamente as políticas de planejamento urbano e de preservação, em que os instrumentos propostos pelo Estatuto da Cidade poderiam auxiliar na redução de conflitos existentes ao compatibilizar os interesses de diversos segmentos atuantes ou que tenham interesse em uma área tombada ou protegida, promovendo o uso desta área para todos os segmentos da população.

A população tem que ser protagonista ao se propor o que realmente se quer preservar, e nós, pessoas que estudam que problematizam isso, também temos que estar, que desenvolver um papel de protagonistas nesta discussão, não só porque nos esquecem, não querem nos ouvir, mas também porque ficamos muito nos nossos artigos, nas nossas pesquisas, e esquece de propor políticas mais de extensão que tenha mais a ver com a própria gestão propriamente dita (TAVARES, 2016).

Em relação à paisagem cultural do $\mathrm{CHB}$ e entorno, inexistem políticas públicas habitacionais de inclusão da população de modo diferente de outros centros históricos, como já assinalamos ao citarmos o caso de Salvador. Desse modo, é desconsiderado no 
processo o contexto social além da área de tombamento e que garante dinamismo, atividade, transformação, vida e, principalmente, identidade a esse bem cultural.

Alguns grupos de artistas têm se mobilizado criticamente quanto à atuação controversa da SECULT e do governo do estado do Pará em relação a alguns bens culturais da área central, como é o caso da desocupação do Museu da Casa das Onze Janelas, sinalizada pelo governo do estado. E, segundo Juliano Ximenes, esses grupos de artistas correspondem a iniciativas recentes, de organização horizontalizada, sem coordenação, que realizam suas atividades culturais em vários pontos da cidade e ao mesmo tempo.

Falando em termos culturais, mas tem esse projeto de fazer um centro culturalizado nesse padrão contemporâneo, da gastronomia, do consumo visual da paisagem, da visitação dos centros culturais, e acho que não foge tanto em termos de conteúdo e do programa desse padrão que é mais ou menos consagrado da revitalização dos centros históricos, eu não vejo grandes inovações no caso de Belém, em termos do formato que institucionalmente vem sendo discutido. E mesmo nessas iniciativas como o projeto circular acho que são ainda muito convergentes do ponto de vista programático, tendo o centro histórico como algo que pode ser relativamente formatado como produto, não é você criticar dizendo que não deve ter atividade econômica a partir desse conteúdo cultural do centro histórico senão irá matar, não é um tipo de purista, é você ver isso como algo contemporâneo e as possibilidades disso (PONTE, 2016).

No entanto, ainda segundo Ximenes (2016), embora esses grupos tenham um questionamento crítico e se apresentem como movimentos de resistência ao processo de patrimonialização da área central, o fator da "cultura" ainda é visto como um "parque da economia da cultura", com a ausência de uma "multiplicidade de atividades". Sua abordagem explora os aspectos visuais de uma paisagem cultural, não incorpora aspectos de inclusão social da população. Sua atuação se limita a alguns aspectos específicos unicamente da abordagem cultural.

Outra questão que este trabalho verifica é o do empreendedorismo urbano (HARVEY, 2005 , p. 230) e o do interesse por uma "inovação cultural local" por meio do processo de patrimonialização de Ver-o-Peso em Belém. Nessas ações, as políticas urbanas são planificadas estrategicamente de maneira competitiva internacionalmente, e conduzidas por interesse de grupos particulares e políticos locais, combinando poderes estatais de diferentes instâncias, instituições de pesquisa e de educação, organizados por instituições de 
preservação do patrimônio, formando coalizões com o setor privado, com diversos atores da sociedade civil e do poder público.

Então, é muito fácil fazer uma requalificação assim, o Estado não tem dinheiro, mas mesmo assim ele banca e depois ele entrega para a gestão da parceria público privado. Então, quem irá gerenciar esses espaços? Então você vê a sorveteria Cairu, não é uma grande empresa, mas é uma empresa consolidada no mercado local, as grandes cadeias de restaurantes, de bares e de serviços, e de turismo, que vão passar a ocupar, então, é uma política voltada para a geração de trabalho e renda em uma perspectiva bastante elitista (TRINDADE JÚNIOR, 2016b). 


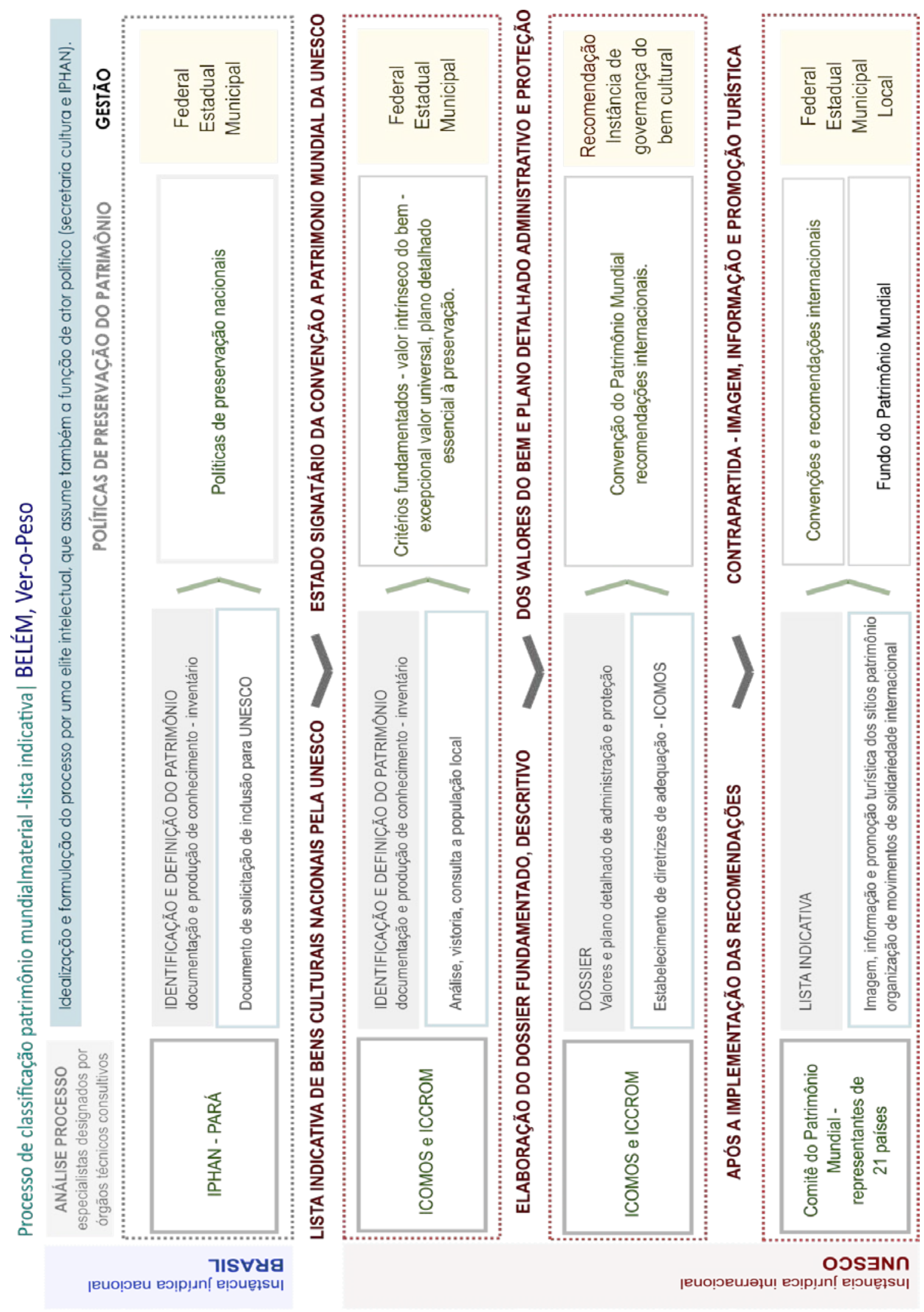

Imagem 60 - Esquema explicativo das chaves de interpretação do processo de classificação a patrimônio mundial. Fonte: autoria própria. 
Considerações sobre o processo de patrimonialização de Belém.

A complexidade do contexto cultural brasileiro torna-se frágil quando exposta aos projetos de cooperação técnica da agência multilateral internacional UNESCO, diante da descentralização do papel de atuação do Estado em relação às suas políticas urbanas e de preservação do patrimônio. Embora esses projetos sejam realizados como cooperações culturais internacionais, eles são empreendidos por meio de uma operacionalização própria dessa organização, que segundo Fernando Silva (2012, p. 29) oferece uma assistência internacional e beneficia à comunidade internacional.

Sua atuação sustenta-se em bases jurídicas de respeito à legislação nacional dos países e regiões, e sua cooperação apresenta, como forma de atuação, parcerias com o governo, com a sociedade civil e com a iniciativa privada de cada país, estendendo-se também à formulação de políticas públicas culturais nesses países, políticas estas que estão em sintonia com as resoluções e definições dos Estados Membros da UNESCO. Expõe-se, desse modo, uma possibilidade de reconfiguração das competências públicas e institucionais do Estado de cada país. Há uma interação supranacional e local e a sobreposição de políticas hegemônicas dos países presentes nos Fóruns da UNESCO (PEIXOTO, 2010), também evidenciadas pelo próprio modo de operacionalização da candidatura a patrimônio mundial.

Vista sob essa perspectiva, a atuação da UNESCO em relação ao local parece-nos contraditória, pois esse organismo se apresenta sobre a base do respeito e da valorização dos patrimônios singulares e excepcionais mundiais dos lugares, mas sua forma de atuação nos propõe:

- uma reconfiguração do contexto cultural local do bem - ao fomentar a construção de uma candidatura patrimonial que enaltece elementos únicos em detrimento de outros, o que assinalamos como "o mote" de cada processo que analisamos;

- uma adequação entre as políticas de preservação internacionais e as nacionais expondo um posicionamento político internacional acerca das cidades detentoras do bem cultural, e em que as organizações e grupos (representados pelo Poder Público municipal) por meio dos quais os processos classificatórios foram também conduzidos - embora seja considerada pela UNESCO como parceria, reconhecemos a 
existência de grupos que "conduzem" os processos - nos permitem questionar quais seriam os interesses envolvidos na produção desses processos - interesses de uma minoria política no poder por meio de coalizações com o setor privado;

- um distanciamento entre ações de preservação do patrimônio, mas que efetivamente são ações de produção de imagens das cidades expostas a uma audiência global, e que podem ou não ter relação com um "produto a ser vendido/consumido" (HARVEY, 1992) - segundo o "mote" do processo, o bem cultural pode ou não ser identificado pela população como um elemento de referência e identidade cultural da cidade - em uma dimensão cultural e como uma forma de produção do solo urbano das cidades contemporâneas, segundo uma lógica neoliberal de produção das cidades.

Nesse sistema, retomamos a questão que consideramos frágil no contexto das localidades, e no caso específico, do Brasil. Aqui, as políticas de preservação, em vez de resguardar e proteger o patrimônio cultural local, acabam contribuindo para que as participações em parcerias não aconteçam de forma equilibrada entre todos os atores envolvidos no processo. Isso faz prevalecer o interesse de alguns grupos em relação ao coletivo da população, prevalência essa reforçada pela falta de convite a uma consulta democrática no desenvolvimento dos processos. Tal questão torna-se bastante grave, pois não há políticas de incentivo à criação ou à manutenção de novas moradias de classes mais baixas e pobres da população.

Mesmo diante do panorama apresentado, permanece presente o processo cultural que consolidou uma paisagem composta pela cultura popular amazônica, pela relação do rio e da floresta, dos vendedores e das mercadorias, no preparo e na venda dos produtos, no vai e vem das canoas, pelos seus imaginários e narrativas, pela religiosidade do Círio de Nazaré.

O "velho Ver-o-Peso", símbolo de Belém, apresenta as várias faces de uma região que teima em resistir à pressão homogeneizadora da memória nacional. Muito mais do que um complexo arquitetônico, é um lugar cultural e humanístico, onde são perpetuadas as relações de troca que caracterizam as cidades portuárias e evidenciam a tendência comercial que a cidade apresenta desde sua origem (Boletim da SEURB, 1988, p.1 apud CAMPELO, 2002, p. 152). 
Concluímos, embasados nos registros, na bibliografia criada a partir destes registros, no conhecimento do campo, por meio das entrevistas, no levantamento histórico e etnográfico da área - elaborado e consultado pela autora - que essa dimensão simbólica da feira, das festas, dos rituais, das tradições e da produção artesanal do lugar resiste e é identificada pelos moradores, pelos trabalhadores, pelos consumidores ou pelos visitantes, para os quais o conjunto patrimonial é representado na expressão formal, material e espacial do Complexo Ver-o-Peso. 


\section{O contraponto internacional, Coimbra (Portugal)}

\section{Saudades de Coimbra}

José Afonso

Ó Coimbra do Mondego

E dos amores que eu lá tive

Quem te não viu anda cego

Quem te não amar não vive

Quem te não viu anda cego

Quem te não amar não vive

Do choupal até à lapa

Foi Coimbra os meus amores

A sombra da minha capa

Deu no chão, abriu em flores

\section{ALTA E SOFIA}


A escolha de um contraponto internacional em Portugal, o bem cultural da Universidade de Coimbra, fez-se conjuntamente à definição do tema específico desta pesquisa ${ }^{139}$, Coimbra representa um bem cultural de características singulares, exposto em uma escala global por meio de um processo de classificação em andamento de uma agência de preservação internacional.

Pensar o conceito de patrimônio mundial, a sua universalidade e a valorização do solo urbano ligada a um discurso patrimonial e à indústria do turismo - foi isso que embasou nossas reflexões neste trabalho. São estas as reflexões fundamentais que propomos aqui: compreender a articulação ou a desarticulação dos processos de patrimonialização ao planejamento urbano e compreender a inserção da cidade numa concorrência entre as cidades por angariar recursos financeiros para requalificar seus espaços urbanos segundo uma lógica capitalista em que o solo urbano e a cultura são vistos como mercadorias.

\footnotetext{
${ }^{139}$ No início do curso de doutorado, por meio do contato com o professor Paulo Peixoto, grandes enriquecimentos foram trazidos à pesquisa, como a conexão da investigação à questão específica do patrimônio em Portugal (dentro do contexto Europeu). Posteriormente, esse contato possibilitou o estreitamento de relações científicas e institucionais com o estágio de pesquisa realizado durante os meses de junho e julho de 2012 no núcleo de pesquisa "Cidades, Culturas e Arquitectura" (CCARq) do Centro de Estudos Sociais (CES) da Faculdade de Economia da Universidade de Coimbra (UC), em Coimbra (Portugal).

Cita-se aqui o conhecimento adquirido através do curso e-learning "Patrimônios de Influências Portuguesa", oferecido pelo Instituto Camões em parceria com o CES da UC, e de sua bibliografia sobre o tema do patrimônio, principalmente da bibliografia específica fornecida no módulo sob a orientação do professor Paulo Peixoto, intitulado "Patrimônio: doutrinas, conceitos e processos de patrimonialização", em que o conceito do patrimônio mundial instituído pela UNESCO foi discutido como o fundamento de uma comunidade humana e como recurso das indústrias culturais urbanas. $\mathrm{E}$, também no curso, foi discutido o tema da retirada de um bem cultural da lista patrimônio mundial, como a solicitação feita por parte do Poder Público da cidade de Dresden (Alemanha), após uma consulta à sua população que decidiu priorizar um planejamento urbano da cidade e intervenções urbanas criticadas pela UNESCO, em detrimento da manutenção da preservação do conjunto da paisagem cultural classificada (UNESCO, 2016).
} 


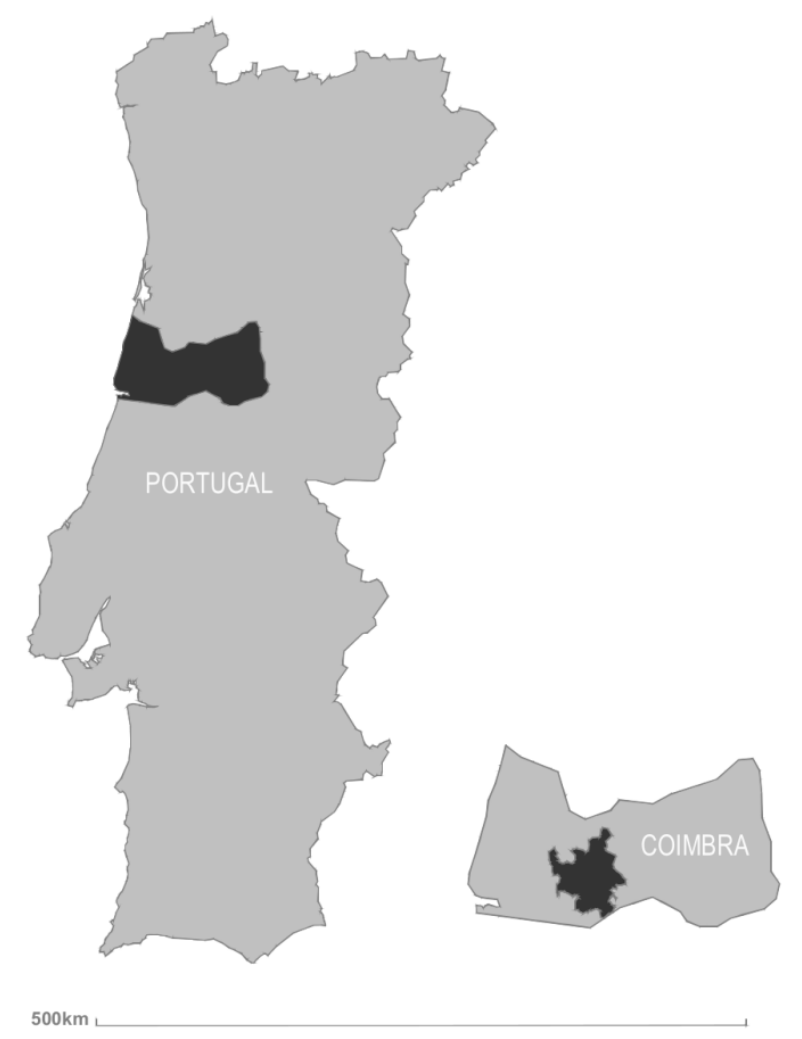

Mapa 30 - Portugal e região de Coimbra, com a localização da cidade de Coimbra. Fonte: autoria própria.

Em nossa pesquisa, buscamos entender alguns aspectos desse processo, com a concepção de cidade internacional por meio de intervenções no patrimônio cultural num processo de "patrimonialização mundial", assim como a operacionalização do processo pela UNESCO. Nossa análise foi fundamentada na documentação de intenção de candidatura, já mencionada anteriormente, e apresentada, no ano de 2004, pela Universidade de Coimbra à UNESCO.

Durante a visita a campo a Coimbra, em 2012, realizamos cinco entrevistas em profundidade. Algumas delas foram transcritas parcialmente e outras foram resumidas em relação aos seus aspectos mais importantes e relevantes para a pesquisa. Essas entrevistas buscaram compreender a estruturação do processo de candidatura, a composição de sua equipe interdisciplinar, sua organização e seu funcionamento, para então interpretar as relações do processo da patrimonialização com a produção da cidade de Coimbra nos dias atuais.

Assim, realizamos entrevistas em profundidade com alguns representantes de grupos participantes desse processo classificatório: Prof. José Raimundo Mendes da Silva, vinculado 
à UC; Eng. Sidónio Simões, vinculado ao Gabinete Técnico do Centro Histórico, subordinado à Câmara Municipal de Coimbra; e os arquitetos Nuno Ribeiro Lopes e Cátia Marques, consultores técnicos do processo.

A primeira entrevista, parcialmente transcrita neste trabalho ${ }^{140}$, foi realizada com o professor José António Raimundo Mendes da Silva ${ }^{141}$, curador da candidatura e um dos idealizadores do processo de candidatura da Universidade de Coimbra como patrimônio mundial. A entrevista nos fez compreender melhor o processo de patrimonialização de um bem cultural desde a sua idealização, seu desenvolvimento, os participantes, o envolvimento do Estado e da sociedade civil, e as particularidades da operacionalização de um processo de patrimônio mundial pela UNESCO.

A segunda entrevista, transcrita neste trabalho ${ }^{142}$, foi realizada com o engenheiro Sidónio Simões ${ }^{143}$, diretor do centro histórico. Essa entrevista nos permitiu compreender melhor a atuação e a organização interna de um escritório técnico ligado ao Centro Histórico da cidade, tanto na composição de um dossiê de candidatura pela UNESCO, como na articulação entre diferentes órgãos do Poder Público.

A terceira entrevista, parcialmente transcrita neste trabalho ${ }^{144}$, foi realizada com os arquitetos Nuno Ribeiro Lopes ${ }^{145}$, coordenador da Candidatura, e Cátia Marques ${ }^{146}$, também participante do processo de candidatura. Essa entrevista surgiu da necessidade de compreender o papel de atuação desse arquiteto com experiência em outros processos de

${ }^{140}$ Ver: apêndice A - entrevista 1.

${ }^{141}$ José António José António Raimundo Mendes da Silva, engenheiro civil, professor do Departamento de Engenheira Civil da UC, e curador da candidatura da Universidade de Coimbra a patrimônio mundial. Entrevista agendada pela autora da tese e concedida no Departamento de Engenharia Civil, Polo II, Universidade de Coimbra, com a presença da pesquisadora Carolina Margarido Moreira a convite da autora, Coimbra, 2012.

142 Ver: apêndice A - entrevista 2.

${ }^{143}$ Sidónio Simões, engenheiro civil e diretor do centro histórico de Coimbra. Entrevista agendada pela autora da tese e concedida no Gabinete para o Centro Histórico da Câmara Municipal de Coimbra, Arco de Almedina, ${ }^{\circ} 14$, com a presença da pesquisadora Carolina Margarido Moreira a convite da autora, Coimbra, 2012.

${ }^{144}$ Ver: apêndice A - entrevista 3.

${ }^{145}$ Nuno Ribeiro Lopes, arquiteto e urbanista, coordenador da Candidatura da Universidade de Coimbra como patrimônio mundial pela UNESCO. Entrevista agendada pela autora da tese e concedida na Praça do Papa, com a presença da pesquisadora Carolina Margarido Moreira a convite da autora, próximo ao CES da Universidade de Coimbra, Coimbra, 2012.

${ }^{146}$ Cátia Marques, arquiteta e urbanista da equipe técnica da Candidatura da Universidade de Coimbra como patrimônio mundial pela UNESCO. Entrevista agendada pela autora da tese e concedida na Praça do Papa, próximo ao CES da Universidade de Coimbra, com a presença da pesquisadora Carolina Margarido Moreira a convite da autora, Coimbra, 2012. 
patrimonialização em Portugal, e a relação de suas experiências anteriores com o caso de Coimbra.

Entrevistas de caráter informal, que foram resumidas, foram feitas com alguns comerciantes da região ${ }^{147}$ da Baixa e da Rua da Sofia, e com estudantes da república "Bota Abaixo" ${ }^{148}$.

Ao longo deste capítulo, retomaremos as abordagens teóricas e conceituais de nosso trabalho e citaremos alguns trechos das entrevistas realizadas. Algumas dessas reflexões e trechos de entrevistas também serão retomados ao final do trabalho, em nossas considerações finais.

A candidatura da Universidade de Coimbra foi vista por esta pesquisa como uma possibilidade de compreensão de um processo de patrimonialização em andamento e que almejava a classificação a patrimônio mundial. Essa candidatura foi apresentada segundo um conceito de conjunto patrimonial urbano e com uma dinâmica própria de transformação ao longo do tempo, devido ao próprio caráter de seu bem cultural, uma Universidade.

\footnotetext{
${ }^{147}$ Entrevistas concedidas à autora da tese, na Rua da Sofia e na região da Baixa, Coimbra, 2012.
}

${ }^{148}$ Entrevista concedida à autora da tese, na república Bota Abaixo, Zona da Alta, Coimbra, 2012. 


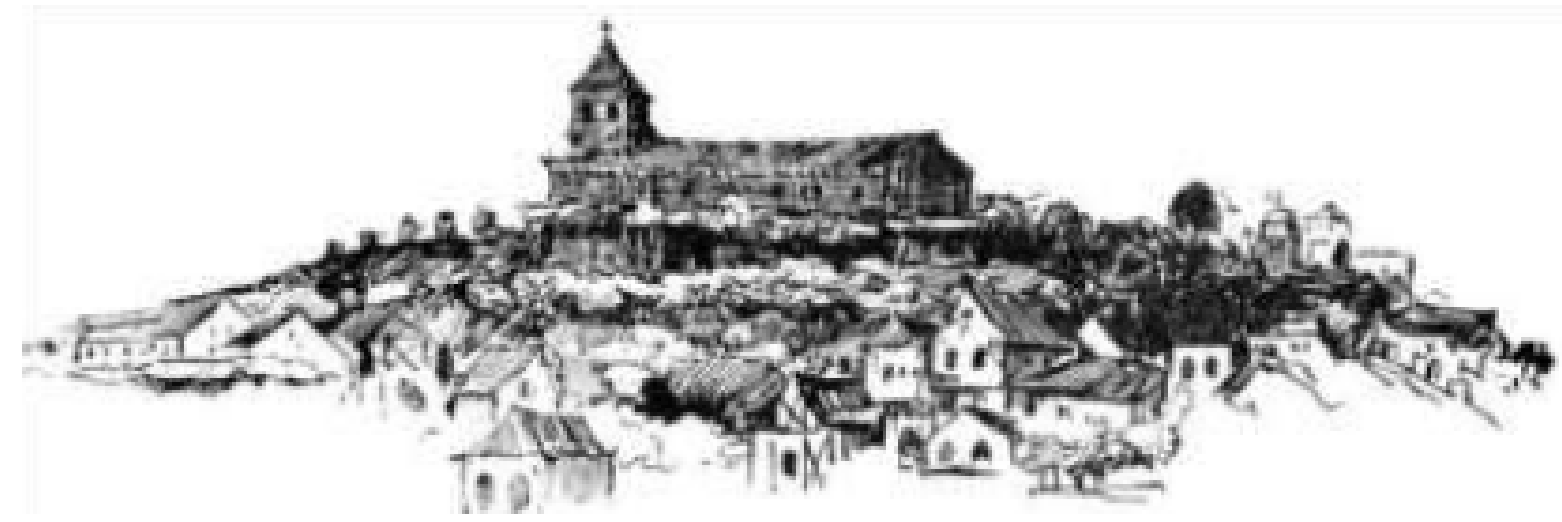

Imagem 61- Imagem do período de fundação da Universidade de Coimbra, século XIV. Fonte: UC, 2016.

A Universidade de Coimbra é reconhecida historicamente por ter sido a única Universidade portuguesa até 1911, com exceção do período em que coexistiu com a Universidade de Évora (Portugal), entre os anos de 1559 e 1759. Desse modo, seu impacto em relação ao universo do conhecimento foi universal, principalmente por corresponder ao império português e espanhol, de escala mundial, com a expansão marítima e seus "achamentos".

Em seu longo período de funcionamento, a Universidade passou por diferentes modos de uso e ocupação, sempre centrados no conhecimento, na pesquisa e no ambiente de ensino. Com a reforma universitária de D. João III, a Instituição Universitária foi transferida definitivamente para Coimbra. Essa alteração levou ao desenvolvimento de um polo escolar maior, devido ao grande afluxo estudantil e com a concessão de grande número de graus acadêmicos.

Desde o início de seu funcionamento, a Universidade ocupou diferentes estruturas físicas. Inicialmente concentrada em colégios jesuíticos, localizados na Rua da Sofia, em Coimbra, o núcleo físico mais antigo da Universidade foi o Paço das Escolas. Anteriormente a seu uso universitário, era a antiga morada régia do país, o antigo Paço Real de Coimbra. Por conta disso, as instalações físicas trazem grande valor arquitetônico e decorativo ao conjunto do bem cultural, como a Biblioteca Joanina, que foi fundada como livraria de estudo e era reservada ao serviço da comunidade universitária.

Além de alterações na ocupação de estruturas físicas, a Universidade também passou por reformas universitárias nos campos ideológicos, pedagógicos e materiais. Tais alterações 216 
estão registradas por meio de seu patrimônio construído, desde a reforma joanina e a reforma pombalina até as ações promovidas pelo Estado Novo e a democratização do ensino e consequente expansão de suas instalações físicas (UC, 2016).

Nesse ambiente universitário, uma série de manifestações culturais são consideradas referências e se mantêm vivas até os dias de hoje. "Práticas simbólicas associadas às festividades cíclicas académicas, cujas origens se perdem nos seus sete séculos de história. Desde a cultura académica institucionalizada (doutoramentos Honoris Causa, Abertura Solene das Aulas etc.) às manifestações mais espontâneas como o cortejo da Latada" (UC, 2016).

Também é papel cultural da Universidade o patrimônio imaterial por meio da oferta de seu conhecimento - uma forma de patrimônio de origem portuguesa no mundo -, tal como um meio de expansão cultural e científica, e que alteraram o panorama científico mundial. Esse papel de divulgação do conhecimento foi reforçado por meio da imprensa da Universidade e de seu campo de atuação em Portugal. Essa Instituição também é detentora de importantes acervos universitários nas áreas das ciências e de patrimônio biológico de propriedade da Universidade, reunidos desde o século XVIII, em que salientam as coleções de História Natural e de Física e o Jardim Botânico.

Vale ressaltar a participação da Universidade na formação do Estado português: ela foi "responsável pela formação dos principais quadros dirigentes nacionais, foi uma das principais e uma das mais enérgicas instituições a participar na formação ideológica do Estado Português ao longo dos séculos" (UC, 2016). Na instituição, sempre houve manifestações políticas, acompanhando "as convulsões políticas e sociais do país, oscilando entre as manifestações de apoio aos regimes vigentes ou em sua oposição" (UC, 2016). 


\section{Expansão urbana de Coimbra e o bem cultural da Universidade}

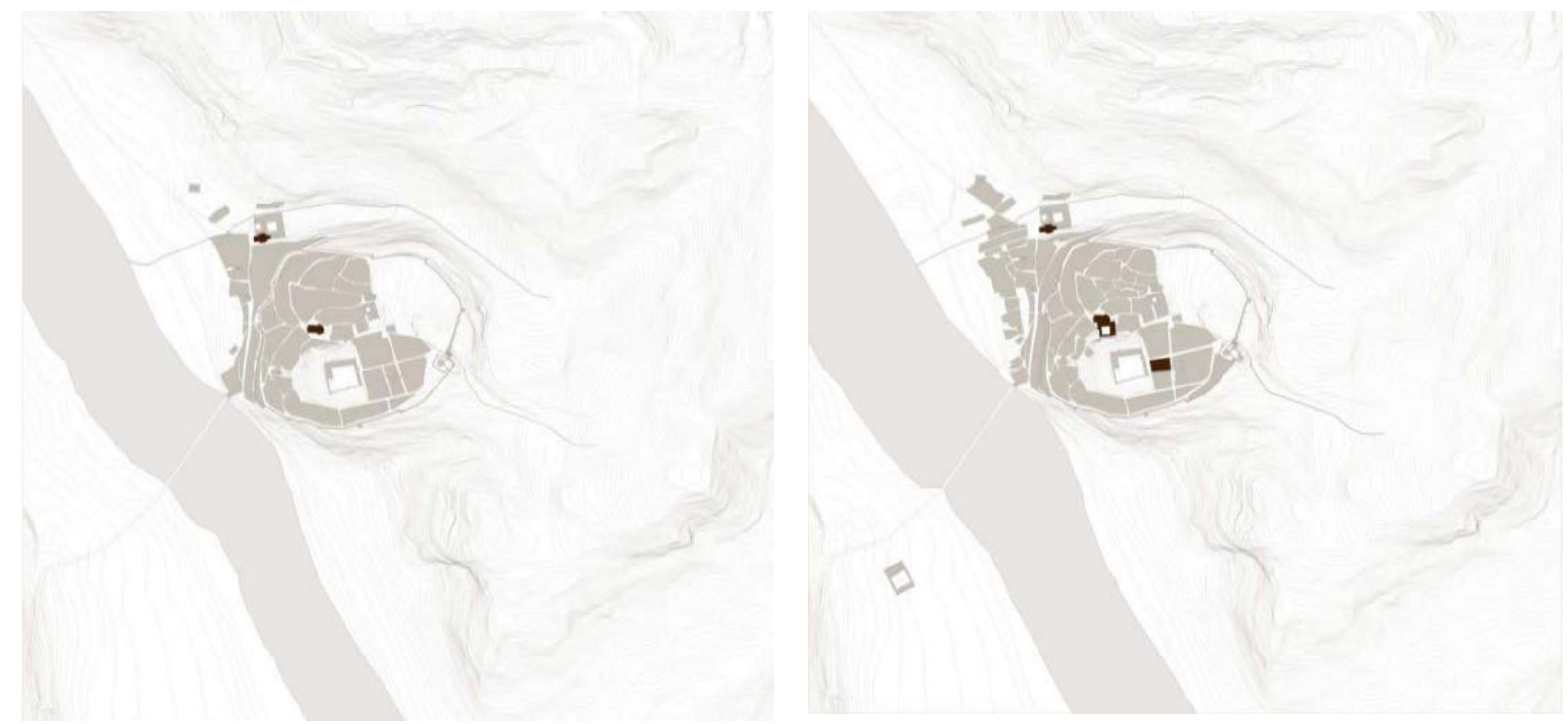

Mapa 31 - à esquerda referente ao processo de Reconquista, em que a cidade de Coimbra foi a primeira capital do Reino. Nesse período, florescem importantes centros culturais na cidade, organizados em torno das escolas instituídas no mosteiro de Santa Cruz de Coimbra e na Catedral (séc. XII e XIII). Mapa 32 - à direita com a fundação da primeira Universidade Portuguesa por D. Dinis, em 1290. Fonte: UC, 2016.

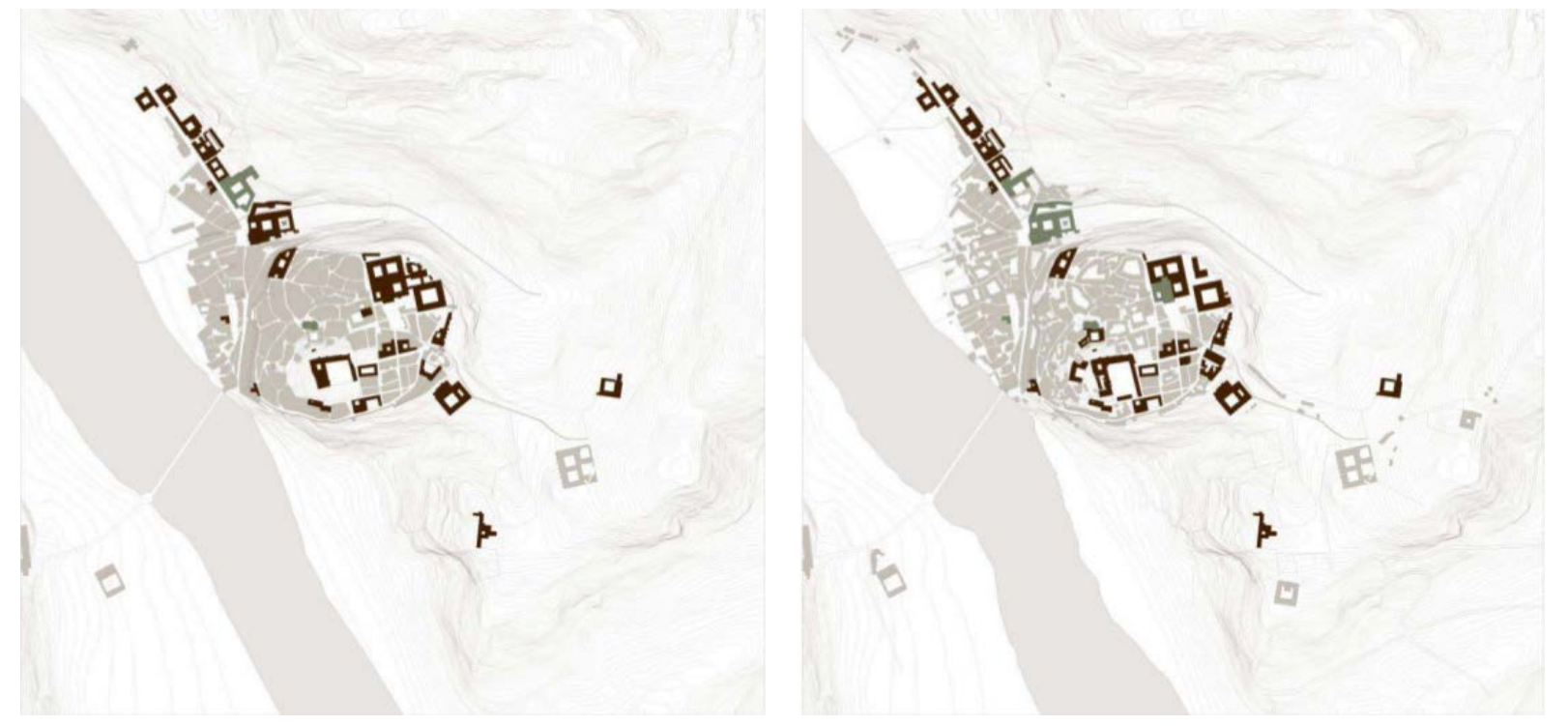

Mapa 33 -à esquerda relativa ao estabelecimento definitivo da Universidade em Coimbra, em 1537. Para tanto, foi construída a Rua da Sofia, junto ao Mosteiro de Santa Cruz; posteriormente, transformou-se o Paço Real na principal Instituição desta Universidade. Esse período foi marcado pela consolidação do restante da estrutura urbana, pois à volta desses equipamentos da Universidade consolidou-se um vasto conjunto de instituições colegiais, ligadas em sua maioria às Ordens Religiosas. Mapa 34 -à direita referente ao período do reinado de D. João V (1707-1750), marcado pela construção de alguns elementos históricos culturais muito importantes para a Universidade, tais como a biblioteca Joanina e a Torre da Universidade, com seu relógio e sinos. Fonte: UC, 2016. 

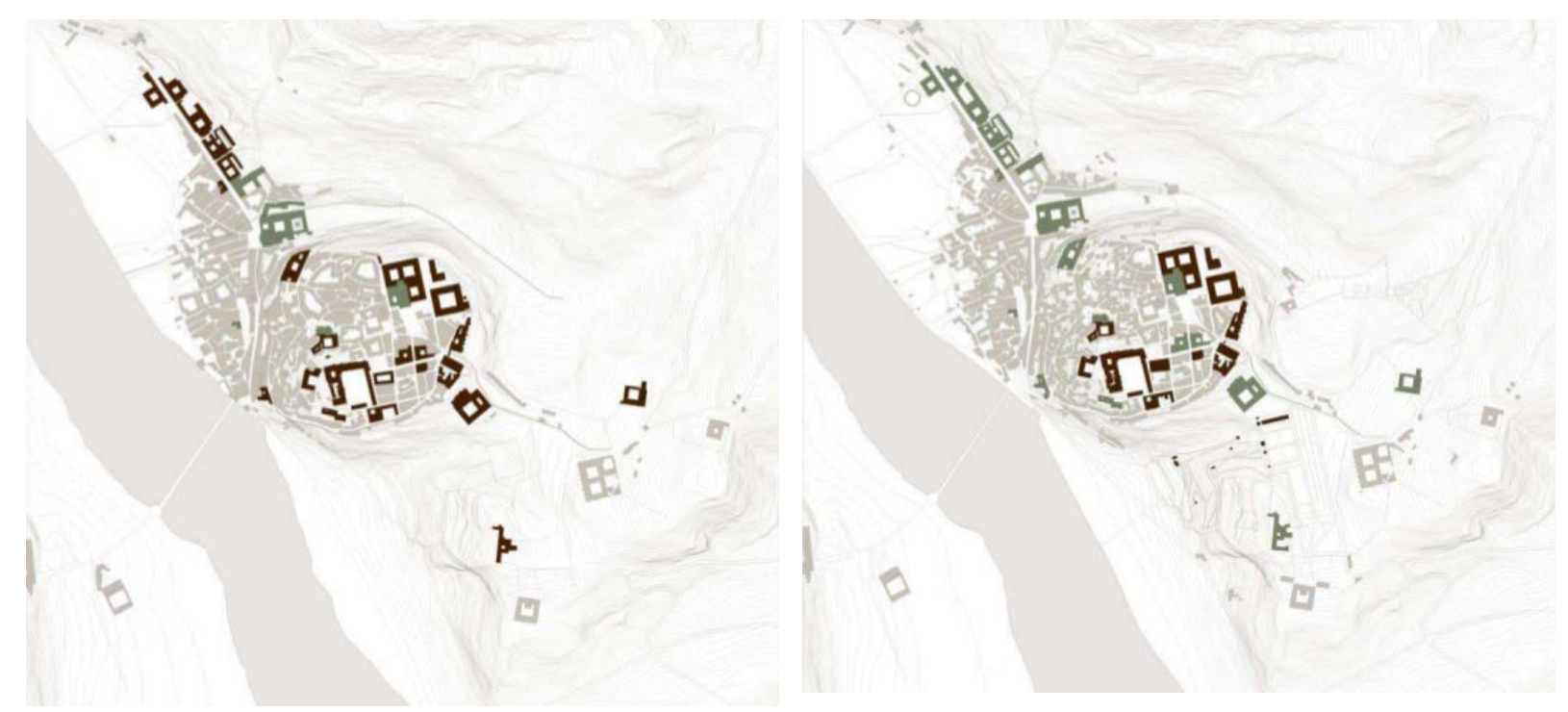

Mapa 35 - à esquerda, do período da reforma pombalina, no século XVIII, de oposição aos programas e práticas pedagógicas da Companhia de Jesus. Em 1772, a Universidade reformula seu Estatuto e seu ensino, e criam-se duas novas Faculdades, levando a uma ampliação física dos estabelecimentos e equipamentos científicos. São desse período o Laboratorio Chimico, e a renovação de parte do Colégio de Jesus, o Jardim Botânico. Mapa 36 - à direita do período de extinção das ordens religiosas e do início do processo de laicização da Universidade, em 1834, com o encerramento dos colégios, a alienação do patrimônio e a extinção da jurisdição universitária privativa, o foro acadêmico e a autonomia financeira, e com o consequente surgimento dos movimentos de associativismo e de sociabilização estudantil. Fonte: UC, 2016.
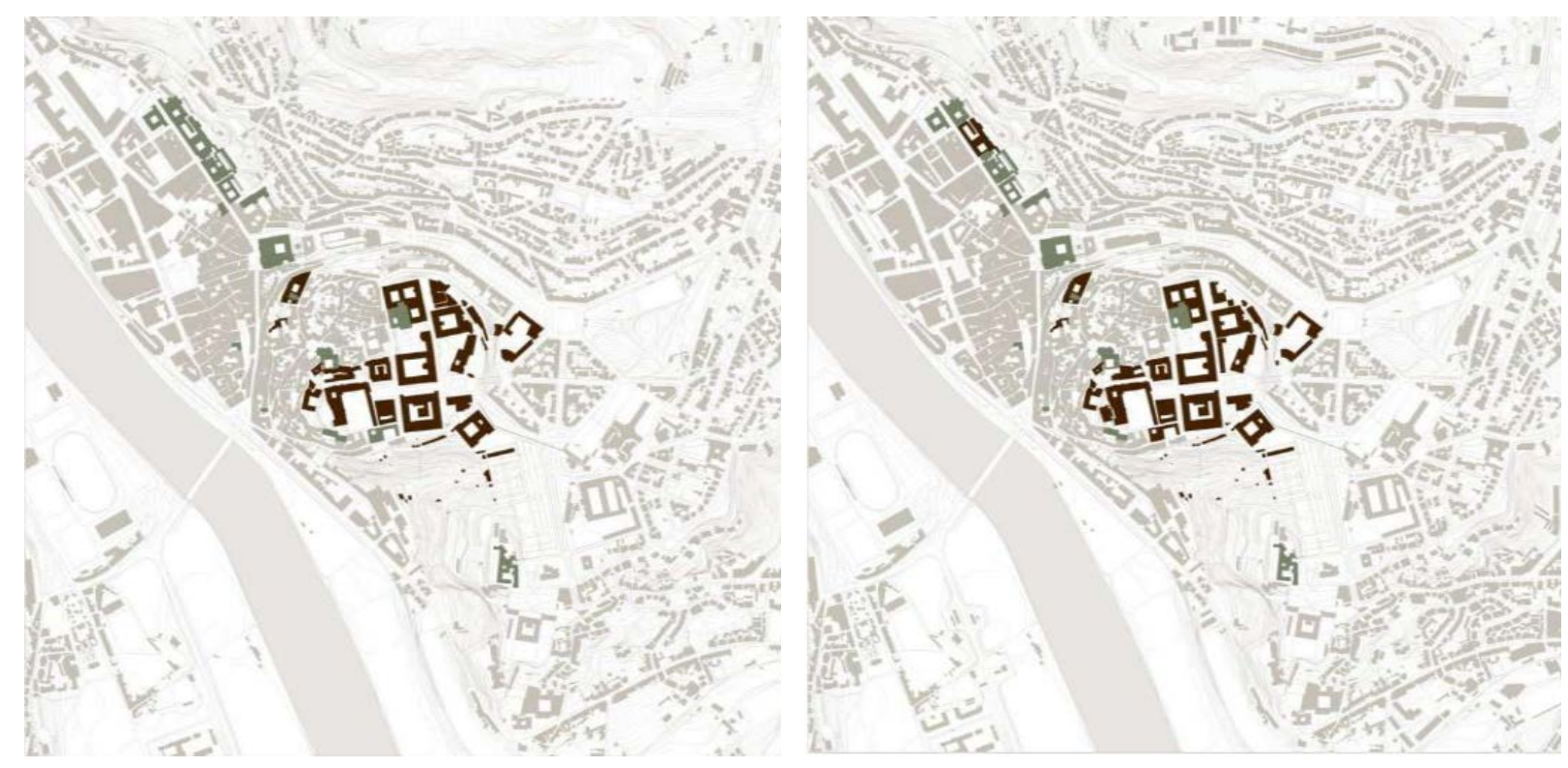

Mapa 37 - à esquerda durante o Estado Novo, no século XX, em que a Universidade promoveu uma grande alteração urbanística no conjunto, período em que sua área foi designada como Alta Universitária. No final desse período, caracterizado pela massificação do ensino universitário, iniciouse um processo de desconcentração da Alta com a transferência do Hospital Universitário. Mapa 38 à direita referente ao período atual, séc. XXI, com a reforçada ação de descentralização das instalações universitárias, nos Polos2 e 3, período marcado pela refuncionalização dos espaços e edifícios da Alta um regresso à Rua da Sofia. XIV. Fonte: UC, 2016. 
O processo de patrimonialização da Universidade de Coimbra.

No decorrer de nossa pesquisa e por meio da primeira entrevista, descobrimos que o processo de "patrimonialização mundial" da Universidade de Coimbra era uma proposta revista da candidatura anterior, que teve origem em 2002, com a nomeação do Centro Histórico de Coimbra, que correspondia ao conjunto urbano antigo da matriz consolidada da cidade.

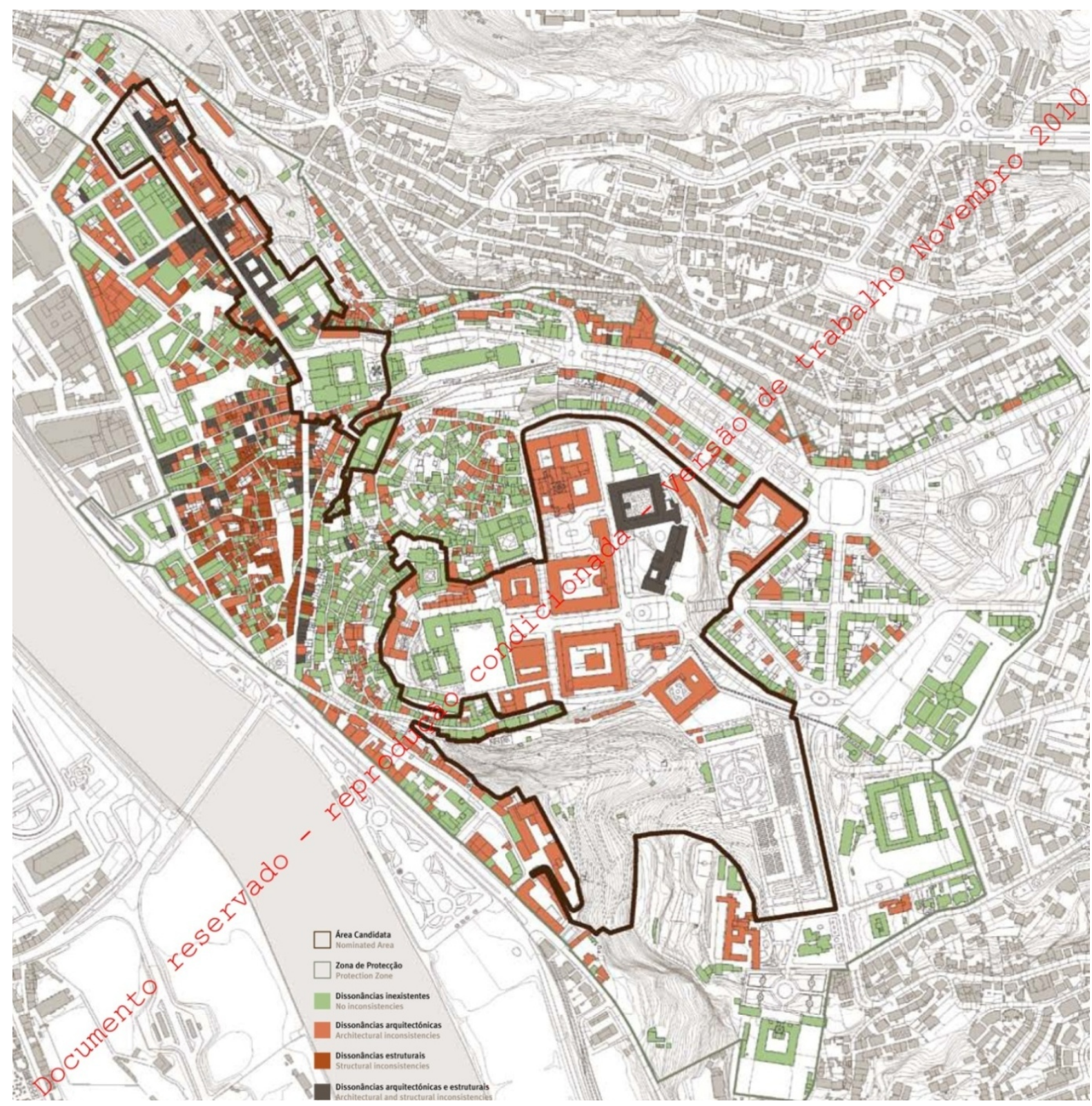

Mapa 39-Delimitação da área de proteção candidata, e leituras arquitetônicas e estruturais do conjunto, Coimbra. Fonte: Dossiê de candidatura a patrimônio mundial de Coimbra, Universidade Alta e Sofia, livro 7 - Zona de Proteção. 
A ideia teve este formato e esta continuidade porque houve várias tentativas ou várias ideias de poderem fazer uma candidatura Centro Histórico ou do Centro Urbano Antigo. É cada vez mais polêmico falar dos Centros Históricos, porque a história é um processo, a questão dos Centros Históricos, é polêmica neste momento, fala-se mais de núcleos urbanos antigos de estruturas consolidadas. Essa ideia de fazer uma candidatura do centro urbano, do centro histórico a patrimônio mundial é uma coisa já antiga, e que teve uma ou duas tentativas claramente informais, portanto não concretizada depois em um dossiê formal perante a UNESCO (SILVA, 2012).

Segundo uma revisão realizada pelo ICOMOS, membro consultor da UNESCO, dentro do contexto europeu de excessivos bens culturais considerados centros históricos e já classificados como patrimônio mundial, a Universidade de Coimbra foi escolhida como novo bem cultural, propondo uma candidatura de bem extraordinário e singular, tal como exigem os critérios seletivos da UNESCO.

Este mote, digamos assim, da cultura, do conhecimento, que agrega também a universidade, que agrega também hospitais, saúde, etc.. fazem de Coimbra aquilo que é tipicamente uma cidade universitária, em sentido apta, a "Universidade do Conhecimento" digamos assim. A indústria que aqui se tinha, a indústria mais pesada que se tinha até umas décadas obviamente foi desaparecendo neste momento. Infelizmente, no sítio empresarial o que está a começar a acontecer é um centro empresarial com muito mais incorporação tecnológica e conhecimento científico. Estou dizendo isto porque numa cidade que tem esta marca e que tem uma universidade que tem setecentos anos em termos eventualmente de escala, e que tem setecentos anos que é uma marca em termos de nome, e em termos de conhecimento porque foi a universidade do Império, então culturas com alguma ligação a Portugal e a língua portuguesa acabaram por ter os seus quadros formados ao longo dos séculos na Universidade de Coimbra, digamos em Instituições que a ela acabavam por estar ligadas. Quer na Universidade, em Colégios religiosos, mas a Universidade de fato era a única (SILVA, 2012).

Com a alteração de seu objeto patrimonial, as propostas apresentadas nessa candidatura aproximavam-se de sua proposição anterior, com o centro histórico como bem cultural. Essas aproximações são perceptíveis na fundamentação da nova proposta, muito semelhante em relação à região da cidade e aos atores envolvidos nesse processo, segundo nos relata o Prof. Raimundo M. Silva. A nova candidatura distingue-se da anterior, 
principalmente, no que se refere à Universidade, novo bem cultural a ser classificado, preservado e conservado.

A mediação da UNESCO auxiliou à articulação entre as instâncias dos órgãos de proteção patrimonial em Portugal para a organização do processo de candidatura. Além disso, criou-se um escritório técnico da região central de Coimbra, a fim de auxiliar em questões locais.

Assim, percebemos que o contexto da economia industrial na cidade de Coimbra, que foi "desaparecendo" ao longo do tempo, cedeu lugar ao interesse na promoção de seu território por meio do patrimônio histórico cultural e científico com a nomeação de bem cultural da Universidade. Essa experiência da cidade revela uma tentativa de concorrência interurbana e inter-regional de Coimbra com outras cidades, até mesmo em relação a outros centros históricos classificados como patrimônios mundiais, o que fez com que as suas iniciativas locais de planejamento urbano e/ou de classificação patrimonial alcançassem uma escala global, mesmo com toda a contradição que as escalas - local e global - podem apresentar.

O novo processo de candidatura foi conduzido segundo o "mote" da Universidade de Coimbra como seu bem cultural. As áreas de proteção e de entorno, ou área tampão segundo a terminologia portuguesa -, eram muito semelhantes às áreas que seriam protegidas na candidatura anterior. As áreas comuns de ambos os processos resultam de uma fundamentação muito semelhante em relação à região da cidade e aos atores envolvidos no desenvolvimento de suas propostas.

Essa busca, entre um processo e outro, por um novo bem cultural, que correspondesse ao interesse por patrimonializar mundialmente uma determinada área da cidade, pode ser vista como um extensivo uso do conceito de patrimônio nos mais diversos discursos. Segundo Paulo Peixoto, a busca incessante de bens culturais pelas cidades cria uma espécie de "histeria patrimonial" (PEIXOTO, 2010, p. 1). Afinal, o processo de nomeação e preservação do "mesmo" espaço urbano da região central de Coimbra seria levado adiante, considerando-se o sucesso de qualquer uma das duas candidaturas mundiais idealizadas para a cidade.

A Câmara também estava exercendo pressão para melhorias dos edifícios, assim, criou-se o projeto da rua da Sofia, com um plano de pedestre, da criação de um calçadão, e, em relação ao seu uso, a componente 
habitacional e de comércio. Portanto, o Plano Diretor deve buscar favorecer o comércio local, pois $30 \%$ do consumo é feito por residentes da própria área (SIMÕES, 2012).

Essa apropriação do discurso patrimonial com interesse em promover determinadas áreas específicas da cidade em um processo de classificação global, revela, atualmente, o fato de que as "políticas de preservação do patrimônio deixaram de ter como local privilegiado os Estados nacionais" (PEIXOTO, 2010, p. 1). Essas políticas de preservação "mundiais" são constituídas segundo uma "normatização das políticas preservacionistas por fóruns da UNESCO (...) [em um novo contexto que] criou uma nova dinâmica e remeteu o patrimônio para a esfera da circulação global de valores, signos e mercadorias" (PEIXOTO, 2010, p. 1).

Nessa nova dinâmica, o bem cultural da Universidade de Coimbra comparece como o elemento singular necessário para o "sucesso" da candidatura pretendida na região do Centro Histórico de Coimbra. 


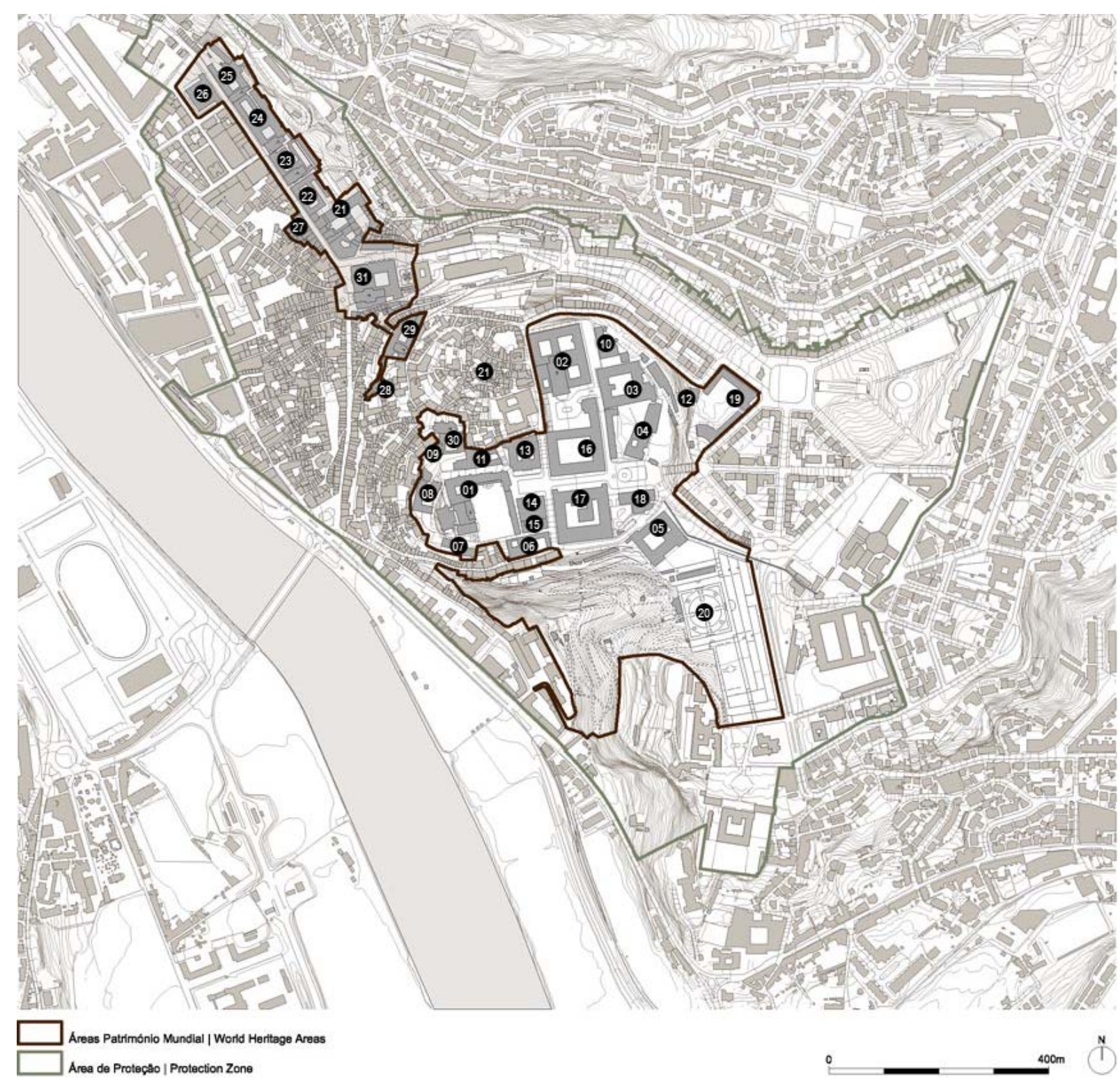

Mapa 40 - Localização dos edifícios principais da zona de proteção do Patrimônio Mundial, Coimbra, 2014. Fonte: UNIVERSIDADE DE COIMBRA - ALTA E SOFIA. 
Legenda do mapa 40 - Edifícios principais da zona de proteção do Patrimônio Mundial:

\begin{tabular}{|c|c|c|c|c|c|}
\hline 1 & Paço das Escolas & 12 & Casa das Caldeiras & 23 & Colégio do Carmo \\
\hline 2 & Colégio de Jesus & 13 & Faculdade de Letras & 24 & Colégio da Graça \\
\hline 3 & Real Colégio das Artes & 14 & Biblioteca Geral & 25 & Colégio de São Pedro \\
\hline 4 & Colégio de São Jerônimo & 15 & Arquivo da Universidade & 26 & Colégio de São Tomás \\
\hline 5 & Colégio de São Bento & 16 & Faculdade de Medicina & 27 & Colégio de São Boaventura \\
\hline 6 & Colégio da Trindade & 17 & $\begin{array}{l}\text { Departamentos de Física e } \\
\text { Química }\end{array}$ & 28 & Palácio de Sub-Ripas \\
\hline 7 & Colégio de Pedreira & 18 & $\begin{array}{l}\text { Departamento de } \\
\text { Matemática }\end{array}$ & 29 & $\begin{array}{l}\text { Colégio de Santo } \\
\text { Agostinho }\end{array}$ \\
\hline 8 & Colégio de Santa Rita & 19 & $\begin{array}{l}\text { Associação Acadêmica de } \\
\text { Coimbra }\end{array}$ & 30 & Sé Velha de Coimbra \\
\hline 9 & $\begin{array}{l}\text { Imprensa da } \\
\text { Universidade }\end{array}$ & 20 & Jardim Botânico & 31 & Mosteiro de Santa Cruz \\
\hline 10 & Laboratório Químico & 21 & $\begin{array}{l}\text { Antigo Colégio das Artes - } \\
\text { Inquisição }\end{array}$ & & \\
\hline & Casa dos Melos & 22 & Colégio do Espírito Santo & & \\
\hline
\end{tabular}

$\mathrm{Na}$ configuração dos atores envolvidos no primeiro e no segundo processos de patrimonialização, percebemos um padrão muito semelhante de conduta na governança urbana, ao combinar os poderes estatais. Esses poderes estavam representados pela Câmara Municipal de Coimbra, por diversas organizações da sociedade civil-como a Associação RUAS e a própria Universidade de Coimbra - e por interesses privados empresariais e individuais. Formaram-se coalizões para fomentar ou administrar o desenvolvimento urbano e regional da cidade, que estão de acordo com nossas de chaves de interpretação desse processo, fundamentadas, sobretudo, no autor Harvey (2005, p. 230).

Portanto, este dossiê que é entregue em janeiro de 2012, este processo pressupõe, como sabem, que já há uma entidade que faz a gestão do bem cultural. A UNESCO não quer vir falar com a Câmara, com a Universidade, com os proprietários, a UNESCO quer ter uma figura formal que responda perante o bem, que fale com as entidades, que disponha de acordo, que responda perante a UNESCO, e que no fundo seja a salvaguarda do bem. Durante este processo, foi nossa colaboração obviamente, criou-se uma Associação chamada RUAS [Associação para Recriar a Universidade Alta e Sofia]. É que nós sempre chamamos a Associação de Univers(sc)idade, com "s" e "c", Univers(sc)idade, sentido de Universidade e de Cidade, para nós ficou RUAS porque em termos materiais não se poderia registrar com este conceito, que era um preceito da Universidade. Portanto, embora se diga que eu sou curador da candidatura, eu não sou de facto, porque a partir do momento que nasce essa Associação, essa Associação que é a entidade gestora do bem (SILVA, 2012). 
Neste trecho de entrevista citado, percebemos que o dossiê de candidatura, documento necessário segundo exigências operacionais da própria UNESCO, foi configurado por sete volumes divididos em: Candidatura a Patrimônio Mundial; Plano de Gestão; Textos Gerais; Influências; Execução; Planos Diretores; e Zona de Proteção.

Um dado importante que observamos diz respeito à necessidade de se criar uma entidade social para a condução e respectiva assimilação do processo de patrimonialização mundial. No caso da experiência de Coimbra, essa entidade corresponde à Associação RUAS.

Portanto, em 2004, Coimbra passou a integrar a lista indicativa de patrimônio mundial, ou seja, não tem deadlines, não tem prazos, tem a explicação de uma ideia, tem uma primeira explicação do que é o âmbito, qual é a abrangência do território. Tem uma primeira proposta de quais são os critérios, que da UNESCO são diversos, mas temos que responder dois ou quatro, e, portanto, tem uma primeira proposta por parte do ICOMOS dos critérios a que deveria responder (SILVA, 2012).

O dossiê de candidatura de Coimbra é intitulado "Candidatura a Patrimônio Mundial", e nele são apresentadas duas áreas da cidade como constituintes do bem cultural. Esse dossiê descreve seus bens culturais materiais, caracterizados principalmente pelos edifícios e espaços da Universidade de Coimbra ao longo da história.

A primeira área do bem cultural remonta ao início da Universidade, a Rua da Sofia, localizada no centro antigo da cidade, em um trecho cujo desenho urbano é composto por uma expressiva avenida alargada, a qual rompe com o traçado medieval da estrutura urbana desta região. Nessa rua, foram construídos colégios, que depois tornaram-se uma Universidade, mas que, atualmente, não compõem sua parte edificada em funcionamento e não são em sua totalidade propriedade da Universidade de Coimbra.

A segunda área do bem cultural é constituída pela zona da Alta, que, nos dias de hoje, é a parte edificada em funcionamento da Universidade de Coimbra ${ }^{149}$, onde se localizam os edifícios datados de 1940 e posteriores a 1965, de valor arquitetônico do período do Estado Novo ${ }^{150}$, momento do regime político autoritário e corporativista de Estado.

\footnotetext{
${ }^{149}$ Citamos a existência do Polo II da UC, com edifícios construídos mais recentemente.

${ }^{150}$ Regime político de 1933 a 1974, designado "Estado Novo". 


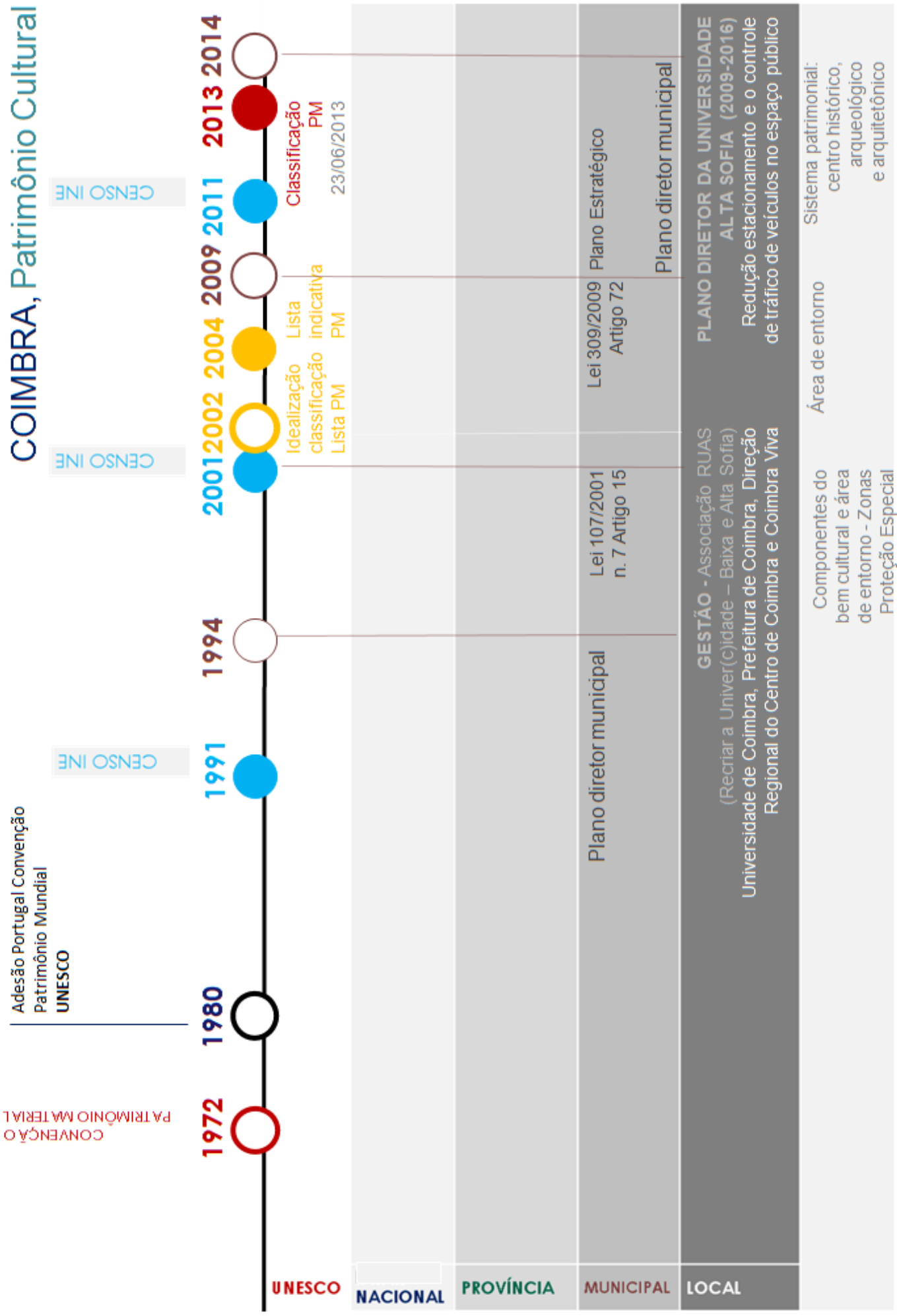

Imagem 62 - Esquema explicativo relativo à classificação do patrimônio material da cidade de Coimbra. Fonte: Autoria própria sobre UC, 2014; UNESCO, 2016.

A fim de organizar os dados obtidos na pesquisa e nos auxiliar na compreensão da experiência da cidade de Coimbra, elaboramos um esquema (imagem 62) explicativo do 
processo de classificação da UC. Nesse diagrama, estão algumas das principais ações empreendidas na constituição de organizações gestoras e alguns dos principais planos gestores e urbanos da candidatura - ligados à operacionalização da UNESCO. Estão, também, os períodos de início e de finalização, com o êxito da candidatura, dentro do contexto da inclusão de Portugal entre os países membros da UNESCO, em 1980.

No dossiê de candidatura, constam seus patrimônios imateriais, como partes de sua história e de sua tradição. Dentre eles, salientamos o fado, como expressão musical, e as repúblicas de estudantes, mencionadas no documento como parte da expressão do ambiente universitário. As repúblicas estudantis, todavia, não recebem nenhuma abordagem particular, por meio de uma expressão formal ou espacial que preveja sua preservação e proporcione a sua continuidade.

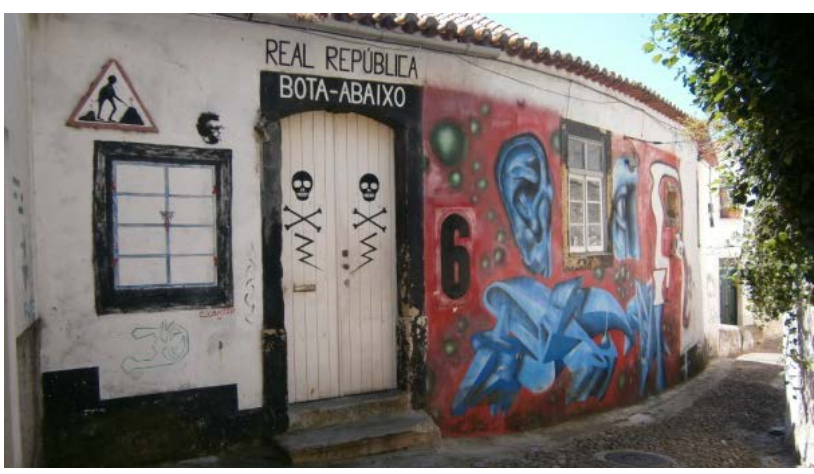

Imagem 63-República de estudantes "Bota-abaixo", Zona da Alta, Coimbra, 2012. Fonte: autoria própria.

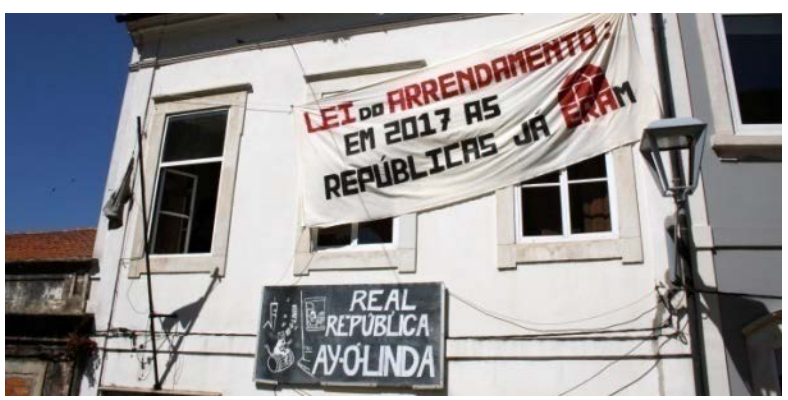

Imagem 64-República de estudantes com uma faixa em protesto contra o final da Lei do Arrendamento, Zona da Alta, Coimbra, 2012. Fonte: autoria própria.

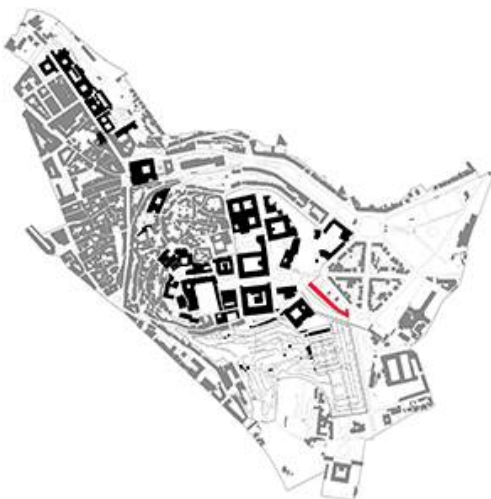

Mapa 41 - Mapa com a localização de uma rua de repúblicas, Zona da Alta, Coimbra, 2012. Fonte: autoria própria sobre mapa base da UC.

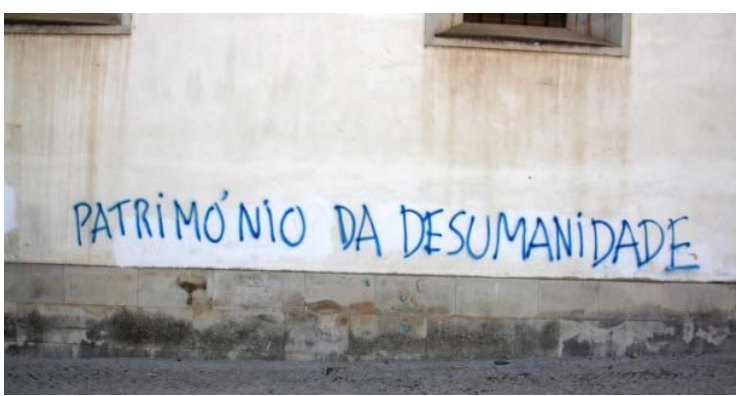

Imagem 65-Manifesto crítico contra a candidatura da Universidade de Coimbra a patrimônio mundial pela UNESCO, Zona da Alta, Coimbra, 2012. Fonte: autoria própria.

A circundar as áreas candidatas (...) é nesta área que se localizam as várias repúblicas universitárias, com origens seculares, ganhando somente no século XIX, provavelmente, em consequência do encerramento dos colégios, a configuração próxima da actual. Este é um dos aspectos mais 
característicos da vivência própria da comunidade estudantil, ao compartilharem não só um espaço, mas sobretudo, ideais de cultura, conhecimento científico e camaradagem, constituindo-se numa das tradições mais mediáticas da Universidade de Coimbra (Documento do dossiê de Candidatura da Universidade de Coimbra a Património da UNESCO, versão digital, Candidatura a Patrimônio Mundial, 2010, p. 27)

As repúblicas de estudantes são organizações de tradição em Coimbra e assim são registradas pelo processo de candidatura apresentado à UNESCO. A origem das repúblicas é coimbrã, e remete ao início do século XIV, quando D. Dinis promoveu a construção de casas na zona de Almedina, as quais seriam habitadas por estudantes do ensino superior, mediante pagamento de aluguel.

Atualmente, as repúblicas de estudantes recebem o suporte da lei do arrendamento, que estabelece que os proprietários dos imóveis não podem alterar o valor de suas rendas. Algumas repúblicas de estudantes têm se manifestado contra a possibilidade de alteração dessa lei, alteração prevista para este ano de 2017, o que impossibilitaria que os imóveis continuassem sendo utilizados como repúblicas.

Por meio de nossa entrevista com os estudantes da república "Bota Abaixo", tivemos conhecimento da existência de um abaixo-assinado contra a candidatura a patrimônio mundial. Segundo os estudantes moradores da república, o abaixo-assinado havia sido entregue à Câmara Municipal - documento ao qual não tivemos acesso. Assinado pelos moradores do entorno da Universidade, principalmente da zona da Alta, cuja população é constituída, em grande parte, por estudantes da Universidade e por idosos, o documento argumentava que, com o recebimento do título de patrimônio mundial e com a alteração da lei do arrendamento, as repúblicas de estudantes próximas à universidade não mais existiriam e o valor do aluguel tornaria inviável a permanência de sua população idosa residente atualmente na área.

De modo diferente de outros centros históricos, não verificamos a manutenção de um programa integrado que incorpore a questão da moradia de sua população já residente na área, ou mesmo a criação de um novo programa que incentive a moradia de uma população nova de baixa renda. Contrariamente, percebemos que, por meio desse processo de patrimonialização, alguns incentivos atuais à moradia serão extintos. 
Pelas entrevistas com o Prof. Raimundo Mendes e com os arquitetos Nuno Ribeiro Lopes e Cátia Marques, verificamos que há previsões futuras de incentivo a novas moradias em novas edificações, ou em edificações reabilitadas na área de proteção do bem cultural, mas não há políticas habitacionais que assegurem a manutenção dos moradores que já residam na região.

Segundo o Eng. Sidónio Simões, em sua entrevista, estabelecemos reflexões críticas a respeito da valorização desse patrimônio histórico e da rigidez das diretrizes da intervenção e da conduta na área impostas pela UNESCO, as quais buscam preservar e salvaguardar o bem cultural.

Vale destacar um trecho do regulamento municipal elaborado pela Comissão Mista (CMC, DRCC, SRU, Coimbra-Viva e GCU), "Regulamento de Edificação, Recuperação e Reconversão Urbanística da Área afeita à candidatura da Universidade de Coimbra a Património Mundial da UNESCO, incluindo a Zona de Proteção", que reforça a existência de diretrizes de intervenção e conduta na área. O projeto desse regulamento foi aprovado pela Câmara Municipal de Coimbra em 24 de outubro de 2011 e foi publicado no Diário da República, 2a série, $n^{\circ}$ 30, de 10 de fevereiro de 2012 (COIMBRA. Regulamento Municipal, 2012):

Com a inclusão da Universidade de Coimbra na Lista Indicativa da UNESCO dos bens suscetíveis de virem a ser integrados na Lista do Património Mundial, iniciou-se um processo em que a Universidade e a Cidade se obrigam a um esforço conjunto para reafirmar o papel de cada uma na cultura portuguesa e universal. A candidatura obrigará à intervenção sobre as áreas candidatas e zona de proteção, redefinindo a vocação dos edifícios e dos espaços, o grau das intervenções sobre o património e a envolvente. Obrigará, também, a pensar a Cidade e os seus habitantes, pensar o tempo e encontrar na história processos de evolução e transformação.

Múltiplos passos já foram ultimamente dados. Importa agora agregar as diferentes estratégias e propostas de ação, à sombra de conceitos, métodos, técnicas e práticas desenvolvidas ao longo dos últimos trinta e cinco anos pela UNESCO e pelas instituições e organizações científicas que a assessoram e, que, com sucesso, têm envolvido um número cada vez maior de entidades e pessoas em todo o mundo.

Este processo passa pela atitude de permanente requalificação do bem no sentido de corrigir, equilibrar e avançar na afirmação desta imensa área e do seu riquíssimo património como fator de desenvolvimento económico e social, com respeito pelas pessoas, pela sua cultura, pela organização social e pelas suas diferenças. Diferenças que se estendem a todos os níveis físicos (tais como topográficos, tipológicos e construtivos) e que, naturalmente, têm expressão no articulado deste Regulamento, o qual 
estabelece - para além dos tipos e princípios gerais das intervenções - os níveis diferenciados de proteção aplicados a cada zona, uso ou função.

Neste cenário de "diferentes estratégias e propostas de ação, à sombra de conceitos, métodos, técnicas e práticas desenvolvidas ao longo dos últimos trinta e cinco anos pela UNESCO", citamos a coibição das manifestações culturais nas Escadas Monumentais da Universidade de Coimbra, localizadas na Zona de Proteção do patrimônio mundial. Tal espaço é historicamente consolidado pelas diferentes manifestações políticas e sociais das quais já foi palco, e foi utilizado até mesmo como suporte de propaganda político-eleitoral. Mas, desde as campanhas legislativas de 2011, esse tipo de manifestação tem sido alvo de críticas em razão da classificação como Patrimônio Mundial, e essas práticas têm sido coibidas e consideradas crime.
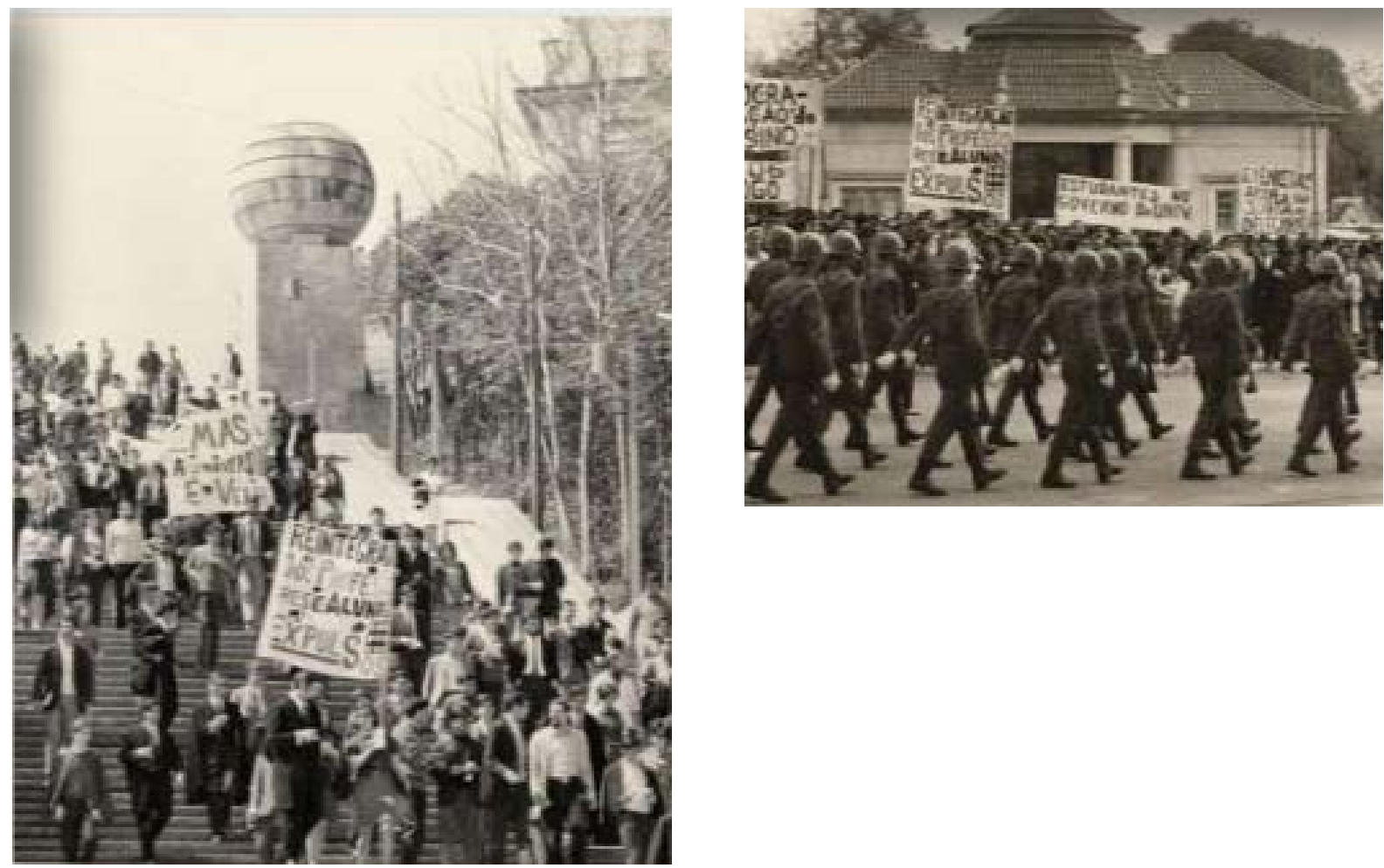

Imagem 66- À esquerda, registro fotográfico histórico de manifestação política nas Escadas Monumentais, Coimbra. Imagem 67 - À direita, registro fotográfico histórico de manifestação política na área protegida, Coimbra. Fonte: Documento de apresentação do bem cultural, UC, 2016 

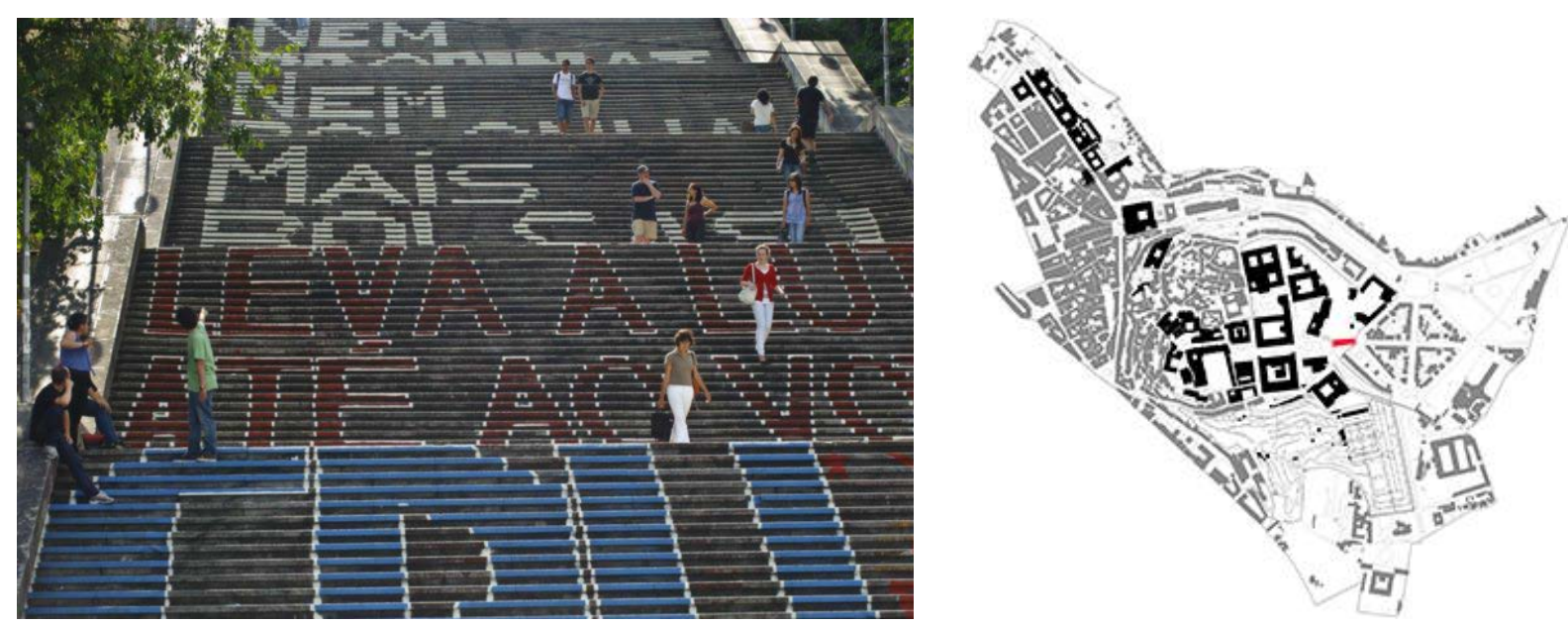

Imagem 68-À esquerda, Escadas Monumentais com manifestação política que foi coibida, Zona Especial de Proteção, Coimbra, 2014.Fonte: VIERA, 2014. Mapa 42 - À direita, mapa de localização das Escadas Monumentais. Fonte: Adaptado pela autora sobre base da UC, 2016.

Para compreender melhor o processo de classificação da UC, levantamos informações sobre alguns de seus projetos e intervenções na cidade de Coimbra e na Zona de Proteção de seu Patrimônio Mundial. Percebemos que, na região da ARU-Baixa e da ARUAlta, segundo o mapa 43 - a seguir-, as intervenções podem ser classificadas de modo geral como propostas de reabilitação e refuncionalização do patrimônio.

Na ARU-Alta, percebemos propostas de refuncionalização da maior parte dos seus edifícios, a partir de obras de restauro, de reabilitação e de renovação de seus espaços. De modo pontual, reconhecemos algumas intervenções de novas edificações, como é o caso do auditório da Faculdade de Direito, obra do arquiteto Fernando Távora (realizada entre os anos de 1995 e 2000), e que corresponde à primeira etapa desse processo de classificação mundial. 


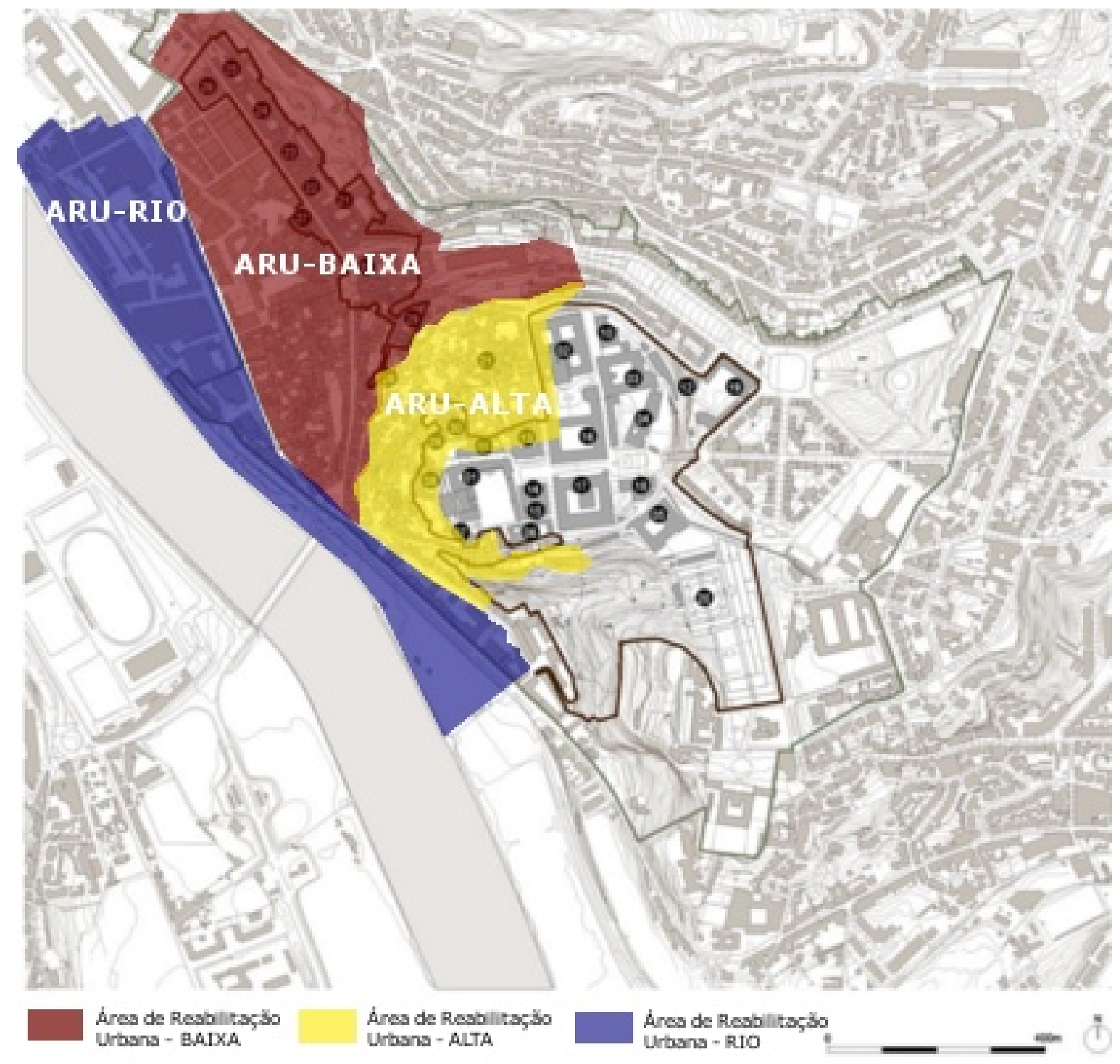

Mapa 43-Identificação das Áreas de Reabilitação Urbanas na Cidade de Coimbra. Fonte: Adaptado pela autora sobre base em Coimbra VIVA, SRU, 2014.

Observamos, na área de reabilitação urbana definida como ARU-Rio, que engloba tanto áreas protegidas quanto áreas fora do limite de proteção, a presença de construções novas que podem ou não estar atreladas ao patrimônio histórico, e que têm maior liberdade de composição e renovação da paisagem cultural do lugar. Tal fenômeno também foi verificado transpondo-se o Rio Mondego, uma região que está localizada fora das áreas definidas como de reabilitação urbana.

Percebemos, então, nessas ações e pelos usos propostos nessas intervenções, um interesse pela internacionalização da cidade de Coimbra, uma busca por um público novo, sejam turistas ou visitantes. Segundo Vainer (2000), essas ações no espaço urbano da cidade 
corroboram para a implantação de novos empreendimentos, na medida em que a tornam uma área mais atrativa para o investimento de um grupo seleto que busca um público seleto, com maior potencial solvável.

A RUAS, portanto, a tal da entidade gestora é que vai fiscalizar se isto está a correr bem, se o tal plano de gestão está a ser cumprido, ou minimamente cumprido, e vai fazer uma coisa que esperamos que seja emblemática, vai fazer aconselhamento, ou seja, esta "RUAS", o gabinete técnico que se vai constituir na RUAS, com pessoas da Câmara, da Gestão Regional da Cultura, da Universidade, etc.. vai apoiar não só as ações de licenciamento, pois a Câmara continuará a dar suas licenças, mas em vez de dá-las sem falar com ninguém, vai dá-las no âmbito desta comissão, uma espécie de comissão de discussão embora depois cada um continue com a sua prerrogativa.

(...)

Também foram pensadas algumas ações buscando organizar, sistematizar e planejar ações conjuntas. Através da apresentação de um plano de Gestão pela Universidade de Coimbra, localização das intervenções propostas através de um sistema geográfico, e foram criadas algumas facilidades considerando-se que um processo de licenciamento demorava em média de 12 a 13 anos. E, com isto, houve um aumento da procura pelo licenciamento.

O processo de licenciamento será feito na Associação para Recriar a Universidade Alta e Sofia (RUAS), com o apoio constante do novo gabinete que será criado, cujo uso ainda está sendo definido. Também será criado um manual que busca auxiliar no processo.

(...)

Com todas essas iniciativas já é notório o interesse da iniciativa privada, e, diante desse aumento, tem-se concentrado ações na busca de agilizar o processo na zona classificada, tornando-o mais rápido ou igual a uma área nova da cidade, pós 25 de abril de 2012 [Data a partir da qual são implantadas as novas tentativas em agilizar o processo de licenciamento de imóveis no centro histórico da cidade de Coimbra] (SIMÕES, 2012).

Podemos afirmar, também, que a valorização do patrimônio cultural da UC, a partir da ordenação urbanística da cidade e de seu centro histórico, oferece investimento em infraestrutura urbana, facilidades de licenciamento e, até mesmo, o financiamento com o objetivo de receber novos investimentos. Segundo o Eng. Sinónio Simões, estar-se-iam" planejando ações conjuntas", em que já se verifica "um aumento da procura pelo licenciamento", um "notório interesse da iniciativa privada".

O processo de candidatura foi um trampolim para o financiamento. É um atrativo turístico. E, por esta razão, a candidatura foi apresentada pelo governo e não pela Universidade. Buscando financiar melhorias. Entre algumas das medidas está a de criação de estacionamento na Alta, buscando retirar os carros da área e reforçar o transporte coletivo. E, para 
tanto, a Câmara se dispôs a melhorar o transporte público da área (SIMÕES, 2012).

Segundo Carlos Vainer (2000), esse processo, como já assinalamos diversas vezes, corresponde a uma produção da cidade atrelada ao planejamento estratégico, em que percebemos a particularidade da classificação a patrimônio mundial comparecer como um modelo a ser difundido por mediação da UNESCO e de sua consultoria internacional.

A seguir, estão algumas imagens e considerações sobre obras atreladas ao processo de patrimonialização mundial do centro histórico da cidade de Coimbra, segundo o "mote" da Universidade de Coimbra.

\section{Área de Reabilitação Urbana - ALTA UNIVERSITÁRIA}

Ressaltamos que os processos de candidatura analisados nesta tese não são lineares nem contínuos. Portanto, houve algumas dificuldades de sistematização e de posterior interpretação do fenômeno. Assim, consideramos como início do processo de patrimonialização da Universidade de Coimbra o plano de pormenor da reconversão da ala nascente da Alta Universitária, de autoria do arquiteto português Gonçalo Byrne, que foi aprovado em 1995.

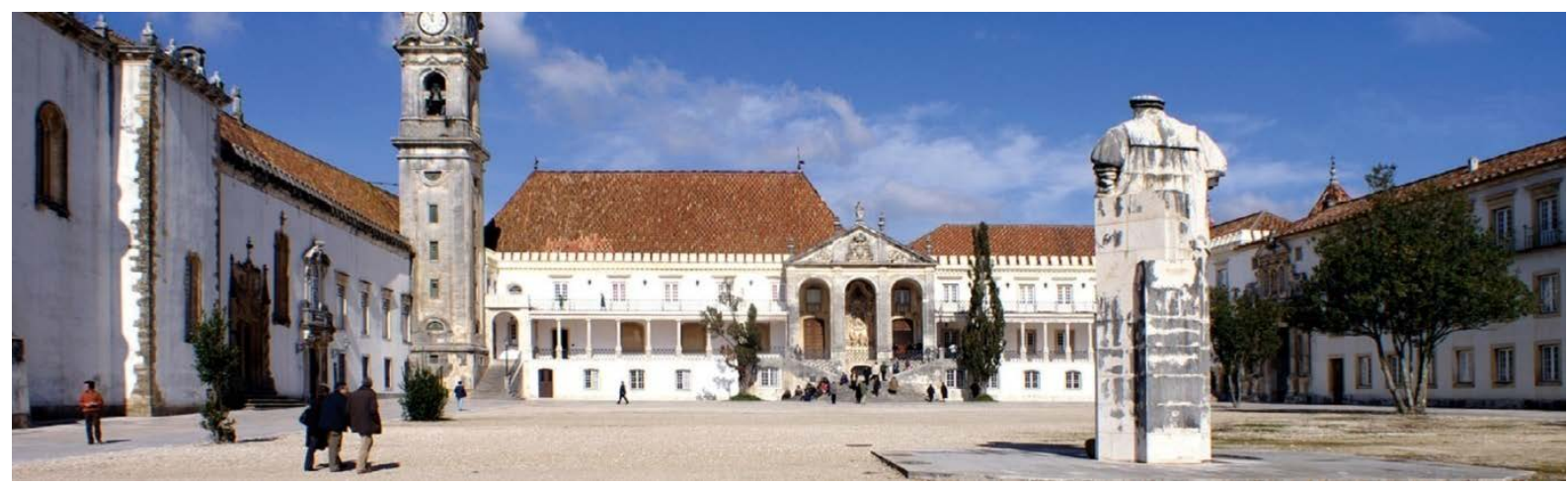

Imagem 69-Vista do Pátio da Universidade antes da intervenção de nova pavimentação. Fonte: Dossiê Intervenção no Patrimônio da UC, 2011, p. 40.

Posteriormente, inicia-se uma série de intervenções no patrimônio, como parte desse plano de reconversão da Alta Universitária. Citamos aqui a reabilitação dos edifícios 
patrimoniais do Paço das Escolas e da Torre do Relógio - que figuram como edifícios principais na área de proteção do bem cultural (ver mapas 39 e43) - e a renovação de seus espaços de convívio social com a substituição de seu pavimento original e o projeto de repavimentação do pátio das escolas, de autoria do arquiteto Gonçalo Byrne.
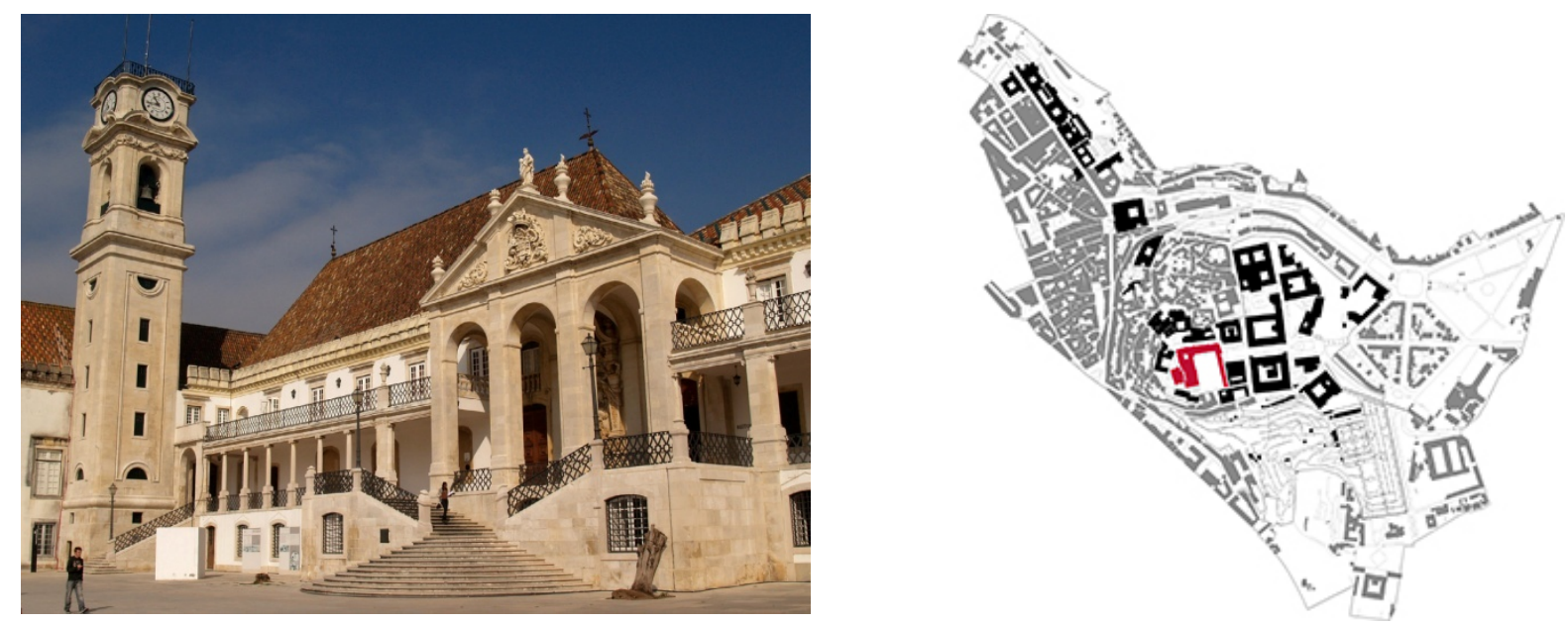

Imagem 70- Fachada do Paço das Escolas e a Torre do Relógio. Fonte: Dossiê Intervenção no Patrimônio da UC, 2011, p. 1-17. Mapa 44-Mapa de identificação do Paço das Escolas, Coimbra. Fonte: Adaptado pela autora sobre base da UC, 2016.

Diante do contexto mais amplo de interesse de patrimonialização mundial da área central da cidade de Coimbra, podemos dizer que essa intervenção patrimonial de Gonçalo Byrne tem início na primeira fase desse processo. Posteriormente, numa segunda fase, em 2005, com a preparação de um projeto de Candidatura da Universidade de Coimbra, conduzido pelo arquiteto Nuno Ribeiro Lopes, os museus da Universidade receberam uma maior atenção e foram inseridos num projeto de requalificação e de organização da zona da Alta Universitária.

Nesse contexto, foi estruturado o projeto de criação do Museu das Ciências, o qual é articulado a diversas entidades locais e nacionais portuguesas (como a Câmara Municipal de Coimbra e a Rádio e Televisão de Portugal), a entidades internacionais (como a Agência Espacial Norte-Americana e a Agência Espacial Europeia) e a entidades institucionais (como o Ministério da Cultura, a Fundação Calouste Gulbenkian e a Fundação para a Ciência e Tecnologia) (Museu da Ciência, 2016). A proposição e a elaboração de um projeto metodológico museológico pela Comissão para o Museu das Ciências receberam consultoria 
internacional ${ }^{151}$ na aplicação de uma metodologia de programas de préfiguração ${ }^{152}$. Além disso, a gestão desse Museu será responsabilidade da Fundação Museu das Ciências, que reúne a Universidade de Coimbra e a Câmara Municipal de Coimbra.

O projeto do Museu das Ciências prevê a sua instalação no edifício do Laboratorio Chimico e no antigo Colégio de Jesus, dois edifícios de estilo pombalino, no Largo Marquês de Pombal. Para receber essas intervenções museológicas, foram pensadas duas fases de ações, em que cada um desses edifícios passará por uma intervenção física de reabilitação e de adaptação ao programa de museu, segundo o seu conceito de exposição, de operação e de abertura ao público.

A primeira fase já foi realizada no Laboratorio Chimico e foi inaugurada em 2006 em um edifício do período da Reforma Pombalina, de menor dimensão que o antigo Colégio de Jesus, que permitiu a aplicação de uma etapa probatória de um conceito expositivo préfiguração -, após um processo de requalificação arquitetônica. A autoria do projeto foi do arquiteto João Mendes Ribeiro e do Atelier do Corvo (arquitetos Desirée Pedro e Carlos Antunes).

A segunda fase de intervenção museológica do Museu das Ciências está prevista para acontecer no antigo Colégio de Jesus, um dos mais antigos colégios da Companhia de Jesus no mundo. A intervenção de reabilitação em um dos edifícios principais foi resultado de um concurso internacional, e a proposta vencedora foi dos arquitetos Carlos Guimarães e Luís Soares Carneiro. O projeto pretende incorporar coleções de diversas áreas científicas da Universidade de Coimbra-Astronomia, Física, Química, Geologia, Biologia, Medicina, Farmácia etc.

${ }^{151}$ Essa consultoria internacional foi realizada por alguns especialistas, dentre eles o museólogo especializado na evolução dos museus e exposições de ciências naturais Michel Van Praët, responsável pela implementação do programa de pré-figuraçãono Museu de História Natural de Paris. Praët foi convidado para analisar o caso dos museus universitários de Coimbra.

152"O conceito de préfiguração foi implementado no Museu de História Natural de Paris (Muséum) para a grande obra de remodelação de sua Galeria de Zoologia, hoje a Grande Galeria da Evolução" (UC, 2016). 

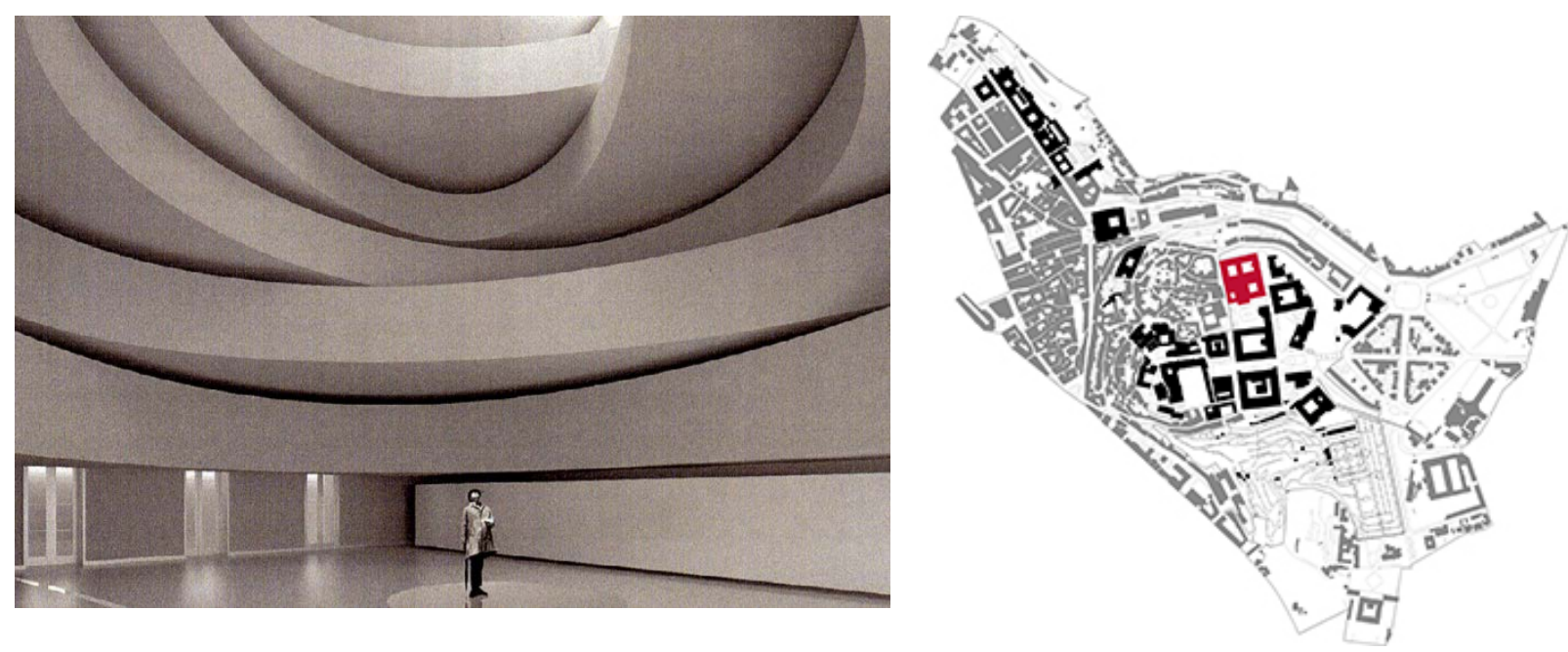

Imagem 71 - Modelo virtual da proposta vencedora do concurso para a intervenção no futuro Museu das Ciências. Fonte: Dossiê Intervenção no Patrimônio da UC, 2011, p. 19. Mapa 45 -Mapa de identificação do futuro Museu das Ciências. Fonte: UC, 2016.

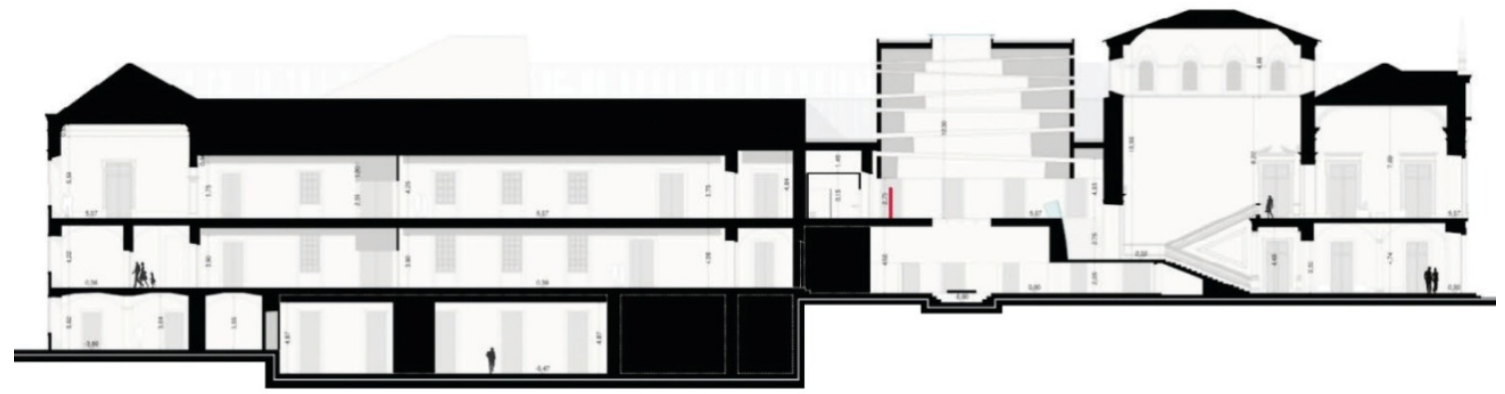

Imagem 72 - Corte da proposta vencedora do concurso do Museu das Ciências da UC, no sentido nascente-poente, pelo átrio principal. Fonte: Dossiê Intervenção no Patrimônio da UC, 2011, p. 21.

Assim, os museus universitários foram enaltecidos no processo de candidatura, valorizando as coleções de objetos relacionados às atividades científicas de ensino e de investigação da Universidade, um acervo que também recebeu outros materiais por meio de doações e de aquisições da própria Instituição. O museu pretende tanto ser aberto à comunidade quanto voltado para especialistas, como um museu-arquivo. 

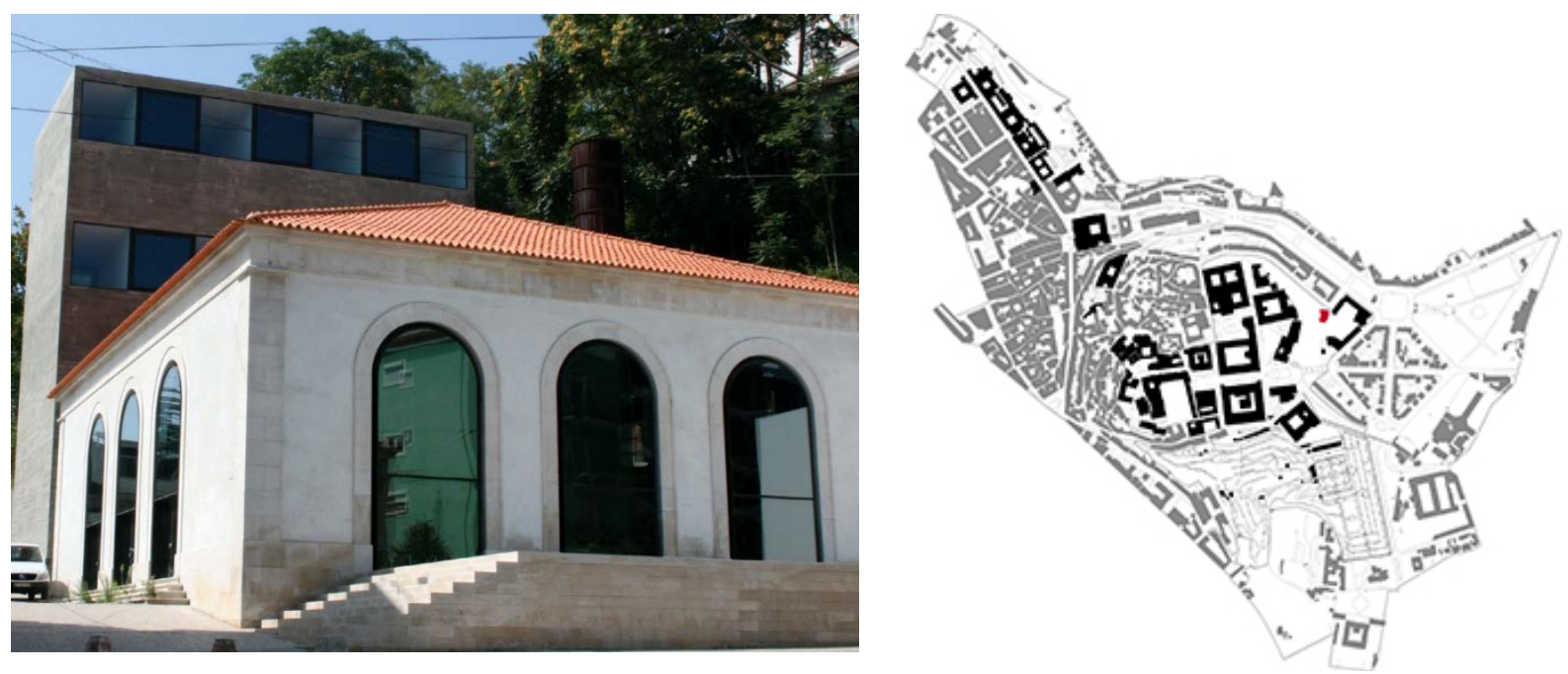

Imagem 73 - Fachada da Casa das Caldeiras, Coimbra. Mapa 46 -Mapa de identificação da Casa das Caldeiras. Fonte: UC, 2016.

Também com alguma função de acervo museológico industrial - embora reduzido a poucos elementos históricos desse uso -, podemos considerar a intervenção do edifício das Caldeiras - um dos principais edifícios na área protegida (ver mapas 39 e 43) patrimônio industrial da cidade de Coimbra, construído em 1941. A intervenção de reabilitação e de restauro do edifício patrimonial é caracterizada por um léxico arquitetônico moderno, com sobriedade e funcionalidade, como uma releitura das antigas funções ali desempenhadas. $\mathrm{O}$ plano, de 1991, de intervenção original e de remodelação do edifício era de autoria dos arquitetos portugueses João Mendes Ribeiro e Cristina Guedes, com a finalidade de receber o Centro de Estudos Fotográficos da Universidade de Coimbra. No entanto, a obra só foi executada dez anos mais tarde, para a Faculdade de Letras da Instituição, com o estabelecimento do Instituto de Estudos Artísticos de pós-graduação.

Apesar de o uso e o programa do edifício terem sido alterados, o projeto traçado originalmente foi mantido, buscando preservar seu contexto histórico e sua arqueologia industrial, bem como recuperando e reintegrando o edifício à estrutura da cidade. A intervenção arquitetônica buscou manter as estruturas arquitetônicas originais, tais como "a disposição interior, os acessos, as amplas janelas e a alta chaminé, assim como a maioria da maquinaria, com as duas caldeiras de grande porte, adquiridas em 1939 à firma inglesa S.E. de C. Babcock \& Wilcox" (UC, 2016). Alguns sistemas de ar-condicionado e de iluminação foram criados para o novo programa de uma cafeteria e de uma loja de livros e artes. 
A linguagem e a representação arquitetônicas dessa nova obra podem ser consideradas neutras em relação ao estilo arquitetônico do edifício histórico, pois elas não se sobrepõem, e ao mesmo tempo expõem a nova intervenção. Evidenciam a nova intervenção as aberturas para iluminação e acesso, e o concreto aparente, por exemplo, em contraposição à construção histórica anterior.

Trazemos, também, o exemplo importante da construção de novo edifício para o Auditório da Faculdade de Direito, de autoria do arquiteto Fernando Távora, obra de 1995 a 2000. Por meio dessa obra, observamos a atuação do arquiteto embasada em seu olhar sobre a cidade e o lugar, registrado em seu croqui. Esse desenho expôs sua leitura dos edifícios históricos, da composição física deles articulada ao tecido urbano da cidade, o que, aliado à topografia e à composição da paisagem, levaram o arquiteto à escolha de um partido arquitetônico em um plano abaixo, implantado segundo o desnível do terreno, e que permitisse uma continuidade de leitura prolongada do pátio central dos edifícios da Faculdade de Direito, enquadrando a paisagem.

Percebemos, nessa abordagem, uma fundamentação conceitual embasada nas tradições arquitetônicas e urbanísticas portuguesas, com um grande estudo do território e com um modo de conceber a arquitetura a partir dessa leitura.
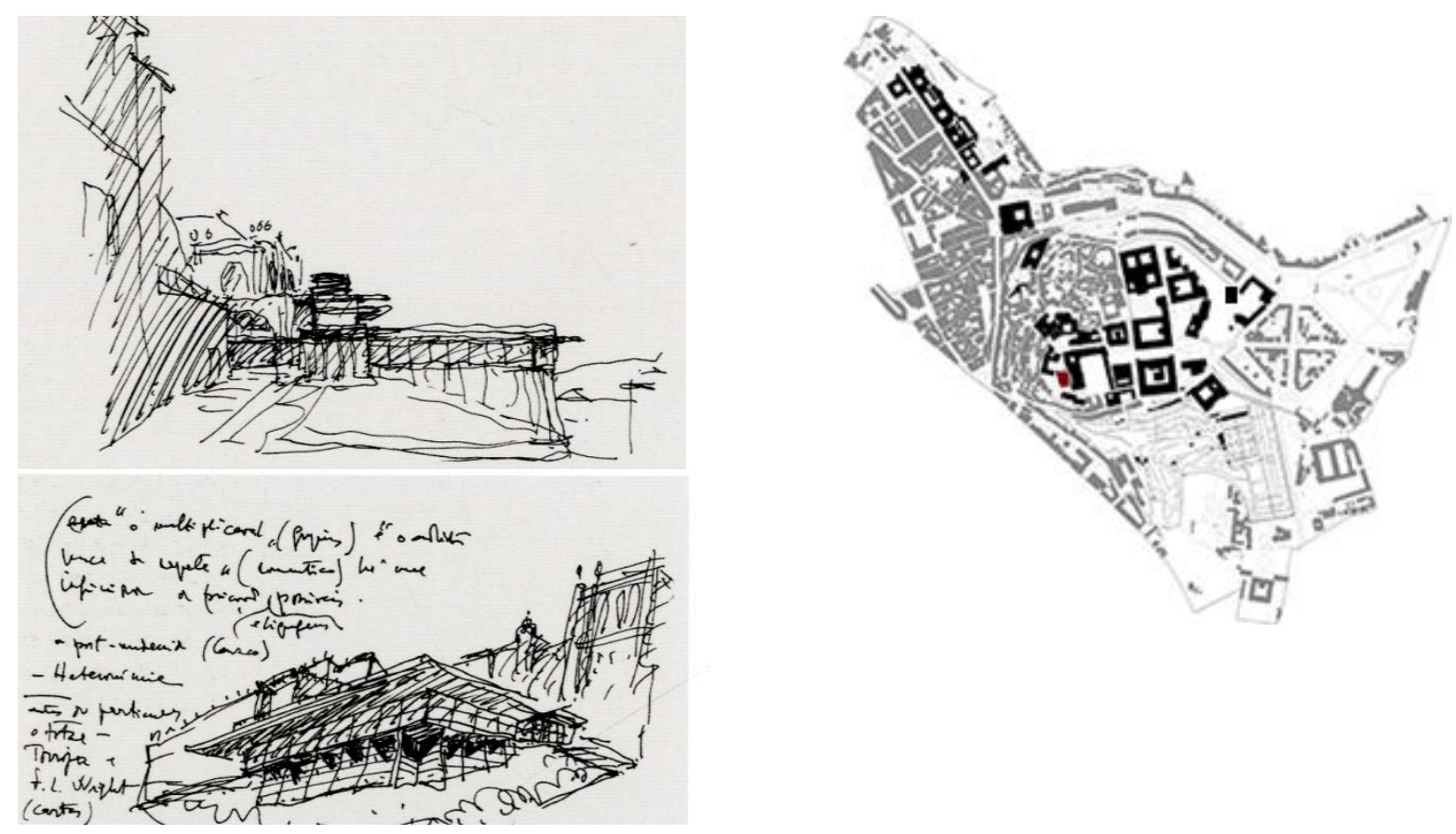

Imagens 74 e 75- Croquis do auditório da Faculdade de Direito, Coimbra. Fonte: ESPOSITO, 2005, p. 266. Mapa 47-Mapa de identificação do auditório. Fonte: autoria própria adaptado sobre mapa base da UC, 2016. 

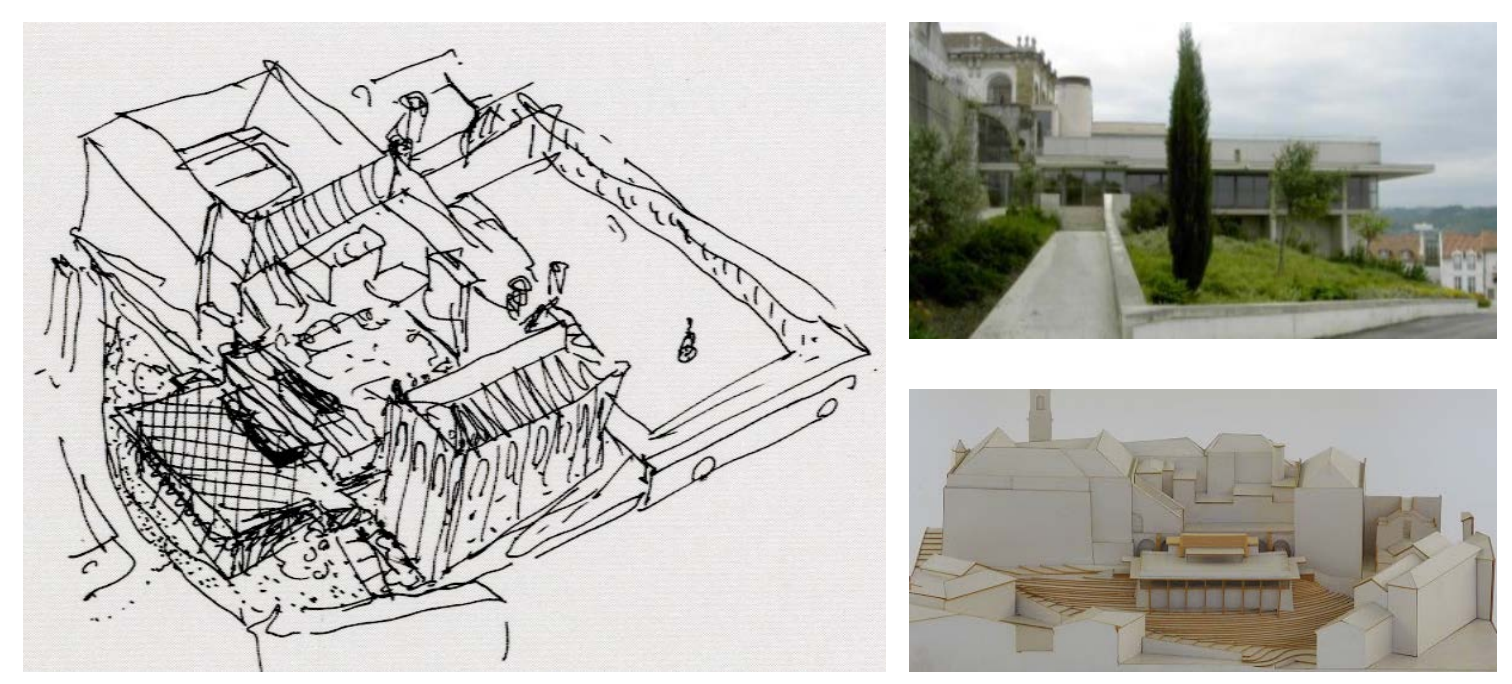

Imagem 76 -Croqui do auditório da Faculdade Direito, Coimbra. Fonte: ESPOSITO, 2005, p.266. Imagem 77 -Vista do acesso principal do auditório da Faculdade de direito, Coimbra, 2012. Fonte: autoria própria. Imagem 78 - Maquete do auditório. Fonte: ARKITECTOS, 2014.

Outra intervenção de reabilitação é o Museu Nacional Machado de Castro, uma obra de restauro e renovação arquitetônica, com a proposição de ampliar o edifício existente e de dar novos usos e atividades a ele. Foi um projeto do arquiteto Gonçalo Byrne, datado de 1999 e que teve a obra finalizada em 2004.

A refuncionalização desse edifício como um museu recebeu o apoio de algumas entidades nacionais (dentre elas a Secretaria da Cultura do Estado do Governo português e a Direção-Geral do Patrimônio Cultural de Portugal, com o apoio do Programa Operacional Sociedade do Conhecimento, POS_Conhecimento) e da entidade política internacional da União Europeia por meio do Fundo Europeu de Desenvolvimento Regional (FEDER).
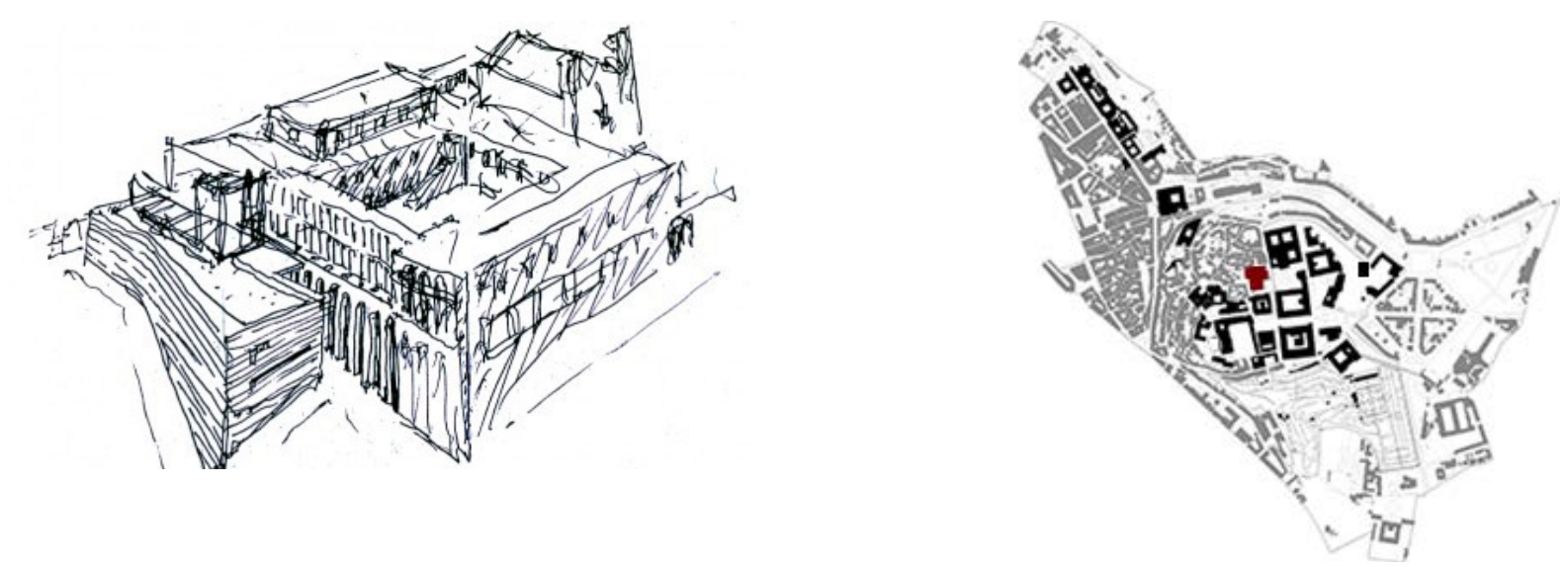

Imagem 79-Croqui do Museu Nacional Machado de Castro, Coimbra. Fonte: GONÇALO BYRNE ARQUITECTOS, 2016. Mapa 48- Mapa de identificação do Museu Nacional Machado de Castro, Coimbra. Fonte: Adaptado pela autora com base da UC, 2016. 

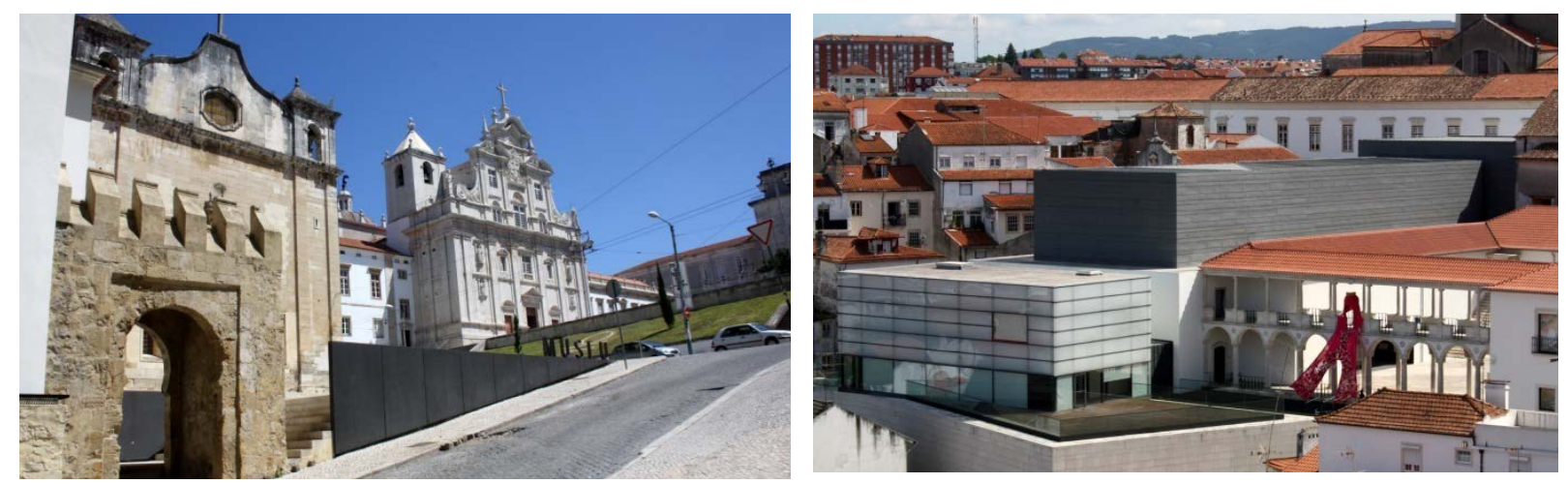

Imagem 80 - Acesso principal do Museu Nacional Machado de Castro, à esquerda, Coimbra, 2012. Imagem 81 - Vista da fachada posterior do Museu, à direita. Coimbra, 2012. Fonte: autoria própria
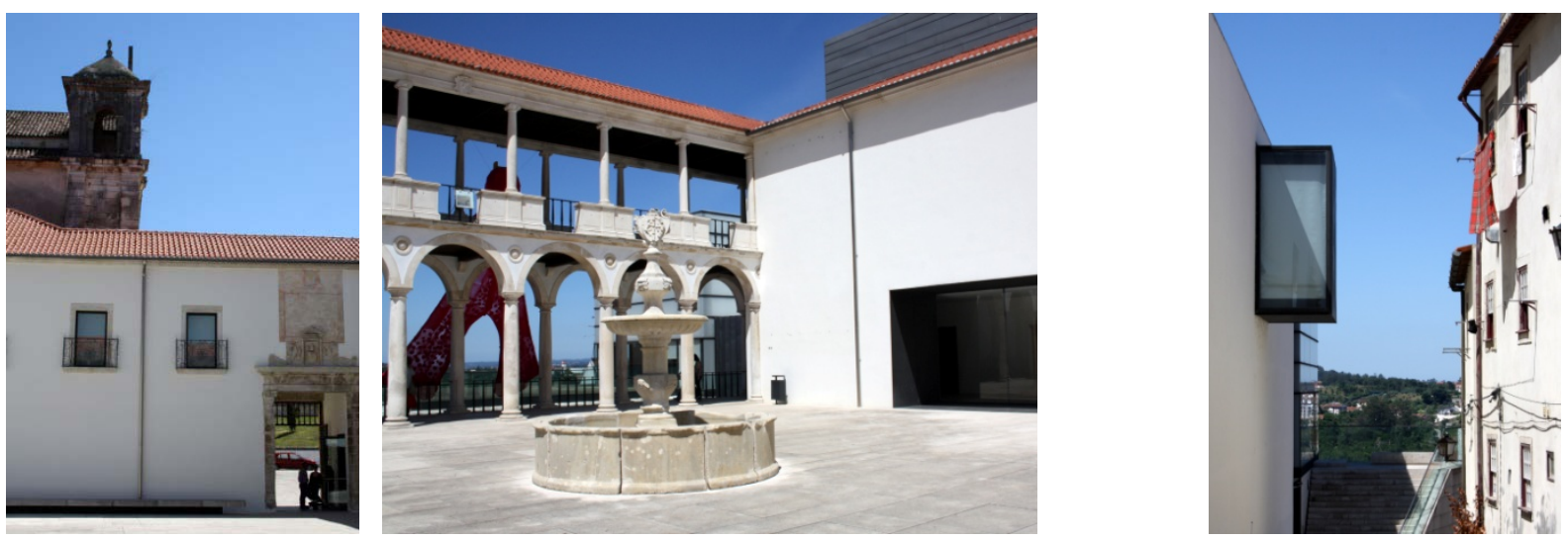

Imagens 82 e 83 - Pátio do Museu Nacional Machado de Castro, Coimbra, 2012. Imagem 84 Fachada lateral contrastante com a arquitetura dos edifícios históricos do entorno, Coimbra, 2012. Fonte: autoria própria

Verificamos nesta obra outro exemplo da tradição da arquitetura portuguesa de intervenção no patrimônio histórico. Percebe-se uma leitura atenta ao edifício histórico existente, sua formalidade, seus espaços de convívio social, e a articulação de um novo programa a ele, com novos usos e acessos, organizando um espaço composto de vários períodos históricos e de diferentes formas de ocupação ao longo do tempo.

Novamente a questão topográfica é central para o projeto de arquitetura, organizando a inserção dos volumes no mesmo. No entanto, se, por um lado, observamos um grande equilíbrio do espaço vazio do pátio central em relação à edificação história, por outro, no contexto da paisagem da cidade, o novo volume anexo expõe uma discrepância em relação às composições físicas dos volumes históricos. Esse aspecto evidencia-se nas imagens anteriores, no encontro da edificação nova com a galeria de passagem, composta 
por arcos e por cobertura com seus ritmos e ordens arquitetônicas, os quais encontram o novo volume de composição contemporânea, excessivamente robusta no encontro.

Também é possível evidenciar o contraste, ainda dentro da paisagem da cidade, em relação às residências próximas ao museu e ao seu novo volume anexo. Percebemos ali uma falta de harmonia e equilíbrio com o contexto cultural local do conjunto histórico, além de uma maior preocupação de composição articulada ao conjunto histórico da área protegida da Universidade de Coimbra, o que, segundo essa perspectiva, nega o contexto da cidade.

Por fim, a construção do edifício do Colégio de São Bento - que figura como uma das principais zonas de proteção do bem cultural (ver mapas 39 e 43) - data de 1576. Seu estilo arquitetônico e artístico é imbuído de uma forte estética maneirista, que "materializou um volume retangular, com amplo pátio e fachadas exteriores seccionadas em três panos horizontais nos quais se abrem fileiras de janelas simétricas" (UC, 2016).

Em razão dos diversos usos da edificação ao longo do tempo, sempre com uma função institucional da Universidade, diversas obras foram empreendidas em seu interior, relacionadas, principalmente, à constituição de salas padronizadas e de um pátio central, de corredores, de átrios e de escadas.

Atualmente, o edifício encontra-se em razoável estado de conservação. São previstas intervenções físicas de "clarificação das áreas de circulação e por ações de manutenção e/ou reabilitação da generalidade dos espaços, com vista à eliminação de eventuais elementos espúrios ou descaracterizadores da espacialidade do edifício" (UC, 2016). Também está proposta uma revalorização dos espaços externos da edificação, voltados, principalmente, para os terraços a sudeste, em que se localiza uma esplanada com um bar, e para o pátio interno, área de convívio social, que atualmente comporta o Departamento de Ciências da Vida, Sede da Associação RUAS. 

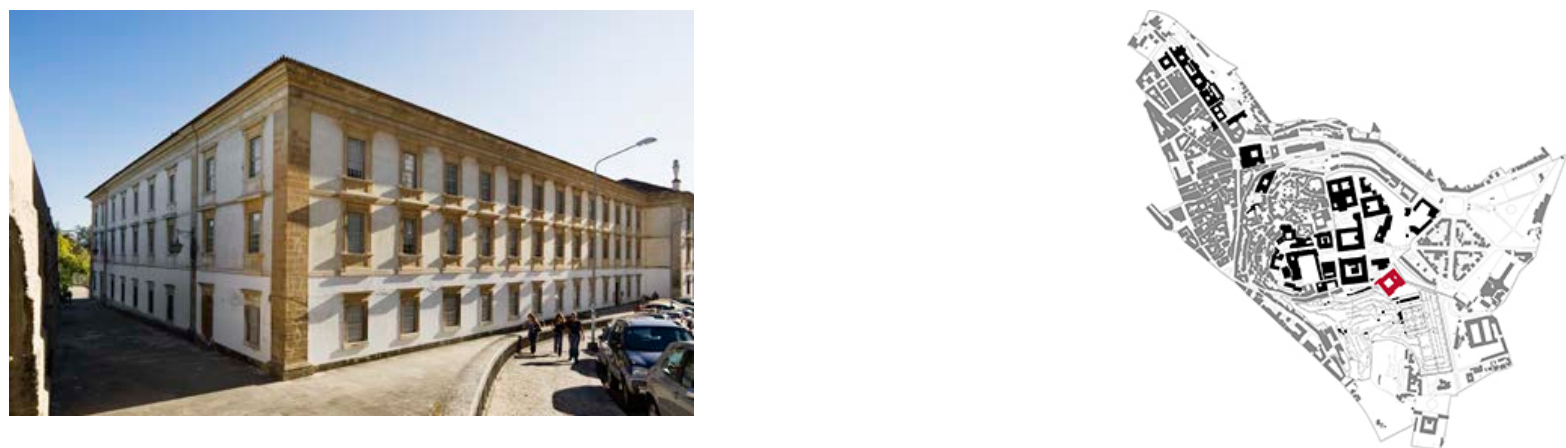

Imagem 85 - Colégio de São Bento, Coimbra. Fonte: UC, 2016. Mapa 49- Mapa de identificação do Colégio de São Bento, Coimbra. Fonte: UC, 2016.

\section{Propostas futuras para a ARU - ALTA}

Reconhecemos algumas particularidades na experiência de Coimbra: suas estratégias de intervenção no patrimônio fundamentam-se numa leitura e numa visão do território que também estão presentes em sua tradição de arquitetura e de urbanismo. Observamos que há uma busca em intervir no território e no patrimônio de modo a estruturar alguns usos e permanências, ou mesmo fortalecê-los, assim como há uma intenção de integração do uso pelo pedestre e do contexto natural da cidade, com sua morfologia urbana, ou seja, com sua topografia e com o rio Mondego.

A estratégia é: vamos criar museus, vamos criar bares, vamos criar esplanadas, vamos transformar o espaço público em áreas peadonais, vamos tirar os automóveis daqui. Porque é que o automóvel aparece? Se o espaço público não servia para nada, é inóspito, é feio, não presta, neste instante a democratização também, digamos, a capacidade de aumentar o acesso ao automóvel acresceu para o ritmo da Dio, é evidente se o espaço público não serve para as pessoas serve para o automóvel imediatamente. Agora é preciso fazer o contrário, se vamos retirar o automóvel, temos que arranjar estacionamentos para o automóvel e vamos devolver espaços as pessoas, e para isto temos que abrir os edifícios que são fechados para o exterior e abri-los para o exterior, temos que criar, digamos, atrativos dentro dos próprios edifícios que levem as pessoas a entrar e sair na rua, e temos que criar na rua situações de conforto e de permanência, daí o edifício de Física ou Química na Alta, o pátio é um projeto, é feito para rios, e para esplanadas e para estas coisas todas, é edifício que se passa pela Rua Larga e que portanto se visiona lá, aquele pátio com vista sob o Rio é um espaço ótimo, o turista vem nos visitar, andar pela esplanada a ver uma festa noturna, sem problemas nenhum (SILVA, 2012). 
As intervenções futuras para a Área de Reabilitação Urbana da Alta constituem questões em comum ao estudo de caso de Belém, sobretudo em relação a novos usos voltados para o consumo e turismo, e quanto às tentativas de propostas não executadas, ou que não tiveram continuidade, na área protegida do Ver-o-Peso. Não nos esqueçamos de que essas propostas foram um importante campo de conflito, por conta exatamente da elaboração um novo projeto para a Feira Livre do Ver-o-Peso sem consulta à população por parte do Poder Público, ou mesmo por conta de propostas para as áreas adjacentes ou de entorno ao Ver-o-Peso, as quais não tiveram continuidade por se ligarem a tentativas de reconversão do patrimônio em instituições relacionadas a espaços de consumo, como por exemplo, na construção do Centro Comercial Bechara, uma obra de renovação arquitetônica num conjunto patrimonial tombado pelo IPHAN.

Atualmente, todas essas descontinuidades que observamos, em Belém, respondem a um novo interesse por um processo classificatório simplificado - por meio do mote do patrimônio imaterial da cidade e de sua classificação como "cidade criativa"-, e culminaram na tentativa do governo do Pará de implementar um instituto culinário no edifício patrimonial "Casa das Onze Janelas", onde atualmente funciona o Museu de Arte Contemporânea.
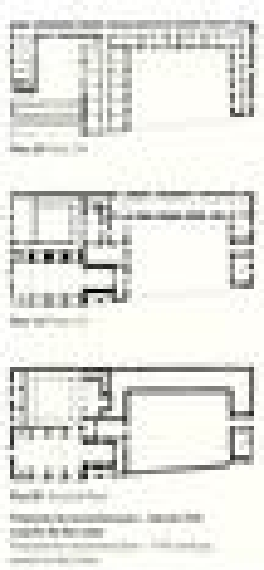
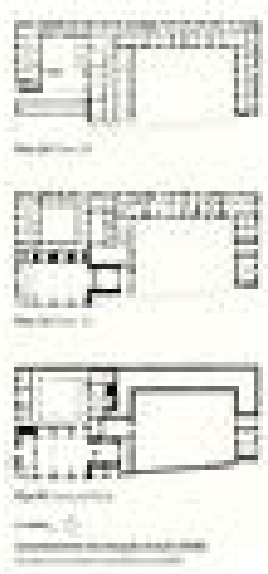

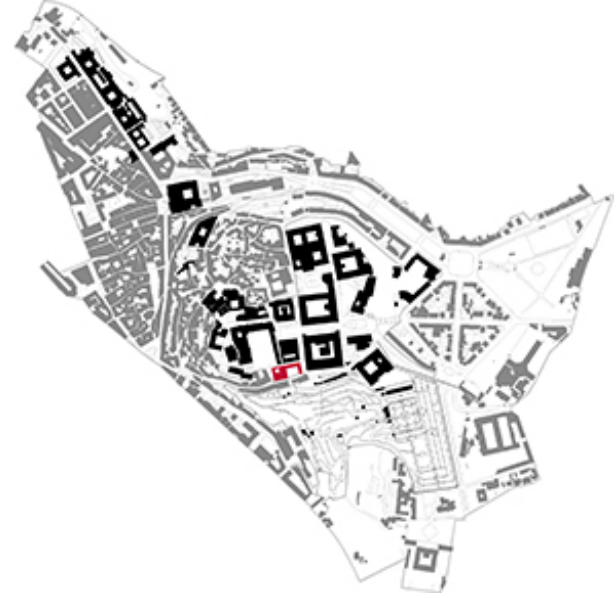

Imagem 86 - Plantas do Colégio da Trindade, Coimbra. Mapa 50 -Mapa de identificação do Colégio da Trindade. Fonte: UC, 2016. 


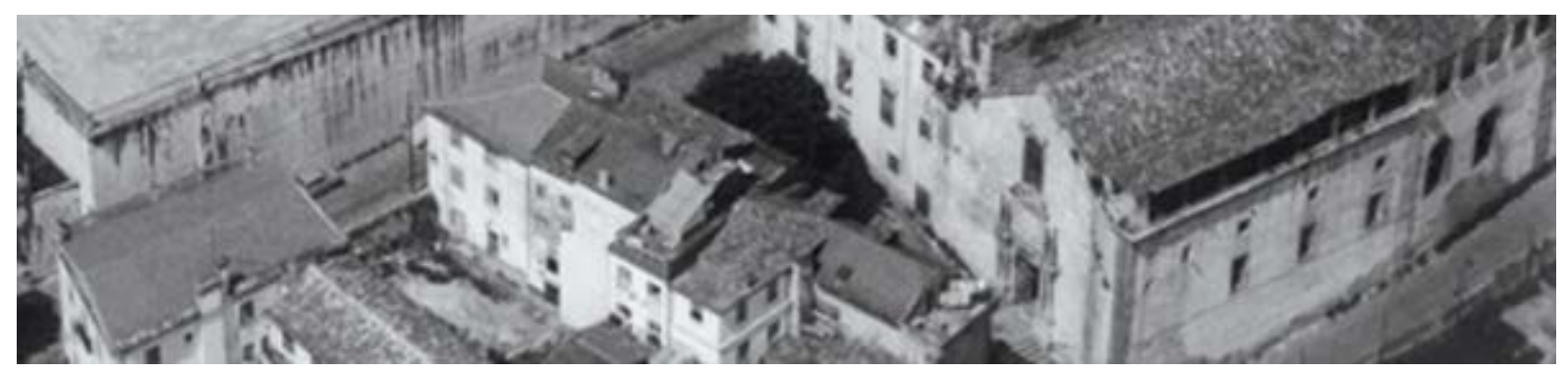

Imagem 87- Colégio da Trindade, onde atualmente está prevista a instalação do edifício do Tribunal Universitário Judicial e Europeu (TUJE), Coimbra. Fonte: UC, 2014.
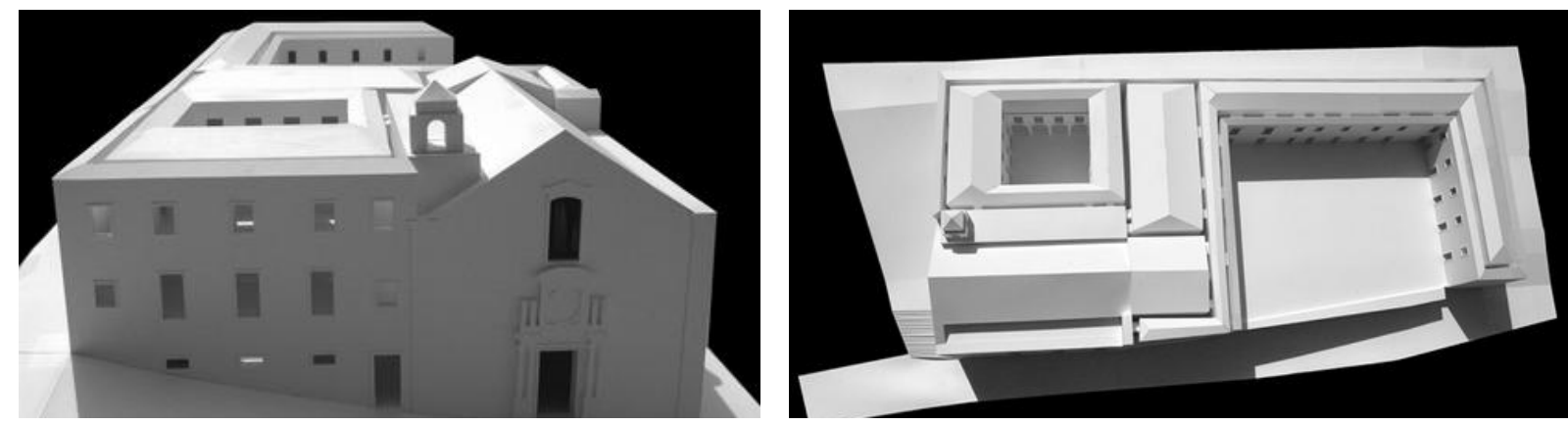

Imagens 88 e 89- Maquete da proposta do edifício do Tribunal Universitário Judicial e Europeu (TUJE), Coimbra. Fonte: UC, 2014.

Em Coimbra, a proposta de renovação do edifício do antigo Colégio da Trindade como o Tribunal Universitário Judicial e Europeu (TUJE) foi aprovada pelo Quadro de Referência Estratégico Nacional (QREN). Essa proposta apresenta um tribunal com funções de administração judiciária, ensino e aprendizagem, e de investigações consideradas transdisciplinares e interdisciplinares, de vocação internacional no contexto europeu.

Atualmente, o edifício encontra-se bastante desfigurado devido a seus sucessivos usos e ocupações. Grande parte dele está abandonada há décadas, por isso encontra-se sem conservação e severamente degradado. Com a finalidade de estabelecer o Tribunal Universitário Judicial e Europeu e outros serviços da Faculdade de Direito, foi realizada uma importante campanha arqueológica, que buscava conhecer as sucessivas fases de ocupação do edifício. Do levantamento decorreu o projeto de adaptação do complexo colegial, de autoria dos arquitetos Francisco Xavier Rocha de Aires Mateus e Manuel Rocha de Aires Mateus.

Outra proposta de intervenção futura é o projeto de construção do novo edifício de biblioteca da Faculdade de Direito, de autoria do arquiteto Álvaro Siza, que ainda não foi realizado. Percebemos nessa leitura de Siza, em relação aos edifícios históricos adjacentes, uma busca por não interferir na composição arquitetônica original, enaltecendo a paisagem 
cultural e mantendo as paisagens visuais do conjunto histórico. Seu partido projetual, um tanto quanto semelhante ao de Fernando Távora, é o de propor o novo edifício em níveis abaixo do nível da rua, integrando-o à topografia do terreno e à cidade.
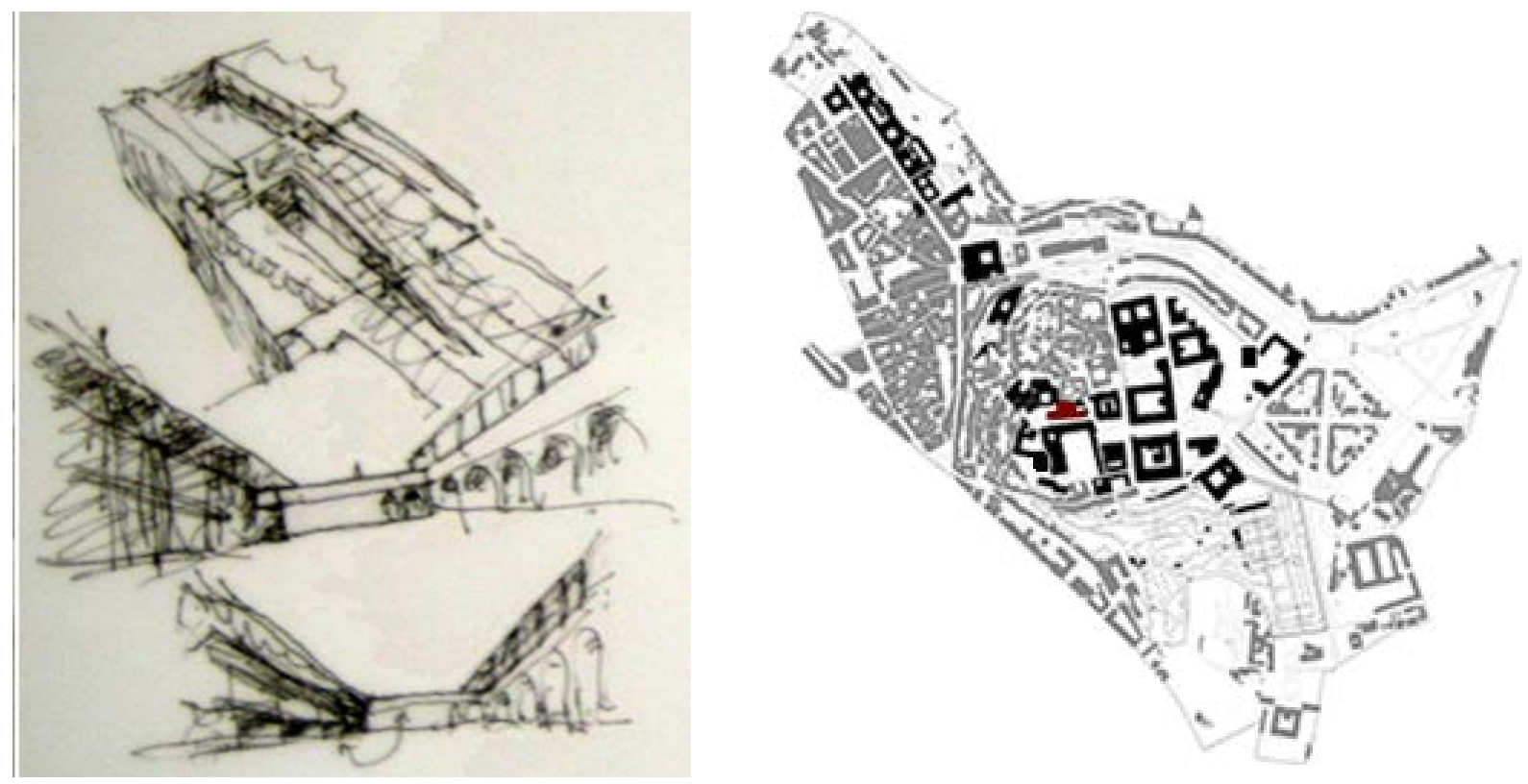

Imagem 90 - Croqui da nova biblioteca da Faculdade de Direito. Fonte: ESPOSITO, 2005. Mapa 51 Mapa de identificação da nova biblioteca da Faculdade de Direito, Coimbra. Fonte: Adaptado pela autora sobre base da UC, 2016.

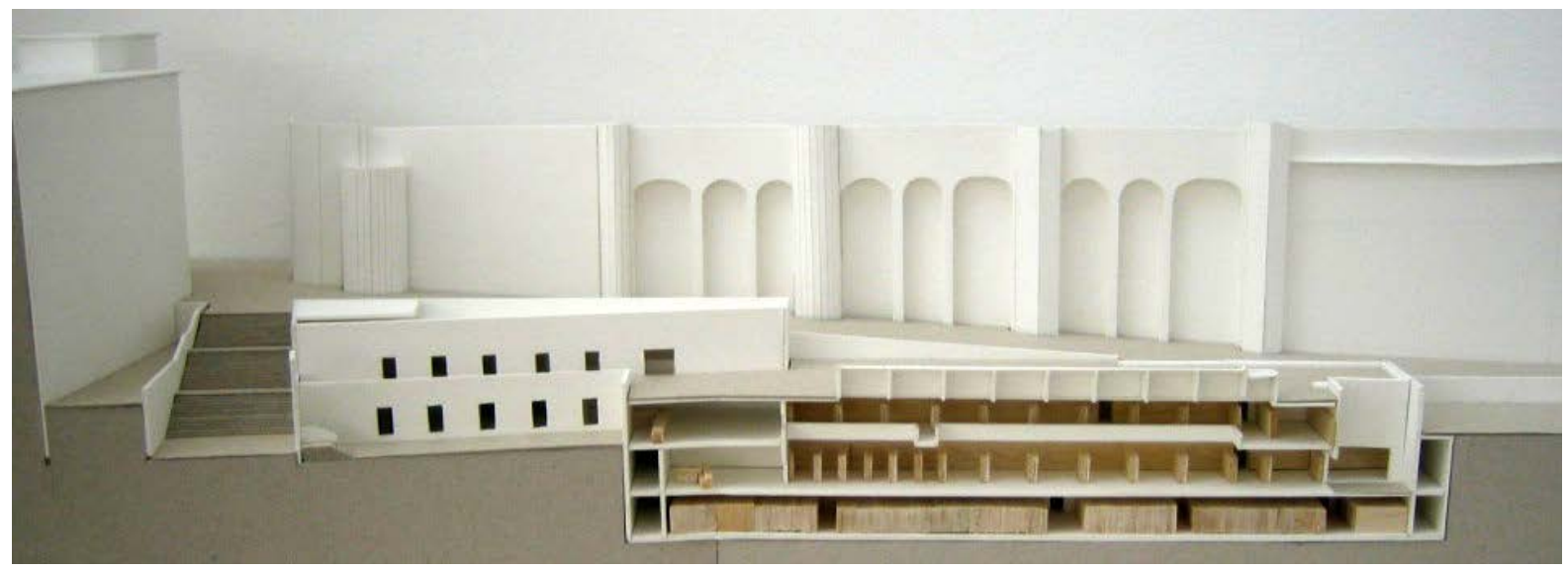

Imagem 91- Maquete da proposta da biblioteca da Faculdade de Direito, Coimbra. Fonte: ARKITECTOS, 2013. 
Segundo nos informou, em entrevista, o arquiteto Nuno Ribeiro Lopes ${ }^{153}$, são propostas renovações dos espaços e suas refuncionalizações, com a criação de novas esplanadas e de áreas de pedestres sem vias de circulação de automóveis e com realocação dos estacionamentos atuais de veículos.

\section{Área de Reabilitação Urbana - BAIXA}

Essa reabilitação foi proposta pelo arquiteto Fernando Távora e finalizada em 1997. Deu-se em área considerada o acesso principal da zona da "baixinha", caracterizada pelo seu comércio tradicional. Procurando valorizar antigas tradições e novos costumes da cidade, propôs espaços públicos abertos para a realização de eventos e de festas.
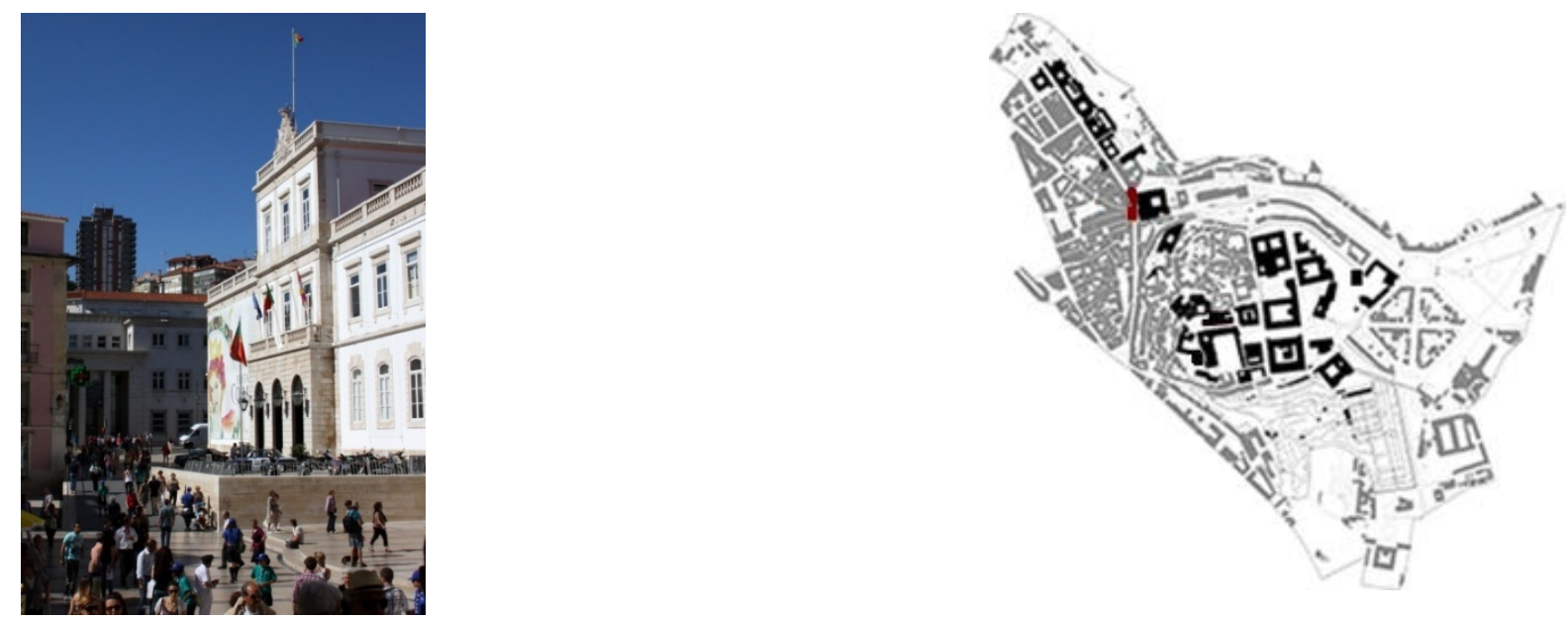

Imagem 92 - Foto da Praça 8 de maio, Coimbra, 2012. Mapa 52- Mapa de identificação da Praça 8 de maio, Coimbra. Fonte: Adaptado pela autora sobre base da UC, 2016.

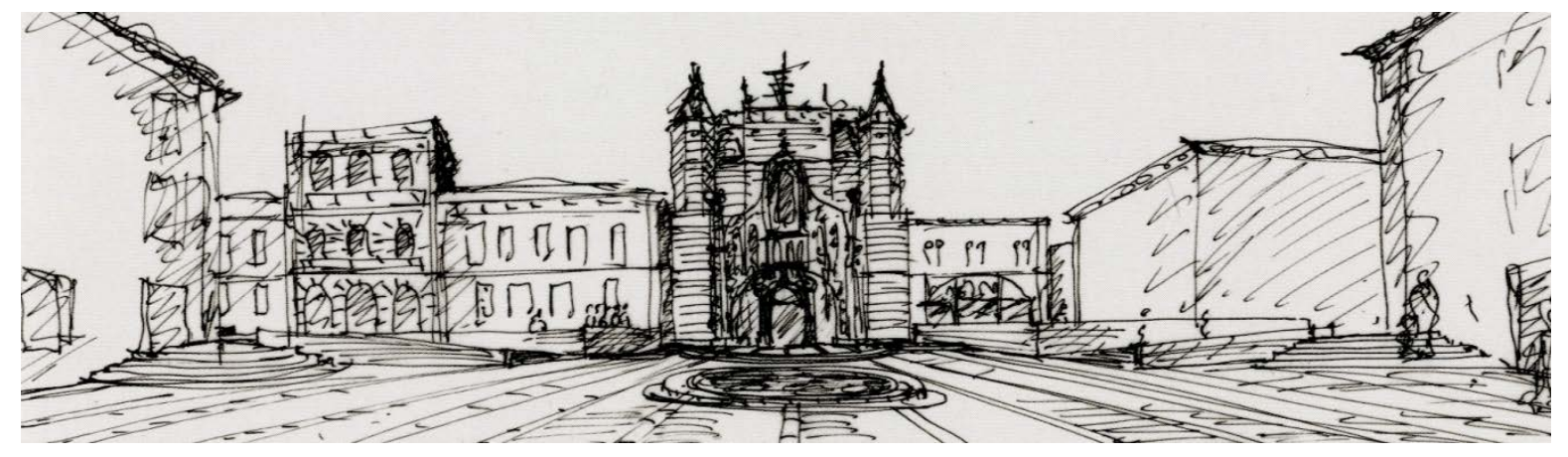

Imagem 93 - Croqui de Fernando Távora para a proposta de intervenção na Praça 8 de Maio, 1992, Coimbra. Fonte: ESPOSITO, 2005, p. 262.

153Ver entrevista 3 - APÊNDICE A. 


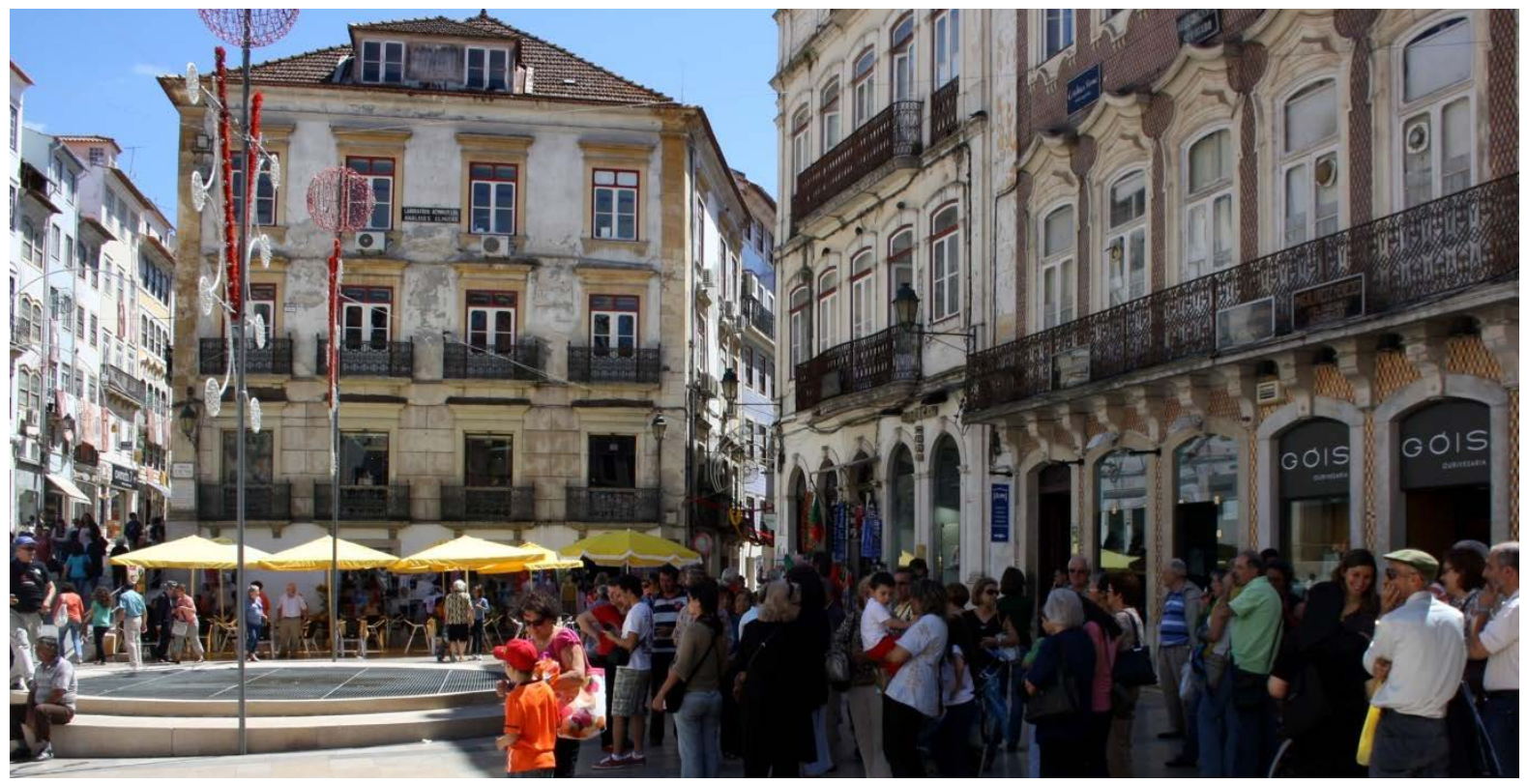

Imagem 94 - Praça 8 de Maio, Coimbra, 2012. Fonte: autoria própria.

Durante o período da visita a campo na cidade de Coimbra, em junho de 2012, a Igreja do Mosteiro de Santa Cruz, localizada na Praça 8 de Maio, passava pela primeira fase de obras de conservação, restauro e valorização. Essas obras estavam inseridas na operação de musealização do Mosteiro de Santa Cruz de Coimbra, com o projeto revitalização do Centro Histórico de Coimbra pelo Programa Operacional Regional do Centro-mais CENTRO, com o apoio da União Europeia pelo Fundo Europeu de Desenvolvimento Regional (FEDER). Suas obras foram realizadas pela Direção Regional de Cultura do Centro (DRCC), e a sua entidade promotora nacional foi o Ministério da Cultura de Portugal.

\section{Área de Reabilitação Urbana - RIO}

Essa reabilitação propunha a renovação dos espaços e de sua refuncionalização, associada à reaproximação e rearticulação entre a cidade e o rio. Inaugurado em 2004, é um parque constituído de esplanadas, pavilhões e equipamentos de ócio e lazer. Destaca-se o Pavilhão Centro de Portugal, originalmente Pavilhão de Portugal na Expo Hannover (Alemanha) de 2000, de autoria dos arquitetos Souto Moura e Álvaro Siza. 

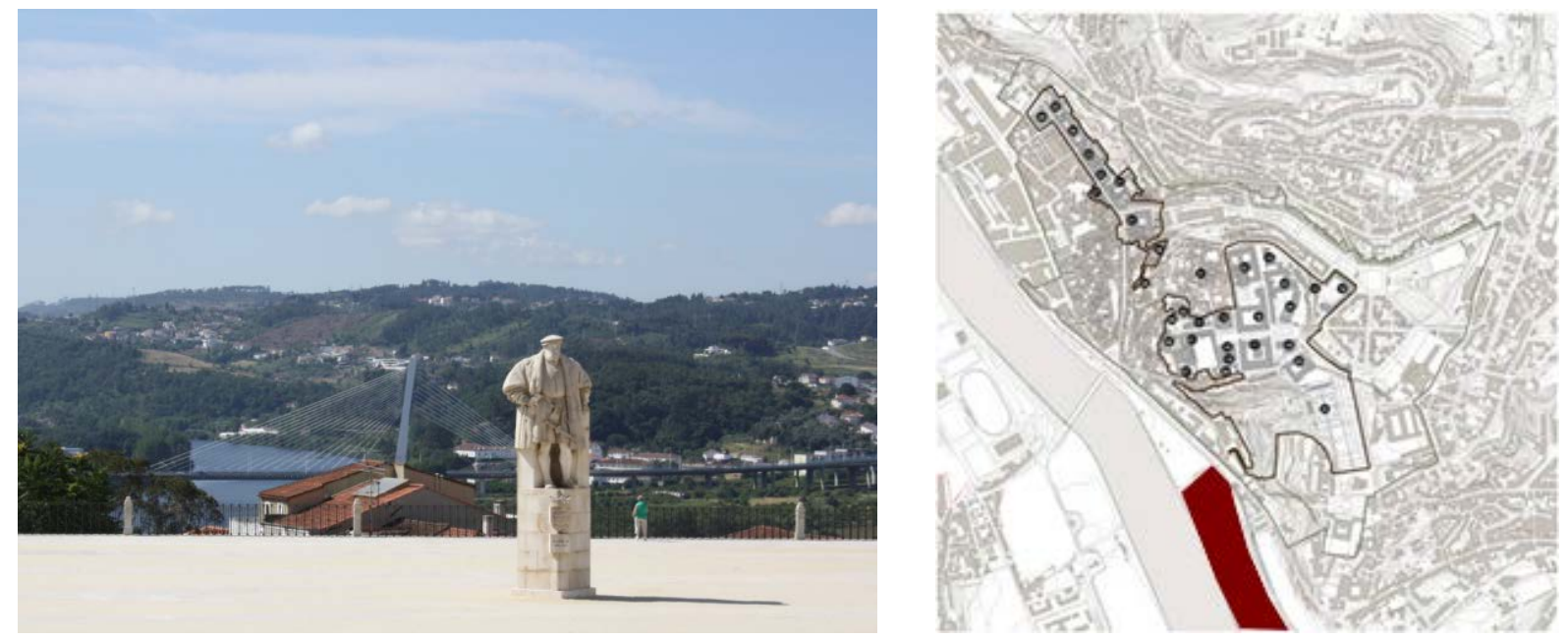

Imagem 95 - Vista da ponte Rainha Isabel desde o Paço das Escolas. Fonte: autoria própria. Mapa 53 -Mapa de identificação do Parque de Coimbra. Fonte: Adaptado pela autora com base da UC, 2016.

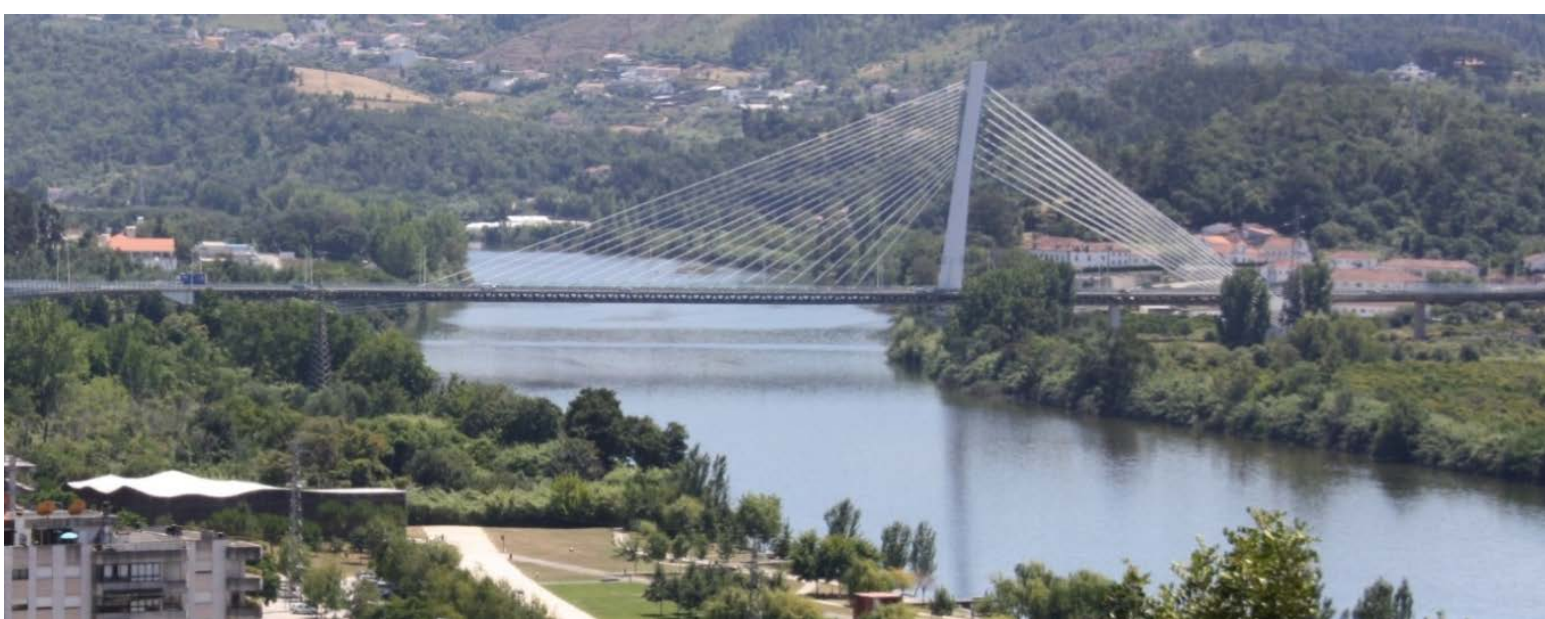

Imagem 96-Vista do Parque de Coimbra e da ponte Rainha Isabel, Coimbra, 2012. Fonte: autoria própria.

\section{Intervenções e proposta futuras- área externa às ARU}
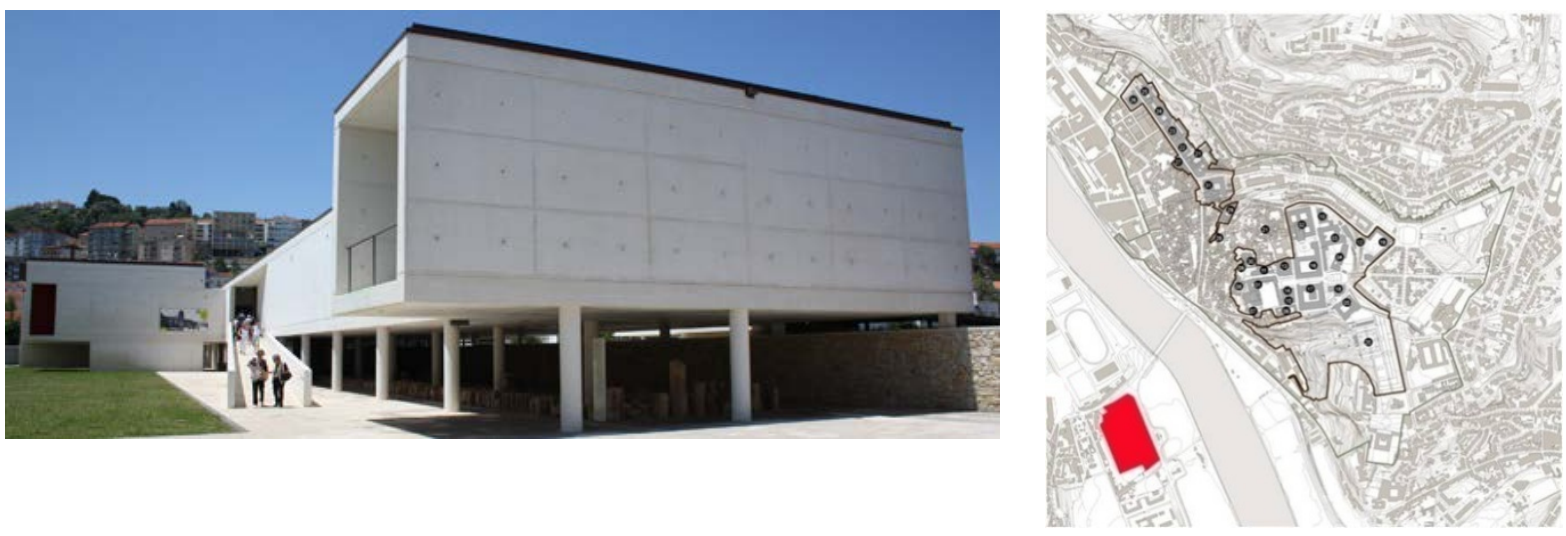

Imagem 97 - Vista geral do Museu de Santa Clara-a-Velha, Coimbra, 2012. Fonte: autoria própria. Mapa 54 - Mapa de identificação do Museu. Fonte: Adaptado pela autora com base da UC, 2016. 
Uma dessas intervenções foi a construção de um Museu anexo ao Convento de Santa Clara-a-Velha, de autoria dos arquitetos Alexandre Alves Costa e Sergio Fernandez, finalizado no ano de 2009.

O Museu foi concebido como uma obra nova, mas com uma linguagem simplificada em seus volumes e materialidade e no uso dos elementos cromáticos. Esse edifício articulase ao antigo edifício histórico do Mosteiro de Santa Clara-a-Velha, de modo a enquadrar sua paisagem não apenas por suas aberturas do interior para o exterior, em que se localiza o bem cultural, mas também pelos percursos externos criados na intervenção, em que os eixos visuais sempre compõem leituras visuais históricas.

Em 2012, estava em construção uma obra de reabilitação do Convento de São Francisco e de construção de seu anexo, um novo edifício de um Centro de Convenções e Espaço Cultural (previsto para ser o Auditório da Fundação Bissaya Barreto). O antigo reitor da Universidade de Coimbra, Fernando Seabra Santos, professor da Faculdade de Ciências e Tecnologia, um dos idealizadores da classificação a patrimônio mundial da UC, é o principal responsável pela programação e pelo modelo de funcionamento desse Centro, a convite do presidente do município durante aquele período, João Paulo Barbosa de Melo.
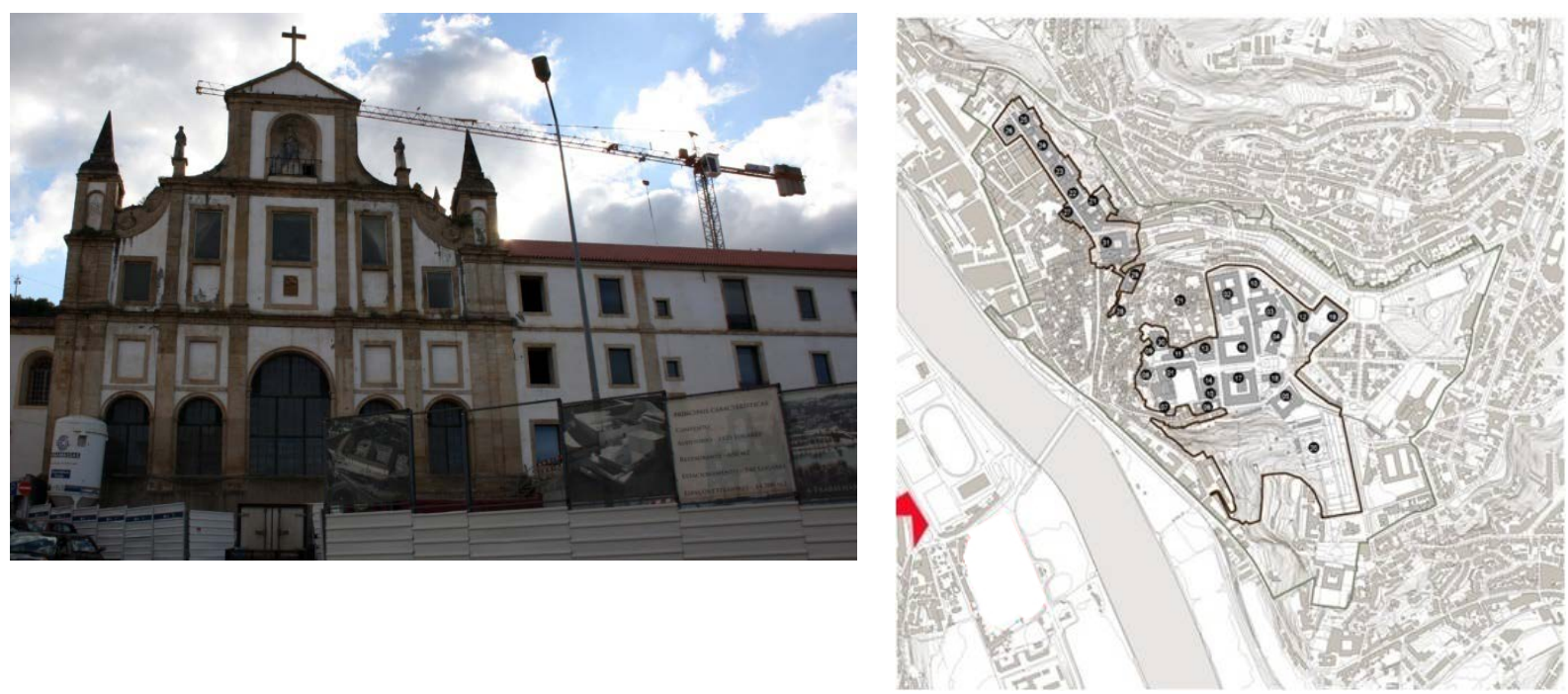

Imagem 98-Construção do Centro de Convenções e Espaço Cultural do Convento de São Francisco, Coimbra, 2012. Fonte: autoria própria. Mapa 55 - Mapa de identificação do Centro de Convenções e Espaço Cultural do Convento de São Francisco, Coimbra. Fonte: Adaptado pela autora sobre base da UC, 2016. 

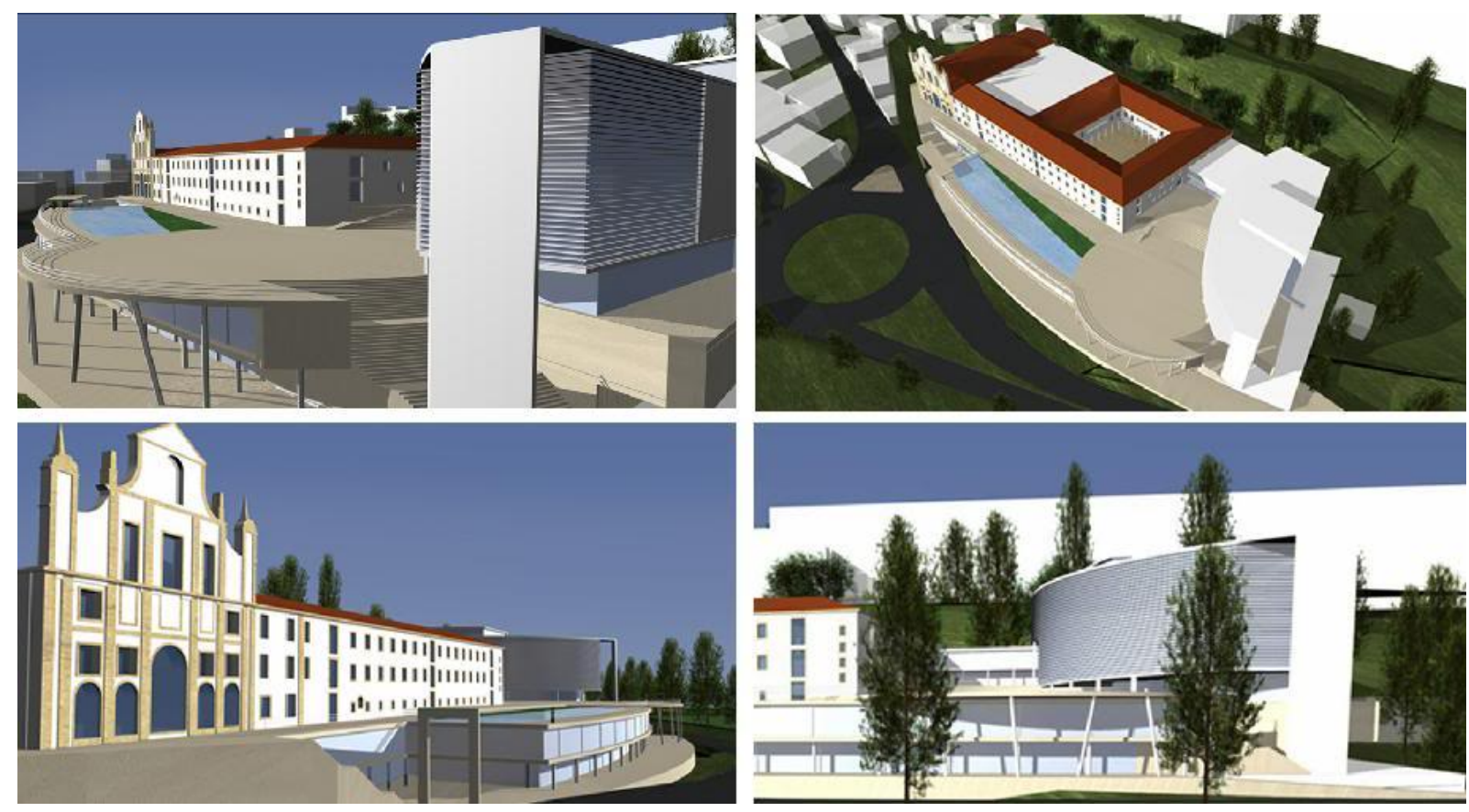

Imagens 99, 100, 101 e 102 - Modelo Virtual do Centro de Convenções e Espaço Cultural do Convento de São Francisco, Coimbra. Fonte: SKYSCRAPERCITY, 2014.

O projeto proposto por esse equipamento prevê um auditório (1125 lugares), salas, um estacionamento (541 lugares), um restaurante e um espaço para a realização de eventos, desde congressos a concertos e óperas ou espetáculos artísticos. No projeto, não observamos uma composição arquitetônica e da paisagem de modo harmonioso com a cidade e com o conjunto histórico do Convento de São Francisco. A contraposição da ordem e do ritmo das aberturas, assim como a materialidade e a composição formal do novo conjunto não evidenciam tão claramente a ideia de um conjunto do antigo e do novo, como sugerem as cartas patrimoniais internacionais (Carta de Veneza de 1964).

Novamente traçamos um paralelo entre essa proposta futura para Coimbra, em Portugal- durante o período de candidatura da UC como patrimônio mundial -, e Belém, no Brasil. São obras já construídas ou em construção, como o Terminal Hidroviário, a Estação das Docas, a Casa das Onze Janelas, o Porto do Sal, o Porto Turístico, o Palacete Pinho, a Escola de Gastronomia, o Boteco Arsenal, o Novo Hotel Atrium, a Quinta de Pedras, o Mangal das Garças, o Portal da Amazônia, a Orla da Estrada Nova. Reconhecemos essas questões em comum nas duas experiências como partes de um sistema de produção do espaço urbano dessas cidades, concatenado com um processo hegemônico que diversas vezes citamos neste trabalho. 
No caso específico de Coimbra, destacamos novamente o trecho da entrevista com o Prof. José António Raimundo Mendes da Silva acercadas proposições futuras na área protegida da UC, na ARU-Alta: "A estratégia é: vamos criar museus, vamos criar bares, vamos criar esplanadas, vamos transformar o espaço público em áreas peadonais, vamos tirar os automóveis daqui". São proposições que expõem uma regularidade de espaços voltados para o consumo, para instituições museográficas, articuladas à indústria do turismo e a uma concepção de cidade voltada para um mercado turístico internacional.

Em relação às intervenções de arquitetura e urbanismo, no contexto da área protegida e seu entorno, observamos, de modo geral, sua coerência, a síntese de linguagem e representação arquitetônica fundamentadas numa leitura embasada do território e de respeito ao patrimônio histórico do bem cultural. Consideramos a experiência arquitetônica portuguesa uma prática positiva de respeito aos elementos históricos e arquitetônicos existentes, à paisagem, à história e ao contexto cultural do lugar nos quais as suas obras arquitetônicas se inserem. 


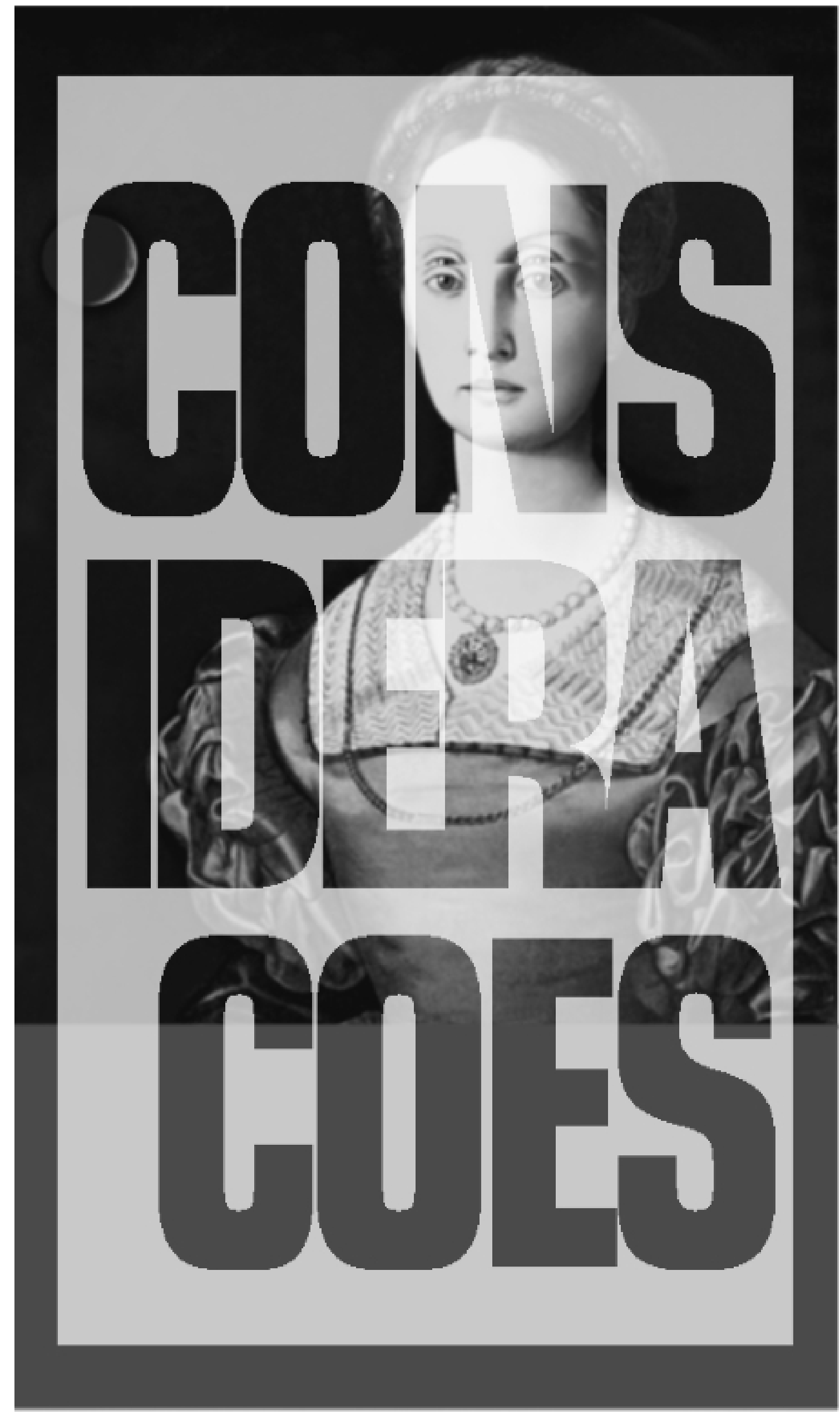




\section{IMAGEM DE CAPA DAS CONSIDERAÇÕES FINAIS}

Montagem feita a partir da obra da artista visual Mariella Bettineschi, L'era successiva. Palma il Vecchio, La bela (Fonte da imagem: DOMUS, 2016). A imagem sugere uma reflexão sobre o corte de uma obra, o arrefecimento da imagem e a partição do olhar. Em nossa reflexão final, do ponto de vista da cultura, questionamos, em determinadas áreas da cidade, as ações preservacionistas que não consideram ou não apreendem a complexidade do território, sua dinâmica de ocupação e uso daquele espaço, e que não permitem intervenções urbanas de ruptura do conjunto patrimonial e o arrefecimento de sua imagem como paisagem cultural. 


\title{
CONSIDERAÇÕES FINAIS
}

\begin{abstract}
Hoy en día, parece evidente que la imagen se ha convertido en una condición necesaria del proceso mismo de la transformación urbana, lo que explica por qué la imagen urbana necesita promoverse y publicitarse antes de que se coloque un solo ladrillo. Si las ciudades actuales necesitan del marketing urbano es porque la imagen de la ciudad es un factor básico para atraer inversiones y capital. No es esta una cuestión poco importante, pues el papel de las políticas urbanas, y también de la arquitectura, se reduce en cierta medida a la producción y reproducción de imágenes urbanas (MUÑOZ, 2005, p. 82).
\end{abstract}

Após nos determos nos meandros de alguns processos de classificação a patrimônio mundial pela UNESCO, nas especificidades de seus conceitos em relação ao patrimônio, nas normativas e diretrizes, bem como nos instrumentos e mecanismos de atuação, percebemos, sob a perspectiva da globalização e da cidade contemporânea, que a operacionalização desses processos está diretamente relacionada à convergência do conteúdo cultural e social nas transformações do espaço urbano.

Os desdobramentos dos processos de classificação mundial que analisamos permitem-nos afirmar que se trata de processos hegemônicos de produção do espaço urbano de Belém e de Coimbra, em que as transformações estão atreladas à implementação de um "modelo de sucesso" nessas cidades, modelo inspirado nos patrimônios já classificados pela UNESCO. Isso nos fez compreender também que os processos de classificação convergem em estratégias de planejamento que tentam internacionalizar as cidades.

Embora durante o período desta pesquisa as iniciativas de candidatura a classificação estudadas fossem recentes, percebemos existirem, nas duas cidades, processos de patrimonialização mundial anteriores à formalização das candidaturas pela UNESCO, ou seja, anteriores à nomeação de seus bens na lista indicativa a patrimônio mundial. Também percebemos que a atribuição do adjetivo "candidato" já foi suficiente para garantir uma promoção e uma publicidade da imagem urbana dessas cidades "antes" de serem classificadas - referimo-nos, segundo Muñoz, a um momento anterior à determinação dos bens culturais como mundiais, devido à possibilidade de promoção que a divulgação da lista indicativa da UNESCO traz às cidades. 
A dimensão de um processo em andamento trouxe-nos algumas dificuldades ao trabalho justamente pela necessidade de estabelecer um ponto final do campo empírico para sua análise e pelos questionamentos interdisciplinares que a pesquisa se propõem a despertar. Assim, mediante à dificuldade de organizar cronologicamente as informações obtidas, de modo estruturado e relacionando o campo da preservação do patrimônio e da produção da cidade, conseguimos aprofundar melhor algumas frentes de problematização em detrimento de outras, que foram apenas esboçadas.

Algumas dessas questões apenas esboçadas referem-se às experiências, comuns aos dois objetos de estudo, de dois momentos principais de ação de seus processos de classificação mundial. A divisão em dois momentos permite elaborar reflexões aprofundadas em relação a seus diferentes conjuntos de ações de intervenção no patrimônio, por meio de uma organização cronológica articulada, em função de seus processos de candidatura. Esses dois momentos são: uma candidatura de caráter preliminar e uma candidatura estruturada e consolidada.

Os documentos primários - documento e dossiê de candidatura - fazem referência à existência de patrimônio imaterial e de certo modo se sustentam nessa existência. No entanto, os dados empíricos levam-nos a questionar a forma de suas abordagens: observamos uma ausência de medidas efetivas de formalização da preservação do bem imaterial ou de diretrizes de ação que os considerem referências culturais existentes e presentes, a fim de não causar interferências e amenizar uma possível reorientação de suas expressões e manifestações.

Essa observação nos leva a contestar - e a apenas esboçar essa contestação - a atual categorização de patrimônio mundial pela UNESCO (natural, material, imaterial, sítio arqueológico, paisagem cultural): seria essa categorização suficiente para salvaguardar ou mesmo expressar/registrar a relação entre patrimônio material e imaterial, segundo a ideia de um "solo cultivado" (FONSECA, 2000, p. 86), nas regiões?

Outros problemas que percebemos ainda sequer foram enfrentados. Por exemplo, as iniciativas internacionais de preservação ao patrimônio, tais como as do BID, comparadas à atuação da UNESCO, e o alcance de suas relações com os órgãos de preservação nacionais de cada país, bem como suas transversalidades na produção do espaço urbano. Esperamos que as questões que despertamos por meio deste trabalho tenham continuidade em novas pesquisas futuras. 
Percebemos problemas presentes, por exemplo, em Coimbra, na criação da Associação RUAS e no depoimento do Prof. Raimundo M. da Silva, segundo o qual "a UNESCO não quer vir falar com a Câmara, com a Universidade, com os proprietários, a UNESCO quer ter uma figura formal que responda perante o bem, que fale com as entidades, que disponha de acordo, que responda perante a UNESCO, e que no fundo seja a salvaguarda do bem" (SILVA, 2012). Não enfrentamos ainda nossa observação direcionada à escala daquele local, numa tentativa de compreender a operacionalização da UNESCO diretamente relacionada às formas de organização social necessárias ou criadas para a assimilação do processo.

Também percebemos a mesma tentativa de construção de formas de organização social local em Belém - Associação de feirantes, Associação das Erveiras e Erveiros, Associação dos Balanceiros do Entreposto Pesqueiro do Ver-o-Peso -, cuja atuação está diretamente relacionada à convergência do conteúdo cultural e social nas transformações do espaço urbano. Ali, identificamos algumas "figuras formais" que "disponham de acordo", naquele universo de mercado, venda e consumo constituído de diferentes "cadeias produtivas" (LIMA, 2016) da Feira Livre do Ver-o-Peso.

Uma dessas tentativas foi, segundo a superintendente do IPHAN-PA, Maria Dorotéa Lima, na sua descrição sobre a experiência de elaboração do Inventário Nacional de Referências Culturais do Ver-o-Peso, o fato de que esse inventário fundamentou, com a participação da Associação Ver-as-Ervas, a documentação do processo de classificação mundial do Ver-o-Peso. Essa ação correspondeu a uma tentativa de parceria entre o IPHANPA e uma associação local, bastante representativa, anteriormente ao processo, como uma organização social na feira:

(...) foi um processo com a Natura [empresa Natura Cosméticos S.A], era uma coisa muito complicada, acabou que o negócio [Associação Ver-asErvas] se implodiu, foi uma coisa muito complicada, alguém ainda deve estar estudando isso, porque tem várias representações lá, mas não tem uma ONG, e como elas estavam bem legalizadas e tudo, a gente conseguiu trabalhar com elas [na elaboração do INCR do Ver-o-Peso]. Então é isso, a gente ia juntar tudo isso, era subsídio para o dossiê e anexar no processo, porque na verdade o dossiê em si não é tanto, mas são esses anexos, que subsidiam a proposta (LIMA, 2016). 
Vale destacar que foi importante ao trabalho a busca pela interpretação interdisciplinar dos vários campos de conhecimento do tema, na sua estruturação e fundamentação segundos diferentes pontos de vista analíticos, ao invés de recorrer a uma única teoria ou conceito para sustentar todo o trabalho. À medida que a pesquisa se desenvolvia, alguns aspectos se tornaram centrais: a dimensão cultural da preservação do patrimônio cultural na atualidade; as especificidades de um processo conduzido pela UNESCO; e o processo de produção da cidade por meio de um planejamento que busque projetar a cidade internacionalmente.

Recorremos a um estudo aprofundado sobre a problemática da valorização dos bens culturais, o que remete à tradução de uma cultura, de uma identidade coletiva, da seleção de camadas da memória, bem como da dialética do "lembrar-esquecer" das políticas de preservação, pois "privilegiam-se certos aspectos em detrimento de outros" (CASTRIOTA, 2009, p. 93). Nesse âmbito, que também remete ao consentimento coletivo, tentar compreender o universo cultural e os valores estabelecidos em sociedade fez-se necessário para compreendermos o sentido dos bens culturais de nossos objetos de estudo.

Deparamo-nos com um sistema de preservação cultural operacionalizado pela UNESCO com uma normativa particular e específica, fundamentada no direito internacional do meio ambiente e na relação de propriedade com os bens culturais. Esse sistema fez-nos repensar a sua dimensão político-institucional, em que percebemos outra dialética: a escala "supranacional-local" configurada pela classificação dos bens culturais considerados mundiais.

Reconhecemos algumas particularidades, nos processos de patrimonialização mundial estudados, quanto a buscar desenfreadamente (PEIXOTO) algum tipo de patrimônio nas cidades e a legitimá-los, ao mesmo tempo em que são legitimados, por meio de imagemaking (ARANTES, 2000, p. 14) e da criação de uma história da cidade que é desarticulada da memória coletiva do lugar. No caso de Coimbra, isso ocorreu com a incorporação da Rua da Sofia à área do bem cultural, por um interesse da Câmara Municipal em classificar essa região da cidade. No caso de Belém, ocorreu com o discurso iniciado nos anos de 1980 em relação à Ladeira do Castelo como a primeira rua da cidade, em vez da rua Siqueira Mendes, já historicamente reconhecida, e também com o discurso de interesse do poder público municipal e estadual do Pará. 
Esses discursos buscam uma "singularidade" e uma "particularidade" que sejam "cruciais para a definição de 'qualidades especiais'" (HARVEY, 2005, p. 223), como requisitos de negociabilidade do espaço urbano. Isso nos leva a refletir sobre alguns aspectos que devem ser levantados, tal como aponta Marilu Márcia Campelo (2002, p. 151):

A quem interessa essa "corrida" em busca do título de Patrimônio da Humanidade? Como preservar uma área cujo processo de descaracterização ambiental e arquitetônico já vem ocorrendo há muito tempo? Será possível reconstruir o que já foi destruído? O Complexo do Ver-o-Peso, principalmente a sua feira, tem condições de receber este título? Por último, a quem pertence, de fato, o patrimônio cultural existente?

É possível verificar que, ao longo dos últimos anos, têm sido construídos, em ambas as cidades tomadas como estudo de caso deste trabalho, espaços e intervenções nos espaços urbanos patrimoniais, patrocinados, em sua maioria, pelo Poder Público, configurando um "padrão de conduta na governança urbana que combina poderes estatais (...), diversas formas organizacionais da sociedade civil [....] e interesses privados (empresariais e individuais), formando coalizões para fomentar ou administrar o desenvolvimento urbano/regional de um tipo ou outro" (HARVEY, 2005, p. 230).

Tal "modelo de sucesso" vem sendo "difundido" pela ação combinada de uma instituição multilateral e de consultores internacionais (VAINER, 2000, p. 8), ação que baliza novos andamentos de classificação a patrimônio mundial segundo os parâmetros e conceitos patrimoniais das cidades. Assim, a classificação como "patrimônio mundial" comparece atrelada à mundialização da cultura e também à busca por novas alternativas de reprodução do capital, inserindo-se num contexto de acirramento da competição entre territórios e regiões.

Esse sistema pode ser também definido como um "modelo de internacionalização patrimonial" operacionalizado pela UNESCO, fundamentado numa dimensão cultural de preservação do patrimônio de "todos os povos" e da permanência dos signos culturais únicos dos lugares. No entanto, por meio de nossos estudos de caso, em Belém e Coimbra, percebemos que tal sistema se apresenta tal como uma nova busca por uma identidade do lugar - "nova" em relação à sua escala de abrangência e pela própria definição que sua classificação almeja, como patrimônio mundial. Essa identidade configura uma tentativa de 
tradução das relações sociais e culturais do lugar, de modo a promovê-lo como algo singular e particular, por meio das "qualidades especiais" (HARVEY, 2005, p. 223) de seu patrimônio cultural.

Desse modo, a operacionalização da UNESCO e seu intermédio por meio de diretrizes e normativas específicas para viabilizar o processo de classificação, é vista por este trabalho como uma estratégia de marketing urbano e de competição entre cidades.

As informações sobre a operacionalização desses processos de classificação, em que verificamos uma série de particularidades, assinaladas no primeiro capítulo de nosso trabalho, são fornecidas por manuais traduzidos em diversos idiomas, e o conhecimento é ofertado por consultorias internacionais. A maioria dessas consultorias é realizada por membros dos órgãos consultores da UNESCO, em sua maioria do ICOMOS. Elas são caracterizadas como um aconselhamento sobre a definição do conceito e do (s) bem (ns) cultural (is) a ser (em) nomeado (s) na cidade e sua respectiva área de entorno. Esse aconselhamento apresenta como referências outros processos de patrimonialização mundial já classificados anteriormente. Assim, os órgãos consultores internacionais de proteção ao patrimônio, composto por especialistas em preservação de bens culturais, corroboram para o desencadeamento de um processo transversal em relação à cidade e à produção de seu espaço urbano.

Nessa transversalidade, alguns aspectos da economia urbana das cidades podem ser verificados, segundo Carlos Vainer (2000, p. 100), através da oferta, por meio da requalificação dos Centros Históricos, de "infra-estruturas e serviços" por um preço de custo reduzido para grupos particulares que possam ali se instalar ou deles usufruir. Esse custo é proporcionado pela própria lógica de concorrência entre cidades, que amplia as possibilidades de escolha para esses grupos, uma vez que oferta "um número cada vez maior de cidades com os atributos locacionais indispensáveis" (VAINER, 2000, p. 100) para sua implantação e para o desenvolvimento de suas atividades.

Em relação a Coimbra, verificamos que o processo de sua classificação mundial se insere numa lógica de "oferta de infra-estrutura e serviços" de modo articulado entre os grupos políticos locais, organizado pelo "poder estatal" (Câmara Municipal de Coimbra), por "diversas formas organizacionais da sociedade civil" (Universidade de Coimbra e Associação RUAS) e por "interesses privados (empresariais e individuais)" (representados principalmente pela indústria do turismo), "formando coalizões para fomentar ou 
administrar o desenvolvimento urbano/regional de um tipo ou outro" (HARVEY, 2005, p. 230). Tal busca pelo desenvolvimento urbano/regional comparece por meio das propostas de seu zoneamento urbano e de planejamento estratégico com diretrizes futuras de uso e de ocupação do solo, relacionados ao plano diretor da cidade e ao próprio patrimônio mundial.

Desse modo, a articulação das ações das organizações de proteção do patrimônio e de planejamento urbano na cidade de Coimbra constitui uma forma de coalizão, e corrobora para a continuidade do processo hegemônico de produção do espaço urbano por meio de um processo de patrimonialização.

Já, no caso de Belém, tais questões não estão tão bem articuladas. Há divergências e falta de continuidade nas medidas de implementação das intervenções no patrimônio. Como consequência, estão ausentes os financiamentos públicos ou mistos nas intervenções de requalificação no patrimônio vinculadas ao processo de patrimonialização mundial do Ver-oPeso. Pela própria ausência de continuidade na operacionalização técnica desse processo por parte do poder público, a implementação do modelo de patrimonialização mundial na área central de Belém tem encontrado diversas ações de resistência por parte da sociedade civil. Verificam-se diversas manifestações coletivas de resistência (manifestações culturais contrárias à implementação de um instituto gastronômico, "Espaço Gastronômico Cultural da Amazônia", na Casa das Onze Janelas; críticas à execução do novo projeto da Feira Livre do Ver-o-Peso etc.), organizadas contra algumas ações do poder público e contra a ausência de uma articulação entre as ações dos órgãos de preservação e de planejamento urbano.

Assim, podemos afirmar que, nos processos de patrimonialização mundial que analisamos neste trabalho, a transformação do solo urbano em uma espécie de mercadoria com uma dimensão cultural, expressa segundo uma questão ideológica, verifica processos hegemônicos de produção da cidade que apresentam regularidades em relação à condução desses processos pela UNESCO. Essa questão ideológica é expressa tanto no planejamento urbano e estratégico que configura a composição da paisagem cultural dessas cidades, quanto na lógica das intervenções no patrimônio que cria novos de espaços de rápida assimilação do passado, por meio da reprodução de imagens, sejam elas imagens subjetivas, apreendidas pela leitura do conjunto patrimonial físico, sejam elas imagens midiáticas planejadas. 
Nesse cenário, algumas das intervenções de requalificação da cidade encontram-se atreladas a discursos de preservação do patrimônio cultural e a processos de "patrimonialização mundial" através de ações conjuntas entre as áreas preservadas e uma concepção internacional de cidade.

Uma das singularidades da experiência de Coimbra, em relação à de Belém, é que a articulação das ações preservacionistas e de requalificação do patrimônio está ligada a um plano estratégico fundamentado em um zoneamento urbano, que estrutura a assimilação mais rápida daquele processo hegemônico de produção da cidade segundo uma lógica capitalista por meio de um zoneamento que prevê uma série de ações de intervenção segundo um planejamento urbano global.

Alguns fatores levaram-nos a compreender que esse "modelo patrimonial", em Coimbra, foi incorporado como um hipotético equilíbrio: a agilidade do processo da Universidade de Coimbra, desde sua idealização à sua classificação; a rápida incorporação das indicações e considerações do órgão consultor internacional; a articulação entre os órgãos de preservação e o Poder Público; e até mesmo a ausência de uma produção crítica científica acadêmica representativa em relação a tal processo de patrimonialização e ao planejamento urbano da cidade. A publicidade da candidatura da Universidade de Coimbra era promovida pelo próprio bem e buscava uma conscientização da população da cidade em relação a esse processo classificatório, tal como uma educação patrimonial, centrada na vinda à cidade dos consultores internacionais e na consulta que eles fariam à população local de modo a avaliar a identificação coletiva dos moradores com o bem cultural.

Em contraposição, em Belém ${ }^{154}$, as ações não são articuladas entre si da mesma forma, o que não garante uma rápida assimilação e incorporação do "modelo patrimonial".

${ }^{154}$ Verificamos, durante o desenvolvimento de nosso trabalho, a ausência de dados do IBGE em relação à evolução urbana e à cronologia construtiva das edificações. Consideramos que, para a elaboração de uma cartografia com o mapeamento da evolução urbana e da cronologia construtiva do conjunto urbano considerado patrimônio da área central da cidade de Belém (Centro Histórico), definido pela área protegida de Ver-o-Peso e sua área de entorno, seria importante o levantamento da cronologia construtiva das edificações pelo IBGE, tal como é realizado pelo Instituto Nacional de Estatística (INE) em Portugal.

Os dados do IBGE, desde 2001, são estabelecidos segundo um conjunto de conteúdos mínimos comuns - econômicos e sociodemográficos, geográficos, de recursos naturais e meio ambiente para os próximos censos populacionais, com o objetivo de obter informações comparáveis para todos os países membros do MERCOSUL, revelando um esforço de permitir a compatibilização da produção de dados demográficos de diferentes países - esse acordo acompanha a tendência 
Isso nos faz pensar na fundamentação das bases desse modelo em um conceito ocidentalizado de patrimônio e de cidade, que pode vir a favorecer processos centrados na patrimonialização de bens culturais considerados "ocidentais". Assim, reforçamos nossa compreensão de que o caso de Belém se apresenta como maior resistência em relação à assimilação do "modelo de patrimonialização", mas a produção de seu espaço continua atrelada a outras formas de transformações urbanas que esse modelo hegemônico constitui. Persiste um cenário de intervenções na orla e nas áreas patrimoniais do Centro Histórico da cidade, ainda que de modo desarticulado entre si, sem uma concepção global de todas as iniciativas, corroborando para a descaracterização do conjunto de sua paisagem cultural.

No entanto, o planejamento urbano da cidade de Belém já tem se beneficiado da publicidade de uma imagem patrimonial ao promover o Ver-o-Peso - talvez em uma escala de menor alcance de divulgação e como uma possibilidade futura e incerta - como um bem cultural candidato a patrimônio mundial, buscando a transformação urbana e a captação de investimentos para a cidade.

Portanto, fazer parte desse processo de classificação mundial revela um posicionamento, por parte do Estado membro (país), em relação a uma política internacional conduzida pela UNESCO, ao aderir à sua Convenção do Patrimônio Mundial, como é o caso do Brasil e de Portugal, e em relação as outras instâncias de âmbito nacional que almejam essa classificação por meio de seus processos classificatórios.

internacional, particularmente o empenho da ONU e de agências multilaterais, de compatibilizar a produção de estatísticas oficiais dos diferentes países (IBGE, 2016). Buscando complementar e ampliar análises ambientais relacionadas ao tema do patrimônio e do espaço urbano, este trabalho propõe a incorporação de alguns novos conteúdos auxiliares em novos censos demográficos, pois esse tipo de informação complementar subsidiaria um estudo sistemático de identificação das tipologias arquitetônicas, as formas de ocupação mantidas, modificadas e criadas no conjunto urbano da área, considerando o perímetro de tombamento delimitado pelo IPHAN em 2011 e suas edificações, e poderia também ser estendido para a infraestrutura urbana, mapeando a cronologia do aterro e demais arruamentos, largos e praças na organização do Centro Histórico de Belém. Isso permitiria analisar as transformações ocorridas no tecido urbano original, identificar a implantação das capelas e das igrejas no século XX, becos ou ruas suprimidos, ampliados ou alterados, abertura de novos arruamentos no sítio ou de acesso a ele, a cronologia dos logradouros públicos no século XX. 
Esse posicionamento em relação a uma política internacional talvez seja a principal dimensão das experiências de Coimbra e de Belém, relativa à existência de um processo hegemônico de produção do espaço urbano em uma escala global. Nossa observação de seus processos em curso faz-se numa perspectiva que considera as dimensões e articulações existentes em uma escala local e a sua passagem, ou tentativa de passagem, à uma dimensão global, considerando as diferentes escalas compreendidas nessa transformação da escala nacional, regional e da cidade -, e as interações existentes dentro desses universos inseridos numa ideia de mercantilização e mundialização da cultura.

A experiência comum das duas cidades, em relação a uma dimensão territorial atrelada à questão cultural, revela-nos efeitos controversos ao ser aplicada em contextos singulares, diversos e localizados (WARNIER, 2000), tal como rege o preceito conceitual dos bens culturais priorizados pela classificação da UNESCO.

A observação dessas duas experiências indica diferenças quanto ao andamento e ao desencadeamento de seus processos. São diferenças relacionadas, principalmente, à ausência ou não de conflitos políticos na cidade, à capacidade ou à incapacidade de articulação entre os diferentes órgãos de preservação e o Poder Público e à participação em maior ou menor medida da população na construção dos processos, acima de qualquer outra questão técnica que poderia ser apresentada na construção de um processo de preservação patrimonial.

Analisando as diferenças culturais, econômicas, administrativas e legislativas de seus países, fundamentamos nosso olhar na atual existência dos dois processos classificatórios, o que, grosso modo, igualou as possibilidades de classificação de seus bens culturais, pois foram anteriormente avaliados pela UNESCO quanto à estrutura dos órgãos de preservação, à sua legislação e às normativas nacionais.

Esse olhar levou-nos a aprofundar o estudo das políticas de preservação no Brasil. Buscando compreender melhor a questão da legislação e das políticas de preservação do patrimônio no país, salientamos, a partir de uma visão antropológica, algumas iniciativas de construção de processos de classificação mais democráticos, legitimados com a Constituição de 1988, e que propunham experiências inovadoras de preservação de bens culturais e produtos brasileiros, como foi o caso do Centro Nacional de Referência Cultural (CNRC). Posteriormente, como um aprimoramento dessas experiências, surgem os Inventário 
Nacional de Referências Culturais (INRC), que abrangem uma dimensão mais ampla do patrimônio ao incorporar seus aspectos materiais e imateriais.

Tais INCR auxiliaram a registrar e a compreender parte da dimensão cultural e simbólica do Complexo Ver-o-Peso. A importância desses inventários fica evidente quando eles aparecem citados no processo de classificação mundial, o que revela um reconhecimento de uma dimensão cultural ampla por parte dos idealizadores do processo ligados ao órgão de preservação nacional - IPHAN.

Embora no estudo de caso de Coimbra existam patrimônios imateriais incorporados ao processo classificado, eles estão relacionados à dimensão cultural acadêmica universitária e são centrados em tradições e vivências dos estudantes universitários e suas práticas. Mas não observamos nenhum tipo de registro ou produção acadêmica que se aproximem dos INCR brasileiros, assim como percebemos a ausência de políticas de preservação que busquem salvaguardar essas referências culturais da cidade.

O mote da patrimonialização, no nosso caso, deveria ser a relação metrópole-floresta, metrópole-rio, essa é a nossa identidade maior, e o Ver-o-Peso expressa bem como síntese disso, mas não é só o Ver-o-Peso, existem vários espaços que expressam muito bem isso. $E$ aí poderia entrar o Paracurí, poderia entrar os portos e trapiches todos da cidade, agora, é claro, antes disso é preciso que a prefeitura e o[governo do] estado em vez de criarem polos gastronômicos, deveriam criar políticas para preservar estes espaços, que estão descobertos do ponto de vista das políticas urbanas, porque eu acho que tem algo anterior, a cultura está viva, ela resiste, o patrimônio imaterial e material também, porque as pessoas estão lá, as funções estão lá. Mas faltam formas arquitetônicas espaciais urbanas que traduzam isso, essa riqueza desses conteúdos e isso não está colocado [nas atuais políticas] (TRINDADE JÚNIOR, 2016).

Segundo Saint-Clair Trindade Júnior, quanto aos aspectos de uma paisagem cultural em Belém, o dinamismo do contexto cultural do Complexo Ver-o-Peso configura um sistema que não está concentrado apenas na área central da cidade. Ele configura um sistema de redes localizado em diversos pontos da cidade. Ou seja, está presente além dos limites do tombamento do bem cultural (COSTA, 2015, p. 27) e seu contexto social e territorial guarda relações com a cidade como um todo. Essas redes - a rede de fornecimento e distribuição do Ver-o-Peso e de outros trapiches da cidade, a rede gastronômica, a rede de artesanato de 
ICOARACI, entre outras - distribuem-se em diversos pontos do território ${ }^{155}$ belenense e são consideradas "descobertas" em relação à existência de políticas culturais que garantam a preservação de sua existência.

No entanto, constatamos que mesmo desamparadas de políticas de preservação, essas manifestações resistem e expressam a vida atual na cidade de Belém. Elas mantêm seu dinamismo - expresso pelas próprias relações que guardam com o bem cultural do Ver-oPeso, uma vez que fazem parte de seu sistema de redes de fornecimento e distribuição -, embora não haja uma forma arquitetônica espacial urbana que as traduza e que estruture seu processo de conservação. Essa concentração de políticas de preservação urbana é contraditória na conservação do patrimônio na cidade, pois não consideram a complexidade de seu sistema patrimonial, ligado às particularidades do ambiente urbano amazônico. Desse modo, consideramos que a estruturação da candidatura de Ver-o-Peso como patrimônio mundial é contraditória quanto às manifestações culturais deste bem cultural, cujo patrimônio imaterial e cujas áreas além das limitadas pelo tombamento pelo IPHAN deveriam ser abarcados.

Nossas reflexões em relação ao caso do Ver-o-Peso também nos levam a questionar as limitações impostas pelos critérios de classificação estabelecidos pela UNESCO: eles seriam realmente aplicáveis em regiões como a Amazônia, em que a complexidade do ambiente urbano, relacionado diretamente com o contexto natural, se distanciam de muitos dos conceitos de bens culturais anteriormente classificados no Brasil e no mundo, e que são concebidos segundo uma concepção de bem cultural ocidentalizada?

Nessa dinâmica, as áreas de entorno do Centro Histórico, que também são áreas de entorno do Complexo Ver-o-Peso, são consideradas áreas de transição por este trabalho e correspondem a "faixas" mais flexíveis de proteção e preservação do patrimônio histórico, pois nessas áreas a legislação municipal permite construções de renovações arquitetônicas em relação ao conjunto patrimonial. Esse foi o caso da proposta de intervenção do Centro Comercial Bechara, no Conjunto da Praça Frei Caetano Brandão, que a princípio recebeu uma licença de construção pelo Poder Público municipal, mas acabou sendo revogada após críticas dos órgãos técnicos de preservação e de uma audiência pública.

\footnotetext{
${ }^{155}$ Ver: APÊNDICE B - Entrevista 4.
} 


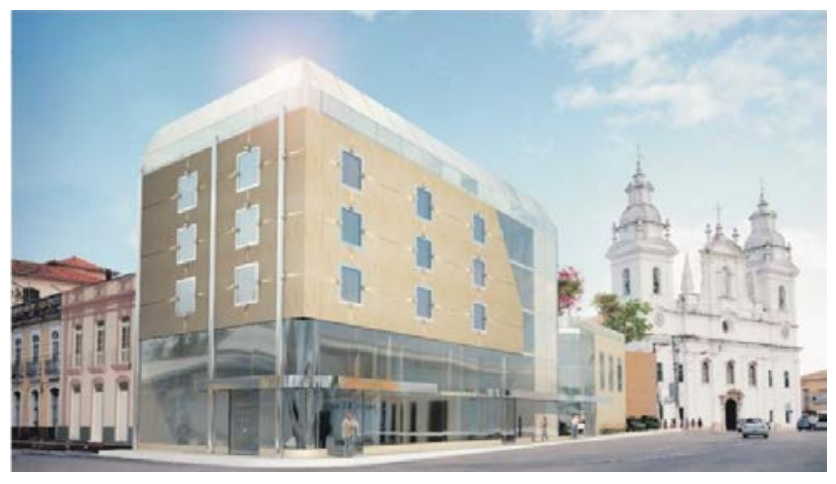

Imagem 51-Vista da maquete eletrônica da proposta do novo centro comercial Bechara Mattar Diamond, na área de entorno do Vero-Peso, Belém, 2014. Fonte: Página de abaixo-assinado Change.org.

A proposta desse Centro Comercial foi considerada uma obra que descaracterizaria o conjunto, e a crítica acusou o projeto de não ter elaborado um estudo de impacto à vizinhança (EIV), um instrumento de planejamento e gestão urbana instituído pelo Estatuto das Cidades. A aprovação do projeto, pela esfera municipal, revelou, naquele momento, a falta de consonância dos instrumentos e normativas de preservação no município de Belém, a falta de articulação entre as diferentes esferas de proteção do patrimônio (municipal, estadual e federal) e a falta de um planejamento urbano que considerasse medidas preservacionistas nas áreas protegidas e de entorno de modo mais coerente.

Em relação às articulações das diferentes instâncias de proteção, averígua-se, no espaço urbano, a existência de espaços "de transição" entre as áreas internas e externas (áreas de entorno) protegidas. Neles, as intervenções no patrimônio não são pautadas por considerações particulares e distintas das diretrizes e normativas de preservação estabelecidas para o CHB. Reconhecemos, na configuração dessas áreas, uma lógica de produção das cidades regida pelo lucro como critério de uso do solo urbano, o que facilita o estabelecimento e a implementação de ações por parte do setor privado em espaços urbanos próximos às áreas patrimoniais, posto que tais áreas oferecem a materialização de um consumo sofisticado (CHAUÍ, 1992, p. 38).

Salienta-se, assim, um planejamento urbano desarticulado, pois é nas áreas "de transição" que acontece a pré-seleção para investimentos do setor privado, justamente porque a mudança é mais suscetível. Isso escancara uma incapacidade do planejamento urbano de conceber tais áreas de maneira global e integral em relação à cidade e à ideia de conjunto patrimonial e de conformação de uma paisagem cultural. 
No que tange algumas possibilidades de tentativa de democratização do espaço urbano por meio da manutenção da população em áreas de interesse histórico, e de suas funções de interesse social, salientamos a utilização de benefícios fiscais e tributários. Seria possível criar políticas habitacionais que favoreçam a locação social e possibilitem um retorno às atividades mistas de uso e ocupação do solo, tal como a região da cidade era constituída quando a sua matriz histórica foi criada e consolidada (MENA, 2003, p. 132). Vale ressaltar que esses imóveis considerados patrimônios históricos costumam apresentar um custo de conservação mais oneroso em detrimento de outros tipos de imóveis sem o mesmo valor.

No entanto, de modo diferente de outros centros históricos, Belém não conta com um programa integrado que incorpore a moradia de sua população já residente, ou que incentive a moradia de uma população de baixa renda. Já, em Coimbra, foi possível verificar que há previsões de incentivo de novas moradias em novas edificações ou em edificações reabilitadas na área de proteção do bem cultural, mas não há políticas habitacionais que assegurem a manutenção dos moradores que residem na região.

Também ressaltamos, em relação a Belém, a possibilidade de aplicação de instrumentos do Estatuto da Cidade que poderiam ser utilizados em parceria com o tombamento, tal como a Transferência do Direito de Construir. Tais instrumentos ofereceriam, aos proprietários de imóveis localizados em sítios tombados ou protegidos, uma possibilidade de preservar a ambiência e a paisagem cultural do local, e impediriam que novas intervenções na área interferissem e modificassem os elementos e as características culturais do conjunto urbano.

Abaixo, cita-se um texto produzido pelo Departamento do Patrimônio Histórico de São Paulo, em 1991, para o Congresso Internacional Patrimônio Histórico e Cidadania, em razão do debate sobre o tema da preservação patrimonial, expondo alguns impasses que ainda não foram superados em relação à produção do espaço urbano nas cidades:

As razões para esta disparidade não são difíceis de compreender: aplicadas a bens móveis como objetos de arte, coleções de documentos privados, fotografias, mobiliário, e assim por diante, a legislação de proteção ao patrimônio histórico contribui para valorizá-los ao máximo perante as leis de mercado, por significar na prática uma espécie de certificado de autenticidade e valor cultural - que, nas sociedades capitalistas, significa igualmente valor financeiro no restrito e sofisticado negócio das "antiguidades"; mas quando aplicada aos bens imóveis de significação 
histórica e cultural, esta mesma legislação tem sido entendida e duramente combatida entre nós como um verdadeiro atentado aos direitos de propriedade, porque significaria na prática a desvalorização de bens particulares, na maioria das vezes com alto valor monetário(CHAUí, 1992, p. 38).

No entanto, os resultados demonstram, sob os aspectos econômico e social, tais intervenções nesses espaços não condizem parcial ou inteiramente com os critérios de preservação adotados pelos órgãos responsáveis pela proteção do Patrimônio Cultural. Seus sistemas de gestão não beneficiam diretamente as comunidades locais nas quais se inserem, tal como aponta a Carta do Turismo Cultural, do ICOMOS.

No processo de patrimonialização de Ver-o-Peso, verificamos o desenvolvimento econômico problemático das comunidades. Afinal, se, por um lado, são reconhecidas atividades que geram empregos e produzem dinheiro e lucro em uma escala local, por outro, o controle deste local é também reconhecido como de "qualidade especial" por atores sociais específicos, os quais controlam de alguma forma as suas atividades, e que não necessariamente correspondem a uma escala local.

Verificou-se, a partir da análise dos projetos Ver-o-Rio e Praça do Pescador, inseridos no Complexo Ver-o-Peso -cujas propostas de intervenção foram elaboradas com a participação das comunidades de trabalhadores e pescadores -, que foram realizadas tentativas de auxiliar na economia local, incentivando cooperativas de trabalhadores e de pequenos empreendedores. Por outro lado, no projeto da Estação das Docas, verificou-se um favorecimento a grupos de empreendedores considerados mais aptos a requalificar e a oferecer atividades voltadas aos interesses de um público seleto, de maior potencial solvável.

No Brasil, quanto à paisagem do conjunto patrimonial, as intervenções muitas vezes não respeitam a harmonia e o equilíbrio estabelecidos pela composição, sobretudo no que diz respeito a projetos considerados como "renovação arquitetônica". Citamos, como exemplos, intervenções em centros históricos próximos a orlas marítimas, como é o caso do Projeto Novo Recife, no Cais José Estelita, com a previsão da construção de torres integradas ao centro histórico e à orla Recife-Olinda, ou mesmo o caso recente, bastante divulgado pela mídia brasileira, da construção de uma torre de trinta andares em Salvador (BA), na Ladeira da Barra, cuja obra foi suspensa em 2016 pelo IPHAN. 
No Brasil, também é possível verificar inúmeras tentativas de intervenções no patrimônio por meio de abordagens conceituais recentes dos bens culturais, que contam com um processo de classificação sem aprovação dos órgãos locais ou nacionais. Essas intervenções revelam um conflito de interesses no campo da preservação patrimonial em centros históricos. É o caso, por exemplo, da cidade de Ribeirão Preto (SP), com a tentativa de configuração de uma "Paisagem Cultural do Café"156 e sua solicitação de tombamento pelo IPHAN - ainda não aprovada -, a qual se liga a uma série de intervenções na cidade, que preveem a construção de um "Museu do Amanhã", uma Universidade ou Instituto Cervejeiro, Bibliotecas e Centros Culturais em patrimônio industrial desativado e em desuso.

Observamos, também, algumas especificidades em relação a outros processos de patrimonialização mundial, em que não é necessária a mediação de órgãos locais ou nacionais de preservação do patrimônio, tal como é caso do patrimônio imaterial mundial pela UNESCO. Destacamos a recente classificação do Círio de Nazaré e Cidade Criativa da Gastronomia da cidade de Belém, classificados em 2013 e 2015, respectivamente. Constatamos que esses processos têm despertado o interesse de setores privados em detrimento de outros processos cuja operacionalização pela UNESCO exige a mediação e a condução por órgãos articulados ao Estado do país.

Assim, nossas constatações gerais, por meio deste trabalho, propõem como desafio uma ampla revisão conceitual das práticas e das soluções adotadas pelos países em relação à preservação do patrimônio, buscando superar impasses teórico metodológicos e apontando caminhos e alternativas para futuras intervenções. Nas áreas de preservação, é possível verificar a permanência de grupos privados que buscam materializar um espaço de consumo sofisticado, por meio de estratégias atreladas ao patrimônio cultural, mas que contradizem alguns aspectos de políticas públicas de preservação patrimonial inclusivas e relativas aos aspectos social e econômico do local. É o que já assinalamos em relação a algumas intervenções anteriores na Feira Livre do Ver-o-Peso, visto como uma possibilidade de

${ }^{156}$ Informações obtidas pela autora por meio de uma disciplina cursada na FEA-USP sobre gestão cultural, em que uma das alunas era a atual Secretária da Cultura de Ribeirão Preto. Ela apresentou os projetos dessa secretaria que estavam em andamento ou haviam sido elaborados parcialmente na busca por angariar financiamentos promovidos em razão da cidade ser uma subsede da Copa de 2014 no Brasil, e pela candidatura da cidade a patrimônio pelo IPHAN pela "Paisagem Cultural do Café". 
inclusão social por meio da participação democrática da população, e um caso em que essa inclusão social não é verificada, com o exemplo do Complexo Estação das Docas.

Esta disparidade caracteriza a permanente tentativa de controle das classes dominantes sobre os critérios e as práticas de preservação neste país, que se materializa por um lado pelo cultivo do consumo sofisticado e, por outro, na aposta quanto à permanência do jogo da especulação imobiliária e o lucro desenfreado como último critério no uso do solo urbano. Se em uma grande metrópole como São Paulo a preservação do patrimônio ambiental urbano imóvel encontra tantos obstáculos, desencadeia tanta discussão e dá origem a tantos protestos de proprietários e incorporadores indignados, é justamente por ser considerada antagônica aos conceitos e políticas ditadas pelos grandes especuladores e empreiteiras, que transformam a cidade de acordo com suas diretrizes privadas - e, pelo menos até aqui, com a anuência explícita ou implícita dos poderes constituídos. Não é outra a razão pela qual, na prática, persiste a recusa em incorporar a preocupação com o patrimônio histórico e sua preservação à ideia de planejamento urbano. Este é o principal problema a ser enfrentado se queremos tornar a ação dos órgãos do patrimônio histórico em algo efetivo e capaz de contribuir para a transformação do presente... (CHAUÍ, 1992, p. 38)

Ressaltem-se, porém, os problemas tanto da busca desenfreada pelo lucro como critério no uso do solo urbano, quanto do interesse das classes dominantes em apropriar-se dos critérios e das práticas de preservação, o que acaba materializando o cultivo de um consumo sofisticado, desassociado do local e da ideia de localidade, sem a preocupação com a criação de políticas públicas de integração social e econômica das comunidades locais. Nessas áreas, criam-se novas dinâmicas contemporâneas em relação à ideia de patrimônio comum de todos os povos, cuja legitimidade de classificação pode ser questionada, ao estruturar e materializar espaços de interesse de grupos particulares e ao romper com o contexto local.

Assim, verificam-se alguns aspectos dos processos de patrimonialização em que a harmonia entre o local e as localidades não se constitui. É o exemplo do complexo Ver-oPeso, candidato a Patrimônio Mundial, que foi reconhecido por seus usuários como um polo de resistência em relação às "transformações do mundo moderno", segundo o levantamento de referências culturais coordenado por Campelo (2002), onde se manteve a estrutura física sem grandes investimentos de infraestrutura, de modo diferente de outras intervenções patrimoniais em mercados naquele período. 
No entanto, as instâncias de proteção ao patrimônio, ao sobrepor-se do supranacional ao local, por meio de organizações não-governamentais internacionais, facilitam a redução do significado e das singularidades do lugar, quando estabelecem diretrizes e normativas que proporcionam um enfraquecimento da experiência desse espaço urbano em termos políticos, simbólicos e culturais.

Portanto, baseados nos estudos de caso desta pesquisa, afirmamos a existência de conflitos e de contradições entre a ideia de preservação dos bens culturais e a consecução de seus processos de patrimonialização mundial pela UNESCO. Essas contradições desconstituem o significado do patrimônio como um tecido urbano tradicional da localidade e provocam uma ressignificação de sua identidade urbana e, dessa forma, de sua paisagem cultural.

Esta investigação permite afirmar que tal processo de produção do espaço, ao recriar novas articulações urbanas que intensificam e reduzem as realidades complexas do bem cultural, não somente desmantelam seus signos culturais, suprimindo seus atributos do lugar, como também negam a ideia de localidade. 


\section{REFERÊNCIAS}

ALMEIDA, Maisa Fonseca de. Circuito Verde Cultural -Patrimonio Territorial en São Carlos. Dissertação de Master. Sevilha: Universidade de Sevilha, 2009.

ALVES, Manoel Rodrigues. Cidade Contemporânea: questões conceituais da conformação de sua espacialidade. Revista Tópos, Presidente Prudente, v.1, n.2, p. 29-57, 2007.

ARANTES, Otília Beatriz; MARICATO, Ermínia; VAINER, Carlos. A cidade do pensamento único: desmanchando consensos. Petrópolis, RJ: Vozes, 2000.

ARKITECTOS. Disponível em: <http://arkitectos.blogspot.pt>. Acesso em: 10 jul. 2014

Belém se candidata a patrimônio da humanidade. Diário do Pará, Belém, 13 jun. 2004. Negócios, caderno E, p.6. Editorial.

BENKO, Georges. Estrategias de comunicación y marketing urbano. EURE (Santiago), Santiago, v. 26, n.79, p. 67-76, dez. 2000.

BERG, Leo Van Den; KLINK, H. Arjen Van. Planificación Estratégica y Marketing Urbano. Situación: revista de coyuntura económica. Bilbao, no 3, p. 39-53, 1995.

BONELLI, Renato. Architettura e Restauro. Venezia: Neri Pozza, 1959.

BRAGA, Paula Marques. Intervenções Urbanas em Áreas Centrais Históricas: Paisagens Particulares versus a Banalização da Paisagem. Tese de doutorado. São Paulo: Universidade de São Paulo, 2013.

BRICHET, Robert. Étude sur les dispositions juridiques nécessaires pour assurer la protection du patrimoine monumental ou naturel des États. Paris: UNESCO,. 1968 Disponível

em :<http://unesdoc.UNESCO.org/Ulis/cgibin/ulis.pl?catno=186210\&set=53356B19_0_432\& $\mathrm{gp}=0 \& \operatorname{lin}=1 \& \|=3>$. Acesso em: 23 abril 2014.

BRICHET, Robert. Le régime desmonumentshistoriquesen France.Paris: Librairies Techniques - Librairie de la cour de cassation, 1952.

BRIGHENTI, A. M.; MATTIUCCI, C. Mappe: oltrel'artefatto. Scuaderno. Maps: Beyond the Artifact. Trento, n. 15, mar. 2010. Disponível em: $<$ http://www.losquaderno.professionaldreamers.net/wpcontent/uploads/2010/02/losquaderno15.pdf>. Acesso em: 9jul 2016.

CAMINHA, Pero Vaz de. A Carta de Pero Vaz de Caminha, 1500. Disponível em: <http://www.biblio.com.br/defaultz.asp?link=http://www.biblio.com.br/conteudo/perovazc aminha/carta.htm>. Acesso em: 12 jan. 2017. 
CAMPELO, Marilu Marcia. Imagens e representações da cidade ribeirinha na Amazônia. Humanitas. Belém, v.18, n.2, p.149-170, 2002.

CANCLINI. Néstor García. O Patrimônio Cultural e a Construção Imaginária do Nacional. Revista do Patrimônio Histórico e Artístico Nacional, Rio de Janeiro, n. 23, p.95-115, 1994. Tradução de Mauricio Santana Dias. Disponível em: <http://docvirt.com/docreader.net/DocReader.aspx?bib=reviphan\&pagfis=8429\&pesq=>. Acesso em: 9 jul. 2016.

CARDOSO, Ana Claudia Duarte; VENTURA Neto, Raul da Silva. A evolução urbana de Belém; trajetória de ambiguidades e conflitos socioambientais. Cad. Metrop., São Paulo, v. 15, n.29, p. 55-75, jan./ jun., 2013.

CARDOSO, Ana Claudia Duarte; GOMES, Taynara do Vale; MELO, Ana Carolina Campos de; BIBAS, Luna Barros. Quando o projeto disfarça o plano: concepções de planejamento e suas metamorfoses em Belém (PA). Cad. Metrop., São Paulo, n.37, p. 823-844, ago., 2016.

CASIELLO, S. ; PANE, A.; RUSSO, V. (Ed.). Roberto Pane trastoria e restauro: architettura, città, paesaggio. Padova: Editora Marsilio, 2010.

CASTRIOTA, Leonardo Barci. Patrimônio Cultural: conceitos, políticas, instrumentos. São Paulo: Annablume, 2009.

CHAUÍ, Marilena. Política Cultural, cultural política e patrimônio histórico. In: SÃO PAULO (PREFEITURA). O Direito à memória : Patrimônio Histórico e Cidadania. São Paulo: Secretaria Municipal de Cultura - Departamento do Patrimônio Histórico, 1992, p. 37-46.

Chef Alex Atala desiste de participar de Polo Gastronômicoem Belém. G1 - Pará - O portal de notícias da Globo. Disponível em: <http://glo.bo/29aD6Vv>. Acesso em: 10 ago. 2016.

CHOAY, Françoise. Alegoria do Patrimônio. Coimbra: Edições 70, 2010.

COIMBRA VIVA, SRU - Sociedade de Reabilitação Urbana. Disponível em: <http://www.coimbravivasru.pt/>. Acesso em: 06 jun. 2014.

COSTA, Everaldo Batista da.Cidades da Patrimonialização Global: simultaneidade totalidade urbana - totalidade - mundo. São Paulo: Humanitas, FAPESP, 2015.

COSTA, Fernando Reis. Ventos que passam. Coimbra es saudade. Disponível em: <http://www.ventosquepassam.com >. Acesso em: 21 maio 2014.

DELGADO, Manuel. El espacio público como ideología. Madri: Catarata, 2011.

DELGADO, Manuel. La No-Ciudad como ciudad absoluta, No Ciudad. Sileno 14-15, 2003. 
DOMINGUES, Angela. Para um melhor conhecimento dos domínios coloniais: a constituição de redes de informação no Império português em finais do Setecentos. História, Ciências, Saúde. Rio de Janeiro, v. 8, supl. p. 823-838, 2001.

Dossiê - Intervenção no Património da Universidade de Coimbra. Construção Magazine. Porto: Editora Plubindústria, n. 41, p. 1-41, jan./fev. 2011. Disponível em: <www.construcaomagazine.pt>. Acesso em: 8 jul. 2014.

DUARTE JUNIOR, Romei. Programa Monumenta: uma experiência em preservação urbana no Brasil. Revista CPC, São Paulo, n. 10, p. 49-88, maio/out. 2010. Disponível em: <http://www.revistas.usp.br/cpc/article/view/15661>. Acesso em: 25 jul. 2013.

DUMONT, Gérard François. La competencia entre las ciudades. Situación: revista de coyuntura económica. Bilbao, n. 3, p. 55-68, 1995.

ESPOSITO, Antonio; LEONI, Giovanni - Fernando Távora. Opera completa. Milão : Electa Spa, 2005.

FERREIRA, Aurélio Buarque de Holanda. Novo dicionário Aurélio da língua portuguesa. 3 ed. Curitiba: Positivo, 1999.

FONSECA, Maria Cecília Londres. O Patrimônio em Processo: trajetória da política federal de preservação no Brasil. Rio de Janeiro: Editora UFRJ: IPHAN, 1997.

FONSECA, Maria Cecília Londres. Referências culturais: base para novas políticas de patrimônio. In: IPHAN. Manual de aplicação do Inventário Nacional de Referências Culturais. Brasília: IPHAN, 2000.

GONZÁLEZ-VARAS, Ignacio Conservación de bienes-culturales. Madri: Ediciones Cátedra (Grupo Anaya, S.A.), 2008.

TAVARES, Maria Goretti da Costa. Entrevista concedida à autora da tese, na sorveteria Cairu da Estação das Docas, Belém, 2016.

GREFFE, Xavier. La valorization économique du patrimoine. Paris: La Documentation française, 2003.

GUIMARÃES 2012. Disponível em: <http://www.guimaraes2012.pt/index.php?cat=92\&item=48919>. Acesso em: 20 nov. 2012.

HALL, Stuart A Identidade Cultural na Pós-Modernidade. Tradução de Tomaz Tadeu da Silva e Guacira Lopes Louro. Rio de Janeiro: DP\&A Editora, 2006.

HARVEY, David. Do gerenciamento ao empresariamento: a transformação da administração urbana no capitalismo tardio. Espaço e Debates, São Paulo, n. 39, p. 48-64, 1996. 
HARVEY, David. A produção capitalista do espaço. São Paulo: Annablume, 2005.

IBGE - INSTITUTO BRASILEIRO DE GEOGRAFIA E ESTATÍSTICA. Disponível em: <www.ibge.gov.br>. Acesso em: 24 mar. 2016.

ICOMOS - CONSELHO INTERNACIONAL DE MONUMENTOS E SÍTIOS. Disponível em: $<$ http://www.icomos.org.br/>. Acesso em: 10 jun. 2016.

INLOKO. Disponível em: <http://www.in-loko.pt>. Acesso em: 10 jul. 2014.

INSTITUTO DE PESQUISA ECONÔMICA APLICADA. Governança Metropolitana no Brasil. Relatório de Pesquisa - Caracterização e Quadros de Análise Comparativa da Governança Metropolitana no Brasil: arranjos institucionais de gestão metropolitana (Componente 1). Região Metropolitana de Belém. Rio de Janeiro: IPEA, 2015. Disponível em: <http://www.ipea.gov.br/redeipea/images/pdfs/governanca_metropolitana/rel_1_1_rm_be lem.pdf>. Acesso em: 07 dez. 2016.

IPHAN - INSTITUTO DO PATRIMÔNIO HISTÓRICO E ARTÍSTICO NACIONAL. Disponível em: $<$ http://portal.IPHAN.gov.br>. Acesso em: 10 jun. 2016.

KITCHIN, Rob. Post-representational cartography. Scuaderno. Maps: Beyond the Artifact. Trento, n. 15, mar. 2010.2 Disponível em: <http://www.losquaderno.professionaldreamers.net/wpcontent/uploads/2010/02/losquaderno15.pdf>. Acesso em: 9 jul. 2016.

KOOLHAAS, Rem. La Ciudad Genérica. Barcelona: Editorial Gustavo Gili, 2011.

KUHL, Beatriz Mugayar (org). Gustavo Giovannoni:- textos escolhidos. Cotia: Ateliê Editorial, 2013.

KUHL, Beatriz Mugayar. Notas sobre a Carta de Veneza. Anais do Museu Paulista: História e Cultura Material, São Paulo, vol. 18, n.2.,jul/dec. 2010. Disponível em: <http://www.scielo.br/scielo.php?script=sci_arttext\&pid=S0101-47142010000200008>. Acesso em: 22 nov. 2016.

LEITÃO, Wilma Marques (org). Ver-o-Peso: estudos antropológicos no Mercado de Belém. Belém: NAEA, 2010.

LIMA, José Júlio; COSTA, Silvana Lima. Análise comparativa das leis urbanísticas municipais quanto à regulação da veriticalização em Belém. In: ENCONTRO DA ASSOCIAÇÃO NACIONAL DE PESQUISA E PÓS-GRADUAÇÃO EM ARQUITETURA E URBANISMO - ENANPARQ, 3., 2014, São Paulo. Anais... Porto Alegre: ANPARQ, 2014. Disponível em: <http://anparq.org.br/dvdenanparq-3/htm/XFramesSumarioSC.htm>. Acesso em: 22 nov. 2016.

LIMA, José Júlio. Segregação Socio espacial e Forma Urbana: Belém no Final dos Anos 90. In: FERNANDES, E.; VALENÇA, M. M., (Eds.). Brasil Urbano. Rio de Janeiro: Mauad, 2004. 
LIMA, Maria Dorotéa de. Ver-o-Peso, patrimônio (s) e práticas sociais: uma abordagem etnográfica da feira mais famosa de Belém do Pará. 2008. 219f. Dissertação (mestrado) Instituto de Filosofia e Ciências Humanas, Universidade Federal Pará.Disponível em:<http://www.ppgcs.ufpa.br/arquivos/dissertacoes/dissertacaoTurma2006MariaLima.pdf>. Acesso em: 06 jun. 2014.

LIMA, Maria Dorotéa de. Entrevista concedida à autora da tese no IPHAN-PA, Belém, 2016.

LUCARELLI, Francesco. Francesco Lucarelli Blog: Argomentazioni sul diritto. Curriculum. Disponível em: <https://lucarellifrancesco.wordpress.com/curriculum/>. Acesso em: 12 jan. 2017.

MACHADO, Jurema; BRAGA, Sylvia. Comunicação e cidades patrimônio mundial no Brasil. Brasília: UNESCO, IPHAN, 2010.2 Disponível em:<http://unesdoc.unesco.org/images/0018/001887/188777por.pdf>. Acesso em: 10 mar. 2016.

MAGALHÃES, Aloísio. E triunfo?:a questão dos bens culturais no Brasil. Rio de Janeiro, Nova Fronteira: Fundação Roberto Marinho, 1997.

MENA, Fernando Carrión. Ciudad y Centros Históricos. Centros históricos y actores patrimoniales. In: BALBO, Marcello; JORDÁN, Ricardo; SIMIONI, Daniela (Comp.). La Ciudad Inclusiva. Santiago de Chile: Naciones Unidas/CEPAL/Cooperazione Italiana, 2003. p.129152. (Cuadernos de la CEPAL). Disponível em: <https://works.bepress.com/fernando_carrion/109/>. Acesso em: 22 nov. 2016.

MENESES, Ulpiano T. Bezerra de. Valor cultural, valor econômico: encontros e desencontros. In: SEMINÁRIO INTERNACIONAL DE HISTÓRIA DA ENERGIA DE SÃO PAULO, 2., 1999, São Paulo. Anais...São Paulo: Fundação Patrimônio Histórico da Energia de São Paulo, 2000, p. 29-48.

MIRANDA, Cybelle Salvador. Cidade Velha e Feliz Lusitânia: cenários do Patrimônio Cultural em Belém. Tese de doutorado. Belém: Universidade Federal do Pará, 2006.

MONUMENTA. Disponível em: <http://www.monumenta.gov.br>. Acesso em: 18 de julho de 2013.

MOURA, Ana Clara Mourão. Geoprocessamento na gestão e planejamento urbano. 3 ed. Rio de Janeiro: Ed. Interciência, 2014.

MOURA, Éride. Com respeito às origens, nova vida é revelada. Revista AU - Arquitetura \& Urbanismo. São Paulo: Editora PINI, $n^{\circ} 121$, p.24-53, Abril 2004. Disponível em: http://www.au.pini.com.br/arquitetura-urbanismo/121/artigo23397-1.aspx>. Acesso em: 22 nov. 2016. 
MUÑOZ, Francesc M. Paisajes banales: bienvenidos a la sociedad del espectáculo. In: EN SOLÀ- MORALES, Ignasi de; COSTA, Xavier (eds). Metrópolis,ciudades, redes, paisajes. Barcelona: Gustavo Gili, 2005. p. 78-93.

MUÑOZ, Francesc. La ciudad multiplicada, la ciudad de los territoriantes. Barcelona: Gustavo Gili, 2010.

OLIVEIRA, Nelma Gusmão de. O poder dos jogos e os jogos de poder: os interesses em campo na produção de uma cidade para o espetáculo esportivo. Tese de doutorado. Rio de Janeiro: Universidade Federal do Rio de Janeiro,2012.

ONUBR - Nações Unidas no Brasil. Disponível em: <https://nacoesunidas.org/agencia/unesco/>. Acesso em: 25 nov. 2016.

ONU - UNITED NATIONS. Disponível em: <http://www.un.org>. Acesso em: 05 dez. 2016.

ORGANIZATION OF WORLD HERITAGE CITIES. Cities. Disponível em: <http://www.ovpm.org/en/cities>. Acesso em: 10 jun. 2013.

ORTIZ. Renato. Mundialização da Cultura. São Paulo: Brasiliense, 2007.

PANE, Roberto. Città antiche edilizia nuova. Napoli: ESI, 1959.

PEIXOTO, Paulo. Patrimônios Mundiais: Fragmentação e Mercantilização da Cultura. Material didático curso de e-learning Instituto Camões/CES Patrimónios de influência portuguesa, 2010.

PENTEADO, Antonio Rocha. Belém - Estudo de Geografia Urbana. Belém: Universidade Federal do Pará, 1968.

Plano Estratégico e Plano de Urbanização de Coimbra. Disponível em: <http://www.cmcoimbra.pt>. Acesso em: 20 maio 2014.

PONTE, Juliano Pamplona Ximenes. A Orla de Belém: intervenções e apropriação. Dissertação de mestrado. Rio de Janeiro: Universidade Federal do Rio de Janeiro, 2004.

PONTE, Juliano Pamplona Ximenes. Entrevista concedida à autora da tese, no Café da Sol, na Doca, Belém, 2016.

PUERTO MADERO. Master Plan Corporación Antiguo Puerto Madero S.A.. Disponível em: <http://www.puertomadero.com/>. Acesso em: 14 jan.217.

RAMO, Beatriz. Il feticcio del passato. Casabella, Milão, n. 812, p.2, 56-73, Apr. 2012. Disponível em: <http://st-ar.nl/casabella-812/>. Acesso em: 22 maio 2014.

REIS, José de Souza. Os monumentos e seus entornos. BOLETIM SPHAN/PRO-MEMÓRIA. Rio de Janeiro, n. 7, jul./ago., 1980, p. 17-18. Disponível em: <http://docvirt.no- 
ip.com/docreader.net/DocReader.aspx?bib=bol_sphan\&pagfis=453\&pesq=>. Acesso em: 20out. 2016.

RIBEIRO, António Sousa. A tradução como metáfora da contemporaneidade: PósColonialismo, Fronteiras e Identidades. Eurozine, Vienna, 2005. Disponível em: < http://www.eurozine.com/articles/article_2005-07-18-ribeiro-pt.html>. Acesso em: 20 out. 2010.

SANTOS, Lusitano dos. Planos de urbanização para a cidade de Coimbra. Coimbra: Museu Nacional de Machado de Castro, 1983.

SKYSCRAPERCITY. Disponível em: <www.skyscrapercity.com>. Acesso em: 10 jul. 2014

SEGEP - Secretaria Municipal de Coordenação Geral do Planejamento e Gestão. Disponível em: <http://www.belem.pa.gov.br/segep/mensagem/02_infraestrutura.htm>. Acesso em: 9 jan. 2016.

SILVA, Fernando Fernandes da. As Cidades Brasileiras e o Patrimônio Cultural da Humanidade. São Paulo: Peirópolis; Editora da Universidade de São Paulo, 2012.

SILVA, José António Raimundo Mendes da. Entrevista concedida à autora da tese, Coimbra, 2012.

SIMÕES, Sidónio. Entrevista concedida à autora da tese no Arco de Almedina, Coimbra, 2012.

SISTEMA DE INFORMAÇÃO PARA O PATRIMÔNIO ARQUITETÓNICO (SIPA). Disponível em: <http://www.monumentos.pt/Site/APP_PagesUser/SIPA.aspx?id=2632>. Acesso em: 29 de junho de 2014.

TOURINHO, Helena Lúcia Zagury. Outorga onerosa do direito de construir: a experiência de Belém. Revista Magíster de Direito Ambiental e Urbanístico. Porto Alegre, v.4, n.22, p.74-87, fev./mar., 2009. Disponível em:<http://www.ibdu.org.br/imagens/OUTORGA_.PDF>. Acesso em: 6 jan. 2016.

TRINDADE JÚNIOR, Saint-Clair Cordeiro da.Formação metropolitana de Belém (1960-1997). Belém: Paka-Tatu, 2016.

TRINDADE JÚNIOR, Saint-Clair Cordeiro da. Entrevista concedida à autora da tese no Núcleo de Altos Estudos Amazônicos, Belém, 2016.

TRINDADE JÚNIOR, Saint-Clair Cordeiro da. Imagens e representações da cidade ribeirinha na Amazônia. Humanitas, Belém, v.18, n.2, p. 135-148, 2002.

UC de olhos postos no futuro. Disponível em: <http://www.uc.pt/noticias/newsletter/052012/destaque>. Acesso em: 28 nov. 2012. 
ULTRAMARI, Clovis. Grandes Projetos Urbanos no Brasil:conceitos, contextualização e discussão de três casos. URBANA: Revista Eletrônica do Centro Interdisciplinar de Estudos sobre a Cidade, Campinas, SP, v. 1, n. 1, abr. 2013. Disponível em: < http://periodicos.sbu.unicamp.br/ojs/index.php/urbana/article/view/8635116 >. Acesso em: 29 jun. 2014.

UNESCO - United Nations Educational Scientific and Cultural.Disponível em: <http://whc.unesco.org >. Acesso em: 05 out. 2016.

UNESCO NO BRASIL. Disponível em: <http://www.unesco.org/new/pt/brasilia/home/>. Acesso em: 05 dez. 2016.

UNIVERSIDADE DE COIMBRA (UC). Disponível em: <http://www.uc.pt/ruas/faqs/10>. Acesso em: 20 dez. 2016.

VAINER, Carlos; ARANTES, Otília Beatriz; MARICATO, Ermínia. A cidade do pensamento único: desmanchando consensos. Petrópolis, RJ: Vozes, 2000.

VARGAS, Heliana Comin; Ana Luisa Howard de Castilho. Intervenções em centros urbanos: objetivos, estratégias e resultados. Barueri: Manole, 2015.

VER-O-SITE. O Mercado e a Cidade de Belém. Um pouco da história do Ver-o-Peso. Disponível em: <http://www.ufpa.br/cma/verosite/historico.html>. Acesso em: 22 nov. 2016.

VEIRA, Álvaro. Militantes do PCP - Coimbra alegam que não sabiam que era crime pintar as "monumentais". PÚBLICO - Comunicação Social SA, Coimbra, 21 dez. 2012. Disponível em: <https://www.publico.pt/local-porto/jornal/militantes-do-pcpcoimbra-alegam-que-naosabiam-que-era-crime-pintar-as-monumentais-25790847>. Acesso: 30 ago. 2014.

WARNIER. Jean-Pierre. A mundialização da cultura. Bauru: EDUSC, 2000.

World heritage. Disponível em:<http://worldheritage.uc.pt>. Acesso: 30 jun. 2014.

DOCUMENTOS OFICIAIS, CARTAS E NORMATIVAS NACIONAIS E INTERNACIONAIS.

\section{Documentos produzidos pelo IPHAN, Brasil.}

Documento de consulta pública a proposta de intervenção para a Feira do Ver-o-Peso disponibilizado pelo IPHAN, 2016, versão digital.

Documento de consulta pública a proposta de intervenção para a Feira do Ver-o-Peso elaborado pela empresa DPJ arquitetura \& engenharia Itda. . Revitalização da Feira do Ver-oPeso - Projeto Básico. Disponível em: 
$<$ http://portal.iphan.gov.br/noticias/detalhes/3490/nota-iphan-abre-consulta-publica-sobrea-reforma-do-ver-o-peso>. Acesso em: 6 ago. 2016.

Documento de intenção de candidatura, IPHAN, 2014, versão digital. Composto de documentos de tombamento: Livro do Tombo Arqueológico, Etnográfico e Paisagístico (inscrição de número 69, fls 16), Livro de Tombo Histórico (inscrição número 460, fls 77), Livro de Tombo das Belas Artes, sob a inscrição de número 525 (fls 96).

Documento de rascunhos do processo de candidatura a patrimônio mundial de 2004, consultado pela autora durante a visita a Superintendência do IPHAN-PA, Belém, 2016.

Portaria $\mathrm{n}^{\circ}$ 127, de 30 de abril de 2009 - Estabelece a chancela da Paisagem Cultural Brasileira. Disponível em: <http://portal.iphan.gov.br/uploads/legislacao/Portaria_127_de_30_de_Abril_de_2009.pdf> . Acesso em: 11 de dezembro de 2016.

Programa Nacional do Patrimônio Imaterial. Disponível em: <http://portal.iphan.gov.br//pagina/detalhes/761>. Acesso em: 11 de dezembro de 2016. Recomendação Paris Paisagens e Sítios. Disponível em: http://portal.iphan.gov.br/uploads/ckfinder/arquivos/Recomendacao\%20de\%20Paris\%2019 62.pdf>. Acesso em: 9 dez.2016.

\section{Documentos produzidos pela Universidade de Coimbra, Portugal.}

Documento do dossiê de Candidatura da Universidade de Coimbra a Património da UNESCO, versão digital, composto por sete volumes: Candidatura a Patrimônio Mundial; Plano de Gestão; Textos Gerais; Influências; Execução; Planos Diretores; e Zona de Proteção. Disponível em: <http://www.skyscrapercity.com/showthread.php?t=852336>. Acesso em: 10 jun. 2014

Dossiê de Candidatura - Universidade de Coimbra. Disponível em: <http://www.uc.pt/unesco_old/dossie>. Acesso em: 12 dez. 2016.

\section{Documentos produzidos pela UNESCO.}

BRICHET, Robert. Étude sur les dispositions juridiques nécessaires pour assurer la protection du patrimoine monumental ou naturel des États" de 26 de janeiro de 1968, documento sobre a adoção de medidas em escala internacional, princípios técnicos, científicos e jurídicos aplicáveis no campo de proteção dos bens culturais, dos monumentos e dos sítios, em um estudo sobre as disposições jurídicas necessárias para assegurar a proteção do patrimônio monumental. Documento disponível em: <http://unesdoc.unesco.org/images/0018/001862/186210fb.pdf>. Acesso em: 13 dez 2016.

Convenção de 1972, Relativa à Proteção do Patrimônio Mundial, Cultural e Natural, Disponível em: <http://whc.unesco.org/archive/convention-pt.pdf>. Acesso em: 8 dez 2016. 
Documento CC-77/Conf. 001/9, UNESCO, Paris, 30 de setembro de 1977, p. 3. Disponível em: <http://whc.unesco.org/en/documents/1914>. Acesso em: 8 maio 2014.

Documento CC-81/Conf. 003/6, Draft Report of the rapport. UNESCO, Paris, 15 de janeiro de 1982, p.9. Disponível em: <http://whc.unesco.org/en/documents/814>. Acesso em: 8 maio 2014.

UNESCO. Lei de bases do património cultural português. Disponível em: <http://www.UNESCO.org/culture/natlaws/media/pdf/portugal/portugal_law_1072001_law _cultural_heritage_pororof.pdf>. Acesso em: 8 maio 2014.

\section{Leis e documentos na escala federal no Brasil.}

BRASIL. Constituição (1937). Constituição dos Estados Unidos do Brasil. Rio de Janeiro, $1937 . \quad$ Disponível em: <https://www.planalto.gov.br/ccivil_03/constituicao/Constituicao37.htm>. Acesso em: 20 dez. 2016.

BRASIL. Constituição (1946). Constituição dos Estados Unidos do Brasil. Rio de Janeiro, $1946 . \quad$ Disponível em: <https://www.planalto.gov.br/ccivil_03/constituicao/Constituicao46.htm>. Acesso em: 20 dez. 2016.

BRASIL. Constituição (1988). Constituição da República Federativa do Brasil. Brasília, DF: Senado, 1988. Disponível em :<http://www.planalto.gov.br>. Acesso em: 21 março 2014.

BRASIL. Decretro-lei n⿳25, de 30 de novembro de 1937. Organiza a proteção do patrimônio histórico e artístico nacional. Disponível em: <http://portal.iphan.gov.br/uploads/legislacao/Decreto_25_de_30_11_1937.pdf>. Acesso em: 11 de dezembro de 2016.

BRASIL. Lei $\mathrm{n}^{\circ} \mathbf{1 0 . 2 5 7}$, de 10 de julho de 2001. Regulamenta os arts. 182 e 183 da Constituição Federal, estabelece diretrizes gerais da política urbana e dá outras providências. Brasília: Poder Executivo, 2001a. Disponível em: <http://www.planalto.gov.br/ccivil_03/leis/leis_2001/l10257.htm>. Acesso em: 10 maio2014.

\section{Leis e documentos oficiais nas escalas do estado e do município de Belém.}

Iconografia do levantamento tipográfico do museu do Forte do Presépio desenvolvido pela sua equipe de arquitetura no ano de 2000.

BELÉM (Município). Lei $n^{\circ} 7683 / 94$. Estabelece medidas aplicáveis à legislação do Plano Diretor Urbano de Belém, de que trata a Lei ${ }^{\circ} 7603 / 93$ de 13 de janeiro de 1993. Disponível em: $\quad$ <https://leismunicipais.com.br/a/pa/b/belem/lei-ordinaria/1994/769/7683/leiordinaria-n-7683-1994-estabelece-medidas-aplicaveis-a-legislacao-do-plano-diretor-urbanode-belem-de-que-trata-a-lei-n-7603-de-13-de-janeiro-de-1993>. Acesso em: 10 dez. 2016. 
BELÉM (Município). Lei Complementar de Controle Urbanístico. Lei Complementar $n^{\circ} 02$ de julho de $1999 . \quad$ Disponível em: <http://www.belem.pa.gov.br/planodiretor/pdfs_legislacao/lccu.pdf?id_lei=724>. Acesso em: 10 dez. 2016.

BELÉM (Município). Lei $n^{\circ} 8.655$ de 30 de julho de 2008. Dispõe sobre o Plano Diretor do Município de Belém, e dá outras providências. Disponível em: < http://ww3.belem.pa.gov.br/www/wp-content/uploads/Lei_N8655-08_Plano-Diretor.pdf>.

Acesso em: 10 ago. 2016.

BELÉM (Município). Decreto $\mathrm{n}^{\circ} 84.986$ de 03 de fevereiro de 2016. Cria o "Espaço Gastronômico Cultural da Amazônia" no Mercado de Carnes Francisco Bolonha e dá outras providências. Disponível em: <www.belem.pa.gov.br/diarioom/baixarDiario?idd=7966>. Acesso em: 10 dez. 2016.

\section{Leis e documentos oficiais na escala do município de Coimbra, Portugal.}

COIMBRA (Município). Regulamento Municipal de Edificação, Recuperação e Reconversão Urbanística da Área afeta à candidatura da Universidade de Coimbra a Património Mundial da UNESCO, incluindo a Zona de Proteção. Coimbra, 2012. Disponível em: <https://dre.tretas.org/dre/1308684/aviso-2129/2012-de-10-de-fevereiro>. Acesso em: 20 dez. 2016.

\section{Cartas Patrimoniais Internacionais.}

CARTA DE ATENAS, 1931. In: IPHAN. Disponível em: <http://portal.iphan.gov.br/uploads/ckfinder/arquivos/Carta\%20de\%20Atenas\%201931.pdf >. Acesso: em 9 jul. 2016.

ICOMOS. Carta de turismo cultural, 1976. Disponível em: <http://portal.iphan.gov.br/uploads/ckfinder/arquivos/Carta\%20de\%20Turismo\%20Cultural \%201976.pdf>. Acesso em: 7 dez. 2016.

CARTA DE VENEZA, 1964. In: IPHAN. Disponível em: <http://portal.iphan.gov.br/uploads/ckfinder/arquivos/Carta\%20de\%20Veneza\%201964.pdf >. Acesso em: 9 jul. 2016.

\section{Entrevistas}

Comerciantes da região da Baixa e da Rua da Sofia. Entrevistas concedidas a autora da tese, na Rua da Sofia e na região da Baixa, Coimbra, 2012.

Estudantes da república "Bota Abaixo. Entrevista concedida a autora da tese, na república Bota Abaixo, Zona da Alta, Coimbra, 2012. 
LIMA, Maria Dorotéa de Lima. Entrevista concedida a autora da tese, Belém, 2016.

MARQUES, Cátia. Entrevista concedida a autora da tese, Coimbra, 2012.

NUNO, Ribeiro Lopes. Entrevista concedida a autora da tese, Coimbra, 2012.

PONTE, Juliano Pamplona Ximenes. Entrevista concedida a autora da tese, Belém, 2016.

SILVA, José António Raimundo Mendes da. Entrevista concedida a autora da tese, Coimbra, 2012.

SIMÕES, Sidónio. Entrevista concedida a autora da tese, Coimbra, 2012.

TAVARES, Maria Goretti da Costa Tavares. Entrevista concedida a autora da tese, Belém, 2016.

TRINDADE JÚNIOR, Saint-Clair Cordeiro da. Entrevista concedida a autora da tese, Belém, 2016.

\section{Acervo}

Instituto do Patrimônio Histórico e Artístico Nacional (IPHAN)

SEPS 713/913 | Lote D | Térreo | Asa Sul | Brasília| DF 70390-135

Museu do Forte do Presépio

Praça Dom Frei Caetano Brandão, s/n - Cidade Velha, Belém - PA, 66020-600

Superintendência do IPHAN no Pará

Avenida Governador José Malcher, 563| Nazaré | Belém |PA 66040-282 


\section{ANEXO 1}

\section{LISTA DO PATRIMÔNIO MUNDIAL NO BRASIL.}

Atualmente, o Brasil apresenta vinte bens culturais, sítios do patrimônio cultural e natural, classificados patrimônio mundial pela UNESCO, discriminados abaixo em ordem cronológica de suas inscrições na Lista do Patrimônio Mundial (Fonte: UNESCO, 2016. Elaboração nossa).

1. A Cidade Histórica de Ouro Preto (MG), 1980 - Ouro Preto.

2. O Centro Histórico de Olinda (PE), 1982) - Olinda.

3. As Missões Jesuíticas Guarani, Ruínas de São Miguel das Missões (RS), 1983.

4. O Centro Histórico de Salvador (BA), 1985 - Salvador.

5. O Santuário do Senhor Bom Jesus de Matosinhos, em Congonhas do Campo (MG), 1985 Congonhas do Campo.

6. O Parque Nacional de Iguaçu, em Foz do Iguaçu (PR), 1986 - Foz do Iguaçu.

7. O Plano Piloto de Brasília (DF), 1987 - Brasília.

8. O Parque Nacional Serra da Capivara, em São Raimundo Nonato (PI), 1991)

9. O Centro Histórico de São Luiz do Maranhão (MA), 1997 - Maranhão.

10. Centro Histórico da Cidade de Diamantina (MG), 1999 - Diamantina.

11. Mata Atlântica - Reservas do Sudeste (SP/PR), 1999.

12. Costa do Descobrimento - Reservas da Mata Atlântica (BA/ES), 1999.

13. Complexo de Áreas Protegidas da Amazônia Central, 2000.

14. Complexo de Áreas Protegidas do Pantanal (MS/MT), 2000.

15. Centro Histórico da Cidade de Goiás (GO), 2001 - Goiás.

16. Áreas protegidas do Cerrado: Chapada dos Veadeiros e Parque Nacional das Emas (GO), 2001.

17. Ilhas Atlânticas Brasileiras: Reservas de Fernando de Noronha e Atol das Rocas (RN), 2001 Fernando de Noronha.

18. Praça de São Francisco, na cidade de São Cristóvão (SE), 2010 - São Cristóvão.

19. Rio de Janeiro, paisagens cariocas entre a montanha e o mar (RJ), 2012 - Rio de Janeiro.

20. Conjunto Moderno da Pampulha (MG), 2016 - Belo Horizonte. 


\section{ANEXO 2}

\section{LISTA DO PATRIMÔNIO MUNDIAL EM PORTUGAL.}

Portugal apresenta quinze bens culturais, sítios do patrimônio cultural e natural, classificados patrimônio mundial pela UNESCO, discriminados abaixo em ordem cronológica de suas inscrições na Lista do Patrimônio Mundial (Fonte: UNESCO, 2016. Elaboração nossa).

1. Centro Histórico de Angra do Heroísmo, 1983 - Angra do Heroísmo, llha Terceira, Açores.

2. Mosteiro dos Jerónimos e Torre de Belém (1983) - Lisboa.

3. Mosteiro da Batalha (1983) - Batalha.

4. Convento de Cristo (1983) - Tomar.

5. Centro Histórico de Évora (1986) - Évora.

6. Mosteiro de Alcobaça (1989) - Alcobaça.

7. Paisagem Cultural de Sintra (1995) - Sintra.

8. Centro Histórico do Porto (1996) - Porto.

9. Sítios de Arte Rupestre do Vale do Côa (1998) - Distrito da Guarda.

10. Floresta Laurissilva da Ilha da Madeira (1999) - Ilha da Madeira, Madeira.

11. Centro Histórico de Guimarães (2001) - Guimarães.

12. Região Vinhateira do Alto Douro (2001) - Nordeste de Portugal.

13. Paisagem da Cultura da Vinha da Ilha do Pico (2004) - Ilha do Pico, Açores.

14. Cidade Fronteiriça e de Guarnição de Elvas e as suas Fortificações (2012) - Elvas.

15. Universidade de Coimbra, Alta e Sofia (2013) - Coimbra. 


\section{ANEXO 3}

\section{O TOMBAMENTO DO VER-O-PESO.}

Fonte: VER-O-SITE, 2016.

O Conjunto Arquitetônico e Paisagístico Ver-o-Peso e áreas adjacentes, incluindo a Praça Pedro Segundo, o Boulevard Castilhos França, o Mercado de Carne e o Mercado de Peixe, é um bem tombado pelo IPHAN com inscrição em três dos quatro livros criados pelo decreto no 25 , de 30 de novembro de 1937 (que conceitua e organiza a proteção do patrimônio histórico e artístico nacional), a saber: Livro do Tombo Arqueológico, Etnográfico e Paisagístico (inscrição de número 69, fls 16); Livro de Tombo Histórico (inscrição número 460, fls 77) e Livro de Tombo das Belas Artes, sob a inscrição de número 525 (fls 96).

O instrumento legal correspondente a tais inscrições é a Notificação no 1121 , assinada pelo então Diretor geral do IPHAN em 09 de novembro de 1977, que, com base no Processo 812-T-69, notifica a decisão do órgão pelo tombamento ex-ofício do perímetro referido, de propriedade da Prefeitura de Belém, ao então Prefeito de Belém. Dez anos depois foi proclamada uma certidão de tombamento, assinada no Rio de Janeiro em 28 de outubro de 1987 pelo chefe do Arquivo da Coordenadoria de Registro e Documentação, revisada pelo secretário do Patrimônio Histórico e Artístico Nacional, certificando que o tombamento encontrava-se devidamente inscrito nos respectivos livros de tombo já mencionados.

Importante destacar que a mesma área é tombada pelo Município de Belém, sob a denominação de Centro Histórico de Belém. Conforme Anexo I da Lei Ordinária № 7.709, de 18 de maio de 1994, o Centro Histórico de Belém, tombado pela Lei Orgânica, de 30 de março de 1990, em seu artigo 228, parágrafo 2ำ, compreende, conforme a Lei de Desenvolvimento Urbano - Lei 7.401, de 29 de janeiro de 1988 -, a área envolvida pelo poligonal que tem início na interseção da Avenida Marechal Hermes com Avenida Assis de Vasconcelos; segue por esta até a interseção com a Rua Gama Abreu; segue por esta até sua interseção com a Avenida Almirante Tamandaré; segue por esta até o ponto de coordenadas 777.54mE e 9.838.245mN, nas margens da Baía do Guajará; dobra à direita e segue, continuando às margens da Baía do Guajará até o ponto de coordenadas 778.940mE e 9.841.245mN, localizados na foz do igarapé sem denominação; sobe por este até sua interseção com o prolongamento da Avenida Marechal Hermes; dobra à direita e segue por esta até o início da poligonal. A preservação do Centro Histórico de Belém já havia sido prevista pelo Plano Diretor do Município de Belém, Lei no 7.603, de 13 de janeiro de 1993, em seu artigo 171 e tornou-se regulamentada pela Lei de Desenvolvimento Urbano (Lei Ordinária № 7.401, de 29 de janeiro de 1988). 


\section{ANEXO 4}

\section{LEVANTAMENTO DO INVENTÁRIO DE REFERÊNCIAS CULTURAIS VER-O-PESO.}

Fonte: VER-O-SITE, 2016 apud O INCR do Ver-O-Peso, 2010.

O Levantamento Preliminar do Inventário de Referências Culturais do Conjunto Ver-o-Peso - INRC Ver-o-Peso, foi realizado entre 2008 e 2010, na cidade de Belém, a partir de proposta apresentada ao edital Petrobrás Cultural pela Associação Ver-as-Ervas e ao Programa Nacional de Apoio a Cultura do Ministério da Cultura, na modalidade mecenato.

Realizado em parceria com o IPHAN/PA a partir de Termo de Cooperação firmado entre as partes, o INRC Ver-o-Peso foi desenvolvido por meio de metodologia adotada pelo IPHAN, a qual consiste em levantamento bibliográfico e iconográfico, além de trabalho de campo onde, a partir de contatos identificados previamente e também no decorrer do trabalho, são documentados, por meio de entrevistas e observação, o sítio físico, localidades e bens culturais nas categorias celebração, ofícios e modos de fazer, formas de expressão, lugares e edificações.

O inventário tem por objetivo, produzir conhecimento sobre o bem cultural inventariado. Os resultados obtidos com a pesquisa possibilitam uma série de desdobramentos em outras pesquisas, bem como podem ser trabalhados e apresentados das mais diferentes formas como, por exemplo, no vídeo produzido no âmbito do projeto; em exposições, como a que está sendo montada pelo IPHAN; em publicações diversas entre outras formas possíveis.

De acordo com a metodologia utilizada, o resultado do trabalho é apresentado em forma de relatório constituído pelos formulários produzidos no decorrer do trabalho, os quais reúnem e organizam os dados da pesquisa que seguem nesta brochura. E também, posteriormente, serão inseridos em banco de dados do IPHAN.

O êxito do trabalho deve-se a disposição da Ver-as-Ervas de apresentar o projeto à Petrobras e de firmar a parceria com o IPHAN, mas sobretudo ao entusiasmo dos trabalhadores do Ver-o-Peso que perceberam nesta oportunidade a possibilidade de valorização e divulgação de seu trabalho e de seu patrimônio cultural que é o Ver-o-Peso. Patrimônio este que preservam por meio da transmissão de seus saberes e ofícios por gerações e cuja dimensão e significados extrapolam os limites locais e do estado do Pará, fazendo desse lugar tão especial um patrimônio cultural brasileiro.

O que é o INRC?

O Inventário Nacional de Referências Culturais - INRC - é uma metodologia de pesquisa desenvolvida pelo IPHAN que tem como objetivo produzir conhecimento sobre os domínios da vida social aos quais são atribuídos sentidos e valores e que, portanto, constituem marcos e referências de 
identidade para determinado grupo social. Contempla, além das categorias estabelecidas no Registro, edificações associadas a certos usos, a significações históricas e a imagens urbanas, independentemente de sua qualidade arquitetônica ou artística.

A delimitação da área do inventário ocorre em função das referências culturais presentes num determinado território. Essas áreas podem ser reconhecidas em diferentes escalas, ou seja, podem corresponder a uma vila, a um bairro, a uma zona ou mancha urbana, a uma região geográfica culturalmente diferenciada ou mesmo a um conjunto de segmentos territoriais.

\section{Os bens inventariados no Ver-o-Peso}

Após a realização do INRC Ver-o-Peso foram inventariados 75 bens, identificados a partir de entrevistas com os trabalhadores do Ver-o-Peso, os bens estão distribuídos nas seguintes categorias: Celebrações; Edificações; Formas de Expressão; Lugar e Ofícios e Modos de Fazer.

\section{Celebrações}

Festas Juninas; Círio de Nazaré; Queima de fogos em homenagem a Nossa Senhora de Nazaré; Festa do Mercado do Peixe; Festa de aniversário do Ver-o-Peso; Festival de Degustação do Peixe Salgado; Festa do aniversário de Belém; e Festa de São Benedito da Praia.

\section{Edificações}

Lojas atrás das portas do Mercado do Peixe; Praça da Palmeira ou "Pracinha"; Praça do Pescador; Prédio da Administração da feira; Mercado de Carne; Mercado do Peixe; Recebedoria; Delegacia; Casa Farol; Casa Chamma; Estação das Docas; Solar da Beira; Necrotério; Hotel Ver-o-Peso; e Depósito do Apolônio.

\section{Formas de Expressão}

Torcida Ver-o-Remo

Lugar

"Lá em baixo"; Porto do Sal; Praça do Relógio; Feira do Açaí; Pedra do Peixe; e Curral das Éguas.

\section{Ofícios e Modos de Fazer}

Ofício de erveira e erveiro; Ofício de mateiro; Modos de tirar e amarrar o mato; Ofício de regateiro; Ofício de barraqueiro de festa de santo; Ofício de funileiro; Ofício de reparador de eletrodomésticos; Ofício de amolador de faca; Ofício de peixeiro; Ofício de balanceiro; Ofício de carregador; Ofício de vendedor de miudezas; Ofício de vendedor de frutas; Ofício de vendedor de polpa de frutas; Ofício de vendedor de produtos importados; Ofício de vendedor de mariscos; Ofício de vendedor de 
animais vivos; Ofício de vendedor de peixe salgado; Ofício de vendedor de muda de plantas; Ofício de vendedor de camarão salgado; Ofício de vendedor de farinha; Ofício de vendedor de roupas; Ofício de vendedor de ferragens; Ofício de vendedor de redes; Ofício de vendedor de calçados; Ofício de vendedor(a) de refeição; Ofício de vendedor de hortifrútis; Ofício de vendedor de tucupi; Ofício de vendedor de artesanato; Ofício de vendedor de mistura; Ofício de vendedor de descartáveis e artigos de mercearia; Ofício de vendedor de pirarucu, piracuí e aviú; Ofício de cambista e rifeiro; Ofício de vendedor de maniva; Ofício de pelador de maniva; Ofício de açougueiro; Ofício de marchante; Ofício de lombador; Ofício de magarefe; Ofício de carregador e arrumador barracas; Ofício de manicure; Ofício de vigia/segurança de apoio; Modo de venda a retalho; Modo de venda na banca; e Modo de venda no tabuleiro. 


\section{ANEXO 5}

\section{Descrição do bem cultural da Universidade de Coimbra pela UNESCO}

Fonte: UNESCO, 2016.

\section{University of Coimbra - Alta and Sofia}

Situated on a hill overlooking the city, the University of Coimbra with its colleges grew and evolved over more than seven centuries within the old town. Notable university buildings include the 12th century Cathedral of Santa Cruz and a number of 16th century colleges, the Royal Palace of Alcáçova, which has housed the University since 1537, the Joanine Library with its rich baroque decor, the 18th century Botanical Garden and University Press, as well as the large "University City" created during the 1940s. The University's edifices became a reference in the development of other institutions of higher education in the Portuguese-speaking world where it also exerted a major influence on learning and literature. Coimbra offers an outstanding example of an integrated university city with a specific urban typology as well as its own ceremonial and cultural traditions that have been kept alive through the ages.

Outstanding Universal Value

Please note that the following Statement of Outstanding Universal Value is a provisional version. The final version will be adopted at the 38th session of the World Heritage Committee in 2014.

\section{Brief synthesis}

Situated on a hill overlooking the city, the University of Coimbra-Alta and Sofia has grown and evolved over more than seven centuries to form its own well-defined urban area of two components within the old town of Coimbra. Created initially as an academy in the late 13th century on the hill above the town (Alta), it was established in the Royal Palace of Alcáçova in 1537 before developing as a series of colleges. Coimbra University is an exceptional example of a university city, which illustrates the interdependence between city and university and in which the city's architectural language reflects the university's institutional functions.

As the centre for training the elite for all the territories under Portuguese administration, the University played a key role in the institutional and architectural development of universities in the Portuguese colonies. Key components of the university's pedagogical institutions are the 16 th \& 17th century buildings including the Royal Palace of Alcáçova, St Michael's Chapel, the Joanine Library, the Colleges of Jesus, Holy Trinity, St. Jerome, St. Benedict, St. Anthony of the Quarry and St. Rita; the colleges along Sofia Street including St Michael (Inquisition - old Royal College of the Arts), Holy Spirit, Our Lady of Carmel, Our Lady of Grace, St Peter of the Third Order, St. Thomas, New St Augustine, and St Bonaventure; the 18th century facilities in the Alta area including the Chemistry 
and other laboratories, Botanical Garden and the University Press, and the large 'University City' created during the 1940s.

Criterion (ii): The University of Coimbra-Alta and Sofia influences educational institutions of the former Portuguese empire over seven centuries received and disseminated knowledge in the fields of arts, sciences, law, architecture, town planning and landscape design. Coimbra University played a decisive role in the development of institutional and architectural design of universities in the Lusophone world and can be seen as a reference site in this context.

Criterion (iv): The University of Coimbra demonstrates a specific urban typology, which illustrates the far-ranging integration of a city and its university. In Coimbra the city's architectural and urban language reflects the institutional functions of the university and thereby presents the close interaction between the two elements. This feature has also been reinterpreted in several later universities in the Portuguese world.

Criterion (vi):The University of Coimbra - Alta and Sofia has played a unique role in the formation of academic institutions in the Lusophone world through dissemination of its norms and institutional set-up. It has distinguished itself from early on, as an important centre for the production of literature and thought in Portuguese language and the transmission of a specific academic culture, which was established following the Coimbra model in several Portuguese overseas territories.

\section{Integrity}

The property contains all the elements that demonstrate its Outstanding Universal Value as a university city that illustrates through its architectural ensemble the several periods of university development relating to ideological, pedagogical and cultural reformations. These periods are represented by the corresponding periods of Portuguese architecture and art. The visibility of the University as a 'citadel of learning' due to its hilltop location is vulnerable to inappropriate surrounding development, and the setting of the University within the old town and the visual and functional relationships that this generates are vulnerable to development within the university itself.

\section{Authenticity}

In formal, architectural and material terms, each of the buildings of the University is representative of the historical, artistic and ideological periods in which it was constructed. Conservation, restoration and rehabilitation interventions have been made in accordance with the prevailing theories in each period. Some interventions used new materials that were incompatible and have been corrected in later conservation campaigns. The topographical setting of a hilltop town in the landscape remains clearly defined, but its authenticity has been modified by the development of large scale buildings in the surrounding landscape. The University of Coimbra-Alta and Sofia also retains its authenticity of use and student traditions. 


\section{Management and protection requirements}

The property components are protected as National Monuments in accordance with Law 107/2001, no. 7 article 15. The Coimbra Municipal Master Plan is anticipated to be completed in November 2013 and will incorporate the property components and buffer zone as Special Protected Zones. The buffer zone is protected according to Decree-Law 309/2009, article 72 and will be supplemented by controls in the revised Coimbra Municipal Master Plan to protect views to and from the property.

Management of the property is the responsibility of the Association RUAS (Recreate the Univers(c)ity - Uptown and Sofia) set up for the purpose whose foundation members are the University of Coimbra (UC), the City Hall of Coimbra (CMC), the Regional Delegation of the Ministry of Culture (DRCC), and Coimbra Viva (SRU - Society for Urban Rehabilitation). The detailed University Alta Master Plan is being reviewed with the aim of improving public space by reducing surface parking, and improving vehicular traffic control. The main goal of the Management Plan (2009-16) is to sustain the University as the raison d'être of the city; preserving the heritage and at the same time reinforcing the functions of education and research. It provides for visitor management and facilities, and will be extended to include a consultative forum for community and non-government organization involvement; provision for impact assessments for all development projects and policies for minor buildings within the property, as well as an improved monitoring system. 


\section{ANEXO 6}

\section{Descrição do bem cultural do Ver-o-peso pela UNESCO}

Fonte: UNESCO,2016.

\section{Category: Cultural property; cultural landscape, organically evolved and continuing.}

An architectural and landscape ensemble, listed by IPHAN as a heritage site in 1977, comprising its urban layout, monumental buildings, rows of houses, iron markets and urban furniture, squares and docks for boats. Its spatial configuration was established and consolidated between the $17^{\text {th }}$ and the first decades of the $20^{\text {th }}$ century. Its origins are attributed to the implementation, in the mid- $17^{\text {th }}$ century, of a tax collection station at the mouth of an igarapé where there was a small natural port now corresponding to the docks.

The Ver-o-Peso is a great open air market of extraction, agricultural and artisanal products brought from the Amazon region. It is formed by small and large fairs, stores selling popular products as well as two markets (one selling meat and the other, fish) extending along the Guajará Bay, in permanent relationship with the neighboring islands and the inland towns from which many of the products sold there are brought. The Ver-o-Peso is, above all, a place of intense social life and cultural exchange, where traditional labor practices take place and a complex web of social relations is woven, involving trade of a commercial but also symbolic nature.

A hub from which the occupation of the Amazon Region and the State of Pará irradiated, the city of Belém concentrated the trade of extraction products from the inlands destined for the local and international markets, as well as manufactured products coming from Europe to supply the local and regional markets, becoming the region's greatest trading post. This intense movement and trade of products gave rise to the Ver-o-Peso, originally a tax collection station where merchandise was weighed and taxes were paid.

The Ver-o-Peso is implanted in an old Colonial ensemble, comprised of rows of houses, churches, a fort and palaces, funded, throughout the $19^{\text {th }}$ and the early $20^{\text {th }}$ centuries, by the production and exploitation of rubber from inland plantations. Its urban ensemble presents an European-influenced layout, with great squares of dense vegetation, Eclectic architecture with Art Nouveau elements, particularly in the Meat Market and in the iron clock at Praça do Relógio. The Fish Market building, built near the docks out of pre-molded imported iron plates, also dates from that period, permanently marking the landscape with the iron towers at the four corners of the building.

After the tax collection station was closed, the Ver-o-Peso was expanded as one of the main supply hubs for the city, as well as one of its most sought-after touristic spots. 


\section{Justification of Outstanding Universal Value}

The Ver-o-Peso, located at the historical centre of Belém, has become an icon of the city and a major expression of the identity of the Amazon region and its cycles of agricultural production, social life and cultural production.

It remains as the heart of the city and a major supplier of fairs and small markets of Belém, along with its outskirts. Ver-o-Peso concentrates a great movement of boats and other vessels bringing extraction products, arts and crafts and agricultural products every day to supply both the fair and the local market.

The site synthesizes, in a unique manner, the culture of the Amazon region in its cultural practices, in its relationship with the river as a pathway, a source of nourishment and of leisure. Its role as a trade post, giving rise to the Ver-o-Peso in 1688, remains alive, even in face of other possibilities for transport and communication between the cities in the state and the region, particularly the capitals and the seat of power, but still distant from the economic and technological reality of many places in inland Amazon.

Its exceptionality is thus expressed in the geographic (Amazônia) and cultural representativeness (interchange of amazonical people), on its antiquity (about 400 years), its location within an ensemble of Colonial buildings, its iron architecture, its vital relationship with the river, supplying the city with agricultural products, but also with traditional knowledge expressed in the preparation of food, in arts and crafts, in speech, in popular medicine, in superstitions, myths and legends from the Amazon.

Criterion (ii): The site witnessed cultural and economic interchange between different peoples and ethnicities over more than three centuries. As the entryway to the Amazon, it plays an important role in this cultural flux from which it also results. An instance of interaction between the Amazon region's natural environment and the project of a Colonial city, strongly marked by elements of European architecture and urban planning.

Criterion (iii): The Ver-o-Peso has remained, through the centuries, the converging hub of the city and region, as the great supplier of fairs and markets with extraction, agricultural and artisanal products brought by boat, representing, in a unique way, the culture of the Amazon region. The production and trade of food products made out of the manioc root, inherited from the Indians, may be appreciated and enjoyed in the fair, as well as natural perfumes made from essences extracted from the Amazon flora.

The Ver-o-Peso translates the riverside vocation of Amazon towns, with their boats, fairs and markets, where the rivers are means of transportation and locomotion, leisure, livelihood and food for the imagination, giving rise to many myths and legends heard and told over and over in the 
market. This identity image was reinforced by the arts, through representations of Ver-o-Peso in novels and poetry, visual arts, photography, music, movies and theater.

Criterion (iv): It harmoniously gathers architectural, urban and landscape elements from the $17^{\text {th }}$ to the $20^{\text {th }}$ centuries, reflecting the masterful implementation, development and consolidation of the occupation of the urban area of a city built very close to the level of the sea: 1) The docks that permeate the city and make the market float on the waters of the bay; 2) The boats flowing into the urban fabric, establishing a dialogue with the rows of houses and the Fish Market itself, with its sharp towers mingling in the skyline with the masts of ships and the steeples of churches in the background; 3) the proximity and coexistence of forts, churches, monumental palaces, houses, markets and fairs juxtaposed in the urban layout, forming the geography and taking over the canals through draining and landfills. Once a year, during the "waters of March", the order of things is reversed and the river invades the city, reaffirming the riverside origins of the great metropolis that is now Belém.

Criterion (vi): In its trade products, daily practices, in the manipulation of herbs, in manioc-based food systems, in the language, gestures and manners of being and doing, the site synthesizes the traditions and beliefs typical of the Amazon Region, perpetuated from generation to generation for more than 300 years.

\section{Statements of authenticity and/or integrity}

Authenticity

In terms of shape, the site preserves its main typological, morphologic and constructive characteristics attained between the $17^{\text {th }}$ and the early $20^{\text {th }}$ centuries, particularly those related to urban design and architecture. The urban layout was enhanced by $19^{\text {th }}$-century interventions, the construction of the first dock; the European-style arrangement and vegetation of the old largos, turned into squares incorporating promenades, lakes, monuments, benches, lamp posts and public lighting. The architecture is notable for the Eclecticism of buildings raised in this period, such as the two markets and the Solar da Beira. Eclecticism also appears in government palaces and mansions for their decoration, particularly in their Art Nouveau features, funded with the revenue of rubber exports. Later additions and alterations are, generally, harmonious with the concept of the ensemble. Some uncharacteristic and conflicting elements do not compromise the perception of the place and its landscape, or of its relationship with the bay, the islands, the Amazon forest seen at the other bank, across from Ver-o-Peso. An interpretation of the landscape, the monuments and the urban interventions allows the perception of distinct periods in the integrity of its shapes and different scales.

Materials are preserved, especially in monumental constructions from the $18^{\text {th }}$ as well as the $19^{\text {th }}$ and $20^{\text {th }}$ centuries. The fairs, on the other hand, because of their transitory character (although they are, 
themselves, permanent), receive, from time to time, new equipment and treatment of open areas, but they are always concerned with preserving the setting, the scale relationship and the visibility of the rows of houses.

The uses and functions of the buildings existing there are preserved and maintained also by the social appropriation of the space and the "spirit of the place", strengthened by the presence of monumental Colonial buildings establishing connections with the past. This past is permanently brought up-to-date by the uses and resignification of the monuments and the meanings attributed to them, but also by the life and the constant dynamics of the dock, the fairs and markets, where material and symbolic exchanges are part of daily life. Social relations and cultural practices are transmitted from generation to generation by the families that trade herbs and natural products, religious products, crafts and food, synthesizing cultural practices and centuries-old customs from the Amazon region, merging the knowledge of Indian and African peoples, appropriated in different manners by Europeans and by Eastern immigrants who came to Brazil in the cycles of foreign labor imports. In Ver-o-Peso, these practices constantly reiterate the ways of life of Paraenses, of riverside populations, of Amazon folks and of Brazilians.

At Ver-o-Peso, tradition and modernity exist side by side, whether in the architecture of the old Colonial buildings and the stretched canvas tents covering the fair, whether in the products traditionally sold in the place coexisting with phone order systems and product delivery. The manual system for loading fish and other products transported in woven straw baskets and wooden boxes, the manipulation of herbs based on traditional knowledge, the beliefs and superstitions permeating the daily life of the fair, side by side with the organization of labor around different activities and its political representation and demands. Protected by Federal legislation since its inclusion in IPHAN's heritage list, the Ver-o-Peso ensemble is also a part of the area of Belém's historical center, listed as heritage in the Federal and Municipal levels, with its protection ensured by specific Municipal legislation. In the Federal sphere, specific norms for listed heritage areas in Pará are being developed. IPHAN has undertaken a preliminary survey of Ver-o-Peso's cultural inventory, as well as a record of the fair's activities and sectors, creating a specific database including a mapping of civil society organizations and public institutions in activity there.

Regarding the surrounding landscape, the Colonial ensemble of Belém's first site, at the outskirts of Ver-o-Peso, is marked by monumental religious and military buildings, but also by rows of Colonial houses. The Eclectic buildings from the late $19^{\text {th }}$ and $20^{\text {th }}$ centuries, however, have been well assimilated, maintaining a certain unity with the ensemble. After the construction of the docks and the reclaiming of this frontal area of the city from the waters with the implementation of a great boulevard, the area received also the English iron sheds of the Belém Harbor, located at the other 
end of Ver-o-Peso. These sheds have been requalified by the "Estação das Docas" project to include theaters, galleries, bars, restaurants and small shops of cultural products.

The limits and boundaries of Ver-o-Peso are defined not exactly by physical and spatial landmarks, but rather by the movement of different types of trade and the web of social relations established around the fairs, markets and stores. A notable feature is the landscape, in which nature, the exuberant river and the forests are associated to European-influenced urban planning and architecture. The conception of the docks allows the river to permeate the city, leaving the impression that, in high tide, the Fish Market with its towers floats on the waters of Guajará Bay.

The spirit and character of the place result from its architecture and urban planning and, above all, from their integration to the natural elements and the people that trade, exchange and circulate there. This is a place, in the anthropological sense of the term, marked by the practices and relationships established around them. By the presence of the old preserved buildings, but also by the docks, the fairs and markets, the close relationship with the river and the coming and going of vessels.

Integrity

The site represents an outstanding conjunction, in the context of the Amazon, of European-style architectural, urban and landscape elements from the $18^{\text {th }}$ to the $20^{\text {th }}$ centuries with the region's exuberant nature and cultural and symbolic elements that have been present for about three hundred years: the activity at the docks, the flow of people and of extraction, artisanal and agricultural products, social and work relations.

The dimension of the ensemble and its integrity, from the tangible and the intangible point of view, allow us to apprehend and understand the representation hereby proposed, based upon the spatial practices and social relations on the urban fabric, with the pertinent dynamics. The information is based upon an observation of the dynamics of occupation and the changes experienced through time, allowing the conclusion that, even in periods of crisis and abandonment of the place, it retains its spirit and the daily cultural practices that mark the space. It was precisely in one of these moments of crisis that the workers of Ver-o-Peso came together to demand from the Municipality the requalification of the ensemble, undertaken between 1999 and 2004.

\section{Comparison with other similar properties}

The Ver-o-Peso is associated to urban typologies of markets and fairs, where the exchange of products and knowledge from different peoples takes place during a certain period. We may identify several European sites in the World Heritage List characterized as fortified market-towns from the Medieval period, such as Provins, France, and Bellinzona, Switzerland. In these sites, one of the main recognized aspects is the fact that they were established as towns where a mercantile character was present in the circulation of products from various origins, as well as the integrity and authenticity of 
the space in which these activities took place through time. In the Middle East, the town of Aleppo, Syria, bombarded in conflicts over the last few years, is representative of the crossroads of different trade routes between East and West. Still, in all these cases, the use as fair or market has not remained alive, unlike in the case of Ver-o-Peso.

There are several historical towns, some of them port towns, located at the intersection of product routes, such as Bordeaux or Naples, although the market, specifically, is not the focus of their recognition, but rather the historical urban space as a whole.

Similar values can be pointed in some African sites, representative of different historical-cultural periods, or witnesses to routes of products such as gold, such as the old towns of Djenné, Mali, and Kano, Niger (in this country's Tentative List). In the town of Kano, the Kurmi market consists of one of the greatest and oldest markets in the continent, reaching beyond national boundaries, where North-African and European merchandise were exchanged for domestic products in the TransSaharian marketplace. This cultural landscape is still alive, and maintains its prominence in the trade of traditional crafts in leather, textiles and clothes. In both sites, traditional earthen architecture achieves relevance as a value for humanity.

Particularly, in terms of geographic and cultural representativeness, no cultural site related to the people of the Amazon is contemplated in the List. The Ver-o-Peso translates, precisely, the riverside vocation of Amazon towns, with their boats, fairs and markets whose relation with the river is established, above all, as a means of transport and locomotion, leisure, livelihood and food for the imagination, giving rise to many myths and legends that were widespread throughout the region. Its originality is associated to the continuous exchange of knowledge associated to Indigenous traditions, African and European influences, since the 17th century.

In the Brazilian context, the Ver-o-Peso also stands out in comparison with other popular fairs and markets, such as São Joaquim, in Salvador, Bahia; Caruarú, in Caruarú, Pernambuco; and São Cristóvão, in Rio de Janeiro.

It is a place of strong symbolic connotations, with its own count of time, marked by periods of heavy rainfall and drought, by seasonal fruit and fish, by never-ending movement, by important festivities such as the Círio de Nazaré, by the "perfumed baths" periods, such as June festivities and the New Year. 


\section{APÊNDICE A}

Entrevistas realizadas na cidade de Coimbra com alguns dos principais idealizadores e responsáveis técnicos envolvidos na elaboração e desenvolvimento do processo e da documentação de candidatura da Universidade de Coimbra como patrimônio mundial pela UNESCO:

1. Prof. José José António Raimundo Mendes da Silva, curador da candidatura da Universidade de Coimbra a patrimônio mundial pela UNESCO, professor associado ao Departamento de Engenharia Civil - FCTUC da Universidade de Coimbra;

2. Nuno Ribeiro Lopes, arquiteto coordenador da candidatura da Universidade de Coimbra a patrimônio mundial pela UNESCO;

3. Sidónio Simões, diretor do Gabinete do Centro Histórico da cidade de Coimbra 


\section{ENTREVISTA 1}

Entrevista realizada no Departamento de Engenharia Civil, Polo II, Universidade de Coimbra, na cidade de Coimbra, às $12 \mathrm{~h}$ do dia 3 de julho de 2012, com o Prof. José António José António Raimundo Mendes da Silva, curador da Candidatura de Coimbra como cidade patrimônio mundial na UNESCO.

Essa entrevista surgiu pela necessidade de compreender melhor o processo de patrimonialização da Universidade de Coimbra e do ansejo por parte da autora da tese de compreender melhor questões referentes a sua idealização, seu desenvolvimento, os participantes deste processo, o envolvimento do Estado e da sociedade civil, e as particularidades de um processo de classificação segundo a UNESCO. Por esta razão fez-se a escolha de entrevistar o idealizador e curador do dossiê de candidatura da Universidade de Coimbra.

Muitas das perguntas ao entrevistado enfocaram na idealização desse processo de patrimonialização e na sua continuidade até a configuração de um dossiê de candidatura.

Maísa Fonseca: Quais foram os critérios para a seleção da Universidade Alta e Sofia como patrimônio mundial?

Prof. Raimundo Mendes: A ideia de fazer uma candidatura da Universidade a patrimônio mundial é uma coisa absolutamente recente, mas que tem um contexto histórico alargado. E, eu diria que é uma ideia de 2002, portanto, há 10 anos. A ideia teve este formato e esta continuidade porque houve várias tentativas ou várias ideias de poderem fazer uma candidatura Centro Histórico ou do Centro Urbano Antigo. É cada vez mais polêmico falar dos Centros Históricos, porque a história é um processo, a questão dos Centros Históricos, é polêmica neste momento, fala-se mais de núcleos urbanos antigos de estruturas consolidadas.Essa ideia de fazer uma candidatura do centro urbano, do centro histórico a patrimônio mundial é uma coisa já antiga, e que teve uma ou duas tentativas claramente informais, portanto não concretizada depois em um dossiê formal perante a UNESCO.

A evolução do conceito de patrimônio mundial tem-se vindo a fazer, sobretudo naquilo que é o patrimônio mundial na Europa, porque o patrimônio mundial de acordo a UNESCO e com os critérios que estão estabelecidos, no fundo pretende é realçar algo que tenha sido absolutamente extraordinário do ponto de vista das civilizações, que tenha sido muito representativo de alguma civilização, de determinada cultura, que não tenha ficado restrito e enclausurado, naquele espaço e que tenha de alguma maneira influenciado o mundo e, e que seja singular. E, aí que começa a 
primeira dificuldade de quem que pensa fazer uma candidatura a patrimônio mundial, esta distinção entre o que é muito bom, o que é interessante e o que é de fato singular. E, eu digo isto com alguma clareza e é sempre polêmico, mas Coimbra, cidade núcleo urbano antigo, é muito interessante, é, a falar de Portugal, um dos poucos núcleos urbanos antigos com escala suficientemente grande, e que se mantém, apesar de com uma estrutura urbana organizada, apesar de estar em mal estado, mas não é suficientemente singular. Em Portugal é muito importante que se promova, e é absolutamente relevante que se salvaguarde, mas não é suficientemente singular para poder ser patrimônio mundial só por si. Eu sou de Coimbra, e é muito difícil fazer este juízo, mas penso que se tem que fazer. Não é um juízo de desvalorização da cidade, essa é uma primeira razão. A segunda razão é porque nada funciona separado, as coisas funcionam em conjunto. Numa cidade que é universitária e neste momento é também o que se costuma dizer um núcleo de saúde, a componente hospitalar e médica é muito pesada em Coimbra, é muito forte, pois Coimbra tem um dos melhores sítios hospitalares do país.

Embora não se perceba, Coimbra é um ponto de destino em termos de saúde também da Europa e não só em Portugal. Mas eu sou da universidade e encaro esse peso da saúde também numa perspectiva da ciência, não é universitário embora o hospital seja universitário, mas é também no sentido da ciência. Este mote, digamos assim, da cultura, do conhecimento, que agrega também a universidade, que agrega também hospitais, saúde, etc.. fazem de Coimbra aquilo que é tipicamente uma cidade universitária, em sentido apta, a "Universidade do Conhecimento" digamos assim. A indústria que aqui se tinha, a indústria mais pesada que se tinha até umas décadas obviamente foi desaparecendo neste momento. Infelizmente, no sítio empresarial o que está a começar a acontecer é um centro empresarial com muito mais incorporação tecnológica e conhecimento científico. Estou dizendo isto porque numa cidade que tem esta marca e que tem uma universidade que tem setecentos anos em termos eventualmente de escala, e que tem setecentos anos que é uma marca em termos de nome, e em termos de conhecimento porque foi a universidade do Império, então culturas com alguma ligação a Portugal e a língua portuguesa acabaram por ter os seus quadros formados ao longo dos séculos na Universidade de Coimbra, digamos em Instituições que a ela acabavam por estar ligadas. Quer na Universidade, em Colégios religiosos, mas a Universidade de fato era a única.

Ou seja, ela chega ao século XX praticamente com este lastro. Portanto, falar da cidade de Coimbra, e da candidatura de Coimbra a cidade patrimônio mundial, em um primeiro momento sem colocar como marca distintiva a Universidade, só poderia acontecer se a Universidade tivesse por qualquer motivo perdido a importância ou não tivesse marcas físicas suficientemente evidentes. Porque isto é uma candidatura material, não estamos a falar de uma candidatura imaterial. Sempre há certa confusão, estamos a falar de uma candidatura material, numa cidade em que temos esta marca, fez 
desenvolver a cidade, esteve intimamente ligado com ela, tem este poder se quiser imaterial, mas tem materialidade suficiente para poder ter esta expressão de patrimônio mundial, não faria nenhum sentido fazer uma candidatura da cidade e não da universidade como mote. Fazendo isto a ideia de fazer uma candidatura, digamos, a patrimônio mundial da universidade, eu diria que no início poderá ter sido, uma ideia mais curta, mais limitada, no sentido monumental. Isto é, como aconteceu na Europa digamos nas últimas décadas, costuma-se dizer que a UNESCO neste momento não quer mais nenhuma catedral gótica como patrimônio mundial. Não tem nada a ver, não tem nenhum juízo negativo em relação às catedrais góticas, significa que mudou o contexto, o contexto já não é o monumento, o contexto do grupo arquitetônico, da influência arquitetônica, dos conjuntos, até porque apesar de ser uma candidatura material, ela só tem valor se contar uma história e se esta história for verdadeira. Tanto quanto pode ser que uma história pode ter uma componente que não seja tão verdadeira assim, digamos que pode ser da lenda que também ajuda. Ora, essa história é mais fácil contar e é mais lógica que seja contada por um conjunto arquitetônico, construtivo urbano, digamos no seu todo, do que por um monumento.

Portanto, essa evolução da UNESCO também se refletiu aqui, e portanto rapidamente se a Universidade tiver pensado, eu não estou dizendo que pensou, inicialmente em fazer uma candidatura de um monumento e não do entorno, por exemplo, a Biblioteca Joanina, o núcleo do Paço das Escolas, o antigo Palácio Real, Capela, a Biblioteca Joanina, aquele conjunto ao redor do pátio das Escolas, que seria interessante tanto do ponto de vista arquitetônico, do ponto de vista da história muito interessante, digamos a maior parte das coisas é do século XVIII, mas há ali toda uma história que vem não com a Universidade no século XIII, mas que vai para ali no século XVI, mas o sítio em si é um sítio muito interessante porque é um sítio que tem ocupação de diversos urbanos. Naquele pátio fizemos arqueologia há alguns anos e portanto naquele sítio conseguimos recuar 4 séculos na história de Coimbra. Nós tínhamos vestígios de século $V$, e no pátio conseguimos encontrar, dizem os arqueólogos, alguns vestígios do século I. E, portanto, aquele espaço em si, pela história anterior a Universidade, pelo valor patrimonial, e porque agora a expressão em termos arquitetônicos poderia numa filosofia, eu diria, mais ultrapassada da UNESCO em termos patrimoniais poderia ser objeto a patrimônio mundial.

Ok, neste momento, com a evolução da Perspectiva da UNESCO sobre patrimônio mundial e com a exigência da Universidade, não faria sentido, e, portanto rapidamente se conclui uma ideia de candidatar a Universidade e dizer o que é que tem mais valor na Universidade, assim, há a história da Universidade, mas essa é imaterial, que tem uma tradição em âncoras físicas, que tem valor arquitetônico, valor patrimonial e que são no fundo as ancoras a expressão física desse processo. 
E, portanto, depois é muito rápido, um processo de discussão ainda em evolução, o mote passou a ser Universidade Alta e Sofia, abrangemos duas áreas que é uma coisa estranha. Geralmente, as candidaturas têm uma área compacta, duas áreas porque a Universidade no seu núcleo mais antigo concentra-se na zona da Alta e tem um núcleo, que não é um núcleo pouco relevante onde a Universidade já não está mas onde está a tentar regressar, que é a Rua da Sofia. Onde foram construídos colégios no século XVI especificamente para a função Universitária. E, com uma marca ainda maior, que é, se nós pensarmos na cidade antiga, consolidada, nesse centro urbano antigo, quanto a sua malha, sua estrutura urbana medieval quase, que se mantém. A sua estrutura e valor quando um dia quase que se mantém, chega ao século XVI ela ganha portem, por causa da Universidade um rasgo, a ideia é portanto fora de época, de fazer uma avenida larga que lá está hoje, a Rua da Sofia tem aquela expressão, que rompe completamente com a estrutura urbana medieval. No fundo aquilo que se decidiu foi de se contar a história da Universidade, e, portanto, contar a história da Universidade é contá-la, obviamente, a história é imaterial, mas é contá-la através de suas marcas físicas. E, essas marcas físicas levaram, é um bocadinho difícil dizer quem nasceu primeiro, são ideias que se vão estruturando, isto nós é quem vamos contando. A história da Universidade conta-se por décadas, e estas décadas têm uma tradução cartográfica, uma tradução gráfica. Sendo que, isto ainda por cima resolve-nos um problema, que é um problema filosófico complicado, que é o limite da discussão teórica de qual é limite do valor arquitetônico e do valor histórico. Onde é que para a nossa fronteira, onde é que para a nossa história da Universidade, se para no século XVIII, sec. XIX ou se para hoje. E, essa é a questão de contar a história da Universidade de alguma maneira resolvemos esse problema, porque obviamente não integraremos a candidatura ao polo II e ao polo III que são coisas muito em si recentes. Mas integraremos a candidatura tudo o que são intervenções nas zonas onde ela nasceu, digamos assim, mas que foram evoluindo ao longo dos séculos. Num sítio da alta universitária, onde está, aí nesses edifícios são edifícios chamados do Estado Novo. Portanto, do momento da ditadura que foi século XX entre 1940 e depois 1965.

Esses edifícios como é que vamos encarar em uma candidatura a patrimônio mundial? A primeira reação poderia ser que horror esses edifícios não são edifícios históricos nesse conceito tradicional. Só que esses edifícios são as marcas físicas dessa história da Universidade e de uma determinada época que ainda por cima é muito marcante por dois motivos, porque é a época em que o Estado resolve demolir uma parte significativa da cidade, da alta consolidada. E conhecida como a "destruição da Alta". Naquele sítio que haviam os colégios jesuítas, os edifícios mais antigos, e casa e malha urbana, e, portanto, uma intervenção de força e poder, do Estado. Que ponto de vista histórico é relevante embora negativa, encarada pela nossa visão como negativa, é uma altura em que o Estado marca e reafirma a importância da Universidade, e desta Universidade. E, independente de como concordarmos ou não com essa afirmação, é uma afirmação de força, 306 
obviamente choramos e continuaremos a chorar digamos o que foi essa destruição, mas tem um fator adicional muito positivo, é que do ponto de vista arquitetônico, a época é uma solução muitíssimo interessante, isto é, não só é uma solução estrutural, como neste momento é uma solução representativa e de qualidade do que é uma arquitetura de Estado daquela época, que se encontra em Itália, e, também, com o Fascismo, que também se encontra em outros locais, e mais do que isso são edifícios muito interessantes. Portanto, não só o plano, como a representação arquitetônica como os edifícios, se entrar, e vale a pena entrar num daqueles edifícios, e tentar perceber os edifícios que são diferentes.

A faculdade, a faculdade de medicina foi 1965, se não me engano, foi criado para a Faculdade de Medicina. É um edifício, digamos, do ponto de vista estrutural, da organização, dos materiais, notável. Ou seja, esta época, que podia ser uma época "negra" em uma visão profundamente patrimonialista, e, um bocadinho ultrapassada. Acaba por ser, numa candidatura o que eu estava por fazer, era contar as suas marcas físicas, acaba por ser um momento também relevante. E, portanto, é assim que nasce uma candidatura destas.

O Seabra Santos ${ }^{157}$, que foi o antigo Reitor, e que esteve muito tempo na reitoria. Portanto, Seabra Santos foi vice-reitor inicialmente, depois, a partir de 2003, fez um mandato de 2003 a 2007, 2007 a 2001. O prof. Seabra Santos logo no início do mandato, em 2003, achou que a ideia, que essas ideias que andavam no ar se poderiam concretizar e se fundir digamos num plano já para essa candidatura já numa perspectiva alargada.

E, portanto, em 2004, se não estou enganado, fez-se um primeiro dossiê preliminar, uma primeira proposta, que fez com que a Universidade fosse incluída na lista indicativa de patrimônio mundial. Portanto, a UNESCO tem esse processo, de vez em quando, a UNESCO abre as listas indicativas, a lista indicativa não é um processo periódico, digamos, regular. Não há de cinco em cinco anos, de dez em dez, ou seja, o que for. As listas indicativas são uma coisa que se faz de vez em quando, poucas vezes, e que tenta indicar bens que são suscetíveis de ser patrimônio mundial. Portanto, no fundo, é uma pré-lista.

Portanto, em 2004, Coimbra passou a integrar a lista indicativa de patrimônio mundial, ou seja, não tem deadlines, não tem prazos, tem a explicação de uma ideia, tem uma primeira explicação do que é o âmbito, qual é a abrangência do território. Tem uma primeira proposta de quais são os critérios, que da UNESCO são diversos, mas temos que responder dois ou quatro, e, portanto, tem uma

${ }^{157}$ Fernando Seabra Santos foi reitor da Universidade de Coimbra entre 2003 e 2011, e um dos responsáveis pelo lançamento da candidatura da instituição à classificação pela UNESCO. 
primeira proposta por parte do ICOMOS dos critérios a que deveria responder. Portanto, a partir daí começa-se um trabalho, que é um trabalho, eu diria, de assunto técnico de preparação de um dossiê. É evidente que um dossiê deixou há muito tempo de ser um livro muito bonito, como umas fotografias muito bonitas e um texto auto elogiativo, tem que ser também, isto é, deve vender. Mas, um dossiê deixou de ser de fato um documento deste tipo, porque um dossiê tem, por um lado, um fundo de origem que vem da UNESCO muito rigoroso, isto é, em termos de que tem que responder. O dossiê, que não sei se já viram em papel? Viram em pdf que é mais... dossiê é uma coisa enorme. Tem 7 volumes, mas o primeiro volume é a candidatura, fundamentalmente. O segundo volume é o plano de gestão, que era obrigatório, não era obrigatório para outros bens, e, portanto, por isso, neste momento, algumas diferenças entre a UNESCO e o ICOMOS sobre a função de alguns bens que foram patrimônio mundial porque não havia plano de gestão.

Plano de gestão é um plano para 30 anos, que, obviamente, tem que ser revisto periodicamente, mas que há uma indicação sobre o que se pretende fazer. E, pois os outros não são menos importantes, mas são documentos complementares, se quisermos. O livro 3 é o porquê mencionamos textos complementares, porque dos contributos que pedimos a várias pessoas, para nos escreverem sobre alguns assuntos para o livro da candidatura, os textos contributos que nos deram eram coisas grandes demais, e o 3, que nós não podíamos colocar no da candidatura, e, portanto, escolhemos alguns que depois anexamos no livro 3, enfim, são textos gerais, são outros contributos.

Deixe-me fazer um parêntese, que estes contributos são contributos sem autor. É uma questão sempre muito delicada no contexto, há autores dos volumes, colaboradores dos volumes, há uma comissão científica, mas cada texto em si, não tem autores, porque não faz sentido, isto é, a Universidade faz um processo de candidatura que adapta-se com seus contributos, mas isto não é uma revista científica, com cada pessoa a fazer a sua ciência sobre um determinado assunto. Já teve, digamos, que fazer este processo, que é um processo muito difícil, sobretudo em termos universitários. As pessoas, precisam a sua autoria específica, e isto é uma autoria global, no fundo, cada um contribuiu com cada volume, assume-se como autor global do volume. Mas, isso pode parecer interessante, e, ao mesmo tempo, não é interessante, as pessoas são muito mais agradáveis ao que é de sua autoria específica.

O quarto volume, é o volume provavelmente mais frágil ainda, do ponto de vista da UNESCO a candidatura que está entregue é este. Posso, se estiverem interessadas, depois dizer-Ihes o processo, mas, que está entregue é este. Mas uma coisa é o dossiê, outra coisa é o processo em si. O processo de investigação, o volume 4, é uma coisa, que se a Universidade tiver força, vontade e juízo virá a esmiuçar, que é livro sobre as influências. As influências da Universidade no mundo e do mundo na Universidade mas, sobretudo, da Universidade no mundo. E aí, há três ramos muito grandes, que é o 
ramo da África, o ramo da Ásia e o ramo do Brasil. Que são perspectivas diferentes, o que a Universidade influenciou digamos, estes passos.

Não só para a formação de quadros, uma formação, digamos, do contributo para a reflexão e para a cultura, mas, também assim em assuntos diversos, e, também a Universidade é relativamente exemplar nisso. É uma Universidade que ao longo dos anos vai integrando muito da cultura, quando o contata. Há aqui, portanto, um processo... essas coisas tem que dizer com cuidado, não é um processo colonizador. Não quer dizer que a função global não fosse essa, mas de fato a Universidade como Instituição foge de alguma maneira ao que eram os paradigmas da época durante vários séculos que era o processo, digamos, profundamente colonizar que nós é que levamos. A Universidade tem, e eu li que isso tenha sequer é assumido, não é uma questão estruturaria, eu acho que é intrínseco, digamos, a cultura do conhecimento e ao debate e é de facto que é um processo que de facto foi se transformando também com estes input e essas ligações.

O que é que está menos tratado?

Está menos tratado uma, compreende que a UNESCO dá muito valor, e que é difícil numa candidatura destas, a influência arquitetônica. Isto é, estamos a tratar de um bem material, portanto, a questão material é que é um pouquinho delicada porque é preciso perceber se a Universidade influenciou também do ponto de vista arquitetônico este espaço, coisa um bocadinho.. lida de uma maneira muito direta é muito difícil. De uma maneira mais indireta não é tão difícil assim, porque, por exemplo, toda a arquitetura militar da Índia foi fundamentalmente feita e organizada por engenheiros militares que passaram por Coimbra. Não acabaram aqui suas limitações, logicamente não era aqui que se acabavam, mas cuja formação de base era uma formação de Coimbra, não é?! Este é o quarto volume, é o volume das influências. E, é um volume, que eu digo, muito interessante, mas é o mais fininho de todos, implicava agora em um investimento muito grande, porque, por exemplo, nós temos agora divulgado que valia a pena identificar em níveis de investigação no local, nos locais.

Em relação ao Brasil muito concretamente, em relação ao Brasil fazia todo sentido que se viesse a estruturar um nível de investigação, pois com contributos que se fossem dando para esta investigação da influência do patrimônio mundial, da influência mútua da Universidade no Brasil e do Brasil na Universidade.

Agora, o quinto volume, é o maior de todos, falei que eu sei de cor. O quinto volume é o maior de todos, é muito grande, eu diria que nós andamos a fazer o tempo todo, são os planos diretores dos edifícios.

O que é um plano diretor? 
Um plano diretor é uma coisa estranha, porque não há um anteprojeto não é um estudo prévio, não é um plano preliminar, um plano diretor eu diria que é uma definição de intenções de regras gerais para um edifício, mas com duas componentes fundamentais, uma é uma fundamentação histórica e outra um ensaio de futuro. Isto é muito complicado, para arquitetas é mais fácil explicar, vocês provavelmente compreendem este sentido, para um jurista é muito complicado explicar o que é alguma coisa que define regras, que dá ideias mas que não é uma imposição. Isto é, mesmo numa Universidade foi relativamente difícil de explicar. Porque eu olho para um edifício, e para este edifício tem um desenho do que ele pode vir a ser daqui há dez anos, e as pessoas acham que aquilo é o projeto. E, não é, é um mero ensaio para demonstrar que dentro daquela ideia, é possível a que esse edifício venha a usar esses serviços sem se descaracterizar. Agora, a liberdade a seguir ao projetista, isso é, obviamente são definidas regras, é está definido o que é o percurso histórico do edifício. Um plano diretor tem essa figura um bocadinho estranha, que é a ligação da história, a identificação do que são as potências atuais do edifício e do que pode ser, de acordo com o plano de gestão, pode ser a sua proposição futura e, no fundo, digamos, em outros sítios, em outras candidaturas, as pessoas fazem de outra maneira, cada um faz de uma maneira.

Nós optamos por este ensaio duro, porque como deve imaginar, estamos a falar de 200 edifícios, nem todos tem plano diretor, mas há 50 planos diretores daqueles que são usados, estamos a falar de um edifício de $10.000 \mathrm{~m}^{2}$, portanto, fazer um plano diretor para um edifício com $10.000 \mathrm{~m}^{2}$ implica, obviamente, o estudo da história do edifício, implica depois o design, o ensaio para uma determinada função. Portanto, este quintolivro é muito importante, porque eu diria que é o livro de orientação de quem vier a seguir, daqui há muitos anos. Sobretudo, com a crise todas as obras vão durar muito mais tempo para fazer, do que estava previsto.

O livro seis é um livro de concretizações, já, portanto, obras que estão feitas, projetos que estão feitos, mostra alguns exemplos de obras, e, em alguns casos alguns de projetos, alguns estudos prévios, portanto, já não estamos a falar de uma coisa tão vaga, estamos a falar do projeto especificamente.

E, o último livro, é um livro que também não é obrigatório, aliás, nenhum deles, que é sobre a Zona de Proteção, portanto, é o que está para além da Zona Candidata. A Zona Candidata, como sabem, são duas Zonas Candidatas, tanto é a Rua da Sofia e a Alta, e a Zona de Proteção é uma coisa enorme, que inclui a chamada Alta da cidade, também a Baixa, também a Avenida Sá da Bandeira, portanto, toda a cidade medieval mais a cidade do século XIX, numa mancha enorme, que eu estimaria em 2000 edifícios. A Baixa tem 721, a Alta tem 540, acho, portanto, já dá mil duzentos e tal, com mais a Avenida Sá da Bandeira estamos a falar a volta de 2000 edifícios. Sendo que isso pode ser um número engraçado em termos de escala, para se perceber qual é a escala. E, para Portugal, este é um centro urbano antigo consolidado, relativamente interessante, ainda com estrutura, estamos a 
falar entre a Baixa e a Alta, de 1200, 1300 edifícios, e, portanto, não é reativamente e imparavelmente, há núcleos muito maiores, mas em Portugal este núcleo é um núcleo interessante. O que é que significa ser Zona de Proteção em termos de uma urbanização tão grande?

É que esta candidatura, e ainda bem que sim, transformou-se na candidatura da cidade. Porque, isto é, não faz sentido que haja outro plano, que haja outra estratégia, para o núcleo antigo, ou núcleo urbano, digamos, mais conceituado, que não esteja agarrado diretamente a candidatura. E, portanto, aí, a arte será ou é, o de conseguir casar o que são os princípios de reabilitação urbana, e da estratégia de intervenção urbana, sem pensar em patrimônio mundial, casar estes princípios, com o que são os princípios da candidatura em termos de Zona de Proteção.

E, portanto, estamos a entrar num domínio totalmente diferente, que já não é o domínio da Universidade, não é o domínio destes edifícios, é o domínio da cidade.

Maísa Fonseca: Qual foi o papel do Professor enquanto curador?

Prof. Raimundo Mendes:A figura do curador que aparece muito recentemente, nunca houve curador. A estrutura da candidatura foi sempre uma estrutura muito simples. O Reitor como coordenador geral, e o Reitor nomeou dois pró-reitores para coordenar áreas distintas. A área dos conteúdos e de investigação, tanto a área dos conteúdos quanto a de investigação, e a área de reabilitação, da preservação física e da preservação do patrimônio e de sua reabilitação.Portanto, numa primeira fase, o pró-reitor para a área de conteúdos, o Prof. João Gouveia Monteiro, professor da Faculdade de Letras, professor de História. E, o pró-reitor para a área de reabilitação física, portanto, da preservação patrimonial, era eu. Com o evoluir das... e, a par disto a criação de um gabinete técnico. Portanto, a estrutura da candidatura tem a seguir um gabinete técnico que articula com os outros serviços da Universidade, normalmente, dos edifícios, mas criou-se um gabinete técnico específico, e, foi convidado um coordenador, o arquiteto Nuno Ribeiro Lopes, que já tinha sido o coordenador da candidatura das Linhas do Pico a patrimônio mundial, embora seja nos Açores, portanto, é um a coisa um bocadinho diferente, que já tinha sido Diretor do Centro Histórico de Évora, e, portanto uma pessoa com uma enorme experiência nesse contexto, que dirigiu uma equipa técnica com arquitetos, arqueólogos, historiadores da arte, engenheiros, designers, informáticos, uma equipa muito grande.

Como é que se mantém uma equipa destas?

Mantém-se com candidaturas a fundos, " $n$ " candidaturas, e, nomeadamente a nível, tivemos, e, um dos problemas do conhecimento, da ciência e do conhecimento, e, tivemos um financiamento relativamente grande, e tivemos o apoio do Banco Santander durante esse processo. E, portanto, esta estrutura manteve-se ao longo de todos os anos, destes anos todos, este quase 2005, 2006, até 2010, que foi quando se entregou a versão da candidatura pela primeira vez, a primeira versão da 
candidatura. E evoluiu do seguinte modo, o Dr. João Gouveia Monteiro, portanto, o pró-reitor prós foi a esta altura sucedido, portanto,mudou a equipa reitoral, neste segundo mandato ficou Prof. António Pimentel, que também é prof. de História da Arte que, atualmente, é diretor do Museu de Arte Antiga, e que esteve durante algum tempo. E, portanto, eu mantive-me como pró-reitor para, então, nesta altura não havia curador, mantive-me pró-reitor para a componente física e de intervenção, e sempre com a jurisdição direta deste gabinete técnico, embora obviamente comissão científica e Dr. Pimentel. O Dr. Pimentel Museu Caravasco e depois do Anfiseu e depois desta larva antiga. O Reitor não o substituiu nestas funções, e, portanto, eu fiquei a partir daí, 2010, 2009 talvez o último ano, e aí eu fiquei com responsabilidade total da candidatura. Terminado em dezembro de 2009, entregamos o primeiro dossiê a UNESCO com aspecto completamente fechado. E, portanto, a partir daí, esta estrutura de gabinete técnico foi-se obviamente reduzindo para uma expressão, digamos, mais pequena.

Em março de 2011, acaba o mandato do Reitor, o dossiê está entregue, está na UNESCO, e, portanto, nós estamos sem funções, todos. Portanto, é um entre regra, mas, faz parte do processo, a UNESCO faz sempre isso, faz pequenas sugestões, pequenos pedidos de alterações, nomeadamente a UNESCO que disse, foi que o bem do ponto de vista da autenticidade era evidente, era evidente a autenticidade o que para nós é muito bom, do ponto de vista da integridade, portanto, do seu estado de conservação dos planos de conservação, dos planos do que se pretende fazer no futuro valia apena ser mais preciso.

E, portanto, em julho de 2011, o reitor chamou-nos e pediu-nos apoio, quando digo chamou-nos, o novo reitor já a mim e ao arquiteto Nuno Ribeiro Lopes - que era o coordenador da área técnica, do comitê técnico-,e pediu-nos apoio para fazer a proposta da UNESCO. E, portanto, é nesse momento que eu passo a ser curador.Isto é, neste momento era necessário encontrar de alguma maneira para poder falar em nome da Universidade da candidatura, era necessário encontrar uma figura, um nome, para ter esta relação já em articulação com uma nova reitoria.E, aliás faz sentido depois as coisas estarem mais fechadas, enquanto estavam sem o dossiê não faz muito sentido. O processo, digamos, evoluiu, o prazo para a primeira interação com a UNESCO era setembro de 2011, a UNESCO reagiu, também isto estava programado. Uma segunda interação, e última, foi em janeiro de 2012.Portanto, este dossiê que é entregue em janeiro de 2012, este processo pressupõe como sabem que já há uma entidade que faz a gestão do bem cultural. A UNESCO não quer vir falar com a Câmara, com a Universidade, com os proprietários, a UNESCO quer ter uma figura formal que responda perante o bem, que fale com as entidades, que disponha de acordo, que responda perante a UNESCO, e que no fundo seja a salvaguarda do bem. Durante este processo, foi nossa colaboração obviamente, criou-se uma Associação chamada RUAS [Associação para Recriar a Universidade Alta e Sofia]. 
É que nós sempre chamamos a Associação de Univers(sc)idade, com "s" e "c", Univers(sc)idade, sentido de Universidade e de Cidade, para nós ficou RUAS porque em termos materiais não se poderia registrar com este conceito, que era um preceito da Universidade.

Portanto, embora se diga que eu sou curador da candidatura, eu não sou de facto, porque a partir do momento que nasce essa Associação, essa Associação que é a entidade gestora do bem.

Essa Associação a partir de agora é que tem que articular a Universidade, é tem que defender o bem... tem que fazer três funções, as três funções é muito, tem que se repetir cerca de vinte vezes, a pessoa se esquece....promoção, salvaguarda e valorização.

As funções de uma entidade gestora, e neste caso da RUAS, promoção não é promoção, no sentido, não é só de vender, é de mostrar, salvaguarda no sentido de garantir a autenticidade e etc, etc, etc.., mas também valorização, porque, obviamente com os espaços, ninguém quer uma candidatura, nem um espaço cristalizado, ninguém quer um museu. Mas, assim, é tudo menos um museu, no sentido cristalizado do termo, nós vivemos dentro daquele patrimônio, trabalhamos dentro daquele patrimônio, tem que ser competitivo, que é uma componente de valorização, que é determinante também, portanto, é a RUAS que faz isso.

Portanto, o curador da candidatura deixou de fazer sentido, a RUAS tem esta Associação, tem uma Assembleia geral, era impossível de desassociar a Universidade da Cidade, era impossível, e essa candidatura é uma candidatura da cidade, portanto, a Assembleia geral, portanto, quem manda no topo... tem uma assembleia geral que é presidida ou pelo reitor ou pelo presidente da Câmera, prefeito para nós, e que alterna, portanto, ou seja quando é o reitor, e neste momento é o reitor. Está a funcionar a pouco tempo, quando é o reitor é o presidente o presidente da Câmera é o vicepresidente, isto é, Assembleia-Estado.

Eis que tem uma direção, e a direção é ao contrário, portanto, quem é o presidente da direção será, nesse caso como o reitor é o presidente da Assembleia geral, é o representante da Câmera Municipal e o vice-presidente é o representante da Universidade. E, essa direção tem cinco pessoas, tem um presidente e um vice-presidente, tem um da Universidade e um da Câmera, tem dois vocais, nomeados um pelo reitor outro pelo presidente da Câmera. E, tem um representante da direção regional de cultura, no fundo, aquilo corresponde ao vosso IPHAN, uma coisa desse tipo, que está nesta direção, eu sou um destes vocais. Portanto, eu não poderia ser nem o presidente nem o vicepresidente desta direção, porque tem que ser um o vice-reitor e o outro um vereador. Eu sou, neste momento, um dos vocais nomeado pela Universidade. E, não vou empenhar a função de curador porque nas visitas, como sabem as visitas da UNESCO são como do ICOMOS, o ICOMOS faz uma divulgação técnica para vir visitar os locais, e a princípio sou eu que vou acompanhar para visitar o local, eu serei o ponto focal, porque acompanhei o processo, digamos, num período mais longo. 
Eu era pró-reitor, portanto, eu fui pró-reitor durante aquele período todo, e já era antes, antes de ter o segundo reitor, em 2002, com o reitor anterior, para a manutenção dos edifícios, a segurança e o ambiente, ou seja, me foi atribuída a função de dirigir a candidatura do ponto de vista físico. E, portanto, eu coordenava durante este período no fundo, duas equipas, a equipa técnica corrente que faz a manutenção dos edifícios e etc.. e coordenava a equipa técnica que fazia a candidatura e que fez o dossiê.

Maísa Fonseca: Essa candidatura teve uma assessoria ou uma consultoria externa?

Prof. Raimundo Mendes:Teve, a candidatura tinha, o comitê técnico de candidatura tinha três ou quatro figuras chave em áreas um bocadinho diferentes, um bocadinho distintas.

Tinha uma comissão científica muito alargada, a qual se ocorria, mas além disso, pois isso é uma coisa vaga. Havia algumas ajudas muito específicas, nomeadamente em termos de arquitetura, o próprio arquiteto Nuno Ribeiro Lopes, muita a colaboração do departamento de arquitetura, muitas vezes, na pessoa e a figura do arquiteto José António Bandeirinha ${ }^{158}$, provavelmente já ouviram falar, que também é do CES, e do arquiteto Vitório Mestres. O Vitório Mestre não é funcionário da Universidade, não é pessoa da Universidade, é um arquiteto de Lisboa muito ligado a construção do patrimônio e com muitas intervenções e com muita prática neste domínio, e depois colaborações digamos muito específicas, por exemplo, ao nível da história, ao nível da arqueologia, com figuras sobretudo ligadas ao ICOMOS.

Isso pode parecer aqui que há uma certa pescada atirada na boca, mas não é verdade, o ICOMOS que nos vem apreciar é o ICOMOS internacional, e não se trata de dar aqui um policiamento ou não, trata-sedo núcleo das pessoas que acabam por estar mais motivadas e com mais conhecimento técnico nestes domínios, acabam quase por pertencer ao ICOMOS, ou de maneira voluntária ou involuntária, e há aqui figuras absolutamente emblemáticas, mais ao nível do aconselhamento isto é quase que $o$ aconselhamento.

E, portanto, são nomes que encontram... Claudio Torres, o arqueólogo Claudio Torres, é um sênior da arqueologia, uma pessoa da cultura portuguesa, que é prêmio Fernando Pessoa, uma distinção, e que já foi presidente do ICOMOS, o arquiteto José Aguiar ${ }^{159}$, que é professor na Faculdade de Arquitetura Universidade Técnica de Lisboa, na cautela, que também já foi presidente do ICOMOS, sobretudo ao nível das intervenções, das técnicas tradicionais de construção, isto é, estou mais a falar das intervenções. Mas que, claramente, no caso ainda da componente técnica, por exemplo, o doutor Delgado Rodrigues, que é um sênior da área da pedra, Doutor Sales de Rocio.

\footnotetext{
${ }^{158}$ José António Oliveira Bandeirinha é arquiteto pela Escola Superior de Belas Artes do Porto e, atualmente, é docente de disciplinas de Projeto, no Departamento de Arquitetura da Faculdade de Ciências e Tecnologia da Universidade de Coimbra.

${ }^{159}$ José Manuel Aguiar Portela da Costa.
} 
Nos fomos agregando, no meio da história muito os dois pró-reitores, que eram especialistas na área, mas também a doutora Lourdes Caravelo, que é da área de história da arte daqui, da arqueologia. E, numa fronteira, a unir uma fronteira entre a história e a arquitetura, por exemplo, dois nomes que são nomes da Universidade de Coimbra, uns mais novos do que outros, como, por exemplo, o prof. Walter Rossa, que tem um trabalho muito significativo nesta área. E, um mais jovem professor, o professor Rui Lobo que também é da arquitetura que tem um estudo sobre a Alta, sobretudo, sobre os colégios.

É relativamente complicado, falar do que pode ser, e completamente injusto, certeza, o que é uma borda ou um comitê mais direto de apoio, a Universidade tem essa enorme vantagem, tem uma enorme capacidade de buscar pessoas. A revisão final do texto, a revisão final não é só rever se está escrito, é também uma coisa que foi escrita a várias mãos, é tentar rever a coerência da história que se está a contar.E, isso é o professor Otávio da Fonseca, da faculdade de Letras.

Mas o núcleo duro, central se quisermos, eu diria que se poderia situar em torno do arquiteto Vitório Mestre, do arquiteto José Aguiar, do Claudio Torres, da Lourdes Caravelo, do Walter Rossa, e, pois, naturalmente, dos pró-reitores, eu penso que esse é o núcleo mais duro. Embora,seja de facto, é sempre muito difícil, porque para cada pequeno assunto é necessário preciso buscar da pessoa certa, e, embora o assunto seja muito pequeno, e, portanto, no contexto geral tenha um peso muito pequeno, mas que tenha que ser bem tratado. Há muitos contributos de jovens investigadores que foram, absolutamente, determinantes, porque era quem estava a fazer suas teses de doutoramento, e, portanto, estava absolutamente dentro dos assuntos. Há muitas contribuições muito interessantes nessa matéria.

Maísa Fonseca: O Patrimônio proposto no dossiê de candidatura já foi classificado anteriormente pela IGESPAR como patrimônio, porque, então, ser também classificado pela UNESCO?

Prof. Raimundo Mendes:Exatamente a mesma coisa. Porque, assim, o IGESPAR ${ }^{160}$ é o que corresponde ao vosso IPHAN, é o Instituto de Gestão do Patrimônio. Há vários níveis de classificação possíveis, há a classificação de interesse local, interesse da comunidade, há aqui vários níveis de interesse municipal, há uma classificação de interesse nacional. E, portanto, em Portugal quando falamos de alguma coisa que está classificado, geralmente, falamos de alguma coisa que está classificada como monumento nacional. Há um estatuto para monumento nacional, tem um determinado estatuto, tem, aliás, geralmente, uma zona de proteção. Uma zona de proteção que, é

\footnotetext{
${ }^{160}$ Instituto de Gestão do Patrimônio Arquitetônico e Arqueológico. Atualmente, corresponde a Direção Geral do Patrimônio Cultural, junto ao Instituo dos Museus e da Conservação e a Direção Regional de Cultura de Lisboa e Vale do Tejo.
} 
uma coisa, que, geralmente, são cinquenta metros a volta de um monumento que tem determinado elemento. O Pátio da Universidade, o Paço das Escolas é monumento nacional desde 1900 e..., já tem determinadas regras. Essa é regra, que não é da Universidade, essa é Catedral mais antiga aqui ao lado, não é parte da Universidade, e tem sua zona de proteção, com regras diferentes da zona de proteção, porque foi determinada em uma época diferente das da Universidade. Isto ainda por cima dá uma enorme confusão, porque temos não sei quantas, não sei quantos, não sei quantos tipos, com regras diferentes, mas estamos a falar de monumentos nacionais. É completamente diferente o valor como monumento nacional, e como patrimônio mundial, estamos a falar de um contexto diferente.

Como sabem, a UNESCO tem monumentos e sítios, isto é, o conceito de monumento nacional é muito mais restrito a edifícios, digamos, a componentes construídas em uma determinada unidade. Portanto, uma coisa não se confunde a outra. Aliás, há vários monumentos em Coimbra que não vão estar entregados na candidatura, porquê? Porque não são e nunca foram da Universidade. E, portanto, não estira valor nenhum, Santa Clara a Velha, do lado de lá do rio há um ravado enorme, com uma Igreja antiga, que é a Igreja Santa Clara a Velha, notável, que vale a pena ver, não é da Universidade, nunca foi, não está sequer na Zona de Proteção. Não deixou de ser monumento nacional e ainda bem,não são patamares distintos, são, na verdade, distintas regras diferentes. O que é que a Universidade influenciou nesta coisa? É que é que, uma coisa muito interessante num processo de patrimônio mundial, é que a Zona de Proteção Mundial passa a ter direito a ter uma Zona Especial de Proteção (ZEP), e essa ZEP permitiu, num trabalho que eu penso que é, provavelmente, a maior vitória deste processo, que é a vitória de conseguir por as Instituições dialogarem umas com as outras. Isto é, a Câmara Municipal, com a Universidade, com IGESPAR, a dialogar entre si. Foi possível fazer uma proposta de ZEP única, ou seja, uma proposta de uniformização, deixaram de existir estas ZEPS de cada um destes edifícios, deste monumentos, e passou a existir uma ZEP única para toda a Zona Candidata e Zona de Proteção, com regras únicas, não é bem assim, com uma filosofia única. E, eventualmente regras diferenciadas por zonas, que não estivessem a confundir o que eram regras e imposições mas estritas, por exemplo, na zona mais medieval ou na zona mais do século XIX. Mas é um arruamento único, e, portanto, não só se transformou numa ZEP como se conseguiu com a Câmara Municipal fazer um arruamento de gestão urbanística novo. Tem dezoito meses, o arruamento de gestão urbanística de toda zona antiga que é completamente novo. Não sei se no Brasil é assim, mas aqui é sempre muito complicado nas Câmaras Municipais aprovar seja que arruamento for porque há sempre os da oposição e os do governo. Mas o arruamento municipal de urbanização da Zona Candidata foi aprovado por unanimidade, o que é uma coisa absolutamente notável. Já não tem haver com a ligação Universidade e as Instituições, tem haver com a própria Câmara Municipal nas várias sensibilidades 
políticas, ter percebido que aquele foi um processo discutido, que foi um processo amadurecido, e que não seria por aí, e que não valia a pena fazer guerra política, digamos assim.

E, portanto, esta distinção... claro que se amputarem assim, é interessante que na Zona Candidata haja muita coisa que já é Monumento Nacional, é...nem é bom nem é mal. É interessante, e há ali edifícios que só por seu valor intrínseco, já tem reconhecimento, mas é um reconhecimento diferente, eu posso ser patrimônio mundial e até não ser Monumento Nacional, e vice-versa, portanto, no fundo são dois prismas de perspectiva um bocadinho diferentes.

Maísa Fonseca: Quem irá gerir e administrar esse patrimônio?

Prof. Raimundo Mendes:Em princípio cada um vai gerir o seu patrimônio, portanto, aqui há um problema que é, eu não posso colidir com a propriedade. A propriedade é uma coisa complicada, porque assim, de quem é a propriedade da Zona Candidata e da Zona Tampão ${ }^{161}$ (como é conhecida a Zona de Proteção)?

Da Zona Candidata é quase só a Universidade, quase só, mas não é só. Porque na Zona Candidata, por exemplo, na Sofia os Colégios são da Universidade, e os Colégios é que são da Universidade porque ela quem os comprou.Os outros colégios, alguns são ainda de ordem religiosas, embora já muito descaracterizados e degradados. Um é de uma clínica, uma clínica de saúde, uma clínica médica. E um outro é de vários particulares, de um particular depois com vários empenhos muito descaracterizados. Por exemplo, aqui não faremos imposição nenhuma, a não ser a imposição apenas por arruamentos. Portanto, ou seja, cada um faz gestão de sua propriedade, o problema é que, posso dizer que o problema é uma vantagem, é que agora tem um arruamento que é claro e é único. Claro que, para que estas entidades todas possam articular, portanto, eu falo de todas as entidades... pois fora da Zona Candidata, na Zona de Proteção, a Câmara tem muita coisa, mas a parte são particulares, portanto, as pessoas, cada um geri a sua propriedade.

Tem um arruamento novo, quem é que vela, quem é que vai ver se tudo está a correr bem?

A RUAS, portanto, a tal da entidade gestora é que vai fiscalizar se isto está a correr bem, se o tal plano de gestão está a ser cumprido, ou minimamente cumprido, e vai fazer uma coisa que

\footnotetext{
${ }^{161}$ Para o Centro Histórico (com a área de cerca de 620 hectares, de muito maior dimensão do que a área classificada e a zona tampão, que tem cerca de 120 hectares no conjunto), o artigo 56. 0 do Regulamento do PDM define que "as construções existentes devem, em princípio, ser conservadas, restauradas ou remodeladas" e que as novas construções não podem alterar "a escala ambiental da área em que se inserem, nomeadamente no que se refere ao volume dos edifícios e à composição e materiais utilizados nas fachadas". Acresce que a própria classificação da zona especial de proteção da candidatura e um vasto conjunto de servidões e restrições em vigor na área central da Cidade constituem fatores adicionais de proteção, obrigando, por exemplo, a parecer obrigatório e vinculativo da administração estatal responsável pela preservação do patrimônio cultural sobre as intervenções nos edifícios existentes e nos novos edifícios (UNIVERSIDADE DE COIMBRA, 2016).
} 
esperamos que seja emblemática, vai fazer aconselhamento, ou seja, esta "RUAS", o gabinete técnico que se vai constituir na RUAS, com pessoas da Câmara, da Gestão Regional da Cultura, da Universidade, etc.. vai apoiar não só as ações de licenciamento, pois a Câmara continuará a dar suas licenças, mas em vez de dá-las sem falar com ninguém, vai dá-las no âmbito desta comissão, uma espécie de comissão de discussão embora depois cada um continue com a sua prerrogativa.

Mas, além de haver esta comissão de, digamos, discussão, há dentro da RUAS, no corpo técnico irá se criar um outro núcleo, que a princípio eu vou coordenar, já não tem mais o que fazer, que é um núcleo de aconselhamento, promoção de boas práticas, recolha e divulgação de informação técnica relevante para área, para evitar que os projetistas, e os particulares e os proprietários, queiram intervir e sintam dificuldade em fazer os projetos, e, se entra em um processo burocrático de faz um projeto, não corre bem, não é aprovado, volta para trás, tá lá a fazer, portanto, criar aqui um núcleo de aconselhamento que é um núcleo que permita que as pessoas tenham uma ideia, tenham seus projetistas, nós somos todos projetistas, não é? Falam conosco, falam, sobretudo, quem está no, se houver lá alguma dificuldade, falam com este núcleo, que é um núcleo mais de aconselhamento, que se tudo correr bem irá buscar a Universidade, pontualmente opiniões de técnicos...pavimentos de madeira são uma polêmica, pavimentos de madeira não são para tirar, devem ser mantidos, devem ser reabilitados, se for extremamente necessário, substituídos por pavimentos de madeira novamente, obviamente, com técnicas modernas, ninguém está querendo imitar, isto não é um pastiche, não é?! Se eu fizer novos pavimentos de madeira devo fazer novos pavimento de madeira, obviamente, respeitando que é Sofia e etc.. mas com técnicas novas, quem sabe fazer isso, por exemplo, esta avaliação está numa fase de ruína, nós devemos buscar um professor da Universidade da área das madeiras para dar-Ihe um conselho específico, e, portanto, esta RUAS, se correr bem, vai ser não só, e por isso que há um bocadinho vos disse que tem três funções grandes, da promoção, a salvaguarda e a valorização. Essa questão da valorização é muito importante, porque no fundo a RUAS pode ter essa função de ajudar a que as intervenções sejam intervenções valorativas, não é?! Não só intervenções de restauro, porque isso irá interferir em alguns edifícios.

A Torre do Relógio, que não sei se visitaram, mas vale a pena subir fazer um esforço e ver lá de cima. A torre da Universidade, a Torre do Relógio foi restaurada, está lá um restauro, obviamente que há algumas pequenas valências, mas posso falar em restauro, mas em outros casos não se trata de restauro, quer dizer, eu quando entro nas casas da Baixa e da Alta, naquelas casinhas, eu quero preservar e preservar a identidade, mas tenho que melhorar as condições de salubridade, eu tenho que melhorar as condições de insurgência, no que surgiram aquelas condições, esta é uma componente de valorização, não é descaracterização, este é um processo..

Não há nenhum processo, esquecendo a Universidade e pensando na cidade agora, não há nenhum processo de reabilitação urbana com sucesso mínimo, que não tenha por trás um plano de 
intervenção social-econômico, nenhum, desse nenhum digo... o problema é que, atualmente, não é essa filosofia, a questão na Europa, a filosofia na Europa, com a questão dos fundos europeus, está por ter muitas feições naquelas que podem ser componentes de caráter mais social, e, portanto, há mais a rentabilização dos investimentos que é uma intervenção no centro antigo. A RUAS fará esta função, penso eu e espero que sim, de ajuda aos projetistas e de aconselhamento.

Maísa Fonseca: Como foi a participação da população neste processo, por exemplo, dos moradores? Prof. Raimundo Mendes:Curta, pequenina, por culpa, eu diria, nossa culpa. E, portanto, eu diria que pelo facto de o processo durante um determinado período ser eminentemente técnico, isto é, é necessário explicar ou discutir com toda a gente o que é o plano diretor para o Colégio das Artes. Não o cujo Colégio das Artes, obviamente, esta interação esta discussão, eu tinha havido, vou dizer assim, muito facilitada porque eu era pró-reitor, fui pró-reitor durante dez anos para habilitação dos edifícios, tinha uma relação muito direta com as pessoas, e, portanto, podia fazer esta interlocução qualquer do plano diretor. Mas, a população em geral, a comunidade em geral, sem falar do mais vasto, foi tardio o processo de comunicação, provavelmente andamos muito embrenhados muito preocupados com o processo técnico, e porque nem sempre foi claro na nossa relação com a UNESCO qual era o grau de publicidade que a UNESCO gostava num processo desses, agora não, agora estamos num processo claramente de abertura de comunicação, portanto, este é o último ano, é o processo de motivação, um bocadinho tardio, mas que acho que vai correr bem. E, portanto, a população em geral e a população tem muitos níveis, a população universitária que é mais flutuante, que a população mais residente, que as pessoas, que os agentes econômicos, tenham a noção, não só que vai virar uma candidatura, um bocadinho o que é que ela representa, mas, sobretudo, o que pode ser o seu pequeno contributo para uma coisa que é Patrimônio Mundial, não é?! As pessoas podem até nem crer, e, portanto, ninguém vai impor nada ninguém, as pessoas podem dizer "então agora vou ser obrigado a", além de regras urbanísticas, mas isso é vivência em sociedade.

As Repúblicas, não sei se já ouviram falar nas Repúblicas?

Repúblicas são aquelas casas de estudante unitárias, e tal, que são teoricamente muito tradicionais, muito engraçadas, são muito específicas de Coimbra, e tem uma história complexa, elas tiveram, digamos, um período áureo, não é? E, depois tiveram um certo declínio, e depois tiveram novamente algum reavivar, mas elas são muito diferentes uma das outras, e tem vivências muito diferentes.

$E$, aparecem naturalmente, e tem que aparecer na Candidatura como algo que é relevante nessa diferenciação, não são a única coisa, mas as repúblicas são uma componente, mas haviam repúblicas que diziam "e o quê? E, agora seremos obrigados a ter a porta aberta e quando os turistas cá passarem, entrarem e bisbilhotar cá para dentro e tal?". Não, obviamente que não, mas não é esse o objetivo, isso é só para o turista, não faz sentido agora. Se isso for, se uma república achar que isso é 
um incentivo a ser conhecida e quiser, por exemplo, estou imaginar que as terças-feiras, servir almoços, as repúblicas tem muito essa coisa de ter "x" pessoas que dormem lá, mas tem muito mais que pessoas que almoçam mensais. Tem geralmente uma cozinheira, vivem lá cinco ou seis, mas há lá dez que comem.

E, a Universidade houve uma altura que apoiava, que eles podiam comprar os alimentos nos supermercados da Universidade, supermercados de assistência social por metade do preço. E, se alguma república se sentir bem com isso e achar que tem graça, a terça-feira dizer assim, a terçafeira aceitamos dez pessoas para almoçar conosco e para a gente contar as histórias da república e não sei que, e damos cá um almoço, por um preço até simpático. Ok, é uma maneira engraçada de estar na candidatura, digamos de aderir a esse projeto e até tirar um benefício com isto, e entrar no jogo, mas ninguém irá impor isso. Portanto, essa é a questão da comunicação, absolutamente importante, não se trata apenas de fazer alguns flyers, trata-se de facto, e esse é um processo muito lento.

Não sei se conhecem Guimarães, no norte?

Deviam ir a Guimarães. Eu sou suspeito porque eu vivo aqui, mas levo sempre muita gente lá, outro dia estiveram cá uns investigadores de Marrocos, e no final de semana nós pegamos "nós vamos a Guimarães", e disseram, "Guimarães, fazer publicidade dos outros?". De facto, Guimarães é uma cidade do Norte do país (Portugal), uma hora e meia de viagem, não mais. Patrimônio Mundial, o centro é Patrimônio Mundial, não tem uma Universidade, aí nós estamos a falar de uma coisa que tem, digamos, da cereja, estamos a falar da malha urbana, mas ela é mais pequena do que Coimbra, mas com o Centro Antigo com praticamente o mesmo tamanho. Que teve um processo lento, gradual, de envolvimento das proporções. Não está muita coisa por reabilitar, muita coisa está reabilitada. Obviamente tem muito turismo, aliás este ano (2012) é a Capital Europeia da Cultura ${ }^{162}$, mas é exemplar no ponto de vista da comunicação e do envolvimento das populações, isto é, quando nós dizíamos assim, gostamos de fazer como Guimarães, mas o nosso processo foi diferente, até por que tinha a Universidade, tínhamos que fazer um processo técnico da Universidade. Ali era mais uma questão de planeamento urbano e de estratégias, e depois de ir trabalhando aos poucos com as populações, com as empresas e reabilitando, e ir criando inclusivamente pequenas empresas especializadas novos trabalhos, até um contexto diferente. Aí, digamos, aproximação as populações foi muito mais evidente.

${ }^{162} \mathrm{~A}$ Capital Europeia da Cultura é um título recebido segundo uma eleição da Comunidade Europeia, para promoção da cultura de uma cidade da Europa. E, em 2012, a cidade eleita como Capital Europeia da Cultura foi Guimarães (Portugal). 
Aqui eu diria que as pessoas abraçam a ideia, mas se perguntarem efetivamente o que é que é ser Patrimônio Mundial não sabem. Mas a culpa é nossa. Isto é, estamos neste momento, quem coordena é a reitoria em si, é a professora Clara Almeida Santos, que é professora de comunicação, do Jornalismo, e que é absolutamente assertiva, e que tem promovido muitos dos vídeos e das coisas que andam no Youtube, que fazem e que promovem, e que, neste momento, está clara com esta questão da comunicação ligada a Candidatura, digamos, muito viva, e é seu mote, sua grande tarefa, não é?Está se a falar da Candidatura por todos os momentos e por todos os motivos. Pois vai haver um espetáculo no Pátio da Universidade à noite, um espetáculo muito grande, com Ivan Benz e Carlos Carmen e com os antigos estudantes, e professora Clara dos Santos já promoveu como sendo o espetáculo da Candidatura.E, as pessoas de facto, com algumas exceções de quem tem algumas reações negativas, e que são típicas, há uma reação de um grupo de intelectuais, que acham que o ICOMOS e, sobretudo, a UNESCO é neste momento uma máquina dependente da máquina do turismo, e, portanto, perfeitamente subvertida em relação ao que eram os seus princípios, e, portanto, uma questão de princípio. E que tem uma reação muito negativa, há alguns que são do contra, pois são sempre. $\mathrm{E}$, há alguma reação melindrosa de algum tipo de população, que não tem a ver com a candidatura, que sofre sempre, atualmente, nos Centros urbanos Antigos com a questão dos ruídos, com as discotecas, e que tem uma reação um bocadinho mais negativa, com receio que isso possa agravar-se. A expectativa, as pessoas tem uma expectativa positiva. Falam mais disso do que fazem alguma coisa para.

Maísa Fonseca: Existe alguma medida ou lei de proteção para um possível aumento de aluguel das residências desse entorno imediato, ou mesmo no caso das Repúblicas? Eles pagam aluguel?

Prof. Raimundo Mendes:As Repúblicas tem um estatuto auspiciado do ponto de vista do arrendamento.

Eles pagam aluguer, mas há um estatuto especial, porque o aluguer pode mudar de nome para nome, portanto, não precisa ser um inquilino, é um contrato especial, pagam aluguéis geralmente baixos, e este é um dos problemas, porque a maior parte daqueles edifícios... algumas já são da própria, dos próprios amigos, vão constituindo um núcleo de amigos que se juntam uma vez por ano, e algumas já compraram as próprias casas, entretanto, as casas vão desvalorizando, as pessoas vão crescendo, arranjando emprego. Mas é um número muito reduzido, algumas são da Universidade, muito poucas, algumas são da Câmara, a maior parte são de particulares. E, portanto, com os particulares há alguma tensão, e haverá uma lei nova de rendas em Portugal que vai permitir a renegociação dos contratos ao fim de "X" anos, e, portanto, as Repúblicas que estiveram sempre, digamos, em um estatuto um bocadinho especial haverá alguma dificuldade. 
E, aquilo que estava a perguntar, como é que se vai regular o mercado no fundo, isso não está pensado. Eu diria que nesta fase, não haverá. Porque há sempre o medo da especulação no princípio. Para a escala de Coimbra, e para a atração de investimento que Coimbra tem por enquanto, a questão da especulação não possa ser determinante, o que se sabe de fato é de atrair de investidores para que o centro histórico não morra. Aquilo que é complicado em termos de especulação e a habitação em Coimbra é caríssima, até porque que não está na moda no Centro Urbano Antigo, é fora do Centro Urbano Antigo, mas por outro motivo, por causa dos hospitais. Como disse há um bocadinho, Coimbra tem um dos maiores centros hospitalares do país, neste momento, acho que estou a mentir, mas acho que não, é a única cidade do país que tem um hospital pediátrico, hospital para crianças, um hospital enorme. Ou seja, em todos outros sítios do país, normalmente em Lisboa, estão agregados a outros hospitais centrais, não é? Coimbra tem o hospital central enorme, e com algumas unidades, para vocês terem uma ideia, eu sei que as notícias não são boas, mas as unidades de transplantes, as unidades de queimados, as unidades de oftalmologia, as mais chaves são aqui. E, portanto, isso tem uma implicação complicadíssima, que é do ponto de vista financeiro, a saúde, os médicos, as clínicas atraem sempre muito dinheiro, e, portanto, o preço da habitação, a especulação imobiliária vem, sobretudo, pela presença do Hospital, não tanto pela presença da Universidade, e há, obviamente, alguma com a casa dos estudantes, que Coimbra tem uma característica que provavelmente também saberão, a Universidade tem 23000 habitantes, mais ou menos. Coimbra tem 100000 habitantes, vamos dizer assim, se 23000 são da Universidade, mais 10000 são do Politécnico, mais não sei quantas são da Secundária e do Liceu, nós estamos aqui quase com metade da população é estudante, estudam de alguma maneira. Depois com pessoas e funcionários, e depois pensamos no que é a componente dos médicos e dos hospitais, do ponto de vista econômico, isto gira tudo a volta destas duas ou três coisas. Os estudantes têm um peso grande também, embora a especulação seja para um nível diferente, que é o nível, obviamente, dos aluguéis, mas, sobretudo, sobre a compra de casas pequenas, nós não temos população para isto, isto é, esta população é... estes 23000 estudantes não são de Coimbra, obviamente, não é? Não tem área geográfica pra isso, portanto, o que acontece é que, há muito, agora o mercado está a diminuir, mas há muito o pai que tem cá dois filhos a estudar, e quando tem dois filhos a estudar, melhor eu comprar um apartamento enquanto ela cá está, acaba de estudar ou fica por lá ou se vem alugo apartamento vou pagando, aqui já está um negócio a volta disto. Se esse negócio, digamos, fosse direcionado para a Alta e para a Baixa, não era mal, era interessante, porque isso podia ser uma potencialidade grande para a reabilitação. Mas não há, neste momento, uma grande atratividade em termos de investidores e eu não sei se a questão do patrimônio mundial vai mudar muito isso, vai aumentar o número de visitantes, isso é certeza. Mas também aumentariam isso tem um peso, as 
coisas aumentam tem um patamar, apesar do número de visitantes isso será muito interessante, a Universidade percebe, em termos de bilhetes comprados, e acaba-se em meio milhão de visitantes. O Portugal dos pequeninos, que é um mini-parque temático com casinhas de Portugal pequeninas, feitas nos anos 50, portanto, na altura do Estado Novo, na altura do Fascismo, aquela promoção da imensualidade, para época e para quem gosta, tem 600000 visitantes por ano, que não são os mesmos da Universidade, eu diria que nós do patrimônio mundial vamos ficar aqui com um problema, nós já articulamos estas entidades, há algumas que não articularam, são as entidades que gerem o turismo. Isto é, vai ser preciso aqui para continuar a vender saúde, continuar a vender ensino, continuar a vender ciência, tecnologia, mas também tem que vender turismo. $E$, essa articulação é uma articulação que não está suficientemente feita, mas pronto alguém fará. Coimbra não tem um aeroporto, mas para quem vem do Brasil vem sempre por Lisboa, não é? Mas o aeroporto de Lisboa não é longíssimo, em qualquer cidade da Europa os aeroportos não são longe, o aeroporto do Porto é aqui, é uma hora, estou no metro e depois no comboio, não é esse o drama.

Maísa Fonseca: Já há contatos do Brasil sobre esse modelo, o Brasil incorpora muito estes modelos do exterior para aplicar também nas cidades brasileiras, existe este diálogo?

Prof. Raimundo Mendes:Há duas ou três pessoas que trabalham muito com o Brasil, o professor Walter Rossa, eu digo da Universidade, ele é professor nosso mas está no Algarve a montar uma cátedra ${ }^{163}$ sobre o patrimônio Luso-Brasileiro, com o patrocínio da Odebrecht. Ele tem também uma publicação muito grande sobre o patrimônio de origem portuguesa no mundo da Fundação Calouste Gulbenkian, ele é um autor de um destes volumes.

O Walter tem muito trabalho no Brasil, o Paulo Peixoto também tem, portanto, há aqui várias pessoas que tem trabalho pontual no Brasil. E que, portanto, são experiências localizadas que eu não sei ao certo, há uma outra coisa que é também interessante em termos de relação universitária, o grupo Coimbra de Universidade Brasileiras, há um europeu e um brasileiro, são cinquenta universidades que se assumem, digamos, como um grupo, que tem uma relação com Coimbra. Eu não sei se há projetos, neste especificamente sobre a candidatura, eu não tenho ideia.

Estas coisas estão muito concentradas em uma ou duas pessoas, que tem esta relação mais direta, estou a falar, nestas áreas, o professor Walter Rossa, a professora Lourdes Caravelo, Paulo Peixoto, na volta deste circuito, penso eu.

Maísa Fonseca: Quais são as Instituições envolvidas?

\footnotetext{
${ }^{163}$ Professor Catedrático Convidado da Universidade do Algarve, como titular da Cátedra Odebrecht-Capistrano de Abreu, instituída através de protocolo entre aquela universidade, a Fundação para a Ciência e Tecnologia e a Fundação Odebrecht. Lugar obtido através de concurso público internacional.
} 
Prof. Raimundo Mendes:Em termos locais, a Câmara e a Universidade são as determinantes, mas, obviamente tem que se juntar aqui algumas, nomeadamente a Sociedade de Reabilitação Urbana, uma figura nova que existe, que pertence também a Câmara, são um bocadinho Portugal resiste sem estas SRU, Sociedades de Reabilitação Urbanas, um pouquinho polêmicas, porque tem uma intervenção muito marcante, com alguns exemplos até agora, muito pouco cuidado de preservação de entidade, embora com uma comitação importante de minimizar... e, depois, diocese, portanto, a Igreja, as misericórdias, a Santa Casa da Misericórdia, que é uma Instituição que tem muitos imóveis, e as Instituição de casa da Cultura, portanto,a Direção Regional de Cultura, mas a Direção Regional de Cultura esta que depois está ligada ao IGESPAR, que tem caráter nacional, portanto, estas Instituições também. Claro que aqui é um pouco difícil dizer o que é Instituição, a Associação Acadêmica é uma coisa com peso enorme, ela também é um parceiro da candidatura. Esta RUAS está agora a tentar encontrar uma lista grande de sócios não fundadores, que são Instituições que vai convidar a fazer parte deste processo. Embora no fundo as principais são estas, quem detém e quem gere o patrimônio, que são determinantes além das pessoas.

Maísa Fonseca: E qual é a ideia principal da questão de recriar a Universidade e de não criar-se um patrimônio estável?

Prof. Raimundo Mendes:A questão é muito simples, nós estamos convencidos de que a Universidade deve ser patrimônio mundial, porque ela tem em si as características e as valências necessárias para ter este reconhecimento, porque ao longo destes anos tem sido singular, é singular não só do ponto de vista a História mas também das suas marcas físicas, e tem influenciado o mundo de uma maneira também singular, mas essa singularidade que se dá de seu valor e do valor de ligação com o mundo, que está um pouco ligada ciência, a questão da tecnologia e a cultura, e eminentemente não estática, ou seja, ninguém faz ciência e ninguém faz cultura de uma maneira estática. Portanto, é uma contradição se eu agora arranjar aqui agora um patrimônio edificado, que eu vou é cristalizar, para mostrar isso como se fosse um museu ou como fosse um quadro, porque não só não faz sentido para a comissão da UNESCO porque não é essa a filosofia atualmente do patrimônio edificado. Como isso seria uma contradição em relação ao uso e a função da Universidade, e, portanto, quando nós dizemos que, e o recriar para nada mais do que fazer completamente novo, de maneira nenhuma, mas é o aceitar o desafio de uma tensão permanente entre o que é identidade, e o que é evolução e o viver este patrimônio, isto é, eu consegui ser competitivo, ter laboratórios de biotecnologia, ter desenvolvimentos na área do direito ou da informática, ou das clássicas neste espaço, adaptando, preservando e valorizando. $E$, isso significa que em algumas coisas eu posso construir novo. Por exemplo, vamos tentar fazer, desde que haja dinheiro, uma biblioteca nova para a Faculdade de Direito feita pelo arquiteto Álvaro Siza, num sítio primosíssimo do ponto de vista patrimonial, entre a Sé Velha, a Catedral e o Paço das Escolas, há ali umas partes completamente desqualificadas, 
horríveis, vamos tentar demolir, e fazer ali uma peça muito engraçada, enterrada, do arquiteto Álvaro Siza, é valorizar, é criar, é construir de novo. Portanto, esta diferença que é no fundo, vamos dizer assim, a defesa do patrimônio não se pode confundir com conservadorismo, de maneira nenhuma, e uma Universidade não pode ser conservadora, se for não é Universidade, porque a Universidade implica em desenvolvimento permanente, porque para ser professor tem que investigar, porque eu posso ensinar, dizer que sim, ok... eu sou professor de Engenharia Civil, as ações de tração e conversão desde o princípio do mundo, são. Mas se eu não investigar, se eu não souber o que são as novas estruturas, não souber de novos desafios, eu estou a fazer um ensinamento estático, nem as técnicas tradicionais, são tradicionais por quê? Porque foram influindo, foram sendo triadas, foram sendo selecionadas, até que, aquelas que se foram afinando e apurando ficaram. Porque as argamassas de cal são tão interessantes e agora estamos a dizer que correm tão bem? Das várias que se fizeram e dos materiais que haviam, aquelas foram sendo selecionadas, triadas, a um estágio...

É um bocadinho neste sentido, e uma interpretação contrária a isso, claro que é muito perigoso este discurso, porque este discurso pode me levar a mudar tudo, não, não, eu posso mudar tudo, a torre já nem me serve, o relógio da torre é grande demais, coloca lá um digital.

Um discurso tem que ser contextualizado com uma formação para o patrimônio, uma formação de domínio filosófico e cultural para o patrimônio e para reabilitação, por exemplo, que as pessoas não tem. Eu falo com mais facilidade na rua qualquer pessoa sabe, com mais facilidade, o que é o concreto, o betão e o aço, e o que é aço em uma peça de concreto armado, do que se eu perguntar como é que é feito, o que é que um frechal.

Não sei se sabem o que é um frechal, não sei como se diz em brasileiro, é uma peça de madeira na qual apoiam os telhados de madeira por cima da parede. Há também aqui também um hiato patrimonial, que em relação ao patrimônio é complicado, olhar para um azulejo e dizer se tem valor..não tem valor nenhum, e porque, e porque é que tem valor?

Pronto, não quero que as pessoas sejam historiadores de arte, mas há aqui um processo no fundo de aprender o valor das memórias, e o porquê, nem tudo que é velho é bom, que nem se recriar a Universidade é extremamente fundamental, está aqui uma cultura para patrimônio no sentido da cultura das memórias, não memórias passadistas, mas memórias que impulsionam.

O rasgo, o brilhantismo de quem no século dezesseis chega a Baixa e diz eu tenho uma cidade com esta estrutura e faço aqui uma rua com esta rua toda, Colégio de um lado e Colégio do outro, para servir a Universidade para que isto seja arranjado, é um tão grande rasgo como o de quem faz agora aí um núcleo de positrões como nós temos no Polo III, que é o Polo da Saúde, para fazer os rádios e os altos de supervisão do Cancro, o rasgo é esse processo que é um processo não se pode parar em 
uma Universidade, portanto, fazer uma candidatura numa Universidade nunca pode ser uma candidatura estática, o que não significa deitar a torre abaixo.

Eu fui responsável pelo restauro da torre, e, portanto, na torre podem crer que aquilo foi tudo... mas ao mesmo tempo que foi tudo com as técnicas mais tradicionais, quando nós quisemos avaliar a resistência aos sismo da torre, viemos buscar os nossos colegas mais especialistas e fizemos, por exemplo, nós uma simulação da torre só com a simulação do vento, colocamos na torres acelerômetros da mais alta sensibilidade para perceber como é que ela treme, sem ter que abanar, só com a ação do vento, para depois podermos por no computador, e ver se o modelo de anemômetro sísmico que se havia criado para ver a estabilidade se ele correspondia a aquela Torre, nós nos agarramos a realidade. Portanto, não é incompatível a preservação patrimonial, a preservação de identidade, função e novidade. E, é esse o discurso que eu espero continuar a fazer durante mais uns anos. 


\section{ENTREVISTA 2}

Entrevista realizada no Gabinete para o Centro Histórico da Câmara Municipal de Coimbra, Arco de Almedina, $\mathrm{n}^{\circ} 14$, às 9 h30min do dia 6 de julho de 2012, com engenheiro civil Sidónio Simões, diretor do centro histórico de Coimbra.

Esta entrevista surgiu pela necessidade de compreender melhor a participação e a atuação por meio de um escritório técnico relacionado ao Centro Histórico de Coimbra, no processo de preservação do patrimônio, na composição de um dossiê de candidatura pela UNESCO, da articulação entre diferentes órgãos do Poder Público na cidade e neste processo, e da organização interna deste escritório.

Muitas das perguntas a entrevistada enfocaram na atuação técnica e prática desse escritório.

Maísa Fonseca: Como funciona a organização do Gabinete do Centro Histórico? Ele é vinculado diretamente ao município ou constitui uma entidade que funciona e é gerida de maneira autônoma? Quais são os seus objetivos?

Sidónio Simões: O Gabinete do Centro Histórico é uma parte, é uma unidade orgânica do município, embora tenha um funcionamento até há pouco tempo mais autônomo do que agora. Porque agora com a redução que a Administração Central obrigou as Câmaras a fazerem das FIAS acabamos por desintegrar autoridade orgânica,até agora éramos uma unidade orgânica autônoma com regras próprias, mas mantemos, porque mesmo estando integrados em outra unidade orgânica acabamos por funcionar do mesmo modo, não temos que dar, nós não estamos ligados ao presidente, mas agora estamos ao vereador, é a única alteração.

A única diferença que passou com esta alteração foi esta, nós funcionávamos melhor ligados com o presidente, tínhamos uma linha direta com presidente, tudo saía mais rápido, nesta altura temos um bocadinho mais de dificuldade, já não é tão eficaz como já foi, mas foi um problema da organização de serviços e, portanto, teve que ser assim.

Depois, em termos de autonomia, nós não temos certa "autonomia financeira" porque por principio só trabalhamos com obras comparticipadas. Portanto, nós temos, temos a lá da habitação, temos a lá das pessoas, temos um Gabinete de Relações Internacionais, que tem duas técnicas de relações internacionais que o papel delas é só pesquisar financiamentos, quer comunitários quer nacionais, e para depois nós tentarmos enquadrar as ações que nós queremos fazer dentro da área. 
Por norma, temos um, e esta é a única unidade orgânica a funcionar, aliás, um dos indicadores nosso de medida é esse, que é para a média das obras anuais temos que garantir setenta por cento de financiamento. Portanto, é um gabinete que vai trabalhando com projetos à frente para ver, com algum tempo, para depois financiar e depois escutar, pois não escutamos nada que não tenha financiamento.

Depois temos dois programas de apoio de reabilitação, um deles que é o chamado PRAUD (Programa de Recuperação de Áreas Urbanas) gravadas, PRAUD OBRAS, que tem o financiamento da Administração Central, do governo, com vinte e cinco por cento do valor da obra, a Câmara também comparticipa com vinte e cinco por cento, e o proprietário com cinquenta por cento, portanto, acabam por ser obras em parceria.

O proprietário candidata-se, e nós fazemos um projeto, é um projeto, como eu costumo dizer, que resume um bocado a filosofia do provérbio chinês, nós não damos a comida, ensinamo-lo a buscar, portanto, o que nós fazemos uma intervenção a nível de fachadas, coberturas, redes, elétrica e hidráulica, em cozinhas e casas de banho. As salas, os quartos, nós fazemos a eletricidade, fazemos tudo, mas não arranjamos pavimentos nem nada.

Isto porque nas fichas do grau, que são umas fichas que foram criadas pelo NEC, a pedido do governo, para a classificação dos prédios, se eu tiver um prédio com a fachada e cobertura, aqueles vidrinhos todos e janelas, com cozinhas e casas de banho, e redes todas a funcionar, o prédio está bom, o prédio muito bom é ótimo, nós não temos dinheiro para ótimo, estamos em um país pobre, embora muita gente pense que é rico, não é verdade, então tentamos aí.

$E$, depois, o que acontece normalmente nestes projetos, nestes prédios, nós refazemos tudo, porque o município não tem trabalho nenhum, nós fazemos o projeto, fazemos a obra, lançamos a obra, a fiscalização, portanto, fazemos todo esse trabalho. Ele recebe a obra já feita, entregamos a obra depois de já feito o que acordar conosco, pois também depende, esta forma também tem dependência da capacidade financeira do próprio proprietário, não é? Porque imagine que o proprietário não tem capacidade financeira para fazer todas as obras que nós propúnhamos, tentamos chegar a acordo com ele para fazer o mínimo, mas o mínimo que nós fazemos é fachada e cobertura para garantir que o prédio não vai ruir.

O problema destes edifícios antigos é que se entrar água, se começar a entrar água, degradam-se muito rapidamente, porque a nossa construção em Coimbra é muito frágil, ela é pedra até, com qualquer ligante, com argila pura e simples, e, portanto, quando começar a entrar água o prédio muito rapidamente se degrada.

Portanto, nós o mínimo, fachadas e coberturas, fazemos sempre, e as entradas da rede que é, pois, quando fizerem as obras deles, quando vierem a ter dinheiro não terem que estar a partir outra vez a fachada, isso nós fazemos sempre. 
Depois também vamos intervindo nas ruas, à medida que vamos arranjando financiamento para adotar a rua de todas as infraestruturas e melhor conforto, aliás, já fácil ver que já intervencionamos quase todas elas, eu tenho uma passadeira para as pessoas andarem melhor, é um espaço, um pavimento diferente, principalmente para as senhoras, para os idosos, que são as pessoas que tem mais dificuldade em circular nesta calçada.

Muita gente veio propor a substituição desta calçada, mas os estudos que nós fizemos os nossos antepassados que pensavam nas coisas muito bem, esta calçada tem uma razão muito forte de existir, é que, esta calçada diminui drasticamente a velocidade da água nas enxurradas, se eu tirasse esta calçada e metesse outro material o que ia ter aqui embaixo eram inundações constantes porque a velocidade que a água ganhava na encosta era muito grande. Então, nós fomos obrigados a manter esta calçada por uma questão funcional, não é só porque queríamos manter, porque a água ao circular nos interstícios da calçada faz um percurso muito maior, do que se for num pavimento liso que escorre rapidamente, portanto, demora mais para chegar cá abaixo e as condutas conseguem absorvê-la, e numa situação normal não conseguia.

Portanto, o que nós estamos nestes pavimentos é tentar introduzir o que a lei das acessibilidades obrigada, são percursos acessíveis é um bocado de percursos mais confortável para as pessoas que tem mais dificuldade, e melhorar a acessibilidade, já que a encosta não pode melhorar.

Nós já reabilitamos com base neste programa, O PRAUD - OBRAS, cerca de quarenta e três a quarenta e quatro edifícios, que para um período dez anos parece pouco, mas nós temos que perceber que os três primeiros anos foram muito difíceis porque ninguém acreditava, porque nós estamos a trabalhar com a linha privado-pública e linha público-privada e os privados não acreditavam que se conseguissem fazer obras a preço de custo, pelo preço que lhes era dado. Isso porque o que aparecia nos televisores, acredito que já perceberam, que qualquer obra do estado, da administração central, derrapa sempre quarenta, cinqüenta por cento, ainda apareceram aquelas da BARQUEXPO, que toda a gente falou que os coroas custaram cento e cinqüenta a mais, e as pessoas não acreditavam. Portanto, a primeira coisa foi criar a confiança dos proprietários, e isso fizemos passeando pelas ruas, conversando com as pessoas, discutindo com elas, dizendo-lhes que faríamos uma gestão regrada, até ganhar confiança, a partir daí as coisas começaram a andar.

Embora estejamos a trabalhar numa área de alto valor patrimonial, que qualquer escavação obriga a arqueologia, que aparecem achados com freqüência que param as obras, pronto, é uma área de difícil intervenção com alguma complexidade, mas que se tem feito, e cada vez melhoramos mais.

Pois temos outro problema associado a isso tudo, que é o problema da perda do conhecimento, da tradição, atualmente, os nossos empreiteiros ou os empresários da construção civil estavam 
habituados a trabalhar em edifícios de betão e estes edifícios não podem levar betão, portanto, há aqui um conflito.

Para este fim, foi criado o Gabinete de Serviços, e foi chamado o engenheiro civil Sidónio Simões para atuar neste gabinete. E, também, prevendo-se a candidatura da cidade a patrimônio mundial pela UNESCO.

Também foram pensadas algumas ações buscando organizar, sistematizar e planejar ações conjuntas. Através da apresentação de um plano de Gestão pela Universidade de Coimbra, localização das intervenções propostas através de um sistema geográfico, e foram criadas algumas facilidades considerando-se que um processo de licenciamento demorava em média de 12 a 13 anos. $\mathrm{E}$, com isto, houve um aumento da procura pelo licenciamento.

O processo de licenciamento será feito na Associação para Recriar a Universidade Alta e Sofia (RUAS), com o apoio constante do novo gabinete que será criado, cujo uso ainda está sendo definido. Também será criado um manual que busca auxiliar no processo.

Com todas essas iniciativas já é notório o interesse da iniciativa privada, e, diante desse aumento, tem-se concentrado ações na busca de agilizar o processo na zona classificada, tornando-o mais rápido ou igual a uma área nova da cidade, pós 25 de abril de $2012^{164}$.

Lei do inquilinato estabelece que os proprietários de imóveis não poderiam alterar o valor de suas rendas. A partir da alteração dessa lei, atualmente, algumas repúblicas de estudantes tem se manifestado contra a possibilidade de alteração do valor do aluguel, o que impossibilitaria que os imóveis continuassem sendo utilizados como repúblicas. Também deve-se considerar a grande concentração de população idosa, atualmente, no centro de Coimbra. Assim como, a característicada desraização dos proprietários. Muitos dos imóveis são herança, e são constituídos de muitos proprietários.

A UNESCO utiliza-se de regras muito rígidas para reabilitação e intervenções novas, e a Câmara de Coimbra tem ocupado-se da parte prática do processo. Enquanto a Associação RUAS constitui-se como conselho da Universidade para consulta da população, auxiliando através dos projetistas.

Também pode-se afirmar que trata-se de uma questão política, em que o programa (PRAU-obras) será concluído em 2013, com a criação de um gabinete com uma imagem nova para os munícipes: de caráter prático rápido, que consiga ser uma administração aberta, com funcionários novos, constituído de pessoas que receberam formação arquitetônica, como por exemplo, técnicos, anteriormente não havia cursos desse gênero na Universidade.

\footnotetext{
${ }^{164}$ Data a partir da qual são implantadas as novas tentativas em agilizar o processo de licenciamento de imóveis no centro histórico da cidade de Coimbra. 
Na cidade do Porto pode-se dizer que há muita publicidade sobre o que foi feito, mas na verdade, reabilitaram pouca coisa. Não há muita publicidade em Coimbra, mas tem-se feito um trabalho com as crianças, nas escolas, onde um especialista em história da arte faz um trabalho nas escolas.

A cidade tem recebido muitas visitas de turistas estrangeiros, em maior número do que de grupos organizados portugueses.

Em relação a definição dos limites da área, houve um trabalho conjunto de equipes multidisciplinares. Diante dos custos de manutenção envolvidos a Universidade solicitou apoio físico, a partir de um mínimo de restauração e diante dele possam ser feitas melhorias. Este apoio a intervenção física fez-se para o bem não se degradar.

A Câmara também estava exercendo pressão para melhorias dos edifícios, assim, criou-se o projeto da rua da Sofia, com um plano de pedestre, da criação de um calçadão, e, em relação ao seu uso, a componente habitacional e de comércio. Portanto, o Plano Diretor deve buscar favorecer o comércio local, pois $30 \%$ do consumo é feito por residentes da própria área. Já no Comércio da Baixa pode-se afirmar que não tem se apresentado uma dinâmica muito grande.

A Sociedade de Reabilitação Urbana Coimbra Viva atualmente não apresenta financiamento gerido por outra Instituição. Enquanto a iniciativa do programa JESSICA ${ }^{165}$ (Joint European Support for Sustainable Investment in City Areas) apresenta juros muito baixos e prazos de 25 a 30 anos, e, em que o retorno a iniciativa tem que partir da própria administração.

E o Investimento Induzido, por parte de pessoas que procuram investir em parceria porque consideram rentável o investimento.

Deve-se considerar que uma área que demorou $\mathrm{X}$ anos para degradar demora o dobro para reabilitar-se.

Através do processo de diretrizes para a área, propõem-se a abertura de lojas na Alta e não na Baixa. A partir de um novo tipo de comércio, enquanto a Baixa é constituída de um comércio considerado tradicional. Não há empresas de reabilitação de patrimônio classificado em Coimbra, e, portanto, percebe-se falta de cuidado por parte da Universidade.

${ }^{165}$ O programa JESSICA foi lançado pela Comissão Europeia, Banco Europeu de Investimento e Banco de Desenvolvimento do Conselho da Europa e tem como objetivo apoiar os estados membros no financiamento de projetos de reabilitação urbana. 
A previsão é de que os técnicos da UNESCO comecem a vistoriar alguns aspectos relativos ao dossiê em setembro ou outubro de 2012. E, vale destacar nesse processo o papel da Clara Almeida Santos $^{166}$. Geralmente, utiliza-se uma figura marcante relacionada ao processo de candidatura.

O Centro Histórico tem um blog, mas não há tradição de gestão participativa em Portugal. Pode-se considerar que a participação pública é baixa. Nos últimos anos Coimbra foi uma das cidades que mais cresceu em Portugal.

No que se refere a distinção do processo de candidatura em relação das atuais medidas de preservação e conservação, pode-se dizer que busca-se alargar a área. E desenvolver maior controle sobre ela. Ao longo do tempo ganhou-se muito conhecimento técnico através da atuação do gabinete, que tornou-se especializado na área. A Câmara ganhou muito em especializar o Gabinete.

Pode-se dizer que o Instituto de Gestão do Património Arquitectónico e Arqueológico (IGESPAR) apresenta maiores facilidades, com princípios conjuntos únicos.

O processo de candidatura foi um trampolim para o financiamento. É um atrativo turístico. E, por esta razão, a candidatura foi apresentada pelo governo e não pela Universidade. Buscando financiar melhorias. Entre algumas das medidas está a de criação de estacionamento na Alta, buscando retirar os carros da área e reforçar o transporte coletivo. E, para tanto, a Câmara se dispôs a melhorar o transporte público da área.

\footnotetext{
${ }^{166}$ Maria Clara Moreira Taborda de Almeida Santos Vice-Reitora para a Cultura e Comunicação da Universidade de Coimbra. Ela tem organizado uma campanha de divulgação do processo de candidatura a nível nacional em Portugal. Ver: UC de olhos postos no futuro, 2012 


\section{ENTREVISTA 3}

Entrevista realizada na praça do papa, próximo ao CES da Universidade de Coimbra, às 19h do dia 11 de julho de 2012, com Nuno Ribeiro Lopes ${ }^{167}$, arquiteto coordenador da Candidatura de Coimbra como cidade patrimônio mundial na UNESCO, e Cátia Marques, também participante do processo de candidatura.

Essa entrevista surgiu pela necessidade de compreender o papel de atuação do arquiteto Nuno Ribeiro Lopes com experiência de atuação profissional em outros processos de patrimonialização em Portugal, e a relação de suas experiências anteriores com o caso de Coimbra.

Muitas das perguntas a entrevistada enfocaram, basicamente, na sua atuação neste processo e na comparação com outras experiências anteriores do arquiteto.

Maísa Fonseca: Qual a sua formação e área de atuação? Qual foi a sua atuação no desenvolvimento do dossiê de candidatura?

Nuno Ribeiro Lopes: Sou arquiteto, formado na escola do Porto ${ }^{168}$, projeto basicamente, depois eu trabalhei com Siza ${ }^{169}$, eu aprendi com Siza Viera. E, como todos nós, aprendemos a trabalhar em arquitetura moderna, não há nenhuma outra formação nas escolas, nas universidades. Depois por uma razão de um convite da Câmara de Évora na altura, convidaram para dirigir o centro histórico, eu fui, portanto, por seis anos estive a frente do centro histórico de Évora, que é uma cidade já classificada patrimônio mundial. E, portanto, sem experiência nenhuma de reabilitação a não ser praticamente algumas experiências meramente urbanas em 74,75 , pós a revolução ${ }^{170}$, no Porto e no Barreto, que foi a primeira experiência de reabilitação em Portugal, a esta altura há vinte anos por assim dizendo, portanto, é uma experiência a nível da escola, não é? E, depois, portanto, neste instante, convidaram para dirigir o Centro Histórico e, é um pouco a partir daí, digamos, que eu entro

\footnotetext{
${ }^{167}$ Licenciado em Arquitetura pela Escola Superior de Belas Artes do Porto, foi responsável pelo projeto da Malagueira, em Évora, de autoria de SizaVeira, de 1979 a 1996, pela Divisão de Iniciativas Urbanísticas Municipais da Câmara Municipal de Évora, de 1990 a 1996, e Diretor do Departamento do Centro Histórico de Évora de 1996 a 2002. Coordenador do Gabinete e Vogal da Comissão Diretiva da Paisagem Protegida da Vinha da Ilha do Pico de 2002 a 2005 e responsável pela Candidatura da Paisagem Protegida da Vinha da llha do Pico a Patrimônio Mundial - Paisagem Cultural. Também responsável pelo projeto de Candidatura da Universidade de Coimbra a Patrimônio Mundial e coordenador de seu Gabinete de 2004 a 2012. E, coordenador do projeto Paisagem Cultural do Montado desde 2011.

${ }^{168}$ Universidade do Porto, atual de Faculdade de Arquitetura da Universidade do Porto.

${ }^{169}$ Álvaro Joaquim de Melo Siza Vieira formou-se arquiteto em 1955, na Escola Superior de Belas-Artes do Porto.

${ }^{170}$ Com a revolução dos Cravos, em 1974, foi deposto o regime ditatorial do Estado Novo em Portugal, vigente desde 1933.
} 
na área quer da gestão, quer da reabilitação. Acabado isso, fui fazer a candidatura do Pico ${ }^{171}$, da ilha de Pico nos Açores, a Patrimônio Mundial foi bem sucedida, tinha acabado de ser aprovada a nocumenta da UNESCO em 2004, e a Universidade de Coimbra convida para vir alguma coisa digamos uma coisa semelhante aqui, só que ao invés de dois anos agora são oito. Estas coisas tem a ver basicamente com a candidatura, e, por exemplo, já entrando no tema, não é fazer um dossiê, se fosse só fazer o dossiê significa que a Instituição e neste caso a Universidade já sabe o que quer, tem tudo organizado, tem um plano estratégico, sabe o que quer fazer, sabe qual é o seu futuro, portanto, que tem tudo delineado.

O que acontece normalmente é que estas entidades, ou seja, no Pico através do governo ocasional, ou seja, aqui através da candidatura da Universidade, a candidatura da própria Universidade, querem ser candidatas, mas não tem as coisas definidas, e, portanto, o trabalho demora mais tempo ou menos tempo em função daquilo que é preciso organizar, fazer o trabalho conjunto, neste caso era preciso organizar, digamos, o que a Universidade queria ser do futuro.

Isso significa uma discussão interna muito alargada, porque a Universidade tinha vindo, digamos as Universidade portuguesas eram só estatais, após o 25 de abril em $1974{ }^{172}$, passou a haver Universidades privadas, e houve também uma explosão de acesso a Universidade, uma questão de democratização do ensino, uma democratização, digamos, a todos os níveis, como toda democratização do ensino. O ensino passou a ser mais acessível economicamente, e uma aspiração de pessoas, normalmente dos pais, muitas vezes que já não querem colocar os filhos já não na agricultura, já não em cursos profissionais, mas queriam que os filhos fossem engenheiros, arquitetos, e que as pessoas infelizmente continuassem, e ninguém quer ser técnico profissional. Por exemplo, agora ou há pessoas quase sem formação nenhuma ou tudo licenciados, não há meio termo, faz falta. A questão dos programas de ajustamento em Portugal e não só em Portugal, por exemplo, na Europa toda, a excesso de licenciados e a falta de pessoas com cursos médios.

Mas, pronto, essa democratização do ensino provocou, de repente, numa Universidade que estava preparada para trinta mil estudantes, vinte mil, passou a ter oitenta, noventa mil. No caso de Coimbra o que isso significou isso? Isso significou que as instalações passaram a ser sobre-ocupadas, portanto, os colóquios foram metidos em gabinetes, digamos as salas, ao invés de ser uma sala passaram a ser duas, barracas, faz-se o termo, e iam-se acrescendo anexos em todos os sítios.

Pronto, a Universidade perdeu em termos arquitetônicos perdeu o seu caráter, na medida em que, o edifício era uma espécie de colméia, em que os edifícios estavam tão subdivididos, que a leitura do

\footnotetext{
${ }^{171}$ A Paisagem da Cultura da Vinha da Ilha do Pico é um sítio classificado pela UNESCO desde 2004.

${ }^{172}$ Revolução dos Cravos refere-se a um período da história de Portugal resultante de um golpe de Estado militar, ocorrido a 25 de abril de 1974, que depôs o regime ditatorial do Estado Novo, vigente desde 1933, e que iniciou um processo que viria a terminar com a implantação de um regime democrático, com a entrada em vigor da nova Constituição a 25 de abril de 1976.
} 
próprio do vão do edifício, de como ele foi projetado, seja ele do século XVI, um poeta, seja do século $\mathrm{XX}$, perderam-se nestas obras. Digamos, normalmente, pouco cuidada, para desenrascada, mas isto. Só com o processo de expansão da cidade, em termos de Universidade para Polo I, para Polo II e agora para Polo III, é que a Universidade passou a esvaziar estes edifícios aqui do Polo I, começou a, digamos, perder gente, e começou a recuperar a dimensão dos espaços. E, portanto, só recentemente, digamos, é que a Universidade pode começar a pensar o que ia fazer com os edifícios por um lado, se criou Polos novos, muitos edifícios ficavam vazios de funções, por não ser museu, não devia ser museu, podiam lá abrigar outra Faculdade que estava apinhada, ou estava, digamos, mal acondicionada num outro edifício, provisoriamente para algum que vagou e mais tarde para um novo. Portanto, tudo isso, estudar aquilo que nós chamamos de dança das cadeiras, por exemplo, se podia estar ali, vai ocupar espaço da Medicina, a Medicina vai lá para baixa até ter um edifício final feito.

E, portanto, isso origina que organizar o processo de candidatura foi no fundo organizar juntamente com a Reitoria, com o serviço técnico da Reitoria, com os departamentos, com as Faculdades. Organizar duas coisas, e tem mais, ter um plano ao longo destes anos como é que, na medida em que vai dar em um edifício como é que os outros edifícios, como este edifício era ocupado temporariamente, e com o que, e, segundo saber qual era a vocação final.

E, portanto, isto vai demorar mais dez ou quinze anos até tudo ir ao sítio, até as Faculdades estarem todas reusadas, estarem todas com edifícios novos, ou aqui, mas com edifícios arrancados, recuperados, e, portanto, percebe-se que se daqui quinze acabaram com este trabalho todo, durante quinze anos temos que saber como isto circula tudo. Portanto, temos que fazer vários planos sucessivos de re arranque e participando das coisas, e mudar a mentalidade de que uma obra provisória é feita de qualquer maneira. Uma obra provisória tem que ter quase tanta coisa que uma obra definitiva. E, em qualquer momento a Universidade tem que ser agradada, e não o que ela é neste momento que ainda tem uma imagem muito degradada, digamos, com mais convenções.

$E$, segundo, mudar também a maneira como se projetam os edifícios, não tanto numa lógica que precisa responder a modernidade, a contemporaneidade no sentido de infraestrutura, estou cheio de calor e o edifício não responde, temos lá uma vaca e eu não quero saber, mas é preciso antes testar. E, segundo, andar a corrigir as asneiras que se fizeram antes, sabendo que obviamente recuperar o edifício não significa que o edifício perdeu o ar-condicionado, e não pode ter rede estruturada para sistema de computador não um edifício reabilitado tem que ser tão moderno a este nível que um edifício feito agora. 
Portanto, é preciso criar algo, uma escola e fazer algumas implementações que, digamos, funcionassem como uma pedagogia para a Universidade de como organizar, como fazer projetos, como entremeios, sem perder qualidade.

Isto significa que antes de fazer um dossiê de candidatura é preciso pensar juntamente com as estruturas políticas acadêmicas da Universidade o que fazer com o São Jerônimo ${ }^{173}$, o que quer fazer com o Colégio de Belas Artes, o que fazer com São Bento, o que fazer com todos eles, são vinte sete edifícios, mais ou menos, são vinte e oito com o Jardim Botânico também.

Por outro lado, havia a questão da Rua da Sofia, porque a candidatura não era a candidatura da Universidade como ela é hoje, ela ia ser, portanto, a candidatura da história da Universidade e, portanto, é meio difícil, já tinha sido a Universidade e já não é, foram alterados e mantém outras funções. A candidatura deveria intervir também sobre estes edifícios que já são não da Universidade, basicamente da Universidade da Sofia, alguns aqui na Alta também, mas basicamente na Sofia. E, na Sofia num ponto do processo o que aconteceu nesta altura foi o regresso da Universidade a Rua da Sofia através do Colégio da Graça, que é uma espécie de renascer,uma espécie de Fênix ${ }^{174}$, em que a Universidade começou pelo Colégio da Graça, tem algum simbolismo. Portanto, fazer um projeto global intervir, por exemplo, a Universidade tinha comprado uma parte do Colégio da Graça, e nos dissemos que não tem sentido comprar edifícios aos bocados, ou é o edifício global, porque um edifício de artes deve ter uma função, e não pode ter dez funções lá dentro e ser compartimentados, o edifício tem que ser calado.

Se é um edifício oriento e homogêneo, tem que ter uma funcionalidade orienta e homogênea, e, portanto, a Universidade vai assumir que o Colégio da Graça deveria todo ele deveria ser adquirido. É um processo que, pois passaria pela a compra ao Estado Português, passa também por saber o que se vai fazer neste edifício. Houve estudos objetivos, em que todos os edifícios tem qualidades e ao mesmo tempo tem coisas más, portanto, nós o que nos fizemos foi aquilo que chamamos um Plano Diretor de Edifícios.

O que é um Plano Diretor de Edifícios? Por um lado é fazer um estudo, é correr o risco. Há estudos teóricos, críticos, a História da Arte tem a História do Edifício por texto, mas não o tem cartografado, não há cartografia, nós assumimos o risco de fazer a transposição da parte escrita para a cartografia, e isso obviamente dá muita indefinição, portanto, tivemos que categorizar, tivemos que investigar, e tivemos que correr o risco de propor uma solução. Que obviamente deverá ser discutida na medida

${ }^{173}$ O Colégio de São Jerónimo é um edifício barroco construído no século XVI, constituído por uma planta longitudinal irregular e vários corpos.

${ }^{174} \mathrm{O}$ Mito da Fênix remonta a mitologia grega e a outras civilizações, esta ave após a morte, e de suas próprias cinzas, retorna a vida simbolizando os ciclos naturais de morte e renascimento, e a ideia de continuidade da existência após a morte. Anteriormente, o povo egípcio acreditava que este pássaro simbolizava a imortalidade. 
em que, por exemplo, se houverem momentos novos, obviamente que esta investigação será ostentada e será corrigida.

Mas alguém tem que dar o primeiro passo, normalmente historiadores não gostam muito e nunca dão o primeiro passo porque não gostam de arriscar nada. Historiadores são mais uns purificadores do que está escrito, não são capazes, infelizmente, eu acho que deveriam fazer senão inventários deveriam propor, deveriam teorizar, não quiseram fazer isso, foi preciso a nós arquitetos fazer, basicamente, historiadores, arqueólogos, todos juntos o dossiê de candidatura, isso para fazer o que? Isso aqui é do século XVI, essa aqui é uma coisa século XVII, século XVIII, século XIX, século XX e século XXI, há, portanto, vários layers um em cima dos outros.

Primeiro para entender o edifício, técnicas construtivas, diferentes tipologias, e também perceber o que é que o edifício foi as diferentes funções, ou as funções também nos dão também organizações, é ao contrário, nos permitem ir buscar a planta para o que é que aquilo foi.

Segundo, a partir daquilo fazer uma análise crítica do que é espúrio, é o que é mal, e aquilo que destrói o inteiro do edifício ou aquilo que pode ficar. Sendo que não há um edifício puro, um edifício puro é como um português, se quisermos, é uma mistura de cigano, preto, europeu, digamos do norte, do sul, é uma mistura de todas as raças.

Um edifício, normalmente, é assim, são vários layers sobrepostos, não há nenhum edifício puro que tenha permanecido, houve essa teoria há muito anos atrás, nos anos cinquenta, em que das fortificações tirava-se tudo ficava só na idade média que era o período interessante.

Hoje em dia já não é assim, obviamente, é como nos próprios, não é? Nós também temos o corpo humano e o edifício como um ser vivo, como um ser humano, portanto, todos nós temos as marcas do tempo, temos as diferentes épocas, e fomos todos nós coisas diferentes ao longo do tempo, não estamos falando sempre a mesma coisa, nunca fizemos sempre a mesma função, nunca tivemos, digamos, sempre a mesma construção teórica, fomos variando, não é? O edifício é na mesma, portanto, estas marcas... muda a porta, muda a sala, façam a volta em cima das outras, e há edifícios fantásticos.

A Câmara de Évora, por exemplo, teve uma situação muito curiosa, e permite-se perceber, muitas vezes, como é que o edifício em que há umas termas romanas no interior do edifício, e outro em cima no século XVI fizeram uma sala perfeitamente circular pousada em cima das termas, fizeram circular e as portas que se podiam levar aos sítios, onde se faziam as passagens, digamos, entre as diferentes partes, digamos, do templo. Quem fez o edifício no século XVI e a sala de cima sabia muito bem o que é que estava para baixo e aproveitou a forma para fundações.

Isso permitiu que mais tarde, digamos, o edifício houvesse essa recuperação das termas inteiras numa sala do século XVI exatamente com mesma forma e esse processo. Portanto, as coisas podem 
coexistir, nós procuramos fazer nas atitudes foi a partir das épocas e a partir daquilo que era espúrio, obviamente tínhamos que ter uma visão crítica destas coisas, saber o que é que se podia aproveitar o que é que se podia demolir, o que é que estava a mais, o que é que se podia manter exatamente e só tinha que ser restaurado. Portanto, dar informações, ao dono da obra, neste caso a Universidade, quando se quisesse fazer um concurso de arquitetura, por exemplo, para refuncionalizar um edifício patrimônio, por exemplo, o Colégio da Graça para o CES, o programa tinha que ser feito e o projeto de arquitetura tinha que ser feito naquelas condições histórico-físicas do uso, portanto, nós decidimos para cada edifício dar um estudo, evidentemente científico nos dossiês são cerca de seiscentas páginas para que todos os edifícios, daquilo que é a história do edifício cartografada, aquilo que estava no aval, e no fundo é a proposta que nós fazemos de um programa também, que nem todos os programas se adaptam. E, eu fui organizar esta estrutura toda, obriga a decidir à vocação do edifício a função futura, obriga a perceber o edifício a fazer um extrato de consolidação, enfim, uma base de dados que é um extrato de consolidação do edifício, o que eu preciso, obras de demolição, obra de conservação, corpo, necessidades, no fundo que financiamento é que se podem ir a organizar para fazer esta alteração, esta obra, e o timing em que ela está prevista, ao mesmo tempo todas as situações transitórias até a chegar a situação definitiva, portanto, é um trabalho grande. No fundo, o gabinete de candidatura se tornou quase no Gabinete da própria Universidade, um gabinete de apoio para a Reitoria e as Faculdades para a Universidade decidir o que ela ia ser da vida daqui para frente, já não é a Universidade...

Como Portugal gosta muito de viver do fado, do velho, sempre do passado, o descobrimento, não interessa nada, interessa na medida em que o passado, o passado só nos interessa a construir que perspectiva do futuro sem por em causa, digamos, aquilo que nós fomos do passado, mas também ficar só a olhar para o passado, “isso de ficar parado",chega, isso não me interessa.

Portanto, o projeto do Museu da Ciência, o projeto da Biblioteca de Direito, ou da Trindade para Tribunal Europeu, são projetos todos construídos em uma lógica de aproveitamento dos edifícios, e nunca negando por outro lado, e não é por ser candidata a Patrimônio Mundial que isso está em causa, é que uma Universidade precisa sempre de edifícios novos, precisa de sempre ir mudando, se transformando, este estudo nunca pode ser estático, portanto, nós fizemos um plano em que há edifícios a construir de rios neste momento para responder a algumas das necessidades e tudo bem. Não é pelo fato de ser uma zona do século XVI, do século XVII, que não possa ter um edifício do século XXI e do século XXII, ela sempre foram alteradas, as cidades são assim vão se alterando, se refazendo, vão se reconstruindo, ocupando espaços em função que exercem no momento.

Por exemplo, o espaço público é um espaço desagradabilíssimo aqui, porque é um espaço feito todo no tempo Fascismo, depois da crise acadêmica, depois da determinação do Estado Novo, para que não tivesse gente, para controle dos estudantes, por questões públicas, portanto, é um espaço 338 
desagradável, é inóspito, os edifícios são austeros, são ao mesmo tempo são opressivos na medida em que são de uma escala enorme, portanto, o conhecimento está dentro do edifício, e não entra na medida com exterior, o espaço exterior é um espaço de transição entre edifícios, porque eram proibidos os ajuntamentos de mais de duas pessoas, havia eixos no fundo para que a polícia pudesse controlar as manifestações ou encurralar as manifestações, a organização funcional urbanística da Alta foi reorganizada em função de uma lógica política, de controle político e policial.

O que é que nós queremos agora, queremos ao contrário, se não é possível regressar para habitação alta, porque não vamos agora rezar, fazer casinhas no meio, nem rezar o que está, digamos, o edifício para tornar a população cá. E, pelo menos fazemos com que a população sinta que a Alta Universitária também é dela, porque ela neste momento a população está excluída desta coisa, isto é um gueto Universitário, isso poderia ter portões à volta, só entram aqui quem são? Pessoas, alunos, os pais dos alunos quando há alguma manifestação acadêmica, funcionários, o resto ninguém vem cá acima, não há esplanadas, não há discotecas, não há cafés, não há espetáculos, digamos, não há edifícios a funcionar vinte e quatro horas ou fora das horas, portanto, tudo isso é preciso mudar e fazia parte dessa estratégia.

A estratégia é: vamos criar museus, vamos criar bares, vamos criar esplanadas, vamos transformar o espaço público em áreas peadonais, vamos tirar os automóveis daqui. Porque é que o automóvel aparece? Se o espaço público não servia para nada, é inóspito, é feio, não presta, neste instante a democratização também, digamos, a capacidade de aumentar o acesso ao automóvel acresceu para o ritmo da Dio, é evidente se o espaço público não serve para as pessoas serve para o automóvel imediatamente. Agora é preciso fazer o contrário, se vamos retirar o automóvel, temos que arranjar estacionamentos para o automóvel e vamos devolver espaços as pessoas, e para isto temos que abrir os edifícios que são fechados para o exterior e abri-los para o exterior, temos que criar, digamos, atrativos dentro dos próprios edifícios que levem as pessoas a entrar e sair na rua, e temos que criar na rua situações de conforto e de permanência, daí o edifício de Física ou Química na Malta, o pátio é um projeto é feito para rios, e para esplanadas e para estas coisas todas, é edifício que se passa pela Rua Larga e que portanto se visiona lá, aquele pátio com vista sob o Rio é um espaço ótimo, o turista vem nos visitar, andar pela esplanada a ver uma festa noturna, sem problemas nenhum.

As pessoas, às vezes, acabam escandalizadas quando a outra vista vai ter discoteca, a biblioteca, por exemplo, fecha às duas horas da manhã às quatro da manhã, mas ninguém vem porque todo o resto está fechado, não existe cidade. É preciso devolver isto a cidade, não significa não ter cá habitação, nem pessoas a morar cá, significa, digamos, criar condições para que o primeiro tipo de atividades em que este espaço funcione vinte e quatro horas e com população que não seja só estudantes, não seja só funcionários ou só professores, obviamente que é preciso também criar força de residencial. 
E para isto havia alguns edifícios, um dos quais atrás da Trindade que já foi um colégio, é um que está em cima do Jardim Botânico, que nós poderíamos transformar aquilo em residencial, uma parte da Medicina uma parte também vamos transformar em residencial,

Portanto São Jerônimo a vocação é mesmo um hotel, não tem problema nenhum, não é por isso que o edifício perde particularidade ou perde nobreza, digamos assim, em termos de função. Nós não vamos trazer a cidade para cá, mas poderemos trazer um determinado tipo de residência que é uma residência estudantil em alguns casos, ou eu digo as pessoas, convidados, um hotel que possa obrigar, por exemplo, aliás nós temos um que é da Psicologia, que eles transformaram a em um edifício, mais até para um trabalho que estavam a fazer, para a World Heritage Portuguese Origin ${ }^{175}$ (WHPO).

Criamos uma rede, que é a rede WHPO, e no fundo abria uma carta da UNESCO, é um patrimônio português, mas também não só português, é um patrimônio que é de origem portuguesa, mas que depois tem influências locais. Mas, até o vinte e cinco de abril quem tinha estes arquivos, estas técnicas todas quem dominava, obviamente, era o país colonizador, e, portanto, no fundo ele cria algum apoio sobre como intervir neste patrimônio de origem portuguesa, não digo mais para além, porque o patrimônio já que não é de origem portuguesa, mas é um patrimônio local, já do próprio país possa também ter algumas gêneses de materiais que são impossíveis de determinar, mas também nos interessa o retorno e também aqui em Portugal destas origens, quer seja do Brasil, quer seja da África, da Índia.

Portanto, esta troca de experiências, no fundo até o edifício era reservado para ter uma unidade de apoio a que servia aos investigadores, aos alunos, quase um Erasmus [Programa Erasmus de apoio interuniversitário de mobilidade de estudantes e docentes do Ensino Superior entre Estados-membro da União Europeia] do mundo lusófono que permitisse organizar estas funções, essa Cátedra neste edifício.

Portanto, é muito mais do que Faculdade lá e essas coisas todas, é tentar criar um Polo de dinamização cultural e habitacional, e no fundo fazer a cidade tornar a subir cá acima, e fazer com que a Universidade não seja uma coroa. É a cereja em cima do doce, neste caso, a cereja não tem nada a ver com o doce foi só lá pousada, é preciso fazer com que o doce observe a cereja.

Oito anos no fundo a candidatura é isso tudo, no fim é fazer um dossiê resumindo no dossiê, e é uma coisa que dá trabalho, fazer não sei quantas páginas, aquela esta senhora [Cátia Marques] tem esta responsabilidade comigo de resolver.

Maísa Fonseca:Em que o processo de Coimbra se difere do processo de Évora?

\footnotetext{
${ }^{175}$ A Rede Internacional do Património Mundial de Origem ou Influência Portuguesa (WHPO na sigla original) ou Heritage of Portugues e Influence (HPIP). 
Nuno Ribeiro Lopes: Este gabinete chegou a vinte e três pessoas, historiadores, arqueólogos, engenheiros, arquitetos, arquitetos eram oito, arqueólogos eram quatro, engenheiros o máximo que tivemos eram três, informáticos, engenheiros informáticos eram seis, historiadores da arte. Portanto, no fundo, o gabinete aumentava ou diminuía em função das necessidades do momento, o máximo que chegou a ter era vinte três, começou com quatro, portanto, foram se acabando aos poucos, e a Cátia é a última resistente desta estrutura e que conhece isso de trás para frente. Digamos, principalmente até porque depois disto fizemos trabalhos para a Universidade já fora da Candidatura, como, por exemplo, o programa preliminar, mais que um Plano Diretor, era o programa preliminar para a reorganização do Instituto de Física e Química, esse tipo de coisa. Já fomos os dois que fizemos a proposta final do São Jerônimo só para um hotel.

Isto não é um estudo fixo, como é evidente, agora entramos em grifos, portanto, no caso daqui a quatro ou cinco anos, a oportunidade de ser um hotel desapareceu, portanto, não se pode ficar agarrado a esta visão imobilista, quer dizer, algum estudo para um hotel, aqui tem que ser um hotel, não pode ser outra coisa.

Maísa Fonseca: É flexível?

Nuno Ribeiro Lopes: Tem que ser flexível, os edifícios estão lá, não podem ficar abandonados, tem que ter uma função, agora nunca devem ter uma função sempre persuária, aos bocadinhos, isso que é um desastre, porque senão nos permite fazer uma intervenção..

Agora, a Universidade... agora vou falar mal da Universidade, a Universidade é muito retrógrada, é muito conservadora, como é evidente, portanto, há um plano para demolir o CES, pode-se dizer assim, é praticamente o CES.

Maísa Fonseca: O CES? Mas eu achei que ele funciona muito bem.

Nuno Ribeiro Lopes: Porque são edifícios que foram sendo obviamente melhorados, mas são anexos sucessivos. Se nós olharmos para a Candidatura, vai ver que o que era o São Jerônimo, o que era o Colégio das Artes são despidos daquela..e a Muralha fica morta. Portanto, aquelas áreas foram construídas para o hospital, na altura, e que, portanto não tem qualidade muitas vezes, outras ficarão.

Agora, a Universidade, mesmo quando os edifícios vão vagando, para deitar abaixo, há sempre alguém que diz que precisa daquele bocadinho, daquela coisa.

Um drama que eu acho, neste momento, o ponto crítico atual, a Reitoria mudou, portanto, a outra Reitoria, isso significa, normalmente em Portugal que quem venha a seguir, eu penso que no mundo inteiro, mas nos países latinos e em Portugal é assim, se não fui eu que fiz eu tenho que discordar do que está feito.

Maísa Fonseca: E não continuar o que estava sendo feito. 
Nuno Ribeiro Lopes: E não continuar, portanto, em princípio está tudo mal, vamos aproveitar, vamos re-analizar, e algumas coisas vão se aproveitar. As que se aproveitarem já são segundo a minha visão e não segundo a visão do que fizemos, primeira questão. O que significa que neste momento, associado a uma crise financeira, significa que tudo o que foi feito antes está parado, basicamente, até se pensar melhor.

Segundo, uma candidatura implica correr riscos, correr riscos como sempre implicava numa data anterior com o anterior Reitor, e com ele, implica buscar com direitos anteriores, que não são direitos, são algumas manias adquiridas, alguns privilégios, como poder estacionar aqui, eu tenho o privilégio por ser professor e posso estacionar o carro aqui, se me tirar o carro daqui já estou contra a Candidatura. Isso existe, e é tão real, e é mesquinho, que é ridículo, e, portanto nesta dimensão a Universidade é ridícula, ela e outra qualquer, porque é um jogo, pequenos poderes, pequenas coisinhas, pequenas vitórias, que são uma visão estreita das coisas.

Isso significa que quem estiver à frente tem que ter a capacidade e o arrojo de ir contra com estas coisas, que quem estiver à frente do processo pode criar em alguns casos amizades, mas sim inimizades. Daí, nós a divulgamos, que a intervenção no espaço público devia ser a primeira, para quê? O espaço público não pertence basicamente a ninguém, e, portanto não estou a tirar gabinete a ninguém, não estou a mudar outro sítio, não estou a tirar privilégio, já tenho problema de estacionamento, apesar de tudo já mecho com alguma coisa.

Mas o espaço público é capaz de galvanizar, para uma transformação posterior, deve ser a primeira transformação, para no fundo poder galvanizar não só a cidade, e, portanto trazer outros públicos, outras pessoas cá para cima, animá-la, e as pessoas perceberem sem ter perdido ainda o edifício, não perderam nada, só ganharam, e, portanto, estarem com outra disponibilidade para que quando chegar ao edifício onde eles trabalham, dão aula, onde eles aprendem, digamos, que vai obrigar a algumas alterações também mais disponíveis para que estas alterações aconteçam, no fundo é uma espécie de galvanização.

Como começar? Começamos por aquilo que não afeta teoricamente ninguém, que é capaz de por toda gente a favor desta mudança, deste ciclo de mudança.

Se começamos logo por um edifício conquistamos logo inimigos e a partilha, e as pessoas dizem, tem que sempre ter a coragem de cortar a direita. Uma candidatura só se faz com ruptura, porque se não houver ruptura mantém-se como está até agora, mantém-se tudo a fazer gabinetes, anexos e barracos, essas coisas, não se afeta nada não se consegue encher, só fica a ruptura, se não houver ruptura pode haver dossiê de Candidatura, mas não há um boletim técnico de afirmação da Universidade.

A Candidatura só faz sentido se for um meio de afirmação, se for uma espécie de avião, é aquilo que nós discutimos, é um plano estratégico, nós estivemos a discutir oito anos, sabemos o que 
queremos, portanto, agora, vamos para este meio. Agora, se for para ficar um tempo na gaveta não vale nada, e o ponto em que estamos, é ver se fica na gaveta ou se vai servir, obviamente a falta de dinheiro pode justificar, desculpar e ficando na gaveta mais um ano ou dois anos, e ir adiando, e se corre o risco.

A Candidatura também pode funcionar ao contrário, porque uma Candidatura, por exemplo, se for aprovada, se a Universidade for classificada, ela vai obrigar que, digamos, a Coimbra que não fique na gaveta, que não fique na estante, seja aberto e que tenham que seguir alguma das coisas que lá estão, mesmo que não seja tudo, algumas das coisas tem que ser feitas.

O compromisso com a UNESCO, e a própria UNESCO obrigam que estas coisas não fiquem paralisadas, vão começar a ver a porção, porque é que não se fez isso, vai começar a porque é que não se cumpre, porque é que não sai à resposta.A classificação está em risco, pode levar um cartão amarelo, depois pode ser pode desclassificada, enfim, estes tipos de questões, e as pessoas começam também a perceber.

E o que eu acho é que a Câmara mudou também, a Câmara nisto mantém um papel fundamental. $O$ antigo presidente de Câmara dizia que apoiava, mas na prática não apoiava nada. Este está muito empenhado, até porque percebeu que uma rede a Coimbra a se afirmar em território português, ou capital, neste momento, é através da classificação da própria Universidade. Portanto, é um dos principais interessantes neste momento em que a Candidatura avance e a transformação se faça ou é pela própria Câmara, portanto, este é um evento imobiliário poderoso.

O que é que isto tem de diferente, para arrematar, o que é que esta Candidatura tem de diferente em relação a qualquer outra, pelo menos em Portugal?

Foi feita uma Associação, que é a associação entre a Universidade, a Câmara, a Sociedade de Reabilitação Urbana, e Direção Geral de Cultura fizeram uma Associação que se chama RUAS que é uma Associação que vai gerir este território todo. Ou seja, pela primeira vez temos quatro Instituições aparentemente coordenadas ou com interesses comuns para gerir este território em bloco, em vez de ser um para cada lado. E, essa é a primeira vez em Portugal que se faz essa experiência, é uma experiência que eu acho que tem todas as condições porque aparentemente só trará vantagens para todos.

Obviamente que tem alguns inconvenientes, mas são inconvenientes mais formais e operacionais, porque obriga, digamos, ao estar sozinho não tem que responder a ninguém, tem que falar com os outros, portanto, tem esse inconveniente, obviamente tem lá as vantagens todos falaremos porque as pessoas e os cidadãos deixam de estar, um parecer deu parecer positivo, outro deu negativo, sem perceber, e, portanto, a ideia de que a Zona Classificada é uma chatice porque só traz inconvenientes, só traz problemas, pode ser completamente alterada e pode ser só benefícios. 
Agora estamos por ver o espaço, é a própria instalação da associação no Colégio São Bento, que é onde vai ser sede, na antiga Galeria de Exposições de Antropologia. Que em princípio deve haver nesse tempo, com uma exposição da própria Candidatura e com as instalações da Associação com os técnicos a funcionar, a receber pessoas, atendimento, enfim, essas coisas todas.

Maísa Fonseca: Quando acontecerá?

Nuno Ribeiro Lopes:Deveria acontecer, teoricamente, até quinze de setembro, vinte de setembro como limite, depende muito das obras, porque agora mesmo agosto é muito complicado.

Maísa Fonseca: Existe algum processo no qual vocês se basearam como referência, já que trata-se de um bom exemplo?

Nuno Ribeiro Lopes:Há um processo que é assim, primeiro há uma espécie de guião de questões que a UNESCO põe, e que é preciso responder no Dossiê.A outra questão é nos não estamos fazendo um trabalho destes que pode ser feito com a lógica da Candidatura. Para serem consistentes, para terem alguma lógica da sustentabilidade esses trabalhos são feitos para quem trabalha e para quem vive aqui, portanto, eles só podem manter-se ao longo dos anos e ser reais, e forem sustentáveis, se forem vividos, se forem aceitos, pela população universitária e pela população da cidade, digo, globalmente.Porque se for uma coisa imposta, só para um Dossiê de Candidatura, se for artificialmente, rapidamente se desfaz. Portanto, não há guião nenhum, a esse nível, há guião, mas depois não há guião, não há peça escrita.

Depende, porque uma Candidatura no Pico obviamente é diferente de uma Candidatura em Coimbra, embora o guião seja o mesmo, as perguntas são as mesmas, mas as realidades são diferentes, os objetivos são diferentes, e, portanto, não há nenhum neurinho agora tem que se fazer assim, agora tenho que fazer assim, sim, quer dizer, depende.

Maísa Fonseca: Se falou-se que é a primeira vez em Portugal, existe algum outro assim?

Nuno Ribeiro Lopes:Não, não..quer dizer, existe em alguns casos em Espanha, uma coisa comum, algumas experiências, como o caso de Santiago de Compostela ${ }^{176}$, na questão do Jubileu, era o ano dois mil, e foi criada uma Organização conjunta, digamos, entre o Rei, sob o patrocínio do Rei, mas o governo federal, no fundo o governo central, o governo regional e o governo Autárquico, que dividiram tarefas com o mesmo objetivo, e participavam, e tinham uma questão que era criar uma comissão de especialistas de várias áreas, de diferentes departamentos. Por exemplo, cada projeto que entrava era apreciado por esta comissão, que tanto poderia ser aprovado contra ao regulamento, quanto podia ser chumbado mesmo cumprindo o regulamento. Digamos havia um nível regulamentar, mas depois havia um nível qualitativo que era apreciado.

\footnotetext{
${ }^{176}$ A cidade de Santiago de Compostela (ES) foi classificada como Patrimônio Mundial pela UNESCO em 1985.
} 
Isso cá em Portugal é impossível, porque a lei sobrepõe, que se a lei tem que ser clara ela não pode ser omissa, não pode ir contra o regulamento, isto dá perda de mandato, essas coisas todas. Portanto, o que tem que se criar é um regulamente que de alguma maneira, não diga que a janela tem que ser deste tamanho, tenha que ser só deste, mas que ao mesmo tempo defina critérios de intervenção, que não seja tão objetivo, ou tão fechado, que vá por a menor da medida ou de um único material, mas que se crie conceitos e objetivos.

O que deixa em aberto é que o projetista quer o técnico que aprecia tem que se entender numa visão, e, portanto, o que nós estamos a tentar criar nesta Associação não é só fazer a apreciação dos projetos, onde está a Universidade, a Câmara e todas as Entidades, mas é também fazer, a parte do Planeamento, que tem a ver Plano de Gestão, o que é que está no Plano de Gestão para fazer os próximos anos, portanto, esta própria Associação vai ela encarregar-se a obrigar a Câmara, de obrigar aos diferentes parceiros, a Universidade a cumprir esse Plano Estratégico, portanto, tem uma função de impulsionador, de coordenador, ao mesmo tempo de fiscalizador, se quiser.

E, uma função fundamental, que é uma função pedagógica, é uma função de formação, de apoio aos projetistas, de apoio à população geral. Por exemplo, eu quero fazer uma intervenção, mas não domino as técnicas de reabilitação, não sei muito bem, a arqueologia é uma trapalhada, assusta muito, não quero investir, portanto, esta Associação tem que criar esse apoio, isso na Universidade é vital nisso, porque a Universidade tem toda a gama de técnicos que podem me dar apoio, que podem me dar ajuda, podem me dar formação em cada caso específico. Portanto, há um apoio aos projetistas, um apoio aos investidores, um apoio aos próprios proprietários deste território, seja a Universidade, seja o senhor fulano de tal que tem uma casinha lá no Centro Histórico, que é vital que é para mudar a mentalidade.

No fundo, se isso funcionar, passo daqui a, sei lá, cinco anos, seis anos, sete anos, esta coisa que é esquisita de formar uma Associação que é novidade torna-se uma coisa corriqueira e banal, no fundo, é isso que se pretende.

Agora, eu tive uma experiência um pouco no Pico que era um bocadinho diferente, que era um território também agrícola, com aldeias e com vilas no meio, portanto, diferente num território urbano, era misto, e que tinha uma comissão diretiva, que dirigia todo aquele território, era uma paisagem protegida.

E tinha três representantes, um representante das autarquias, dos municípios, um presidente que era o representante político do governo, e estava eu, que era o responsável pelo Gabinete, pela Candidatura e também pelos parceiros que, digamos, que esse Gabinete tinha que dar naquele território, e que eram vínculos ativos. E eu era o vogal desta Comissão Diretiva, e, no fundo, eu transmitia aos outros parceiros qual era o parceiro, porque, porque é que se chumbava, porque é 
que se aprovada, e era discutido entre os três, e essa Comissão Diretiva poderia corrigir, dizer assim, não, não concordo, queremos saber mais sobre isso, acho que isto não está bem estudado deste ângulo, estudem mais.

Isso obriga que o técnico da Câmara, o técnico da Direção Regional de Cultura, e o próprio técnico da Universidade tenham que se explicar porque é que apreciaram aquele projeto daquela maneira. Não podem ser só assim, é meu poderzinho eu decido como quero não tenho que dar satisfação a ninguém. Isso é vital, parar com esses processos em que o arquiteto muitas vezes, porque até tem pouca formação, é recém formado muitas vezes, tem a pista azul da censura, e é capaz de estragar a vida de alguém ou premiar a vida de alguém. $E$, portanto, ele tem que explicar o porquê, e essa explicação tem que ser feita a um coletivo de três a quatro pessoas, que no fundo validam a situação. Portanto, a ideia é por os técnicos todos das diferentes entidades a trabalharem em conjunto, a discutirem em conjunto, independentemente de cada um ser responsável ou parceiro por um determinado projeto, ou um estudo, apresentarem a esta mesma comissão, e, no fundo, alargar outra vez a discussão. $E$, assim, haver menos riscos de erro, e ao mesmo tempo maior coerência entre as Instituições porque cada uma delas já tinha que dar um parceiro específico, portanto, ao invés de ser um parceiro específico, no fundo, é um parceiro das diferentes Instituições todas condensado num único parceiro. Portanto, ganha-se tempo, ganha-se coerência, e se calhar ganhase formação em termos dos próprios técnicos.

E todos nós temos que aprender com isso, digamos, nenhum de nós está na posição de ensinar ao outro como deve ser, porque não há nenhum caso igual, nem estas coisas tem cartilha, não é? Por muita experiência que eu possa ter, e outro não ter só um ano de experiência destas coisas, se calhar aprende sempre alguma coisa, desde que se esteja disponível pra isto, sempre alguma coisas com as pessoas que tem menos experiência, pode-se ter uma visão diferente, pode ser até mais adequada, a minha já pode ser viciada, alguma coisa.

No fundo, o poder a uma pessoa, não há Deus, não há ninguém que seja capaz de sozinho decidir a vida dos outros cidadãos. Portanto, por população toda a perceber que isto é um coletivo que se discute e que as coisas também não são estancas, pode-se variar, e vamos aprendendo com isso, quer os construtores, os projetistas, os proprietários e mesmo quem licencia também, os políticos no fundo.

$E$, portanto, que a questão seja melhor gerida, e obviamente também mais racionalidade em termos de custos, mais atrativo para quem visita, e, portanto, um pouco, podemos imaginar que é uma espécie de oasis que vamos aqui a criar, não é, porque isto é acessível. Haja vontade que sim, assim, a nossa responsabilidade foi dar o pontapé cheio de fazer com que as pessoas aceitassem este modelo. 
Conseguimos, ao longo deste tempo todo, está em cima da mesa, estão a se criar os meios, já é o gabinete que estas pessoas vão estar, a estrutura já está criada, agora é tentar que o funcionamento corresponda à ideia de que isto era possível de funcionar. Isso obviamente não tem que ser sempre com os mesmos, não pode depender de eu estar lá, ou estar outra pessoa, isso tem que funcionar por sistema, por estrutura, e não porque a pessoa que lá está é que faz com que aquilo funcione assim, se eu for embora isso morre tudo. Não pode ser assim, é um bocadinho de idealismo eu continuar a acreditar que é possível estas coisas todas.

E há algumas experiências já foram feitas bem interessantes, eu já participei em algumas, outras pessoas fizeram, e há experiências bem interessantes de vinte ou trinta anos, as coisas vão evoluindo, e, em alguns casos, o patrimônio é sempre uma questão muito frágil.

Basta mudar muitas vezes o presidente da república, digamos assim, quem determina tudo é o presidente da Câmara, e que uma assinatura pode estragar trinta anos de trabalho porque acaba com aquele gabinete, nesse sentido tudo isso é muito frágil. Mas, por outro lado, nós já vimos outras situações em que isto, não havendo as roturas políticas é possível continuar com diferentes presidentes, com diferentes técnicos, as direções vão continuando este processo. Obviamente que há sempre terremotos, e estamos sempre sujeitos a que haja de repente um tipo que chegue aqui e diga, isto acabou tudo, não tenho interesse, vamos fechar.

Pelo menos ficaram vinte ou trinta anos de trabalhos, e as pessoas depois também tem que se manifestar se aceitam que esta ruptura possa acontecer sem mais nem menos, sem consequências, é porque já não estavam interessadas. Ou, então, acabaram por não participar, por se desligar do processo, se é um processo que já não é renovado é porque evidentemente já acontecia alguma coisa.

Eu também acho que as pessoas tem que mudar, eu, por exemplo, no Pico fui responsável por três anos e meio por aquilo, quando passou a ser patrimônio mundial, quando foi classificado, e foi criado o gabinete formal, eu achava que a altura de alguém nos substituir e ficar a frente daquilo porque ia nascer uma nova etapa, tanto melhor, era a melhor altura para haver outra pessoa, com uma nova visão para concluir aquilo, e acho que é preciso mudar de vez em quando, as pessoas não podem ficar eternamente naqueles lugares senão as tantas acham que já fizeram tudo, e começam a desleixar-se, a brandar, a dizer-se insatisfeito, não preciso pensar mais nada, só preciso pensar com as férias, quando é que vão começar as férias, se é essa a motivação, tem que haver motivação permanente, e autocrítica permanente, portanto, quanto mais participado for, menos pessoas a de desleixo, porque há uma participação constante, e há uma crítica constante, tanto o diga quem está a esforçar-se e a superar-se. 
Maísa Fonseca: O trabalho de vocês fez-se em termos técnicos, houve também um trabalho desenvolvido diretamente com a Universidade em termos de questionamento sobre as mudanças do edifício e nesse sentido? E com a população?

Nuno Ribeiro Lopes:Nós fizemos uma coisa que se chama pomposamente, e tem um nome muito esquisito, o Plano de Desenvolvimento Físico da Alta Universitária, no fundo consiste em que os edifícios vão ser, o que eles são daqui um ano, o que vão ser daqui dois, obviamente em muitos casos, foi uma discussão direta com o Reitor, e com os pró-reitores, com os departamentos.

Maísa Fonseca: Sempre com a comunidade da Universidade?

Nuno Ribeiro Lopes:Obviamente muito mais com as cúpulas e com as direções. Agora discutimos com a Associação de Estudantes, discutimos com as Repúblicas, mas obviamente que é impossível fazer uma plenária ou global, porque muitas vezes a nota nem aparece, nem está interessada, nem quer saber. Agora com as faculdades, com as aliações da faculdade sempre que possível, mas as coisas só podem ser alargadas e participadas não numa logicamente, quer dizer, tem que ter trabalho prévio, já aceito, não pode ser estamos todos aqui, cada um assenta, cada um diga o que quiser, e depois no fim vamos fazer um resumo disso tudo, não pode ser assim.

Tem que ter alguma coerência, tem que ter uma estrutura, tem que estar pensado, portanto, o que nos fizemos sempre foi em torno de todos os trabalhos, dos projetos de uma habitação, num equipamento, primeiro temos que pensar a sua função depois vamos discuti-la e apreciar se esta tudo bem, se é preciso reproduzir pontualmente, se está mal, e porque e começar de novo, agora nunca é em vazio.

Agora não foi tanto que nós achávamos que deveria ser, mas isso por uma questão de estratégia da Reitoria, porque sempre que alguém quis fechar mais, o que eu acho que em alguns casos teve algum risco da Universidade de não conhecer a Candidatura.

Aliás, é alguma das críticas que é feita, e que eu acho que é correta, eu acho que ela é fechada em alguns setores. Foi menos divulgada qual que deveria ter feito, foi menos participada do que poderia ter sido, mas isso tem a ver com os tais corredores do poder, e discussões da própria Universidade interna e confluídos, e, obviamente não são técnicos que podem dizer que é assim e que não é assim, são os políticos que tem que modificar. Mas também não foi até agora tão corrosiva, tão de ruptura quanto devia ter sido. Portanto, estes são os déficits que a Candidatura tem, podia ser muito mais interessante, mas tinha que ser muito mais corrosiva, muito mais violenta, digamos, na quebra de alguns hábitos, digamos assim. Mas isso é uma avaliação que são os políticos que têm forças para fazer, no momento. O que pode haver força para fazer uma coisa hoje daqui a um mês ou dois meses se mudar a situação, se perdeu a oportunidade, muitas vezes já não é possível fazer, agora se estivesse no papel... 


\section{ENTREVISTA 4}

Entrevistas de caráter informal sem sistematização da informação coletada com comerciantes da região da Baixa, localizada no Centro Histórico da cidade de Coimbra, em junho de 2012, sobre o conhecimento do processo de candidatura.

Pode-se afirmar que de uma maneira geral os comerciantes da área da Baixa desconhecem com exatidão o processo de candidatura e a questão do patrimônio que está se candidatando. Como uma das etapas da avaliação da UNESCO consiste em questionar os moradores, comerciantes e usuários da cidade e das áreas envolvidas sobre o conhecimento esse patrimônio considerando a necessidade de conhecimento pelo ator social, a Universidade tem se empenhado em desenvolver publicidade sobre a candidatura explicando a importância desse patrimônio, no que consiste e como buscam fazê-lo, através principalmente de vídeos divulgados em redes sociais, tais como, o youtube. 


\section{ENTREVISTA 5}

Entrevista em caráter informal com estudantes de uma república chamada Bota Abaixo, localizada no Centro Histórico, na cidade de Coimbra em junho de 2012.

A Lei do inquilinato em Coimbra estabeleceu, de 1975 a 2005, que os proprietários de imóveis não poderiam elevar o valor de suas rendas. A partir da alteração dessa lei, atualmente, algumas repúblicas de estudantes tem se manifestado contra a possibilidade de elevação do valor do aluguel, o que impossibilitaria que os imóveis continuassem sendo utilizados como repúblicas de estudantes. Eles também alegaram que com o título de cidade patrimônio mundial e a alteração da lei do inquilinato, as repúblicas próximas a universidade não mais existiram ou seriam menor número devido a uma possível valorização da área que poderia tornar-se atrativa para hotéis e comércio.E, assim, conjuntamente a alguns moradores residentes próximo a Universidade, na Alta, onde localizase grande concentração de população idosa, escreveram um documento que foi entregue a Câmara de Coimbra, posicionando-se contra a candidatura a cidade Patrimônio Mundial pela UNESCO. 


\section{APÊNDICE B}

\section{Entrevistas realizadas em Belém}

Entrevistas realizadas na cidade de Belém com alguns acadêmicos e intelectuais, professores e pesquisadores da UFPA, que analisam e discutem a questão da produção da cidade de Belém, da identidade e do patrimônio cultural, o contexto local e o lugar, e a superintendente no Pará do órgão nacional de preservação do patrimônio no Brasil, uma das idealizadoras e responsável envolvida na elaboração e desenvolvimento da proposta de intenção de candidatura de Ver-o-Peso como patrimônio mundial pela UNESCO:

6. Prof. Saint-Clair Cordeiro Trindade Júnior, vinculado ao Departamento de Geografia da UFPA, ao Núcleo de Altos Estudos Amazônicos, e membro do Instituto Histórico e Geográfico do Pará;

7. Prof. Juliano Pamplona Ximenes Ponte, vinculado Faculdade de Arquitetura e Urbanismo da UFPA, e pesquisador associado ao Observatório das Metrópoles BelémInstituto Nacional de Ciência e Tecnologia.

8. Profa. Maria Goretti da Costa Tavares, vinculada ao Departamento de Geografia da UFPA, e autora do roteiro geo-turísticode visitação aos espaços, que inclui o Ver-o-Peso e Centro Histórico.

9. Maria Dorotéa Lima, superintendente do IPHAN-PA, idealizadora e autora da proposta de inclusão de Ver-o-Peso na Lista Indicativa do Patrimônio Mundial pela UNESCO. 


\section{ENTREVISTA 6}

Entrevista realizada no Núcleo de Altos Estudos Amazônicos (NAEA) da UFPA, sala 216, na Universidade Federal do Pará, na cidade de Belém, às 13h do dia 20 de julho de 2016, com o Prof. Saint-Clair Cordeiro da Trindade Júnior.

Essa entrevista foi realizada pelo interesse em compreender melhor as dinâmicas socioculturais da cidade de Belém e suas relações e articulações com o espaço urbano histórico de Ver-o-Peso e sua área de entorno, buscando compreender também questões relacionadas a identidade cultural da cidade, a relação deste bem cultural com o território, as políticas públicas relacionadas a área e aprofundar a compreensão no contexto da região amazônica, principalmente voltado para a cidade de Belém.

A escolha do entrevistado, professor e pesquisador Saint-Clair Trindade, fez-se em razão de seu vínculo com o Departamento de Geografia da UFPA, com o Núcleo de Altos Estudos Amazônicos, e como membro do Instituto Histórico e Geográfico do Pará. Atualmente, Saint-Clair desenvolve pesquisas na área de planejamento e estudos urbanos regionais, voltadas para o tema de cidades, urbanização e urbano diversidade na Amazônia, desenvolvimento urbano e regional, planejamento e gestão urbanos, direito urbanístico e ordenamento territorial.

Muitas das perguntas a entrevistada enfocaram nas dinâmicas territoriais da cidade, na identificação do patrimônio cultural da cidade e sua relação com o território, e na comparação com outros processos de patrimonialização relacionados ao patrimônio imaterial pela UNESCO.

Maísa Fonseca: Houve um processo anterior ao atual processo de patrimonialização de Ver-o-Peso e Belém, como patrimônio mundial material pela UNESCO?

Prof. Saint-Clair Cordeiro da Trindade Júnior: Em são Luiz é mais a arquitetura colonial, a presença da cidade colonial. Belém não é tão rica quanto São Luiz, do ponto de vista da arquitetura colonial, mas ela tem um ecletismo muito grande, você tem arquitetura colonial, depois você tem o barroco italiano do Landi, você tem essa influência da Belle Époque e tem essa arquitetura mais modernista. Então, se pegava exatamente essa riqueza da complexidade do ecletismo arquitetônico da cidade que eram colocados como elementos virtuosos para a candidatura. Mas depois parou e aí ficou mais na questão do Ver-o-Peso, do Complexo Ver-o-Peso, mas seria interessante pegar esse estudo, é um estudo assim pequenininho, quer dizer, o estudo deve ser maior, mas o que eles publicaram era tipo um livretozinho, para ser uma coisa mais pública e didática. É Cristovão Araújo o nome do autor, posso ver com detalhe essa referência, e acho que o IPHAN tem esse livreto. 
Maísa Fonseca: Gostaria de saber a visão do professor em relação ao contexto, do lugar, em relação ao processo de patrimonialização do complexo Ver-o-Peso em relação ao Centro Histórico, a cidade e a região.

Prof. Saint-Clair Cordeiro da Trindade Júnior: Eu tenho acompanhado pouco essa coisa da candidatura, tenho acompanhado mais pela imprensa. Pelos estudos que a gente tem da área central, por esta questão da requalificação, a gente acaba acompanhando de maneira mais próxima essas questões que envolvem a patrimonialização e os processos de requalificação. Como é que eu vejo, eu acho que tem sempre se elegem algumas coisas muito padrão para se pensar o que é o patrimônio, o destaque acaba sendo o elemento arquitetônico, ou então, o traçado arquitetônico, isso é muito forte, e no caso de uma cidade como Belém há um patrimônio imaterial muito grande, muito rico, que às vezes acaba não sendo contemplado, e também não é objeto de políticas de resguardo, de preservação.

Vamos pegar como exemplo o caso de Ver-o-Peso, claro tem todo um contexto arquitetônico e paisagístico interessante, sem dúvida, eu não coloco em questão isso. Inclusive agora, em relação a este projeto de requalificação do Ver-o-Peso, a gente fez um debate aqui no NAEA, questionando um pouco inclusive isso, porque o projeto arquitetônico para a feira de certa maneira sugeria uma transformação da feira em uma espécie de mercado, e para nós a feira é simbolicamente do ponto de vista arquitetônico muito significativa, é a configuração da barraca. Inclusive o que chamou a atenção neste projeto de requalificação era a maquete eletrônica que eles jogaram na mídia, você tinha as barraquinhas, aí eles jogaram uma maquete eletrônica que cobria as barraquinhas, desestruturando aquela concepção de feira.

Acho que isso é importante, nós temos uma concepção de feira, inclusive as nossas feiras aqui, diferente das feiras de São Paulo, são permanentes, elas não são de rodízio, nós temos uma feira apenas que é a da Batista Campos, apenas que ela acontece de sexta, sábado e domingo. Mas normalmente as feiras são permanentes, e elas têm uma marca definitiva no espaço, como o Ver-oPeso, e sempre remete a questão das barracas. Então, do ponto de vista paisagístico, do ponto de vista da paisagem, nós temos um imaginário do que seja a feira pra gente então isso é importante.

Fora isso nós temos os mercados, todo um complexo arquitetônico que é muito rico ali, mas para além disso, e eu acho que isso tem que estar como elemento central na patrimonialização é a relação da cidade com o rio, e da cidade com a floresta, que foi um pouco o mote que o Rio de Janeiro utilizou para ganhar também essa classificação com o contexto de paisagem natural, e não só como a paisagem natural, mas também alguns elementos que em algum momentos não estavam colocados como referência arquitetônica, como por exemplo, estação ferroviária de não sei onde, a quadra de samba de não sei onde, tudo isso começou a chamar a atenção para um complexo que era muito 
maior do que um centro urbanístico e uma relação da montanha com o mar simplesmente, então, eu acho que o Rio de janeiro caminhou numa linguagem diferenciada e que foi bem aceita pela UNESCO.

De modo diferente de Buenos Aires, que não conseguiu, e o mote de Buenos Aires era a relação da cidade com o rio, como o nosso, que eu estou achando que é o elemento central. E lá, que é bem mais descaracterizado, eles tentaram colocar a relação da cidade com o Rio da Prata, como elemento fundamental para pensar a patrimonialização, só que a descaracterização desta relação com o rio é muito forte em Buenos Aires, inclusive com uma relação com o rio mais padronizada, como tem aquele passeio no Rio Tigre, um passeio meio aburguesado, você coloca as pessoas num barco meio que de elite e você vai ver as mansões dos burgueses ali no delta.

Quando o Rio [de Janeiro] foi se candidatar eles já sabiam dessa experiência de Buenos Aires, então tudo o que era frágil eles tentaram potencializar, então, essa ideia de pensar um complexo maior, da paisagem natural, da paisagem histórica, da paisagem cultural, foi um elemento importante para que o Rio pudesse ser classificado como patrimônio pela UNESCO.

Belém, eu acho que tem esse elemento forte, que eu acho que a síntese é o Ver-o-Peso, mas o Ver-oPeso é apenas uma expressão disso, é muito maior, e está em grande parte da cidade, que é uma cidade que dialoga com o rio, que dialoga com a floresta, então isso está presente em portos, agora se tu vais olhar os s e portos da cidade, eles estão muito descaracterizados, ainda que o patrimônio imaterial seja muito forte, e seja muito vivo, tu tens isso que está presente na área central da cidade, nessa área do entorno do Ver-o-Peso, a chegada dos produtos, já fostes ver a Feira do Açaí de madrugada?

Precisas ir, é algo fabuloso, é uma das cenas mais bonitas que nós temos em Belém, tem que chegar lá por volta de duas, três horas da madrugada que é quando o açaí está chegando, chegando das ilhas, ele chega ali, desembarca e abastece toda a metrópole, então, o movimento é algo muito bonito. E quando tu vais de manhã, tu não tens o elemento material que identifique essa relação da floresta com o rio, que na verdade, é o corpo humano, é a atividade humana que define essa cultura e esse patrimônio que está ali presente. É o momento da cidade que tu tens que olhar aquele tempo, é a demarcação da relação da cidade com o rio. Claro existe lá a Feira do Açaí mas ela fica vazia a partir das sete horas da manha, quando ela não tem quase nada, a não ser os caroços que mostram que ali tem uma atividade muito dinâmica durante a madrugada.

Então, isso é um exemplo que está na área central, que faz parte do Complexo Ver-o-Peso, mas que não é só esse. Se tu vais aqui pela orla sul da cidade, desde a Universidade até lá do Ver-o-Peso, tu vais ver vários portos e vários trapiches, como nós chamamos aqui, trapiche é píer, com uma relação muito intensa da cidade com o rio, de uma vida ribeirinha que se organiza e que está muito presente nessa orla da cidade, e aí são as frutas, são o peixe, são as pessoas chegando, são os barcos os 
trabalhadores dos portos, um circuito informal da economia que está ali presente e que demonstra toda essa relação que Ver-o-Peso expressa. Porque a síntese Ver-o-Peso é essa, é o fato de ser uma cidade que ainda que se metropolize ela tem muito, traz para si muito do que é a cultura, do que é a vida da floresta, através dos seus produtos, mas não só através dos seus produtos, através do seu imaginário, das suas representações, das suas estórias, das suas histórias, que está ali na vida material, quando tu conversas com as pessoas no porto, tá ali, algumas acreditando mais nas histórias e nos mitos, outros menos, mais ainda sim, sabendo da importância que isso tem para a preservação de uma cultura, para a preservação da própria floresta e isso está ali presente.

$E$, eu acho que isso é pouco colocado quando se pensa na ideia da patrimonialização, e eu acho que esse é o elemento mais rico do processo, e quando tu olhas esses relatórios para tombamento, para classificação, aparece muito as formas espaciais, e quando muito as funções, mas os processos, os contextos nos quais essas formas, essas funções estão colocadas desaparecem.

Inclusive eu tive uma aluna de doutorado, a Raquel Ferreira, ela mostrava exatamente isso, como a ideia do patrimônio histórico se restringe muitas vezes as formas, e se estende outras vezes as funções, mas esquece os processos e as estruturas em que essas formas e funções se inserem.

Então, não apenas olhar apenas o Ver-o-Peso, mas o que representa o Ver-o-Peso numa cultura material e imaterial da cidade, mas todo o espaço em que estas relações do rio com a cidade e da floresta com a cidade, nesse caso não é só Ver-o-Peso que merece ser tombadoe classificado, mas é todo o espaço em que essas relações da cidade com o rio e da cidade com a floresta se expressam, e aí, as formas espaciais elas deixam a desejar no sentido de expressar esse conteúdo material e imaterial, quando tu vais a estes pequenos portos, feiras, e trapiches, o que tu vês é a precariedade da infraestrutura colocada. E alguns portos, como por exemplo, o porto do sal, que inclusive ele é um porto, um trapiche, ele é um patrimônio porque ele é antigo, ele é uma estrutura antiga, ele está deteriorado ele está completamente precarizado pela falta de manutenção e pela falta de pensar este porto como um patrimônio da cidade.

Então, há uma ausência completa de políticas que transformem em formas esses conteúdos, não só para ficar na paisagem, não é isso, mas porque estes conteúdos, essas práticas sócias espaciais elas precisam de formas para se reproduzir, do ponto de vista da qualidade ambiental, da qualidade de vida dessas pessoas e do trabalho que elas têm, mas também do ponto de vista da necessidade que esses conteúdos e essas práticas sócio espaciais precisam para existirem, se elas não têm as formas elas vão se precarizando e desaparecendo, e a tendência tem sido essa, se tornarem menores, se tornarem precárias e as pessoas deixarem de frequentar.

Eu tiro por mim mesmo, poucas vezes tenho ido as feiras, e eu gosto muito das feiras, porque são precárias, porque são inseguras, porque não existe uma política que pense essas feiras como parte 
da economia urbana, então, às vezes você tem um produto malcuidado que aí está melhor oferecido no supermercado. Como o próprio açaí, às vezes, pela falta de higiene, pelo barbeiro, tem que feito que as pessoas deixem de comprar nas pequenas baiucas, nessas pequenas vendas que estão nos portos, como no Ver-o-Peso.

Então, falta uma política que transformem em formas esses conteúdos, que não está só no centro como eu te disse, que está na Orla sul da cidade toda, nós fizemos um estudo inclusive, Belém a cidade e o rio, que mapeou um pouco esses portos, essas feiras, só aqui nós temos o porto da palha, o porto certo, o porto da açaí, aqui nessa faixa da estrada Val, essa rua aqui da beira da orla, depois nós temos o porto da conceição, e aí vai, são pequenos portos, que como se fossem pequenos Ver-oPeso com toda expressão de atividades que o Ver-o-Peso possui. Só que Ver-o-Peso pela forma arquitetônica, com o Mercado de Ferro, mais expressiva, acaba assumindo uma importância muito grande, que de fato tem, mas em toda orla sul da cidade a gente vê estes pequenos Ver-o-Pesinhos, que eu penso, tem que entrar, se nós formos patrimonizalizar o Ver-o-Peso como uma referência para a humanidade, é o Ver-o-Peso e suas miniaturas que dão sentido para a cidade.

E se tu fores, por exemplo, para a orla oeste e norte da cidade, já tem menos, porque aí estes portos já foram todos arrasados pelas grandes empresas, porque a zona oeste da cidade ela é das empresas, se transformou numa espécie de setor industrial, de empresas de transporte de área de logística que ali se localizaram, então, tu não tens mais estes portos, desapareceram, e é uma tendência também na zona sul, mas tu tens alguns espaços que se expressam estesVer-o-Pesinhos.

Icoaraci, por exemplo, tem uma feira muito importante, que chega o peixe, mas que também é muito precária, mas que é a mesma relação que Ver-o-Peso tem, só não tem a arquitetura do Ver-o-Peso. Depois, já nesta relação om a floresta, com outra temática, que é a temática do artesanato, tens o Paracuri, ali em Icoaraci, que é o bairro artesanal, onde moram os artesãos que fabricam a cerâmica marajoara.

Eu acho inclusive que o Paracuri é uma das coisas mais belas que nós temos, e poucas pessoas conhecem, tem um grupo de pesquisadores e professores da Alemanha que todo ano vem aqui pra Amazônia e trazem os alunos, e nós fazemos palestras, seminários, e têm alguns lugares que eu costumo levá-los, para além os pontos turísticos, claro Ver-o-Peso e a Feira do Açaí, o porto do Açaí, uma favela que fica à beira do rio que a Vila da Barca e o Paracuri.

O Paracuri é interessante porque passa o igarapé dentro do bairro, que está sendo descaracterizado também completamente porque o saneamento está retificando o igarapé, tornando em canais, e os barcos chegam, pequenas canoas chegam com argila que é a matéria prima da cerâmica, eles desembarcam ali em trapiches, pequenos trapiches precários no interior do bairro, e aí, saem as argilas dali e vão paras olarias, pros espaços onde eles produzem a olaria, outra coisa maravilhosa é ver essa produção, como funciona essa produção e a vida dessas pessoas que é muito precária. 
E é isso que causa impacto pros alemães, eu pergunto quanto vocês compram uma cerâmica destas na Alemanha, eles colocam um preço assim altíssimo, quando eles vêm o quanto é o produto ali, e a precariedade da vida do artesão, é o esquema de circulação que é altamente de exploração, e a vida precária que tem o bairro, então, o bairro também tem essa relação, veja, é uma relação com o rio, porque a argila vem com o rio, e com a floresta porque toda a cultura da cerâmica é uma cultura majorara, dos ancestrais indígenas marajoaras, e de com a cultura ribeirinha que chegou e se implantou ali na cidade, e grande parte dos artesãos é de marajoara, vem da ilha do Marajó, a tradição vem de lá, então é um bairro tem muitas pessoas que vieram do arquipélago do Marajó que está morando ali.

Então veja, quando se fala o Ver-o-Peso, eu não consigo ver só o Ver-o-Peso, não é só o Ver-o-Peso em si, não é só a área central e o patrimônio arquitetônico, o mais importante está espalhado pela cidade, e está desparecendo, isso que é o grande problema, está aniquilando, primeiro porque não há um processo de reprodução social que é assimilado pelas novas gerações, segundo não existe uma valorização cultural disso por parte das políticas urbanas.

Lá no Pacuri até tem uma escola de artes e ofícios que ensina os filhos dos artesãos a aprender a arte marajoara e se interessar a arte marajoara, mas é muito pouco, então, o Pacuri deveria ser um bairro de referência, para o Brasil eu diria, pela importância que ele tem, porque marajoara é uma cultura indígena, da floresta, do rio, do interior da Amazônia que é trazido para a cidade, e isso está presente no Ver-o-Peso no seu artesanato, nos valores, nos costumes, e que está ali, Ver-o-Peso expressa isso, mas ele é apenas uma das expressões. Quando eu acho que pensam no Ver-o-Peso pensam muito como um espaço muito restrito, e ele é síntese de uma cidade, e ele é muito mais do que isso do que a área central, do complexo do Ver-o-Peso.

Claro, ele tem que ser reconhecido, valorizado, classificado, porque ele expressa a cultura de uma cidade que tem desaparecido, que não pode ficar só nisso, muito pelo contrário, que tem que ganhar expressão para toda uma cidade.

Maísa Fonseca: Em relação a classificação recente do Rio de Janeiro como patrimônio mundial, o conceito de patrimônio estava muito mais ancorado no conceito novo do IPHAN de Chancela Cultural, eles perceberam que se tratava de uma rede.

Prof. Saint-Clair Cordeiro da Trindade Júnior: O Rio conseguiu isso porque ele fez uma leitura maior do que a paisagem cultural e da cidade, e essa leitura do Ver-o-Peso é reduz muito, é contrário do Rio de Janeiro, porque o Rio ampliou a leitura de paisagem.

Mas por outro lado é uma faca de dois gumes, porque quando você vai ver esses espaços que dialogam com a floresta e com rio, eles não têm o cuidado que deveriam ter para ser reconhecidos 
como patrimônio, mas aí está o perigo, mas ao mesmo tempo que aí está o perigo, aí está a riqueza que seria a patrimonialização.

Anterior a essas políticas deveria haver algumas políticas internas de valorização desses espaços, por exemplo, agora que está se pensando em Belém como cidade criativa, como polo gastronômico. Inclusive saiu uma reportagem da Carta Capital que eu conversei com a Brenda Takeda, você precisa conversar com a Brenda Takeda, ela é uma aluna de doutorado, ela se interessa muito por estas coisas e tem feito muitas reportagens sobre isso, ela está estudando o polo gastronômico, ela veio conversar comigo sobre o que eu pensava sobre o polo gastronômico, e é a mesma leitura que eu estou fazendo contigo agora eu estava fazendo para aquele momento que se aplica, nós temos várias manifestações gastronômicas por cidade, riquíssima, e quando se pensa no polo gastronômico se volta novamente para vitrine centro histórico, que deve fazer parte, mas não só, inclusive desestruturando o museu que ali existia para colocar um espaço de apoio ao polo, ou seja, um a coisa completamente incabível, não está dando mais a leitura, não está dando mais sentido, vamos criar outro, uma nova imagem para a cidade que possa ser atrativa descaracterizando o antigo, é ruim o projeto como inclusão social da Feliz Lusitânia, é muito precária porque não tem inclusão social ali, mas é uma conquista um espaço cultural como um museu, isso eu não tenho dúvida, se o projeto não é completo, ele não é perfeito, tem coisas que não dá para se descaracterizar em função de se criar outro mote de atratividade para a cidade.

Então, eu queria colocar nessa entrevista a mesma coisa, há vários polos pela cidade que podem ser pensados como elementos, a ideia de polo gastronômico já existe e ele é espontâneo, não precisa se criar nada, são necessárias políticas que reconheçam a invisibilidade dessa nossa gastronomia, mas que reconheçam não para vender para o turista, inclusive tinha uma aluna que fez um trabalho de doutorado faz uma análise sobre isso, o consumo do açaí na cidade e como ele se descaracteriza em função da globalização, ela faz uma análise da região metropolitana toda, como determinados espaços perdem essa tradição do consumo ou mudam essa tradição do consumo a partir do momento em que o açaí se globaliza.

Por toda a cidade nós temos várias referências gastronômicas, é a tapioquinha lá no Mosqueiro, são as sopas da Cremação, eu já morei na Cremação e eu adorava tomar sopa na Cremação depois das farras da madrugada, todo mundo sabe que lá tem as sopas especiais lá que são vendidas, o mingau do Ver-o-Peso, as bancas de tacacá, as bandeirinhas de açaí, principalmente, no bairro do jurunas, porque os bairros centrais já perderam isso, um dia minha cunhada que é mineira passando pelo bairro me perguntou o que é isso tudo vermelhinho, tive que explicar isso para ela que tu não vês mais isso lá no nosso bairro, eu moro no Marco, porque lá não tem a cultura de tomar todo o dia, como eu quando morava no juruna tomava açaí todo dia de manhã e à noite, faz parte da dieta alimentar, do cotidiano. 
Onde aparece o Jurunas com esta questão do consumo, é o bairro mais representativo do consumo do açaí na cidade, onde é que aparece? Não aparece nesse polo gastronômico.

Onde é que aparece, por exemplo, os restaurantes regionais de Icoaraci, que já é um restaurante maior voltado para a classe média, de qualquer maneira é interessante pensar? Tá fora, são espaços fora do centro da cidade, e essas feiras todas que nós temos, no marco, a, a feira do Guamá, tudo isso são polos gastronômicos espontâneos, criativos, né.. cidade criativa, são criativos porque são estratégias de sobrevivência da população, porque é que não se pensam políticas que possam pensar, apoiar e visibilizar essas coisas, aí volta-se a atenção para uma rua da gastronomia que se vai criar, um corredor gastronômico, se cria toda uma política para uma classe média e empresários já estabelecidos.

Ali no Mercado Bolonha se instalou um dos caras mais conhecidos da cidade, o Mecias, com o seu boteco no meio dos feirantes, todo chique, num preço horroroso, descaracterizando nossos produtos, na verdade, porque eles criam umas coisas, eu não sou contra que se crie isso, mas não é a nossa identidade, não é o nosso dia a dia, não é o nosso cotidiano gastronômico.

Nosso cotidiano gastronômico é muito mais parecido com o dos portugueses, dos africanos, dos indígenas que não á a gastronomia sofisticada, é uma gastronomia é simples, mas criativa porque ela usa produtos que estão à disposição, é como a comida dos africanos, a comida dos indígenas, é gostoso pela simplicidade e pela quantidade, também é isso, né, a gente come muito, não é aquela coisa que os chefes fazem, aquelas porções, não, as nossas mesas são enormes, com vários produtos com muita quantidade de comida, essa é a nossa identidade. Aí vem toda uma gastronomia sofisticada, que é gostosa também, eu consumo, mas eu prefiro o meu peixe com açaí do cotidiano, na forma como as nossas, que eles chamam de boieiras, cozinheiras que eles apelidaram as mulheres de boieiras, é comadre, é tia, é freguesa, é como nós chamamos elas, mas quando chegaram os chefes chamaram de boieiras, eles fazem uma parceria entre os chefes e as boieiras, e aí eles fazem uma parceria com as boieiras, e dizem que eles ensinam as boieiras e eles ensinam as boieiras, eu não sei até onde isso é verdade, mas tem que ter isso também, acho que faz parte isso, mas isso é uma dimensão, mas não é a nossa dimensão cotidiana. Então o polo gastronômico é a na mesma ideia, se coloca uma vitrine para o centro da cidade, se concentram as coisas ali.

No caso do Ver-o-Peso, é até interessante, porque é até um potencial mesmo grande, é o maior potencial realmente da nossa cultura, tudo bem, está certo, mas existem outros, a gente precisa descentralizar essas políticas, e fazer com que as pessoas conheçam a cidade, e vivam a nossa cidade, porque elas não vivem.

Então se voltou a atenção para esse centro histórico, que se tornou uma vitrine da cidade, e acha que tudo tem que ser feito ali e a cidade ficou vazia de políticas culturais, de preservação de 
preservação patrimonial, que existem, mas estão descobertos, não estão resguardadas, porque as políticas não se voltam para eles.

Eu penso que essa coisa da patrimonialização ela tem que olhar a cidade, por mais que você selecione um ou outro espaço como representativo, mas não pode se concentrar na área central, até porque a representatividade destes espaços que se quer transformar em patrimônio está em todos os cantos da cidade, é preciso fazer uma cartografia deste patrimônio de fato.

Mas são espaços importantes que tem dinâmicas semelhantes como Ver-o-Peso e merecem, merecem um mercado como Ver-o-Peso, claro que não será um mercado como Ver-o-Peso, mas pensar numa arquitetura, os arquitetos deveriam pensar qual a melhor forma que nós temos para acolher este conteúdo do que eu estou chamando da relação da cidade- rio, relação cidade-floresta Eu sei que lá no porto do açaí os próprios trabalhadores do porto, os feirantes, eles fizeram um croqui, porque veio o estado com uma política lá de infraestrutura que não atendia muito ao que eles queriam, então eles têm lá um desenho arquitetônico, eles fizeram, deve ter pegado a ajuda de alguém, para dizer o que eles queriam o que eles precisavam, claro a ajuda de um arquiteto, engenheiro, um bom designer para pensar essa demanda que está na vida cotidiana dessas pessoas.

Esse olhar que precisa ser colocado, e talvez na sua tese você possas chamar um pouco a atenção para isso, acho importante, são bem-vindas as ideias de classificação de patrimônio no tombo da UNESCO, mas que se amplie essa ideia do que é patrimônio, com um olhar mais nosso e menos de primeiro mundo, até porque, as cidades que eu conheço que são patrimônio da humanidade que eu conheço, elas se tornaram muito iguais, porque elas tomam como referência aquelas que foram reconhecidas como patrimônio e vem as políticas culturais e enquadram.

Eu fiz estudo sobre requalificação urbana na Europa para entender melhor o que estava acontecendo aqui, porque tudo era copiado de lá, então eu fiz um Pós-doc na França, e eu visitei várias cidades, tinha um momento que eu dizia que não precisava mais visitar cidades, parecia que eu já conhecia tudo igual, tudo bem, elas têm uma relação história que é muito igual, talvez os centros sejam muito iguais, mas começam a se tornar muito repetitivas, parece uma padronização, as políticas. Existe todo um roteiro da União Europeia que diz como devem se comportar se adequar, para entrarem como cidades que possam demandar recursos desses órgãos, e que se choca com o conceito de cultural e diversidade

E Belém tem uma coisa assim, que eu acho singular, até mais que Manaus. Eu diria queManaus é menos uma cidade da floresta do que Belém, porque Manaus foi concebida muito em cima da ideia de zona franca, polo industrial, zona de livre comércio, e isso padronizou muito a cidade, tornou a cidade muito moderna, muito globalizada, muito ligada aos circuitos globais, claro que tem os portos, as feiras, mas eu acho que Belém interage muito mais, traz muito mais para dentro de si, a floresta, a cultura da floresta esses valores do interior da Amazônia, ela é singular por isso. Tu não vês isso nas 
capitais nordestinas, por exemplo, a relação com o mar é mais forte, e o nosso a relação com o rio. Tu vês isso em Santarém, Belém, Cametá, um pouco em Manaus, um pouco em Rio Branco, menos em Boa Vista mas vê um pouco, Porto velho também, Macapá tem uma forte relação com a floresta e com o rio.

O mote da patrimonialização, no nosso caso, deveria ser a relação metrópole-floresta, metrópole-rio, essa é a nossa identidade maior, e o Ver-o-Peso expressa bem como síntese disso, mas não é só o Ver-o-Peso, existem vários espaços que expressam muito bem isso. E aí poderia entrar o Paracurí, poderia entrar os portos e trapiches todos da cidade, agora, é claro, antes disso é preciso que a prefeitura e o estado em vez de criarem polos gastronômicos, deveriam criar políticas para preservar estes espaços, que estão descobertos do ponto de vista das políticas urbanas, porque eu acho que tem algo anterior, a cultura está viva, ela resiste, o patrimônio imaterial e material também, porque as pessoas estão lá, as funções estão lá. Mas faltam formas arquitetônicas espaciais urbanas que traduzam isso, essa riqueza desses conteúdos e isso não está colocado.

Seria interessante, você conhecer esses portos, eles são muito precários, mas tu vais de manhã e vês as frutas chegando, os trabalhadores, os barcos, a população vindo a cidade comprar as coisas, levando coisas para a floresta, trazendo coisas da floresta, um dia que tu pudesses tirar para conhecer todos esses portos até lá, na beira na Feira-Açaí.

Maísa Fonseca: Mas se esse processo fosse ampliado e se ele fosse mais articulado ao contexto do processo de patrimonialização da UNESCO, será que essa diversidade não seria perdida?

Prof. Saint-Clair Cordeiro da Trindade Júnior: Eu também penso que qualquer discussão sobre patrimônio tem que também sugerir um questionamento do que se concebe como patrimônio mundial. Porque o patrimônio mundial, na verdade, ele toma como referência algumas realidades, e não pensa a diversidade do patrimônio, por exemplo, o que caracteriza Belém é justamente este diferencial, que não se reproduz de maneira igual em outras cidades, mas esse diferencial que está colocado num contexto regional que é a Amazônia, Belém traduz muito o que é a Amazônia, mas as políticas de valorização desse patrimônio, elas vão de encontro com o rio, e não ao encontro, mas de encontro desse potencial.

Por exemplo, quando se fala "vamos resgatar a relação da cidade com o rio", isso eu tenho colocado muito nos meus artigos, a gente tem falado sobre a diferença entre cidade ribeirinha, a cidade ribeirinha ela tem essa característica de uma relação multidimensional com o rio, o rio ele é paisagem contemplativa, mas ele é espaço que é um recurso, você tem a água, você tem o peixe, ele é um espaço onde as pessoas usam para coisas domésticas, lavar roupa, lavar louça, depois ele é um espaço também um espaço de representações e histórias, de mitos, o mito da cobra grande, do boto, etc.. está presente nesse espaço. 
Então a cidade ribeirinha ela é multidimensional na sua relação com o rio, ela não é apenas contemplação, quando se resgata o rio numa cidade metropolitana como Belém, o que se pensa, normalmente, é o uso contemplativo, ou quando se usa pro transporte é um transporte mais para efeito turístico, ou seja, das múltiplas dimensões do rio, de dez funções que o rio tem para cidade ribeirinha no interior da Amazônia, que também existe aqui em Belém em determinados fragmentos, você reduz a duas funções o rio, ou seja, de cidade ribeirinha ela se torna meramente uma cidade beira rio, que contempla, que olha o rio apenas, isso não é uma cidade ribeirinha, isso é um simulacro de cidade ribeirinha. Então, a cidade ribeirinha ela tem que ser resgatada nessas múltiplas dimensões, o rio é apenas um elemento que vai compor o paisagismo, ele é paisagem, mas não é apenas paisagismo, eu diria que mais do que paisagismo ele é espaço em que se vive, espaço em que se interage. Então, você pensa num discurso de direito a cidade, de direito ao espaço, mas quando muito que você oferece é o direito a contemplar a paisagem.

É o que o Lefréve chamaria de um pseudo-direito a cidade, é um falso direito a cidade, porque você reduz a dimensão do espaço a paisagem, da paisagem ao paisagismo, e você vê apenas o rio como um elemento contemplativo, você não interage, você não usa o rio, você apenas vê e contempla o rio, o que eu tenho chamado de cidade beira rio. Então, Belém ao longo do tempo ela tem se tornado com estes projetos que dizem resgatar o rio, ela tem se tornado uma cidade cada vez mais beira rio, e cada vez menos ribeirinha. É claro que estas coisas não são dicotômicas, tipos ideais, você vai encontrar cidades ribeirinhas resistindo, em vários pontos da cidade, mas a tendência é a aniquilar, é reduzir esses espaços, e as políticas públicas de patrimonialização, principalmente, caminham neste sentido, de padronizar, de standartizar as cidades.

Belém se coloca assim, e as cidades médias vão a reboque disso, todas vão querendo ter seus waterfront, as orlas padronizadas, e aí se esquecem da dimensão da vida que estas orlas têm, do ponto de vista da vida cotidiana. É tendencioso, às vezes, se questiona se é melhor com estas políticas ou sem estas políticas, na verdade, elas são bem-vindas, mas tem que se repensar,

A população tem que ser protagonista ao se propor o que realmente se quer preservar, e nós, pessoas que estudam que problematizam isso, também temos que estar, que desenvolver um papel de protagonistas nesta discussão, não só porque nos esquecem, não querem nos ouvir, mas também porque ficamos muito nos nossos artigos, nas nossas pesquisas, e esquece de propor políticas mais de extensão que tenha mais a ver com a própria gestão propriamente dita.

Maísa Fonseca: Mas numa abordagem moderna de patrimônio, a classificação de patrimônio mundial é um tanto reduzida, em sua abordagem em relação ao patrimônio material e imaterial. Amanhã em minha conversa com a Maria Dorotea tentarei compreender um pouco mais sobre a questão das relações entre estes patrimônios, que constam no documento de intenção de candidatura. 
Prof. Saint-Clair Cordeiro da Trindade Júnior:ADorotea é importantíssima nesse processo, ela tem uma boa visão de patrimônio, ela abre a discussão, até para democratizar a discussão sobre patrimônio, ela tem feito muito isso.

Outra pessoa também é aCybelle Salvador Miranda, ela discute patrimônio e ela fez trabalho em Coimbra, seria interessante conversar com ela, ela é da arquitetura, não sei se ela está aqui, da última vez que ela postou algo ela estava em Coimbra, acho que era assim missão de pouco tempo, acho que ela já passou mais tempo lá, num pós-doutorado.

Maísa Fonseca: Seria interessante conversar e saber um ponto de vista especifica sobre Coimbra, pois embora haja muitas diferenças, também há algumas similaridades no processo que eu gostaria de aprofundar minhas reflexões, por exemplo, durante o processo de classificação de Coimbra, diante de um aconselhamento do ICOMOS eles alteraram o objeto patrimonial e o discurso em relação ao patrimônio, o que parece ter acontecido também aqui em Belém.

Prof. Saint-Clair Cordeiro da Trindade Júnior: A construção do discurso do Rio de Janeiro é muito importante, é muito nesse sentido, eles construíram um discurso, o patrimônio é um discurso, você discursa sobre o patrimônio, independente de qualquer coisa ele existe, você constrói uma retórica sobre o patrimônio, para se dizer esse é o patrimônio. Uma sede de uma escola de samba, a estação ferroviária, a linha ferroviária, uma das primeiras do país, não é só a relação montanha, praia e centro histórico, é muito mais do que isso, mas se soube construir.

Eu acho que talvez no caso de Belém, pela peculiaridade da floresta, do rio nem tanto, porque Buenos Aires usou também como discurso o rio, mas o nosso caso seria o rio e a floresta, acho que estes elementos seriam fortíssimos para sustentar um discurso, que não é o Ver-o-Peso, o complexo do Ver-o-Peso, é muito mais do que isso, o Ver-o-Peso entra como uma expressão da relação cidade floresta, uma expressão, mas a patrimonialização é como a cidade consegue trazer a cultura da floresta para dentro de si, e consegue a partir dela preservar a floresta. Porque todo ciclo extrativista é respeitado, o momento do açaí, da pupunha, cada época do ano que você consegue trazer para a cidade por meio dos produtos que vão ser consumidos sem criar aquela subversão do ciclo da natureza, então de certa maneira há um respeito a esse tempo da natureza, a floresta. Os mitos também, são uma coisa fabulosa, como, de certo modo, é possível através dos mitos também construir um pouco de respeito a natureza.

Maísa Fonseca: Essas dimensões constam nos documentos de candidatura, mas não há definições em relação a como estas abordagens ganharão forma e espaço. Eu pretendo tentar conversar com algumas pessoas da feira, e talvez com as erveiras. É fácil conversar com as erveiras?

Prof. Saint-Clair Cordeiro da Trindade Júnior: As erveiras traduzem isso muito bem, algumas são cooptadas, eu sei que a cheirosinha é a mais famosa, minha erveira lá é a tia Coló, a tia Coló é a 
menos famosa, a cheirosinha tinha um contrato com o Jader de fazer comercial só com a NBA. A cheirosinha tem um currículo, e diz lá "contrato exclusive NBA", quando tu vais lá, se tu pedires ela te mostra, e eu sei que agora eu sei que ela está dando entrevista para o Liberal, acho que ela era paga pela NBA, e o próprio jeito dela falar, ela já se preparou para as entrevistas e para aparecer na mídia, mas é bom conversar para além dessas, a Tia Coló também é famosa, mas ela é menos midiática, ela faz os preparos.

Maísa Fonseca: Há em relação às políticas culturais e aos financiamentos, sejam eles públicos ou privados, nestas áreas algumas particularidades neste processo, que em alguma medida a minha pesquisa me trouxe aproximações à teoria de Carlos Vainer em relação à existência de espaços solváveis. Segundo seus artigos, essas políticas são muito pontuais e correspondem a ações desarticuladas entre si, e que não possuem uma visão total da cidade, gostaria que o professor falasse um pouco a este respeito, em relação à área do Centro Histórico, principalmente, concentrado na área do entorno imediato do Complexo Ver-o-Peso.

Prof. Saint-Clair Cordeiro da Trindade Júnior: Essas políticas de requalificação, a primeira ideia que se teve foi na década de 80 , que hoje é o PSDB, mas são as primeiras pessoas que estavam na prefeitura naquele momento, a primeira ideia de volta ao centro foi nessa década de 80 com uma reforma do Ver-o-Peso, e depois houve uma requalificação da Feira do Açaí e se abriu o que eles passaram a chamar, a partir daquele momento, da primeira rua de Belém, e isso eu digo que é uma invenção, porque historicamente eles não comprovaram isso, a primeira rua de Belém sempre foi a rua do Norte, a Siqueira Mendes. Se a gente for entender um pouco a história você também vai achar que é, porque o forte é um elemento que deu sentido para a cidade e depois a cidade cresceu a partir do forte.

Ao lado do Forte, havia algumas casas na ladeira e ela estava totalmente obstruída, na década de 80 quando fizeram essa requalificação do Ver-o-Peso e da Feira do Açaí e tudo mais aí, abriram essa rua, inclusive o atual secretário de cultura começou a dizer que aquela foi a primeira rua de Belém, mas em documentos, em nada foi comprovado que aquela rua foi a primeira de Belém, e talvez nem seja, pela estrutura das casas.

Então, a partir daí se começou aquilo que já estava começando na Europa, que a ideia era trazer a classe média e algumas pessoas que tivessem algum tipo de negócio, comércio, de restaurante voltado para a classe média pudesse se instalarem aí, houve todo tipo de subsídios para essas pessoas se instalarem e se instalou num primeiro momento, de fato, então, você tinha restaurante e bares inclusive nessa ladeira.

E se fez toda uma programação de final de semana Pôr-do-som, colocava música clássica, teatro ao ar-livre, feira de artesanato e a classe média ia pra ali para escutar música clássica, assistir o teatro a céu aberto, ver os artesãos, para frequentar os bares e restaurantes da Ladeira do Castelo. 
No Ver-o-Peso se requalificou o Solário da beira, se tornou uma espécie de espaço de exposição e se implantou o que hoje é uma espécie de posto da polícia militar, só que naquele momento se chamou café chique que era uma espécie de café chique para a classe média, no meio da feira, isso durou mais ou menos um ano e meio essa ideia, essa vida, essa animação desse espaço, e logo em seguida o café começou a ser frequentada pelas prostitutas, e lógico, e a Feira do Açaí começou a ser frequentada pelas prostitutas, pelos trombadinhas, pelos malandros que sempre frequentavam ali, e em função disso começou a se tornar perigoso, e a classe média recuou, ou seja, a territorialidade imposta foi recuando gradativamente, e isso repercutiu nos bares e restaurantes que se instalaram também ali e que começaram a fechar gradativamente, política de moradia não tinha nenhuma, era só esse sentido mesmo de uma gentrificação apontada para o consumo, vamos dizer assim, e aí entra em decadência novamente.

Quando chega o início dos anos 2000, aí vem essa política novamente de requalificação, com os mesmos personagens que estavam lá na gestão na década de 80 , os mesmos voltaram e aí já trouxeram novidades e aí vem Feliz Lusitânia, vem Estação das Docas, e o interessante desse momento é que ao lado de uma política estadual de requalificação aparecia uma política municipal de requalificação com uma proposta de inclusão social, completamente diferenciada, de diálogo com as pessoas, de bolsa escola, de famílias de bolsa escola, e com a ideia pegar essas famílias e trabalhar a geração de renda na área central.

E aí começa a ter um efeito demonstração muito grande das políticas municipais do PT, e as políticas estaduais do PSDB, e esse enfrentamento foi tão forte que as intervenções na área central começam a pipocar, tanto por da prefeitura quanto da parte do estado, e assim, algumas políticas copiadas inclusive do modelo francês, vieram pessoas ligadas as políticas urbanas da França aqui para dialogar com esses planejadores, com estes técnicos daqui, tinha uma ideia muito interessante que era a mixte aquela ideia da mixte colocada nas políticas europeias, com habitação e transporte, se pegar a ideia da Lusitânia, ele é completo, ele tem a questão do transporte, da habitação social, da geração de trabalho e renda e o patrimônio imaterial, tá colocado lá.

Na hora em que se coloca isso em prática se esquece a política habitacional, se esquece o trabalho e renda, e se trabalha apenas a questão da paisagem patrimonial, e aí o investimento, de modo diferente dos modelos de primeiro mundo não é a parceria público e privado neste momento, é a parceria público-público, único e exclusivamente, então, o investimento é do estado, no momento de ocupar este espaço, aí entra o que poderia se chamar de parceria. Então, por exemplo, a organização Pará 2000, ela é uma organização que é de pessoas do estado e do setor privado que gerenciam esses espaços requalificados. 
Então, é muito fácil fazer uma requalificação assim, o Estado não tem dinheiro, mas mesmo assim ele banca e depois ele entrega para a gestão da parceria público privado. Então, quem irá gerenciar esses espaços? Então você vê a sorveteria Cairu, não é uma grande empresa, mas é uma empresa consolidada no mercado local, as grandes cadeias de restaurantes, de bares e de serviços, e de turismo, que vão passar a ocupar, então, é uma política voltada para a geração de trabalho e renda em uma perspectiva bastante elitista. De modo diferente do que vinha acontecendo até então na prefeitura que eram pessoas que provinham do bolsa família, do bolsa escola, meninos de rua que era trabalhados num projeto que a prefeitura tinha relacionada a formação da escola circo, então, se traziam essas pessoas e se organizavam em cooperativas, através da economia solidaria, só que o PT ficou oito anos só no governo, passado isso o PSDB foi hegemonia, passou a ser hegemonia.

Então, este enfrentamento de políticas que se tinha num primeiro momento, num segundo momento deixou de ter, e os espaços, de certa maneira são espaços que são requalificados e entregados a iniciativa privada, é uma política que eu nem sei se tem a ver com a lógica neoliberal, de planejamento estratégico, gestão estratégica de cidade, é uma política bem distorcida inclusive disso, quando você pensa numa economia neoliberal, gestão estratégica, a parceria pública privada é colocada desde o início, inclusive com investimento no processo de requalificação o que não acontece aqui, então, é estado bem feitor que entrega os espaços requalificados numa lógica de parceria de público privada muito distorcida eu diria, e quando vês estes espaços, eles têm pouco de espaço públicos, eles são espaços de classe média, não são espaços públicos, quando a população pobre visita estes espaços ela visita de maneira muito passageira, é um passante, não usa de fato os equipamentos desse espaço, não usa os restaurantes, não usa os teatros, porque não existe uma política de incentivo a isso. A população só pode visitar gratuitamente os museus de terça-feira, quem é que vai deixar de ir para o trabalho para visitar museu numa terça-feira? Então, é uma política muito seletiva, e essa razão do investimento no centro histórico da cidade, de requalificação do centro histórico da cidade, tem muito a ver com a estrutura urbana que nós temos o centro histórico não se renova em termos de moradia, não existe praticamente um processo de gentrificação propriamente dito no centro histórico, mas se tu fores olhar o valor dos imóveis do centro, eles não alteraram muito ao longo dos anos no centro histórico, mas se tu saíres 50 metros do centro histórico, tu vais ver uma explosão imobiliária no entorno que tem tudo a ver com a política de requalificação do centro histórico, porque esses espaços requalificados estão próximos aos bairros de classe média de Belém que formam uma espécie de cinturão em torno do centro histórico.

Então, a classe média em Belém não quer morar no centro histórico, como na Europa, ele é um centro de visitas, de serviços, cultural, mas ela quer morar próximo ao Centro Histórico para que ela possa ir a Estação, ela possa usar museu, os equipamentos culturais ali próximo, para o consumo, é 
uma cultura consumista que é colocada ali, eles não vão tanto ao teatro, eles vão mais aos restaurantes, mais aos bares, as casas que são mais voltadas para a questão do consumo de uma classe média. Então é uma política que reforça um processo de segregação da estrutura metropolitana.

Maísa Fonseca: Existe algum trabalho que evidencia este processo de segregação da estrutura metropolitana?

Prof. Saint-Clair Cordeiro da Trindade Júnior: O IBGE tem isso, pela renda média da população distribuída por bairro, tu consegues ver onde é que estão os bairros, a concentração é neste cinturão entorno do centro histórico, com algumas manchas para fora que começam a aparecer, mas a grande concentração é ainda entorno, neste cinturão.

Existem trabalhos que mostram que não há uma valorização do solo na área central, que é o trabalho da Helena Lúcia Zagury Tourinho e do Marco Aurélio Arbage Lobo, eles são professores da UNAMA, e o Marco Aurélio é inclusive do IBGE, eles vão mostrar que não existe uma valorização do solo na área central, mas existe um limite neste trabalho dela, é interessante, mas existe um limite, porque ela faz o estudo de dois bairros, Cidade Velha e Campina, que são bairros do centro histórico, onde estão os equipamentos requalificados, ela não estende o trabalho para o entorno, se ela estendesse o trabalho para um bairro que fosse o Umarizal, aí ela conseguiria perceber o quanto existe sim uma gentrificação, que é diferenciada, não é uma gentrificação igual da Europa, em que a gentrificação acontece nos centros históricos requalificados, no nosso caso não, o centro histórico requalificado não se gentrifica para o efeito de moradia, mas ele se gentrifica para efeito do consumo cultural poderia chamar isso gentrificação do consumo ou gentrificação cultural, e aí os bairros do entorno sim, eles se gentrificam.

Na minha tese de doutorado eu coloco um pouco essa tendência já, mas eu não analiso a questão de requalificação urbana, mas eu fiquei tentado a fazer um artigo porque eu analisei os processos de requalificação, mas eu não analisei essa relação com as classes médias do ponto de vista dos dados, e quando eu assisti ao trabalho da Helena, que eu polemizei um pouco com ela,uma polêmica pessoal é intelectual, eu colocava isso, eu disse "Helena, é interessante o teu trabalho, mas ele é limitado, você está trabalhando com bairros que não fazem a leitura da cidade, fazem a leitura apenas de uma fração da cidade", e o que acontece no centro histórico repercute na cidade como um todo, eu diria muito mais, repercute na metrópole como um todo. A lógica da segregação ela acompanha o que está acontecendo nesses espaços requalificados, então se você for plotar onde estão os espaços requalificados, eles estão no centro histórico e nesse entorno imediato, e logo em seguida vêm os bairros de classe média que não estão no centro histórico, é uma cidade "Umanizada", uns edifícios de 40 andares, aquele padrão de condomínio vertical com tudo dentro, com piscina, sauna, tudo no 
entorno, então você tem um espaço de moradia fechado, blindado, e você tem uma visita furtiva e pontual ao centro histórico, que não usa o centro histórico em sua plenitude, Polo Joalheiro, Estação das Docas, Feliz Lusitânia, etc.. Inclusive os bacanas de Belém casam suas filhas e seus filhos lá na Feliz Lusitânia, ali na Igreja chique, que é a Santo Alexandre, mas vão ali só para casar seus filhos, não conhecem, não visitam, porque é perigoso o centro histórico, então eles seguem como se fosse um túnel, né, camuflado, blindado, é aquele "eu vou de carro e tudo, e acesso as ruas mais seguras", chegam lá e usam esses espaços, saem e voltam para seus lares.

O centro histórico não é usado em sua plenitude, quem usa o centro histórico? É a população pobre, é o comércio, é a vida ribeirinha que chega através do centro histórico também, então, é um espaço cheio de contradições, de políticas e de contradições sociais. Eu fiquei tentado, depois que eu assisti à explanação da Helena a escrever alguma coisa pegando os dados de distribuição de renda, pegando onde cresceu a renda relacionando com os projetos de requalificação urbana.

Tem uma tese de doutorado da Valéria Greice Costa geógrafa do IBGE do Rio, e ela fez na FAUUSP, com a orientação da Suzana Pasternak, intitulada "Indicadores sociais espaciais no habitat de grandes cidades brasileiras, Belém e Rio de Janeira", em que ela faz essa discussão da renda, ela pegou os dados que ela trabalha com geoprocessamento, ela tenta entender um padrão de segregação.

Seria interessante olhar o trabalho da Raquel Ferreira, arquiteta, sobre o centro histórico.

E o trabalho da Soraia Costa, psicóloga, intitulada "põe tapioca, põe farinha d'água? " Em que ela seleciona mais ou menos uns dez bairros diferentes com padrões econômicos diferentes, desde a alta classe a popular, e ela seleciona alguns pontos representativos desses bairros de consumo do açaí, para mostrar como é que se dá o consumo desse açaí, se ele é mais tradicional, menos tradicional, ela trabalha uma relação entre psicologia, sociologia, e geografia, e ela fala das mudanças da gastronomia e do padrão dos bairros, e ela escolhe bairros representativos, e explica um pouco sobre estes bairros, inclusive um dos bairros que ela seleciona é o Ver-o-Peso. 


\section{ENTREVISTA 7}

Entrevista realizada no Café da Sol, na Av. Visconde de Souza Franco, 1122, na Doca - Bairro Reduto-, na cidade de Belém, às 11h no dia 25 de julho de 2016, com o Prof. Juliano Pamplona Ximenes Ponte

Essa entrevista foi realizada pelo interesse em compreender melhor as políticas públicas e instrumentos legais de proteção ao patrimônio cultural de Belém, principalmente voltados para a compreensão do processo de patrimonialização de Ver-o-Peso pela UNESCO, e em relação a atuação dos órgãos de proteção do patrimônio em instância municipal, estadual e federal na cidade.

O professor e pesquisador Juliano Ximenes foi convidado a participar da entrevista em razão de sua investigação, atual, sobre questões relacionadas a área de planejamento urbano e regional e a sua experiência na área de pesquisa histórica e urbanística para regulamentação de proposta técnica de habilitação do município de Belém junto ao programa MONUMENTA-BID, inventário nacional de bens imóveis e sítios urbanos tombados pelo IPHAN.

Muitas das perguntas ao entrevistado enfocaram nestes instrumentos urbanísticos e mecanismos de proteção ao conjunto do patrimônio e sua área de entorno na cidade de Belém, e na atuação dos órgãos de proteção ao patrimônio cultural.

Maísa Fonseca: Em razão do tema de minha tese que aborda o processo de patrimonialização pela UNESCO em Belém, e por meio dele, o processo de produção da cidade e a ressignificação cultural que este processo implica, e uma vez que este processo global incorpora diferentes escalas de proteção patrimonial dos conjuntos urbanos, e devido a sua experiência de trabalho e pesquisa anterior pelo IPHAN, gostaria de saber sua opinião sobre a atuação e relação dos órgãos de preservação atuantes em Belém, de diferentes instâncias, federal, estadual e municipal, principalmente em relação ao Centro Histórico e seu entorno.

Prof. Juliano Pamplona Ximenes Ponte: O Programa Monumenta em Belém foi muito simplória, uma proposta de edifícios, praticamente uma proposta de edifícios e praças,e a proposta no município de Belém começou estruturada por causa da articulação com governo do estado e as prefeituras de uma forma diferente da concepção dos órgãos de patrimônio, principalmente o IPHAN e a Fundação Cultural do Município de Belém (FUMBEL), tinha uma concepção diferente de patrimônio de sítio urbano, e o Departamento de Patrimônio Cultural da SECULT (DEPHAC) não, tinha uma concepção com edifícios, estava preocupado em ter dinheiro para restaurar os edifícios e as praças, porque 
estava muito mal escolado da proposta do Paulo Chaves, da Estação das Docas, e acabou vingando esta proposta, por causa do governo do estado, do PSDB, e da prefeitura.

E a proposta era de restaurar a Sé, o Mercado de Peixe, o Mercado de Carne, a praça da Sé, que era a proposta dos formulários, a proposta que os órgãos daqui, de Pará, Belém daqui fizeram para o [Programa] Monumenta. Mas a partir daí o IPHAN tinha começado, no início dos anos 2000, essa batalha para fazer o reconhecimento até então o Centro Histórico era tombado pelo município, inicialmente depois só pelo Estado, e a prefeitura obrigou os dois tombamentos, o IPHAN acompanhou, hoje em dia ele é protegido pelos três níveis como conjunto urbano. Como o setor é muito desaparelhado, não tem grana historicamente, ele acaba ficando ao sabor dos dinheiros que aparecem ou das promessas de dinheiro que aparecem. Tanto é que quando teve a possibilidade do PAC Cidades Históricas foi uma movimentação também em torno disso, tem muito disso essa sazonalidade, digamos assim, dos editais, dos recursos, dos programas e dos instrumentos que estão disponíveis.

Maísa Fonseca: Então ele tem um reconhecimento pelo Estado do Pará?

Prof. Juliano Pamplona Ximenes Ponte: Nos três níveis, ele é tombado pelo município, mas existe um protocolo administrativo, não sei dizer exatamente que ano, o governo do estado acompanha como eles chamam, ele reconhece o tombamento, cria uma dinâmica onde nos protocolos deles administrativamente, quando você vai fazer uma intervenção que tem algum porte no centro histórico, passa pelos três níveis de governo. O tombamento do conjunto urbano é do departamento de patrimônio histórico da fundação cultural do município de Belém, a FUMBEL, então ele é municipal, mas ele passa pelo balcão dos três órgãos, e o Estado, o departamento histórico cultural da Secretaria de Cultura do Governo do Estado do Pará (SECULT), o estado acompanha o tombamento do município e posteriormente o IPHAN conseguiu acompanhar também. Então, na verdade, existe uma proteção a um nível federal, um acompanhamento a nível Estadual e um tombamento num nível municipal.

Maísa Fonseca: Então é apenas um acompanhamento?

Prof. Juliano Pamplona Ximenes Ponte: No nível estadual, mas o IPHAN conseguiu colocar como sítio urbano tombado a nível federal, o centro histórico, então, o IPHAN tem uma certa ingerência, por assim dizer, fora os tombamentos individualizados, porque você tem esses tombamentos e dos entornos, por exemplo, Ver-o-Peso, Ver-o-Peso e Feira, Feira do Ver-o-Peso, Ladeira do Castelo, Feira do Açaí, o conjunto todo, os dois mercados, a feira toda e esses espaços, no tombamento anterior, e o seu entorno, o conjunto do Porto, que é um tombamento posterior, e o seu entorno esse tombamento do Porto era inicialmente do Estado, tem esses fragmentos que acabam tendo seis entornos específicos e tem uma certa influência no que hoje a gente chama de Centro Histórico como um todo, então há uma sobreposição. 
Maísa Fonseca: Há a definição destes entornos em uma cartografia?

Prof. Juliano Pamplona Ximenes Ponte: Tem uma lista de bens tombados da Secretaria de Cultura, isto costumava ficar na internet, acredito que ainda esteja, e do IPHAN no site do IPHAN, da FUMBEL acredito que não porque o site da prefeitura é muito ruim. Mas você deve conseguir lá, ou a gente consegue te colocar em contato com a Beth Almeida, que foi a diretora do departamento da FUMBEL e ela consegue te passar este contato.

Aqui acaba tendo uma situação talvez diferente um pouco de São Paulo porque há uma concentração muito grande de bens tombados na capital, você tem alguma coisa no baixo Amazonas, o IPHAN tem ampliado mais isso em termos regionais no Estado, mas ainda é muito concentrado na região metropolitana, você vai ver, a não fica, fica em Santa Isabel, mas é aqui na região metropolitana, tem o Educandário lá, muito concentrado aqui, isso é um problema, porque tu tens um patrimônio muito ameaçado fora daqui.

Maísa Fonseca: Sobre a poligonal delimitada pelo Plano Diretor no Centro Histórico, no anexo 8 ou 9, trata-se de uma área de outorga onerosa?

Prof. Juliano Pamplona Ximenes Ponte: Há a questão da outorga e do gabarito no entorno do Centro Histórico, por exemplo, quando acaba aqui na Avenida Assis de Vasconcelos, aqui a gente está na Doca, que corresponde a uma faixa de entorno do Centro Histórico, em que o nível de proteção é mais baixo, mas que é necessário observar o gabarito e os índices urbanos específicos, e também uma outorga também aqui incidente. $O$ problema desta outorga em Belém é que os vereadores fazem um monte de trambiques, então, historicamente esvaziam a outorga, há poucos exemplos efetivos de aplicação da outorga, de cobrança. Porque houve uma época em que os vereadores conseguiram colocar o coeficiente básico igual ao máximo, se não tem diferença entre o básico e o máximo que tu podes construir para cobrar a outorga, tu não podes cobrar a outorga, se não há um intervalo. Tu podes construir o que o exceda o básico, aqui todo mundo tem direito até o máximo, mas você só constrói esse excedente pagando, para compensar a verticalização maior. Se você esvazia o instrumento desta maneira não cobra, não acontece nada.

Depois houve um questionamento no município de que a outorga não era efetiva se não tivesse uma lei específica, o que era uma bobagem, o que não tem nada a ver, a outorga era prevista constitucionalmente, está prevista no plano diretor, ela era praticamente autoaplicável, só tem que dar alguns parâmetros, na época era 1,4 o básico, daí de 1,4 para cima, até 2, até 4 . Então esse excedente acima de 1,4 poderia ser outorgado. Mas em tese formalmente, não há outorga no Centro Histórico, atualmente, há exemplos muito pontuais de outorga fora do Centro Histórico, eles são aqui, nos bairros do Reduto, Umarizal, entre outros. 
Maísa Fonseca: O Plano Diretor possibilita a existência de uma franja de edifícios mais altos, de caráter residencial em sua maioria, em torno do Centro Histórico desde quando?

Prof. Juliano Pamplona Ximenes Ponte: A legislação urbanística em Belém é muito recente, o primeiro código de obras de Belém é de 1988. Então houve um período imenso de absoluta desregulação do mercado imobiliário, com o prefeito biônico durante a ditadura, não tinha legislação nenhuma. Você vai ter o código de obras em 1988, é um código de edificações, antes disso havia um código de postura de 1974, e como todo código de postura é a coisa mais caduca do mundo, não serve para nada, do meu ponto de vista não serve para nada, ele deveria cair em desuso. Ele vai fazer a vez de uma lei sanitária, e para isso existe as leis sanitárias, são muito melhores e mais específicas. Ele vai fazer uma coisa meio moralista, tipo como as pessoas devem se comportar no espaço público, não existe, ou então de dizer que o cara fazendo obra não pode jogar o lixo na calçada, sim, mas para isso existe legislação específica, ou seja, é um dispositivo que enfim...

A legislação é muito recente, por isso que você vê coisas além dos processos de corrupção que acontecem hoje, contemporaneamente, você vê, por exemplo, na verticalização muito exemplos distantes da legislação, porque ela é muito recente, você vai ver prédios relativamente altos aqui no Reduto, que embora seja o entorno do Centro Histórico os prédios são do início dos anos 90, são anteriores aos dos anos 80, são anteriores ao tombamento do Centro Histórico como conjunto.

Eles não são incoerentes se você pensar que a legislação urbanística é extremamente recente, e aqui em Belém como é uma capital muito isolada você tem um mercado imobiliário que não compete com outros, o que você vai ter próximo, São Luís e Macapá, para alguém que está investindo nisso, Belém tem uma infraestrutura razoável num pedaço muito pequeno da cidade, daqui da Cidade Velha até o bairro do Marco. O resto é muito inferior, muito pior a infraestrutura, você pode ter áreas mais arborizadas, mas a dificuldade de transporte público é muito maior, a qualificação do sistema de áreas e disponibilidade de equipamentos é pior. A infraestrutura da cidade é muito pequena, muito restrita e concentrada.

Como você não tem esses outros, são cidades próximas que tem um mercado imobiliário para o investidor que represente um parâmetro, de você poder investir na cidade vizinha, acabou historicamente potencializando todos os proprietários a terem preços exorbitantes.

É o que acontece aqui em Belém, é uma coisa a nível do delírio, mesmo antes desse aquecimento do [programa habitacional] "Minha Casa Minha Vida" ou dos grandes eventos, que fez o preço disparar nas capitais todas, Belém já era muito cara. Depois destes megaeventos você teve uma distorção maior ainda, mas até então você tinha preços aqui em Belém nas áreas nobres regulando com a zona sul carioca, que não faz menor sentido, você ter um apartamento num lugar que fica a duas quadras da praia, com metrô, e você ter o mesmo preço por metro quadrado aqui. 
Até então, até primeira metade dos anos 2000 era o que acontecia, tem esse problema, de uma dinâmica aqui que é muito forte, e ela é muito poderosa politicamente, mas como tem essa elite rentista e que tem um papel razoável, ela ajuda muito fortemente a moldar a cidade, tem essa questão aqui que é muito forte. Uma concentração imobiliária absurda, poucas famílias, tu vais ver a lista no cadastro imobiliário, algumas poucas famílias que concentram um parque imobiliário bem grande, proporcionalmente falando pelo tamanho da cidade, aí você pensa nestas distorções.

E aqui no centro histórico tem também uma sobrevivência destes empreendimentos comerciais ou populares, ou essas coisas ligadas a esse uso portuário do rio, que tem um discurso reiterado de conflito com as normas de preservação, um discurso muito conservador de negar a importância das normas de preservação, também por outro lado, uma postura historicamente muito autoritária dos órgãos de preservação que não ajudou muito ao longo do tempo porque, se comportavam de uma forma heroica, bastião da preservação do patrimônio e não tinham um trabalho de base junto ao morador, e aí não conseguia trazer para perto, a sensibilizar e brigar contra essa capital imobiliário e esses comerciantes que sempre foram muito fortes, e aí virou uma situação de fragilização do contexto muito grande.

Maísa Fonseca: Mas a voz popular, por meio de alguns atores do Ver-o-Peso, é bem articulada politicamente o suficiente para conseguir pausar alguns processos de intervenção na área?

Prof. Juliano Pamplona Ximenes Ponte: Tu deves ter acompanhado esse projeto problema absurdo do projeto do Governo do Estado e da Prefeitura, e esse projeto foi barrado. O Ver-o-Peso tem um histórico, de mobilizar de articular, uma certa de coesão, mas isso é uma coisa de Ver-o-Peso, você vai ter dois sindicatos estivadores e tal, mas você tem no Ver-o-Peso uma mobilização grande, que tem a ver eu acho, com a reforma do Edmilson Rodrigues quando foi prefeito fortaleceu esse ativismo de Ver-o-Peso, o Ver-o-Peso era muito tradicional o espaço mais importante da cidade, sempre foi atacado por estas gestões mais de elite.

O projeto que o PSDB tem com o Secretário de Cultura Paulo Chaves é para esvaziar o Ver-o-Peso totalmente, quer transformar numa espécie de mercado agrícola de Mercado de Montevideo (UY), num mercado desses de Barcelona, ele quer elitizar e limpar, tirar esses usos populares, transformar num espaço desta nova gastronomia, frios essa coisa toda, com os argumentos da logística, que não pode entrar carga no Ver-o-Peso, que você não deveria ter esses veículos pesados, isso tem sido insistentemente colocada no debate pelo governo do Estado e pelo Secretário da Cultura, uma ameaça constante que era mais o menos o que o prefeito queria com esse projeto absurdo.

Maísa Fonseca: E a chegada de produtos no Ver-o-Peso tem funcionado sempre nesse horário?

Prof. Juliano Pamplona Ximenes Ponte: Tem registro histórico desde meados do século XVII, logo depois da cidade ser fundada. O horário de sábado de manhã é interessante por causa da lógica da 
saída da cidade,aqueles caminhões geleiros, sobre o pescado especificamente você pode procurar a tese Jesus Luís Dias da Silva sobre a movimentação de pescado no Ver-o-Peso e nas feiras de Belém, ele fez uma tese de doutorado na antropologia da UFPA, o título do trabalho é algo como redes malhas, e ele fez um levantamento de quantas toneladas circulam, para onde vão, de onde vão, especificamente do pescado, não de frutas.

No sábado de manhã é o dia que tem uma movimentação proporcionalmente maior, existe uma combinação do sábado de manhã como um horário nobre de comercializar, de também poder escoar que num dia de semana seria muito mais complicado. Eles se programam para chegar ali entre $4 \mathrm{~h}$ ou 5h da manhã, ou mesmo até antes e fazerem a comercialização, mas é uma espécie de pacto que eles têm. Mas não sei te dizer se muito antes do transporte rodoviário se existia necessariamente também essa observação de horários, acredito que essa questão de manhã cedo há muito tempo ela é praticada, mesmo antes do carro.

Maísa Fonseca:E em termos de centralidade atualmente, é possível mapear a sua relação de centralidade?

Prof. Juliano Pamplona Ximenes Ponte: Como a região metropolitana toda é muito pobre, e Belém é muito pobre, essa área do centro da cidade é uma centralidade metropolitana muito forte, Ver-oPeso é uma centralidade regional muito grande como entreposto, por exemplo, teve coisa que a gente fez sobre este tema especificamente centralidade, a gente publicou um livro dentro da pesquisa com o observatório das metrópoles, aquele projeto com a UFRJ, e livro está de graça na internet si tu quiseres dar uma olhada tem alguns dados estatísticos sobre isso, e que inclusive apontam as centralidades mais metropolitanas.

Tu vais ter basicamente três centralidades: o centro de Belém, os bairros nobres de Belém, o centro histórico destes bairros nobres até mais ou menos o bairro do Marco; outro que é o centro de Ananindeua; e outro que é o centro de Castanhal, mas estes outros dois são muito inferiores em termos à densidade de capital instalado, número de empregos, e até da renda média da população, então, na verdade, a grande centralidade metropolitana é Belém e é o Centro Histórico tem um potencial muito grande, mas é essa mancha daqui o Centro Histórico até mais ou menos do bairro do Marco, que é o que a gente chama de primeira légua patrimonial, mas não ela toda, uma parte dela. Neste livro nosso tem inclusive uns mapas disso que acho que dá para aproveitar, lá tem uma discussão, uns dados sobre isso e uma cartografia e acho que é bem prático para apropriar rapidamente, dá para dizer com toda segurança que por causa dessa concentração, por causa estagnação dessa conduta relativa você não tem uma relação policêntrica, isso não existe, você vai ter sub sub centralidades na região, um shopping center, uma rede de supermercados e farmácias, uma rede de abastecimento do cotidiano, você não vai ter uma outra base de empregos, embora você tenha, por exemplo, um outro pequeno parque industrial de espécies em Benevides e em 
Ananindeua, você não necessariamente cria outra centralidade em vista do número de empregos, da densidade capital instalado, de infraestrutura instalada.

Maísa Fonseca: O setor censitário de Belém dos dados do IBGE invade uma parte do rio, haveria uma relação direta com a existência de palafitas?

Prof. Juliano Pamplona Ximenes Ponte: Use o setor inteiro no levantamento, é devido à planície de inundação, mesmo em áreas onde não tem palafitas ele considera manchas, a cartografia do município termina aqui e o setor censitário termina aqui. Aqui no centro você não tem palafitas, mas já na região do porto. Talvez a imagem que tenha sido usada ainda tivesse planícies de inundação, bancos de areia.

Maísa Fonseca: Por meio de meu levantamento de geoprocessamento e da criação de mapas, evidenciei algumas das relações das dinâmicas socioeconômicas da região do Centro Histórico e, principalmente, Ver-o-Peso com o resto da cidade, e numa conversa anterior com o Prof. Saint Clair ele expôs sua opinião sobre essas dinâmicas e das articulações do patrimônio com outras áreas da cidade, e de que de certa forma há a consolidação de um cinturão em torno do Centro Histórico caracterizado por uma população principalmente de classe média, e que de certa forma ela usufrui desta região para o consumo, além de outras populações originárias de outras regiões da cidade e de fora da cidade. Assim, gostaria de saber sua opinião sobre a questão da dimensão cultural do Centro Histórico.

Prof. Juliano Pamplona Ximenes Ponte: Uma coisa que eu acho que é uma divergência nossa em relação ao Saint-Clair, mas ele geralmente diz que suas pesquisas tendem a não reforçar a ideia de gentrificação no centro histórico, e a gente está há muito tempo dizendo que está. Por exemplo, se nós utilizarmos aquela formulação de gentrificação da Sharon Zukin, que é uma formulação bem clássica, você tem primeiro um vetor dos artistas, você tem toda uma densidade do conteúdo cultural histórico de algumas áreas fabris, e essa subutilização do parque imobiliário, e você tem determinadas classes, por exemplo, os artistas que chegam primeiro e que usam uma disponibilidade muito grande de terra ou de imóveis, espaços por um preço muito baixo e a atividade econômica dos artistas acaba trazendo atividades associadas, por exemplo, a alimentação. E aí você cria uma espécie de padrão de prestação serviço muito ao gosto de determinadas camadas médias, ou padaria a francesa, a loja de frios, a galeria associada com café, e isso tende a trazer um público consumidor, e detona um processo esse sim, imobiliário. Pelo menos é o que a literatura traz como narrativas, e aqui você tem uma série de dinâmicas que atravessa isso, você tem ainda esse perfil rentista, mercantilista, muito arraigado, um processo bastante importante para essa elite local que tem no aluguel boa parte da sua renda, existe isso bastante presente, famílias que tem no aluguel uma fonte de renda, e a transação imobiliária, alguns destes agentes tem essa predominância. Inclusive 
associados no caso de alguns que operam no centro histórico com o vendedor ambulante existe certa associação. Mas você tem já uma dinâmica da economia cultura que existe aqui e acolá, mas o que você não teve foi um grande financiador. Porque em algum lugar que tem uma economia mais dinâmica, você vai ter um fundo de pensão investindo numa área como essa ou vai ter um aporte de recurso maior, aqui isso não aconteceu tanto, essa história toda da retração da economia, talvez se não tivesse acontecido a reboque do PAC seria provável que teria detonado um retrocesso aqui no centro histórico nesse sentido. Mas o que falta na verdade é um investimento de grande parte para elitizar de vez.

Mas, você já vê um primeiro movimento dos artistas desde os anos 90, tem uma série de fotógrafos, artistas visuais, que moram no centro histórico, procuraram comprar casas no centro histórico, compraram casas baratas no centro histórico, isso já acontece há algum tempo. Além disso, você tem claro todos os investimentos do estado, do governo do estado, que criaram certa paisagem cultural do centro, que foram criando uma certa dinâmica do centro, e posteriormente essas associações mais livres, esses centros culturais de jovens, grafiteiros, skatistas, de gente que vende disco de vinil, de gente que é envolvido com a fotografia ou envolvido com a culinária regional, isso tem sido uma coisa relativamente mais recente, dos anos 2000, 2010, e também tem uma outra camada que tem acontecido e aí você começa a ver essa dinâmica de reapropriação.

Nesse sentido, é interessante estudar o caso específico do projeto circular, acho interessante o circular porque ele tem um discurso crítico em relação a SECULT e ao Governo do Estado, mas eu acho que em termos programáticos o que ele faz é muito parecido com o que a "vocação", que é uma coisa totalmente perigosa, essencialista, determinista do que se coloca pro Centro Histórico. As áreas históricas na cabeça dessas pessoas são parques de economia da cultura elas não têm a multiplicidade de atividades.

Por exemplo, o Porto do Sal, uma área muito antiga bem no centro da cidade, como um lugar que tem plasticidade que tem uma visualidade, e o discurso deles é de que está apoiando as atividades que estão ali, mas eles não conseguem ir além, eu acho, essa é a minha opinião, da visualidade, eles têm essa mesma concepção de incorporar a imagem do centro, essa visão muito estetizante das práticas do centro, mas do pouco conteúdo efetivo que elas têm.

O projeto circular tem tido um alcance grande, é um evento muito contemporâneo no sentido que ele acontece em vários lugares, ele tem esse formato dessas iniciativas mais recentes, não é muito verticalizado, não tem uma coordenação, ele é espalhado com uma série de atividades culturais acontecendo ao mesmo tempo, são variados. Mas se pretende crítico ao que o estado preconiza, claro ele é socialmente muito mais inclusivo do que a Estação das Docas, mas eu tenho dúvidas se em termos programático ele consegue ir tão além assim, essa é uma outra questão. Mas eu acho que 
ele é um caso importante para ser discutido da paisagem cultural do centro em relação ao que se está fazendo contemporaneamente.

No centro histórico e no entorno de Belém tem muita coisa acontecendo, que a tese da Cybelle ${ }^{177}$ inclusive mapeou em parte, muito a partir dos discursos das famílias portuguesas. Você tem esse contorno dessas famílias portuguesas, você tem toda uma geografia cultural do centro histórico e do entorno, principalmente no bairro do Jurunas que tem a ver com migrantes do interior do estado, o livro do Antonio Rocha Penteado ${ }^{178}$, você vai ter migrante do baixo tocantins num pedaço, você tem marajoaras pobre no outro pedaço, você vai ter marajoaras de classe média em outro pedaço, você tem esses pequenos pedaços dos bairros que são colônias, libaneses também em algumas áreas, na Rua Siqueira Mendes, em alguns pedaços do centro histórico que têm essas famílias ocupantes, que têm toda uma herança específica e uma forma de se vincular com a economia, alguns trabalham, por exemplo, com essa economia de navegação, são comerciantes de peça de embarcação, outros são padeiros, ou trabalham com fábrica de velas, outros trabalham com atividade portuária com comércio de fruta, do pescado e do transporte, então tem essa questão de uma geografia dentro deste centro histórico e no entorno também, mas falando em termos culturais, mas tem esse projeto de fazer um centro culturalizado nesse padrão contemporâneo, da gastronomia, do consumo visual da paisagem, da visitação dos centros culturais, e acho que não foge tanto em termos de conteúdo e do programa desse padrão que é mais ou menos consagrado da revitalização dos centros históricos, eu não vejo grandes inovações no caso de Belém, em termos do formato que institucionalmente vem sendo discutido. E mesmo nessas iniciativas como o projeto circular acho que são ainda muito convergentes do ponto de vista programático, tendo o centro histórico como algo que pode ser relativamente formatado como produto, não é você criticar dizendo que não deve ter atividade econômica a partir desse conteúdo cultural do centro histórico senão irá matar, não é um tipo de purista, é você ver isso como algo contemporâneo e as possibilidades disso.

177 Ver: MIRANDA, Cybelle Salvador. Cidade Velha e Feliz Lusitânia: cenários do Patrimônio Cultural em Belém. Tese de doutorado. Belém: Universidade Federal do Pará, 2006.

178 Ver: PENTEADO, Antonio Rocha. Belém - Estudo de Geografia Urbana. Belém: Universidade Federal do Pará, 1968. 


\section{ENTREVISTA 8}

Entrevista realizada na sorveteria Cairu, na Estação das Docas, Av. Boulevard Castilho, s/n - Campina, na cidade de Belém às $11 \mathrm{~h}$ do dia 22 de julho de 2016, com a Profa. Maria Goretti Tavares

Esta entrevista foi realizada pelo interesse em compreender melhor os programas e políticas públicas relacionados a valorização, educação e preservação do patrimônio cultural de Belém, principalmente voltados para a compreensão do processo de patrimonialização de Ver-o-Peso pela UNESCO, e identificar os grupos de interesses, seus atores e suas formas de coalização.

A professora e pesquisadora Maria Goretti foi convidada a participar da entrevista por ser atualmente vinculada ao Departamento de Geografia da UFPA, desenvolver pesquisas na área de geografia, turismo e cartografia, segundo as linhas de pesquisa sobre Turismo e Produção do Espaço na Amazônia, Turismo de Base Comunitária, Políticas de Turismo na Amazônia, Turismo, Geografia e Patrimônio e Redes e Organização do Território na Amazônia e pela coordenação do Projeto de Extensão Roteiros Geo-Turísticos, ganhador do Premio Rodrigo Melo Franco, IPHAN 2016, Ação de Educação, e que inclui a visitação aos espaços patrimoniais de Ver-o-Peso e do Centro Histórico de Belém.

Muitas das perguntas a entrevistada enfocaram nas questões relacionadas ao patrimônio cultural, aos grupos envolvidos neste processo, enfocando no bem cultural Ver-o-Peso e sua área de entorno na cidade de Belém.

Maísa Fonseca: Na entrevista com a Maria Dorotea, ela comentou sobre o processo da culinária, mas eu não entendi se será patrimônio imaterial ou não porque ela disse que não passou pelo IPHAN, porque ela disse que não toca o IPHAN.

Profa. Maria Goretti Tavares: É uma proposta de Belém como cidade criativa na gastronomia, então é uma proposta que surge no ano passado de se fazer o projeto, muito em função desta questão desta coisa que gastronomia paraense está em alta. Então, todo ano tem um festival que é organizado aqui, inclusive pelos proprietários do restaurante "Lá em casa", também que tu podes entrevistar a Joana e a irmã dela que é a chefe do restaurante, mas o pai e a avó que já morreram que criaram o restaurante há quarenta anos, então é um restaurante de identidade local, então eles organizam o festival desde que o pai estava vivo, que era um festival do "Ver-o-Peso da gastronomia", então entram os restaurantes, mas eles articulam-se com as cozinheiras do Ver-oPeso, que eles chamam de boieras, trazem chefes de fora, e aí no ano passado surgiu a proposta de a cidade ganhar a chancela da cidade criativa da gastronomia, que é um processo via UNESCO, e na época neste seminário estavam algumas pessoas representativas que tem entrada na UNESCO, uma 
delas era o Roberto Smeraldi, que é lá do Instituto ATÁ, também lá do chefe famoso, do Atala, então, na verdade, na época ele que acabou encaminhando essa proposta pelas articulações que ele tem e Belém foi eleita "cidade da gastronomia".

Maísa Fonseca: Ela já foi eleita?

Profa. Maria Goretti Tavares: Já, ela é a cidade gastronomia, ela tem chancela da UNESCO, nada passa pelo IPHAN, uma coisa é a coisa do patrimônio imaterial, a chancela do IPHAN, e outra coisa é essa chancela da UNESCO. E aí a grande questão que está se discutindo é a questão da gestão disso tudo, porque se quer a discussão questão da gastronomia, mas que ela seja ampliada, que haja a participação dos diversos setores ligados a restauração, tanto um grande restaurante como os pequenos, tanto os que estão fora do circuito, como o Ver-o-Peso. E aí esse ano em função dessa criação dessa Chancela, o Governo do Estado fez um projeto também gerenciado em Roberto Smeraldi com a participação da Joana, que ela é administradora do "Lá em Casa", para o polo de Gastronomia, só que sem nenhuma discussão com a sociedade sobre isso. E o mais grave é que decidiram implantar este polo [gastronômico] dentro da Casa das Onze Janelas, do lado do Forte do Castelo, que é um local onde funcionava antigamente um restaurante, um bar que já tinha tradição na cidade, embora não fosse local, que era o "boteco das onze", que era uma concessão lá de proprietários lá de Pernambuco, mas já tinha uma tradição, e nos altos funciona o Museu de Arte Contemporânea do Pará, então se criou o grande celeuma, principalmente para a classe artística porque vai se colocar lá esse projeto e vai se tirar o museu, ainda não se sabe pra onde, então são duas discussões, uma é a discussão sobre a concepção do projeto que discutir o polo [gastronômico] de gastronomia sem discutir amplamente com diversos setores da sociedade e o que é essa gastronomia, porque tem uma discussão sobre cultura alimentar, que posso te dar a indicação de pessoa que vem discutindo isso, a Tainá Marajoara que vem discutindo da cultura Marajoara, da cultura alimentar amazônica melhor dizendo, de identidade de produto, e outra coisa é a gastronomia mais gourmetizada, na verdade o projeto veio para atender os restaurantes e a gastronomia gourmetizada, e não dialogou com esses outros setores, com Ver-o-Peso, então essa é a discussão do polo [gastronômico], então todo mundo se reuniu, está tentando resistir, por conta de todo esse debate, isso chegou nacionalmente essa discussão, e chegou também com o Atala, que ia ser uma das principais figuras e ele saiu, evidentemente.

Maísa Fonseca: E é verídico que ele saiu, eu vi a nota dele no jornal ${ }^{179}$ ?

179 Ver: Chef Alex Atala desiste de participar de Polo Gastronômico em Belém. G1 - Pará - 0 portal de notícias da Globo. Disponível em: <http://glo.bo/29aD6Vv>. Acesso em: 10 ago. 2016. 
Profa. Maria Goretti Tavares: Ele anunciou que saiu porque não quer o seu nome envolvido nesse tipo de coisa. E, portanto a gente não sabe o que vai agora, essa coisa toda aconteceu agora de junho para julho, está tendo atividade de toda quarta e domingo de ocupação dos artistas no polo [gastronômico], nesse domingo vai ter, tu podes ir lá durante a manhã, tem atividade para mostrar que a classe artística está de olho e não vai deixar isso acontecer. Então, são duas vertentes, uma coisa é essa coisa da classe artística, e outra coisa é a discussão da gastronomia, no sentido de discutir muito mais do que a gastronomia a questão da cultura alimentar e de integrar também toda essa diversidade, e não fazer um projeto para inglês ver mas um projeto que integre aqui os pescadores, integre o Ver-o-Peso, integre tanto um restaurante como esse como e também o boteco lá que tem uma referência para a cidade e que não está nesse circuito todo "chicão", isso é uma questão. Aí o que é interessante nessa coisa da identidade é que nos últimos anos, nós por exemplo, essa discussão do patrimônio, precisava discutir sobre a gastronomia, mas nós estamos discutindo para tudo também, sobre patrimônio material e imaterial, nos últimos dez anos foram criadas mais três associações, a Civiva, Associação da Cidade Velha e Cidade Viva, que a presidente é a Dulce Roque, que atua mais ali na questão da Cidade Velha, na questão do patrimônio, tem a ASAPAN, que é a Associação dos Agentes do Patrimônio na Amazônia, que ela tem um cunho mais tem acadêmico, de fazer seminários, mas eles também estão de olho em qualquer irregularidade, mas fazer palestras, também são duas pessoas que estão hoje a frente, o Bernardo e a Verena, e tem a AAPBEL, Associação dos Amigos do Patrimônio de Belém, que já foi criado há um ano, por um grupo de pesquisadoras, senhoras que se aposentaram e que começaram a fazer uma proposta. $O$ que é interessante, essas Associações são criadas e dão um novo ânimo no sentido de estar de olho de qualquer coisa que aconteça. Assim, se tu olhares aqui nessa parte aqui da orla, tu vais ver que tem um prédio dentro da baía, que foi construído há cinco anos, então a associação acompanhou essa questão, houve um aterramento da Baía, fez uma proposta para construir um Shopping Center aqui na Cidade Velha, essa coisa da gastronomia. E também a gente tem uma atuação intensa do IPHAN nos últimos dez anos, que coincide com a atuação da Dorotea lá. Acho que antes da Dorotea era uma Instituição muito lá em cima, e a Dorotea que deu uma democratizada, se cria uma casa do patrimônio, que não tem um local físico, mas são ações a ligadas a questão do patrimônio seja material ou imaterial, e convida os diversos setores da sociedade, todas as ações que tiverem sobre a educação do patrimônio, e a gente faz reunião de dois em dois meses, e tem o projeto que eu coordeno, que é o Roteiros Geo-Turísticos, que é um projeto de extensão, que nós fazemos circuitos a pé pelo centro histórico, que acontecem de uma a duas vezes por mês, hoje nós temos sete circuitos formatados, e que qualquer pessoa pode participar, que é feito por mim e por alunos da graduação, do ensino médio e que são monitores, a ideia de falar do patrimônio material e imaterial, mas na perspectiva da cidade, na perspectiva da geografia, mas inclui também a questão da 380 
arquitetura, lógico da história e da cultura em geral. Se tu tiveres aqui, o próximo é dia 21 de agosto, que vai ter um, e depois dia 17 de setembro a gente vai ter o próximo. Aí, 21 de agosto, é importante também tu saberes de existe chamado Projeto Circular, Cidade Velha, Campina e Reduto, são três bairros, que este projeto ele existe há dois anos, artistas e ateliês se reuniram com a ideia de dar um movimento no Centro Histórico dia de domingo, e também colocar os ateliês para abrirem, outras atividades, associações, atividades musicais, culturais, quando acontece esse projeto circular nós somos convidados a participar, nós oferecemos um roteiro faz parte da programação também, a responsável é a Makiko Akao, uma japonesa paraense, e ela deve estar no domingo, ela está a frente do movimento circular. E fora isso tem essas iniciativas específicas, por exemplo, o Círio Patrimônio Mundial da Humanidade 2014, é uma outra coisa que também foi colocada, têm várias chancelas da prefeitura, do estado, do IPHAN é a coisa do Círio, por exemplo, tem municipal tem o Tacacá patrimônio imaterial da cidade, a mangueira é patrimônio imaterial da cidade, seria bom também tu conversar com alguém da prefeitura, a FUMBEL, mas tu deves ter visto que eles são complicados, e aí te o Ver-o-Peso tem uma proposta para se fazer no início, ou fosse patrimônio da humanidade, ou se fizesse a proposta da paisagem cultural, a gente começou a discutir isso pelo IPHAN, mas aí essas turbulências entre governo, estado, governo federal, o fato do governo federal ser PT e aqui ser PSDB, isso sempre dificultou essa articulação, e aí foi uma época e isso sempre foi passado para a prefeitura tomar pé disso, eu fui chamada para uma reunião, fui colocada lá como comitê técnico, mas que na verdade nunca aconteceu, tu tens que ver isso lá na Prefeitura onde está, a Dorotea deve ter dito, deve estar no CODEM, não sei em que pé está esta discussão. 


\section{ENTREVISTA 9}

Entrevista realizada no gabinete do IPHAN-PA, Av. Governador José Malcher, 563, Bairro Nazaré, na cidade de Belém,às 15h no dia 21 de julho de 2016, com a superintendente do IPHAN-PA Maria Dorotéa Lima.

Essa entrevista surgiu pela necessidade de compreender melhor o processo de patrimonialização de Ver-o-Peso e da dificuldade em conseguir acessar documentos e informações aprofundadas sobre este processo após acessarmos a documentação entregue pelo IPHAN-PA para a nomeação do bem cultural Ver-o-Peso para a lista indicativa do patrimônio mundial pela UNESCO, por meio da Lei do Acesso a Informação ${ }^{180}$ pela internet. Assim, por intermédio do IPHAN - Brasília, que disponibilizou a documentação digital dos documentos originais entregues neste processo, pudemos perceber que 0 processo de candidatura não estava tão completo quando o processo de candidatura de Coimbra (PT), e com o interesse de melhor compreender o processo e sua atual fase de desenvolvimento, realizamos a entrevista com a responsável técnica deste órgão nacional pela solicitação formal de candidatura à UNESCO.

A arquiteta e urbanista Maria Dorotéa Lima foi convidada a participar da entrevista devido a sua atuação na preservação do patrimônio pelo Instituto do Patrimônio Histórico e Artístico Nacional, integrando a equipe do Pará, onde, desde 2005, responde pela superintendência. E também pela sua experiência na área de antropologia, com ênfase em inventários e instrução de processos de registro e na área de arquitetura e urbanismo, experiência em relação a áreas de inventário, projetos de restauração e estudos de tombamento e entorno. Ela também foi membro do júri do concurso instituído pelo IAB - PA no ano de 1998, para uma proposta de restauração de alguns edifícios, revitalização e melhorias urbanísticas de circulação e infraestrutura da área que abrangia todo o conjunto de prédios históricos que abrigam o Mercado do Peixe, o Mercado da Carne, Solar da Beira, o antigo necrotério na Praça do Açaí, as praças do Relógio e dos Pescadores, um conjunto tombado e classificado como patrimônio pelo Departamento de Patrimônio Histórico do Município e pelo IPHAN.

Muitas das perguntas a entrevistada enfocaram, basicamente, na idealização do processo de patrimonialização de Ver-o-Peso, nos trâmites envolvidos neste processo, em outros processos de patrimonialização relacionados ao patrimônio imaterial pela UNESCO.

${ }^{180}$ Lei no $12.527 / 2011$ que regulamenta o direito constitucional de acesso às informações públicas. 
Maísa Fonseca: Na minha pesquisa eu acompanhei uma parte do processo de patrimonialização da Universidade de Coimbra, em Coimbra (PT), pela UNESCO, anteriormente a classificação, a equipe envolvida neste processo estava seguindo algumas diretrizes e aconselhamento da UNESCO, ejá havia um dossiê elaborado. Aqui em Belém, eu tive acesso ao documento de intenção de candidatura, cuja assinatura está em seu nome, chegue também a solicitar alguma documentação sobre o Círio de Nazaré, neste sentido de patrimônio mundial, mas não consegui o acesso a documentação até o momento, buscando aprofundar meus questionamentos em relação aos questionamentos da minha tese.

Maria Dorotéa Lima: A gente nem sabe te responder ainda, a gente observa, eu não sei se estas alterações são deste dinamismo e reflexo, e por enquanto do título nacional, porque o Círio fez dez anos de registro como patrimônio nacional e a gente vai começar um processo de revalidação, estamos proposta de metodologia de chamar quem está estudando o Círio, os acadêmicos que estão fazendo alguma pesquisa nesse sentido, e avaliar isso, se algumas coisas que tem surgido de lá para cá, se são decorrentes deste título, ou se é um processo natural decorrente da proporção do evento, ainda nem falaria de impacto de patrimônio mundial, patrimônio da humanidade no caso do Círio. Que é uma coisa pelo pouco tempo desse reconhecimento de natureza imaterial a gente ainda está iniciando estes processos de avaliação, de possíveis impactos e tal, como é que se deu algumas questões. E, no caso do Ver-o-Peso, que era uma coisa que há alguns anos o prefeito teve uma iniciativa de fazer isso, primeiro de tudo ele quis pular o IPHAN, mandando direto para Brasília, e acabou voltando para o IPHAN, depois voltou e veio parar aqui comigo. E depois com a mudança de prefeito entraram outras pessoas, e resolveram ampliar do Ver-o-Peso, e ficou uma coisa meio fora da realidade, uma coisa muito gigantesca para atingir todas as exigências da UNESCO e que seria um percurso da Belém ao longo do tempo a partir dos bens tombados na cidade, e era uma coisa gigantesca. E, também chegaram a desenvolver estudos, trouxeram pessoas de fora, mas não avançou aqui dentro do IPHAN, com a documentação que eles haviam dado entrada, depois deram entrada num texto, com a mudança da prefeitura num outro momento, se eles teriam interesse de manter, a gente apontou uma série de questões que precisava responder, que o estudo precisava atender, no entanto eles nunca devolveram, não tinha uma imagem, um mapa, não tinha nada, então a gente pediu uma série de complementações e apesar de sinalizarem que dariam continuidade, não houve uma continuidade.

E depois houve uma reunião aqui da UNESCO para discutir critérios para novas indicações, naquela tentativa de ampliar o leque dos patrimônios já reconhecidos para diversificar de coisas que não estavam contempladas, já tinha muito centro histórico brasileiro, e nós colocamos a questão do Vero-Peso, mas havia uma orientação de Brasília para a gente trabalhar a questão da arquitetura do 
ferro, e a gente conduziu num outro sentido de relacionar o espaço e as práticas, por que ali tu tens em termos de arquitetura o que a gente colocou na candidatura uma evolução, uma transformação no tempo em que as práticas se mantiveram, e ganharam força ali naquele local, criou uma espécie de um tipo de território, e acabou que gostaram dessa proposta, apesar de ter ido com a indicação da candidatura do ferro, o próprio grupo de consultores teve essa ideia que no Ver-o-Peso deveriam ser trabalhadas outras questões. E, aí voltamos a proposta que a gente tinha feito por aqui, mas também ficou parada, quando no IPHAN houve uma necessidade de organizar e sistematizar os bens que tinham esta perspectiva, a gente já estava na fila dentro do IPHAN, foi quando a gente finalizou o formulário, mandou e aí entrou na lista das candidaturas, mas aí já tinha um trabalho para fazer aqui, e que a gente passou quase um ano fazendo uma articulação, construiu um grupo multidisciplinar e interinstitucional, e haviam duas coisas, o IPHAN trabalha com duas coisas, um comitê estratégico e outro grupo técnico, porque a prefeitura deveria conduzir o trabalho técnico sob a nossa orientação, então, esse comitê que dá as diretrizes, que é formado pela presidente do IPHAN e o preposto, o governo do estado e o proposto, e o município e um preposto, seria um termo maior que envolve gestores, uma instância mais acima, e o grupo de trabalho que é nomeado pelo prefeito, ou seria uma equipe para eles contratarem o projeto e esse grupo faria termo de referência e fariam o acompanhamento, ou eles desenvolveriam o trabalho, e a prefeitura fez a opção de contratar, mas a gente levou quase um ano para conseguir fechar esse grupo de trabalho, com quais instituições, com quais profissionais, só que por questões políticas, toda hora acontecia mudança ou no estado ou na prefeitura, e a gente não conseguia publicar porque estava toda hora mudando os titulares, as pessoas, ou os técnicos mudavam de um órgão para o outro e ai já não tinham vínculo, quando conseguimos que saísse saiu sem designação de coordenação. E aí tinha outra discussão dentro da prefeitura, ser a CODEM, com SEURB, ou a FUMBEL, que deveria ser sido a FUMBEL, mas a presidente da FUMBEL alega sempre a FUMBEL que não tem gente e que não tem estrutura, e não tem recurso e jogou para a SEURB, saiu a portaria mas saiu sem coordenação, e eu voltei para o prefeito dizendo que não funcionaria se não tivesse coordenação designada, e começou um longo processo que ate hoje não saiu essa portaria, e por outro lado acho que foi uma estratégia deles, porque eles começaram a trabalhar por trás dos panos, ou seja, sem abrir para esse grupo que tinha vários representantes de vários órgãos, a questão da cidade da gastronomia, que é um outro processo, mais simples, e que não passa pelo IPHAN e eu nem sei como é, mas é UNESCO também.

Maísa Fonseca: Mas este processo da gastronomia é patrimônio imaterial?

Maria Dorotéa Lima: Não, tem várias categorias, eu não conheço bem isso e não sei como funciona, mas tem cidade da alegria, cidade da gastronomia, tem várias categorias, formaram um grupo, chamaram consultoria internacional, tudo o que poderiam ter feito por Ver-o-Peso e não fizeram, ai direcionaram para isso, porque não passava pelo IPHAN e era um processo mais rápido, e 
conseguiram esse título e esqueceram, largaram o outro de lado, e atropelou todo o processo, porque quando a gente começou este trabalho a assessoria de relações internacionais do IPHAN que acompanha estes processos por Brasília veio aqui, a gente fez uma visita na área, a gente explicou como tudo como funcionava o processo para este grupo todo e já fez uma avaliação para discutir a questão da poligonal, se era aquilo mesmo, se deveria reduzir, e das implicações da área que a gente deveria costurar muito bem, ver algumas coisas que na área ainda não via, essa leitura de continuidade, porque que isso tem a ver com Ver-o-Peso, a gente incluiu a princípio praça Frei Caetano Brandão que chama Feliz Lusitânia hoje, ia dali da Feliz Lusitânia até antes Estação das Docas, e andando na área ele perguntou qual a conexão que teria entre o Feliz Lusitânia, que isso seria questionado se não estivesse muito bem escrito, colocou a dificuldade da área ser maior de gestão e de uma série de coisas, então, havia um grupo defendendo esta inclusão, mas no final a gente chegou a conclusão que a gente deveria restringir ao Ver-o-Peso, e aí a gente restringiu, a outra coisa era o estado de conservação que estava muito ruim, e aí como estava, como está incluída no PAC Cidades Históricas, só que aí tu tens um problema de articular os processos por causa dos tempos, então a gente deveria ir no próximo ano, mas eu acho que a gente não vai conseguir, porque tem o dossiê já deveria estar sendo trabalhado e não está, porque a prefeitura largou de mão, e ainda houve esse processo de atropelamento do projeto, porque a gente deu todas estas diretrizes, e na verdade era para acontecer paralelamente isso grupo acompanhado desse comitê que trabalharia o dossiê, o grupo de trabalho projeto e a questão do dossiê tinha que dialogar, um ficou parado e o outro andou, enfim, eles deram um rumo pro negócio, apesar de a gente participar, mas a gente estava falando e as pessoas insistindo com aquela coisa, até quando ele foi divulgar a coisa do projeto, foi um escândalo, o projeto não foi aprovado, logicamente, foi pedido uma série de alterações, e aí tudo atrapalha, porque a gente tinha que trabalhar afinado, isso provavelmente, ele já está em final de mandado, se ele não se eleger a gente vai ter que recomeçar esse diálogo, então a gente meio que parou com isso, porque também essa reconfiguração das instituições envolvidas, é sempre uma questão de política, deixou de ser técnica, que a princípio haviam uns técnicos bons, pessoas com um bom currículo em práticas para trabalhar nesse dossiê, e aí com essa mudança de configuração das instituições, aí a questão está meio parada porque não dá para trabalhar sem a prefeitura, essa parte do dossiê ficou um pouco como responsabilidade deles e está desarticulado, porque até constituir outro comitê e o grupo, porque era o IPHAN que estava conduzindo, mas depois que a prefeitura constituiu esse grupo, e aí eles que deveriam tomar a frente para trabalhar termo de referência e tudo mais, e aí eles resolveram trabalhar esta questão da gastronomia porque tem um projeto aí com o governo do estado voltado para isso, que é um grande caixa preto também.

Maísa Fonseca: $\mathrm{E}$ a atuação do governo estado nesse processo do Ver-o-Peso? 
Maria Dorotéa Lima: No grupo tinha um técnico do estado da área de patrimônio, eles que inclusive estavam nessa tentativa de insistir pela SECULT de insistir que ficasse o Feliz Lusitânia, mas no final a gente acabou fechando que essa área ficaria como área de entorno, fechou mais a indicação do Vero-Peso que isso seria trabalhado e justificado no dossiê.

Maísa Fonseca: E a área de entorno do Ver-o-Peso ficou delimitada como o Centro Histórico? Maria Dorotéa Lima: A ideia era o Centro Histórico, mas hoje dentro dessa discussão primeira a gente reviu que o Ver-o-Peso seria mais restrito a área que é designado como Complexo do Ver-oPeso e o entorno ficaria como a primeira área que a gente estava propondo como B.P. Zona, D.P. Zona, e essa área, o miolinho mesmo ficaria com a candidatura.

Maísa Fonseca:Sobre essa informação não há cartografia?

Maria Dorotéa Lima: Não isso a gente trabalhou em atas, eram indicativos para o dossiê ser trabalhado nessa direção.

Maísa Fonseca:Em relação a hegemonia das nações dentro da UNESCO, dentro da União Europeia, há algumas facilidades nos processos de classificação em relação aos países?

Maria Dorotéa Lima: Há toda uma política que é feita, para conseguir incluir essas coisas que saem desse contexto, eles são muito centralizadores ali, no entendimento deles é muito em cima das cidades europeias, então, quando você entra com uma coisa diferente tem que fazer todo uma costura com os países-irmãos daqui que têm características como nós, e que têm menos expressividade nessa coisa das cidades antigas históricas e se apoiar.

Maísa Fonseca: Por outro lado eu achei muito interessante que eles vinculam o patrimônio imaterial ao processo desse patrimônio material no processo de patrimonialização da Universidade de Coimbra, mas durante o processo muitas dessas questões acabaram se perdendo, segundo o meu ponto de vista.

Maria Dorotéa Lima: É,eles estão fazendo muita coisa lá [Coimbra] também para atrair investimento estrangeiro.

Maísa Fonseca: Já aqui me pareceu muito interessante os inventários culturais como registro do patrimônio imaterial, com o apoio do IPHAN.

Maria Dorotéa Lima: Como o Ver-o-Peso é tombado, ele não é registrado, mas a gente sempre achou que tinha que ter esse processo para cobrir, quando a gente trabalhou esse processo do inventário, a ideia seria discutir a partir daí que caminho com os trabalhadores lá da área que a gente seguiria, se eles queriam registro, patrimônio mundial, mas até na nossa visão a gente trabalharia essa coisa que dentro do IPHAN estava coisa da "chancela", se a gente trabalharia a "chancela" ou o "registro como lugar", e acabou que como estava essa coisa da "chancela trabalhadorista" a gente começou a caminhar pra lá.

Maísa Fonseca: Para a questão da "chancela"? 
Maria Dorotéa Lima: É, e o IPHAN com essa coisa da "chancela" que não foi maturada, no sentido de que não foi amadurecida e não foi praticada devidamente para se corrigir distorções e tal, e tem duas chancelas, tem uma que foi lá para o conselho que se posicionou que deveria ser reconhecida, que é lá do "roteiro da imigração", tem muitos problemas, então eles decidiram que vamos investir nisso, para construir por meio dessa experiência em vez de abrir várias frentes para ver se a coisa funcionará, então eles suspenderam todos os processos de "paisagem" que ainda não estavam com o processo aberto. Então a gente parou aqui de mexer com isso, e foi quando se retomou essa ideia da candidatura, e a gente começou a trabalhar, como já tinha tombamento a gente começou a trabalhar direto a questão da candidatura, então, nesse processo, a gente tinha trabalhado esse inventário, que foi uma boa aproximação, é um inventário preliminar ele não é avançado, tem um mapeamento, umas publicações que a gente fez, tipo umas cadeias produtivas que a gente observou lá, tem duas coisas, uma é uma coisa que faz uma análise bem antropológica e tem essa outra que é uma espécie de um catálogo, de um guia do Ver-o-Peso, montamos uma exposição, fizemos um filme e depois a própria associação que era nossa parceira se implodiu, praticamente.

Maísa Fonseca: Parceira local?

Maria DorotéaLima:Que foi um processo com a Natura, era muito complicada, acabou que o negócio se implodiu, foi uma coisa muito complicada, alguém ainda deve estar estudando isso, porque tem várias representações lá, mas não tem uma ONG, e como elas estavam bem legalizadas e tudo, a gente conseguiu trabalhar com elas. Então é isso, a gente ia juntar tudo isso, era subsídio para o dossiê e anexar no processo, porque na verdade o dossiê em si não é tanto, mas são esses anexos, que subsidiam a proposta.

Maísa Fonseca: Então em relação a gestão do bem, tal como a UNESCO coloca essa questão como algumas das suas diretrizes, não há nenhum avanço neste sentido atualmente?

Maria Dorotéa Lima: O gestor da feira e do complexo é o município através da secretaria de economia, e tem outros agentes que atuam ali na área, pessoal da limpeza, várias secretarias, social, cada uma cumpre o seu papel, mas a gestão mesmo que faz a sessão dos boxes é a SECON.

Maísa Fonseca: No processo de patrimonialização de Coimbra eles partiram de um processo inicial que era centrado no Centro Histórico da cidade, mas por um aconselhamento da UNESCO o bem cultural foi alterado para a Universidade de Coimbra. Por meio do entendimento deste processo foi possível verificar que a mediação da UNESCO auxiliou na questão da sobreposição das instâncias dos órgãos de proteção patrimonial para a organização do processo de candidatura. Ainda nesse sentido eles criaram um escritório técnico da região central, buscando auxiliar em questões locais. Eu gostaria de saber se houve alguma análise e planejamento neste sentido, aqui em Belém. 
Maísa Fonseca: A ideia da minha pesquisa é analisar um processo em andamento. Entre outras questões, eu buscava compreender em termos de instância como a UNESCO se sobrepõe a ideia da nação. Mas no caso de Belém, após ter acesso aos documentos de intenção de candidatura do IPHAN, eu não consegui mais informações sobre o andamento deste processo.

Maria DorotéaLima: Agora no momento nem adianta se mexer muito, período de eleição, projeto empacado, porque se a gente fosse avançar com o dossiê, porque isso foi outra coisa que a gente discutiu porque assim o Ver-o-Peso até mesmo na questão do projeto, ele não tem uma configuração única a feira, ela já sofreu várias transformações, então na verdade você tem duas questões ali que a gente se prende para analisar, é a questão dos significados das praticas, e da configuração, em termos de escala, de relação, de proporção, então, não dá para dizer que não dá para mexer, porque esse projeto é super recente, agora ele tem essa relação muito bem estabelecida com o conjunto, não compete com nada, e é isso que tem que atentar e que tem que ser mantido, não é exatamente a forma (aspas em a forma).

Então o que eu comentei com Brasília, que é muito difícil, que a gente tem que defender não a forma, mas a questão da preservação das praticas apesar das transformações, porque ai mesmo urbanisticamente você sofreu diversos processos, e como a gente diz aqui, o Ver-o-Peso nasceu com a cidade praticamente, porque era um porto natural, e já tinha o escambo, essa coisa das trocas, e naturalmente foram surgindo os comércios e ele só foi se espalhando e se institucionalizando, e foi ganhando outras formas, houve o aterramento, houve o cais, houve uma série de coisas que foram se incorporando dentro do complexo.

Maísa Fonseca: No caso de Coimbra a equipe coordenadora do processo partiu de um processo de patrimonialização do Centro Histórico, e depois após um aconselhamento da UNESCO eles nomearam a Universidade de Coimbra. Esse processo foi vinculado a uma elite cultural da própria Universidade e ele auxiliou na sobreposição e na organização da ação de órgãos de preservação de diferentes instâncias em Portugal, do nacional ao local. É possível fazer uma correlação entre o processo de Coimbra e o de Belém, segundo este ponto de vista?

Maria Dorotéa Lima: Não, a gente conseguiu fazer o grupo que tem diversos atores, porque aqui a gente já tem uma área que a gente atua tem uma sobreposição principalmente União e município, e o estado em algumas áreas, em que a gente trabalha junto, mas depende muito dos momentos políticos, então assim, em algumas áreas o IPHAN conseguiu chamar o que ele define um escritório técnico que agrega algumas coisas, mas aqui, apesar de a gente já ter feito algumas tentativas, na hora $\mathrm{H}$ na consegue fechar, tecnicamente a gente fez uma costura, mas quando chega na hora dos gestores baterem o martelo eles não batem porque acham que estão perdendo poder para o IPHAN.

Maísa Fonseca:Então ele atua em termos de municipalidade? 
Maria Dorotéa Lima: E porque a gente tem ainda muito aquela coisa, o IPHAN é sempre o recurso, quando a prefeitura fura, quando o estado, quando todo mundo entra na política, aí eles recorrem ao IPHAN, porque não pode aprovar, as vezes a gente faz, mas muitas vezes nem é nossa área, não tem o que fazer. Porque é essa coisa, é muito fácil mudar uma lei local, vai lá na Câmara de Vereadores, pega um lobby e muda, algumas coisas a gente conseguiu barrar com movimento social, alguma coisa a gente conseguiu barrar, ir pra Câmara, tomar conta, recorrer ao Ministério Público, principalmente a questão de gabarito, por outro lado, Ver-o-Peso é uma área muito visada, porque é uma área de centralidade, e momento com essa olho na culinária da Amazônia, tem muita gente pensando em ganhar dinheiro com isso, então o Ver-o-Peso ganha uma dimensão, mas de modo diferente de alguns mercados que tem algumas coisas sofisticados para comer, aqui é uma coisa muito popular. Então hoje você tem dentro do mercado um bar sofisticado, que abriu lá, que funciona mais de noite, mas que não tem um funcionamento regular, mas acho que é já uma tentativa nesse sentido e que olhando isoladamente eu não vejo problema, mas se for uma tendência, a gente tem que pensar, se é um processo de expulsão branca se não é...

Então eu sempre falei para os feirantes, "vocês tem que se apropriar desse título, porque isso mais que qualquer outra coisa é que vai segurar a permanência de vocês aqui" porque a candidatura se prende nisso, nessas práticas, então hoje a cidade toda está muito preocupada com este projeto que se fala com esse projeto gastronômico, que se fala e se fala, e eu não sei se é uma questão política tem umas coisas assim que eles não abrem, apesar de a gente ser parceiros em algumas coisas, tem um projeto que falam por ai de um polo gastronômico que as pessoas falam, "tem que ver, eu fui numa apresentação não sei aonde",e eu pergunto: “quem fez a apresentação?”, a SEICON, aí eu fiz uma ligação para o secretário e disse que eu soube que ele fez um apresentação de uma proposta e ele respondeu: "não existe um projeto, mas uma proposta, assim que tiver uma coisa mais concreta a gente vai apresentar para vocês, a gente está apresentando um projeto procurando parceiros", então tem uns negócios assim de esconde, não sei te dizer exatamente polo gastronômico, nem a dimensão disso, nem como cidadã, nem pessoa representante de pesquisa.

Maísa Fonseca: E nessa equipe que tinha sido montada, interdisciplinar, havia a participação popular ou ela estava prevista?

Maria Dorotéa Lima: Haviam algumas pessoas do Ver-o-Peso gente fez uma escolha lá com eles e tinha três representantes, com suplentes todos três, mas até as vezes que a gente convocou eles não vieram para a reunião. Inclusive eram dois e eles pediram mais um, e as suplências. Mas a gente chegou a fazer duas convocações, uma foi quando o Marcelo veio de Brasília que veio explicar como era o processo e deixou uma série de tarefas e que não aconteceram por essas histórias todas que eu já contei, eles não vieram. 
Maísa Fonseca: E esses consultores internacionais que foram chamados, eles eram relacionados a UNESCO?

Maria Dorotéa Lima: Esses consultores..foi um tempo atrás, não foi nesse processo, foi num processo do Ver-o-Peso, mas numa outra gestão da prefeitura. Chamou alguém, não sei de onde surgiu, era um italiano que segundo ele falou trabalhava nesses processos da UNESCO naquele lugar e ele fez, publicou um livro, mas é isso que eu estou te falando, quando decidiram ampliar isso e ficou uma coisa impraticável. E também não apresentavam toda a documentação, ainda se tivesse tudo você poderia dizer como poderia ser redirecionado, digamos assim, então ficou um pouco parado também.

Maísa Fonseca: E desse processo anterior, chegou a ter algum documento, algum registro?

Maria Dorotéa Lima: Tinha uma carta que eles fizeram, que endereçaram para o MinC, e depois eles mandaram para cá um texto, muito longo, assim, muito grande, que ficou registrado, e eu nem sei onde está. Assim, terias que procurar na biblioteca, eu não me lembro se foi entregue formalmente. Até onde eu lembro ele estava na estante, mas não tinha entrada de processo, não tinha nada. Quando eu assumi aqui, que já faz bastante tempo, ele estava lá. 